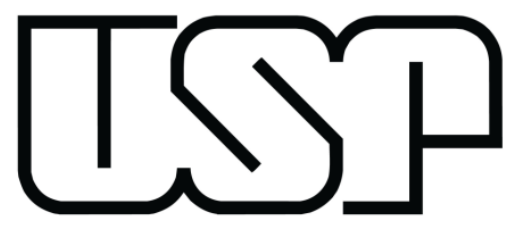

Universidade de São Paulo

Faculdade de Filosofia, Letras e Ciências Humanas

Departamento de Geografia

Programa de Pós-Graduação em Geografia Física

PAULO MIGUEL DE BODAS TERASSI

VARIABILIDADE PLUVIOMÉTRICA E OS EVENTOS PLUVIAIS EXTREMOS EM BACIAS HIDROGRÁFICAS DO LESTE DO ESTADO DO PARANÁ

Versão Corrigida

SÃO PAULO

2019 
PAULO MIGUEL DE BODAS TERASSI

\title{
VARIABILIDADE PLUVIOMÉTRICA E OS EVENTOS PLUVIAIS EXTREMOS EM BACIAS HIDROGRÁFICAS DO LESTE DO ESTADO DO PARANÁ
}

\author{
Versão Corrigida
}

Tese de Doutorado apresentado ao Programa de Pós-Graduação em Geografia Física do Departamento de Geografia da Faculdade de Filosofia, Letras e Ciências Humanas, da Universidade de São Paulo para a obtenção do título de Doutor em Ciências.

Orientador: Prof. Dr. Emerson Galvani Área de concentração: Geografia Física Linha de pesquisa: Estudos teóricos e aplicados em Climatologia Agência financiadora: CAPES - Código de financiamento 001 
Autorizo a reprodução e divulgação total ou parcial deste trabalho, por qualquer meio convencional ou eletrônico, para fins de estudo e pesquisa, desde que citada a fonte.

Catalogação na Publicação

Serviço de Biblioteca e

Documentação

Faculdade de Filosofia, Letras e Ciências Humanas da Universidade de São Paulo

\section{Terassi, Paulo Miguel de Bodas}

T315v Variabilidade pluviométrica e os eventos pluviais extremos em bacias hidrográficas do leste do Paraná

/ Paulo Miguel de Bodas Terassi; orientador Emerson

Galvani. - São Paulo, 2019.

$293 \mathrm{f}$.

Tese (Doutorado) - Faculdade de Filosofia, Letras e Ciências Humanas da Universidade de São Paulo.

Departamento de Geografia. Área de concentração: Geografia Física.

1. Climatologia Geográfica. 2. Geografia Física.

3. Meteorologia. 4. Bacias Hidrográficas. 5. Climatologia Estatística.

I. Galvani, Emerson, orient. II. Título. 


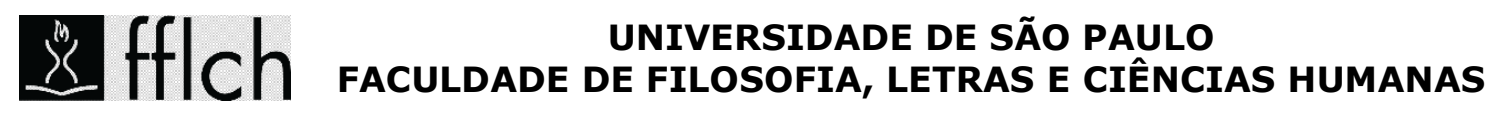

\author{
ENTREGA DO EXEMPLAR CORRIGIDO DA TESE \\ Termo de Ciência e Concordância do orientador
}

Nome do aluno: Paulo Miguel de Bodas Terassi

Data da defesa: 29/10/2019

Nome do Prof. orientador: Prof. Dr. Emerson Galvani

Nos termos da legislação vigente, declaro ESTAR CIENTE do conteúdo deste EXEMPLAR CORRIGIDO elaborado em atenção às sugestões dos membros da comissão Julgadora na sessão de defesa do trabalho, manifestando-me plenamente favorável ao seu encaminhamento e publicação no Portal Digital de Teses da USP.

São Paulo, 29/12/2019

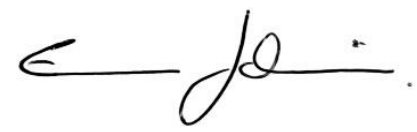

Assinatura do orientador 
TERASSI, P.M.B. Variabilidade pluviométrica e os eventos pluviais extremos em bacias hidrográficas do leste do estado do Paraná. 2019. 293f. Tese (Doutorado). Faculdade de Filosofia, Letras e Ciências Humanas da Universidade de São Paulo para obtenção do título de Doutor em Ciências (Geografia Física).

Aprovado em /

\section{Banca examinadora}

Professor Doutor Emerson Galvani (Orientador)

Instituição: Universidade de São Paulo - USP

Assinatura:

Julgamento:

Professora Doutora Maria Elisa Siqueira Silva

Instituição: Universidade de São Paulo - USP

Assinatura:

Julgamento:

Professor Doutora Núbia Beray Armond

Instituição: Universidade Federal do Rio de Janeiro - UFRJ

Assinatura:

Julgamento:

Professor Doutor Fabio de Oliveira Sanches

Instituição: Universidade Federal de Juiz de Fora - UFJF

Assinatura:

Julgamento: 
Dedico aos meus pais, que estiveram ao meu lado, mesmo à distância, em todos os momentos. 


\section{AGRADECIMENTOS}

Agradeço aos meus pais e avós por estarem comigo nos mais difíceis momentos e serem meu substancial alicerce. Aos amigos agradeço pelo suporte em diversas fases e, sobretudo, àqueles que estavam ao meu lado nas dificuldades. Alguns amigos ficaram pelo caminho e me recordo de vocês com muita gratidão e afeto. Sinto saudades da Thalita Dal Santo, do Rodrigo Vilas Boas, do Luiz Paulo S. Almeida, da Thaynara G. Cantero, da Liriane Barbosa, da Juliana Teixeira, do Everton H. Fragal, do Fabio Alves, da Karine B. Vargas "Shore", da Larissa P. Dorigon, da Larissa Coutinho, da Bruna Thaís, da Rízzia Mendes, da Solange Santos, do Vagner Batistela, da Daniela Polla, do Elerson Cestaro, da Honória Rigolin e de outras muitas pessoas.

Dos amigos, agradeço ao Diego Pereira Santos, de bondade infindável, que esteve ao meu lado nos momentos mais difíceis e divertidos em São Paulo. Agradeço ao Márcio G.G. Correa pelos trabalhos acadêmicos compartilhados, mas principalmente por todas as cervejas bebidas, por todas as ansiedades compartilhadas e por todo suporte. Por dar o suporte e por toda zoera, agradeço ao "Gente Baixa” (Diego Benfica, Jessyca Souza, Mariana Matias, Marina Badina, Renato Abreu e Roberta Munhoz). Aos meus roomies ao longo de todos estes anos, agradeço especialmente ao Yuri Parra Castilho, ao Thales Pescarini e ao Victor Pereira Bussiki pelo convívio e por compartilhar bons momentos. Às gurias, agradeço à Denise Dias Santos e a Jakeline Baratto pelas "buenas indiadas", pelos mates quentes e por compartilhar todas os anseios da vida acadêmica.

Agradeço ao orientador do curso de Doutorado, o Emerson Galvani, homem de brilhante generosidade e inteligência. Sem dúvidas, colaborou para a minha evolução científica e, com seus gestos e atitudes, tornou-se um excepcional exemplo profissional e pessoal. Agradeço ao meu orientador de Iniciação Científica e Mestrado, o gentil e muito competente Hélio Silveira, pelas primeiras oportunidades de pesquisar Climatologia e Pedologia. Agradeço ao também orientador de Mestrado, o parceiro José Tadeu Garcia Tommaselli pela orientação e paciência em explicar as planilhas e softwares.

Agradeço à Maria de Lurdes Orsini Fernandes Martins e à Sônia Maria Soares Stivari por terem sido incentivadoras e inspiradoras para pesquisar e crescer ao longo da Graduação. Ao Carlos Henrique da Graça agradeço pela amizade e por todo o auxílio e colaboração científica em uma etapa anterior. Ao Vitor Hugo Rosa Biffi agradeço pela parceria pessoal e colaboração na elaboração dos produtos cartográficos, que sem dúvidas ajudaram muito no progresso desta pesquisa. À Camila Carou, à Caroline Freire, à Natália 
Nunes Patucci e à Professora Déborah de Oliveira agradeço por toda parceria ao longo do estágio do Programa de Aperfeiçoamento de Ensino (PAE), bem como à Universidade de São Paulo pela concessão das bolsas ao longo de quatro semestres.

Agradeço ao José Francisco de Oliveira-Júnior pelas contribuições e parcerias ao longo dos últimos anos, essenciais para a minha qualificação acadêmica e, principalmente, junto ao Givanildo Góis, qualificaram os aspectos estatísticos e meteorológicos desta tese de doutoramento. Agradeço ao Centro de Estatística Aplicada (IME/USP), ao Professor Doutor Pedro Alberto Morettin e aos discentes Leonardo Marassi, Marcos T. Shimabukuro e Stephan L. Hsu pela consultoria estatística. Agradeço ao Antonio Carlos Oscar Júnior por me ajudar gentilmente a trabalhar com o RClim Dex e por me receber no Rio de Janeiro de forma tão acolhedora. À Núbia B. Armod pelo incentivo em aplicar à técnica "Spatial Synoptic Classification" e ao Professor Scott Christopher Sheridan por gentilmente gerar estes resultados tão importantes para a finalização desta pesquisa.

Agradecimentos à Coordenação de Aperfeiçoamento de Pessoal de Nível Superior pela concessão das bolsas de Doutorado e pelo apoio do Programa Nacional de Cooperação Acadêmica (071/2013) - Processo número 88881.068465/2014-01. Agradecimentos ao Instituto Nacional de Meteorologia, ao Instituto Agronômico do Paraná, ao Sistema Meteorológico do Paraná, ao Instituto das Águas do Paraná e à Agência Nacional das Águas pela concessão dos dados meteorológicos que compuseram este trabalho. 
"So much has come before those battles lost and won

This life is shining more forever in the sun Now let us check our heads And let us check the surf Staying high and dry's more trouble Than it's worth in the sun Just a mirror for the sun Just a mirror for the sun These smiling eyes are just a mirror for". Road trippin' - Red Hot Chili Peppers 


\section{RESUMO}

TERASSI, P.M.B. Variabilidade pluviométrica e os eventos pluviais extremos em bacias hidrográficas do leste do estado do Paraná. 2019. 293f. Tese (Doutorado). Faculdade de Filosofia, Letras e Ciências Humanas, Universidade de São Paulo.

Esta pesquisa parte da prerrogativa da compreensão da elevada variabilidade espacial da pluviosidade para a área de estudo a partir da influência de atributos como a maritimidade, a orografia e a diversidade de mecanismos atmosféricos para a geração das chuvas. $O$ objetivo da presente pesquisa consiste em avaliar a variabilidade pluviométrica e a ocorrência de eventos pluviais extremos para as bacias hidrográficas (BH) do Alto Iguaçu, Litorânea e do Ribeira, situadas na região leste do estado do Paraná, analisando os eventos mais intensos e a influência de atributos como a orografia, a maritimidade e a dinâmica atmosférica. Para tanto, foram obtidos os dados diários, mensais e anuais de precipitação pluviométrica de 54 postos pluviométricos do Instituto das Águas do Paraná, da Agência Nacional de Águas e da Companhia Paranaense de Energia, além de dados provenientes de 08 estações meteorológicas do Instituto Agronômico do Paraná, do Instituto Nacional de Meteorologia, do Sistema Meteorológico do Paraná, para o segmento temporal de 1976 a 2015. Foram utilizados os principais procedimentos metodológicos: a krigagem para a caracterização espacial pluviométrica e a análise de agrupamento (Ward e K-Means) para a obtenção de regiões homogêneas pluviométrica em cada bacia hidrográfica; os quantis para a classificação e a identificação dos eventos pluviais extremos; o modelo auto regressivo vetorial (VAR) para analisar as correlações entre as anomalias pluviométricas e os indicadores climáticos marítimos (IOS, ONI, ODP e GMAT), a partir dos dados disponibilizados pelo National Oceanic and Atmospheric Administration; os testes estatísticos Mann-Kendall e Pettitt para a avaliação de tendências e rupturas nas séries históricas pluviométricas; para gerar os indicadores de tendências de precipitação pluvial, utilizou-se o software RClimDex, desenvolvido pelo Sistema Meteorológico Canadense; foram definidas as condições sinóticas para os eventos pluviais extremos pela Análise Rítmica Climatológica, enquanto que a gênese pluviométrica foi analisada pela Spatial Synoptic Classification (SSC). As análises espaciais indicaram uma estrutura pluvial de maiores totais anuais e diários na BH Litorânea e, a sotavento da Serra do Mar, um representativo setor da BH Ribeira apresenta uma redução expressiva da pluviosidade total anual e dos totais diários pluviais em relação à costa litorânea. O modelo VAR mostrou que o indicador climático ONI é o que apresentou uma maior significância e abrangência espacial para determinar as anomalias de precipitação pluviométrica na área de estudo. O teste de tendência (Mann-Kendall) e os indicadores climáticos mostraram que a área em estudo apresenta a preponderância da elevação dos totais pluviométricos anuais associada ao aumento da precipitação pluviométrica diária concentrada, sendo este um indicativo de mudanças climáticas neste recorte de estudo. As principais rupturas encontradas nas séries históricas se deram na década de 1990, semelhante as demais rupturas observadas anteriormente no estado do Paraná. A Análise Rítmica Climatológica demonstrou que durante o inverno há a predominância das frentes frias e os totais pluviais são espacialmente mais homogêneos, ao passo que durante o verão verificou-se maiores diferenças espaciais e condições atmosféricas mais frequentemente associadas aos sistemas atmosféricos extratropicais. A SCC demonstrou que os tipos de tempo mais úmidos se dão com maior frequência em Paranaguá, devido à maritimidade, e em Castro e Curitiba, as tipologias indicaram uma maior frequência dos tipos de tempo associados aos sistemas atmosféricos extratropicais.

Palavras-chave: Eventos Extremos. Dinâmica Atmosférica. ENOS. Bacia Hidrográfica. Tendências Climáticas. 


\begin{abstract}
TERASSI, P.M.B. Rainfall variability and extreme rainfall events in watershed of eastern Paraná State. 2019. 293f. Thesis (Doctorate). Faculty of Philosophy, Languages and Literature, and Human Sciences, University of São Paulo.
\end{abstract}

This research is premised to understand the high spatial rainfall variability for the study area from the influence of attributes such as maritimity, orography and the diversity of atmospheric mechanisms for rainfall generation. The goal of this research is to measure the pluviometric variability and the occurrence of extreme rainfall events for the Alto Iguaçu, Litorânea and Ribeira river basins (RB), located in the eastern region of the State of Paraná, analyzing the most intense events and the influence of factors such as orography, maritime dimension and atmospheric dynamics. To that end, the daily, monthly and yearly rainfall data of 54 pluviometric stations of the "Instituto das Águas do Paraná", the "Agência Nacional de Águas", and the "Companhia Paranaense de Energia", as well as data from 08 weather stations of the "Instituto Agronômico do Paraná", "Instituto Nacional de Meteorologia" and "Sistema Meteorológico do Paraná", for the period of 1976 to 2015 were obtained. The following methodological procedures were used: kriging for the rainfall spatial characterization and the group analysis (Ward and K-Means) to obtain homogeneous pluviometric regions in each river basin; the quantiles for the classification and identification of extreme rainfall events; the vector autoregressive model (VAR) for analyzing the correlation between the pluviometric anomalies and the maritime indicators (IOS, ONI, ODP and GMAT), from the data provided by the National Oceanic and Atmospheric Administration; The Mann-Kendall and Pettit statistic tests for evaluating trends and breaks in the pluviometric historical series; in order to create the rainfall trend indicators, the software RClimDex, developed by the Canadian Meteorological System was used; the synoptic conditions for the extreme rainfall events were defined by the Climate Rhythmic Analysis, while the pluviometric origin was analyzed by the Spatial Synoptic Classification (SSC). The spatial analysis has shown a rainfall structure of greater yearly and daily amounts in the Litorânea river basin and at leeward of the Serra do Mar (Sea Ridge), an expressive sector of the Ribeira river basin presents a significant reduction of the yearly and daily rainfall amounts compared to the sea coast. The VAR model has shown that the climate indicator ONI is the one which presented greater significance and spatial breadth to determine the rainfall anomalies in the studied area. The trend test (Mann-Kendall) and the climate indicators have shown that the studied area presents the predominant rise of the yearly rainfall amounts associated to the increase of the daily concentrated rainfall amount, which is indicative of climate changes in the studied area. The main breaks in the historic series happened in the 1990's, similarly to the other breaks that had been observed in the State of Paraná. The Climate Rhythmic Analysis has shown that during winter there is a predominance of cold fronts and the rainfall amounts are more spatially homogeneous, while during the summer it was observed larger spatial differences and atmospheric conditions more frequently associated to the extratropical atmospheric systems. The SCC has shown that humid climate types happen more frequently in Paranaguá, due to the oceanity and, in Castro and Curitiba, the typologies have indicated a greater frequency of the climate types associated to the extratropical atmospheric systems.

Keywords: Extreme Events. Atmospheric Dynamics. ENSO. Watershed. Climatic Trends. 


\section{LISTA DE FIGURAS}

Figura 1 - Localização das bacias hidrográficas do Alto Iguaçu, Litorânea e Ribeira Paraná.

Figura 2 - Registro fotográfico dos deslizamentos de encostas e inundações associadas às corridas de lama em Morretes (PR), decorrente do evento pluvial extremo do dia 11 de março de 2011. 28

Figura 3 - Registro fotográfico de alagamento no Parque do Barigui em Curitiba (PR) no dia 07 de julho de 2014.

Figura 4 - Esquema da estrutura geológica do relevo do Paraná. 1: sedimentos cenozóicos da Planície Costeira e Plataforma Continental; 2: sedimentos cenozóicos da Bacia de Curitiba; 3: Grupos Bauru e Caiuá (Cretáceo); 4: Bacia de Santos; 5: derrames de basalto da Formação Serra Geral; 6: unidades paleozóicas e mesozóicas da Bacia do Paraná; 7: Formação Furnas; 8: embasamento pré-cambriano. Cidades - PAR: Paranaguá; CTB: Curitiba; PGR: Ponta Grossa; GUA: Guarapuava. Escarpas: SM: Serra do Mar; ED: Escarpa Devoniana; SG: Serra Geral.

Figura 5 - Unidades litoestratigráficas das bacias hidrográficas do Alto Iguaçu, Ribeira e Litorânea - Paraná.

Figura 6 - Hipsometria (A) e classes de declividade (B), conforme as classes da Embrapa (1979), das bacias hidrográficas do Alto Iguaçu, Ribeira e Litorânea - Paraná. 35

Figura 7 - Climograma e classificação climática de Köppen (1948) para a estação meteorológica de Ponta Grossa - Paraná.

Figura 8 - Climograma e classificação climática de Köppen (1948) para as estações meteorológicas de Curitiba (a), Pinhais (b), Antonina (c), Guaraqueçaba (d) - Paraná. 38 Figura 9 - Climograma e a classificação climática de Köppen (1948) para as estações meteorológicas de Morretes (a), Paranaguá (b), Cerro Azul (c) e Castro (d) - Paraná. . 39 Figura 10 - Tipos de solos (A) e formações fitogeográficas originais (B) das bacias hidrográficas do Alto Iguaçu, Ribeira e Litorânea - Paraná.

Figura 11 - Divisão político-administrativa dos municípios inseridos nas bacias hidrográficas do Alto Iguaçu, Ribeira e Litorânea - Paraná.

Figura 12 - População total dos municípios inseridos nas bacias hidrográficas do Alto Iguaçu, Ribeira e Litorânea - Paraná........................................................................ 44

Figura 13 - Taxa de urbanização (\%) e Índice de Desenvolvimento Humano (IDH) para os municípios inseridos nas bacias hidrográficas do Alto Iguaçu, Ribeira e Litorânea Paraná..

Figura 14 - Participação (\%) dos setores da economia nos municípios inseridos nas bacias hidrográficas do Alto Iguaçu, Ribeira e Litorânea - Paraná.

Figura 15 - Organograma teórico-conceitual da composição e a abrangência da fundamentação teórica e metodológica. 46

Figura 16 - Esquema teórico da distribuição espacial das chuvas e o efeito orográfico na Estrada de Castelhanos, Ilha de São Sebastião, município de Ilha Bela - São Paulo..... 52 Figura 17 - Tipos climáticos segundo a classificação de Strahler (1951) e e a dinâmica atmosférica para o território brasileiro 58 
Figura 18 - Regiões dos Niños. 64

Figura 19 - Os componentes dos desastres naturais conforme Álcantara-Alaya (2001). 78

Figura 20 - Localização geográfica dos postos pluviométricos e estações meteorológicas situadas dentro e no entorno das bacias hidrográficas do Alto Iguaçu, Ribeira e Litorânea - Paraná...... 80

Figura 21 - Gráfico Normal Q-Q para os resíduos do modelo VAR para o grupo 3 do Alto do Iguaçu e o indicador ODP. 90

Figura 22 - Distribuição espacial da pluviosidade média anual (mm) para as bacias hidrográficas do Alto Iguaçu, Ribeira e Litorânea (PR) para o período de 1976 a 2015. 98

Figura 23 - Dispersão gráfica, coeficiente de determinação $\left(\mathrm{R}^{2}\right)$, correlação linear de Pearson (r), não significativo ao nível de 97,5\% pelo teste t de Student (**) entre a pluviosidade média anual $(\mathrm{mm})$ e a altitude (metros) dos postos pluviométricos e das estações meteorológicas inseridas na bacia hidrográfica do Alto Iguaçu - Paraná. ....... 98 Figura 24 - Dispersão gráfica, coeficiente de determinação $\left(\mathrm{R}^{2}\right)$, correlação linear de Pearson (r), não significativo ao nível de 97,5\% pelo teste t de Student (**) entre a pluviosidade média anual $(\mathrm{mm})$ e a altitude (metros) dos postos pluviométricos e das estações meteorológicas inseridas na bacia hidrográfica Litorânea - Paraná.

Figura 25 - Dispersão gráfica, coeficiente de determinação e correlação linear de Pearson, significativo ao nível de $97,5 \%$ pelo teste t de Student (*) entre a pluviosidade média anual $(\mathrm{mm})$ e a altitude (metros) dos postos pluviométricos e das estações meteorológicas inseridas na bacia hidrográfica do Ribeira - Paraná.

Figura 26 - Perfil esquemático da precipitação pluviométrica média anual (mm) e a altitude dos postos pluviométricos e estações meteorológicas das bacias hidrográficas Alto Iguaçu, Litorânea e Ribeira - Paraná.

Figura 27 - Distribuição média mensal da precipitação pluviométrica (mm) das bacias hidrográficas Alto Iguaçu, Litorânea e Ribeira - Paraná. 103

Figura 28 -Distribuição espacial da pluviosidade média mensal $(\mathrm{mm})$ para os meses de janeiro (A), fevereiro (B), março (C), outubro (D), novembro (E) e dezembro (F) para as bacias hidrográficas Alto Iguaçu, Ribeira e Litorânea - Paraná .... 104

Figura 29 - Distribuição espacial da pluviosidade média mensal (mm) para os meses de abril (A), maio (B), junho (C), julho (D), agosto (E) e setembro (F) para as bacias hidrográficas Alto Iguaçu, Ribeira e Litorânea - Paraná. 105

Figura 30 - Perfil esquemático da pluviosidade média mensal $(\mathrm{mm})$ para os meses de janeiro em (A - B) e agosto (C - D) e a altitude dos postos pluviométricos e. 106 Figura 31 - Dendograma para os postos pluviométricos da bacia hidrográfica Litorânea (PR) e respectivos grupos pluviométricos homogêneos. 107

Figura 32 - Dendograma para os postos pluviométricos da bacia hidrográfica do Alto Iguaçu (PR) e respectivos grupos pluviométricos homogêneos 108

Figura 33 - Dendograma para os postos pluviométricos da bacia hidrográfica do Ribeira (PR) e respectivos grupos pluviométricos homogêneos 108 
Figura 34 - Distribuição espacial dos grupos homogêneos e dos postos pluviométricos anômalos para as bacias hidrográficas do Alto Iguaçu, Ribeira e Litorânea - Paraná. 111 Figura 35 - Distribuição espacial dos grupos homogêneos $(\mathrm{GH})$ e dos postos pluviométricos anômalos (PA) pelo método Ward para as bacias hidrográficas do .... 112 Figura 36 - Precipitação pluviométrica média mensal dos grupos homogêneos $(\mathrm{GH})$ e do posto pluviométrico anômalo (PPA) das bacias hidrográficas Litorânea (BHL) e Alto Iguaçu (BHAI) - PR 113

Figura 37 - Precipitação pluviométrica média mensal dos grupos homogêneos $(\mathrm{GH})$ e do posto pluviométrico anômalo (PPA) das bacia hidrográfica do rio Ribeira (BHR) - PR. 114

Figura 38 - Distribuição anual da precipitação pluviométrica (mm) nas bacias hidrográficas Litorânea (BHL) e do Alto Iguaçu (BHAI) - PR................................... 116 Figura 39 - Distribuição anual da precipitação pluviométrica $(\mathrm{mm})$ na bacia hidrográfica do rio Ribeira - PR. 117

Figura 40 - Boxplots da pluviosidade diária $(\mathrm{mm})$ nos grupos homogêneos $(\mathrm{GH})$ da bacia hidrográfica Litorânea - PR.

Figura 41 - Classes dos quantis e o número de dias chuvosos em Antonina - ID 21 (GH I-A), Morretes - ID 31 (GH I-B), 123

Figura 42 - Boxplots da pluviosidade diária $(\mathrm{mm})$ nos grupos homogêneos $(\mathrm{GH})$ da bacia hidrográfica do rio Alto Iguaçu - PR.

Figura 43 - Classes dos quantis e o número de dias chuvosos em São Mateus do Sul - ID 13 (GH I), Quitandinha ID - 20 (GH II), Lapa - ID 03 (GH III) e Pinhais ID - 07 (GH VI) na bacia hidrográfica do Alto Iguaçu - PR.

Figura 44 - Boxplot da pluviosidade diária $(\mathrm{mm})$ do posto pluviométrico anômalo (PPA) da bacia hidrográfica do rio Alto Iguaçu - PR.

Figura 45 - Classes dos quantis e o número de dias chuvosos em Piraquara (Mananciais da Serra - PPA) na bacia hidrográfica do rio Alto Iguaçu - PR. 126

Figura 46 - Boxplots da pluviosidade diária $(\mathrm{mm})$ nos grupos homogêneos $(\mathrm{GH})$ e no posto pluviométrico anômalo (PPA) da bacia hidrográfica do rio Ribeira - PR.......... 128 Figura 47 - Classes dos quantis e o número de dias chuvosos em Cerro Azul - ID 51 (GH I), Tunas do Paraná - ID 58 (GH II), Ponta Grossa - ID 55 (GH III) e Doutor Ulysses ID 53 (PPA) na bacia hidrográfica do rio Ribeira - PR

Figura 48 - Média de silhuetas de cada observação dado o número de grupos para as bacias hidrográficas Litorânea (A), Alto Iguaçu (B) e Ribeira (C). Soma dos quadrados dentro dos grupos dado o número de grupos para as bacias hidrográficas Litorânea (D), Alto Iguaçu (E) e Ribeira (F) 131

Figura 49 - Análise de cluster $(\mathrm{GH})$ pelo método K-means para as bacias hidrográficas do Litorânea (A), Alto Iguaçu (B) e Ribeira (C) 132

Figura 50 - Distribuição espacial dos grupos homogêneos $(\mathrm{GH})$ pelo método K-means para as bacias hidrográficas do Alto Iguaçu, Ribeira e Litorânea - Paraná. 133 Figura 51 - Variabilidade pluviométrica anual (mm) e rupturas identificadas nas séries históricas de Mandirituba (ID 06), Antonina (ID 22), Guaraqueçaba (ID 27) e Paranaguá (ID 35) - Paraná. 
Figura 52 - Variabilidade pluviométrica anual (mm) e rupturas identificadas nas séries históricas de Adrianópolis (ID 37 e 39), Campina Grande do Sul (ID 42) e Cerro Azul (ID 48) - Paraná.

Figura 53 - Variabilidade pluviométrica anual $(\mathrm{mm})$ e rupturas identificadas nas séries históricas de Doutor Ulysses

Figura 54 - Precipitação pluviométrica máxima diária $(\mathrm{mm})$ e ruptura identificada na série histórica de Castro (ID 60) - Paraná. 164

Figura 55 - Precipitação máxima diária $(\mathrm{mm})$ e rupturas identificadas nas séries históricas de Curitiba (ID 02), São Mateus do Sul (ID 12), Palmeira (ID 62) e Guaraqueçaba (ID 27) - Paraná. 165

Figura 56 - Precipitação máxima diária $(\mathrm{mm})$ e rupturas identificadas nas séries históricas de Morretes (ID 33), Campina Grande do Sul (ID 42), Cerro Azul (ID 48) e Doutor Ulysses (ID 52) - Paraná. 166

Figura 57 - Registros de chuvas fortes (R95p) e ruptura identificada na série histórica de Guaratuba (ID29) - Paraná. 171

Figura 58 - Registros de chuvas fortes (R95p) e rupturas identificadas nas séries históricas de São Mateus do Sul (ID 12 e ID 14), São José do Triunfo (ID 15) e Quitandinha (ID 19) - Paraná.

Figura 59 - Registros de chuvas fortes (R95p) e rupturas identificadas na série histórica de Guaraqueçaba (ID27) e Morretes (ID 33) - Paraná. 173

Figura 60 - Registros de chuvas muito fortes (R99p) e ruptura identificada na série histórica de Guaratuba (ID29) - Paraná. 175

Figura 61 - Registros de chuvas muito fortes (R99p) e rupturas identificadas nas séries históricas de Mandirituba (ID 06), Antonina (ID 21), Campina Grande do Sul (ID 41) e Ponta Grossa (ID 55) - Paraná. 176

Figura 62 - Registros de chuvas muito fortes (R99p) e rupturas identificadas na série histórica de Antonina (ID 22) e Campo Largo (ID 45) - Paraná.

Figura 63 - Tendências da precipitação pluviométrica total anual (PRCPTOT) nas BH do Alto Iguaçu (AI), Litorânea (L) e Ribeira (R) - Paraná. 184

Figura 64 - Tendências da precipitação pluviométrica máxima diária anual (RX1day) nas BH do Alto Iguaçu (AI), Litorânea (L) e Ribeira (R) - Paraná. 186

Figura 65 - Tendências da precipitação pluviométrica máxima anual em cinco dias consecutivos (RX5day) nas BH do Alto Iguaçu (AI), Litorânea (L) e Ribeira (R) - Paraná.

Figura 66 - Tendências da precipitação pluviométrica diária superior a 95\% dos percentis dos quantis (R95p) nas BH do Alto Iguaçu (AI), Litorânea (L) e Ribeira (R) - Paraná. 191

Figura 67 - Tendências da precipitação pluviométrica diária superior a 99\% dos percentis dos quantis (R99p) nas BH do Alto Iguaçu (AI), Litorânea (L) e Ribeira (R) - Paraná.

Figura 68 - Boxplot da chuva diária (mm) para Castro (a), Curitiba (b) e Paranaguá (c). 194 
Figura 69 - Classes de quantis e o número de registros de dias chuvosos em Castro(a), Curitiba (b) e Paranaguá (c).

Figura 70 - Variabilidade mensal das chuvas diárias (mm) em Castro (a), Curitiba (b) e Paranaguá (c) - Paraná.

Figura 71 - Registro de chuva máxima diária mensal (mm) em Castro, Curitiba e Paranaguá - Paraná. 202

Figura 72 - Agrupamento das chuvas diárias superiores a 99\% dos quantis e a identificação da ocorrência dos maiores totais pluviais diários em Castro (ID 59) - Paraná.

Figura 73 - Agrupamento das chuvas diárias superiores a 99\% dos quantis e a identificação da ocorrência dos maiores totais pluviais diários em Curitiba (ID 02) e Paranaguá (ID 35) - Paraná 203

Figura 74 - Valores do teste Run na escala anual das chuvas diárias para a área de estudo. 205

Figura 75 - Boxplot das chuvas diárias $(\mathrm{mm})$ dos anos abaixo ou acima dos limites críticos de Z para Castro (a), Curitiba (b) e Paranaguá (c) - Paraná..... 206

Figura 76 - Análise rítmica climática do evento pluvial de maio de 2005 em Castro Paraná.

Figura 77 - Cartas sinóticas da América do Sul entre os dias 21 e 26 de maio de 2005.

Figura 78 - Análise rítmica climática do evento pluvial de agosto de 2011 em Castro Paraná.

Figura 79 - Cartas sinóticas da América do Sul entre os dias 29 de julho e 03 de agosto de 2011.

Figura 80 - Análise rítmica climática do evento pluvial de junho de 2012 em Curitiba Paraná.

Figura 81 - Análise rítmica climática do evento pluvial de junho de 2012 em Paranaguá - Paraná.

Figura 82 - Cartas sinóticas da América do Sul entre os dias 03 e 08 de junho de 2012. 220

Figura 83 - Análise rítmica climática do evento pluvial de junho de 2013 em Curitiba Paraná.

Figura 84 - Cartas sinóticas da América do Sul entre os dias 18 e 23 de junho de 2013.

Figura 85 - Análise rítmica climática do evento pluvial de dezembro de 2014 em Castro

- Paraná.

Figura 86 - Cartas sinóticas da América do Sul entre os dias 22 e 27 de dezembro de 2014. 230

Figura 87 - Análise rítmica climática do evento pluvial de dezembro de 2010 em Curitiba - Paraná. 231

Figura 88 - Cartas sinóticas da América do Sul entre os dias 10 e 15 de dezembro de 2010. 
Figura 89 - Análise rítmica climática do evento pluvial de janeiro de 2004 em Paranaguá - Paraná......

Figura 90 - Cartas sinóticas da América do Sul entre os dias 22 e 27 de janeiro de 2004.

Figura 91 - Análise rítmica climática do evento pluvial de março de 2011 em Paranaguá - Paraná......

Figura 92 - Cartas sinóticas da América do Sul entre os dias 09 e 14 de março de 2011. 236

Figura 93 - Frequência decendial (\%) dos tipos de tempo conforme o método SSC para o período de 2007 a 2015 em Castro (A) e Curitiba (B), Paraná.

Figura 94 - Frequência decendial (\%) dos tipos de tempo conforme o método SSC.. 248 Figura 95 - Gênese pluvial (A) e tipos de tempo (B) em Castro, Paraná, entre 2007 e 2015. 250

Figura 96 - Gênese pluvial (A) e tipos de tempo (B) em Curitiba, Paraná, entre 2007 e 2015. 252

Figura 97 - Gênese pluvial (A) e tipos de tempo (B) em Paranaguá, Paraná, entre 2007 e 2015 . 254

\section{LISTA DE TABELAS}

Tabela 1 - Pluviosidade média mensal e anual ( $\mathrm{mm}$ ) para as bacias hidrográficas e seus respectivos grupos homogêneos e postos pluviométricos anômalos.

Tabela 2 - Estatística descritiva dos grupos homogêneos das BH`s conforme o método de K-means.

Tabela 3 - Aplicação do modelo auto regressivo vetorial (VAR) para o IOS e respectivos lag's

Tabela 4 - Aplicação do modelo auto regressivo vetorial (VAR) para o ONI e respectivos lag's

Tabela 5 - Aplicação do modelo auto regressivo vetorial (VAR) para a ODP e respectivos lag's

Tabela 6 - Aplicação do modelo auto regressivo vetorial (VAR) para o GMAT e respectivos lag's 144

Tabela 7 - Síntese da aplicação do modelo auto regressivo vetorial (VAR), destacandose a relação significativa entre os indicadores climáticos oceânicos e os atrasos (Lag) com significância estatística.

Tabela 8 - Aplicação do teste Box-Pierce para resíduos do modelo VAR para os grupos homogêneos $(\mathrm{GH})$ das bacias hidrográficas $(\mathrm{BH})$ em conformidade ao indicador climático oceânico. 146

Tabela 9 - Coeficientes de correlação e níveis de significância entre as séries de anomalias de precipitação pluviométrica e as anomalias de temperatura de superfície do mar.

Tabela 10 - Testes de tendências (Mann-Kendall) e rupturas (Pettitt) para a precipitação pluviométrica total anual (mm) na BH do Alto Iguaçu - Paraná. 155 
Tabela 11 - Testes de tendências (Mann-Kendall) e rupturas (Pettitt) para a precipitação pluviométrica total anual (mm) na BH Litorânea - Paraná.

Tabela 12 - Testes de tendências (Mann-Kendall) e rupturas (Pettitt) para a precipitação pluviométrica total anual $(\mathrm{mm})$ na BH do rio Ribeira - Paraná. 156

Tabela 13 - Testes de tendências (Mann-Kendall) e rupturas (Pettitt) para a precipitação pluviométrica diária máxima anual $(\mathrm{mm})$ na $\mathrm{BH}$ do Alto Iguaçu - Paraná. 163

Tabela 14 - Testes de tendência (Mann-Kendall) e rupturas (Pettitt) para a precipitação pluviométrica diária máxima anual $(\mathrm{mm})$ na BH Litorânea - Paraná.

Tabela 15 - Testes de tendências (Mann-Kendall) e rupturas (Pettitt) para a precipitação pluviométrica diária máxima anual $(\mathrm{mm})$ na $\mathrm{BH}$ do rio Ribeira - Paraná..... 164 Tabela 16 - Testes de tendências (Mann-Kendall) e rupturas (Pettitt) para a precipitação pluviométrica diária superior a 95\% dos quantis na BH do Alto Iguaçu - Paraná ........ 170 Tabela 17 - Testes de tendências (Mann-Kendall) e rupturas (Pettitt) para a precipitação pluviométrica diária superior a 95\% dos quantis na BH Litorânea - Paraná. 170

Tabela 18 - Testes de tendências (Mann-Kendall) e rupturas (Pettitt) para a precipitação pluviométrica diária superior a 95\% dos quantis para a BH do rio Ribeira - Paraná... 171 Tabela 19 - Testes de tendências (Mann-Kendall) e rupturas (Pettitt) para a precipitação 174

Tabela 20 - Testes de tendências (Mann-Kendall) e rupturas (Pettitt) para a precipitação pluviométrica diária superior a 99\% dos quantis para a BH do Alto Iguaçu - Paraná. 174 Tabela 21 - Testes de tendências (Mann-Kendall) e rupturas (Pettitt) para a precipitação pluviométrica diária superior a 99\% dos quantis na BH Litorânea - Paraná. 175 Tabela 22 - Indicadores de tendências da precipitação pluviométrica na BH do Alto Iguaçu - Paraná.

Tabela 23 - Indicadores de tendências da precipitação pluviométrica na BH Litorânea Paraná.

Tabela 24 - Indicadores de tendências da precipitação pluviométrica na BH do rio Ribeira - Paraná.

Tabela 25 - Mudanças e rupturas da intensidade da precipitação pluviométrica diária em acordo com o teste Mann-Kendall e o teste de ruptura de Pettit. 208

Tabela 26 - Totais pluviométricos acumulados ( $\mathrm{mm}$ ) durante os eventos extremos e nos dois dias anteriores e posteriores a sua ocorrência em estações meteorológicas do IAPAR, INMET e SIMEPAR. 239

\section{LISTA DE QUADROS}

Quadro 1 - Informações referentes aos postos pluviométricos e estações meteorológicas localizadas dentro e no entorno das bacias hidrográficas $(\mathrm{BH})$ do Alto Iguaçu, Ribeira e Litorânea - Paraná. 80

Quadro 2 - Categorias de tipos de tempo (weather-types) classificados através do método SSC. .. 88

Quadro 3 - Classificação do teste Mann-Kendall $\left(Z_{M K}\right)$ com o intervalo de $95 \%$ de

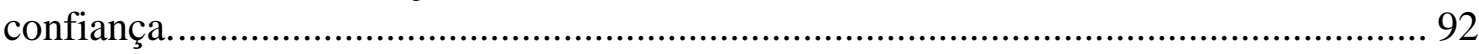
Quadro 4 - Definição e unidade dos indicadores de extremos climáticos analisados no trabalho. 


\section{SUMÁRIO}

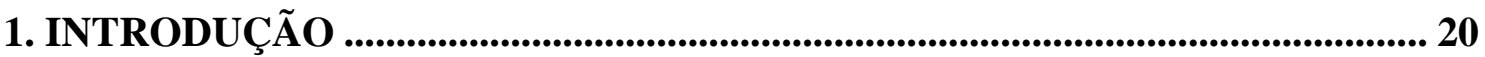

2. JUSTIFICATIVAS E A ÁREA DE ESTUDO …............................................. 24

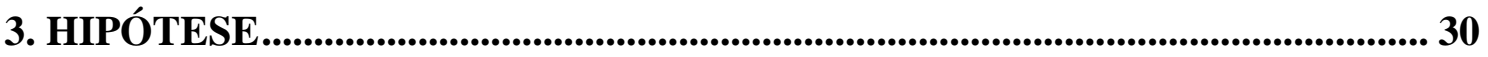

4. OBJETIVOS ……...................................................................................................... 31

5. CARACTERIZAÇÃO DA ÁREA DE ESTUDO ............................................... 32

5.1 Caracterização dos aspectos físicos ........................................................................ 32

5.2 Caracterização histórica e socioeconômica .......................................................... 42

6. FUNDAMENTAÇÃO TEÓRICA E METODOLÓGICA....................................... 46

6.1 A análise climática em bacias hidrográficas......................................................... 46

6.2 O efeito orográfico, a maritimidade e a variabilidade pluviométrica............. 49

6.3 Variabilidade pluviométrica e a dinâmica atmosférica regional....................... 57

6.4 Os índices climáticos oceânicos e a dinâmica atmosférica do Brasil Meridional 62

6.5 Eventos pluviométricos extremos e riscos socioambientais ................................ 68

7. PROCEDIMENTOS METODOLÓGICOS E TÉCNICOS .................................. 80

7.1 Obtenção de dados, preenchimento de falhas e estatística descritiva ............. 80

7.2 As técnicas de agrupamento e a regionalização das chuvas................................ 83

7.3 Os eventos pluviais extremos, a Análise Rítmica em Climatologia e a Spatial Synoptic Classification ........................................................................................... 85

7.4 As anomalias de pluviosidade, os indicadores climáticos oceânicos e a modelagem estatística ................................................................................................... 89

7.5. Os testes estatísticos e os indicadores climáticos de tendências....................... 91

7.6 Forma de análise de resultados e produção cartográfica.................................... 95

8. RESULTADOS E DISCUSSÕES ....................................................................96

8.1 Análise da distribuição espacial da precipitação pluviométrica ............................ 96

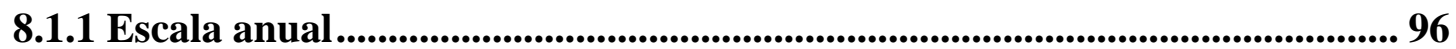

8.1.2 Escala mensal ....................................................................................... 102

8.2 Análise espaço-temporal pluviométrica.................................................................. 107

8.2.1 Análise de agrupamento via método Ward ...................................................... 107

8.2.2 Frequência e intensidade pluviométrica diária.............................................. 118

8.3. Variabilidade temporal pluviométrica e os indicadores climáticos oceânicos 130

8.3.1 Análise de agrupamento via método K-means............................................... 130 
8.3.2 As anomalias pluviais e os indicadores climáticos oceânicos ...................... 138

8.4. Tendências, rupturas e indicadores pluviométricos ......................................... 150

8.4.1 Tendências e rupturas da precipitação pluviométrica anual........................ 150

8.4.2 Tendências e rupturas da precipitação pluviométrica máxima anual...... 160

8.4.3 Tendências e rupturas de chuvas fortes (R95p) e chuvas muito fortes (R99p)

8.4.4. Indicadores de tendências da precipitação pluviométrica .......................... 178

8.5. As chuvas diárias em Castro, Curitiba e Paranaguá ...................................... 193

8.5.1 Frequência e intensidade das chuvas diárias ................................................... 193

8.5.2 Estatística exploratória, tendências e rupturas.............................................. 204

8.6 Avaliação das condições atmosféricas associadas aos eventos pluviais extremos 209

8.7 Gênese pluvial e a "Spatial Synoptic Classification" ............................................ 245

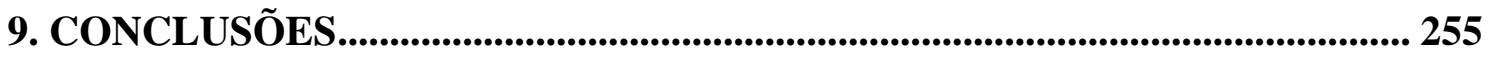

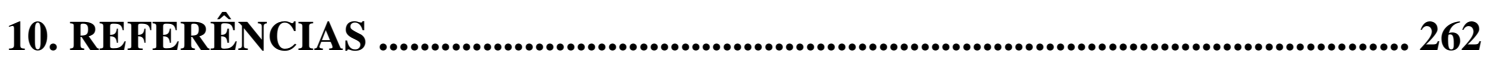

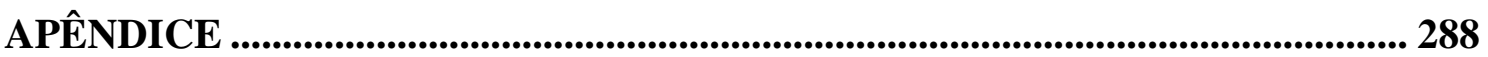




\section{INTRODUÇÃO}

A presente tese investiga a variabilidade das chuvas e os eventos pluviométricos extremos diários em bacias hidrográficas do leste do estado do Paraná, região na qual a complexidade climática será explorada sistematicamente ao longo desta pesquisa. Como uma premissa base desta tese, os estudos sobre a variabilidade pluviométrica possibilitam identificar padrões espaço-temporais que servem como subsídio para o planejamento e desenvolvimento de diversos segmentos econômico, social e territorial. Destacadamente, o conhecimento da magnitude e frequência dos eventos pluviométricos extremos permite compreender amplamente a variabilidade pluvial para além das normais climatológicas e subsidiar os mais diversos setores econômicos e sociais, como a agricultura, a engenharia civil, a defesa civil, a geração de energia elétrica, entre outros (SILVA; CLARKE, 2004).

Neste contexto, a variabilidade climática corresponde "a maneira pela qual os parâmetros climáticos variam no interior de um determinado período" (TAVARES, 2001, p.15) e, segundo Ribeiro (1996), é uma característica própria aos fenômenos climáticos, pois nenhum deles atua isoladamente e são resultantes das interações entre si e com o meio geográfico, consolidando uma de suas principais atribuições que é a espacialidade. Denominam-se como eventos climáticos extremos os registros excepcionais dos atributos climáticos ocorrentes em uma determinada localidade e período, designado conforme os critérios estabelecidos para reconhecê-los e ressaltá-los como anômalos em relação às normais climatológicas, destacando-se sua relevância de análise e estudo, "uma vez que estes episódios são os que em realidade, repercutem no espaço/território, provocando desarranjos em seu interior"' (SANT'ANNA NETO, 2008, p.54).

A precipitação pluviométrica ${ }^{1}$ corresponde ao atributo ou componente climático de maior importância em regiões de clima tropical porque a energia térmica nos trópicos é superavitária devido à baixa amplitude térmica, e por sua elevada interação com os componentes da dinâmica ambiental. Pereira et al. (2002) menciona que nos países tropicais, a precipitação pluvial corresponde a forma principal pela qual a água retorna da atmosfera para a superfície terrestre após os processos de evaporação e condensação, completando e sistematizando o ciclo hidrológico. Silva (2004), Hoyos et al. (2005) e Panagos et al. (2017) discorrem que em países de predominância dos climas tropicais

\footnotetext{
${ }^{1} \mathrm{O}$ termo "precipitação" é utilizado para designar qualquer forma de deposição líquida ou sólida e derivada da atmosfera e, segundo Ayoade (2002), o termo precipitação pluvial é sinônimo de precipitação nos trópicos, pois se verifica a inexistência de neve, com exceção de montanhas altas como o Kilimanjaro na África Ocidental ou a Cordilheira dos Andes na América do Sul.
} 
como o Brasil a precipitação pluviométrica é o principal atributo climático e, devido a elevada quantidade, é responsável pelo elevado potencial erosivo das chuvas, principalmente devido ao inerente regime de concentração de chuvas no verão. Uma das principais problemáticas em países tropicais, a erosividade corresponde ao potencial das chuvas em causar erosão (OLIVEIRA et al., 2012) e está diretamente relacionada com a quantidade de energia cinética e intensidade da chuva gerada em determinada porção de solo. Portanto, conhecer as características físicas das chuvas (intensidade, frequência e duração) é essencial para determinar os setores e os períodos de maior susceptibilidade a erosividade, um dos agentes ativos dentre os fatores componentes da Equação Universal de Perda de Solos (WISCHMEIER; SMITH, 1978), especialmente o suporte às práticas de uso e conservação dos solos em bacias hidrográficas (ZHANG et al., 2005; MA et al., 2012; SOUZA; GASPARETTO, 2012).

Portanto, os elevados totais das chuvas é uma das principais características do clima tropical (LYRA et al., 2014) e, entretanto, a distribuição dos totais de pluviosidade em escalas temporais e espaciais ocorrem em diferentes ritmos nas distintas localidades, o que se atribui aos fatores que geram as chuvas. Conforme explicam Vianello e Alves (1991), as variações climáticas não se dão somente pelos cinturões latitudinais, mas são atingidas pela distribuição espacial da circulação geral da atmosfera e pela configuração dos oceanos e dos continentes. Contudo, ressalta-se que preponderante frente à orografia e à maritimidade, a circulação atmosférica apresenta um escoamento em forma de ondas (estacionárias e não estacionárias), o que junto aos atributos climáticos destacados acima determinam o padrão de áreas com as maiores e menores precipitações da Terra.

Um dos atributos de investigação desta pesquisa e de maior relevância para o entendimento da distribuição espacial da precipitação pluviométrica, o efeito orográfico é comumente definido como a atribuição da morfologia do relevo na interação com a dinâmica atmosférica de uma determinada localidade. A chuva de origem orográfica tem a sua gênese na ascensão da parcela de ar úmido e quente sobre a rugosidade do relevo, na perda de temperatura nos níveis mais elevados (processo adiabático), pela saturação da quantidade de vapor d'água numa parcela de ar e na formação de nebulosidade, sendo que a continuidade do processo de ascensão ocasiona maiores totais de chuvas na encosta denominada de barlavento. Inversamente, ao transpor a barreira orográfica, o fluxo de ar torna-se descendente e, com a perda do conteúdo higrométrico, a vertente situada no reverso da orografia caracteriza-se pelos menores totais de pluviosidade, denominada de sotavento (MILANESI; GALVANI, 2011). 
Especialmente, esta pesquisa versa sobre a influência orográfica da Serra do Mar para a distribuição das chuvas em bacias hidrográficas da região leste paranaense. Os estudos acerca do desempenho orográfico para a distribuição das chuvas em bacias hidrográficas são de alta relevância, pois a orografia é um importante fator atuante na dinâmica dos elementos constituintes do clima, de forma a intensificar ou reduzir os totais de pluviosidade (CANDIDO; NUNES, 2008). O conhecimento das características do relevo e sua relação com a distribuição espacial da ocorrência de chuvas intensas, responsáveis direta ou indiretamente por impactos socioambientais decorrentes, permite subsidiar a gestão e o manejo de bacias hidrográficas com a identificação de setores mais susceptíveis à ocorrência de eventos pluviais extremos (ARAÚJO et al., 2008; CUNHA et al., 2014).

Outro importante fator de geração das chuvas é a maritimidade. Usualmente, a proximidade das terras continentais com os oceanos influencia na geração de maiores alturas pluviométricas para as zonas litorâneas, mormente naquelas mais próximas às correntes marítimas quentes. Em regiões de clima tropical, as elevadas temperaturas e o elevado conteúdo de umidade advindos do oceano para o continente são responsáveis pela constante formação de chuvas convectivas, marcadas pela intensidade e pelos maiores valores históricos de pluviosidade do globo terrestre (PELL et al., 2007; PANAGOS et al., 2017). As regiões próximas as correntes mais frias são aquelas que estão associadas às menores taxas anuais de precipitação pluvial, o que se deve a redução significativa do potencial de formação das chuvas e coincidem com as regiões desérticas ou semiáridas.

Segundo Cavalcante e Ambrizzi (2009) e Silva e Silva (2012), dentre os elementos climáticos que influenciam a variabilidade da atmosfera, a temperatura de superfície do mar e suas anomalias apresentam elevada associação com a variabilidade climática da atmosfera devido à capacidade térmica e das águas oceânicas. Dentre as anomalias de temperatura de superfície do mar (TSM), o El Niño-Oscilação Sul (ENOS) é o principal fenômeno atmosférico de grande escala responsável pela variabilidade interanual de pluviosidade para o Sul do Brasil e que determina as principais anomalias pluviométricas anuais em relação às normais climatológicas (GRIMM et al., 1998; GRIMM et al., 2000; NERY; CARFAN, 2014). Devido à relevância da atuação do Oceano Atlântico na dinâmica atmosférica do território brasileiro, Limberger (2016) aponta esta anomalia de TSM como a principal teleconexão influente na alteração do regime de chuvas no Brasil e, no entanto, há uma carência de estudo que abordam a importância desta teleconexão com a variabilidade pluviométrica na região Sul do Brasil. 
Amplamente utilizada, as normais climatológicas apresentam de forma sintética e superficial as características climáticas de uma região, ocultando e/ou mascarando as excepcionalidades dos atributos climáticos. Partindo do conceito de Sorre (1951), de que o clima corresponde à sucessão habitual de estados atmosféricos em um dado lugar, a utilização das normais climatológicas desconsideram as amplitudes dos elementos climáticos, que são os eventos climáticos que ocasionam os maiores impactos na dinâmica ambiental e em diferentes segmentos da sociedade. Neste contexto, as chuvas intensas se destacam pela constante ocorrência em regiões de clima Tropical e repercutem em avarias ambientais, sociais e econômicas.

Sant'Anna Neto (1998) discorre sobre as limitações do enfoque quantitativo da análise espaço-temporal dos elementos climáticos, que apesar de representar um viés importante na tentativa de compreensão dos fenômenos, estão longe de responder as indagações inerentes à Climatologia Geográfica. Reconhecendo as limitações e rigidez dos métodos quantitativos amplamente utilizados nesta tese de doutoramento, buscou-se a incorporação a esta pesquisa da fundamentação teórica na Climatologia Dinâmica, por entender-se que o caráter dinâmico e genético dos tipos de tempo auxilia no entendimento dos processos formadores dos sistemas geográficos, tanto naturais quanto antrópicos, e que junto aos registros das estações meteorológicas, possibilitam identificar os climas predominantes, suas flutuações, variações e variabilidades.

Dos atributos físicos, o clima é de fundamental importância na análise ambiental de uma bacia hidrográfica, pois influencia os demais componentes ambientais e controla o processo de entrada e saída de energia nesta unidade de estudo (SANTOS; ARAÚJO, 2013). Ainda, a adoção do recorte espacial das bacias hidrográficas para a avaliação da ocorrência dos eventos pluviométricos extremos se atribui, sobretudo, às características de estrutura, organização e funcionamento desta unidade de análise ambiental, conforme discorrem Dickel e Godoy (2016). Seguindo esta perspectiva, a análise climática desta pesquisa almeja atender às demandas da gestão e do planejamento ambiental e territorial, partindo das ideias difundidas por Monteiro (1991) para a compreensão do desempenho do clima enquanto um fenômeno geográfico.

Tendo como base estas premissas, a presente tese integra o projeto intitulado "Análise integrada em bacias hidrográficas: estudos comparativos com distintos usos e ocupação do solo", financiado pela Coordenação de Aperfeiçoamento de Pessoal de Nível Superior e desenvolvido e coordenado pelo Laboratório de Climatologia e Biogeografia da Universidade de São Paulo junto a Universidade Federal de Goiás (Campus Jataí) e a 
Universidade Federal de Santa Maria. Espera-se que esta pesquisa possibilite subsidiar a compreensão da interação dos atributos climáticos descritos acima e as atividades dos setores sociais e econômicos da sociedade, especialmente para a prevenção de riscos decorrentes dos eventos extremos pluviais.

\section{JUSTIFICATIVAS E A ÁREA DE ESTUDO}

O conhecimento sobre as características do regime pluviométrico contribui para a tomada de decisões em áreas estratégicas para o desenvolvimento econômico e social, como por exemplo, a geração de energia elétrica, a defesa civil, em atividades industriais e no planejamento agrícola (QUEIROZ et al., 2001). Smit et al. (2000) descrevem que a variabilidade pluviométrica consiste nas variações em relação ao estado médio, seja mensurada pelos desvios estatísticos ou pelos eventos extremos, que podem ser atribuídos aos processos internos naturais do sistema climático ou às modificações antropogênicas. Nesta perspectiva, compreender a ocorrência dos eventos pluviométricos extremos e as condições atmosféricas associadas são de suma importância para diversos âmbitos de interesse à Climatologia e para a predição de perdas humanas e materiais (MARCELINO et al., 2006; SILVA et al., 2010).

A área selecionada para o presente estudo corresponde às bacias hidrográficas do Alto Iguaçu, Ribeira e Litorânea, situadas no setor leste do estado do Paraná, entre os meridianos $48^{\circ} \mathrm{W}$ e $50^{\circ} \mathrm{W}$ e os paralelos $24^{\circ} \mathrm{S}$ e $26^{\circ} \mathrm{S}$, e apresentam, respectivamente, a abrangência de $10.261 \mathrm{~km}^{2}, 9.736 \mathrm{~km}^{2}$ e $5.630 \mathrm{~km}^{2}$ (ITCG, 2015), conforme mostra a Figura 1. Conforme Grimm (2009), na costa leste da região Sul, principalmente no litoral do Paraná, há significativa contribuição do efeito orográfico para a ocorrência de maiores totais pluviométricos, uma vez que os ventos em superfície divergem da Alta Subtropical do Atlântico Sul perpendicularmente à costa, e são forçados a ascender pela presença da Serra do Mar, próxima ao Litoral, favorecendo as condições de formação e geração de chuvas.

A afirmação citada acima parte de diversos trabalhos que destacam a influência orográfica da Serra do Mar na distribuição espacial da pluviosidade. Dentre os mais recentes estudos, Pellegatti e Galvani (2010) evidenciaram que a Serra do Mar, ao longo do litoral paulista, em sua vertente a barlavento, apresenta totais pluviométricos anuais que estão entre os mais elevados do Brasil, superiores a $3.000 \mathrm{~mm}$, ao passo que a vertente situada a sotavento caracteriza-se por uma pluviosidade de aproximadamente $1.500 \mathrm{~mm}$, 
demonstrando a importância das elevações e da orientação do relevo frente à atuação dos sistemas atmosféricos e o efeito da maritimidade para o aumento nos totais pluviais, como também foi observado por Nunes e Modesto (1992), Sant'Anna Neto (1994) e Milanesi e Galvani (2011) para a Zona Costeira Paulista.

Araki e Nunes (2008), Nunes (2008) e Koga - Vicente e Nunes (2011) destacam que o efeito da maritimidade e os eventos diários de elevada pluviosidade associados às condições de litologia, topografia e de elevada impermeabilização do solo em áreas urbanas, são os grandes responsáveis pelos impactos socioambientais no Litoral Paulista. Seluchi et al. (2011) destacam que este padrão se repete para os demais setores da Serra do Mar ao longo do território brasileiro, principalmente por compreender a região mais densamente povoada do território brasileiro por abrigar importantes cidades, portos, indústrias e vias de comunicação, e que apresenta vulnerabilidade aos movimentos de massa e às perdas econômicas, humanas e sociais devido às frequentes chuvas intensas, que ocorrem principalmente no período de verão com a condição persistente da Zona de Convergência do Atlântico Sul (CARVALHO et al., 2002; SELUCHI; CHOU, 2009) e dos demais mecanismos das chuvas de monções na América do Sul (REBOITA et al., 2010).

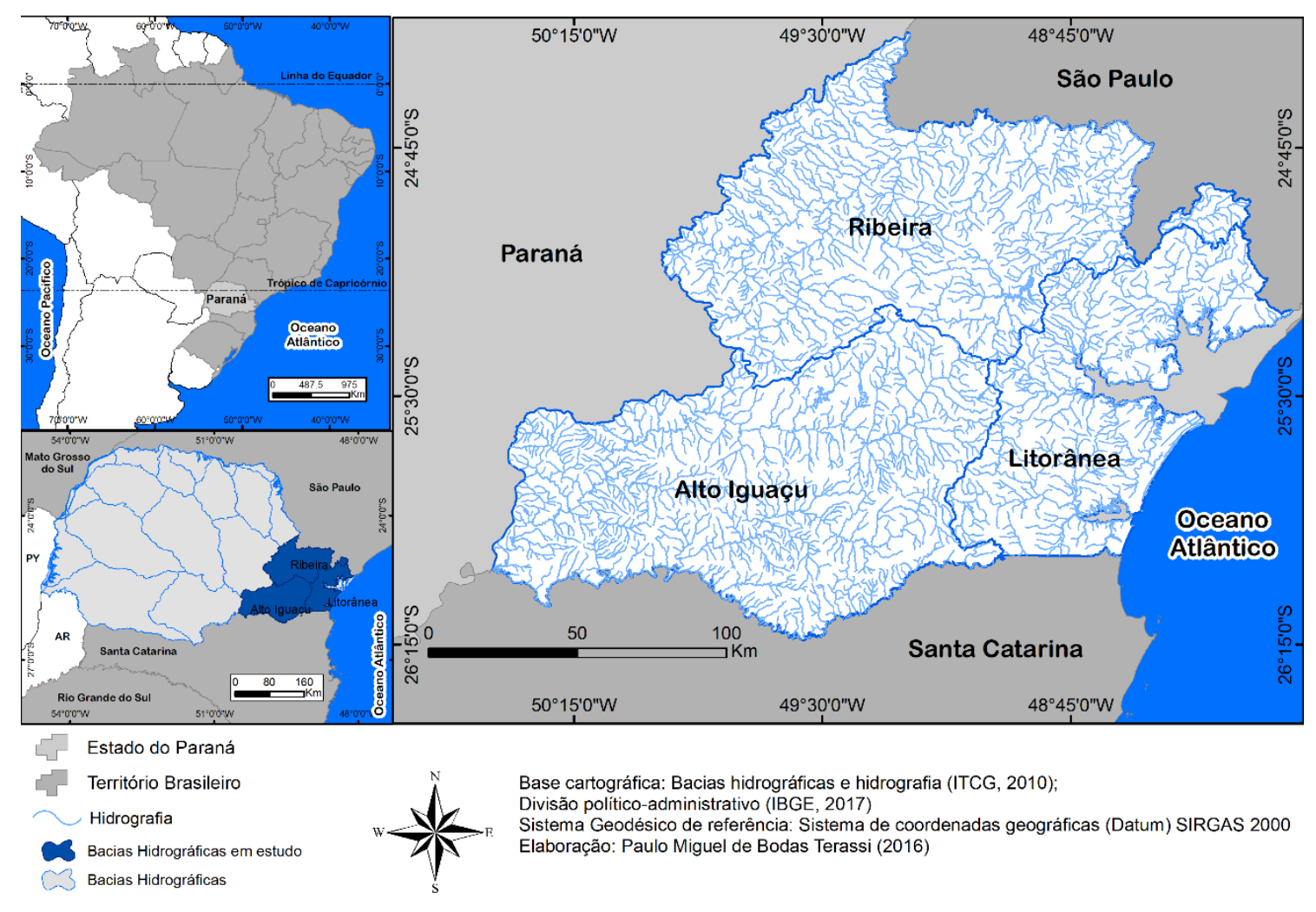

Figura 1 - Localização das bacias hidrográficas do Alto Iguaçu, Litorânea e Ribeira - Paraná. 
Segundo Jorge e Mendonça (2008), o Litoral do Paraná apresenta os maiores totais pluviométricos do estado, com valores médios anuais superiores a $3.000 \mathrm{~mm}$, demarcados pelo máximo de chuvas no período do verão, devido à atuação máxima da massa Tropical Atlântica e da Zona de Convergência do Atlântico Sul (ZCAS) durante esse período (REBOITA et al., 2010; AMBRIZZI; FERRAZ, 2015; QUADRO et al., 2016; MELLO et al., 2017). Inversamente, a bacia hidrográfica do rio Ribeira caracteriza-se por uma das menores alturas pluviométricas médias do território paranaense, com médias pluviométricas anuais entre 1.200 a $1.400 \mathrm{~mm}$, por localiza-se na região a sotavento da Serra do Mar, e com um regime de chuvas de concentração no período de verão e significativa redução no inverno. Por sua vez, verifica-se na região do Alto Iguaçu uma pluviosidade média anual entre 1.500 a 1.700 mm e uma distribuição homogênea dos totais mensais, características mais próximas ao clima subtropical do Brasil Meridional (NERY et al., 2002; MAACK, 2012; FRITZSONS et al., 2011; SILVA et al., 2015).

Um dos fenômenos que controlam diretamente a variabilidade interanual da pluviosidade para o recorte de estudo é o ENOS, conforme apontam Grimm et al. (2000), Grimm (2003), Nery et al. (2005), Cavalcanti e Ambrizzi (2009) e Nascimento e Sant'Anna Neto (2016). Os estudos mais recentes de Nery e Carfan (2014) indicaram que as maiores alterações de pluviosidade para a região Sul do Brasil estiveram relacionadas com a fase quente (El Niño), com um aumento significativo de pluviosidade, e com a fase fria (La Niña), períodos nos quais são verificadas as maiores reduções pluviométricas. Grimm e Tedeschi (2009) discorrem que as alterações mensais de pluviosidade mais significativas estão relacionadas à ocorrência do fenômeno ENOS e, mormente, destacam que as maiores mudanças estão relacionadas aos eventos pluviais extremos diários.

Para além das normais climatológicas, ressalta-se que dentre os aspectos mais relevantes dos estudos sobre a pluviosidade estão às ocorrências de eventos extremos diários de pluviosidade nas regiões tropicais e subtropicais, responsáveis por enchentes, inundações, escorregamentos de encostas, erosões e perdas de solos agricultáveis e, consequentemente, inúmeras perdas humanas e materiais (VALVERDE; MARENGO, 2014; SEPÚLVEDA; PETLEY, 2015; SILVA et al., 2015; SOUSA et al., 2016).

A questão da ocorrência dos eventos de pluviosidade extrema no Litoral do Paraná trata-se de uma problemática constante, dado a influência da maritimidade para a geração de chuvas intensas, refletida em significativas perdas humanas e materiais (TONETTI et al., 2013). Barros et al. (2015) destacam a ocorrência de inundações e deslizamentos nos 
municípios de Antonina, Guaratuba, Morretes e Paranaguá durante os episódios de pluviosidade extrema que ocorreram em março de 2011. Segundo os dados da Defesa Civil, foram registradas quatro mortes e 221 feridos, mais de dois mil desabrigados e os prejuízos de mais de 100 milhões de reais, devido às destruições em pontes, ruas, estradas, casas, além das perdas agrícolas, agravantes que fizeram com que o Governo Estadual decretasse Estado de Calamidade Pública para os municípios de Antonina e Morretes (PARANÁ, 2016).

Silveira et al. (2014) descreve que no dia 11 de março de 2011 ocorreu na Serra do Mar paranaense um conjunto de escorregamentos associados a um volume de $321 \mathrm{~mm}$ em 24 horas observada na estação meteorológica de Morretes, tendo como consequência prejuízos como a destruição parcial ou total de casas, ruas, estradas, pontes e lavouras. Observaram que a Serra do Mar em território paranaense está naturalmente exposta à alta susceptibilidade de processos de deslizamentos, corridas de detritos e inundações associadas às corridas de lama durante a ocorrência de elevados totais pluviométricos concentrados, típicos para o período do verão e que, entretanto, segundo o Boletim de Monitoramento e Análise Climática (CLIMANÁLISE, 2016) foram acima da média para este episódio extremo devido a elevada advecção da vorticidade ciclônica de leste, que transportou elevado volume de umidade do oceano para o continente, durante a ocorrência desta instabilidade tropical (Figura 2).

A compartimentação geomorfológica realizada por Oka-Fiori et al. (1997) para a bacia hidrográfica Litorânea mostrou que as Serras e os Morros do complexo da Serra do Mar são naturalmente expostos a um conjunto de características que favorecem a intensificação dos processos erosivos, dentre eles estão as vertentes acentuadamente declivosas, os elevados totais pluviométricos, a presença de afloramentos rochosos e a rede de drenagem densa. Ainda, a planície litorânea paranaense compreende uma região frágil do ponto de vista do uso e ocupação da terra, devido às enchentes periódicas, além de apresentar material geológico de baixa consistência para edificações urbanas. 


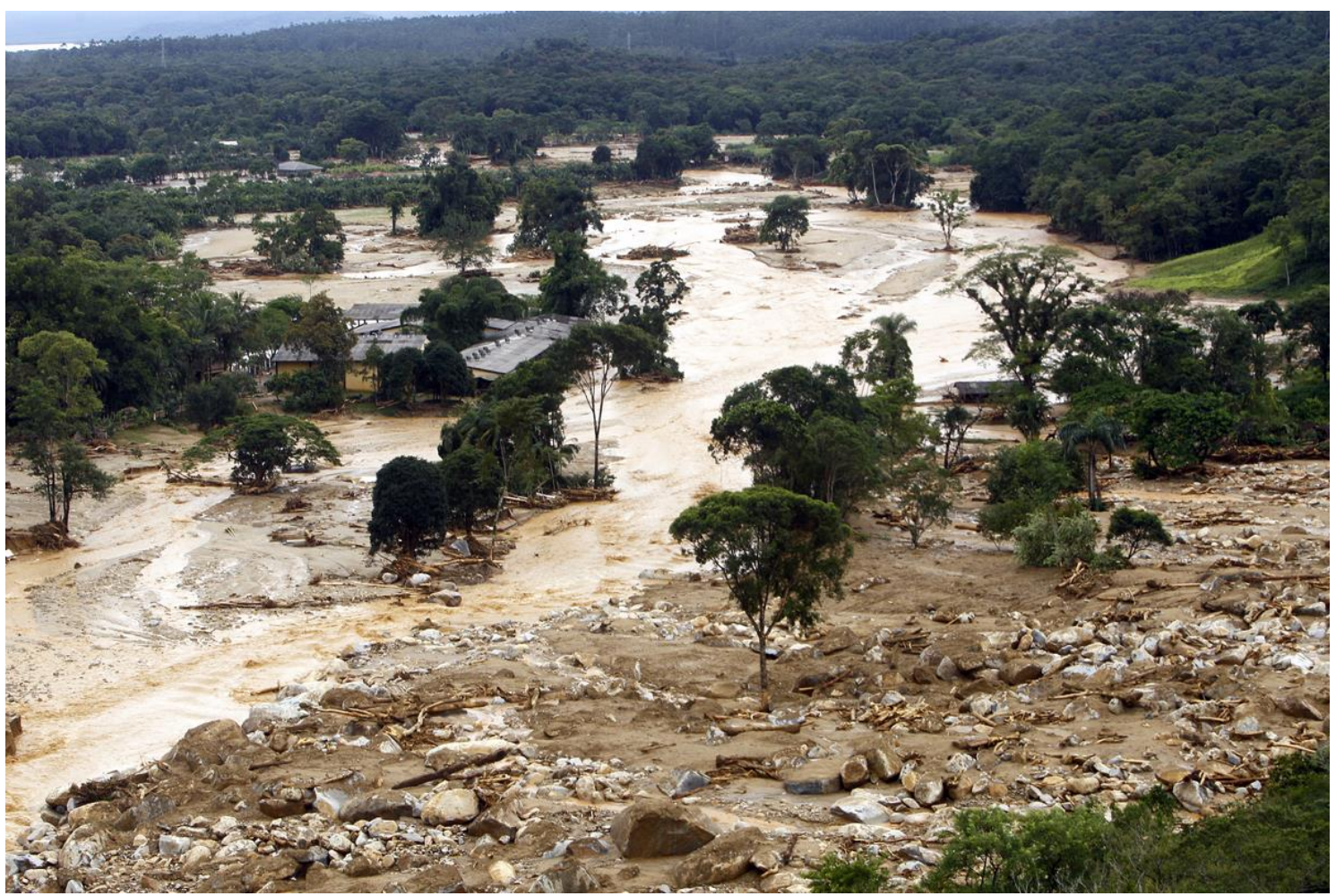

Figura 2 - Registro fotográfico dos deslizamentos de encostas e inundações associadas às corridas de lama em Morretes (PR), decorrente do evento pluvial extremo do dia 11 de março de 2011. Fonte: Paraná (2011).

Esta característica de maior susceptibilidade para ocorrência de deslizamentos na Serra do Mar em território paranaense agrava-se, sobretudo, em sua vertente oceânica, exposta a maiores totais de pluviosidade e, principalmente, ao elevado potencial erosivo das chuvas, posto que Waltrick et al. (2015) obtiveram um índice de erosividade superior a 10.000 MJ.mm.ha ${ }^{-1} \cdot h^{-1}$.ano ${ }^{-1}$ para a bacia hidrográfica Litorânea do estado do Paraná. Comparativamente, a região litorânea caracteriza-se por valores de erosividade das chuvas superiores em relação à bacia hidrográfica do Alto Iguaçu, nas proximidades da Região Metropolitana de Curitiba, e à bacia hidrográfica do rio Ribeira devido ao papel desempenhado pela orografia da Serra do Mar para o transporte de umidade para o continente, com isoerodentes inferiores a $6.000 \mathrm{MJ} \cdot \mathrm{mm} \cdot \mathrm{ha}^{-1} \cdot \mathrm{h}^{-1} \cdot \mathrm{ano}^{-1}$.

As pesquisas realizadas por Zanella (2006b) e Zanella (2007) sobre eventos pluviométricos intensos no bairro do Cajuru, localizado às margens do rio Atuba, no município de Curitiba (PR), identificaram que a ocorrência dos eventos de pluviosidade próximos a $60 \mathrm{~mm}$ em 24 horas foram os grandes responsáveis pelas situações de extrema calamidade, como a remoção da população de suas residências e as perdas materiais e humanas. Como exemplo, o evento pluviométrico de 07 de julho de 2014, equivalente a 93 milímetros de chuva, ocorrido entre às 00:00 e às 10:30, registrados pelo SIMEPAR (Sistema Meteorológico do Paraná), fez com que a Prefeitura Municipal de Curitiba 
declarasse Estado de Alerta, com alagamentos em diversos pontos, como o Parque do Bariqui (Figura 3), e cerca de 15.300 pessoas afetadas pelo desalojamento devido às inundações no seu perímetro urbano (GAZETA DO POVO, 2014).

Zanella (2006a) indicou que, junto ao crescimento da cidade, aumentou o número de eventos pluviométricos intensos em Curitiba (PR), bem como de inundações e seus impactos, e que com a ampliação de ocupação de área de risco junto aos rios, um número cada vez maior de pessoas vem sendo atingidas. Zandonadi et al. (2015) apontam que os eventos de pluviosidades diárias extremas têm aumentado nas últimas décadas em Curitiba, o que Vicente e Nunes (2004) e Shastri et al. (2015) sugerem que seja decorrente do processo de urbanização, dado que o adensamento do solo acelera as condições do processo convectivo e, consequentemente, o aumento da geração de chuvas concentradas.

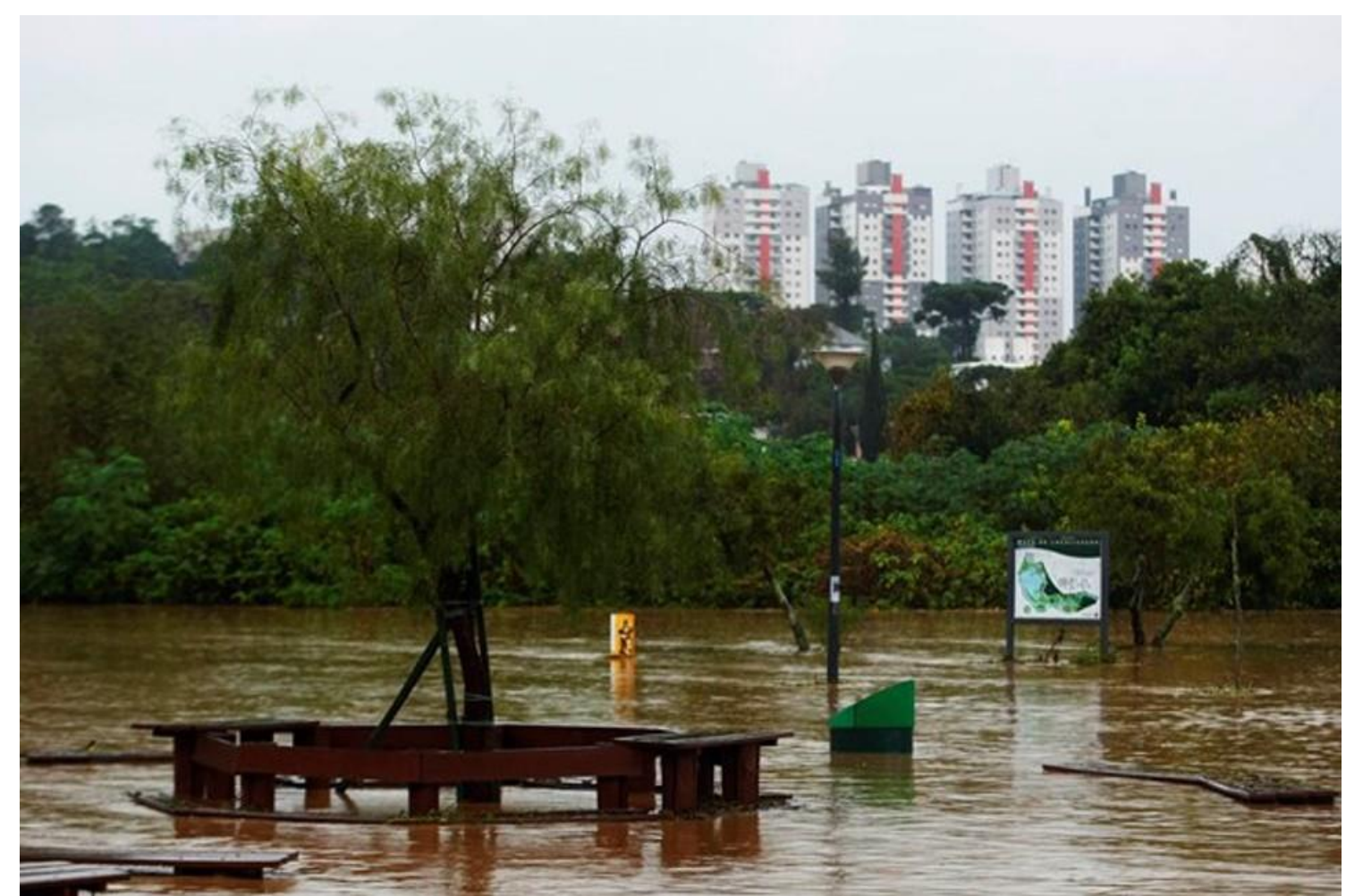

Figura 3 - Registro fotográfico de alagamento no Parque do Barigui em Curitiba (PR) no dia 07 de julho de 2014. Fonte: Gazeta do Povo (2014).

Embora não tenha sua delimitação enquadrada no segmento da Climatologia Geográfica, compreende-se que este trabalho tem como base o entendimento do clima enquanto fenômeno geográfico e destaca o seu papel na organização do espaço a partir de sua interação com os demais componentes da dinâmica ambiental, econômica e social (MONTEIRO, 1991; SANT'ANNA NETO, 1998, SANT'ANNA NETO, 2001, NUNES 
et al., 2007; SANT'ANNA NETO, 2008), principalmente ter como um dos seus pilares o estudo da frequência e da intensidade dos eventos pluviais extremos.

Considerando a literatura consultada, a presente pesquisa tem sua relevância devido aos elevados totais pluviométricos e aos impactos decorrentes dos eventos pluviométricos extremos, sejam pelas perdas humanas ou materiais, além de apresentar uma população residente de aproximadamente quatro milhões de habitantes e, sobretudo, por abranger a Região Metropolitana de Curitiba, uma das mais populosas e importantes Regiões Metropolitanas do Brasil (IBGE, 2016), pois estas são as regiões mais atingidas pelos problemas decorrentes dos episódios de pluviosidade extrema associados ao maior adensamento populacional (LIEBMANN et al., 2004; AMORIM; MONTEIRO, 2010; CASTELLANO; NUNES, 2010; ARMOND; SANT’ANNA NETO, 2017).

\section{HIPÓTESE}

Esta pesquisa parte da prerrogativa da compreensão da elevada variabilidade espacial da pluviosidade para a área de estudo a partir da influência de atributos como a maritimidade, a orografia e a diversidade de mecanismos atmosféricos para a geração das chuvas. Dentro do contexto da hipótese, presume-se que a área de estudo apresenta uma variabilidade espaço-temporal pluvial que está associada às anomalias de temperatura e de pressão das superfícies dos Oceanos Atlântico e Pacífico para o segmento temporal de 1976 a 2015, além da provável mudança dos totais pluviométricos nas séries temporais decorrentes das modificações dos tipos de uso e ocupação do solo nesta área de estudo. 


\section{OBJETIVOS}

O objetivo principal da presente pesquisa é avaliar a variabilidade pluviométrica e a ocorrência de eventos pluviais extremos para as bacias hidrográficas do rio do Alto Iguaçu, Litorânea e do Ribeira, situadas na região leste do estado do Paraná, analisando os eventos mais intensos, dada à importância de suas repercussões no espaço geográfico, e a influência de atributos como a orografia, maritimidade e a dinâmica atmosférica. Os objetivos específicos são os seguintes:

- Analisar a distribuição espacial pluviométrica, o desempenho do efeito orográfico e marítimo e definir as regiões pluviométricas homogêneas;

- Estudar a frequência e a intensidade das chuvas diárias, destacando-se os padrões espaciais e temporais das precipitações extremas diárias;

- Investigar o impacto e a repercussão das anomalias de temperatura de superfície do mar (TSM) a partir dos indicadores climático do El Niño-Oscilação Sul, da Oscilação Decadal do Pacífico e o Gradiente Meridional do Atlântico Tropical na variabilidade espaço-temporal pluviométrica da área em estudo;

- Averiguar a existência das mudanças e rupturas nas séries temporais pluviais e as tendências indicadores de extremos climáticos de precipitação pluviométrica;

- Avaliar a ocorrência de eventos pluviais extremos, descritos pelos percentis de 99\% dos quantis, e a atuação dos sistemas atmosféricos para a ocorrência destes totais de chuva;

- Compreender as características atmosféricas predominantes na determinação dos tipos de tempo e responsáveis pela gênese pluviométrica, utilizando-se do Spatial Synoptic Classification (SSC). 


\section{CARACTERIZAÇÃo dA ÁREA DE ESTUDO}

\subsection{Caracterização dos aspectos físicos}

As bacias hidrográficas em estudo estão inseridas em quatro unidades da divisão geomorfológica proposta por Maack (2012), originalmente publicada em 1968: a Zona Litorânea; a Serra do Mar; o Primeiro Planalto (Curitiba); e o Segundo Planalto (Ponta Grossa). Esta divisão geomorfológica está diretamente associada às características de sua formação geológica (Figura 4) e permite uma associação direta da litoestratigrafia (Figura 5) com as formas do relevo, nesta pesquisa expressa pela hipsometria e pela declividade (Figura 6), que serão descritos conjuntamente a seguir.

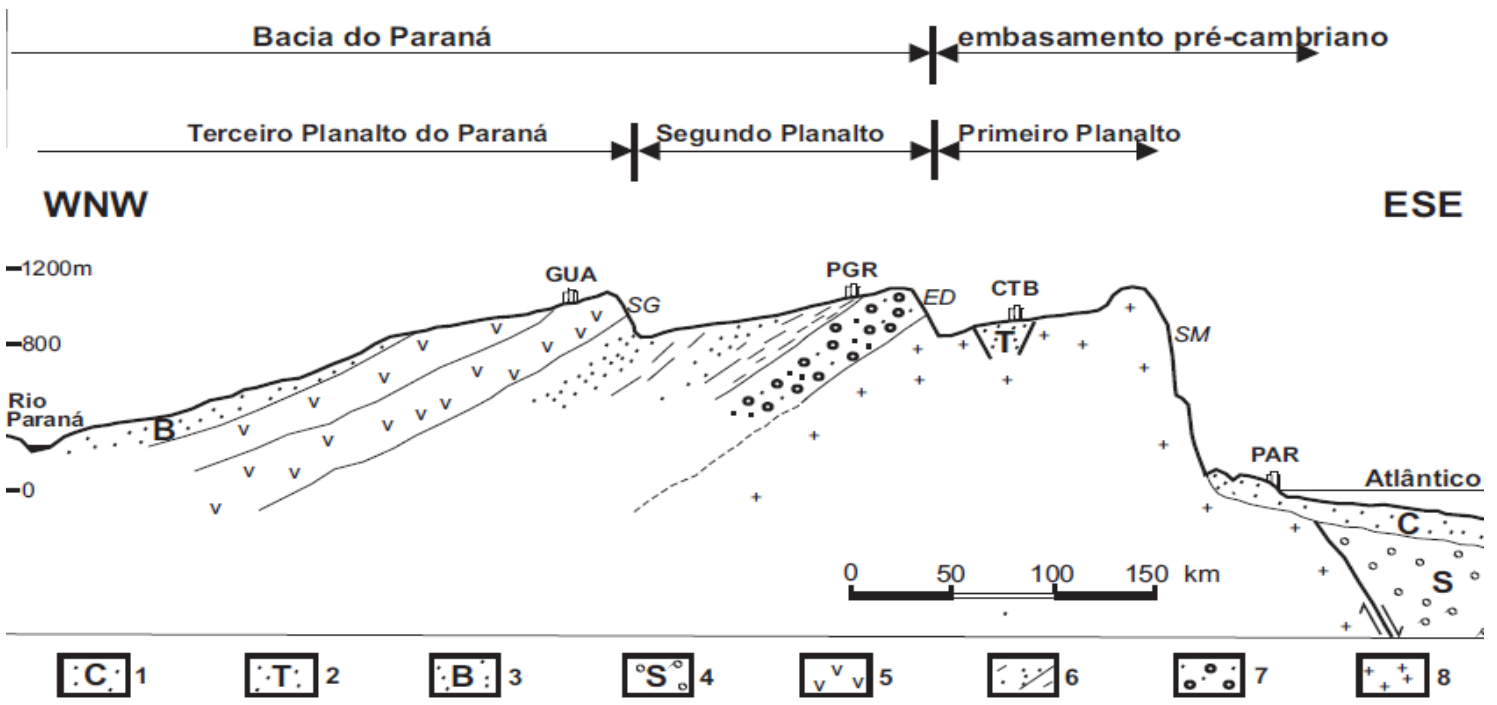

Figura 4 - Esquema da estrutura geológica do relevo do Paraná. 1: sedimentos cenozóicos da Planície Costeira e Plataforma Continental; 2: sedimentos cenozóicos da Bacia de Curitiba; 3: Grupos Bauru e Caiuá (Cretáceo); 4: Bacia de Santos; 5: derrames de basalto da Formação Serra Geral; 6: unidades paleozóicas e mesozóicas da Bacia do Paraná; 7: Formação Furnas; 8: embasamento pré-cambriano. Cidades - PAR: Paranaguá; CTB: Curitiba; PGR: Ponta Grossa; GUA: Guarapuava. Escarpas: SM: Serra do Mar; ED: Escarpa Devoniana; SG: Serra Geral. Fonte: Melo et al.(2007).

A Zona Litorânea corresponde à Planície Costeira e à encosta da Serra do Mar, formadas por um complexo de rochas mais antigas, que datam da Era Arqueozóica e Proterozóica, e pelas rochas cenozóicas da Formação Alexandra e Guabirotuba. A Planície Costeira caracteriza-se por altitudes inferiores a 150 metros com a predominância do relevo plano a suave ondulado, entre 0 e $8 \%$ de declividade, e no setor da encosta da Serra do Mar as altitudes se elevam a mais de 1.800 metros de altitude e os declives são superiores a 75\% (MINEROPAR, 2006; MAACK, 2012). Por sua vez, a Serra do Mar corresponde a um complexo de diversos maciços de blocos altos e baixos, composta por rochas do Arqueano e do Proterozóico inferior, formada por elevadas declividades (superiores a 75\%) e de altitude média superior a 1.300 metros, com o 
máximo no pico do Paraná, a maior elevação do estado do Paraná, com 1.877 metros (ALMEIDA; ARAÚJO, 1998; MAACK, 2012; NASCIMENTO et al., 2016).

O Primeiro Planalto (Planalto de Curitiba) limita-se a leste pela Serra do Mar e a oeste pela Escarpa Devoniana, caracteriza-se pela predominância de rochas dos xistos metamórficos e gnaisses, cortados por diques de pegmatitos e intrusões graníticas, com altitudes médias entre 850 a 950 metros. Os sedimentos da Formação Guabirotuba preenchem a bacia de Curitiba, depositados durante o Pleistoceno e constituindo uma área de relevo plano a suave ondulado, de 0 a $8 \%$ de declividade, que se articulam às planícies fluviais mediante suaves rampas. Ao norte comparecem as rochas do Grupo Açungui, onde a drenagem do Ribeira produziu uma intensa dissecação e declividades entre 45 e $75 \%$, modelando um relevo montanhoso, com altitudes variando entre 400 e 1.200 metros (MINEROPAR, 2006; MAACK, 2012).

O Segundo Planalto (Planalto de Ponta Grossa) encontra-se esculpido na faixa de rochas Paleozóica da grande unidade morfoestrutural Bacia Sedimentar do Paraná (SANTOS et al., 2006; SANTOS et al., 2009), denominado por Ross (2013) como a Depressão Periférica da Borda Leste da Bacia do Paraná. Este planalto limita-se a leste pela escarpa Devoniana, que recebe o nome genérico de Serrinha, e a oeste pela escarpa arenito-basáltica, chamada de Serra Geral, que regionalmente recebe o nome de Serra de São Luiz do Purunã. Esse planalto é constituído por relevos tabulares, que formam "cuestas" e plataformas estruturais mais dissecadas (MAACK, 2012) e, na bacia hidrográfica do Alto Iguaçu, caracteriza-se por declividades predominantes entre 3 a $20 \%$, com altitudes entre 750 e 1.050 metros.

Desta forma, as bacias hidrográficas do Alto Iguaçu, Ribeira e Litorânea apresentam uma complexidade litológica representada pela elevada quantidade de unidades litológicas (Figura 4). A maior parte da área de estudo está situada no Escudo Paranaense, que se constitui no setor mais antigo e elevado, formado essencialmente por rochas cristalinas, ígneas e metamórficas, da Plataforma Sul-Americana, e pelas rochas sedimentares, que remontam ao Arqueano, de maior grau metamórfico e ao paleozóico inferior, com as rochas magmáticas ácidas, e ao paleozóico, com as bacias vulcanosedimentares. O setor oeste da bacia hidrográfica do Alto Iguaçu situa-se parcialmente na Bacia Sedimentar do Paraná, com as rochas do paleozóico superior, dos grupos Guatá e Passa Dois. Principalmente a sudeste da bacia hidrográfica Litorânea, verifica-se a ocorrência dos sedimentos inconsolidados do período Cenozóico (THOMAZ, 1984; MINEROPAR, 2001). 


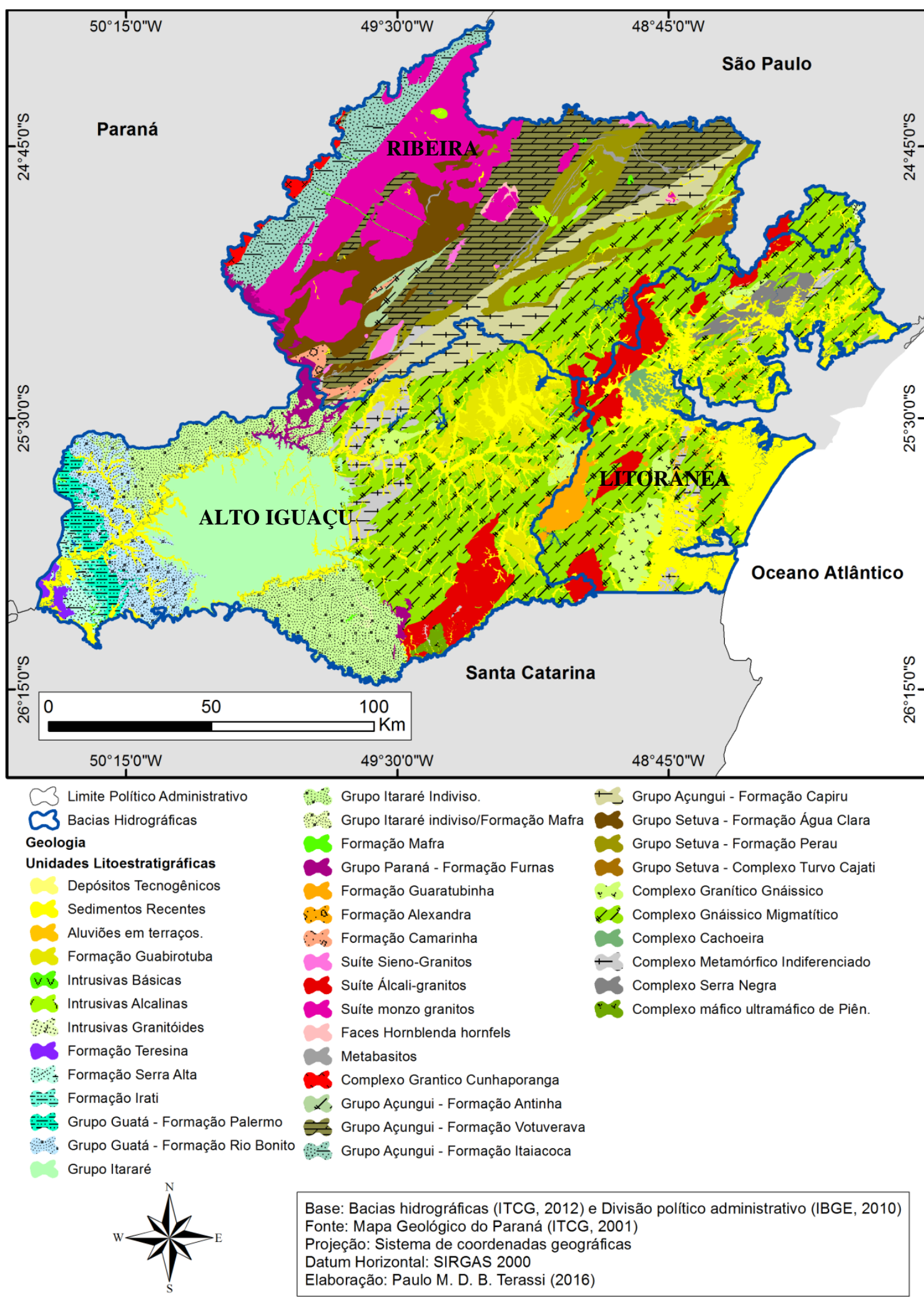

Figura 5 - Unidades litoestratigráficas das bacias hidrográficas do Alto Iguaçu, Ribeira e Litorânea Paraná. 

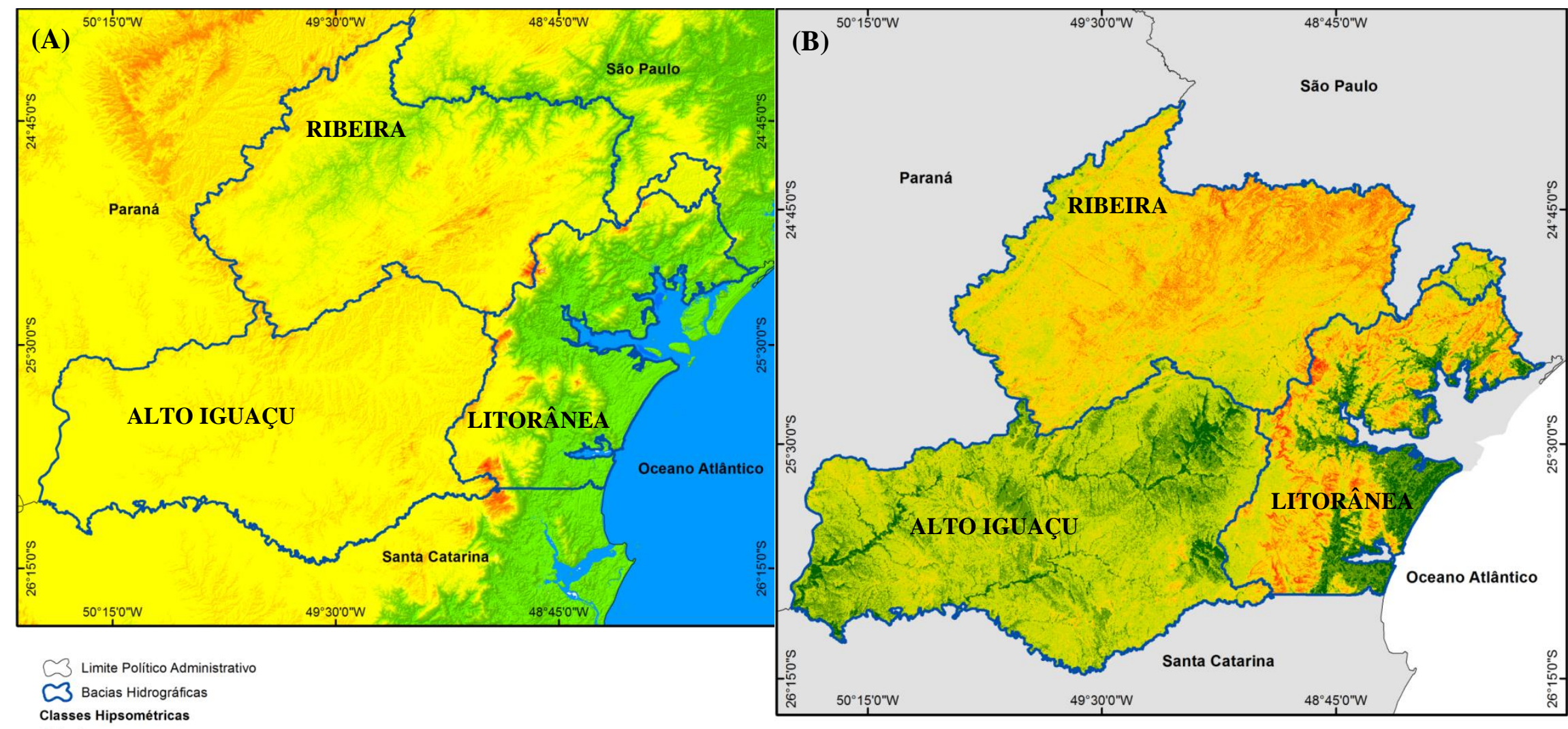

Altitude

C3 $1.751-1.854$

$1.501-1.750$

$1.351-1.500$

1201-1.350

$1.201-1.350$
$1.051-1.200$

政 $1.051-1.200$

$\sqrt{3} 751-900$

N361-750

C3 $451-600$

S3 $301-450$

ㄱ. $151-300$

1. 150

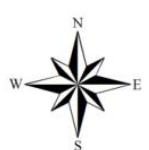

$\approx$ Limite Político Administrativo

C Bacias Hidrográficas

Classes de declividade

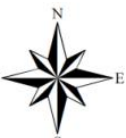

3 Plano (0-3\%)

3 Suave Ondulado (3-8\%)

3 Ondulado (8-20\%)

3 Forte Ondulado (20-45\%)

Base: Bacias hidrográficas (ITCG, 2012) e Divisão Politico

Fonte: Imagem SRTM (Shuttle Radar Topography Mission), projeto TOPODATA, (INPE, 2011).
Projecăo: Sistema de coordenadas geográficas
Datum Horizontal: SIRGAS 2000 Elaboraçắo: Paulo M. D. B. Terassi (2016)

3 Montanhoso $(45-75 \%)$

Escarpado (acima de $75 \%$ )

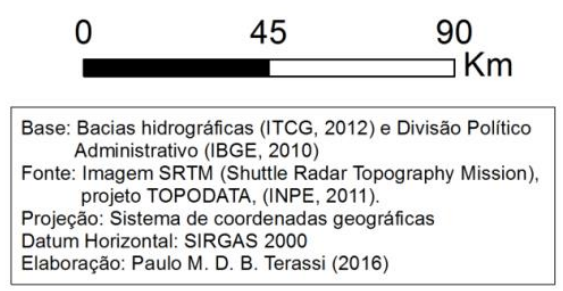

Figura 6 - Hipsometria (A) e classes de declividade (B), conforme as classes da Embrapa (1979), das bacias hidrográficas do Alto Iguaçu, Ribeira e Litorânea - Paraná. 
A área de estudo apresenta peculiaridades e singularidades quanto ao regime de pluviosidade e temperatura. Deste modo, as características termo-pluviométricas abaixo descritas demonstram de forma simplificada a complexidade, a dinâmica e a interação dos atributos climáticos componentes da problematização desta pesquisa. Observam-se a presença de diferentes tipos climáticos e características do regime de precipitação e temperatura, associados aos fatores estáticos e dinâmicos, como o relevo, maritimidade, orografia e dinâmica atmosférica regional.

Os dados de pluviosidade das estações meteorológicas de Curitiba (Figura 8A) e Pinhais (Figura 8B), localizadas na bacia hidrográfica do Alto Iguaçu, e de Ponta Grossa (Figura 7), mais próxima à bacia hidrográfica do Alto Iguaçu, mostraram uma pluviosidade média anual entre 1.460 e $1.580 \mathrm{~mm}$, caracterizando-se pela homogeneidade dos valores médios mensais, embora os maiores totais mensais seja observado de setembro a março. Quando ao regime térmico, observam-se para a bacia hidrográfica do Alto Iguaçu as menores médias mensais da área de estudo, com médias próximas aos $14^{\circ} \mathrm{C}$ nos meses de junho e julho e inferiores a $22^{\circ} \mathrm{C}$ nos meses de janeiro e fevereiro. Estas características termo-pluviométrica conferem a estas localidades a tipologia climática "Cfb" (Subtropical úmido brando sem estação seca definida), predominante para a bacia hidrográfica do Alto Iguaçu, partindo-se dos estudos de Cavaglione et al. (2000), Mendonça e Danni-Oliveira (2002) e Álvares et al. (2013).

A bacia hidrográfica Litorânea corresponde ao setor da área de estudo com os maiores totais anuais de pluviosidade, entre 2.000 e $2.500 \mathrm{~mm}$, conforme obtido para as os dados das estações meteorológicas de Antonina (Figura 8C), Morretes (Figura 8D), Guaraqueçaba (Figura 9A) e Paranaguá (Figura 9B). Nota-se que, devido ao efeito da maritimidade e da atuação preponderante da Zona de Convergência do Atlântico Sul (FREITAS, 1998; REBOITA et al., 2010), a pluviometria nesta bacia hidrográfica concentra-se nos meses de verão, entre janeiro e março, com totais superiores a $220 \mathrm{~mm}$, enquanto as chuvas se reduzem nos meses de junho, julho e, principalmente, em agosto, mês em que as médias são de aproximadamente $80 \mathrm{~mm}$, o que não indica necessariamente uma condição de seca e/ou subseca. Os dados obtidos para estas estações meteorológicas mostram que a bacia Litorânea é o setor de maiores temperaturas dentre as localidades selecionadas, com médias anuais próximas a $21^{\circ} \mathrm{C}$, com máximas superiores a $24^{\circ} \mathrm{C} \mathrm{em}$ janeiro e fevereiro e, contudo, inferiores a $16^{\circ} \mathrm{C}$ em julho. Desta forma, o tipo climático predominante nesta bacia hidrográfica é o "Cfa" (Subtropical quente sem estação seca 
definida), anteriormente obtidas por Cavaglione et al. (2000), Jorge e Mendonça (2008) e Álvares et al. (2013).

A bacia hidrográfica do Ribeira corresponde à área dos menores totais anuais de pluviosidade, entre 1.360 a $1.470 \mathrm{~mm}$, conforme indicam os dados registrados em Cerro Azul (Figura 9C) e Castro (Figura 9D), com aproximadamente 70\% do total anual concentrado no período de setembro a março, demonstrando proximidades com as características do regime de chuvas do clima Tropical (FRITZSONS et al., 2011). No entanto, as características térmicas indicaram temperaturas médias inferiores a $16^{\circ} \mathrm{C}$ para o mês mais frio (julho), condição inerente ao clima Subtropical e, desta forma, com a predominância do clima "Cfa" para os setores de menores altitudes e de médias térmicas superiores a $22^{\circ} \mathrm{C}$ nos meses de verão como registrado em Cerro Azul e, especificamente nas maiores altitudes, a ocorrência da tipologia climática " $\mathrm{Cfb}$ " para as porções de maiores altitudes e médias térmicas inferiores a $22^{\circ} \mathrm{C}$ no mês mais quente como o registrado em Castro. A transição entre os tipos climáticos de Köppen (1948) "Cfa” e "Cfb" foi obtida anteriormente por Cavaglione et al. (2000) e Álvares et al. (2013) e restringe-se apenas a descriminar a variação espacial da temperatura média dos meses de verão em conformidade a altimetria da área de estudo.

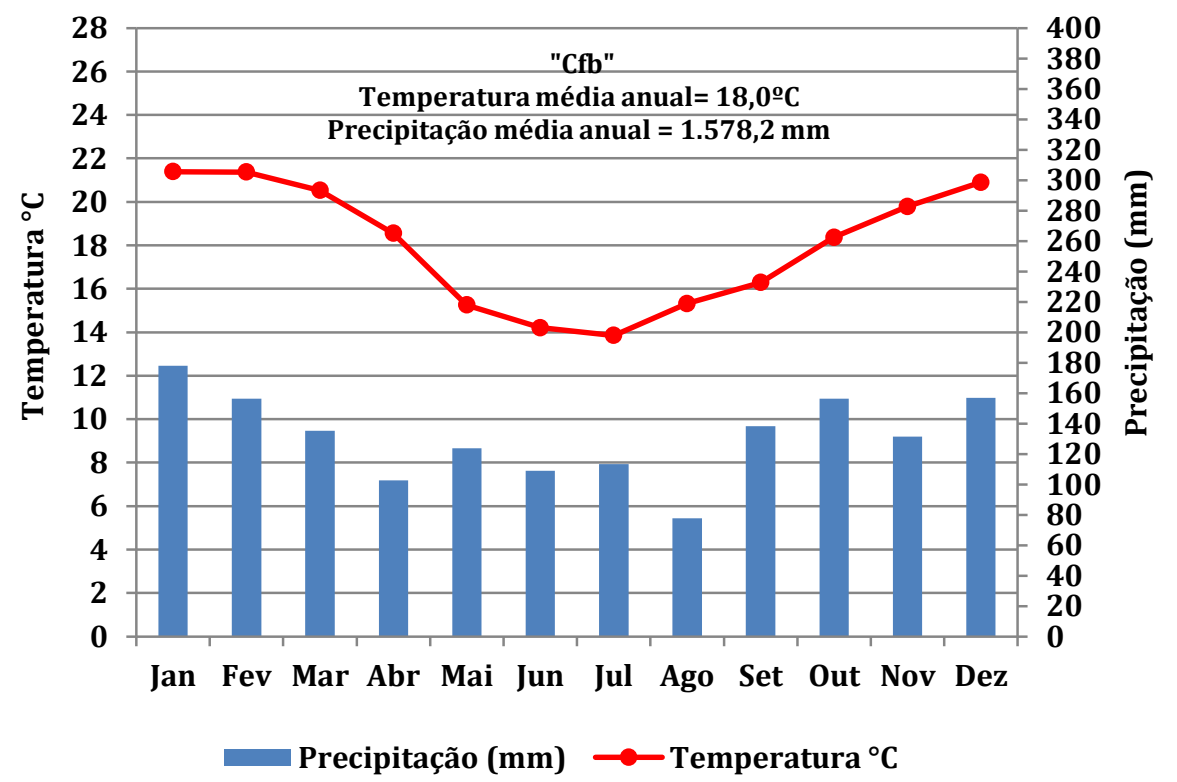

Figura 7 - Climograma e classificação climática de Köppen (1948) para a estação meteorológica de Ponta Grossa - Paraná.

Fonte: IAPAR (2016). 


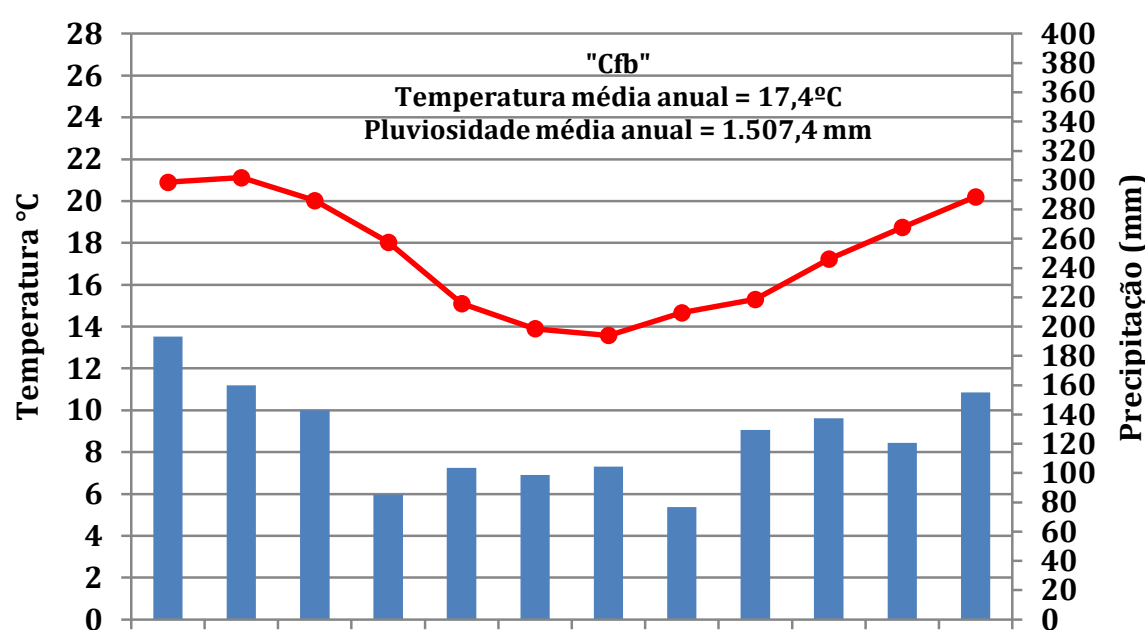

Jan Fev Mar Abr Mai Jun Jul Ago Set Out Nov Dez

(A)

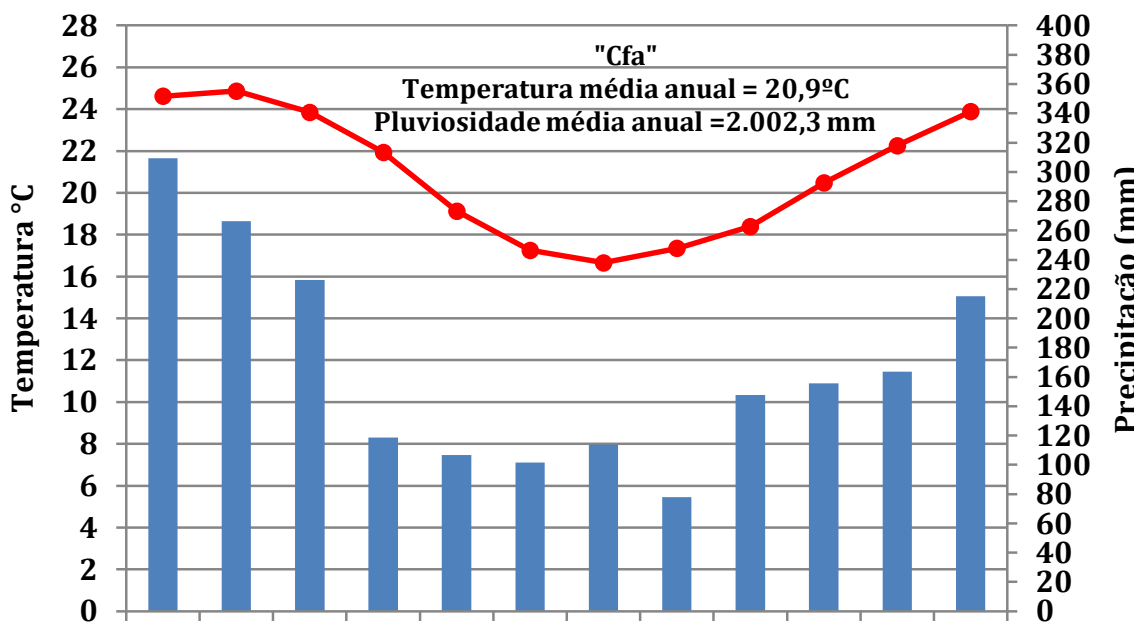

Jan Fev Mar Abr Mai Jun Jul Ago Set Out Nov Dez

(C)

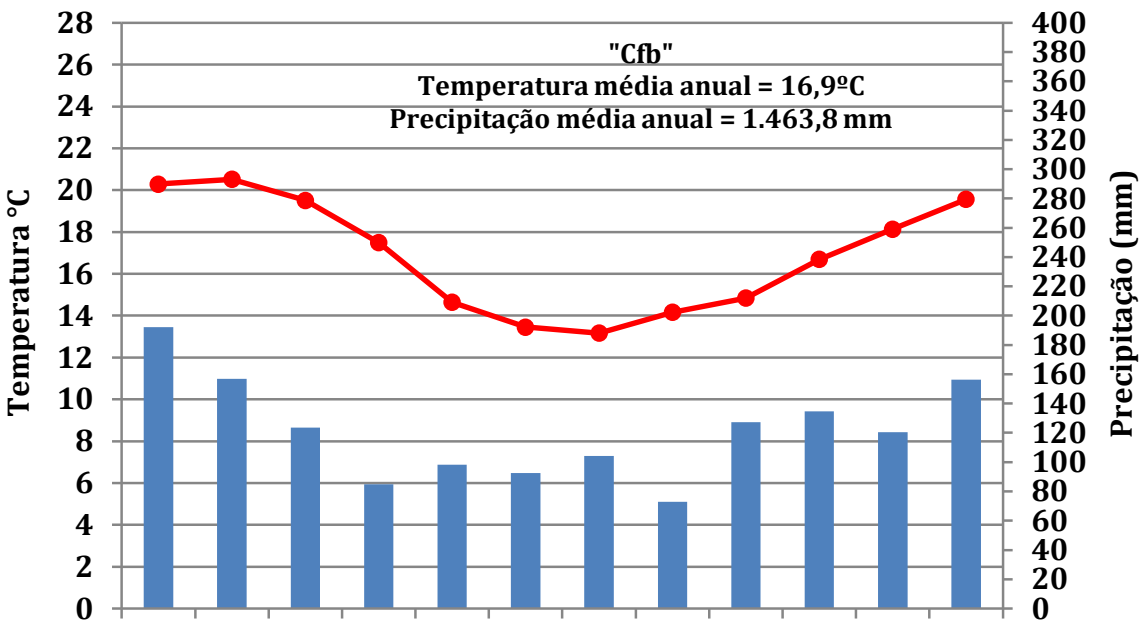

Jan Fev Mar Abr Mai Jun Jul Ago Set Out Nov Dez

(B)

Precipitação (mm) —Temperatura ${ }^{\circ} \mathrm{C}$

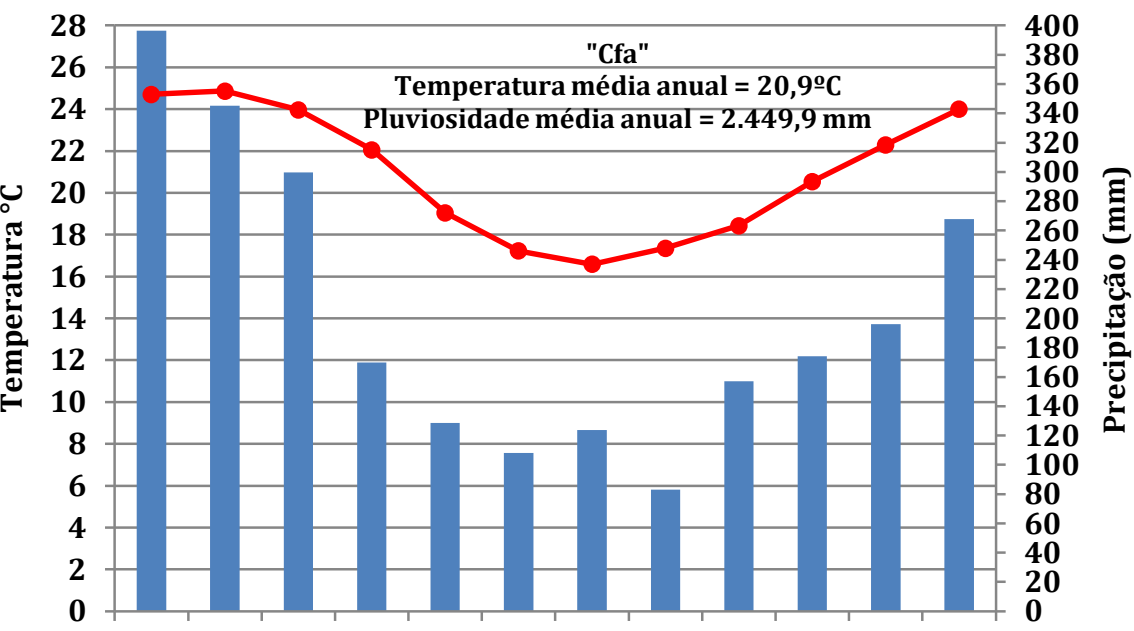

Jan Fev Mar Abr Mai Jun Jul Ago Set Out Nov Dez
Precipitação (mm) —Temperatura ${ }^{\circ} \mathrm{C}$

Figura 8 - Climograma e classificação climática de Köppen (1948) para as estações meteorológicas de Curitiba (a), Pinhais (b), Antonina (c), Guaraqueçaba (d) - Paraná. Fonte: IAPAR, INMET e SIMEPAR (2016). 


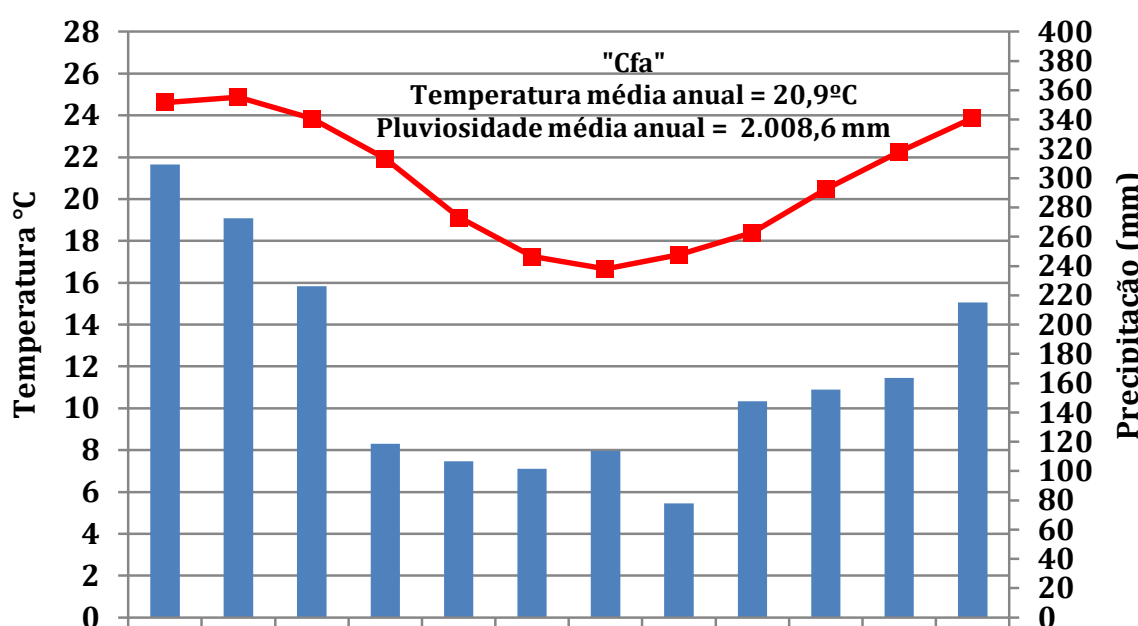

Jan Fev Mar Abr Mai Jun Jul Ago Set Out Nov Dez

(A)

Precipitação $(\mathrm{mm}) \rightarrow$ Temperatura $^{\circ} \mathrm{C}$

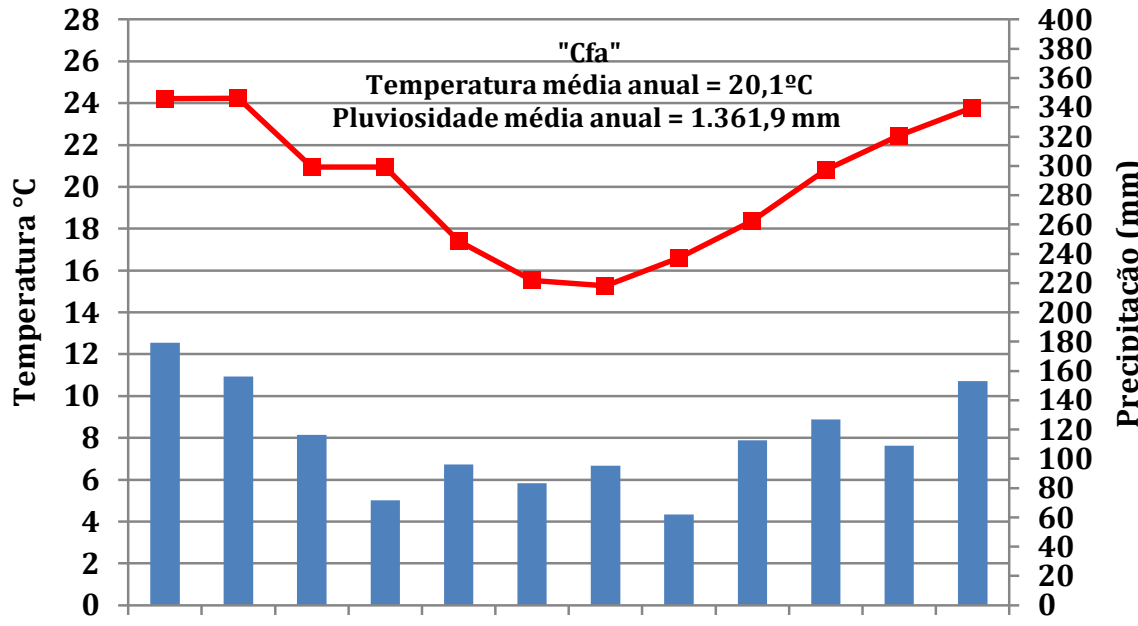

Jan Fev Mar Abr Mai Jun Jul Ago Set Out Nov Dez

(C)

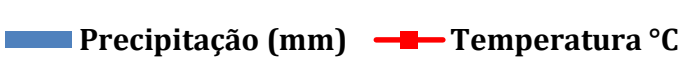

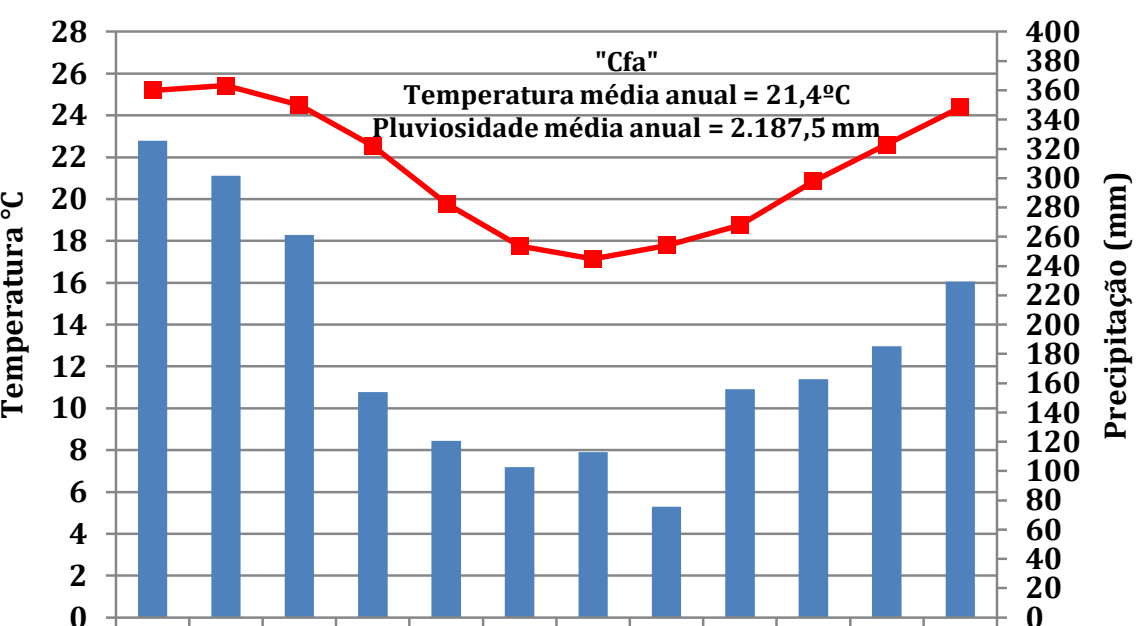

Jan Fev Mar Abr Mai Jun Jul Ago Set Out Nov Dez

(B)

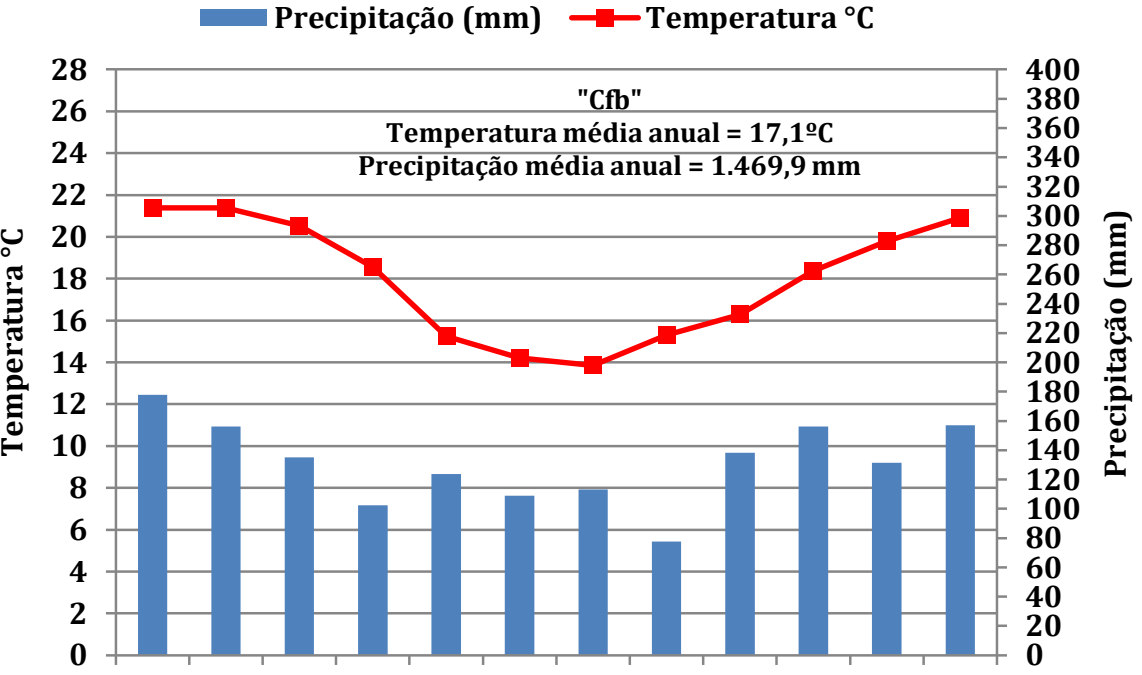

Jan Fev Mar Abr Mai Jun Jul Ago Set Out Nov Dez

Precipitação (mm) $\rightarrow$ Temperatura ${ }^{\circ} \mathrm{C}$

Figura 9 - Climograma e a classificação climática de Köppen (1948) para as estações meteorológicas de Morretes (a), Paranaguá (b), Cerro Azul (c) e Castro (d) - Paraná Fonte: IAPAR, INMET e SIMEPAR (2016). 
As bacias hidrográficas do Alto Iguaçu, Litorânea e Ribeira caracterizam-se pela diversidade de tipos de solos originários da complexidade dos fatores de formação dos solos e, consequentemente, os tipos de formações fitogeográficas originais. Conforme mencionado anteriormente, observa-se que a complexidade do material de origem ou formação litológica (MINEROPAR, 2001), as diversas formas do relevo (SANTOS et al., 2006), dadas pela variação espacial da hipsometria e declividade, e a distribuição espacial da pluviosidade e temperatura respondem pelas características da cobertura pedológica e da fitogeografia originária para este recorte em estudo.

De modo geral, as características do relevo determinam a distribuição espacial dos tipos de solo na área de estudo para a escala de 1: 600.000 (EMBRAPA, 2007). Nos setores de relevo plano, de declividade entre 0 a 3\%, ocorrem o Gleissolo Háplico, Gleissolo Melânico, Gleissolo Sálico, Espodossolo Cárbico e o Organossolo Mésico. Em condições de relevo suave ondulado (3 a 8\%) predominam o Latossolo Vermelho distrófico, Latossolo Vermelho-Amarelo e o Latossolo Bruno Ácrico. Nas porções de relevo ondulado (8 a 20\%) ocorrem o Argissolo Vermelho-Amarelo distrófico/eutrófico e o Nitossolo Háplico alumínico e Nitossolo Vermelho distroférrico. Em relevo forte ondulado (20 a 45\%) ou montanhoso (45 a75\%), observam-se os seguintes tipos de solos: Cambissolo Háplico alumínico/distrófico, Cambissolo Húmico alumínico, Chernossolo Rêndzico, Neossolo Litólico distrófico ou húmico. Sob os relevos de declividades superiores a 75\% estão os Afloramentos de Rocha (Figura 10A).

Associada diretamente com as características climáticas, a principal formação fitogeográfica natural do Litoral paranaense e do Vale do Ribeira é a Floresta Ombrófila Densa (Mata Atlântica), que se atribui às chuvas abundantes e regulares (TROPPMAIR, 1990). Igualmente caracterizada pela regularidade do regime de chuvas, a Floresta Ombrófila Mista (Araucária Angustifolia) ocupa grande porção das bacias hidrográficas do Alto Iguaçu e do Ribeira e caracteriza-se principalmente pela redução das médias térmicas e pela ocorrência de geadas invernais. As Formações Pioneiras constituem-se pelos ambientes revestidos por vegetação de primeira ocupação, que se instala nas áreas de constantes deposições sedimentares ao longo da bacia hidrográfica Litorânea, nas margens dos cursos d'água e ao redor de pântanos, lagunas e lagoas (RODERJAN et al., 2002). Considerado um enclave meio às paisagens úmidas atuais e um relicto do antigo clima semiárido do Pleistoceno, Ritter et al. (2007) destaca que os Campos naturais da estepe gramíneo-lenhosa (Campos Gerais) que ocorrem em setores da bacia hidrográfica do Alto Iguaçu estão associados à ocorrência de solos mais rasos (Figura 10B). 


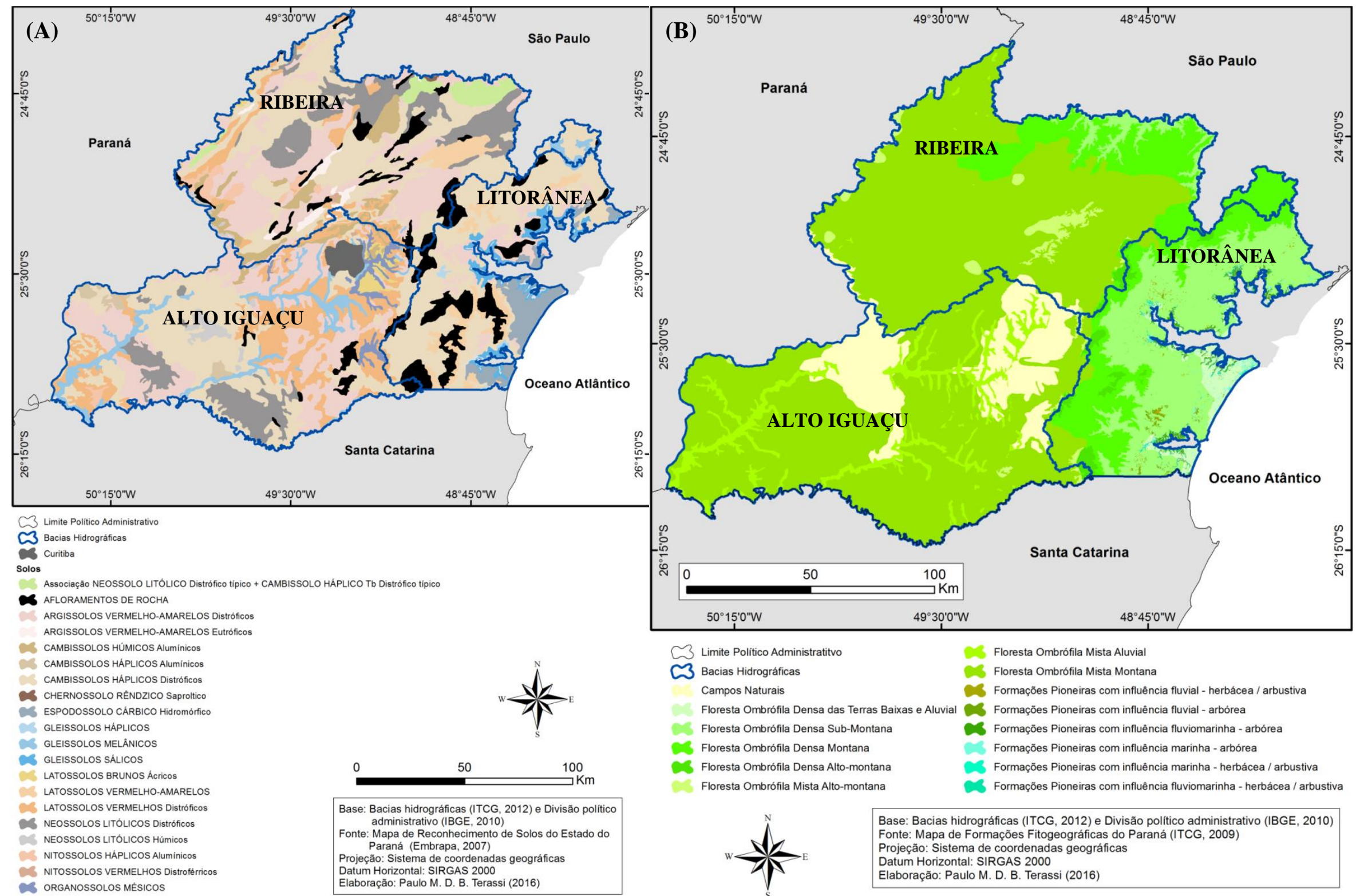

Figura 10 - Tipos de solos (A) e formações fitogeográficas originais (B) das bacias hidrográficas do Alto Iguaçu, Ribeira e Litorânea - Paraná. 


\subsection{Caracterização histórica e socioeconômica}

A História da região leste do estado do Paraná remonta aos índios Kaiagang, que povoavam os Campos Gerais na região do interflúvio dos rios Ribeira e Itararé há aproximadamente 3.000 anos. Por sua vez, a ocupação europeia iniciou-se nos primeiros anos de 1.500, com amplo conhecimento pelos navegantes da baía de Paranaguá, período em que a região era habitada pelos Tupiniquins (MOTA, 2011). Fundada em 1.648, com a ocorrência da primeira eleição para a Câmara Municipal, Paranaguá é a cidade mais antiga do estado do Paraná, e atualmente corresponde a cidade mais populosa e importante da bacia hidrográfica Litorânea.

Na primeira metade do século XVII os faiscadores de ouro chegaram ao primeiro planalto paranaense em busca do metal precioso. A região era habitada pelos índios Guarani, que exploravam os imensos pinheirais da região, e mantinham relações sociais e comerciais com os habitantes não índios do litoral. Com o crescimento da povoação, no final de século XVII foram eleitas autoridades locais com a constituição da Câmara Municipal em 1693, data da fundação da cidade de Curitiba (MOTA, 2011).

Situados no segundo planalto paranaense, os Campos Gerais começaram a serem povoados por fazendeiros de São Paulo, Santos, Paranaguá e Curitiba, no início do século XVIII, quando foi descoberto ouro em Minas Gerais, e se criou uma demanda por animais cavalares e muares, criados em abundância nos campos do Sul do Brasil (SOARES; MEANDRI, 2002). Essa demanda fez com que as famílias mais abastadas de São Paulo requeressem enormes sesmarias na região e para ali enviassem parentes ou capatazes para estabelecerem fazendas de criar gado. Com o início do Tropeirismo, as povoações formadas para subsidiar o descanso dos tropeiros, passaram a aglutinar pequenos artesãos e pequenos comerciantes, e logo se transformaram em vilas e cidades como Ponta Grossa, Castro e Lapa (MOTA, 2011).

As bacias hidrográficas do Alto Iguaçu, Ribeira e Litorânea compõem-se por 41 municípios parcialmente ou totalmente inseridos em suas áreas de abrangência (Figura 11), que apresentam uma população total de 3.920 .765 habitantes, equivalente a $37,5 \%$ de toda população paranaense. Em números absolutos de população residente, os municípios mais populosos são: Curitiba (1.751.907), Ponta Grossa (311.611), São José dos Pinhais (264.210), Colombo (212.967), Paranaguá (140.469), Araucária (119.123), Pinhais (117.008), Campo Largo (112.337) e Almirante Tamandaré (103.204). Segundo os dados do IBGE (2016), a área em estudo apresenta 91,2\% de sua população residente 
em áreas urbanas, sobretudo nos municípios mais populosos da região Metropolitana de Curitiba, nos quais a população residente na zona urbana é superior a 95\% (Figura 12).

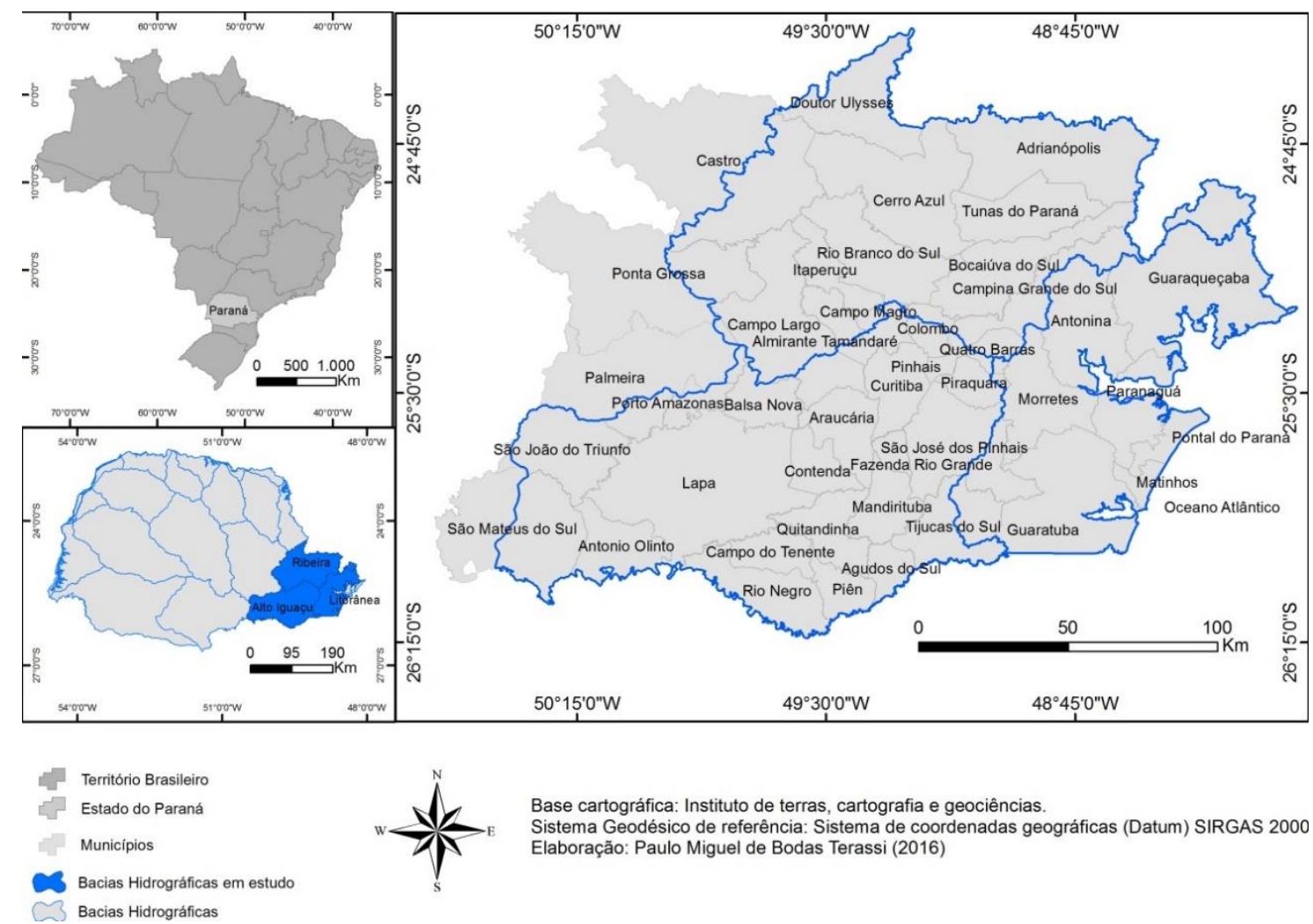

Figura 11 - Divisão político-administrativa dos municípios inseridos nas bacias hidrográficas do Alto Iguaçu, Ribeira e Litorânea - Paraná.

Os municípios mais populosos e mais urbanizados concentram-se na região a montante do Alto Iguaçu, especificamente na Região Metropolitana de Curitiba. Os municípios menos populosos e de menores taxas de urbanização localizam-se na bacia hidrográfica do Ribeira, com destaque para Adrianópolis, Cerro Azul e Doutor Ulysses, com população inferior a 20 mil habitantes e urbanização inferior a 35\%. Na bacia hidrográfica Litorânea, apenas Paranaguá apresenta uma população superior a 100 mil habitantes e $95 \%$ de urbanização, sendo que Guaraqueçaba possui população inferior a 8 mil habitantes e taxa de urbanização de 35\% (Figura 12 - Figura 13).

Os dados do Índice de Desenvolvimento Humano (IDH) mostraram que a área em estudo se caracteriza pela desigualdade social entre os municípios. O município de Curitiba destaca-se pela obtenção do IDH equivalente a 0,823 , considerado muito alto, enquanto que os municípios de Paranaguá, Pinhais, Ponta Grossa, Rio Negro e São José dos Pinhais mostraram IDH superior a 0,750. Os municípios de Cerro Azul, Doutor Ulysses e Guaraqueçaba obtiveram IDH inferior a 0,600. De modo geral, os municípios 
do Vale do Ribeira apresentam as menores taxas do IDH e os municípios da região Metropolitana de Curitiba, no Alto Iguaçu, caracterizam-se pelo maior IDH, o que se atribui ao maior desenvolvimento econômico (Figura 13).

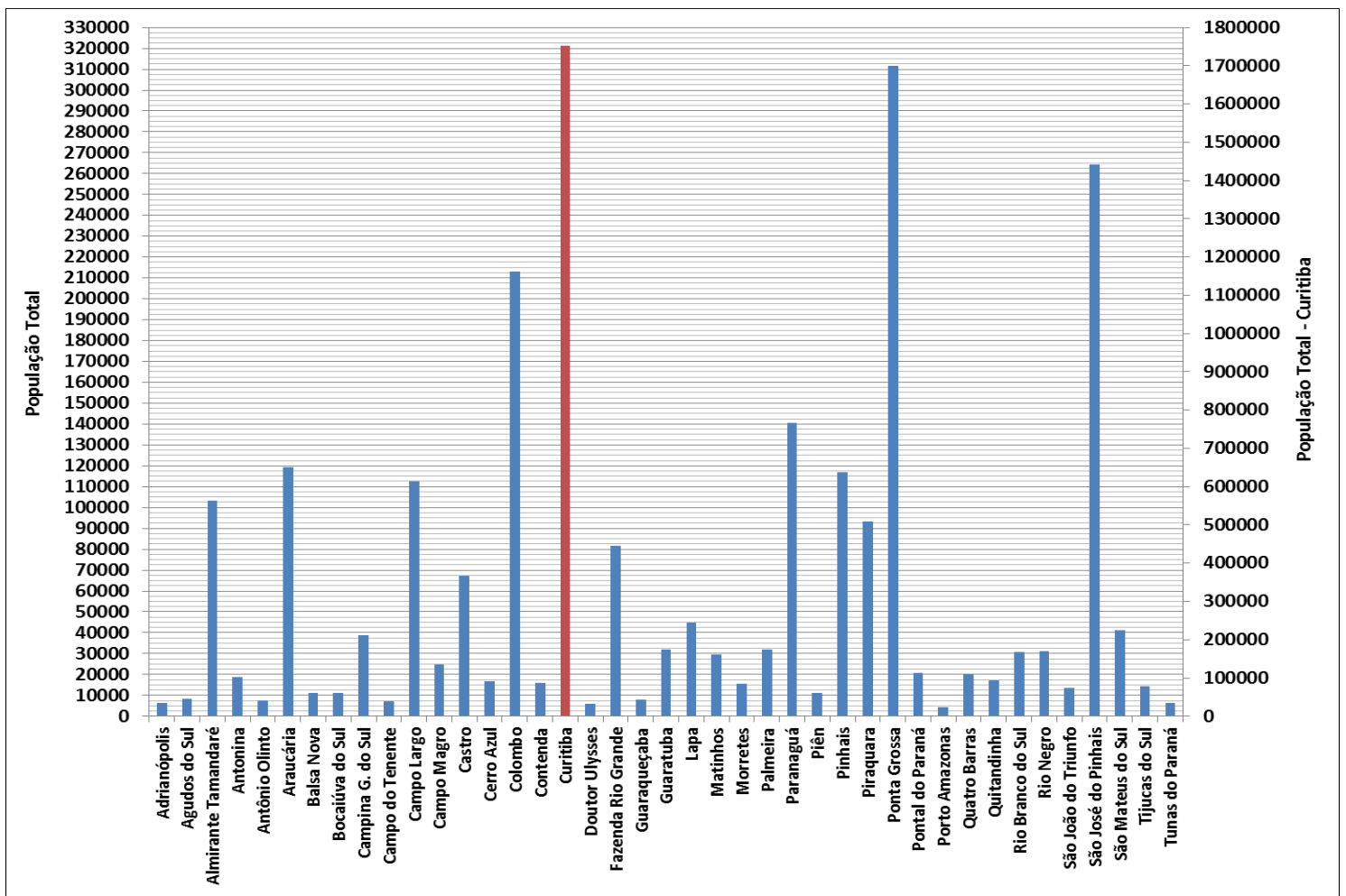

Figura 12 - População total dos municípios inseridos nas bacias hidrográficas do Alto Iguaçu, Ribeira e Litorânea - Paraná. Fonte: IBGE (2010).

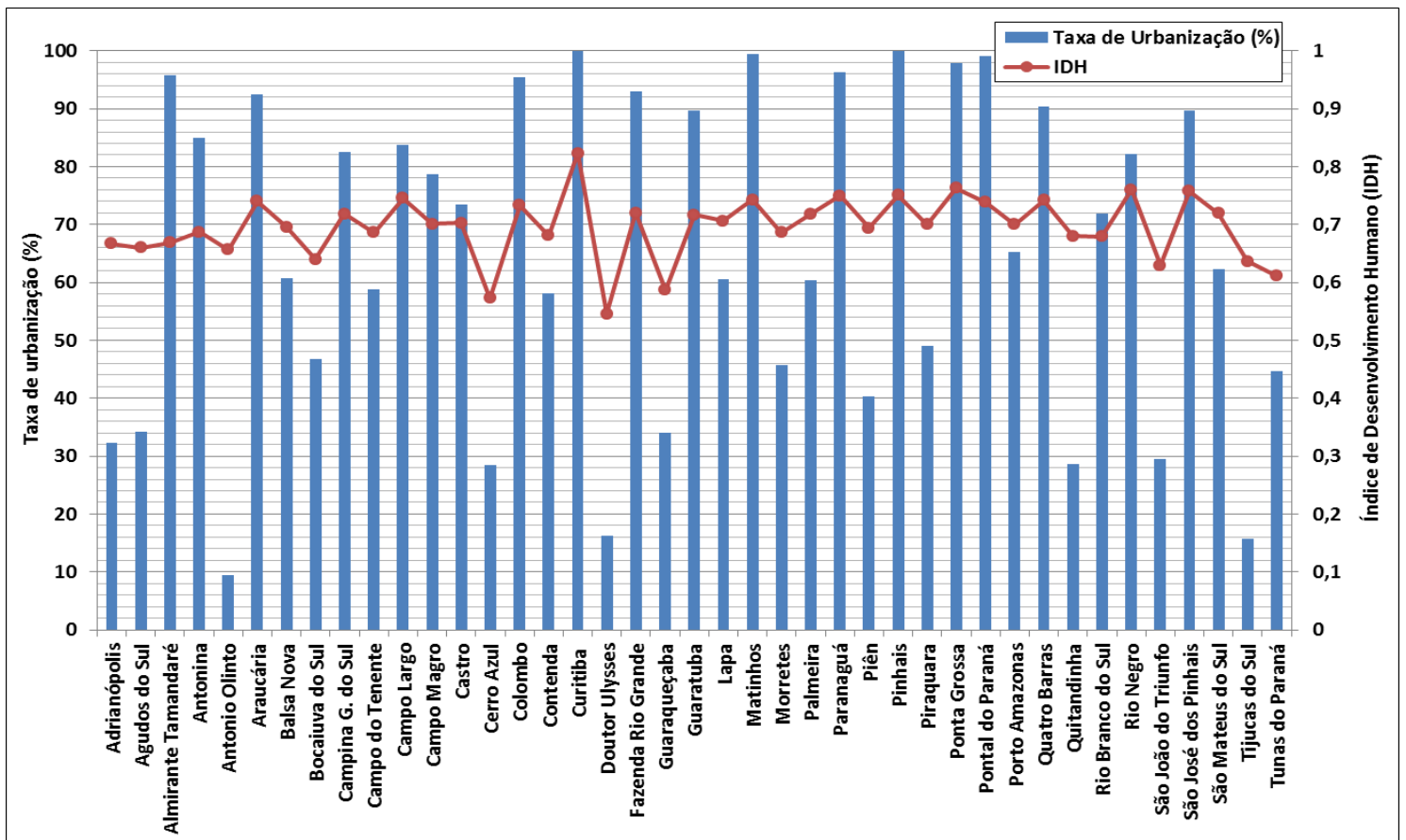

Figura 13 - Taxa de urbanização (\%) e Índice de Desenvolvimento Humano (IDH) para os municípios inseridos nas bacias hidrográficas do Alto Iguaçu, Ribeira e Litorânea - Paraná. Fonte: IBGE (2010); IPARDES (2016). 
Os dados econômicos fornecidos pelo Ipardes (2016) referentes ao ano de 2010 permitem identificar padrões da estrutura econômica regional a partir da participação dos setores econômicos na riqueza produzida pelos municípios. Os municípios da bacia hidrográfica Litorânea têm a sua economia predominantemente associada ao setor terciário, devido à grande atividade turística durante o verão. As municipalidades da região Metropolitana de Curitiba destacam-se pela economia industrial, principalmente em Araucária, Balsa Nova e São José dos Pinhais, com participação do setor secundário superior a $65 \%$ das riquezas produzidas. Os municípios da bacia hidrográfica do rio Ribeira destacam-se pela maior participação do setor terciário, enquanto que na porção do Alto Iguaçu mais distantes da Região Metropolitana, como em Antonio Olinto, Porto Amazonas, Quitandinha e São José do Triunfo, observa-se a participação superior a $60 \%$ do setor primário na economia municipal (Figura 14).

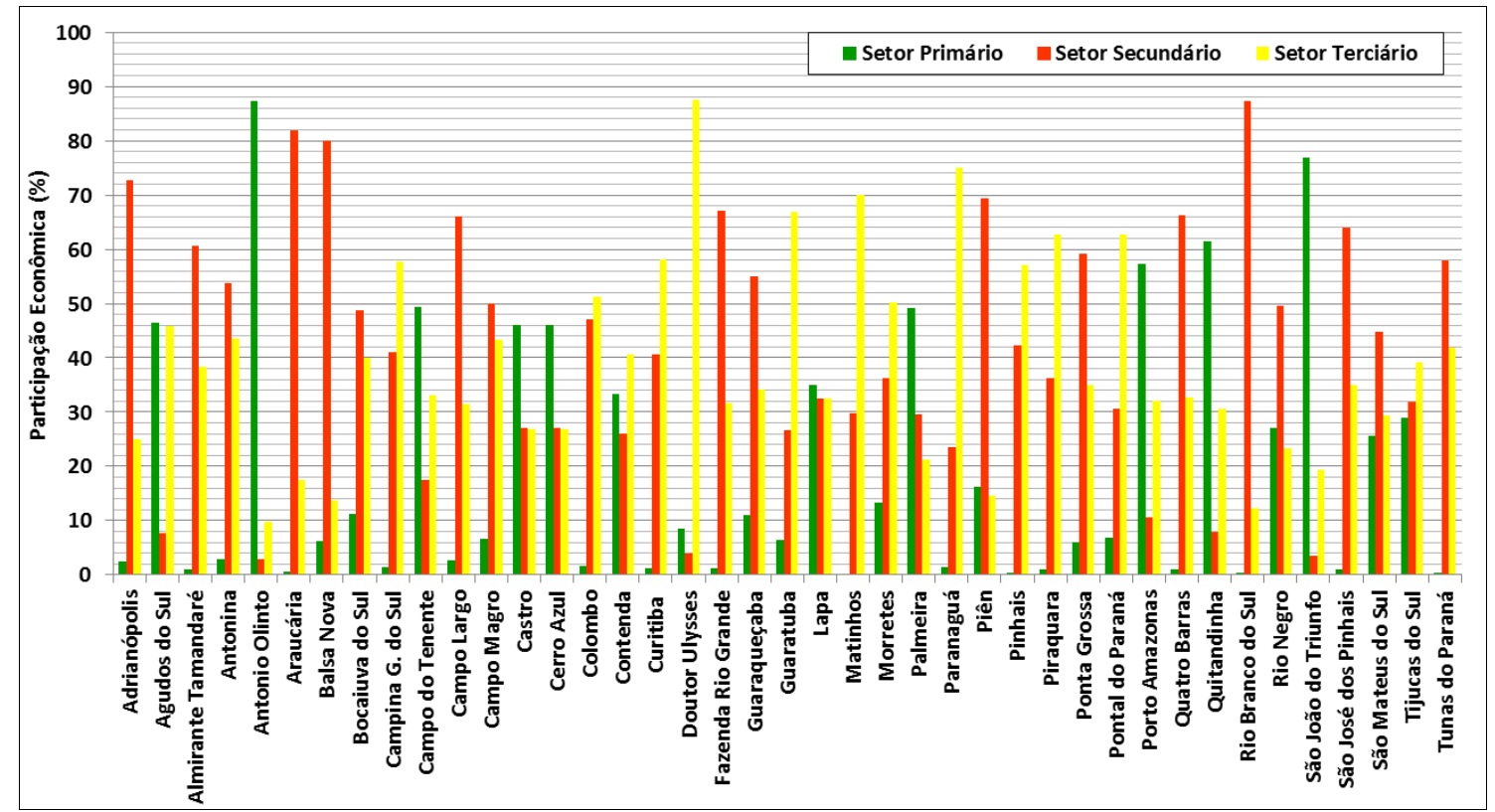

Figura 14 - Participação (\%) dos setores da economia nos municípios inseridos nas bacias hidrográficas do Alto Iguaçu, Ribeira e Litorânea - Paraná. Fonte: IPARDES (2016). 


\section{FUNDAMENTAÇÃO TEÓRICA E METODOLÓGICA}

Os estudos dos fenômenos associados à variabilidade da atmosfera são orientados no sentido da compreensão de sua extensão (espaço) e de sua duração (tempo). O gráfico da figura 15 descreve em forma de organograma teórico-conceitual, no qual a base fornecida por este item, "Fundamentação Teórica e Metodológica".

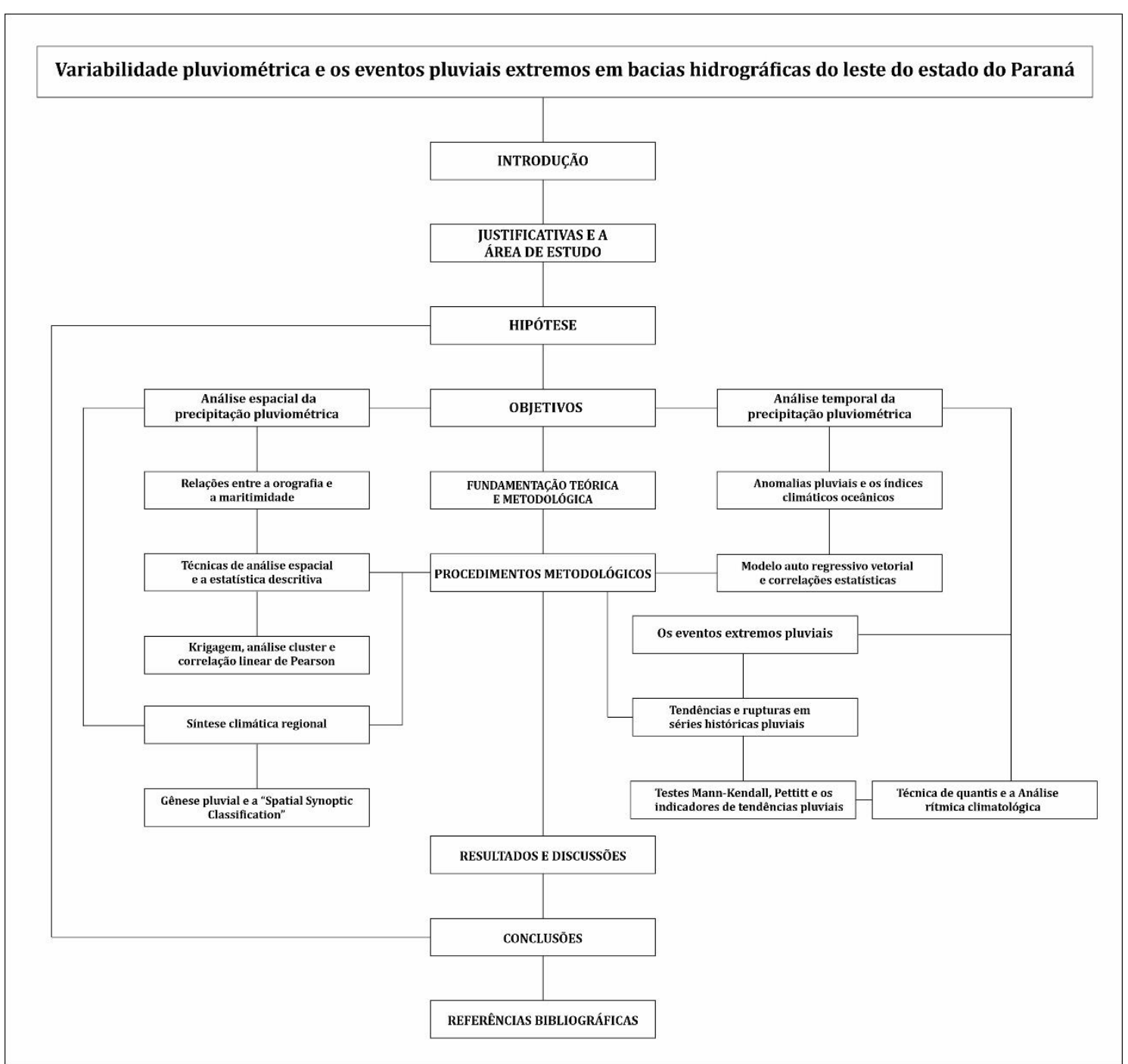

Figura 15 - Organograma teórico-conceitual da composição e a abrangência da fundamentação teórica e metodológica desta tese de doutoramento.

\subsection{A análise climática em bacias hidrográficas}

As bacias hidrográficas possibilitam o conhecimento e a avaliação dos seus diversos componentes, processos e interações que nela ocorrem e reforçam a ideia de visão sistêmica e integrada do ambiente (CARVALHO, 2014; LUZ; RODRIGUES, 
2015). Desta forma, a bacia hidrográfica ${ }^{2}$ é uma unidade apropriada ao gerenciamento, à utilização de usos múltiplos e o desenvolvimento sustentável, a partir da adoção do planejamento e gestão integrada com o detalhamento dos aspectos físicos e sociais (PORTO; PORTO, 2008; SHELTON, 2009).

Zandonadi (2013) discorre sobre a escolha das bacias hidrográficas como limite territorial das pesquisas pode ser vista como facilitadora para analisar as discussões que envolvem o meio hídrico, especialmente no caso da precipitação pluviométrica, uma vez que esta regula e condiciona diretamente a variabilidade do volume hídrico dos rios e, sobretudo neste ponto, a Climatologia possibilita a compreensão da inter-relação entre este atributo climático e a dinâmica ambiental.

A compreensão das características climáticas é fundamental para o planejamento do uso e gestão de bacias hidrográficas e que, baseada na abordagem geossistêmica, permite verificar as relações existentes entre a natureza e seus fenômenos e a sociedade e suas dinâmicas. Por conseguinte, os trabalhos consultados ressaltam a importância do clima dentre os atributos físicos da dinâmica ambiental das bacias hidrográficas e demonstraram a diversidade de técnicas advindas de bases conceituais como a Climatologia Tradicional, a Meteorologia, a Climatologia Geográfica e a Geografia do Clima (RIBEIRO, 2000; BARROS; ZAVATTINI, 2009; CONTI, 2009).

A precipitação pluviométrica corresponde a um dos atributos climáticos de maior importância na dinâmica ambiental da unidade espacial da bacia hidrográfica. Nóbrega et al. (2015) destacam o papel desempenhado pelo componente climático no reconhecimento e delimitação das unidades de paisagem das bacias hidrográficas, dada a sua interação geoecológica com os padrões e dinâmicas dos componentes físicos naturais, além da influência exercida na organização do espaço habitado, especialmente em regiões de clima Tropical, nas quais as condições desenvolvimento agrícola são ressaltadas devido à ocorrência de elevados totais pluviométricos.

O conhecimento da variabilidade pluviométrica em bacias hidrográficas subsidia o planejamento agrícola, fornecendo informações para o calendário agrícola e para a aplicação de práticas conservacionistas do solo. As ocorrências de grandes volumes concentrados de chuva em ambientes tropicais propiciam o desenvolvimento de erosões

\footnotetext{
${ }^{2}$ Christofoletti (1980) conceitua a bacia hidrográfica como a área na qual ocorre a captação de água do escoamento superficial em qualquer ponto que converge para um ponto fixo, o exutório, seja para um rio principal ou seus afluentes, em conformidade com as características dos desníveis topográficos, delimitados pelos divisores de águas, que são habitualmente pontos de cota altimétrica entre as bacias hidrográficas que orientam os cursos d'água das áreas mais baixas para as mais altas.
} 
e, portanto, o conhecimento da duração, frequência e intensidade das chuvas fornece informações importantes no âmbito do planejamento agrícola para as práticas de drenagem superficial e para decisões quanto ao preparo do solo, semeadura, irrigação e colheita (SANTOS et al., 2010; BERTONI; LOMBARDIN NETO, 2012).

Anjos e Nery (2005) e Carmello e Sant'Anna Neto (2016) destacam que a precipitação é um dos componentes de maior interação com os demais elementos climáticos pela sua associação às condições hídrica ao crescimento e desenvolvimento das plantas em diversas fases do ciclo de uma cultura e, consequentemente, influenciam os rendimentos agrícolas e econômicos, principalmente no estado do Paraná, unidade federativa de grande destaque no cenário nacional pela sua produção de diversos produtos, com destaque para a produção de grãos. Inclusive, Carmello e Sant'Anna Neto (2016) descrevem que, de modo geral, existe uma estreita relação entre a produtividade da soja, umas culturas mais expressivas no território paranaense, e as mais significativas variações da pluviosidade para a vertente paraense da bacia hidrográfica do rio Paranapanema.

Os componentes socioeconômicos e ambientais das bacias hidrográficas urbanas afetadas diretamente pelas excepcionalidades pluviométricas. Por exemplo, Costa e Wollmann (2016) mencionam que a pluviosidade é um dos aspectos mais relevantes nos estudos de bacias hidrográficas urbanas, dado a influência dos eventos extremos de pluviosidade para a ocorrência de enchentes e inundações urbana, conjugados aos aspectos naturais da bacia de drenagem e alterações decorrentes do processo de urbanização, tais como a impermeabilização do solo, retirada da vegetação natural e consequente aumento no escoamento superficial. Ainda, destacam que esse quadro é frequente em cidades tropicais devido às ocorrências elevadas de eventos concentrados de pluviosidade e que, se o conhecimento das características naturais e a manutenção de áreas verdes para o aumento do tempo de escoamento e da permeabilidade do solo, muitos dos episódios de chuvas intensas não resultariam em enchentes.

Segundo Limberger (2015), a vazão é um bom indicador das características hídricas de uma bacia hidrográfica, sendo uma variável robusta estatisticamente para demonstrar, indiretamente, a variabilidade da precipitação, e por demonstrar em partes as características do ciclo hidrológico de uma bacia hidrográfica e sua associação com o regime de chuvas. Desta forma, o conhecimento das características pluviométricas da área de estudo se torna altamente relevante, dado a elevada utilização dos recursos hídricos para a irrigação agrícola, abastecimento urbano e industrial e, destacadamente, para a 
geração de energia hidrelétrica, uma vez que o território paranaense se destaca pela grande presença de usinas hidrelétricas que fornecem grande potencial energético para $o$ território brasileiro.

Destacadamente, as águas drenadas pela bacia hidrográfica do Iguaçu chegam à reservatórios de algumas importantes Usinas Hidrelétricas ao longo de seu percurso e, segundo Azevedo (2006), a geração de energia hidrelétrica é um fator importante para a economia do estado do Paraná e o conhecimento da variabilidade pluviométrica é um condicionante essencial no planejamento dessa atividade, tornando mais eficiente e racional a utilização dos recursos hídricos.

Portanto, os demais itens componentes da fundamentação teórica e metodológica aliaram uma visão pragmática, ao considerar a compreensão estatística da variabilidade pluviométrica e dos eventos extremos pluviométricos, aliada a uma visão conjuntiva, por associação das excepcionalidades climáticas aos impactos e às vulnerabilidades. Sobretudo, adotou-se a visão sistêmica ao conjugar a dinâmica da pluviosidade com os demais aspectos ambientais e sociais das bacias hidrográficas.

\subsection{O efeito orográfico, a maritimidade e a variabilidade pluviométrica}

Um dos pioneiros ao investigar a relação entre a orografia, a maritimidade e a distribuição espaço-temporal das chuvas, Leopold (1949) descreveu que as elevações topográficas correspondem ao aspecto de maior importância na distribuição espacial da pluviosidade a partir da avaliação da dinâmica da brisa marítima com os ventos alísios ${ }^{3}$ nas ilhas do estado do Havaí, Estados Unidos. Observou que a elevação e a forma das cadeias de montanhas determinam se a brisa marítima ultrapassa a orografia ou se divide em duas correntes, a barlavento ${ }^{4}$ ou a sotavento ${ }^{5}$. Relatou que durante a noite, a sotavento, a continentalidade reforça o fluxo de ventos alísios e determina a condição de pouca nebulosidade.

\footnotetext{
3 Os alísios são os ventos constantes de sudeste no hemisfério Sul e de nordeste no hemisfério Norte, resultantes dos ramos inferiores das células de Hadley, e são formados pela força do gradiente de pressão entre o Equador e os Trópicos e defletidos pelo efeito da rotação da Terra, a chamada de força de Coriolis (VAREJÂO-SILVA, 2006);

4 Os termos barlavento ou ventos Foehn referem-se ao vento ascendente que ocorre nas encostas expostas ao ar quente e úmido, que se resfria em decorrência do aumento de altitude e diminuição de pressão e, ao chegar a determinado nível, ocorre à condensação e a formação de nuvens com a ocorrência de chuvas; 5 Após atingir o ponto mais elevado do relevo, o vento descendente que ultrapassa a encosta é denominado de sotavento ou ventos Chinook, que com um menor conteúdo de umidade, condição que resulta na sombra de chuvas (PEREIRA et al., 2002).
} 
Em território brasileiro, diversos pesquisadores vêm investigando a influência orográfica e marítimica para a distribuição espacial das chuvas. Magalhães e Zanella (2011) estudaram a distribuição espacial da pluviosidade na Região Metropolitana de Fortaleza e identificaram que os setores mais próximos ao Oceano Atlântico registraram as maiores alturas pluviométricas, superiores a $1.670 \mathrm{~mm}$ anuais, demonstrando o papel da maritimidade no incremento de pluviosidade, enquanto que o setor oeste, a sotavento das Serras do Maranguape e Pacatuba, caracterizou-se pelas menores totais anuais, inferiores a $800 \mathrm{~mm}$, inerente ao clima Tropical semiárido.

Silva et al. (2018) identificaram as regiões pluviometricamente homogêneas para o estado do Rio Grande do Norte utilizando-se dos dados estimados pela Tropical Rainfall Measuring Mission (TRMM). A partir da aplicação da técnica de agrupamento, obtiveram quatro diferentes regiões homogêneas e indicaram que a região costeira ao leste e sul apresenta uma pluviosidade média anual superior a $1.100 \mathrm{~mm}$, opondo-se ao setor oeste, de aproximadamente $700 \mathrm{~mm}$ anuais e que se caracteriza alarmantemente por raras e fracas chuvas no período de setembro a novembro, características próprias ao semiárido nordestino. Este cenário proporciona para $56 \%$ do estado um quadro generalizado de situações de carência de água durante os meses mencionados acima.

Teodoro et al. (2015) aplicaram a análise cluster utilizando-se do método Ward para a escala mensal e identificaram os sistemas meteorológicos que controlam o regime de chuvas nos biomas inseridos no estado do Mato Grosso do Sul. Foram identificadas cinco regiões pluviometricamente homogêneas e concluíram que a interação dos sistemas atmosféricos que predominam em cada bioma junto à altitude são as causas da distribuição espacial e temporal no estado. A análise cluster baseada no algoritmo Ward mostrou três estações com precipitação homogênea para todo o território sul matogrossense marcadamente própria do clima tropical: chuvosa, de novembro a março; a seca, de junho a agosto; e a transicional, em abril, maio, setembro e outubro.

André et al. (2008) identificaram seis regiões homogeneamente pluviométricas para o estado do Rio de Janeiro a partir da estruturação da análise de agrupamento hierárquica pelo método Ward e com medida de semelhança a distância euclidiana, sendo que, a posteriori, utilizou-se a análise não-hierárquica de agrupando K-means para a estratificação das estações meteorológicas. Observaram que a encosta sul da Serra do Mar e a Serra da Mantiqueira correspondem aos setores mais chuvosos do estado do Rio de Janeiro, o que evidencia o papel desempenhado pela orografia e da proximidade com o Oceano Atlântico para registros de totais pluviométricos superiores a $3.000 \mathrm{~mm}$ anuais. 
Embora tenha sido observada uma elevada variabilidade espacial, notou-se que todas as regiões homogêneas do estado do Rio de Janeiro apresentam uma concentração superior a 70\% da pluviosidade nos meses de verão (dezembro a março), o que segundo Álvares et al. (2013) caracteriza o clima tropical no território brasileiro.

Brito et al. (2016) aplicaram a técnica de análise de agrupamento, utilizando-se do método hierárquico de Ward (1963) e da distância euclidiana para mensurar a dissimilaridade entre os grupos homogêneos quanto ao regime de pluviosidade para o estado do Rio de Janeiro. Obtiveram oito grupos homogêneos com padrões similares da distribuição espaço-temporal da pluviosidade e, assim como André et al. (2008), destacaram o papel desempenhado pela orografia e pela maritimidade para a ocorrência dos maiores totais pluviométricos na face costeira da Serra do Mar, de pluviosidade média anual superior a $2.750 \mathrm{~mm}$, enquanto que a região Norte do Rio de Janeiro, de clima mais próximo ao domínio climático Tropical semiárido (ALVARES et al., 2013), e a face continental da Serra do Mar mostraram média anual inferior a $1.100 \mathrm{~mm}$. Observaram que em todos os grupos homogêneos, os meses de junho, julho e agosto foram os mais secos e, inversamente, os meses novembro, dezembro e janeiro foram os mais chuvosos e ressaltaram que episódios de veranicos, períodos de 4 a 15 sem chuvas, são comuns até mesmo em meses chuvosos como janeiro, fevereiro e março.

A partir da análise da participação dos sistemas atmosféricos e do estudo da variação sazonal e gênese das precipitações, Sant'Anna Neto (1990) e Sant'Anna Neto (1994) investigou a dinâmica atmosférica e o caráter transicional da zona costeira do estado de São Paulo. Conforme observado anteriormente por Conti (1975), a altitude do relevo e a sua disposição em relação à direção predominante dos sistemas atmosféricos provenientes do quadrante sul. Sant'Anna Neto (1994) identificou três setores com diferentes aspectos quanto à circulação atmosférica e a gênese pluvial: no litoral norte, de maior atuação dos sistemas tropicais e, conjugadamente, dos maiores volumes de pluviosidade decorrente da frequência de frentes estacionárias; o litoral central, complexo devido à alternância dos sistemas atmosféricos tropicais e extratropicais, corresponde à zona de transição dos climas tropicais e extratropicais; o litoral sul caracteriza-se por sua menor pluviometria, dada a maior dependência dos sistemas extratropicais para a geração de chuvas e, principalmente, por menores condições de frentes estacionárias.

Milanesi (2007) e Milanesi e Galvani (2011) avaliaram a importância do relevo na distribuição das chuvas orográficas para a Ilha de São Sebastião, localizada no município de Ilhabela (SP). Indicaram que as vertentes expostas aos fluxos do setor SE 
(barlavento) receberam totais de pluviosidade $60,1 \%$ superior em relação às vertentes opostas (sotavento), demonstrando a importância do relevo para a distribuição da pluviosidade. Obteve-se uma pluviosidade anual superior a $4.300 \mathrm{~mm}$ para o posto pluviométrico mais elevado (600 metros) situado a barlavento da brisa marítima do Oceano Atlântico. Portanto, estes resultados apontaram o relevo como imprescindível na análise da distribuição espacial da pluviosidade, com uma intensificação significativa a partir dos 300 metros de altitude na vertente oceânica a barlavento e, inversamente, na vertente continental observa-se a formação da sombra de chuva, conforme esclarece o esboço teórico da figura 16.

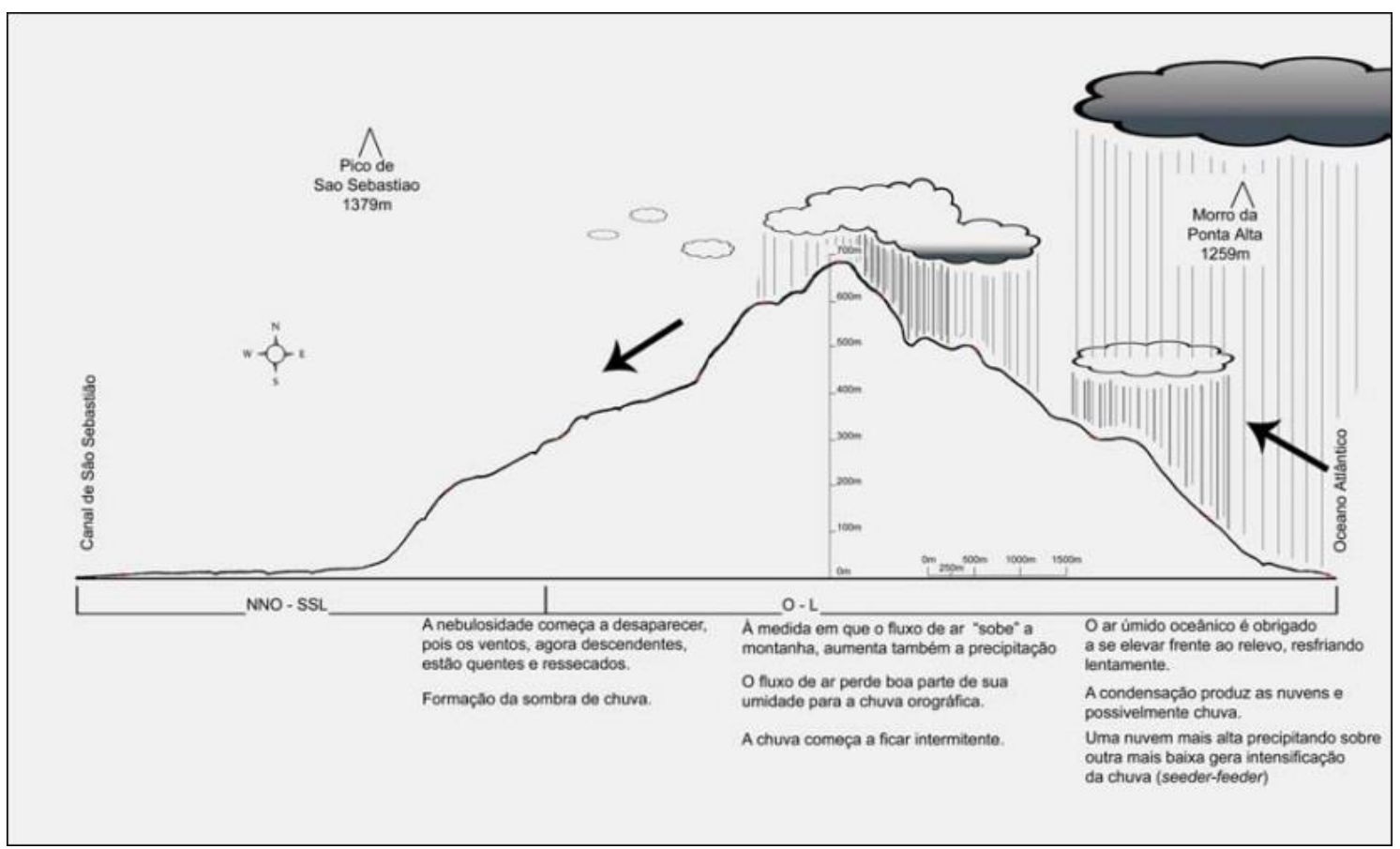

Figura 16 - Esquema teórico da distribuição espacial das chuvas e o efeito orográfico na Estrada de Castelhanos, Ilha de São Sebastião, município de Ilha Bela - São Paulo. Fonte: Milanesi (2007).

Pellegatti e Galvani (2010) discorrem que a Serra do Mar, em seu trecho ao longo do litoral paulista, tem como um dos seus aspectos climatológicos mais marcantes, a influência da orografia nos totais de precipitação, com destaque para a configuração do obstáculo e a atuação dos sistemas atmosféricos. Para as normais climatológicas, identificaram que os setores mais elevados da Serra do Mar situados a barlavento da vertente oceânica apresentam uma pluviosidade superior a $3.300 \mathrm{~mm}$ anuais, enquanto que na "sombra da chuva" a precipitação se reduz a uma média de $1.500 \mathrm{~mm}$ anuais. Estes autores indicaram que os eventos de pluviosidade de curta duração estiveram 
relacionados à predominância dos sistemas convectivos, ao passo que durante os eventos de longa duração houve a dominância dos sistemas frontais.

Santos e Galvani (2014) averiguaram a sazonalidade da precipitação e sua relação com a distribuição horária em Caraguatatuba, situada no litoral Norte do estado de São Paulo. Observaram que $64,4 \%$ dos totais de pluviosidade estão concentradas no período de primavera e verão, principal característica do clima tropical chuvoso predominante para este setor do litoral paulista. Analisaram a ocorrência horária de nove eventos extremos de pluviosidade diária superior a $40 \mathrm{~mm}$ e concluiu-se que durante o verão estes eventos estiveram associados à Zona de Convergência do Atlântico Sul (ZCAS), enquanto que durante o outono os sistemas frontais foram os mecanismos responsáveis pela geração destes totais pluviométricos.

Ao estudar a influência da orografia na precipitação da área entre o vale do rio Tietê e a Serra da Mantiqueira (SP), Cândido e Nunes (2008) afirmam que nos locais de relevo mais irregular notam-se maiores amplitudes nos totais pluviométricos, tanto pela altimetria quanto aos aspectos morfológicos e, contrariamente, a distribuição espacial da precipitação é mais regular nas áreas menos elevadas e mais planas, posto a menos significativa influência da morfologia do relevo para a intensificação das chuvas. Concluíram que o desempenho da orografia é minimizado durante o inverno, uma vez que a gênese da precipitação prevalecente neste período está associada aos sistemas frontais, que são espacialmente mais abrangentes. Com uma condição contrastante, no período do verão, com as elevadas temperaturas e elevado potencial higrométrico, predominam as chuvas convectivas e observa-se uma maior influência da orografia para a distribuição espacial da precipitação.

Chierice e Landim (2014) utilizaram-se da técnica da análise multivariada de agrupamento (cluster) para delimitar as regiões similares de padrão de pluviosidade na bacia hidrográfica do rio Mogi Guaçu (SP), tendo como base o método aglomerativo hierárquico de Ward e a medida de dissimilaridade a distância euclidiana. Afirmaram que o emprego desta técnica foi eficaz para a regionalização das chuvas, dividindo esta área de em quatro grupos pluviometricamente homogêneos conforme as características do relevo, com maiores alturas pluviométricas nos setores de maiores altitudes.

Fontão e Zavattini (2014) compartimentaram a bacia do rio do Pardo (SP/MG) a partir da homogeneidade do ponto de vista altimétrico, geomorfológico e hidrológico. A análise da distribuição espaço-temporal da pluviosidade evidenciou a concentração das chuvas nas proximidades da Serra da Mantiqueira, de maiores elevações do relevo, com 
uma significativa redução dos totais pluviométricos nos setores a jusante do curso principal do rio do Pardo. Entretanto, ressaltaram que os setores mais aplainados do Alto Mogi, mesmo em elevadas altitudes, apresentaram menores alturas pluviométricas anuais em relação à montante do rio do Pardo, dado às características de relevo aplainado da Depressão Periférica Paulista.

Forgiarini et al. (2014) analisaram a ocorrência das chuvas orográficas no município de Silveira Martins, localizado nos limites entre a Depressão Central e o Planalto Meridional Riograndense, na porção central do estado do Rio Grande do Sul. Com o monitoramento de 30 eventos de chuva, a análise estatística sugeriu a ocorrência do efeito orográfico, dado a ocorrência de uma pluviosidade aproximadamente $10 \%$ superior a barlavento. Os gradientes pluviométricos calculados apontaram um acréscimo de $0,83 \mathrm{~mm}$ por metro de altitude na vertente a barlavento e decréscimo de $0,37 \mathrm{~mm}$ de chuva por metro a sotavento.

Sousa (2006) realizou a regionalização das chuvas no estado do Paraná a partir da utilização de 41 postos pluviométricos e estações meteorológicas e com a técnica da análise de agrupamento. Dentre os resultados mais importantes, mostrou que no setor leste a maritimidade associada à elevada é responsável pela elevada pluviosidade desta região, ao passo que a Noroeste as chuvas diminuem principalmente durante o inverno, quando a massa Tropical continental junto à baixa pressão do Chaco inibe a atuação das frentes frias para a geração de chuvas. Notou-se um elevado gradiente de precipitação de menores valores no setor norte e maiores valores nos setores sul e leste do Paraná, condição diretamente associada às características do relevo e as direções predominantes das entradas das massas de ar.

Andrade e Ney (2003) aplicaram a técnica de agrupamento para verificar a similaridade e homogeneidade de dados de postos pluviométricos da bacia hidrográfica do rio Ivaí (PR) utilizando-se do método Ward e da distância euclidiana. A partir da obtenção do dendograma, apontaram um ponto de corte realizado subjetivamente e determinaram quatro regiões pluviométricas homogêneas. Destacaram que em todas as análises estatísticas a distribuição pluviométrica para esta área de estudo é homogênea e, entretanto, que o Centro-Sul apresenta maior variabilidade e totais de pluviosidade, associado ao desempenho da orografia.

Em estudos para a bacia hidrográfica do rio Ivaí (PR), Baldo (2006) destaca um padrão de valores mais elevados de precipitação pluviométrica, superiores a $1.800 \mathrm{~mm}$, e de uma distribuição mensal regular a montante, devido ao efeito orográfico e ao clima 
subtropical desta porção. Os menores valores de precipitação, inferiores a $1.450 \mathrm{~mm}$, e com uma maior concentração nos meses de verão, foram obtidos para o setor a jusante, por predominar o clima tropical e de baixas altitudes.

Correa (2009) analisou a distribuição espacial e temporal da pluviosidade para a bacia hidrográfica do rio Piquiri (PR). Observou a interação entre o relevo à atuação dos sistemas atmosféricos no controle da variação espacial das chuvas nas escalas anual, sazonal e mensal e que, invariavelmente, o efeito da orografia ocorre de forma mais incisiva entre as cotas de 400 a 900 metros, ao passo que os setores com altimetria inferior a 400 metros ou superior não apresentam correlação direta entre o relevo a pluviosidade média anual. A porção nordeste da bacia hidrográfica do rio Piquiri apresenta características semelhantes ao do clima Tropical do Brasil Central com a maior redução das chuvas durante o período do inverno, sendo que o setor centro-sul caracteriza-se por uma relativa homogeneidade do regime mensal das chuvas.

Comparando o desempenho da orografia para o controle espacial das chuvas, Correa et al. (2016) observaram que as correlações entre o acréscimo da altitude e a ocorrência de maiores totais pluviométricos são mais elevados na bacia hidrográfica do rio Piquiri (PR) em relação a bacia hidrográfica do rio Pirapó (PR), principalmente nos meses de inverno, com a predominância de sistemas frontais para a geração das chuvas. Constataram que o predomínio do clima Subtropical e as passagens mais frequentes das frentes frias respondem pela homogeneidade do regime de chuvas na bacia hidrográfica do rio Piquiri, ao passo que a distribuição mensal das chuvas na bacia hidrográfica do rio Pirapó apresenta maiores similaridades com o clima Tropical devido às tendências de maior concentração de chuvas nos meses de verão e primavera.

Ao espacializar os dados de precipitação pluviométrica da bacia hidrográfica do rio Pirapó (PR), Ribeiro (1988) identificou para os setores mais elevados da área de estudo uma pluviosidade média anual superior a $1.700 \mathrm{~mm}$ em altitudes próximas a 900 metros, ao passo que a precipitação se reduz a totais anuais inferiores a $1.400 \mathrm{~mm}$ para o setor à jusante do curso principal do rio supracitado em altitudes de aproximadamente 350 metros. Destacou que, devido à similaridade com o clima tropical, o setor norte da bacia hidrográfica apresenta maiores valores de pluviosidade diária concentrada em 24 horas.

Ao utilizarem-se da técnica de análise de agrupamentos, Terassi et al. (2016) mostraram resultados semelhantes para a Unidade Hidrográfica Pirapó, Paranapanema III e IV. Mostraram a importância do relevo para a distribuição espacial da pluviosidade e que a dinâmica atmosférica regional determina que a marcha anual da precipitação se 
distinga espacialmente, pois a precipitação no setor norte apresenta uma maior de concentração de chuvas nos meses de verão devido à proximidade com as características do clima Tropical e, inversamente, o setor sul apresenta uma distribuição mensal mais regular dos totais pluviométricos pela predominância do clima Subtropical do Brasil Meridional, concordantes com Nimer (1989) e Silva et al. (2006).

Jorge e Mendonça (2008) e Jorge e Mendonça (2009) destacaram a influência da maritimidade para os elevados totais pluviométricos no litoral paranaense e afirmaram que a configuração geral do relevo é o fator estático mais importante no controle climático nesta região, pois contribui para a existência da variedade de climas e paisagens, devido às diferenças de altitudes e da disposição de suas formas. Desta forma, a Serra do Mar funciona como uma barreira para o avanço de massas de ar, influenciando na distribuição de umidade e pluviosidade nas suas adjacências.

Wrege et al. (2016) utilizaram a série temporal de 1976 a 2005 e o método de agrupamento hierárquico Ward (1963) para compreender a disponibilidade hídrica, dada pela diferença entre precipitação total e evapotranspiração potencial, na região Sul do Brasil. Observaram que o sudoeste do Paraná e oeste de Santa Catarina, bem como o litoral leste e norte catarinense e todo litoral paranaense, caracterizam-se por uma média pluviométrica superior a $2.000 \mathrm{~mm}$ anuais, com superávit hídrico entre 800 a $1.200 \mathrm{~mm}$. Destacam ainda que, conforme o Atlas Climático da Região Sul do Brasil (WREGE et al., 2011), a zona litorânea formada pelo Paraná e divisa com Santa Catarina (Litoral Norte) é a região tropical com a maior pluviosidade da Região Sul, chegando na Serra do Mar a totais que variam entre um total anual de 3500 a $4000 \mathrm{~mm}$.

Baldo et al. (2001) observaram elevados totais de pluviosidade para a região costeira dos estados do Paraná e Santa Catarina, com valores superiores a $2.000 \mathrm{~mm}$, dada a influência à associação de uma transição entre as correntes frias das Malvinas e a corrente quente do Brasil, especialmente com o incremento de pluviosidade nos meses de janeiro, fevereiro e dezembro. Ainda, discorreram que o papel desempenhado pela Serra do Mar, compartimento geomorfológico que divide a orla marítima do interior planáltico de altas altitudes, e que forma uma barreira que dificulta a entrada das massas de ar e, inversamente, ao transpor as montanhas no movimento ascendente geram as chuvas orográficas a barlavento da brisa marítima. A variabilidade pluviométrica da região Sul e sua dinâmica atmosférica estão descritas com maiores detalhes a seguir. 


\subsection{Variabilidade pluviométrica e a dinâmica atmosférica regional}

A dinâmica atmosférica do Brasil Meridional é significativamente complexa, com a atuação de diversos mecanismos importantes, como os sistemas atmosféricos intertropicais e extratropicais e as relações e interações com o relevo, a maritimidade e a continentalidade (NERY et al., 2002; NERY, 2006; SILVA, 2006; GRIMM, 2009). Segundo Nery e Carfan (2014), a região Sul do Brasil caracteriza-se pela uniformidade preponderante da distribuição mensal da pluviosidade ao longo do ano e que, entretanto, algumas partes dos estados do Paraná e Santa Catarina tem uma bem marcada onda anual da pluviosidade, com o máximo durante o verão e o mínimo no inverno.

A homogeneidade do regime de chuvas para a região Sul do Brasil se deve às características da circulação atmosférica, uma vez que esta região caracteriza-se principalmente pela atuação dos sistemas polares para a formação das chuvas e, no entanto, como destacam Nimer (1989), Baldo et al. (2001), Baldo (2006), Silva (2006) e Zandonadi (2013), no trimestre de janeiro, fevereiro e dezembro verifica-se a intensificação dos sistemas atmosféricos intertropicais, nos quais predominam a convecção, sobretudo no Paraná e Santa Catarina, e que associados as frentes frias geram elevados totais de pluviosidade para estes estados.

A circulação atmosférica na região Sul do Brasil, na qual está inserida a área de estudo, é destacada em relação às demais regiões do Brasil por apresentar como característica singular, mesmo que não exclusiva, da atuação da massa Polar Atlântica e do sistema frontal denominado de Frente Polar Atlântica (Figura 17). A frente polar atlântica é o sistema frontal que corresponde à perturbação atmosférica com uma a maior atuação na região Sul do Brasil e que resulta numa queda significativa da temperatura, em aumento da nebulosidade e da umidade relativa e, consequentemente, na geração da precipitação pluviométrica. Seguida à frente polar atlântica, frequentemente há a incursão da massa Polar Atlântica, que possui uma maior atividade no outono e inverno, se origina do anticiclone polar atlântico e tem como características de tempo o rápido declínio de temperatura, maiores amplitudes térmicas e umidade relativa do ar muito baixa (NERY, 2006; SILVEIRA, 2006; REBOITA et al., 2010; BORSATO; MENDONÇA, 2015; CERA; FERRAZ, 2015; CARDOSO et al., 2015). 


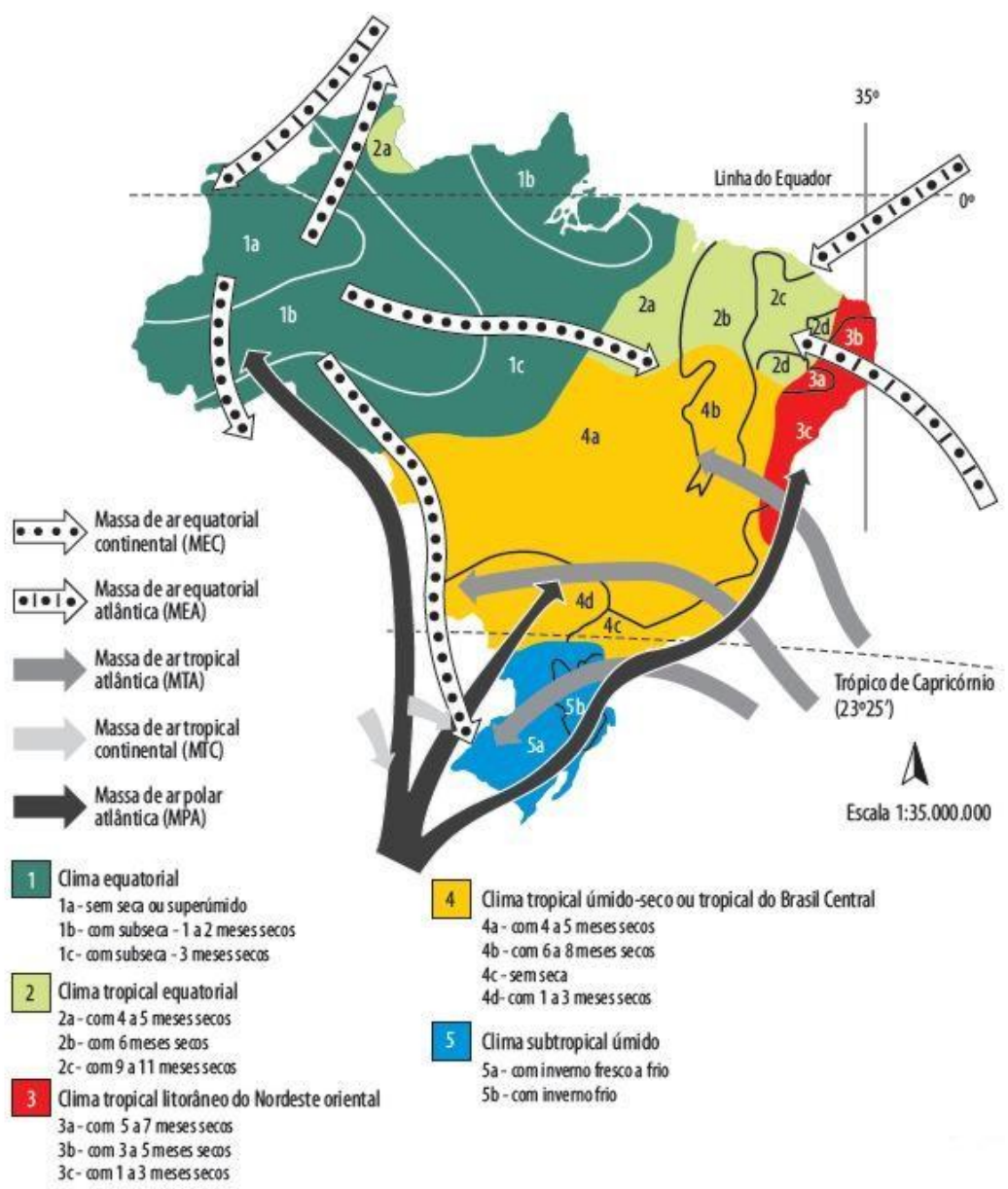

Figura 17 - Tipos climáticos segundo a classificação de Strahler (1951) e a dinâmica atmosférica para o território brasileiro (MONTEIRO, 1968). Fonte: Mendonça e Danni-Oliveira (2007).

De características quente e úmida, a massa Tropical Atlântica ocorre na região marítima quente do Atlântico Sul nas imediações do trópico de Capricórnio, onde recebe muito calor e umidade na superfície. Nimer (1989) descreve que a movimentação do ar nessa região é determinada pelo anticiclone subtropical e devido à presença da corrente marítima (quente), a massa sofre grande aquecimento na costa da América do Sul, predominantemente no verão, quando é maior a temperatura dessa corrente. No entanto, Baldo (2006) e Zandonadi (2013) discorrem que após superar as barreiras orográficas da Serra do Mar, a incursão deste sistema atmosférico no continente normalmente é responsável pela condição de tempo quente e estável.

A massa Tropical Continental é oriunda da frontólise na Frente Polar Pacífica, cujos ciclones se movem para sudeste ocluindo depois de transpor os Andes, onde se transforma pelo efeito de dissecação adiabática e, portanto, caracteriza-se pelas condições de elevada temperatura e baixa umidade relativa do ar (BARATTO et al., 2013). Baldo (2006) cita que sua baixa umidade aliada à forte subsidência dificulta a formação de 
nuvens de convecção sendo, portanto, responsável por tempo quente e seco e é o principal mecanismo atmosférico responsável pela ocorrência de veranicos no estado do Paraná, períodos de 15 dias ou mais sem chuvas durante a estação chuvosa e que são frequentes, conforme afirmam Bernardes et al. (1988).

A massa Equatorial Continental, com centro de origem na parte ocidental da Amazônia, tende a avançar para o interior do continente nos sentidos Noroeste e Sudeste, tendo como característica predominante a instabilidade, e constitui-se em um dos mecanismos que mais transportam umidade para a região Sul do Brasil no período do verão (MARENGO, 2006).

As linhas de instabilidade tropical geralmente antecedem a entrada de uma frente polar atlântica. Esse sistema é responsável pela formação de tempo instável, aumento na nebulosidade e na umidade relativa, gerando num curto período chuvas de forte concentração no tempo e no espaço. Este tipo de tempo sucede quase sempre ao tempo estável e quente motivado pelo domínio do anticiclone subtropical e, mesmo não ocorrendo somente no período de verão, perdura do período que vai de quase toda primavera até o início do outono, desde que a configuração atmosférica regional esteja dotada da presença de calor e umidade, propiciando os processos de convecção (BEREZUK; SANT’ANNA NETO, 2006).

A Zona de Convergência do Atlântico Sul (ZCAS) é um importante fenômeno que ocorre principalmente durante o verão na América do Sul, que tem na sua atuação mais frequente de setembro a março, causando constantes chuvas com significativos volumes (REBOITA et al., 2010; BORSATO et al., 2012; QUADRO et al., 2012; AMBRIZZI; FERRAZ, 2015). O acréscimo dos totais pluviométricos na primavera e no outono também se atribui à formação dos Complexos Convectivos de Mesoescala caracterizamse por sua grande extensão de ocorrência e por determinar eventos de chuvas torrenciais em um período de tempo que varia habitualmente entre 6 a 12 horas (VELASCO; FRITSCH, 1987; FEDOROVA; KHAN, 1999; REBOITA et al., 2010).

Em estudos da dinâmica atmosférica para a bacia hidrográfica do rio Ivaí (PR), Baldo (2006) observou que a frente polar atlântica é o sistema atmosférico de maior importância na sucessão dos tipos de tempo para esta área de estudo. Esta mesma autora destacou que a participação dos sistemas frontais com diferentes intensidades no decorrer do ano apresenta estreita relação com distribuição da pluviosidade e suas irregularidades. Ressaltou que a quantidade de passagens de sistemas frontais não é determinante na 
gênese da pluviosidade, mas sim a associação de suas características com outros mecanismos responde pelos maiores totais de pluviosidade.

Correa e Galvani (2017) estudaram a variabilidade da precipitação pluvial para a bacia hidrográfica do rio Piquiri (PR), a partir da técnica de ano padrão de Sant'Anna Neto (1995). Destacaram que em durante as estações do ano chuvoso (1983) e seco (178), o setor norte da área de estudo mostrou os menores totais de precipitação e o aumento gradativo em direção sul, destacando o aumento nos totais pluviométricos em 1983 e sua relação com o El Niño. Observaram que utilização da média climatológica restringe-se a uma análise generalizada, enquanto que a análise dos anos-padrão fornece informações detalhadas das características da dinâmica temporal das chuvas.

Segundo Fritzsons et al. (2011), o Paraná apresenta uma notável variabilidade pluviométrica por estar situado numa área de transição entre regimes de clima tropical e temperado. Utilizando-se da do método hierárquico da variância mínima Ward e da distância euclidiana, observaram quatorze grupos homogêneos quanto ao regime de pluviosidade para todo território paranaense. Destacaram que litoral do estado do Paraná sobressai-se como o setor de maior pluviometria da região Sul do Brasil devido à frequente entrada de frentes polares associadas ao relevo de escarpas abruptas e a umidade advinda do Oceano Atlântico.

Fritzsons et al. (2011) verificaram que as estações meteorológicas e postos pluviométricos do litoral paranaense se separaram nitidamente dos demais grupos nas análises empregadas, decorrente de fatores condicionadores ao longo da encosta e da Serra do Mar: orografia, brisa marítima, contraste térmico entre terra e oceano e águas interiores. Observaram que a região mais próxima ao Alto Iguaçu apresenta uma pluviosidade mais heterogênea ao longo do ano devido ao relevo e a entrada frequente de sistemas frontais associados ao jato subtropical. Por sua vez, a região do Vale do Ribeira caracterizou-se por uma variabilidade pluviométrica mais aproximada do clima tropical, com um máximo de precipitação nos meses de verão e primavera e uma redução significativa no outono e inverno, principalmente por localizar-se circundado por serras e planaltos elevados a mais de 1.000 metros.

Jorge e Mendonça (2008) mostraram que, embora não apresente nenhum período seco ao longo do ano, o litoral paranaense apresenta um máximo acentuado de pluviosidade nos meses de verão, especialmente no período de dezembro a março, recebendo nesta época a atuação predominante da massa tropical atlântica. Destacaram que o total anual de chuvas se apresentou significativamente acima da média histórica em 
anos de El Niño, evidenciando a ligação entre este evento no Oceano Pacífico e as chuvas no litoral Atlântico.

Segundo Silva e Guetter (2003), a maior frequência dos eventos pluviométricos extremos responde pela intensificação da ocorrência de enchentes urbanas e do maior escoamento superficial em áreas rurais, que são responsáveis pela aceleração de processos erosivos. Discorreram que alguns municípios do estado do Paraná têm apresentado uma aceleração do ciclo hidrológico desde o início da década de 1970, na qual houve a aceleração do êxodo rural e da expansão urbana, com o aumento da frequência de chuvas mais intensas, do aumento das vazões médias e da ocorrência das estiagens com maior duração.

Machado et al. (2013) identificaram que a região Litorânea corresponde ao setor de maiores totais anuais de pluviosidade, com médias superiores a $2.600 \mathrm{~mm}$, ao passo que setores isolados da bacia hidrográfica do Ribeira caracteriza-se por médias anuais inferiores a $1.200 \mathrm{~mm}$. Observou-se que o tempo de retorno de uma precipitação diária superior a $100 \mathrm{~mm}$ é inferior a 01 ano no setor nordeste da bacia hidrográfica litorânea, sendo que para o Vale do Ribeira este tempo de retorno se reduz para 15 anos. Portanto, seus resultados demonstraram o papel desempenhado pela orografia da Serra do Mar não tão somente para as normais climatológicas, mas como também para a ocorrência dos eventos pluviométricos máximos diários.

Silva et al. (2015) utilizaram-se dos indicadores climáticos R95p (chuvas fortes superiores a 95\% dos percentis) e R99p (chuvas intensas superiores a 99\% dos percentis) e, a partir do teste estatístico não paramétrico de Mann - Kendall, buscaram avaliar averiguar as tendências nas séries históricas de 37 estações meteorológicas do estado do Paraná. Contrapondo-se a Silva e Guetter (2003), identificaram que não houve para o período analisado significância estatística para os indicadores de extremos climáticos associados à precipitação.

O estudo das modificações espaciais e temporais da precipitação pluviométrica no estado do Paraná realizada por Ely e Dubreuil (2017) revelou que as tendências mais significativas indicaram o aumento dos totais anuais, sendo que dentre os setores de maior significância de aumento nos testes de correlação linear e Mann-Kendall estão o litoral norte e a região metropolitana de Curitiba. Entretanto, revelaram que a tendência de redução da pluviosidade anual é mais abrangente espacialmente no Paraná, embora não sejam estatisticamente significativas. 
Os resultados de Carmello e Sant'Anna Neto (2016) indicaram que a vertente paranaense da bacia hidrográfica do rio Paranapanema apresenta a predominância de séries históricas homogêneas, ou seja, sem tendência de alteração significativa nos totais pluviométricos interanuais, a partir dos testes de Mann-Kendall e Pettit, para o período de 1999 a 2010. Entretanto, estas mesmas técnicas indicaram uma tendência de elevação das chuvas para o período chuvoso, que vai de outubro a abril, inclusive nos setores de predominância do clima Tropical.

Utilizando-se da metodologia da Spatial Synoptic Classification (SSC), Armond (2014) caracterizou os tipos de tempo responsáveis pelas condições atmosféricas próprias para a ocorrência dos episódios e eventos extremos pluviométricos na cidade do Rio de Janeiro. Este método de classificação climática foi utilizado anteriormente para os dados dos Estados Unidos (SHERIDAN, 2002) e da Europa Ocidental (BOWER et al., 2007) e, mais recentemente, foi empregada para a cidade de São Paulo por Fontão et al. (2018). Este estudo para a capital paulistana destacou a eficácia deste procedimento metodológico para avaliar as condições atmosféricas em um período mais extenso e, contudo, destacam as limitações do emprego da SSC devido ao fato de que este método atribui classes de tipos de tempo a partir de variáveis climáticas por meio de um software e desconsidera aspectos como a análise das cartas sinóticas e da circulação atmosférica local.

Este item especificou as características de distribuição espacial e temporal das chuvas na região Sul do Brasil e os mecanismos atmosféricos associados aos diferentes regimes pluviométricos identificados, haja vista que um dos objetivos específicos desta pesquisa é associar a variabilidade pluviométrica com as características da gênese das chuvas, seguindo os pressupostos da Análise Rítmica Climatológica de Monteiro (1971) para a análise de eventos pluviais extremos e a Spatial Synoptic Classification (SSC) de Sheridan (2002) para a gênese pluvial do segmento temporal de 2007 a 2015 . Explicitouse também subsídio teórico-metodológico para a utilização da técnica Mann-Kendall para averiguar mudanças nos padrões de pluviosidade previamente utilizadas em território paranaense e que serão utilizadas com um maior nível detalhamento devido a maior densidade de dados pluviométricos selecionados nesta pesquisa.

\subsection{Os índices climáticos oceânicos e a dinâmica atmosférica do Brasil Meridional}

As anomalias extremas de precipitação em diversas regiões do Globo Terrestre são muitas vezes associadas ao aquecimento ou resfriamento anômalo da temperatura de 
superfície dos Oceanos e suas teleconexões correspondentes (SILVA; SILVA, 2015). Segundo Coelho et al. (2002) e Nascimento Júnior e Sant'Anna Neto (2016), conceituase as teleconexões como a associação das condições climáticas entre as diferentes regiões do mundo, inicialmente descoberta por Walker (1924) a partir do estudo entre a correlação linear entre os dados de pressão atmosférica, temperatura do ar e precipitação e observou três padrões de teleconexões: no hemisfério norte (Oscilação do Atlântico Norte e a Oscilação do Pacífico Norte) e um no hemisfério sul (Oscilação Sul).

Atualmente, Stenseth et al. (2003) e Limberger (2016) listaram as seguintes teleconexões: Oscilação Antártica; Oscilação Ártica; Padrão do Atlântico de Leste; Padrão do Atlântico Leste/ Rússia Oeste; El Niño - Oscilação Sul; Padrão do Pacífico Leste; Modo de Anular Norte; Oscilação do Atlântico Norte; Oscilação do Pacífico Norte; Oscilação Decadal do Pacífico; Padrão Escandinavo; Modo Anular Sul; Oscilação Sul; Padrão Tropical Norte; Padrão do Pacífico Oeste. No entanto, Limberger (2015) discorre que apesar de todas estas teleconexões, a maior parte da literatura verifica a associação de uma variável particular majoritário com o padrão de teleconexão da região IOS (Índice de Oscilação Sul), um dos índices mais utilizados para caracterizar os eventos ENOS (El Niño - Oscilação Sul).

Os fenômenos El Niño e La Niña são caracterizados, respectivamente, pelo aquecimento e resfriamento anômalo das águas do Oceano Pacífico Equatorial central e leste. Concomitantemente, o Índice de Oscilação Sul (IOS) representa um fenômeno de grande escala caracterizado pela diferença de pressão ao nível do mar entre o Pacífico central, nas proximidades do Taiti, e o Pacífico oeste, no estado australiano de Darwin, gerando o enfraquecimento ou intensificação dos ventos alísios sobre o Oceano Pacífico Equatorial. Segundo Cera e Ferraz (2015), o acoplamento destes fenômenos, oceânico e atmosférico, nestas regiões é denominado de El Niño - Oscilação Sul (ENOS), e a variação anômala destes componentes (El Niño/La Niña e IOS) mostram duas fases opostas do ENOS, que em média tem uma periodicidade de quatro a sete anos e duração de doze a dezoito meses.

Segundo Ambrizzi (2003), os ENOS caracterizam-se como uma "gangorra" de pressão atmosférica em grande escala que atua sobre o Oceano Pacífico Tropical e é marcado por condições anômalas no oceano e na atmosfera, atribuídas às oscilações recorrentes na zona de ressurgência da Corrente de Humboldt, que ocorrem no Pacífico Equatorial Leste e nas regiões costeiras do Peru e Equador. Com estas alterações, verificam-se mudanças nos processos entre oceano e atmosfera, que perturbam e 
modificam as condições de tempo e clima em diferentes regiões do Globo Terrestre (McPHADEN, 1999). As observações de Ambrizzi (2003) e McPhaden (1999) são concordantes com a ampla bibliografia difundida para as diferentes regiões do planeta e com as informações do Centro de Previsão de Tempo e Estudos Climáticos (CPTEC, 2016) do Instituto Nacional de Pesquisas Espaciais (INPE), que demonstram a existência de significativas alterações de temperatura e precipitação ao longo do Globo Terrestre que estão relacionadas aos eventos de El Niño e La Niña.

A ocorrência dos eventos de ENOS é definida por meio de índices calculados com base em variáveis atmosféricas e oceânicas, como o Índice de Oscilação Sul (IOS), o Multivariate ENSO Index (MEI) e a Anomalia de Temperatura de Superfície do Mar (TSM) das diferentes regiões de Niño (Figura 18). Segundo Silva e Silva (2015), a TSM da região do Niño 1+2, nas adjacências da costa equatoriana, obteve os valores mais altos de correlação linear com a precipitação do Sudeste da América do Sul para a defasagem de 01 mês, ao passo que o MEI e a TSM da região Niño 4 mostraram valores significativos de correlação linear para a defasagem em até 03 meses para a mesma região sulamericana.

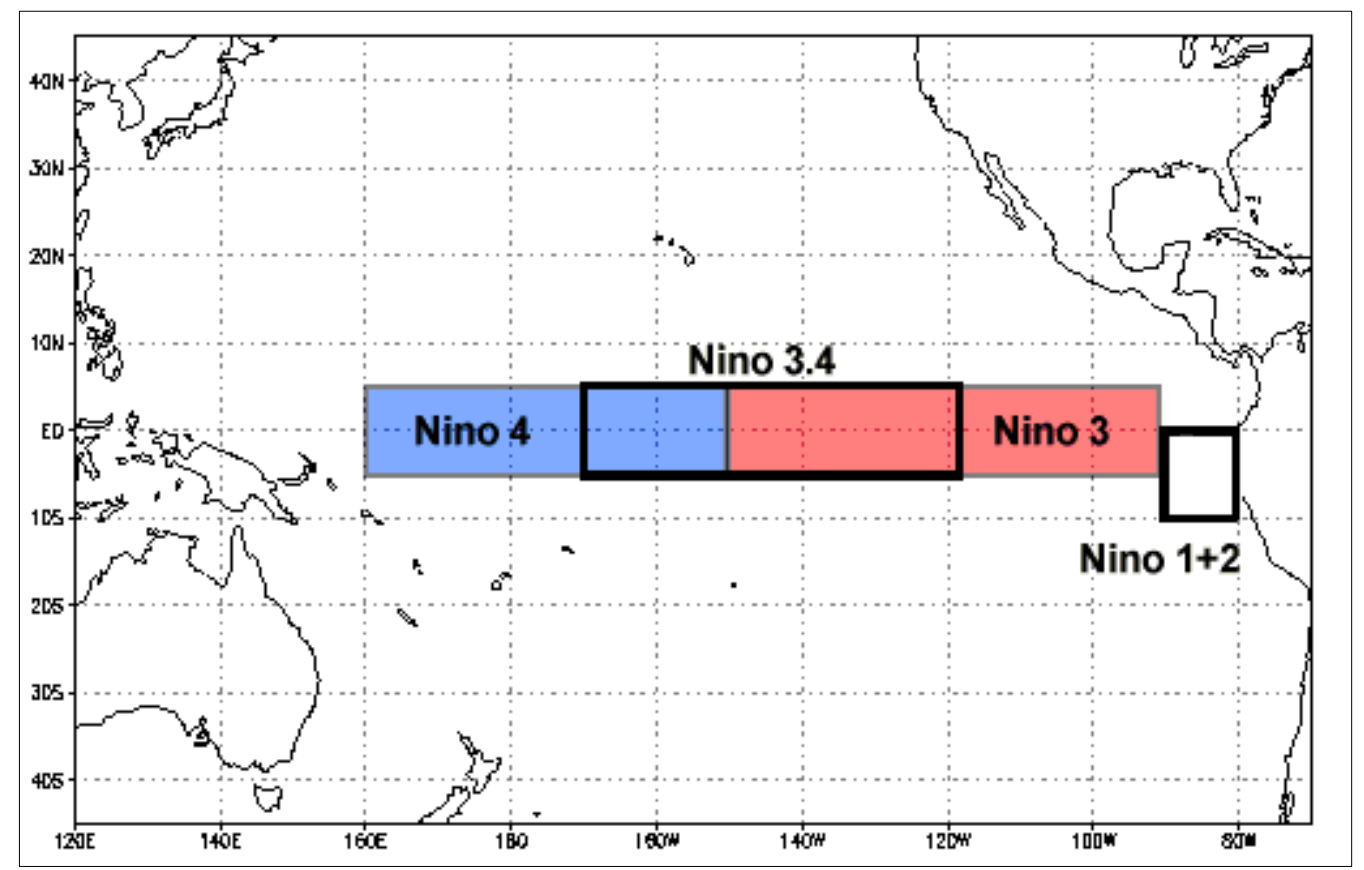

Figura 18 - Regiões dos Niños. Fonte: NOAA (2016).

Dentre as anomalias de temperatura de superfície do Mar (TSM), o aquecimento ou o resfriamento das águas do Oceano Pacífico Equatorial, que recebem os nomes de El Niño e La Niña, correspondem ao maior modulador das precipitações nas escalas 
interanuais e intersazonais na região Sul do Brasil e tem sido o mecanismo atmosférico de macroescala mais estudado para analisar ou explicar a variabilidade das chuvas nesta região do Brasil Meridional (RAO; HADA, 1990; GRIMM et al., 1998; GRIMM et al., 2000; BALDO et al., 2001; GRIMM, 2009).

Grimm et. al. (1998) investigaram o impacto dos eventos de El Niño e La Niña (fase quente e fria da Oscilação Sul) para a região Sul do Brasil utilizando-se de dos dados mensais de precipitação de 250 estações pluviométricas. A estrutura espacial das anomalias de precipitação em sub-regiões indicou a influência latitudinal, do relevo e da proximidade com o oceano e observaram que toda a região Sul do Brasil obteve uma maior relação entre os eventos ENOS e as anomalias de chuva do que na Argentina e Uruguai. Notaram que durante a primavera do evento de La Niña ocorrem consistentes tendências às secas, com um máximo durante o mês de novembro e que, principalmente, a relação entre a fase quente (El Niño) é mais consistente com o aumento dos totais de pluviosidade do que a ocorrência de redução de chuvas com a fase fria (La Niña).

Grimm (2003) observou a influência do El Niño na circulação monçônica de verão na América do Sul, concluindo que as anomalias de precipitação são favorecidas pela perturbação na circulação das células de Walker e Hadley sobre o Oceano Pacífico Leste e a América do Sul, e pelos trens de ondas de Rosby sobre a América do Sul. Ao estudar o impacto do El Niño durante o período de chuvas na América do Sul esta mesma autora relata que com a intensificação do calor da baixa atmosfera na porção subtropical por aquecimento anômalo durante a primavera, ocorre uma convergência anômala de baixo nível e da circulação ciclônica no sudeste do Brasil, enquanto que nos níveis superiores prevalecem as anomalias de divergência e circulação anticiclônica. Esta estrutura termodinâmica aumenta a precipitação no Centro-Leste do Brasil, ao passo que as anomalias secas no Norte do Brasil são deslocadas para o norte, e as anomalias no Sul do Brasil quase desaparecem.

Portanto, embora se tenha verificado a influência do El Niño para a ocorrência das anomalias de precipitação na região Sudeste do Brasil durante a primavera, o aumento de chuvas no mês de janeiro está diretamente relacionado às condições locais com a intensificação da circulação monçônica e o aquecimento das águas do Oceano Atlântico e, por esta razão, recorreu-se a avaliação da correlação entre o modo de variabilidade GMAT, dada a sua influência em outras regiões brasileiras (LIMBERGER, 2016; SANTOS; MANZI, 2012). 
Nery e Carfan (2014) afirmam que o principal período de atuação do ENOS na região Sul do Brasil ocorre durante a primavera, especialmente em outubro e novembro, com um período de significativa atuação durante o outono, particularmente nos meses de maio e junho. De modo geral, observaram que o Brasil Meridional se caracteriza por uma precipitação acima/abaixo da normal climatológica durante as fases de El Niño/La Niña, embora nem todos os eventos dos ENOS produzam as mesmas alterações nos totais pluviométricos.

Coelho et al. (1999) realizaram um estudo climatológico sazonal da influência dos eventos extremos de ENSO. Para a região Sul do Brasil, observaram os seguintes padrões: as maiores anomalias negativas de pluviosidade ocorreram durante o inverno de La Niña moderado a forte; os maiores desvios positivos de pluviosidade durante a primavera dos eventos de El Niño foram verificados no estado do Rio Grande do Sul; excepcionalmente no verão, toda região Sul apresentou os maiores desvios de chuva na fase positiva da anomalia TSM. Especificamente para o evento de El Niño dos anos de 1997/1998, de elevado aumento da temperatura de superfície do Pacífico Equatorial (McPHADEN, 1999), toda região Sul caracterizou-se pelo significativo aumento da precipitação pluviométrica em relação às normas climatológicas.

Fontana e Berlato (1997) afirmam a influência dos fenômenos ENOS sobre a distribuição da precipitação pluvial no estado do Rio Grande do Sul. Mostrou-se que a média da precipitação mensal para este estado durante os eventos de ENOS é distinta conforme a fase do fenômeno e que o período de maior intensidade de influência do fenômeno, para ambas as fases, ocorre em outubro e novembro e, secundariamente, em maio e junho. O estudo de Santos (2008) concluiu que os eventos El Niño influenciam significativamente no aumento do potencial erosivo das chuvas devido aos acréscimos nas intensidades das precipitações em todas as regiões do Rio Grande do Sul.

Britto et al. (2008) estudaram a variabilidade temporal da chuva no estado do Rio Grande do Sul e observaram uma significativa associação com a ocorrência de El Niño e La Niña. Sobretudo, destacaram que as maiores alterações dos totais anuais de pluviosidade não ocorrem uniformemente no espaço, posto que as regiões oeste, central e nordeste gaúcho apresentaram os maiores acréscimos de chuva nos episódios de El Niño de 1982/1983 e 1997/1998.

Nery et al. (2006) demonstraram que a bacia hidrográfica do rio Uruguai, que divide os estados do Rio Grande do Sul e Santa Catarina, apresenta elevada influência do El Niño e La Niña, com chuvas acima e abaixo, respectivamente, para estes eventos, 
sendo que o setor a montante do curso principal do rio Uruguai apresenta as maiores anomalias de precipitação. Embora toda área de estudo apresente um regime de chuvas bem distribuídas ao longo do ano, estes autores utilizaram a análise de componentes principais e da análise multivariada para a obtenção dos grupos pluviométricos homogêneos para distinguir a atuação dos ENOS para as suas diversas porções.

Nos últimos anos, algum estudo tem-se voltado para averiguar a influência dos ENOS para a variabilidade interanual da pluviometria no estado do Paraná. Dentre eles, Sousa (2006) estudou a variabilidade da precipitação no território paranaense e sua associação com a anomalia TSM do Oceano Pacífico, identificando que os eventos de El Niño dos anos 1982/1983 e 1997/1998 foram os mais significativos para o aumento de chuvas e, inversamente, os eventos de La Niña de 1985 e 1988 influenciaram para a redução pluviométrica em relação às normas climatológicas. Entretanto, observou-se que as fases opostas dos ENOS não afetam todas as regiões do estado do Paraná com as mesmas proporções, sendo que a porção Centro-Sul.

Os estudos de Andrade e Nery (2003) indicaram que os fenômenos El Niño e La Niña explicam a variabilidade pluviométrica interanual para a bacia hidrográfica do rio Ivaí (PR), pois os anos de máximas e mínimas precipitações são considerados anos de ocorrência de tais fenômenos, tanto para as alterações dos totais de pluviosidade precipitada quanto para a ocorrência do número de dias de chuva. Demonstraram que o evento de El Niño ocorrido nos anos de 1982 e 1983 foram os responsáveis pela maior elevação de pluviosidade e os eventos de La Niña nos anos de 1985 e 1988 explicam a maior redução dos totais anuais de pluviosidade na referida área de estudo.

Silva et al. (2001) utilizaram-se da técnica de agrupamento para a identificação de regiões pluviometricamente homogêneas para a bacia hidrográfica do Iguaçu (PR) e identificaram que os eventos de ENOS apresentam diferentes atuações no controle da variabilidade interanual das chuvas, sendo que a região do curso médio do rio principal desta bacia hidrográfica obteve as maiores correlações com o IOS (Índice de Oscilação Sul). Seus resultados demonstraram valores mais significativos de correlação para a defasagem de 01 mês e que, invariavelmente, os eventos de ENOS apresentam uma significativa variabilidade intranual entre os grupos homogêneos obtidos.

Azevedo et al. (2006) estudaram a influência dos fenômenos ENOS na vazão do rio Iguaçu (PR). Seus resultados indicaram que os dados interanuais de todos os postos fluviométricos analisados apresentaram correlações significativas com esta anomalia TSM e que, majoritariamente, as melhores correlações foram obtidas para três meses de 
defasagem. Os eventos de El Niño em 1982/1983 e de La Niña em 1988 foram os mais significativos para o aumento e redução, respectivamente, dos volumes de vazão ao longo do curso principal do rio Iguaçu, o que demonstra a importância do fenômeno ENOS para a dinâmica fluviométrica em toda a área da bacia.

Este estudo, assim como os demais descritos acima, fundamentou a metodologia de análise dos eventos ENOS (IOS e ONI), a Oscilação Decadal do Pacífico e o Gradiente Meridional do Atlântico Tropical e seu impacto na variabilidade interanual pluviométrica das bacias hidrográficas do Alto Iguaçu, Ribeira e Litorânea.

\subsection{A problemática dos eventos pluviométricos extremos}

A precipitação pluviométrica é uma das variáveis climáticas mais associadas aos impactos socioeconômicos. Seus impactos ambientais podem estar relacionados à falta de chuvas, com as estiagens e secas severas, ou aos volumes excessivos, com alagamentos, enchentes, inundações e, de modo geral, nos movimentos de massa. Desta forma, a compreensão da variabilidade pluviométrica e, especialmente, da ocorrência dos eventos extremos é essencial para subsidiar a formulação de políticas públicas e a implantação de atividades econômicas e serviços públicos em muitas áreas tais como a agricultura, o monitoramento de desastres naturais, a previsão do tempo, fornecimento de energia elétrica, entre outros (OSCAR JÚNIOR, 2015; BRITO et al., 2016).

Uma das principais preocupações com uma mudança potencial do clima é a ocorrência de um aumento dos eventos extremos, dado que estudos observacionais indicaram a intensificação da ocorrência de precipitações extremas em diversas regiões do Globo Terrestre. Easterling et al. (2001) destacaram que o número total de dias de chuvas que excedem 50,8 mm e 101,6 mm nos Estados Unidos da América tem aumentado desde 1910 e, além disso, muitos países ao longo do Mundo que obtiveram o aumento ou decréscimo dos totais anuais ou sazonais de pluviosidade também mostraram uma alteração desproporcional na quantidade de precipitação extremas, repercutindo em elevadas perdas econômicas, humanas e sociais.

Segundo Chu et al. (2009), nos últimos anos, os eventos pluviométricos intensos têm causado danos às propriedades, à infraestrutura pública, à agricultura e ao turismo nas Ilhas do Havaí, nos Estados Unidos da América, e repercutido em grandes perdas econômicas e problemas sociais. Por exemplo, mencionaram que o episódio de chuva torrencial de $940 \mathrm{~mm}$ concentrada em 24 horas causou inundações nas ilhas do sudeste 
havaiano em novembro do ano de 2.000, com prejuízos avaliados em aproximadamente 88 milhões de dólares. Os eventos pluviométricos extremos foram analisados baseandose em três diferentes métodos: a média anual de dias de uma determinada quantidade de precipitação diária; o valor associado a um percentual específico de precipitação diária; os valores máximos diários anuais de precipitação associados com um período de retorno específico.

Os impactos dos eventos de pluviosidade extremos são mais significativos nos espaços urbanos devido à aglomeração de pessoas, à falta de infraestrutura, às formas desorganizadas de ocupação e expansão do espaço urbano, à segregação socioespacial e a fixação de capitais em ambientes frágeis (MARCELINO et al., 2006). Dentre estes impactos, estão os alagamentos, inundações, deslizamentos e escorregamentos, entre outros, que são responsáveis por diversos problemas sociais e ambientais, como mortes, desalojados, danos aos bens públicos e privados, comprometimento de serviços básicos, à saúde pública e a desorganização do espaço (OLÍMPIO et al., 2012).

Amorim e Monteiro (2010) discorrem que normalmente atribui-se à elevada quantidade, intensidade e frequência pela responsabilidade de grandes calamidades e por desarranjos principalmente em ambientes urbanos. Este equívoco se deve à falta de planejamento adequado da ocupação do solo e pelo desrespeito às vulnerabilidades geomorfológicas e climáticas. Desta forma, estas autoras citam que tanto em cidades localizadas em clima tropical quanto temperado, invariavelmente, tem se observado crescimentos que desvalorizam a probabilidade da ocorrência duradora da precipitação e que, consequentemente, as cidades desprovidas de um planejamento sustentável se tornam susceptíveis aos impactos decorrentes dos eventos extremos pluviométricos.

A maior parte dos eventos calamitosos associados a eventos pluviométricos extremos não pode ser evitado devido à característica excepcional de sua ocorrência. No entanto, podem-se identificar padrões com a finalidade de elaborar métodos preventivos para atenuar os efeitos destrutivos dos episódios extremos, posto que uma análise de risco permita correlacionar à probabilidade de ocorrência de eventos futuros às estimativas de danos potenciais (NICHOLLS, 2001). Embora as mudanças dos eventos extremos sejam naturalmente difíceis de detectar e modelar, a sociedade deve basear-se em uma análise de tomada de decisões baseadas nos riscos a partir de investimentos em infraestruturas a fim de reduzir a vulnerabilidade e minimizar os impactos decorrentes dos eventos extremos (MCBEAN, 2004). 
Sepúlveda e Petley (2015) mostraram que a distribuição geográfica dos deslizamentos de terra é heterogênea para a América Latina e Caribe e reflete a combinação de aspectos como relevo, precipitação e densidade populacional. Identificaram que nas áreas urbanas a presença de ocupações informais tem um significativo impacto para o número de fatalidades, tendo em conta o efeito da pobreza e marginalização. Entretanto, destacaram que em distintas regiões da área estudada, as ocorrências dos deslizamentos de terra refletem a precipitação anual.

Um dos aspectos mais significativos para os problemas e impactos decorrentes de chuvas intensas está na sua frequência e intensidade em regiões de clima Tropical. Ao realizar um estudo ao longo do Globo Terrestre, Panagos et al. (2017) destacam que os maiores potenciais anuais de erosividade se dão nas regiões tropicais $\left(7,104 \mathrm{MJ}\right.$ mm.ha ${ }^{-}$ $\left.{ }^{1} \cdot \mathrm{h}^{-1} \cdot \mathrm{ano}^{-1}\right)$, e nas regiões temperadas $\left(3,729.3 \mathrm{MJ} \mathrm{mm} \cdot \mathrm{ha}^{-1} \cdot \mathrm{h}^{-1} \cdot \mathrm{ano}^{-1}\right)$. Em parte da área em estudo, os resultados de Terassi e Galvani (2017) identificaram que a bacia hidrográfica Litorânea caracteriza-se por uma erosividade média anual de $\mathrm{MJ} \mathrm{mm} \cdot \mathrm{ha}^{-1} \cdot \mathrm{h}^{-}$ ${ }^{1}$.ano ${ }^{-1}$, com um período de maior atenção a efeitos decorrentes de chuvas intensas entre dezembro e março.

Steinke et al. (2006) e Steinke e Barros (2015) identificaram que durante as condições extremas de tempo no Distrito Federal, a população que reside nas áreas onde há a falta dos equipamentos urbanos básicos é mais afetada pelas consequências advindas da relação entre a área urbana e o clima. Mostraram que a configuração dos episódios da Zona de Convergência do Atlântico Sul (ZCAS) correspondeu ao fenômeno atmosférico determinante para a ocorrência dos mais elevados volumes de chuva para a estação chuvosa do verão, que frequentemente provoca inúmeros desastres urbanos, desde alagamentos até deslizamentos de encostas de rios. Ressalta-se que a maior vulnerabilidade aos desastres naturais, no Distrito Federal, tem aumentado em função da retirada da cobertura vegetal para o assentamento de núcleos urbanos, o aumento da impermeabilização do solo incrementando o escoamento superficial e, sobretudo, a falta de planejamento por parte dos governantes.

Rego e Barros (2014) mencionam que o aumento da impermeabilização do solo e a retirada da cobertura vegetal em Goiânia (GO) dificultam a infiltração da água da chuva, que leva ao escoamento de um maior volume de água diretamente para o curso d'água, principal condição responsável pelo aumento das inundações e alagamentos urbanos, uma vez que não se identificou nenhuma tendência de aumento dos totais anuais de pluviosidade. Conforme estes autores, os principais danos decorrentes das chuvas em 
Goiânia não se devem necessariamente aos volumes de precipitação, mas à falta de infraestrutura nos locais onde ocorrem.

Nóbrega et al. (2015) espacializaram a partir do método da Krigagem os dados de precipitação pluviométrica diária provenientes do Climate Prediction Center para analisar a tendência espacial e temporal da pluviosidade do Estado de Pernambuco tendo como base os índices de extremos climáticos extremos e os quantis. Observou-se que as chuvas estão cada vez mais concentradas em poucos dias ao longo do ano nos sertões e agreste de Pernambuco. Encontrou-se para o sertão pernambucano o maior número de episódios extremamente secos e também a mais quantidade de eventos extremamente chuvosos concentrados nos meses de dezembro, janeiro e fevereiro, que corresponde ao período chuvoso nesta região.

Utilizando-se da técnica de quantis para a identificação dos eventos extremos pluviais em Jaboatão dos Guararapes (PE), Nóbrega e Farias (2016) mostraram que os maiores totais pluviométricos mensais e a maior probabilidade da ocorrência de maiores chuvas concentradas se dão no período que vai de abril a agosto. $\mathrm{Na}$ análise episódica, observaram a ocorrência de totais pluviométricos de $209 \mathrm{~mm}$, equivalente a $61 \%$ do total médio mensal, para a localidade pernambucana durante os três primeiros dias do mês de junho de 2005, com a ocorrência de transbordamento dos leitos dos rios Duas Unas e Jaboatão, seis mil desalojados, quatro mil e quinhentos desabrigados, 20 óbitos e 76 pessoas feridas.

Zanella et al. (2009) e Olímpio et al. (2012) constataram que o sítio urbano de Fortaleza (CE) apresenta uma predisposição a ocorrência de episódios pluviais concentrados e caracteriza-se pela elevada vulnerabilidade socioambiental decorrente das formas de uso do espaço e das condições socioeconômicas de determinadas parcelas da população. Durante os eventos diários mais elevados, a população encontra-se em riscos, materializados em impactos como as mortes, os desabrigados, falta de alimentos, o comprometimento dos serviços públicos, os prejuízos econômicos, entre outros.

Olímpio et al. (2013) discorrem que o processo de constituição do território de Fortaleza (CE) implicou na ocupação de áreas ambientalmente frágeis por populações altamente vulneráveis, resultando na formação de espaços de riscos, mais expostos aos episódios pluviais mais intensos. Verificaram que as formações dos eventos de elevada pluviosidade estiveram condicionadas à atuação associada da Zona de Convergência Intertropical (ZCIT) ao Vórtice Ciclônico de Ar Superior (VCAS), que ocasionaram um Complexo Convectivo de Mesoescala (CCM). 
Segundo Olímpio e Zanella (2015), os eventos naturais intensos são perigosos à sociedade, desde que estas não tenham meios para enfrentá-los adequadamente, através da gestão de riscos de desastres e decorrentes das condições socioeconômicas, culturais, político-institucionais frente à dinâmica natural. Mostraram que o estado do Ceará, dada as suas características de predominância do clima semiárido e irregularidade interanual da pluviometria, apresenta grandes avarias com os desastres naturais, seja pela escassez hídrica, através dos fenômenos das secas e estiagens, seja por episódios concentrados ou períodos chuvosos concentrados, que suscitam a desorganização do espaço geográfico, por meio das inundações.

Sousa et al. (2016) realizaram as estimativas dos riscos de chuvas extremas nas nove capitais do Nordeste brasileiro no período de 1910 a 2012 utilizando-se da função de distribuição de probabilidade e retorno de Gumbel (1941). Observaram que São Luís (MA) é a capital nordestina com os maiores riscos de ocorrências de chuvas extremas e que, entretanto, devido à maior densidade população, as ocorrências de chuvas entre 70,1 mm a 90,2 mm/dia causam mais facilmente sérios transtornos em cidades como Fortaleza, Recife e Salvador, as maiores capitais nordestinas, nas quais a população excluída de serviços básicos de infraestrutura são as mais vulneráveis aos transtornos das excepcionalidades pluviométricas.

Ao analisar os episódios extremos de pluviosidade na bacia hidrográfica do Igarapé Cereja, na área urbana de Bragança, no Nordeste do Paraná, Costa e Wollmann (2016) observaram que ocorreram 11 eventos de precipitação extrema entre o período de janeiro a maio de 2014, sendo 07 deles provenientes da formação da Zona de Convergência Intertropical (ZCIT) e 04 provocados pela atuação da Instabilidade Tropical (IT) associadas à ZCIT. Observaram que um mínimo de 54,6 mm em 24 horas é capaz de gerar impactos no espaço urbano de Bragança e que os maiores totais de pluviosidade se concentraram na porção nordeste da bacia hidrográfica supracitada, justamente na região do baixo curso, condição que favorece a ocorrência de enchentes.

Fialho e Brandão (2000) estudaram os eventos pluviométricos extremos, suas condições atmosféricas e sua repercussão para o espaço urbano da cidade do Rio de Janeiro (RJ). Os episódios mais intensos de pluviosidade diária no dia 13 de fevereiro de 1996, com registros de até $245,5 \mathrm{~mm}$ em 24 horas, estiveram associados à atuação da frente estacionária e corresponderam ao acúmulo de $7 \%$ do total pluviométrico anual em apenas 8 horas. Percebeu-se que a desordenada ocupação e a concentração das chuvas, característica do clima Tropical úmido, foram condições decisivas no estabelecimento da 
vulnerabilidade frente à ação das chuvas, uma vez que as regiões mais afetadas estão localizadas nos eixos de vales, sopés das encostas e nas vertentes de ocupação irregular.

Os estudos de Armond (2014) mostraram que a Frente Polar Atlântica foi o principal mecanismo de geração dos eventos e episódios extremos no espaço urbano do Rio de Janeiro (RJ), seguida da Frente Estacionária e da Zona de Convergência do Atlântico Sul. Observou-se que os eventos extremos de pluviosidade ocorreram com maior frequência no período chuvoso, de outubro a março, e ainda que os eventos destas magnitudade possam ser identificados durante praticamente todos os meses do ano. Quanto à repercussão dos eventos extremos de pluviosidade, os episódios se encontraram significativamente relacionados aos padrões de construção da cidade, devido à produção do espaço desigual e combinada do município do Rio de Janeiro.

Os eventos pluviométricos extremos ocorridos em 11 e 12 de janeiro de 2011 na região Serrana do estado do Rio de Janeiro foram um dos maiores desastres ambientais mais recentes. Chuvas torrenciais que atingiram de forma mais intensa sete municípios da Serra da Mantiqueira e Serra dos Órgãos, na porção central do estado do Rio de Janeiro, causaram a morte de mais de 905 pessoas, afetaram a vida de mais de 300 mil pessoas, decorrentes dos impactos gerados pelos grandes deslizamentos de terra e inundações, devido ao grande volume de chuva que atingiram a região, e repercutiram em avarias de 4,78 bilhões de reais. Segundo o INPE (Instituto Nacional de Pesquisas Espaciais), em dois dias foram registrados 166 milímetros de chuva em Nova Friburgo, mais de 70\% do valor médio histórico para o mês (BANCO MUNDIAL, 2012).

Durante o episódio pluviométrico extremos dos dias 17 e 18 de março de 2013, as estações meteorológicas pertencentes ao Instituto Estadual do Ambiente (INEA) e do Instituto Nacional de Meteorologia (INMET) registram um acumulado total de 424,5 mm para o município de Petrópolis e de $263 \mathrm{~mm}$ para Teresópolis, os dois municípios do estado da região Serrana fluminense normalmente são os mais atingidos pelas chuvas torrenciais concentradas. Segundo Andrade et al. (2015), este evento pluviométrico extremo esteve associado à passagem de uma frente fria acompanhada de intensos ventos em baixos níveis, favorecendo a convergência de umidade. Como um incremento, a orografia da região Serra do Rio de Janeiro e da Serra do Mar também foi apontada como um aspecto que favoreceu a intensificação da atividade convectiva.

Roseghini (2007) destacou a sazonalização das chuvas e a concentração de mais de $40 \%$ dos totais pluviométricos anuais no período do verão para o litoral norte do estado de São Paulo, características próprias do clima tropical úmido e que, entretanto, 
corresponde a um aspecto alarmante devido à convergência de uma elevada quantidade de pessoas para esta região durante o verão, o que representa um grande potencial de transtornos e de atingir o maior número de vítimas. A análise rítmica de Roseghini (2007) possibilitou indicar que o principal elemento a desencadear os eventos de precipitação intensa foi o estabelecimento da Zona de Convergência do Atlântico Sul (ZCAS), a partir dos sistemas frontais estacionários, associada à baixa pressão das frentes frias e aos ventos úmidos que sopram do oceano para o continente. Desta forma, entende-se que os eventos extremos pluviométricos no litoral norte paulista são controlados pelos sistemas tropicais (massa Tropical atlântica) e a ZCAS, auxiliados por sistemas frontais e pela orografia, condições imprescindíveis para os registros de maior quantidade de precipitação pluvial na vertente Atlântica da Serra do Mar.

Seluchi e Chou (2009) afirmam que os deslizamentos de terra na Serra do Mar ocorrem em casos de precipitações intensas que se acumulam não só ao longo de algumas horas, mas frequentemente ao longo de alguns dias. Portanto, devido a este aspecto, é importante estudar a variabilidade da precipitação durante os poucos dias anteriores aos episódios de deslizamentos de terra e de chuvas extremas. Estes autores observaram que a maioria dos deslizamentos de terra durante o período de 1995 a 2005 ocorreram de novembro a abril, com os maiores registros durante os meses de janeiro, fevereiro e março e descreveram que a formação da Zona de Convergência do Atlântico Sul (ZCAS), característica comum durante as monções de verão na América do Sul, corresponde ao principal mecanismo responsável pela ocorrência dos eventos de precipitação intensa e com maior associação aos deslizamentos de terra no verão na Serra do Mar.

Entretanto, Seluchi et al. (2011) discorrem que os eventos extremos pluviais, embora mais comuns durante o verão, ocorrem durante o inverno, como relataram no período entre 16 a 22 de julho de 2004, com a ocorrência de precipitação moderada e constante na região costeira do estado de São Paulo, que causou deslizamentos e inundações, impactos comumente inesperados para esta região brasileira durante o inverno. A condição sinótica que propiciou estas chuvas persistentes caracterizou-se pela passagem de um sistema frontal intenso, que ao atingir latitudes subtropicais tornou-se estacionária, combinada com a descaracterização do anticiclone pós-frontal, normalmente frio e de alta pressão, e os constantes e moderados ventos que sopravam do oceano em direção ao continente. Portanto, devido às condições sinóticas em combinação com os ventos persistentes de sul e sudeste, as chuvas foram causadas pelos efeitos orográficos 
da Serra do Mar, o que causou o aumento da convergência de baixo nível de ar relativamente quente e úmido.

Desta forma, verificou-se o papel desempenhado pelo efeito orográfico da Serra do Mar para o incremento e a intensificação das chuvas. Do ponto de vista geológico, durante as chuvas extremas e abruptas tendem a drenar superficialmente enquanto que as chuvas moderadas tendem a penetrar no solo. No caso estudado por Seluchi et al. (2011), a chuva fraca a moderada constante durante os três primeiros dias (16 a 18 de julho) causou a saturação do solo, e tornou-se moderada a intensa em 19 de julho, causando os grandes deslizamentos de terra.

Koga-Vicente e Nunes (2011) identificaram que, embora não apresentem os maiores montantes pluviométricos do litoral paulista, os municípios de Santos e Guarujá são os mais vulneráveis à ocorrência de eventos extremos pluviométricos diários, devido às expressivas taxas populacionais e de elevada densidade demográfica, que resulta em intensa ocupação da terra e aumenta a possibilidade de ocupação de áreas de risco. Averiguaram que os episódios pluviais impactantes se concentram em 93\% durante a estação chuvosa, de outubro a março, na região Sudeste do Brasil e a análise da duração dos episódios pluviais impactantes mostraram que estes são compostos por chuvas contínuas e com um pico de maior intensidade, variando entre um dia com chuvas fortes até 15 dias com chuvas intermitentes.

Marcelino et al. (2006) mapearam o risco de desastres naturais para o estado de Santa Catarina associados às instabilidades atmosféricas severas, a partir do cálculo do índice de risco, baseando-se em critérios como o número anual de eventos, a densidade demográfica e aspectos sociais e econômicos como educação, longevidade e renda. Observaram que municípios como Florianópolis, Blumenau, Joinville e Chapecó, que estão dentre os mais populosos do estado, obtiveram os mais elevados índices de risco e se destacaram pela elevada densidade demográfica e frequência dos desastres naturais. Estas condições ressaltam a necessidade do estabelecimento urgente de medidas não estruturais, com a implantação de um sistema de monitoramento e alerta de tempestades severa, a identificação de áreas mais seguras nos municípios para a instalação de abrigos e a elaboração de planos de evacuação.

Por suas características naturais de hidrografia, vegetação, solo e relevo natural, o litoral de Santa Catarina é altamente vulnerável aos eventos de movimentos de massa e inundações. Rodrigues et al. (2004) avaliou as condições sinóticas associadas aos eventos extremos de chuva na região litorânea do estado de Santa Catarina a partir da seleção de 
18 eventos ocorridos entre 1969 a 2010, considerando os extremos relativos ao quantis de $99,5 \%$ de chuva acumulada em cinco dias consecutivos. Observou-se que a maioria dos eventos pluviométricos extremos se concentra no período de 24 horas, com uma maior ocorrência durante o verão (56\%), em condições de predominância dos sistemas semiestacionários de alta pressão no mar com ventos persistentes de leste/nordeste em baixos níveis, que favorecem o transporte de calor e umidade para a costa catarinense.

Wollmann e Sartori (2010) averiguaram a relação existente entre a ocorrência de enchentes e a pluviosidade na escala sazonal para a bacia hidrográfica do rio Caí (RS). Concluíram que $50 \%$ dos casos de enchentes ocorreram no inverno em função do fortalecimento dos centros de ação, tanto tropicais quanto polares, as frontogêneses são mais intensas, levando à maior frequência de eventos de enchentes no Rio Grande do Sul. Em relação ao El Niño, afirmam que 62,5\% dos casos de enchentes na área de estudo estão associadas à manifestação deste fenômeno, sobretudo porque durante sua ocorrência, frequentemente, o Anticiclone Tropical Atlântico se fortalece e impede o avanço dos sistemas frontais para latitudes mais baixas, estacionando-o sobre território gaúcho e gerando condições de dias consecutivos de chuva e, consequentemente, possibilitando à ocorrência de enchentes.

Wollmann (2014), em estudo para o estado do Rio Grande do Sul, identificou que 90\% das ocorrências de enchentes estão condicionados à participação de correntes perturbadas de origem polar, com grande predomínio da frente de caráter estacionário para as regiões hidrográficas dos rios Guaíba e Uruguai, enquanto que para a região hidrográfica do Litoral predomina a atuação dos sistemas frontais oclusos (ciclones frontais) para a ocorrência de enchentes. Esta diferença espacial dos mecanismos responsáveis pela geração de elevados totais pluviométricos e, consequentemente, dos registros de enchentes, está associada à disposição do relevo rio-grandense em relação à frente polar atlântica, que se configura como o principal mecanismo de geração de chuvas intensas para este estado.

Murara et al. (2018) utilizaram-se de índices de tendência de precipitação pluvial para bacia hidrográfica do rio Itajaí, situada no nordeste do estado de Santa Catarina, e observaram o aumento significativo nos totais pluviais em algumas localidades. Notouse o aumento significativo dos totais anuais de pluviosidade (PRCTOT) e dos registros de chuvas superiores a $95 \%$ e $99 \%$ dos quantis e chuvas diárias máximas, sobretudo nos setores sudoeste e leste desta bacia hidrográfica, justamente setores que geralmente são os mais afetados pelas grandes enchentes neste setor do território catarinense. 
Os resultados de Zandonadi et al. (2015) demonstraram que algumas regiões da bacia hidrográfica do rio Paraná apresentam significativas tendências crescentes nos valores de precipitação anual e que estas alterações estão relacionadas ao aumento de precipitações mais intensas. Os dados de precipitação superior a $95 \%$ e a $99 \%$ dos percentis mostraram elevada correlação com os históricos de inundação para Curitiba e Goiânia, grandes municípios de muito densas áreas urbanas, responsáveis pelo o aumento de temperatura e, consequentemente, de precipitação máxima diária.

Para Silva et al. (2012), os estudos de eventos extremos são essenciais para que as obras de engenharia suportem os grandes volumes de precipitação, mesmo que excepcionais, possuem altas probabilidades de gerar sérios problemas devido às falhas de estimativas de valores críticos nos projetos. Estes autores verificaram para Londrina (PR) a probabilidade de ocorrer precipitações de 79,61 $\mathrm{mm}$ em apenas um dia para o período de retorno de dois anos e destacaram que 55\% dos 60 maiores totais de precipitação diária estiveram relacionados à atuação do fenômeno El Niño.

Os estudos de Mello et al. (2017) destacaram a excepcionalidade das classes de chuvas mais intensas em Paranaguá (PR), uma vez que 3,8\% dos registros diários foram superiores a 50,1 mm. Ao analisarem a gênese de alguns eventos extremos, mostraram que comumente as chuvas mais fortes estiveram relacionadas predominantemente com a atuação da Zona de Convergências de Umidade e, em menor frequência, pela massa tropical atlântica e frente polar atlântica.

Atualmente, os desastres naturais estão se tornando cada vez mais significativos, expondo a necessidade de documentar de forma eficaz os tipos e a magnitude dos riscos eminentes como um subsídio à tomada de decisão econômica e política. Berz et al. (2001) produziram a terceira edição do mapa mundial dos riscos aos desastres naturais, com os seguintes critérios: terremotos e vulcanismo; tempestades; inundações; perigos marinhos (ondas altas, quebra de blocos de gelos e derivas de icebergs); e os efeitos do El Niño e mudanças climáticas. Estes autores destacaram os prejuízos decorrentes do aumento significativo das chuvas extremas, inundações e tempestades com os eventos de El Niño na América do Sul, inclusive com os riscos extraordinários de secas na região Nordeste deste continente.

Dentre estes aspectos, a intensidade e duração das chuvas, em junção ao sistema natural fluvial e às características geomorfológicas de determinada região resultar as características dos alagamentos, enchentes, inundações e os mais diversos movimentos de terras, ocasionando severas perdas econômicas, sociais e humanas (ALCÁNTARA- 
ALAYA, 2001). Sobretudo, entende-se que os riscos a estes desastres naturais derivam de uma combinação entre a vulnerabilidade natural, resultante de uma interação entre a atmosfera, a biosfera e a litosfera, e a vulnerabilidade humana, decorrente de aspectos culturais, econômicos, sociais e políticos (Figura 19).

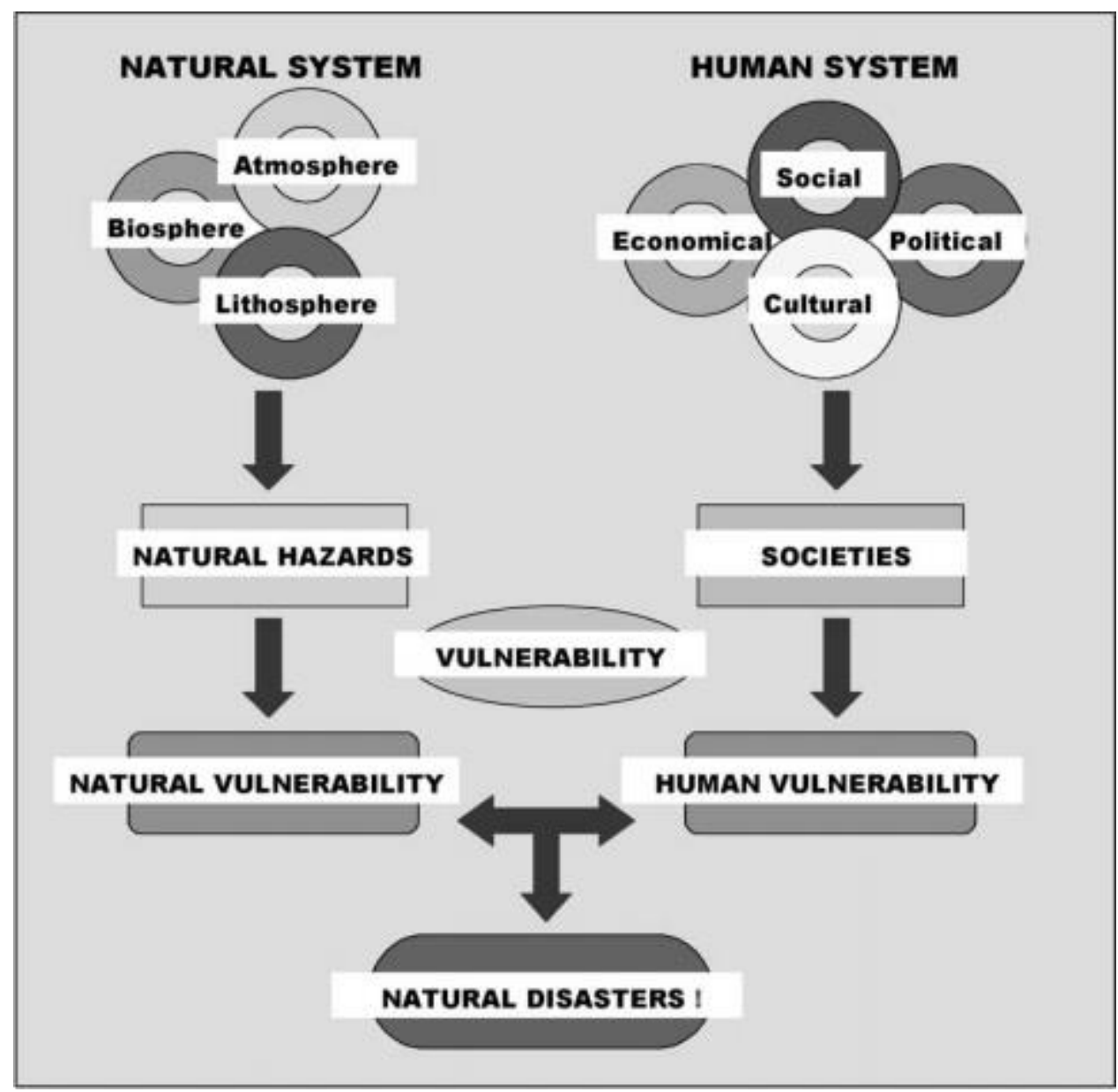

Figura 19 - Os componentes dos desastres naturais conforme Álcantara-Alaya (2001).

Segundo Nunes e Modesto (2002), o meio tropical úmido destaca-se pela grande diversidade importantes processos de modificações na paisagem, uma vez que a conjugação de seus atributos físicos com o acelerado processo de ocupação do espaço territorial tem levado essas áreas a uma rápida degradação ambiental, alterando seu dinamismo e baixando os limiares de estabilidade. Estes mesmos autores destacam que essa desestruturação torna o meio tropical úmido mais vulnerável a processos como movimentos de massa e inundações que, embora sejam naturais nessas áreas, passaram a ter uma frequência maior justamente pela aceleração do uso e ocupação inadequados do solo. 
Especialmente, Nascimento Júnior e Sant'Anna Neto (2014) discorrem que a vulnerabilidade da população frente às chuvas nas regiões de transição climática (entre as zonas tropical e temperada) soma-se ao contexto de climas irregulares com baixa previsibilidade e a estrutura desigual dos sistemas socioespaciais, que são componentes deflagradores de impactos e desastres de diferentes intensidades e consequências. A regionalização dos desastres associados às chuvas extremas no estado do Paraná mostrou que os municípios com as áreas urbanas mais populosas foram as mais afetadas pelos problemas de enchentes e inundações, com grandes perdas materiais, e na região Sul do estado, onde há o predomínio de climas subtropicais.

Desta forma, a dinâmica pluviométrica é bastante importante quando associada às estruturas dos sistemas socioespaciais, principalmente quando as excepcionalidades pluviométricas deflagram os impactos socioambientais, pois se configuram como importantes mecanismos dos arranjos territoriais paranaenses por evidenciarem os níveis de desigualdade territoriais no estado do Paraná (NASCIMENTO JÚNIOR; SANT'ANNA NETO, 2015).

Zanella (2006a) discorre que os eventos pluviais concentrados se constituem em agentes de problemas cuja função de seu grau de intensidade e, consequentemente, as respostas das populações. Desse modo, o grau de vulnerabilidade socioambiental das comunidades envolvidas é primordial para que tais eventos assumam características de desastres ambientais. No estudo realizado pela autora supracitada, na bacia hidrográfica do rio Atuba, na área urbana de Curitiba (PR), várias inundações foram registradas, evidenciando situações de extrema calamidade, com remoção das populações de suas residências, perdas materiais, doenças e até perdas humanas.

Evitar a ocorrência de desastres naturais foge a capacidade humana e, entretanto, por meio da prevenção, medidas mitigatórias podem ser desenvolvidas para minimizar os impactos causados pelos desastres (ZHANG et al., 2005). Nesta perspectiva, Sousa et al. (2016) discorrem que o estudo da frequência e probabilidade de ocorrência de chuvas intensas é fundamental para compreende seus efeitos em bacias hidrográficas, sejam elas urbanas ou rurais, pois as chuvas intensas causam grandes prejuízos nas cidades e repercutem em demais efeitos negativos como a erosão dos solos, inundações, danos à agricultura e problemas com reservatórios de armazenamento de água. Sendo assim, esta pesquisa tem como um dos seus pressupostos fornecer informações para minimizar os impactos decorrentes destes desastres naturais. 


\section{PROCEDIMENTOS METODOLÓGICOS E TÉCNICOS}

\subsection{Obtenção de dados, preenchimento de falhas e estatística descritiva}

Obtiveram-se os dados de pluviosidade de 54 postos pluviométricos pertencentes à Agência Nacional de Águas (ANA), à Companhia Paranaense de Energia (COPEL) e ao Instituto das Águas do Paraná, e os dados de pluviosidade, temperatura, direção e intensidade do vento e pressão atmosférica de 08 estações meteorológicas, ao Instituto Agronômico do Paraná (IAPAR), Instituto Nacional de Meteorologia (INMET) e ao Sistema Meteorológico do Paraná (SIMEPAR), que compreendem a série histórica de 1976 a 2015, e estão espacializados na figura 20 e descritos no quadro 1. Os dados de temperatura e precipitação referentes às estações meteorológicas do IAPAR, INMET e SIMEPAR serviram como base para a caracterização climática da área de estudo.

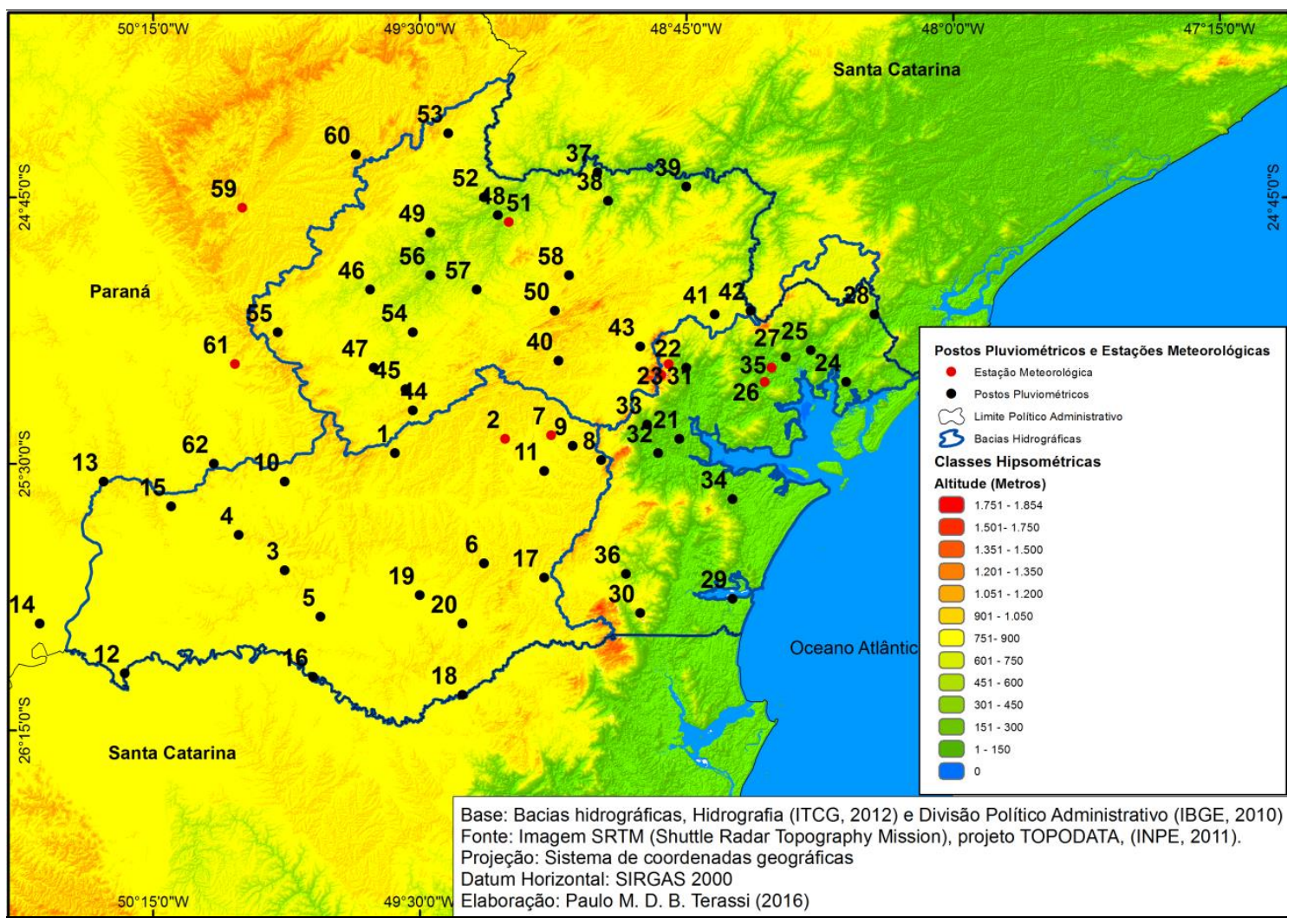

Figura 20 - Localização geográfica dos postos pluviométricos e estações meteorológicas situadas dentro e no entorno das bacias hidrográficas do Alto Iguaçu, Ribeira e Litorânea - Paraná.

Quadro 1 - Informações referentes aos postos pluviométricos e estações meteorológicas localizadas dentro e no entorno das bacias hidrográficas (BH) do Alto Iguaçu, Ribeira e Litorânea - Paraná.

\begin{tabular}{|c|c|c|c|c|c|c|c|c|}
\hline $\mathbf{N}^{\mathbf{0}}$ & $\begin{array}{c}\text { Código } \\
\text { ANEEL }\end{array}$ & $\begin{array}{c}\text { Posto Pluviométrico/ } \\
\text { Estação } \\
\text { Meteorológica* }\end{array}$ & $\begin{array}{c}\text { Alt. } \\
(\mathbf{m})\end{array}$ & $\begin{array}{c}\text { Lat. } \\
\left({ }^{\mathbf{o}} \mathbf{S}\right)\end{array}$ & $\begin{array}{c}\text { Long. } \\
\left({ }^{\mathbf{}} \mathbf{W}\right)\end{array}$ & $\mathbf{B H}$ & $\begin{array}{c}\text { Entidade } \\
\text { Responsável }\end{array}$ & $\begin{array}{c}\text { Falhas de } \\
\text { registros }(\%)\end{array}$ \\
\hline 1 & 2549019 & Campo Largo & 901 & 25,47 & 49,57 & Iguaçu & Águas do Paraná & 0,4 \\
\hline 2 & 83842 & Curitiba* & 923 & 25,43 & 49,26 & Iguaçu & INMET & 2,5 \\
\hline 3 & 2549049 & Lapa & 903 & 25,80 & 49,88 & Iguaçu & Águas do Paraná & 0,0 \\
\hline
\end{tabular}




\begin{tabular}{|c|c|c|c|c|c|c|c|c|}
\hline 4 & 2550028 & Lapa & 929 & 25,70 & 50,01 & Iguaçu & Águas do Paraná & 0,4 \\
\hline 5 & 2549000 & Lapa & 750 & 25,93 & 49,78 & Iguaçu & Águas do Paraná & 2,5 \\
\hline 6 & 2549062 & Mandirituba & 920 & 25,78 & 49,32 & Iguaçu & Águas do Paraná & 1,0 \\
\hline 7 & 2549041 & Pinhais* & 930 & 25,42 & 49,13 & Iguaçu & IAPAR/SIMEPAR & 0,0 \\
\hline 8 & 2548041 & Piraquara & 979 & 25,49 & 48,99 & Iguaçu & Águas do Paraná & 1,5 \\
\hline 9 & 2549004 & Piraquara & 900 & 25,45 & 49,07 & Iguaçu & ANA & 0,0 \\
\hline 10 & 2549001 & Porto Amazonas & 793 & 25,55 & 49,88 & Iguaçu & COPEL & 0,0 \\
\hline 11 & 2549017 & São José do Pinhais & 910 & 25,52 & 49,15 & Iguaçu & Águas do Paraná & 0,4 \\
\hline 12 & 2650005 & São Mateus do Sul & 770 & 26,09 & 50,33 & Iguaçu & COPEL & 12,1 \\
\hline 13 & 2550001 & São Mateus do Sul & 760 & 25,55 & 50,39 & Iguaçu & COPEL & 0,4 \\
\hline 14 & 2550017 & São Mateus do Sul & 770 & 25,95 & 50,57 & Iguaçu & COPEL & 0,8 \\
\hline 15 & 2550037 & São João do Triunfo & 856 & 25,62 & 50,20 & Iguaçu & Águas do Paraná & 0,2 \\
\hline 16 & 2649006 & Rio Negro & 770 & 26,10 & 49,80 & Iguaçu & COPEL & 0,0 \\
\hline 17 & 2549063 & Tijucas do Sul & 913 & 25,82 & 49,15 & Iguaçu & Águas do Paraná & 2,1 \\
\hline 18 & 2649018 & Piên & 790 & 26,15 & 49,38 & Iguaçu & COPEL & 0,8 \\
\hline 19 & 2549061 & Quitandinha & 820 & 25,87 & 49,50 & Iguaçu & ANA & 1,9 \\
\hline 20 & 2549003 & Quitandinha & 810 & 25,95 & 49,38 & Iguaçu & ANA & 0,8 \\
\hline 21 & 2548068 & Antonina & 74 & 25,43 & 48,77 & Litorânea & Águas do Paraná & 0,0 \\
\hline 22 & 2548003 & Antonina & 80 & 25,23 & 48,75 & Litorânea & ANA & 0,2 \\
\hline 23 & 2548070 & Antonina* & 60 & 25,22 & 48,80 & Litorânea & IAPAR/SIMEPAR & 0,0 \\
\hline 24 & 2458023 & Guaraqueçaba & 10 & 25,27 & 48,30 & Litorânea & Águas do Paraná & 6,3 \\
\hline 25 & 2548043 & Guaraqueçaba & 16 & 25,18 & 48,40 & Litorânea & Águas do Paraná & 0,4 \\
\hline 26 & 2548039 & Guaraqueçaba* & 40 & 25,27 & 48,53 & Litorânea & IAPAR & 9,8 \\
\hline 27 & 2548044 & Guaraqueçaba & 73 & 25,20 & 48,47 & Litorânea & ANA & 0,8 \\
\hline 28 & 2548042 & Guaraqueçaba & 9 & 25,08 & 48,22 & Litorânea & Águas do Paraná & 2,1 \\
\hline 29 & 2548053 & Guaratuba & 20 & 25,88 & 48,62 & Litorânea & Águas do Paraná & 15,8 \\
\hline 30 & 2548020 & Guaratuba & 150 & 25,92 & 48,88 & Litorânea & Águas do Paraná & 7,7 \\
\hline 31 & 2548038 & Morretes* & 59 & 25,25 & 48,82 & Litorânea & IAPAR & 0,0 \\
\hline 32 & 2548000 & Morretes & 8 & 25,47 & 48,83 & Litorânea & ANA & 0,0 \\
\hline 33 & 2548047 & Morretes & 88 & 25,39 & 48,86 & Litorânea & Águas do Paraná & 1,5 \\
\hline 34 & 2548049 & Paranaguá & 32 & 25,60 & 48,62 & Litorânea & Águas do Paraná & 2,5 \\
\hline 35 & 83844 & Paranaguá* & 4,5 & 25,23 & 48,51 & Litorânea & INMET & 0,0 \\
\hline 36 & 2548052 & São José dos Pinhais & 237 & 25,81 & 48,92 & Litorânea & Águas do Paraná & 0,6 \\
\hline 37 & 2449000 & Adrianópolis & 180 & 24,68 & 49,00 & Ribeira & ANA & 0,0 \\
\hline 38 & 2448037 & Adrianópolis & 227 & 24,76 & 48,97 & Ribeira & Águas do Paraná & 0,2 \\
\hline 39 & 2448035 & Adrianópolis & 270 & 24,72 & 48,75 & Ribeira & Águas do Paraná & 0,6 \\
\hline 40 & 2549051 & Bocaiúva do Sul & 969 & 25,21 & 49,11 & Ribeira & Águas do Paraná & 1,5 \\
\hline 41 & 2548040 & Campina Grande do Sul & 670 & 25,08 & 48,67 & Ribeira & COPEL & 4,0 \\
\hline 42 & 2548036 & Campina Grande do Sul & 642 & 25,07 & 48,57 & Ribeira & Águas do Paraná & 4,6 \\
\hline 43 & 2548001 & Campina Grande do Sul & 750 & 25,17 & 48,88 & Ribeira & ANA & 5,8 \\
\hline 44 & 2549045 & Campo Largo & 890 & 25,35 & 49,52 & Ribeira & Águas do Paraná & 0,8 \\
\hline 45 & 2549048 & Campo Largo & 781 & 25,29 & 49,54 & Ribeira & Águas do Paraná & 0,2 \\
\hline 46 & 2549056 & Campo Largo & 517 & 25,01 & 49,64 & Ribeira & Águas do Paraná & 1,2 \\
\hline 47 & 2549047 & Campo Largo & 800 & 25,23 & 49,63 & Ribeira & Águas do Paraná & 0,0 \\
\hline 48 & 2449006 & Cerro Azul & 270 & 24,80 & 49,28 & Ribeira & ANA & 2,1 \\
\hline 49 & 2449013 & Cerro Azul & 480 & 24,85 & 49,47 & Ribeira & Águas do Paraná & 0,6 \\
\hline 50 & 2549054 & Cerro Azul & 938 & 25,07 & 49,12 & Ribeira & Águas do Paraná & 0,0 \\
\hline 51 & 2449013 & Cerro Azul* & 360 & 24,82 & 49,25 & Ribeira & IAPAR/SIMEPAR & 0,0 \\
\hline 52 & 2449007 & Doutor Ulysses & 400 & 24,75 & 49,32 & Ribeira & ANA & 0,0 \\
\hline 53 & 2449021 & Doutor Ulysses & 818 & 24,57 & 49,42 & Ribeira & Águas do Paraná & 0,0 \\
\hline 54 & 2549053 & Itaperuçu & 750 & 25,13 & 49,52 & Ribeira & Águas do Paraná & 0,0 \\
\hline 55 & 2549052 & Ponta Grossa & 1012 & 25,13 & 49,90 & Ribeira & Águas do Paraná & 0,0 \\
\hline 56 & 2449063 & Rio Branco do Sul & 150 & 24,97 & 49,47 & Ribeira & ANA & 6,7 \\
\hline 57 & 2449020 & Rio Branco do Sul & 480 & 25,01 & 49,34 & Ribeira & ANA & 3,1 \\
\hline 58 & 2449024 & Tunas do Paraná & 880 & 24,97 & 49,08 & Ribeira & Águas do Paraná & 0,6 \\
\hline 59 & 83813 & Castro* & 1008 & 24,78 & 50,00 & Tibagi & INMET & 5,8 \\
\hline 60 & 2449030 & Castro & 1100 & 24,63 & 49,68 & Tibagi & Águas do Paraná & 2,1 \\
\hline 61 & 2550024 & Ponta Grossa* & 880 & 25,22 & 50,02 & Tibagi & IAPAR/SIMEPAR & 0,0 \\
\hline 62 & 2550042 & Palmeira & 951 & 25,50 & 50,08 & Tibagi & Águas do Paraná & 0,0 \\
\hline
\end{tabular}


As estações meteorológicas e os postos pluviométricos inseridos no entorno das bacias hidrográficas foram selecionadas para preencher adequadamente a pluviometria do recorte espacial e a ausência de registros, conforme preconizado por Bertoni e Tucci (1997). Os dados faltantes dos postos pluviométricos e estações meteorológicas foram preenchidos seguindo o método de ponderação regional de Villela e Matos (1975). Esse método tem como base o registro pluviométrico de três postos localizados o mais próximo possível do posto em que se verifica a falta de dados, com características pluviométricas (distribuição mensal e sazonal) e altitudes semelhantes (OLIVEIRA et al., 2010). Considerando x o posto que apresente a falha e por A, B e C os postos vizinhos, é possível determinar a precipitação (Px) desse posto x pela média ponderada do registro dos três postos vizinhos, nos quais os pesos são as razões entre as precipitações anuais normais (Equação 1).

$$
\mathbf{P x}=\frac{\overline{\mathrm{Px}}}{3}\left(\frac{\mathrm{Pa}}{\overline{\mathrm{Pa}}}+\frac{\mathrm{Pb}}{\overline{\mathrm{Pb}}}+\frac{\mathrm{Pc}}{\overline{\mathrm{Pc}}}\right)
$$

Em que: $x$ é o posto pluviométrico ou estação meteorológica com dados pluviométricos faltantes; Px é a precipitação do mês faltante; $\overline{\mathbf{P x}}$ é a precipitação média mensal da estação $\mathrm{x} ; \mathrm{Pa}, \mathrm{Pb}, \mathrm{Pc}$ são as precipitações mensais reais dos postos pluviométricos selecionados para o preenchimento; e $\overline{\mathbf{P a}}, \overline{\mathbf{P b}}, \overline{\mathbf{P c}}$ são as precipitações médias mensais destes mesmos postos.

Para a melhor manipulação e organização das informações foi realizada a manipulação dos dados de precipitação para a escala anual, mensal e diária utilizando-se de parâmetros estatísticos básicos em planilha eletrônica Microsoft Office Excel $2007^{6}$. Para verificar as relações entre a precipitação pluviométrica e a orografia será utilizada a correlação linear de Pearson (Equação 2), que segundo Yakamoto e Landim (2013) permite avaliar numa medida da intensidade de uma linearidade entre duas variáveis através de coeficientes cujos valores variam entre -1 e +1 . O valor zero, no caso, significa que não há relação linear; o valor +1 indica uma relação linear perfeita; e o valor -1 também indica uma relação linear perfeita inversa. Portanto, quanto mais próximo estiver de +1 ou -1 , mais forte é a associação linear entre as duas variáveis, diretamente ou inversamente proporcional. Segundo Cohen e Holliday (1982), os resultados da correlação de Pearson seguem a seguinte classificação: $\leq 0,20$ - muito fraca e sem

\footnotetext{
${ }^{6}$ Microsoft Office Excel 2007 é um produto registrado Microsoft Corporation.
} 
significância; $0,2<\mathrm{r} \leq 0,39$ - fraca; $0,4<\mathrm{r} \leq 0,69$ - moderada; $0,7<\mathrm{r} \leq 0,89$ - forte; 0,9 $<\mathrm{r} \leq 1$ - muito elevada.

$$
r=\frac{\sum\left(x_{i}-\bar{x}\right)\left(y_{i}-\bar{y}\right)}{\sqrt{\left(\sum\left(x_{i}-\bar{x}\right)^{2}\right)\left(\sum\left(y_{i}-\bar{y}\right)^{2}\right)}}
$$

Em que: $\mathrm{x}_{\mathrm{i}}$ e $\mathrm{y}_{\mathrm{i}}$ indicam as duas variáveis observadas em cada passo de tempo $\mathrm{i} ; \overline{\mathbf{x}}$ e $\overline{\mathbf{y}}$, a média aritmética de cada série temporal; $\sqrt{\left(\sum\left(\mathrm{x}_{\mathrm{i}}-\overline{\mathrm{x}}\right)^{2}\right)\left(\sum\left(\mathrm{y}_{\mathrm{i}}-\overline{\mathrm{y}}\right)^{2}\right)}$ corresponde ao desvio padrão de x e y.

Utilizou-se também o coeficiente de determinação $\left(r^{2}\right)$, que fornece uma informação auxiliar ao resultado da variância da regressão apresentada pela correlação linear, pois identifica a validade comparativa entre os componentes avaliados. O valor de $\mathrm{r}^{2}$ varia no intervalo de 0 a 1 , sendo que os valores mais próximos de 1 indicam que ocorre uma adequada relação na descrição do conjunto em análise (ANDRIOTTI, 2003).

\subsection{As técnicas de agrupamento e a regionalização das chuvas}

Uma das principais metodologias empregadas nesta pesquisa é a técnica de análise cluster (agrupamento), utilizada com a finalidade de realizar uma análise detalhada e setorizada da área de estudo, delimitando regiões similares quanto ao padrão pluviométrico. A análise de agrupamento considera um conjunto inicial de objetos, no qual são associadas medidas de várias grandezas variáveis classificatórias, utilizadas para se obter grupos de objetos assemelhados em relação aos valores assumidos por essas variáveis (EVERITT, 1993). Para tanto, considerou-se como principal aspecto os registros mensais de precipitação pluvial para os postos pluviométricos, considerado por Teodoro et al. (2015) e Brito et al. (2016) essencial para averiguar a relação entre os valores observados e a dinâmica atmosférica regional.

A finalidade do emprego desta técnica está em avaliar de uma forma diferente, em relação ao método de espacialização (Krigagem), a distribuição espacial e temporal das chuvas, estabelecer regiões homogêneas e selecionar postos pluviométricos e estações meteorológicas representativas para analisar a ocorrência dos eventos pluviais extremos nas bacias hidrográficas e sua relação com os tipos de tempos atmosféricos. Este método também foi utilizado para selecionar os eventos pluviais extremos diários, tendo como 
base as chuvas diárias superiores a $99 \%$ dos quantis dos percentis, para a aplicação da Análise Rítmica Climatológica de Monteiro (1971).

Inicialmente, utilizou-se como medida de proximidade a distância Euclidiana ao quadrado, comumente a mais utilizada para a análise de variáveis quantitativas e, segundo Freitas et al. (2013), corresponde a distância geométrica no espaço multidimensional entre duas observações dimensionais. Mello Júnior et al. (2006) a descrevem como a distância geométrica tomada em um espaço de p dimensões. Sendo Xij a observação da i-ésima estação pluviométrica $(\mathrm{i}=1,2, \ldots, \mathrm{n})$, com referência a j-ésima variável ou frequência absoluta em cada classe $(j=1,2, \ldots, p)$ estudada, define-se a distância euclidiana padronizada entre dois postos i e i' por meio da expressão (Equação 3), em que Zij, s(Xj) e $\overline{\boldsymbol{X}}$ são, respectivamente, a variável padronizada, o desvio-padrão e a média da j-ésima variável original (Equação 4).

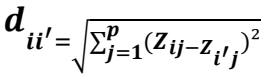

$$
\begin{aligned}
& Z_{i j}=\frac{X_{i j}-\bar{X}}{\delta\left(X_{j}\right)}
\end{aligned}
$$

Amplamente utilizado, usou-se o método Ward (1963) como o mais apropriado para a análise de agrupamento, pois propõe que em qualquer fase de análise a perda de informação que resulta do agrupamento de elementos seja medida pela soma dos quadrados dos desvios de cada elemento à média dos elementos do grupo à qual pertente (NASCIMENTO et al., 2015; WREGE et al., 2016).

Partindo-se dos dados mensais de pluviosidade, elaborou-se uma tabela do tipo "indivíduos" versus "variáveis", considerando-se como indivíduo cada um dos postos pluviométrico, e as variáveis como os totais pluviométricos mensais. A representação do dendograma foi gerada a partir do software Statistica versão $7.0^{7}$ e realizou-se o ponto de corte a partir de uma análise subjetiva que considerou as características do relevo, o regime de pluviosidade e a proximidade espacial entre os postos pluviométricos.

Para um estudo mais detalhado da relação entre a variabilidade pluviométrica e os indicadores climáticos oceânicos (GMAT, IOS, ONI e ODP), aplicou-se o método de agrupamento k-médias (k-means), no qual o número de grupos é escolhido antes de iniciar

\footnotetext{
${ }^{7}$ Statistica é um produto registrado pela empresa StatSoft.
} 
o algoritmo. O emprego desta técnica foi realizado com eficácia para o estado do Rio de Janeiro (ANDRÉ et al., 2008) e da Bahia (DOURADO et al., 2013). Dessa forma, duas medidas foram usadas para definir esse valor: a soma de quadrados total e o valor da silhueta.

A soma de quadrados total (SQT) é composta pela soma de quadrados dentro dos grupos (SQD) e entre grupos (SQE). A SQD é calculada pela soma das distâncias de cada observação em relação ao centroide do seu grupo, e a SQE é calculada pela soma das distâncias dos centroides de cada grupo em relação à média dos centroides de todos os grupos. Quanto maior a quantidade de grupos, menor será a soma de quadrados dentro dos grupos, pois as observações serão melhor ajustadas em cada grupo.

O valor da silhueta indica se uma observação está mais próxima dos elementos de seu próprio grupo ou de elementos de grupos vizinhos e varia entre -1 e 1 , sendo que valores mais próximos de 1, significam um bom ajuste, ou seja, as observações foram bem agrupadas. Sendo assim, para a definição do número de grupos para cada bacia, foi utilizado o valor médio das silhuetas. Para visualizar os agrupamentos realizados para cada bacia, utilizou-se uma análise de componentes principais, que por meio de uma combinação linear das variáveis (chuvas mensais), pode-se considerar a redução da dimensionalidade dos dados, garantindo, deste modo, o máximo da variabilidade possível (EVERITT, 2011). A análise de agrupamento pelo método k-means foi realizado a partir da utilização do software ambiente R versão $3.3 .2^{8}$ (R DEVELOPMENT CORE TEAM, 2016) e as representações do soma de quadrados total e o valor da silhueta se deram em planilha eletrônica Microsoft Office Excel 2007.

\subsection{Os eventos pluviais extremos, a Análise Rítmica em Climatologia e a Spatial Synoptic Classification}

A técnica selecionada foi a dos quantis, que permitem interpretar adequadamente o verdadeiro significado de um total pluviométrico em relação ao conjunto de dados. Os intervalores percentuais de cada quantil, delimitados nos percentis representam as frequências de ocorrência dos eventos pluviométricos e possibilitaram a definição dos eventos extremos de chuva (XAVIER; XAVIER, 1999) e, conforme discorrem Santos et al. (2011), a vantagem da metodologia dos quantis é permitir a representação objetiva de

\footnotetext{
${ }^{8} \mathrm{R}$ é um produto registrado pela empresa GNU General Public License (GPL).
} 
um determinado evento climático em termos da sua intensidade ou categoria de ocorrência.

Segundo Santos et al. (2016) esta técnica baseia-se na distribuição da frequência acumulada, sendo que a aproximação da função densidade de probabilidade (fdp) que descreve o fenômeno é melhor quanto maior é o número de observações disponíveis. Os intervalos de cada percentil representam as probabilidades ou frequências esperadas para cada um dos eventos que podem ocorrer na sequência da série temporal de uma variável $x$ (ANANIAS et al., 2010). Portanto, esta metodologia consiste estritamente na distribuição em ordenamento crescente de uma série amostral contínua.

No presente trabalho, a série temporal está constituída pelos totais registrados de chuva (anuais, mensais e diários), sendo atribuída uma probabilidade $p$ univocamente a cada valor amostral. Assim, a série temporal pode ser distribuída sob a forma $\{x 1, x 2, x 3, \ldots, x n\}$, na qual $x 1$ representa o menor valor e $x n$ o maior valor da série (XAVIER; XAVIER, 1999; SANTOS et al., 2016). Para estabelecer as classes em relação aos valores observados $\left(x_{i}\right)$ de chuva foram utilizadas as ordens quantílicas, em que $\mathrm{Q}$ significa o limite do quantis, conforme adotado por Souza et al. (2012) para a realização dos cálculos $(<25 \%, \geq 50 \%, \geq 75 \%, \geq 95 \%$ e $\geq 99 \%)$.

Após a análise do banco de dados e verificada a qualidade (menores falhas) dos registros diários de precipitação pluviométrica, inferiores a $2 \%$, foram selecionadas os postos pluviométricos representativos de cada grupo homogêneo para a utilização desta técnica, que foram determinados e explorados a partir da utilização do software Statistica 7.0. Os eventos pluviais extremos selecionados para a aplicação da Análise Rítmica em Climatologia (ARC) de Monteiro (1971) se deram a partir da utilização da técnica de agrupamento pelo método Ward para os registros diários superiores a 99\% dos percentis dos quantis.

As condições sinóticas para os eventos extremos pluviométricos foram definidas pela Análise Rítmica Climatológica de Monteiro (1971). Utilizaram-se neste os seguintes atributos climáticos: pressão atmosférica $(\mathrm{hPa})$; umidade relativa $(\%)$; temperatura média, máxima e mínima do ar $\left({ }^{\circ} \mathrm{C}\right)$; precipitação pluviométrica diária $(\mathrm{mm})$, velocidade $(\mathrm{m} / \mathrm{s})$ e direção $\left({ }^{\circ}\right)$ dos ventos; nebulosidade (décimos). A caracterização e definição dos sistemas atmosféricos atuantes seguiram os critérios estabelecidos e descritos por Baldo (2006) e Zandonadi (2013). Identificaram-se os seguintes sistemas atmosféricos: massa Tropical Atlântica (mTa), massa Tropical Continental (mTc), massa Equatorial Continental (mEc), Zona de Convergência do Atlântico Sul (ZCAS), massa Polar atlântica (mPa), massa 
Polar Atlântica tropicalizada (mPat), Frente Polar Atlântica (FPA), Frente Polar Atlântica Estacionária (FPAE), Frente Polar Atlântica em Dissipação (FPAD), Repercussão da Frente Polar Atlântica (RFPA), Recuo da Frente Polar Atlântica (Rec.FPA) e a Linha de Instabilidade Tropical (IT). Para a definição e nomenclatura dos sistemas atmosféricos, foram utilizadas as informações provenientes do "Boletim de Monitoramento e Análise Climática" (CLIMANÁLISE) e do "Boletim Técnico" (INPE, 2019), emitidos pelo Centro de Previsão de Tempo e Estudos Climáticos (CPTEC), pertencente ao Instituto Nacional de Pesquisas Espaciais (INPE).

Para a caracterização dos tipos de tempo responsáveis pelos eventos extremos de pluviosidade, utilizaram-se as cartas sinóticas disponibilizadas pela Departamento de Hidrografia e Navegação da Marinha do Brasil e, contudo, para os eventos pluviais mais recentes, posteriores a 2008, consultaram-se as cartas sinóticas disponibilizadas pelo "Boletim Técnico" do CPTEC (INPE, 2019). Segundo Armani e Galvani (2011), a análise da sequência das cartas sinóticas, vislumbrando a gênese, trajetória e movimentação dos sistemas atmosféricos permite a concepção de ritmo dos sistemas atmosféricos, sendo que as expressões quantitativas dos elementos climáticos estão diretamente ligadas ao mecanismo de circulação atmosférica regional.

Os tipos de tempo para a escala decendial e anual, ao longo do período de 2007 a 2015, foram avaliados pelo software Spatial Synoptic Classification (SSC), desenvolvida por Kalkstein et al. (1996) e aprimorada por Kalkstein et al. (1998) e Sheridan (2002). Foram utilizados os dados de quatro observações diárias nos horários sinóticos padrão das 06,12 , 18 e 00 horas UTM (3hrs, 9hrs, 15hrs e 21hrs no horário oficial de Brasília), de temperatura do $\operatorname{ar}\left({ }^{\circ} \mathrm{C}\right)$, temperatura do ponto de orvalho $\left({ }^{\circ} \mathrm{C}\right)$, umidade relativa do ar $(\%)$, direção $\left({ }^{\circ}\right)$ e velocidade $(\mathrm{m} / \mathrm{s})$ do vento, pressão atmosférica $(\mathrm{hPa})$ e nebulosidade (décimos) das estações meteorológicas automáticas de Castro, Curitiba e Paranaguá, que são pertencente ao Instituto Nacional de Meteorologia (INMET), para o período de 2008 a 2015.

Este procedimento metodológico está próximo à concepção climática da análise rítmica de Monteiro (1971), haja vista que a sua proposição admite a integração entre o processo interativo entre a circulação atmosférica e os atributos climáticos. Contudo, trata-se de um método híbrido, pois a adoção do "seed day" é aprimorado empiricamente a partir da realidade climática local, buscando além de auxiliar na identificação do "diasemente", aumentar a coesão espacial dos tipos de tempo. Para tanto, considerou-se como 
parâmetro os resultados para a cidade de São Paulo (FONTÃO et al., 2018) para os ajustes finais na elaboração dos parâmetros de cada "seed day".

Assim, foram estabelecidos os limiares mais próximos ao padrão dos atributos climáticos, para a definição de seis tipos de tempo tradicionais: Dry Moderate (DM), Dry Polar (DP), Dry Tropical (DT), Moist Moderate (MM), Moist Polar (MP) e Moist Tropical (MT). Foram estabelecidas as classificações Moist Tropical Plus (MT+) e Moist Tropical Double Plus (MT++), que apesar de tratarem-se de variações do tipo de tempo MT, apresentam temperaturas ainda mais elevadas que as do tipo original (MT). O tipo de tempo representa a alternância e não estão contemplados nas categorias anteriores foram denominados de Transicional (TR). Maiores detalhes estão descritos no quadro 2.

Quadro 2 - Categorias de tipos de tempo (weather-types) classificados através do método SSC.

\begin{tabular}{|c|c|c|c|}
\hline Código & Nome & Tradução & Descrição \\
\hline DP & Dry Polar & Polar Seco & $\begin{array}{l}\text { Tipo de tempo frio e seco, aliada à pouca nebulosidade. A } \\
\text { ocorrência desse tipo de tempo à atuação do Anticiclone } \\
\text { Polar migratório em sua trajetória mais continental. }\end{array}$ \\
\hline DM & Dry Moderate & $\begin{array}{l}\text { Moderado } \\
\text { Seco }\end{array}$ & $\begin{array}{l}\text { Tipo de tempo relativamente quente e seco, com } \\
\text { nebulosidade moderada. Está associado às alterações e } \\
\text { reestruturação do ar atmosférico das massas polar e tropical } \\
\text { atlântica em seu movimento migratório à área de estudo. }\end{array}$ \\
\hline DT & Dry Tropical & $\begin{array}{c}\text { Tropical } \\
\text { Seco }\end{array}$ & $\begin{array}{l}\text { Tipo de tempo muito quente e de baixa umidade relativa do } \\
\text { ar, manifestando pouca ou nenhuma nebulosidade. Está } \\
\text { associado à atuação de massas de ar estáveis tropicais. }\end{array}$ \\
\hline MP & Moist Polar & Polar Úmido & $\begin{array}{l}\text { Tipo de tempo frio, úmido e com alta nebulosidade. Trata- } \\
\text { se da incursão modificada do ar de origem polar, com a } \\
\text { diminuição das temperaturas e a instabilidade atmosférica. }\end{array}$ \\
\hline MM & $\begin{array}{c}\text { Moist } \\
\text { Moderate }\end{array}$ & $\begin{array}{l}\text { Moderado } \\
\text { Úmido }\end{array}$ & $\begin{array}{c}\text { Temperaturas relativamente quentes e a umidade do ar } \\
\text { moderadamente elevada, podendo resultar em aumento da } \\
\text { nebulosidade e, em alguns casos, precipitação. }\end{array}$ \\
\hline MT & $\begin{array}{c}\text { Moist } \\
\text { Tropical }\end{array}$ & $\begin{array}{l}\text { Tropical } \\
\text { Úmido }\end{array}$ & $\begin{array}{l}\text { Tipo de tempo quente, bastante úmido e de elevada } \\
\text { nebulosidade. Normalmente, está associado à atuação de } \\
\text { massas de ar tropicais, em alguns casos com linhas de } \\
\text { instabilidade, ou em setores quentes de uma frente. }\end{array}$ \\
\hline MT+ & $\begin{array}{c}\text { Moist Tropical } \\
\text { Plus }\end{array}$ & $\begin{array}{l}\text { Tropical } \\
\text { Úmido } \\
\text { Plus }\end{array}$ & $\begin{array}{c}\text { Adotado para classificar dias mais quentes na região } \\
\text { intertropical. Diferencia-se por apresentar temperaturas } \\
\text { mais elevadas que o "seed day" durante a manhã e a tarde. }\end{array}$ \\
\hline $\mathrm{MT}++$ & $\begin{array}{l}\text { Moist } \\
\text { Tropical } \\
\text { Double Plus }\end{array}$ & $\begin{array}{l}\text { Tropical } \\
\text { Úmido } \\
2 x \text { Plus }\end{array}$ & $\begin{array}{c}\text { Classifica os dias de com temperaturas ainda mais elevadas } \\
\text { que o MT+. Diferencia-se por apresentar temperaturas de } \\
\text { ao menos um desvio padrão acima do "seed day", tanto na } \\
\text { média da manhã quanto da tarde. }\end{array}$ \\
\hline TR & Transitional & Transicional & $\begin{array}{c}\text { Dias em que as condições atmosféricas não são } \\
\text { compreendidas nas classes anteriores, havendo mudanças } \\
\text { sensíveis nos limiares de pressão, ponto de orvalho e vento } \\
\text { ao longo do dia. }\end{array}$ \\
\hline
\end{tabular}

Fontes: Sheridan et al. (2002), Armond (2014) e Fontão et al. (2018). 


\subsection{As anomalias de pluviosidade, os indicadores climáticos oceânicos e a modelagem estatística}

Para entender a variabilidade das séries de anomalia de chuvas a partir do seu passado e do histórico dos quatro indicadores marítimos, foi utilizado o modelo auto regressivo vetorial (VAR). Portanto, a variável responsável é a precipitação pluviométrica mensal, dada pela soma dos acumulados diários, e as variáveis explicativas correspondem aos indicadores climáticos oceânicos (IOS, ODP, ONI e GMAT). Os dados referentes a estes indicadores climáticos foram obtidos a partir do National Oceanic and Atmospheric Administration (NOAA, 2016).

Para cada grupo homogêneo de cada bacia hidrográfica, a série mensal de anomalia simples de chuvas foi modelada em relação à série mensal de cada um dos indicadores, assim tem-se um total de 56 modelos (14 grupos x 4 indicadores), conforme estão transcritas nas equações 17 a 72 do Apêndice. A representação vetorial do par segue conforme a equação 5.

$$
X_{t}=\left[\begin{array}{l}
X_{1 t} \\
X_{2 t}
\end{array}\right]
$$

Em que $X_{1 t}$ é a série de anomalia de chuvas, $X_{2 t}$ é a série de um indicador e té o tempo, em meses. Por exemplo, considerando o caso mais simples (VAR(1)), o modelo se reduz a (Equação 6):

$\left[\begin{array}{l}X_{1 t} \\ X_{2 t}\end{array}\right]=\left[\begin{array}{l}\phi_{10} \\ \phi_{20}\end{array}\right]+\left[\begin{array}{ll}\phi_{11} & \phi_{12} \\ \phi_{21} & \phi_{22}\end{array}\right]\left[\begin{array}{l}X_{1 t-1} \\ X_{2 t-1}\end{array}\right]+\left[\begin{array}{l}a_{1 t} \\ a_{2 t}\end{array}\right]$

ou seja,

$\mid \begin{aligned} & X_{1 t}=\phi_{10}+\phi_{11} X_{1 t-1}+\phi_{12} X_{2 t-1}+a_{1 t} \\ & X_{2 t}=\phi_{20}+\phi_{21} X_{1 t-1}+\phi_{22} X_{2 t-1}+a_{2 t}\end{aligned}$

A utilização deste modelo tem como premissa de que as séries são estacionárias. Determina-se a ordem (p) do modelo VAR a partir do uso de critérios de informação, sendo o bayesiano (BIC) utilizado neste estudo. Com o modelo VAR ajustado, verificase quais variáveis e lags são significantes estatisticamente. Após identificar os modelos, 
é necessário averiguar se eles representam adequadamente os dados e, para isso, foi realizada a análise dos resíduos dos modelos ajustados. Supondo que o ajuste foi feito corretamente, espera-se que os resíduos sejam não correlacionados, homocedásticos e sigam aproximadamente uma distribuição normal.

Os resíduos apresentam ter distribuição normal, indicando que o modelo está bem ajustado, conforme demonstrado para as anomalias pluviais no grupo 3 da $\mathrm{BH}$ Alto Iguaçu e o indicador climático ODP (Figura 21). Como a análise de resíduos para os demais modelos estudados apresentam resultados semelhantes, optou-se por não as apresentar. Além da distribuição normal dos resíduos, é necessário que eles não sejam auto correlacionados. Neste caso, utilizou-se o teste de Box-Pierce (MORETTIN, 2017), que ao nível de confiança de 95\%, conclui-se que os resíduos, para cada modelo da anomalia de chuvas, são não auto correlacionados, ou seja, os modelos estão bem ajustados, conforme está descrito pela tabela 10.

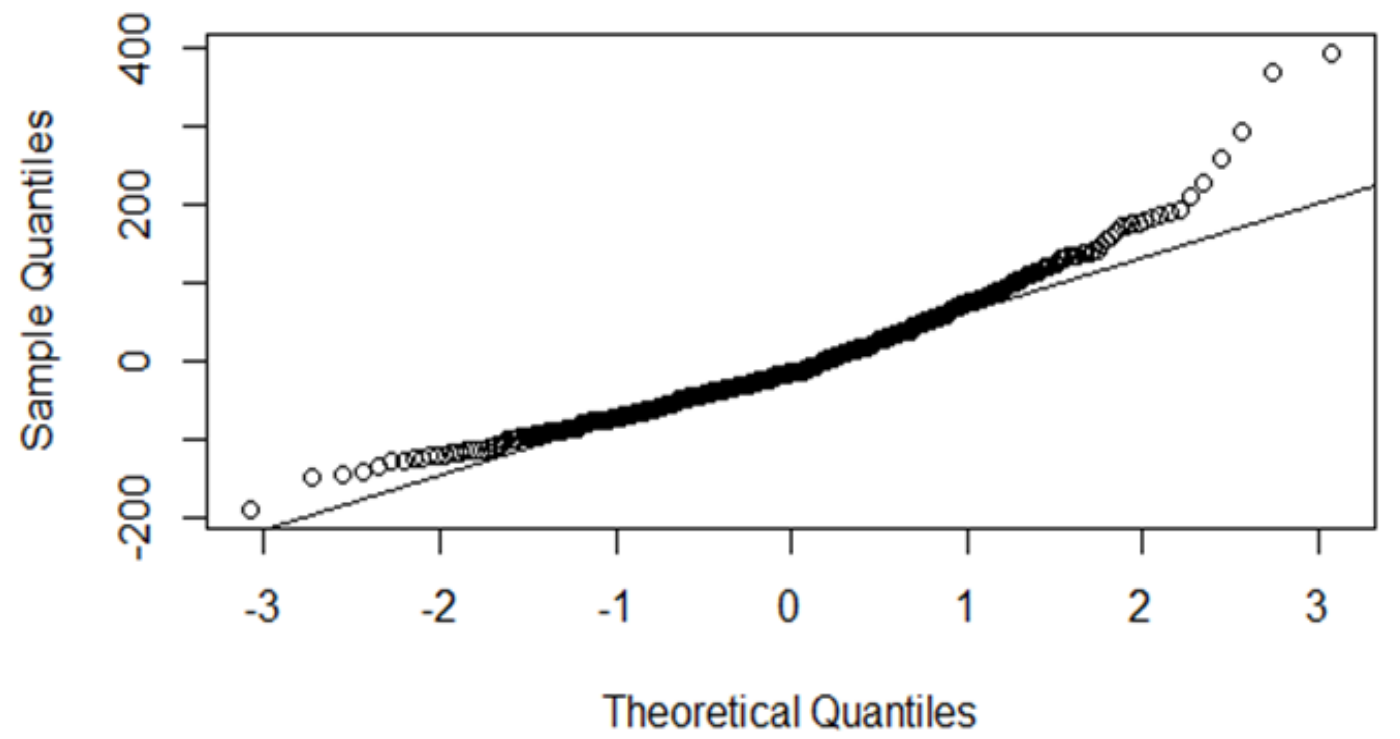

Figura 21 - Gráfico Normal Q-Q para os resíduos do modelo VAR para o grupo 3 do Alto do Iguaçu e o indicador ODP.

A correlação e a interação entre a precipitação pluviométrica e os indicadores climáticos oceânicos foi avaliada com base nos coeficientes (Kendall - $\tau$, Sperman - $\rho$ e Pearson - r). O coeficiente $\tau$ é uma medida de correlação utilizada para dados ordinais, similar ao coeficiente $\rho$. Ambas as variáveis devem ser medidas no mínimo em nível ordinal, de forma que seja possível atribuir postos a cada uma das variáveis. Ou seja, se duas variáveis podem ser consideradas estatisticamente dependentes, o coeficiente $\tau$ deve estar no intervalo de $-1 \leq \tau \leq 1$, sendo definido pela equação 8: 
$\tau=\frac{\left(Q_{y}-Q_{x}\right)}{\frac{1}{2} n(n-1)}$

Em que $\tau$ é o coeficiente de correlação de Kendall; $Q_{y}$ é a quantidade de pares concordantes, $Q_{x}$ é a quantidade de pares discordantes, n é o número de elementos aos quais se atribuíram postos em $\mathrm{x}$ e $\mathrm{y}$.

O coeficiente de Spearman (equação 9), é uma medida de correlação nãoparamétrica. Seu estimador foi derivado a partir do estimador do coeficiente de correlação linear de Pearson (SIEGEL, 1975).

$\rho=1-\frac{6 \sum_{i=1}^{n} d_{i}{ }^{2}}{n\left(n^{2}-1\right)}$

Em que $\rho$ é o coeficiente de correlação de Spearman; $d_{i}$ é a diferença entre as ordenações; $n$ é o número de pares ordenações.

O coeficiente de correlação de Pearson (r) mede o grau da correlação linear entre duas variáveis quantitativas, sendo dado pela equação 2. É um índice adimensional com valores situados ente $-1 \leq r \leq 1$ inclusive, que mostra a intensidade de uma relação linear entre dois conjuntos de dados.

\subsection{Os testes estatísticos e os indicadores climáticos de tendências}

A avaliação de tendências de alterações das chuvas para a área de estudo foi feita a partir do teste estatístico não paramétrico de Mann-Kendall (TMK), proposto por Sneyers (1975), e que se parte da hipótese de que na estabilidade de uma série temporal, a sucessão de valores ocorre de forma independente, e a distribuição de probabilidade deve permanecer a mesma (série aleatória simples).

Portanto, a análise das tendências de alterações dos totais anuais e diários de precipitação para a área de estudo foi realizada a partir do teste Mann-Kendall, que parte da hipótese de que na estabilidade de uma série temporal, a sucessão de valores ocorre de forma independente, e a distribuição de probabilidade deve permanecer sempre a mesma em uma série aleatória simples (HIRSCH; SLAKE, 1974; GOIS et al., 2017). 
Quadro 3 - Classificação do teste Mann-Kendall $\left(Z_{M K}\right)$ com o intervalo de $95 \%$ de confiança.

\begin{tabular}{|c|c|}
\hline Categorias & Escalas \\
\hline Tendência positiva significativa & $Z_{M K}>+1.96$ \\
\hline Tendência positiva não significativa & $Z_{M K}<+1.96$ \\
\hline Sem mudança & $Z_{M K}=0$ \\
\hline Tendência negativa não significativa & $Z_{M K}>-1.96$ \\
\hline Tendência negativa significativa & $Z_{M K}<-1.96$ \\
\hline
\end{tabular}

O teste de Pettitt (1979) é um dos mais utilizados para identificar o período de ruptura das séries temporais. Este teste não paramétrico permite confirmar a estacionariedade da série histórica, ou seja, excetuando as flutuações aleatórias, as observações são invariantes com relação à cronologia de suas ocorrências. Segundo Silva et al. (2015), este teste permite a localização do ponto inicial de determinada tendência e, portanto, adequado para detectar alterações em séries temporais. Cera e Ferraz (2015) destacam que o teste de Pettitt é o mais apropriado para analisar mudanças significativas em séries climatológicas por detectar mais precisamente o ponto inicial de uma tendência.

O teste de Pettitt é definido como sendo um teste não paramétrico e utiliza uma adaptação do teste de Mann-Whintney, na qual verifica se duas amostras $X_{1}, \ldots, X_{t}$ e $X_{t+1}, \ldots, X_{T}$ pertencem à mesma população. A estatística do $U_{i, T}$ faz uma contagem do número de vezes em que um membro da $1^{\mathrm{a}}$ amostra é maior que o membro da $2^{\mathrm{a}}$ amostra, sendo definido pela equação 10:

$U_{t, T}=U_{t-1, T}+\sum_{j=1}^{T} \operatorname{sgn}\left(x_{i}-x_{j}\right) \quad$ para $t=2, \ldots, T$

Em que; $\operatorname{sgn}(x)=1$ para $x>0 ; \operatorname{sgn}(x)=0$ para $x=0 ; \operatorname{sgn}(x)=-1$ para $x<0$.

A estatística $U_{i, T}$ é então calculada para os valores de $1<t<T$, e assim a estatística $k(t)$ do teste corresponde ao máximo em valor absoluto de $U_{i, T}$ e, assim, são estimados os anos onde ocorre a mudança abrupta, dada pela equação 11.

$k(t)=M_{1<t<T}\left|U_{t, T}\right|$

O teste de Pettitt localiza o ponto onde houve uma mudança brusca na média de uma série temporal, e a sua significância é dada pela equação 12. 
$p \cong 2 \exp \left\{-6 k(t)^{2} /\left(T^{3}+T^{2}\right)\right\}$

O ponto de mudança brusca é o $t$, onde ocorreu o máximo de $k(t)$, os valores críticos de k são calculados pela equação 13.

$\mathrm{k}_{\text {crit }}= \pm \sqrt{\frac{\ln (\mathrm{p} / 2)\left(\mathrm{T}^{3}+\mathrm{T}^{2}\right)}{6}}$

Devido às eventuais falhas nas estações meteorológicas do INMET usadas no estudo (Castro, Curitiba e Paranaguá) e para a identificação de anos anômalos, optou-se pela aplicação do teste Run aplicada à série temporal de chuvas diárias na escala anual para a seleção de anos com correlação serial. O teste de Run é um teste não paramétrico que avalia se uma série temporal se distribui de forma aleatória, sendo comum sua aplicação na literatura (BACK, 2001; TEODORO et al., 2015; OLIVEIRA-JÚNIOR et al., 2017). O teste se baseia na contagem do número de oscilações dos valores superiores (codificado com 1) e abaixo (codificado com 0) da mediana, numa série de dados naturalmente ordenada.

O número de oscilações é chamado de "run", e deve-se testar se o valor observado está dentro da faixa de distribuição considerada normal. Um valor alto de "run" indica várias oscilações, enquanto os valores baixos indicam um desvio em relação à mediana durante o período de registros. Deste modo, se a sequência contém $N_{l}$ símbolos de um tipo, e $N_{2}$ símbolos de outro tipo ( $N_{1}$ e $N_{2}$ não são muito pequenos), a distribuição amostral do número de "runs" total pode ser aproximada pela distribuição normal com média descrita pela equação 14, e a variância da distribuição com base na equação 15:

$E(u)=\frac{2 N_{1} N_{2}}{N_{1} N_{2}}+1$

(Eq.14)

$\operatorname{Var}(u)=\frac{2 N_{1} N_{2}\left(2 N_{1} N_{2}-N_{1} N_{2}\right)}{\left(N_{1} N_{2}\right)^{2}\left(2 N_{1} N_{2}-1\right)}$

Nestas relações $u$ representa o número de "runs". Desta forma, a hipótese nula $\left(H_{0}\right)$ de que a distribuição dos símbolos ocorre normalmente e que a amostra é aleatória, pode ser testada com base na estatística descrita pela equação 16: 
$Z=\frac{u-E(u)}{\sqrt{\operatorname{Var}(u)}}$

(Eq. 16)

O valor calculado pode ser comparado com valores de $\mathrm{Z}$ para distribuição normal. Para o nível de significância de 5\% de probabilidade, $\mathrm{Z}$ encontra-se entre o intervalo 1,96 a $+1,96$. Caso $\mathrm{Z}$ calculado seja maior que o valor tabelado, rejeita-se $\mathrm{H}_{0}$. Para o cálculo do teste Run foi utilizado o pacote "randtests" do software ambiente R versão 3.3.2 (R DEVELOPMENT CORE TEAM, 2016).

Para um estudo mais detalhado da variabilidade pluviométrica e dos eventos extremos diários, destacando-se as tendências das séries temporais de precipitação pluviométrica, utilizaram-se os indicadores extremos trabalhados e oriundos do programa RClimDex (Quadro 4), desenvolvido pelo Serviço Meteorológico Canadense (ZANG; YANG, 2004). A partir da Curvatura de Sen, estimou-se a magnitude de tendência de ocorrência desses eventos extremos, tendo como principal critério a significância estatística maior que $90 \%$. Destaca-se que a definição de dia úmido (seco) é definido por $\mathrm{RR}>=1 \mathrm{~mm}(\mathrm{RR}<1 \mathrm{~mm})$ e RR compreende o total pluviométrico diário.

Quadro 4 - Definição e unidade dos indicadores de extremos climáticos analisados no trabalho.
\begin{tabular}{|c|c|c|}
\hline Indicador & Definição & Unidade \\
\hline SDII & Distribuição média da precipitação anual total & $\mathrm{mm} / \mathrm{dia}$ \\
\hline CDD & Número máximo de dias secos consecutivos no ano & dias \\
\hline CWD & Número máximo de dias úmidos consecutivos no ano & dias \\
\hline PRCPTOT & Precipitação anual total dos dias úmidos & $\mathrm{mm}$ \\
\hline R10mm & Número de dias no ano com RR >=10 mm & dias \\
\hline R20mm & Número de dias no ano com RR >= 20 mm & dias \\
\hline R95p & Precipitação anual total dos dias em que RR> percentil 95 & $\mathrm{mm}$ \\
\hline R99p & Precipitação anual total dos dias em que RR> percentil 99 & $\mathrm{~mm}$ \\
\hline RX1day & Máxima precipitação anual em 1 dia & $\mathrm{mm}$ \\
\hline RX5day & Máxima precipitação anual em 5 dias consecutivos & $\mathrm{mm}$ \\
\hline
\end{tabular}

Fonte: Zang e Yang (2004); Silva et al. (2015). 


\subsection{Forma de análise de resultados e produção cartográfica}

Os gráficos de representação dos resultados de dispersão, coeficiente de determinação, correlação linear de Pearson, quantis e os testes Mann-Kendall e Pettitt foram manipulados nos softwares Statistica 7.0 e Minitab 15.0. Os gráficos de análise rítmica de pluviosidade e os demais atributos da análise rítmica foram realizados a partir do software Microsoft Office Excel 2007.

Para a elaboração das cartas de distribuição da precipitação pluviométrica foi utilizado o software ArcGis ${ }^{9}$ versão 10.3. Através do arquivo com o contorno da área de estudo digitalizado, em formato*bln, utilizando-se dos valores de longitude e latitude, e outro arquivo com os valores calculados, em formato * grid (grade regular), de cada estação meteorológica e postos pluviométricos, com suas respectivas coordenadas geográficas, foram elaborados os mapas para as diferentes escalas de análise.

A interpolação dos dados no reticulado do programa foi feita através do método de Kriging Ordinária, considerado o mais adequado para este tipo de interpolação, por permitir uma representação mais adequada da continuidade dos fenômenos geográficos como a precipitação pluviométrica, conforme apontado por Carvalho e Assad (2005), Gois et al. (2015) e Mello e Oliveira (2016).

Landim (1997) esclarece que a krigagem compreende um processo para estimar os valores de variáveis distribuídas no espaço a partir de valores adjacentes enquanto considerados como interdependentes pelo semivariograma. O semivariograma infere sobre a medida do grau de dependência espacial entre amostras, expressando a variabilidade espacial da variável regionalizada e mostra o tamanho da influência em torno de uma amostra (MELLO; OLIVEIRA, 2016).

Como a presente pesquisa recorreu a um número significativo de postos pluviométricos, recorreu-se a elaboração de semivariogramas experimentais que permitiram verificar que a associação do modelo de variograma Nugget Effect com o Esférico foi a mais adequada para as opções avançadas de krigagem, pois combinados demonstraram a menor quantidade de núcleos isolados de isoietas e os intervalos gerados para estas isolinhas foram as mais próximas em relação aos valores reais dos intervalos máximos e mínimos de pluviosidade.

\footnotetext{
${ }^{9}$ ArcGis é um produto registrado da empresa Esri (Environmental System Research Institute).
} 
As informações referentes à base cartográfica e às cartas de formações geológicas, tipos de solos, formações fitogeográficas e divisões municipais, que serviram para caracterizar a área, foram extraídas gratuitamente no sítio eletrônico do Instituto de Terras, Cartografia e Geodésia (ITCG, 2015). A carta de hipsometria e de declividade foram elaboradas a partir de informações adquiridas de imagens SRTM (Shuttle Radar Topography Mission), elaboradas pelo projeto TOPODATA (INPE, 2011). Posteriormente, todas estas informações foram manipuladas e elaboradas no aplicativo ArcGis versão 10.3 .

\section{RESULTADOS E DISCUSSÕES}

\subsection{Análise da distribuição espacial da precipitação pluviométrica}

\subsubsection{Escala anual}

A bacia hidrográfica Litorânea caracteriza-se pelos maiores totais anuais pluviométricos da área de estudo, com uma média $2.351 \mathrm{~mm}$, com isoietas superiores a $2.600 \mathrm{~mm}$ a nordeste e inferiores a $1.900 \mathrm{~mm}$ em seu setor oeste, nas proximidades com a Serra do Mar. Com os menores totais anuais pluviométricos, equivalentes a $1.488 \mathrm{~mm}$, a bacia hidrográfica do Ribeira apresenta totais anuais de chuva superiores a $1.800 \mathrm{~mm}$ no setor sudeste, nas proximidades da Serra do Mar e inferiores a $1.400 \mathrm{~mm}$ ao norte, nos setores de menores altitudes. Dada a sua condição homogênea das elevações do terreno, a bacia hidrográfica do Alto Iguaçu mostrou uma média anual de 1.571,9 mm, com a predominância de totais anuais pluviométricos entre 1.501 a $1.600 \mathrm{~mm}$ (Figura 21).

Estes resultados estão de acordo com os obtidos por Cavaglione et al. (2000) para os setores do estado do Paraná que se situam estas bacias hidrográficas. Estes autores observaram que a bacia hidrográfica Litorânea apresenta maiores totais pluviométricos superiores a $2.500 \mathrm{~mm}$ nos setores nordeste e central, enquanto que nas demais áreas predominam os intervalos de isoietas entre 2.000 a $2.500 \mathrm{~mm}$. Obtiveram a maior abrangência entre os intervalos de 1.400 a $1.600 \mathrm{~mm}$ nas bacias hidrográficas Ribeira e Alto Iguaçu e os menores valores de pluviosidade, entre 1.200 a $1.400 \mathrm{~mm}$, identificados nos setores de menores elevações no vale do Ribeira.

Os gráficos de dispersão permitiram identificar os padrões predominantes entre a precipitação pluviométrica e as altitudes dos postos pluviométricos selecionados para caracterizar as bacias hidrográficas. Observa-se uma homogeneidade da precipitação 
pluviométrica média anual dos postos pluviométricos e estações meteorológicas inseridas na bacia hidrográfica do Alto Iguaçu, entre $1.400 \mathrm{~mm}$ a $1.700 \mathrm{~mm}$, exceto um dos postos pluviométricos que apresenta precipitação média aproximada de $1.900 \mathrm{~mm}$, e os resultados de coeficiente de determinação e correlação linear de Pearson mostram pouca influência do relevo para a variação pluviométrica (Figura 22). Com os maiores totais pluviométricos da área em estudo, verifica-se para a bacia hidrográfica Litorânea uma variação pluviométrica anual entre 2.000 a $2.800 \mathrm{~mm}$, com valores insignificativos do coeficiente de determinação e correlação linear com as altitudes dos postos de registros, o que se atribui principalmente ao predomínio das baixas altitudes da referida bacia hidrográfica (Figura 23). Por sua vez, a bacia hidrográfica do Ribeira caracteriza-se pela maior heterogeneidade pluviométrica, com intervalo predominante entre 1.200 a 1.600 e, entretanto, dois postos de registros com precipitação anual superior a $1.750 \mathrm{~mm}$, com os maiores valores de coeficiente de determinação e correlação linear com o relevo, o que se deve a maior variação das altitudes dos postos pluviométricos e estações meteorológicas nesta bacia hidrográfica (Figura 24).

Os resultados do teste de significância evidenciaram que o conjunto de dados apresentou não significância entre a altitude e a precipitação pluviométrica nas bacias hidrográficas do Alto Iguaçu e Litorânea, inerente a predominância de homogeneidade do relevo e que corrobora o menor desempenho da orografia na distribuição espacial da pluviosidade para estas áreas em estudo. Este mesmo teste demonstrou que o conjunto de dados apresenta uma significância superior a 97,5\% para a bacia hidrográfica do Ribeira, o que revela a maior relevância do fator orográfico para a distribuição espacial da precipitação pluviométrica deste setor em estudo.

Embora tenha sido o resultado de maior expressão, conforme a classificação de Cohen e Holliday (1982), o grau de significância entre as variáveis analisadas (altitude e precipitação pluviométrica) é moderado para a $\mathrm{BH}$ do Ribeira, enquanto que para as $\mathrm{BH}$ do Alto Iguaçu e Litorânea observou-se uma correlação muito fraca e sem significância. 


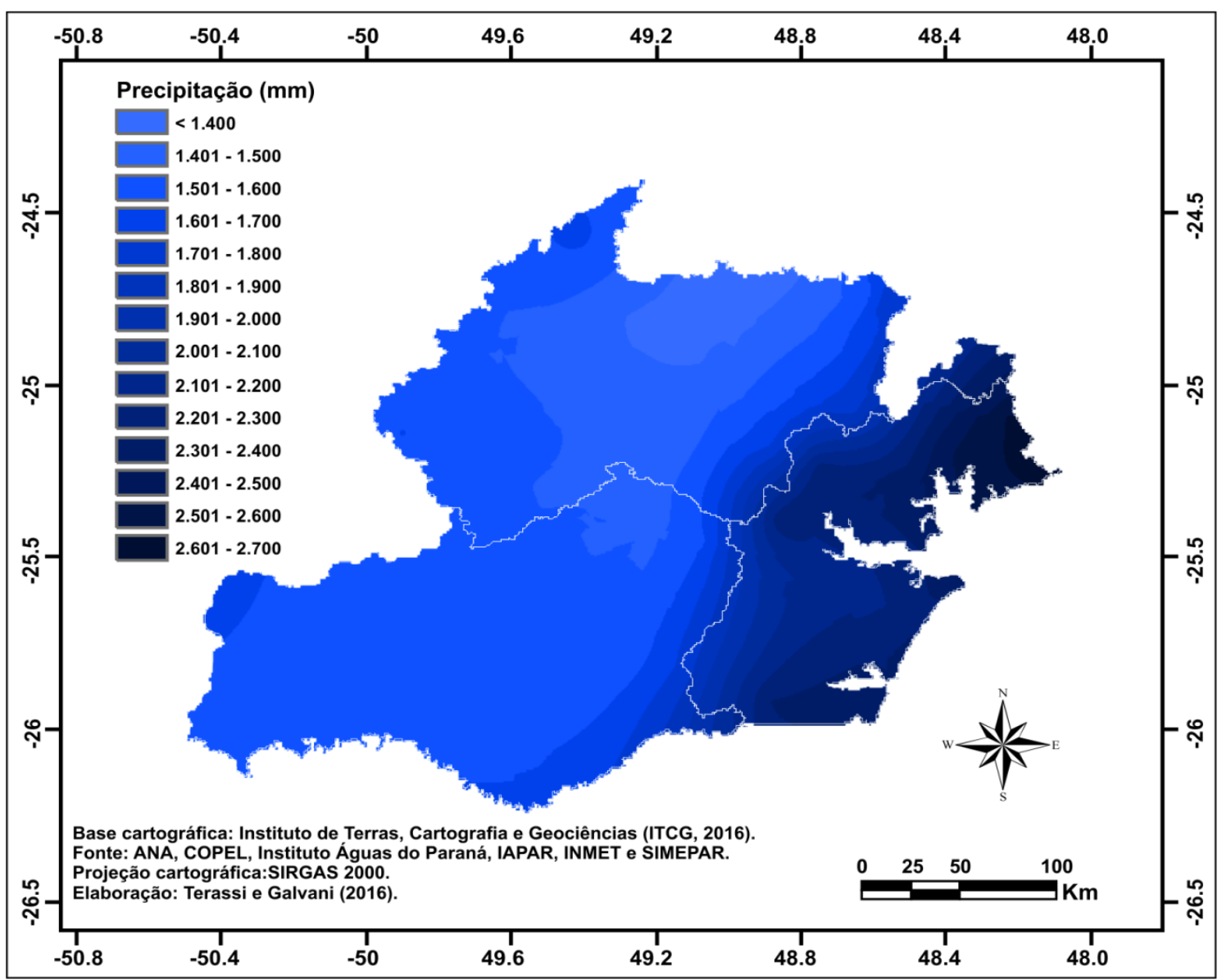

Figura 22 - Distribuição espacial da pluviosidade média anual $(\mathrm{mm})$ para as bacias hidrográficas do Alto Iguaçu, Ribeira e Litorânea (PR) para o período de 1976 a 2015.

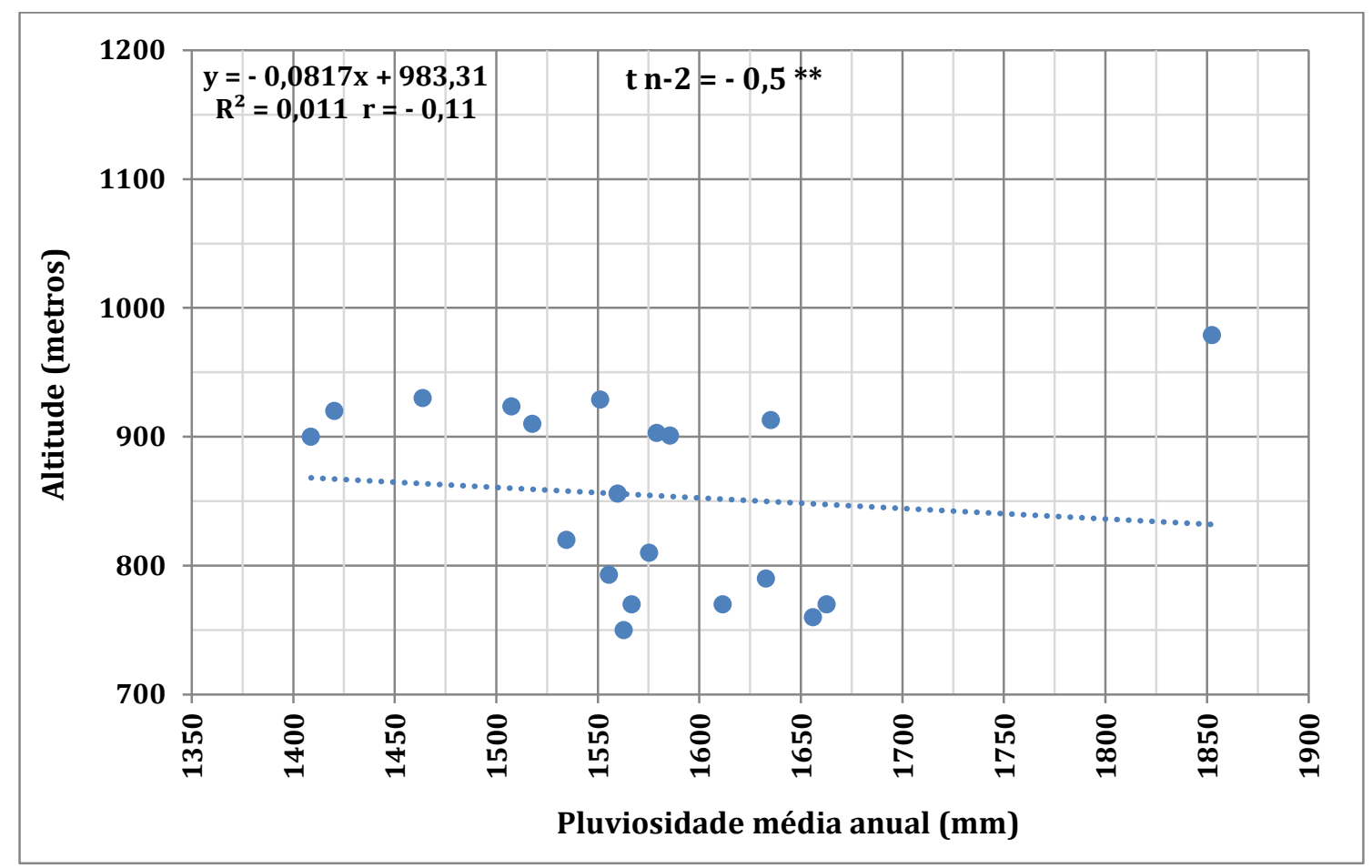

Figura 23 - Dispersão gráfica, coeficiente de determinação $\left(\mathrm{R}^{2}\right)$, correlação linear de Pearson (r), não significativo ao nível de $97,5 \%$ pelo teste t de Student $(* *)$ entre a pluviosidade média anual (mm) e a altitude (metros) dos postos pluviométricos e das estações meteorológicas inseridas na bacia hidrográfica do Alto Iguaçu - Paraná. 


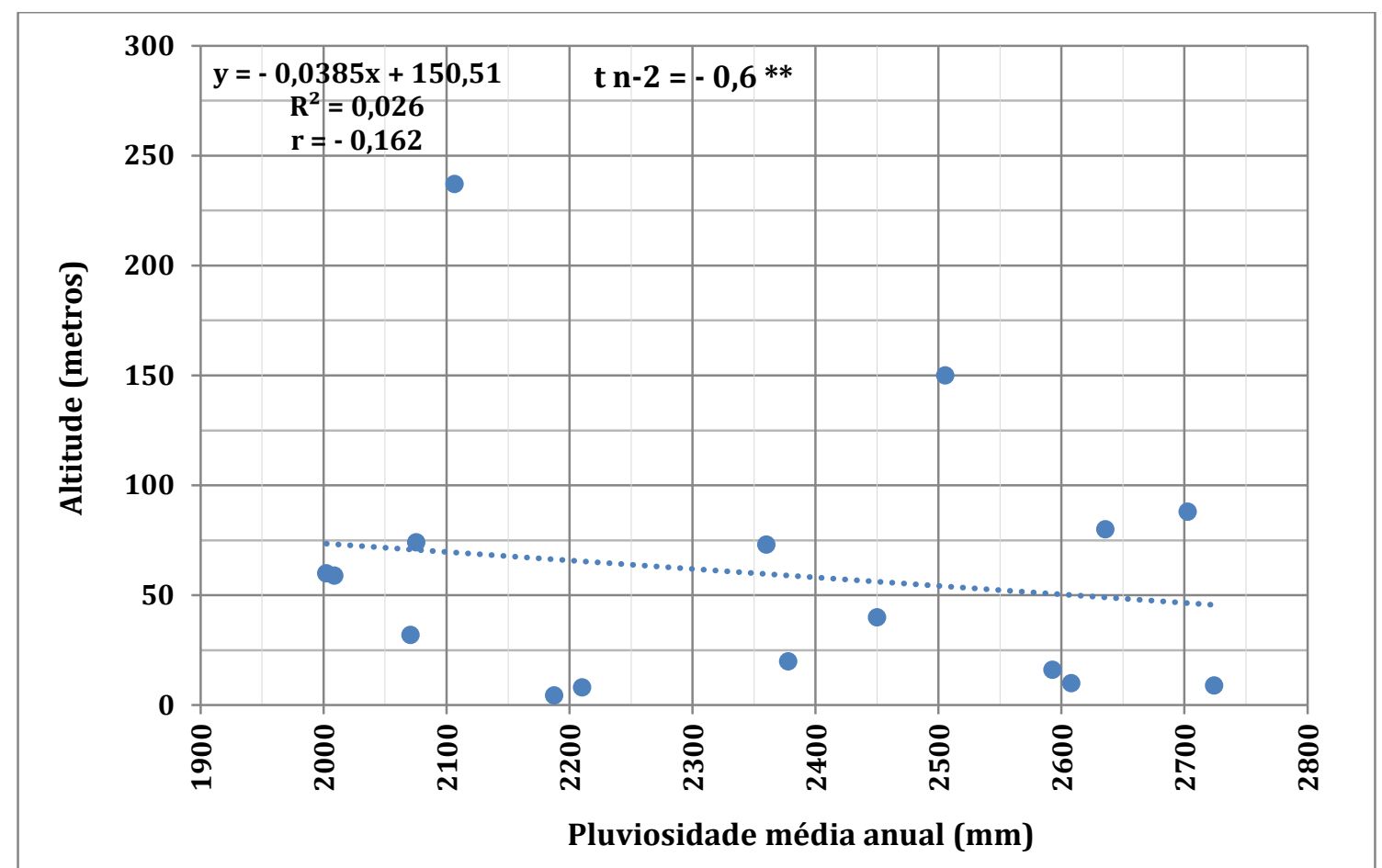

Figura 24 - Dispersão gráfica, coeficiente de determinação $\left(\mathrm{R}^{2}\right)$, correlação linear de Pearson (r), não significativo ao nível de $97,5 \%$ pelo teste t de Student (**) entre a pluviosidade média anual (mm) e a altitude (metros) dos postos pluviométricos e das estações meteorológicas inseridas na bacia hidrográfica Litorânea - Paraná.

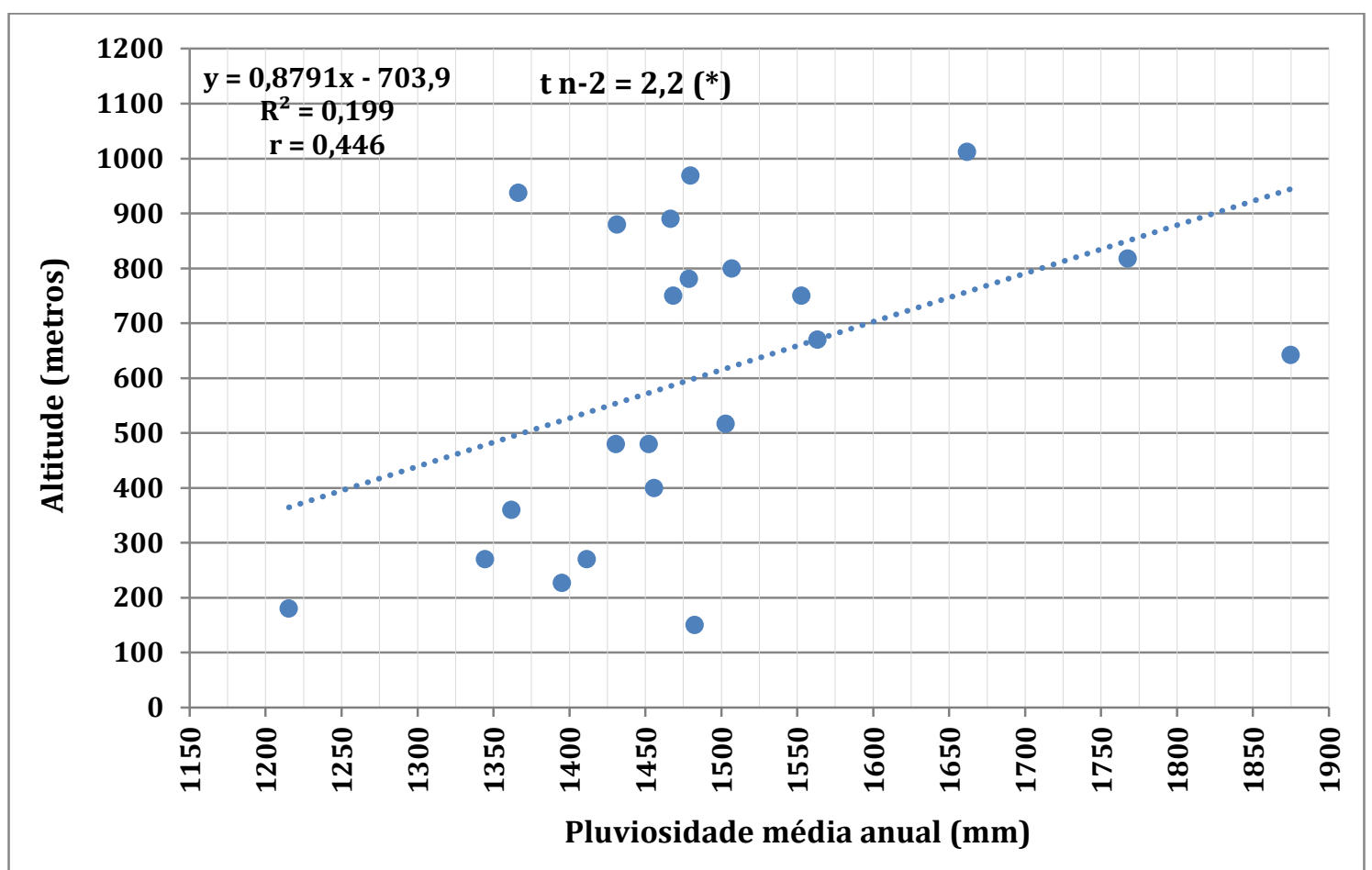

Figura 25 - Dispersão gráfica, coeficiente de determinação e correlação linear de Pearson, significativo ao nível de $97,5 \%$ pelo teste t de Student $(*)$ entre a pluviosidade média anual (mm) e a altitude (metros) dos postos pluviométricos e das estações meteorológicas inseridas na bacia hidrográfica do Ribeira - Paraná. 
Destaca-se que enquanto a BH do Alto Iguaçu caracteriza-se por sua pouca variação da altitude, para a BH Litorânea há a limitação quanto à avaliação da influência orográfica devido à ausência de postos pluviométrico em altitudes superiores a 250 metros, uma vez que esta $\mathrm{BH}$ apresenta o aumento de altitudes até o seu divisor de águas na Serra do Mar, sendo este uma das limitações da presente pesquisa e um empecilho a avaliação do desempenho orográfico na BH Litorânea.

A relação entre a orografia, a maritimidade e a distribuição espacial das chuvas está demonstrada de forma simplificada pelo perfil esquemático com as altitudes e a precipitação média anual dos postos pluviométricos e estações meteorológicas. Na bacia hidrográfica Litorânea, os setores de menores altitudes apresentam maiores totais pluviométricos, próximo a $2.700 \mathrm{~mm}$, destacando o efeito da maritimidade para a geração de maiores totais de chuvas, enquanto que o setor oeste, caracterizado pelas maiores elevações do terreno, mostrou uma redução dos totais pluviométricos anuais (2.000 mm). Na bacia hidrográfica do Ribeira a orografia desempenha um papel inverso em relação à bacia Litorânea, tendo em vista que os setores mais elevados obtiveram maiores médias pluviométricas anuais, e os postos de registros com menores altitudes caracterizam-se por totais pluviométricos, demonstrando uma maior influência do relevo para a distribuição espacial pluviométrica. A bacia hidrográfica do Alto Iguaçu caracteriza-se por uma maior homogeneidade da distribuição espacial pluviométrica, dada a menor variação das altitudes dos pontos de registros neste setor (Figura 25).

Assim como na zona costeira do estado de São Paulo (SANT'ANNA NETO, 1994), a maritimidade aliada à atuação intensificada dos sistemas atmosféricos intertropicais e a predominância dos sistemas frontais na geração de chuvas, respondem pelos elevados totais pluviométricos na Planície Costeira paranaense, como observado por Maack (2012). Fritzsons et al. (2011) descrevem que o Litoral do Paraná apresenta as maiores pluviometrias do território paranaense devido ao fator orográfico da Serra do Mar, brisa marítima e o contraste térmico entre a terra e as águas interiores.

A localização geográfica em relação a Serra do Mar atribui à bacia hidrográfica do rio Ribeira uma condição atípica da distribuição pluviométrica para esta latitude, uma vez que para o setor Meridional do território paranaense predomina a homogeneidade do regime mensal das chuvas devido às características próprias à dinâmica atmosférica do clima subtropical da região sul do Brasil, como ocorre na bacia hidrográfica do Alto Iguaçu, e os resultados demonstraram que a bacia do Ribeira apresenta uma significativa redução pluviométrica, justamente ao que se atribui a redução das chuvas para os meses 
de outono e inverno, condição própria ao clima tropical do Brasil Central, conforme apontado por Nimer (1989), Nery et al. (2002), Nery (2006), Silva et al. (2006), Aparecido et al. (2016) e Wrege et al. (2016).
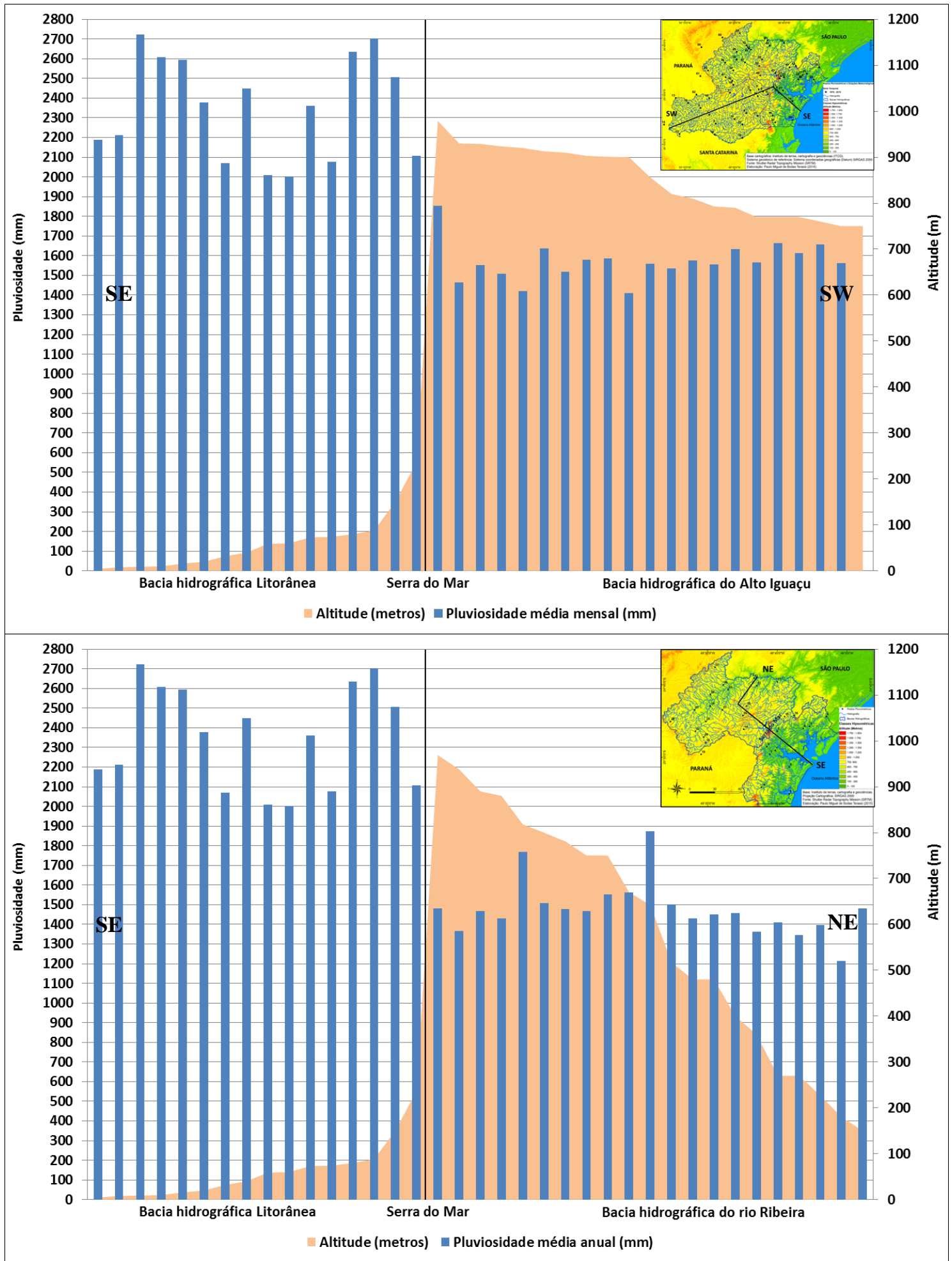

Figura 26 - Perfil esquemático da precipitação pluviométrica média anual $(\mathrm{mm})$ e a altitude dos postos pluviométricos e estações meteorológicas das bacias hidrográficas Alto Iguaçu, Litorânea e Ribeira Paraná. 


\subsubsection{Escala mensal}

A área de estudo apresenta maiores totais mensais de pluviosidade no período que vai de outubro a março (Figura 26) e, inversamente, o período de abril a setembro caracteriza-se pelos menores totais mensais pluviométricos (Figura 27). Os maiores totais de pluviosidade ocorrem em janeiro, com pluviosidade média de $237 \mathrm{~mm}$, com valores superiores a $400 \mathrm{~mm}$ no setor litorâneo e inferiores a $200 \mathrm{~mm}$ para grande parte da bacia hidrográfica Alto Iguaçu. O mês menos chuvoso é agosto, com média de 78,9 $\mathrm{mm}$, com a ocorrência de maiores isoietas na bacia hidrográfica Litorânea, superiores a $110 \mathrm{~mm}$, e menores valores para a região do Vale do Ribeira, inferiores a $60 \mathrm{~mm}$ (Figura 28).

A área de estudo apresenta maiores totais mensais de pluviosidade no período que vai de outubro a março (Figura 26) e, inversamente, o período de abril a setembro caracteriza-se pelos menores totais mensais pluviométricos (Figura 27). Os maiores totais de pluviosidade ocorrem em janeiro, com pluviosidade média de $237 \mathrm{~mm}$, com valores superiores a $400 \mathrm{~mm}$ no setor litorâneo e inferiores a $200 \mathrm{~mm}$ para grande parte da bacia hidrográfica Alto Iguaçu. O mês menos chuvoso é agosto, com média de 78,9 $\mathrm{mm}$, com a ocorrência de maiores isoietas na bacia hidrográfica Litorânea, superiores a $110 \mathrm{~mm}$, e menores valores para a região do Vale do Ribeira, inferiores a $60 \mathrm{~mm}$ (Figura 28).

Em concordância ao obtido em outras bacias hidrográficas por Andrade e Nery (2003) e Candido e Nunes (2008), observa-se que os setores com maiores variações do relevo, sobretudo nas proximidades da Serra do Mar, mostraram as maiores variações dos totais de pluviosidade. De modo inverso, os setores com as menores variações das altitudes mostraram as menores variações espaciais, especialmente nas menores elevações do setor norte da bacia hidrográfica do Ribeira. Nota-se que durante os meses de inverno, no período que vai de junho a agosto, a distribuição espacial das chuvas apresenta menores intervalos em relação ao período de verão, dado que os mecanismos de predominantes na geração de chuvas, os sistemas frontais, atuam de forma mais homogênea em relação ao verificado para os meses de verão e primavera (CARDOZO; REBOITA; GARCIA, 2015; ZANDONADI et al., 2015). 


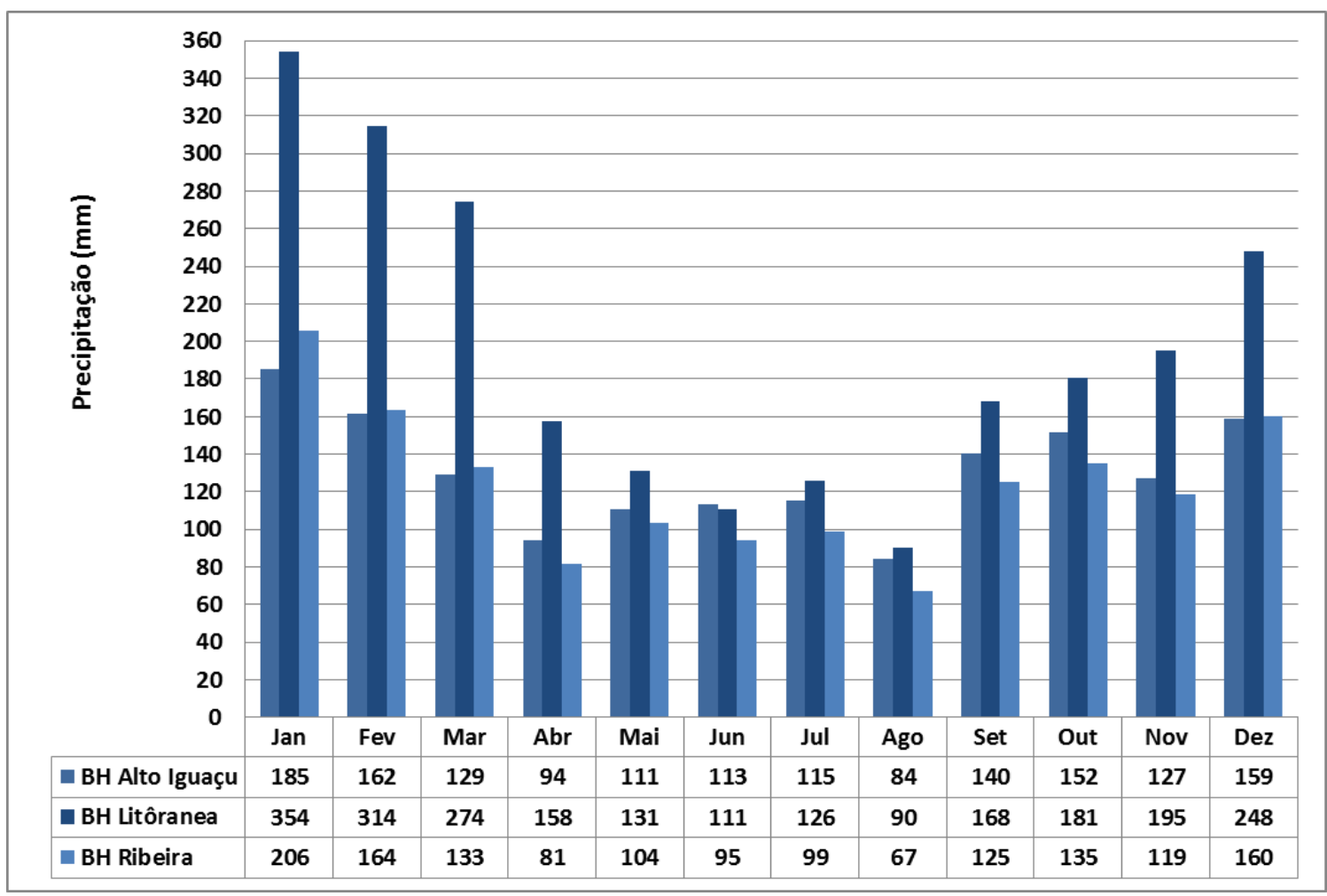

Figura 27 - Distribuição média mensal da precipitação pluviométrica (mm) das bacias hidrográficas Alto Iguaçu, Litorânea e Ribeira - Paraná.

Estes resultados são aproximados aos obtidos por Cavaglione et al. (2000), Sousa (2006), Grimm (2009) e Fritzsons et al. (2011), uma vez que estes observaram que a costa litorânea paranaense se caracteriza pelos maiores totais pluviométricos anuais e com uma marcada concentração das chuvas nos meses de verão, sem estação seca, constantemente com pluviosidade superior a $90 \mathrm{~mm}$ nos meses menos chuvosos. No setor continente adentro, estes autores observaram que no setor Centro-Sul do território paranaense, os totais pluviométricos anuais são menores em relação à costa litorânea e, no entanto, observa-se uma distribuição homogênea da pluviosidade mensal, característica inerente ao clima Subtropical do Sul do Brasil. A região do Vale do Ribeira, por sua vez, corresponde a um dos setores de menores alturas pluviométricas do estado do Paraná, com uma expressiva concentração das chuvas nos meses de verão, evidenciando uma tendência de aproximação com o clima Tropical do Brasil Central. 


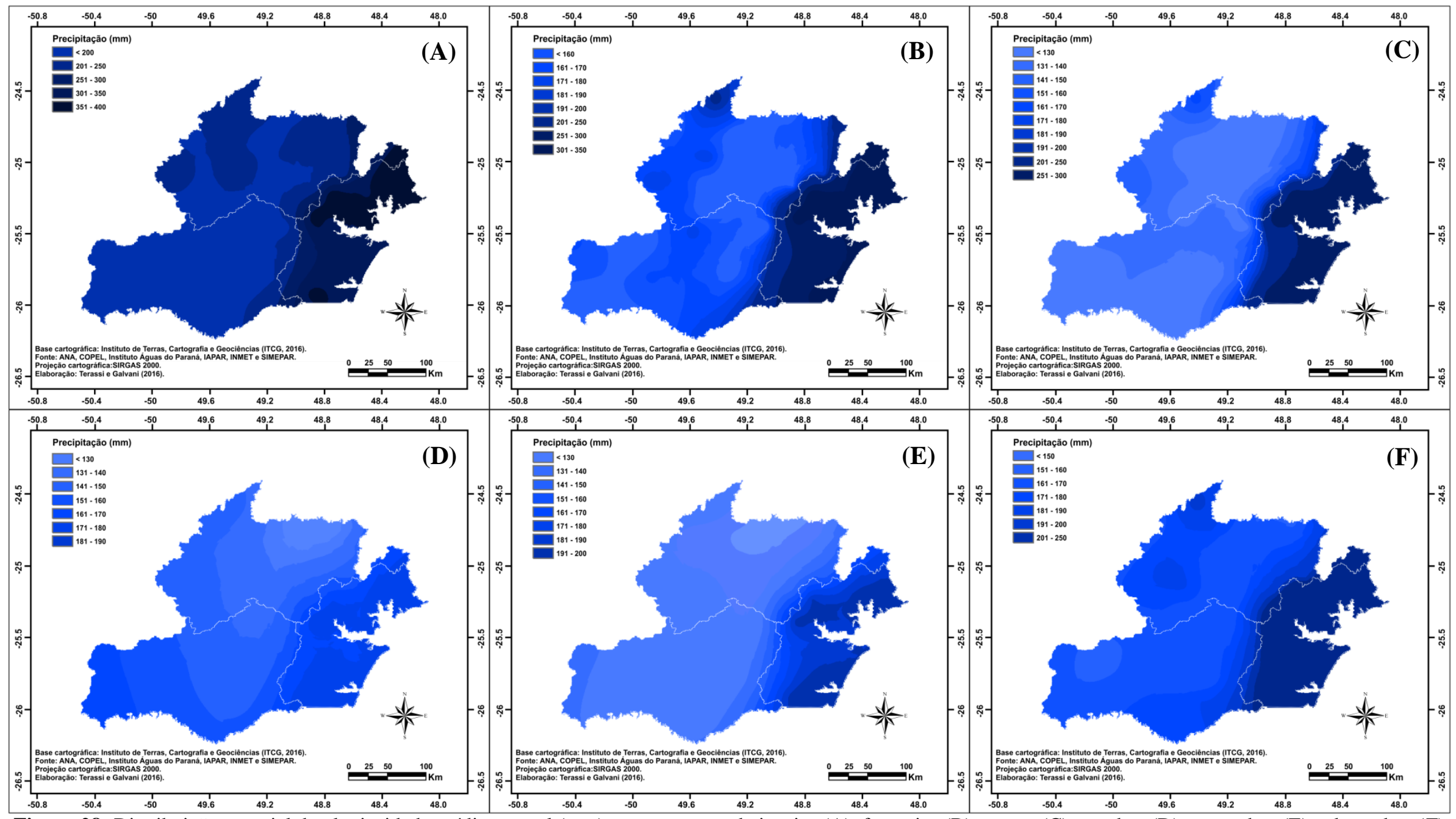

Figura 28- Distribuição espacial da pluviosidade média mensal (mm) para os meses de janeiro (A), fevereiro (B), março (C), outubro (D), novembro (E) e dezembro (F) para as bacias hidrográficas Alto Iguaçu, Ribeira e Litorânea - Paraná. 


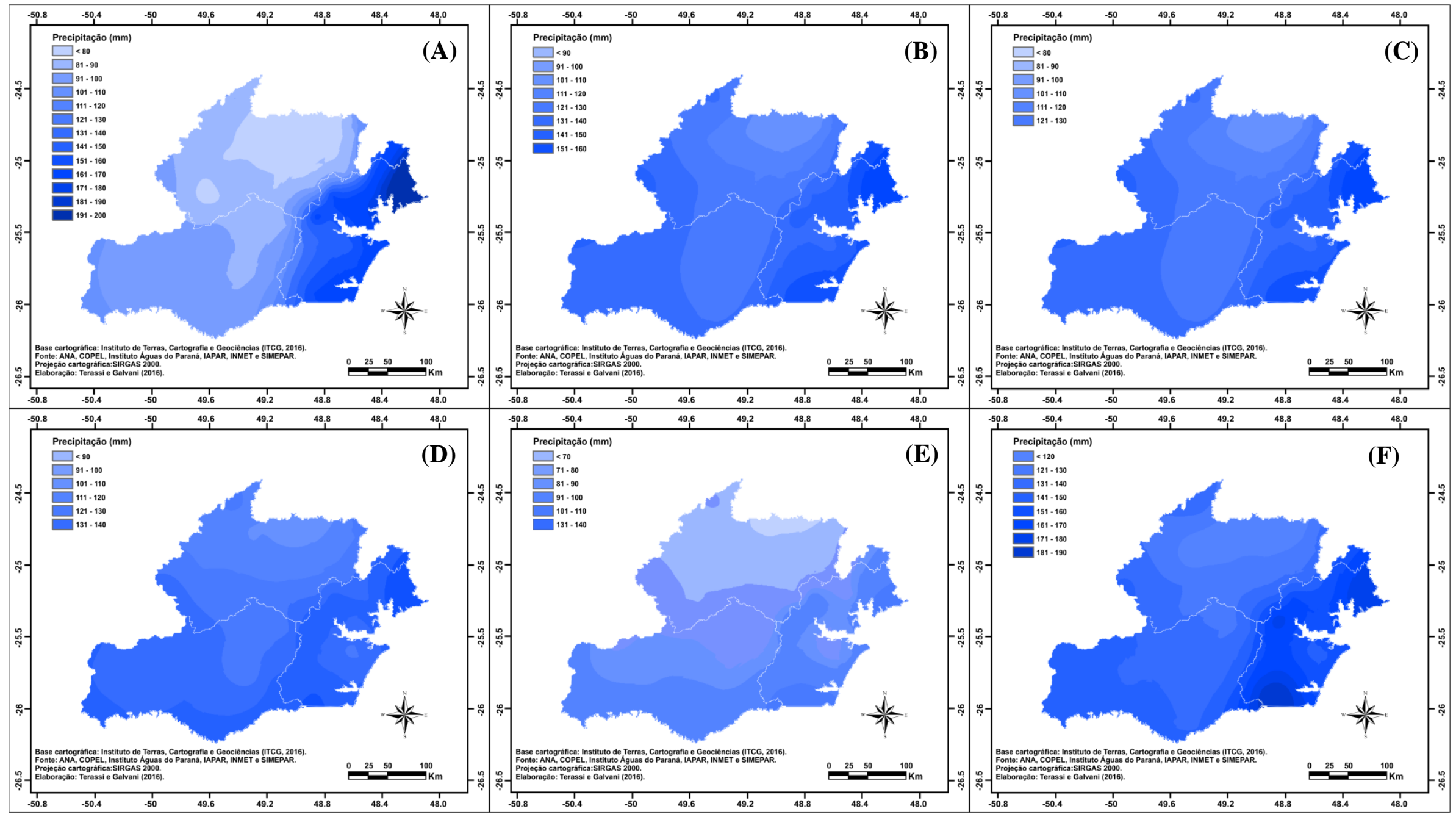

Figura 29 - Distribuição espacial da pluviosidade média mensal (mm) para os meses de abril (A), maio (B), junho (C), julho (D), agosto (E) e setembro (F) para as bacias hidrográficas Alto Iguaçu, Ribeira e Litorânea - Paraná. 


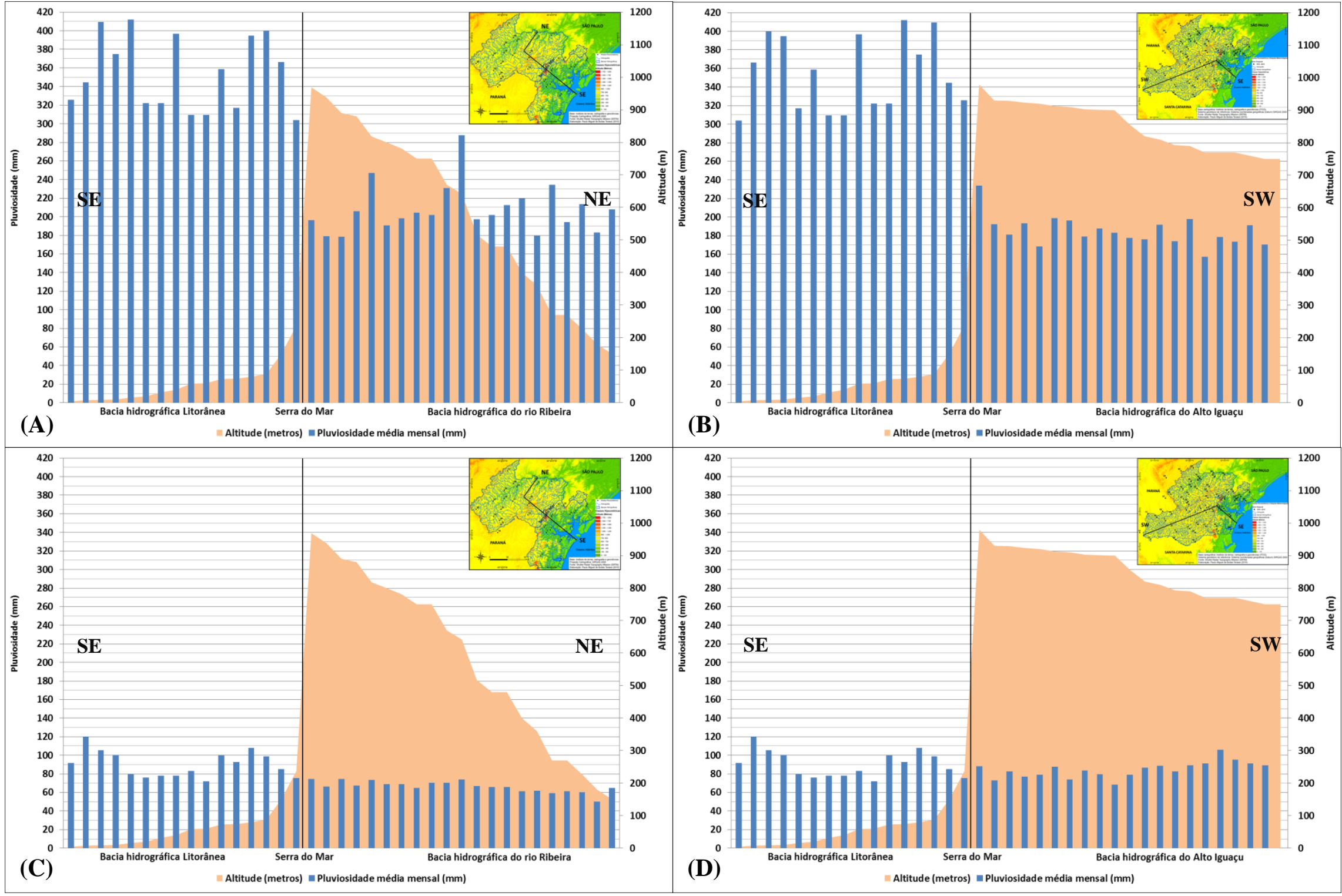

Figura 30 - Perfil esquemático da pluviosidade média mensal (mm) para os meses de janeiro em (A - B) e agosto (C - D) e a altitude dos postos pluviométricos e estações meteorológicas inseridas nas bacias hidrográficas do Alto Iguaçu, Litorânea e Ribeira - Paraná. 


\subsection{Análise espaço-temporal pluviométrica}

\subsubsection{Análise de agrupamento via método Ward}

A análise de agrupamento identificou nove grupos pluviométricos homogêneos e três postos pluviométricos anômalos, que mostraram a estrutura das chuvas para a área de estudo. Os pontos de corte dos dendogramas (Figura 31, 32 e 33), as características de distribuição mensal (Tabela 1), a identificação da dissimilaridade e a similaridade espacial entre os postos pluviométricos e estações meteorológicas permitiram identificar padrões espaciais de pluviosidade (Figuras 34 e 35) e mostrar indícios das relações entre os atributos climáticos controladores da distribuição espacial das chuvas: a maritimidade, a orografia e a dinâmica atmosférica.

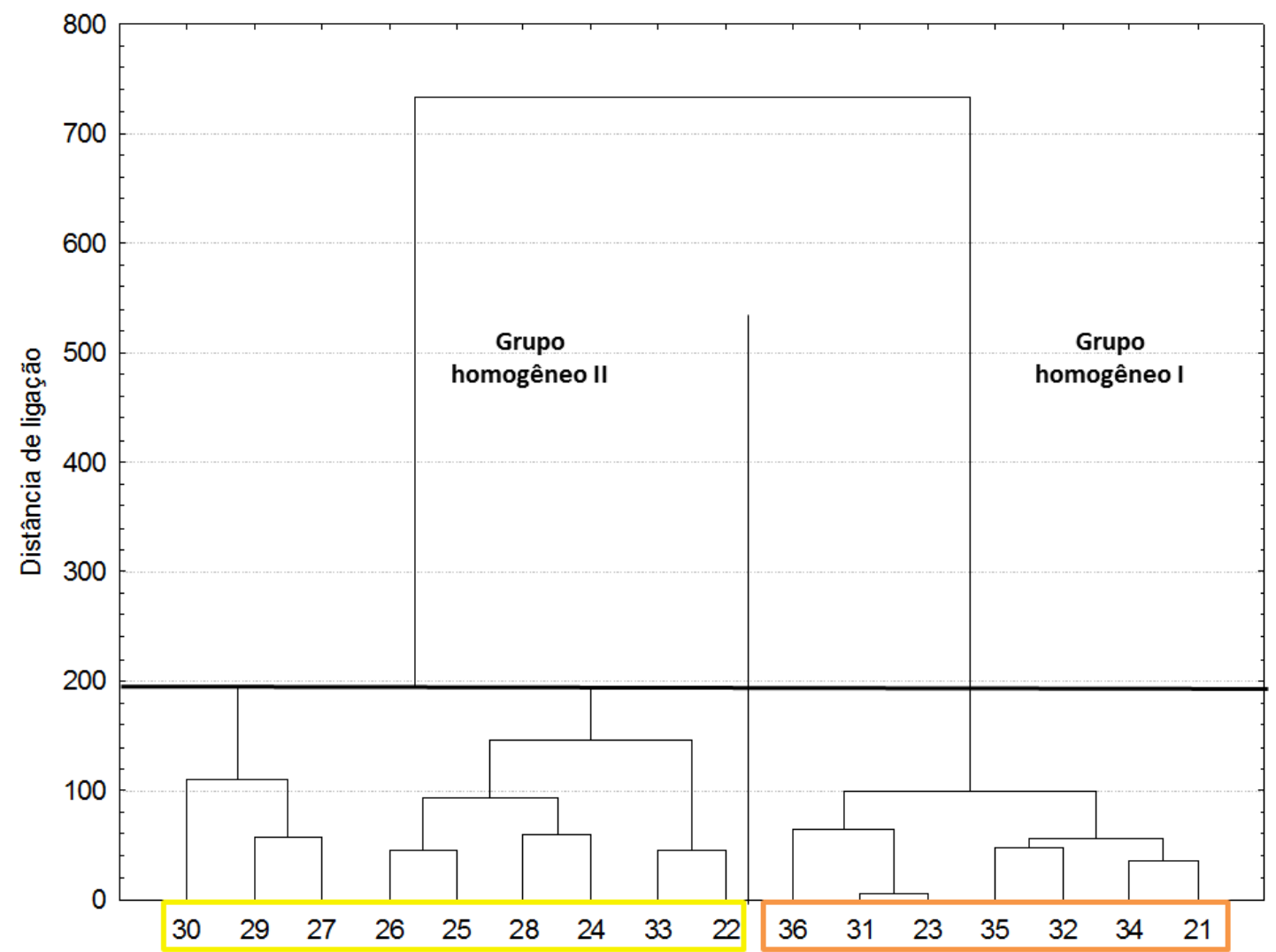

Figura 31 - Dendograma para os postos pluviométricos da bacia hidrográfica Litorânea (PR) e respectivos grupos pluviométricos homogêneos. 


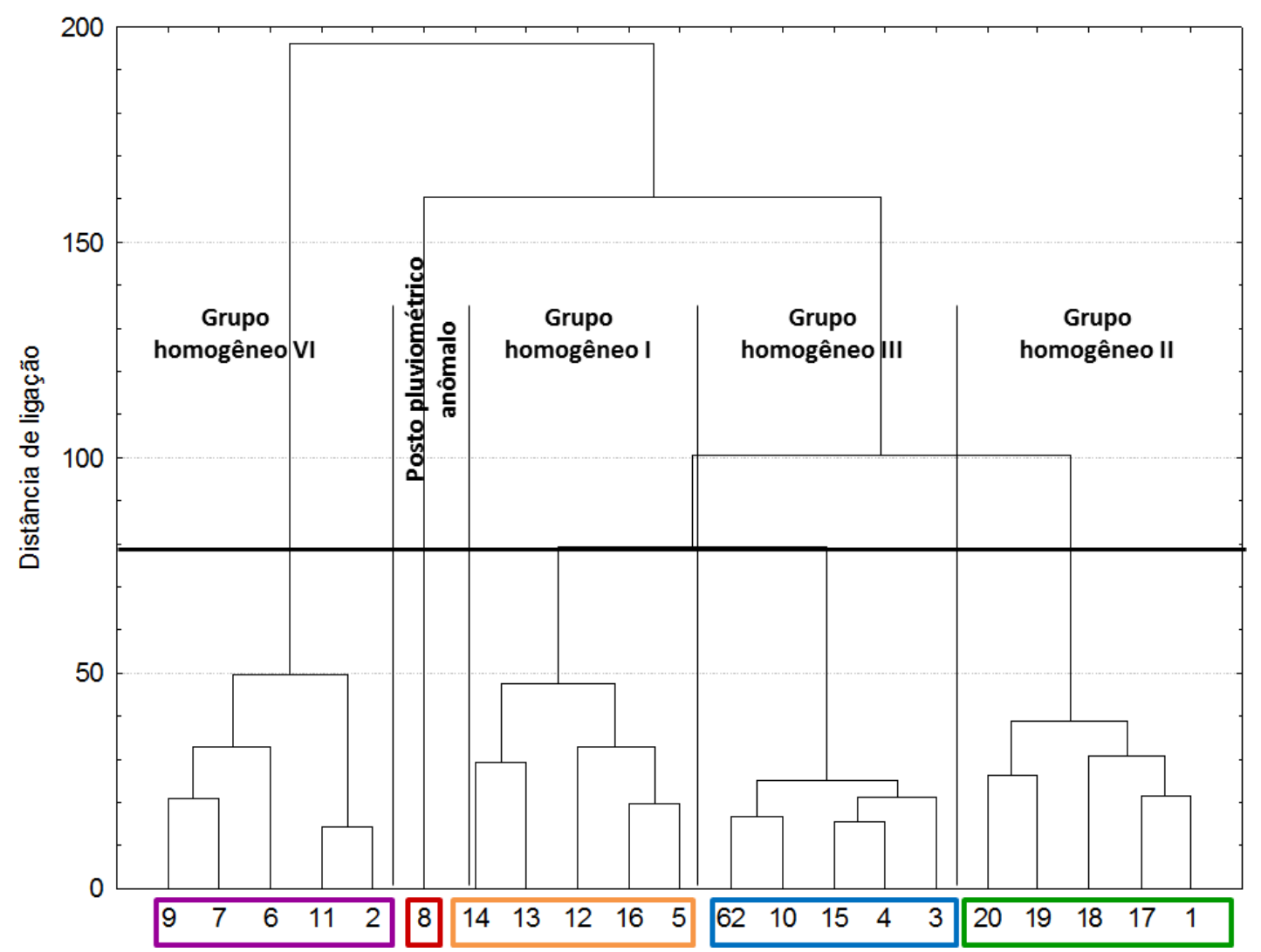

Figura 32 - Dendograma para os postos pluviométricos da bacia hidrográfica do Alto Iguaçu (PR) e respectivos grupos pluviométricos homogêneos.

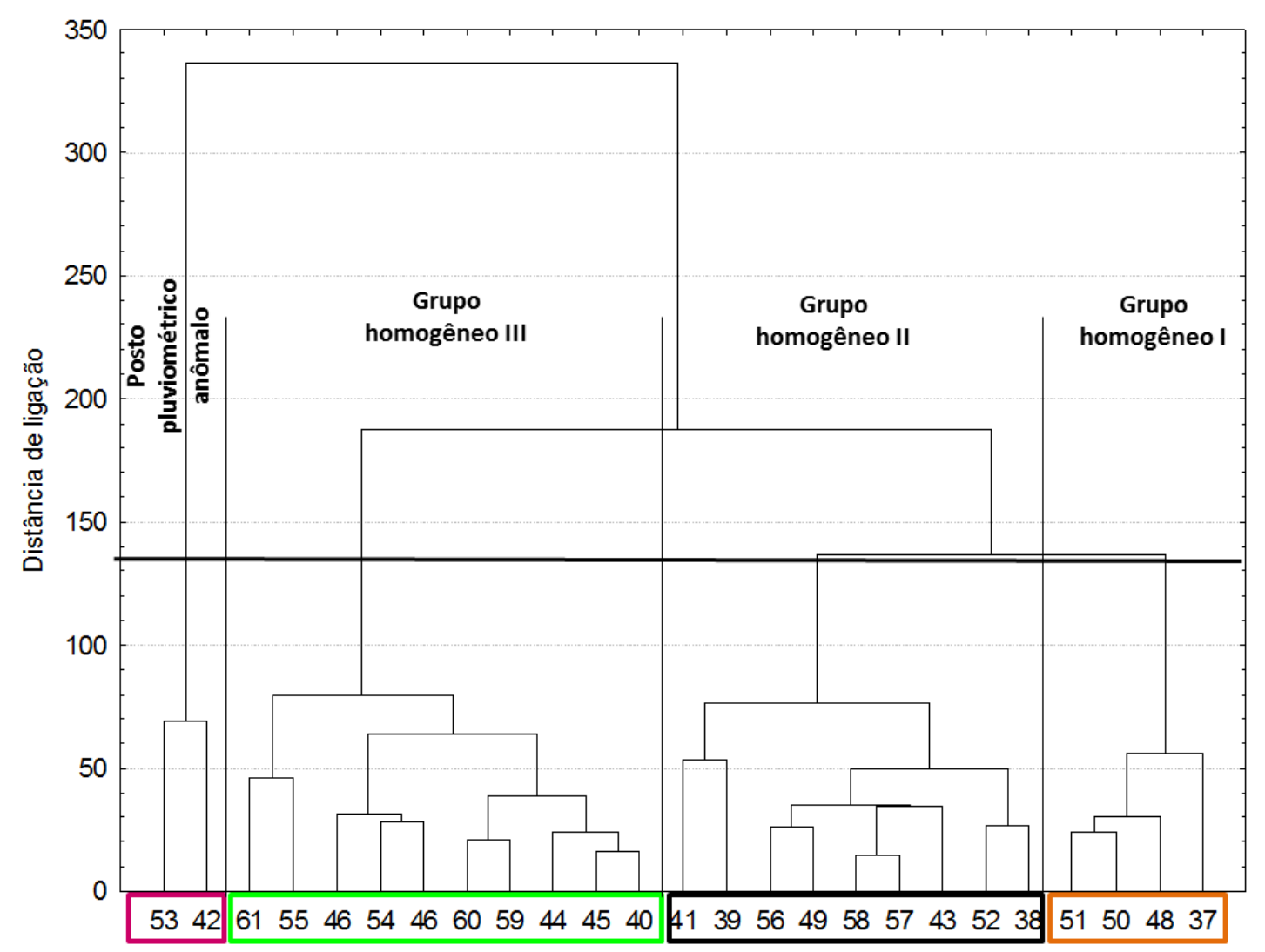

Figura 33 - Dendograma para os postos pluviométricos da bacia hidrográfica do Ribeira (PR) e respectivos grupos pluviométricos homogêneos. 
Tabela 1 - Pluviosidade média mensal e anual $(\mathrm{mm})$ para as bacias hidrográficas e seus respectivos grupos homogêneos e postos pluviométricos anômalos.

\begin{tabular}{|c|c|c|c|c|c|c|c|c|c|c|c|c|c|c|}
\hline $\begin{array}{l}\text { GH } \\
\text { Mês }\end{array}$ & $\begin{array}{c}\text { BH } \\
\text { L }\end{array}$ & I & $\begin{array}{c}\text { GHL } \\
\text { II }\end{array}$ & $\begin{array}{c}\text { BH } \\
\text { AI }\end{array}$ & $\begin{array}{c}\text { GHAI } \\
\text { I }\end{array}$ & $\begin{array}{c}\text { GHAI } \\
\text { II }\end{array}$ & $\begin{array}{c}\text { GHAI } \\
\text { III }\end{array}$ & $\begin{array}{c}\text { GHAI } \\
\text { IV }\end{array}$ & $\begin{array}{c}\text { PA - } \\
\text { BHAI }\end{array}$ & $\begin{array}{c}\mathbf{B H} \\
\mathbf{R}\end{array}$ & $\begin{array}{c}\text { GHR } \\
\text { I }\end{array}$ & $\begin{array}{c}\text { GHR } \\
\text { II }\end{array}$ & $\begin{array}{c}\text { GHR } \\
\text { III }\end{array}$ & $\begin{array}{l}\text { PA - } \\
\text { BHR }\end{array}$ \\
\hline Jan & 354 & 319 & 382 & 185 & 174 & 190 & 179 & 187 & 234 & 206 & 184 & 215 & 195 & 267 \\
\hline Fev & 314 & 278 & 342 & 162 & 157 & 172 & 156 & 153 & 204 & 164 & 145 & 164 & 157 & 224 \\
\hline Mar & 274 & 239 & 302 & 129 & 119 & 131 & 131 & 128 & 169 & 133 & 112 & 131 & 131 & 187 \\
\hline Abr & 158 & 132 & 178 & 94 & 99 & 93 & 94 & 85 & 117 & 81 & 71 & 78 & 87 & 97 \\
\hline Mai & 131 & 114 & 144 & 111 & 118 & 106 & 117 & 98 & 123 & 104 & 94 & 95 & 111 & 120 \\
\hline Jun & 111 & 103 & 117 & 113 & 124 & 116 & 119 & 96 & 109 & 95 & 83 & 90 & 101 & 109 \\
\hline Jul & 126 & 115 & 135 & 115 & 122 & 119 & 115 & 105 & 125 & 99 & 88 & 94 & 106 & 109 \\
\hline Ago & 90 & 80 & 98 & 84 & 95 & 86 & 81 & 74 & 88 & 67 & 60 & 64 & 71 & 74 \\
\hline Set & 168 & 156 & 178 & 140 & 147 & 140 & 141 & 129 & 160 & 125 & 113 & 118 & 132 & 144 \\
\hline Out & 181 & 161 & 196 & 152 & 165 & 148 & 155 & 136 & 168 & 135 & 123 & 130 & 143 & 149 \\
\hline Nov & 195 & 172 & 213 & 127 & 131 & 127 & 124 & 118 & 167 & 119 & 101 & 115 & 124 & 146 \\
\hline Dez & 248 & 225 & 266 & 159 & 161 & 165 & 148 & 154 & 190 & 160 & 148 & 160 & 158 & 196 \\
\hline Tot & 2351 & 2094 & 2551 & 1571 & 1612 & 1593 & 1561 & 1464 & 1853 & 1488 & 1322 & 1455 & 1515 & 1821 \\
\hline Alt & 60 & 68 & 54 & 898 & 764 & 847 & 886 & 917 & 979 & 649 & 437 & 479 & 869 & 818 \\
\hline
\end{tabular}

BH: bacia hidrográfica; GH: grupo homogêneo; PA: posto pluviométrico anômalo; L: Litorânea; AI: Alto Iguaçu; R: Ribeira; Tot: total anual (milímetros); Alt: altitude média (metros).

Os resultados de agrupamento de regiões pluviometricamente homogêneas estão concordantes com os resultados obtidos por Fritzsons et al. (2011) para o estado do Paraná. Nos setores de menor pluviometria, especificamente no grupo homogêneo I, na região do Vale do Ribeira, onde ocorrem as maiores diferenças entre o trimestre chuvoso (dezembro, janeiro e fevereiro) e o trimestre seco (junho, julho e agosto). Estes mesmo autores identificaram que a região em que se localiza a bacia hidrográfica do Alto Iguaçu caracteriza-se pela distribuição homogênea da pluviosidade e menores diferenças entre os trimestres citados acima. O litoral paranaense destaca-se dentre os demais grupos homogêneos identificados para o estado, com a maior pluviometria atribuída a fatores como a maritimidade, a orografia da Serra do Mar e o contraste térmico entre o oceano e continente.

A bacia hidrográfica Litorânea obteve dois grupos homogêneos. O grupo homogêneo I corresponde ao setor menos chuvosa, com média anual de $2.094 \mathrm{~mm}$, predominantemente localizada no setor central. O grupo homogêneo II caracteriza-se pelos maiores totais anuais de pluviosidade, com média de $2.551 \mathrm{~mm}$, e localiza-se principalmente no setor nordeste (Figuras 34 e 35). O grupo homogêneo II apresenta os maiores totais de pluviosidade em todos os meses dentre todos os grupos homogêneos identificados para as bacias hidrográficas da região leste do estado do Paraná, destacandose por valores superiores a $300 \mathrm{~mm}$ no trimestre janeiro, fevereiro e março e pela menor redução nos meses invernais. O grupo homogêneo I mostra maiores totais de pluviosidade em relação às demais porções da área de estudo, exceção dada pelo agrupamento 
supracitado, e com similaridade dos totais mensais com os grupos homogêneos da bacia hidrográfica do Alto Iguaçu para o período de maio a agosto (Figura 36).

A bacia hidrográfica do Alto Iguaçu obteve quatro grupos homogêneos e um posto pluviométrico anômalo. No setor oeste, o grupo homogêneo I apresenta os maiores totais anuais de pluviosidade $(1.612 \mathrm{~mm})$, mesmo em condições de menores altitudes, ao passo que o grupo homogêneo IV, situado a leste, caracteriza-se pelos menores totais pluviométricos (1.464 $\mathrm{mm})$, provavelmente pelo efeito de sombra de chuvas da Serra do Mar. O posto pluviométrico anômalo (8 - Piraquara) apresenta os maiores totais pluviométricos anuais desta bacia hidrográfica, que pode ser atribuída a sua condição a barlavento da Serra do Mar (Figuras 34 e 35). De modo geral, o grupo homogêneo I apresenta os maiores totais pluviométricos mensais no período que vai de maio a setembro, provavelmente pela atuação mais incisiva dos sistemas atmosféricos frontais, dada sua maior aproximação com o domínio climático subtropical, enquanto que para os demais meses o posto pluviométrico anômalo apresenta os maiores totais pluviométricos mensais. Os grupos homogêneos II e III mostraram similaridades tanto quanto aos totais anuais e, entretanto, devido a sua localização mais aproximada ao Oceano Atlântico, o grupo homogêneo II apresenta maiores totais pluviométricos nos meses de janeiro, fevereiro e dezembro. O grupo homogêneo IV apresenta os menores totais de pluviosidade para o período de maio a novembro dentre todos os grupos identificados (Figura 36).

A bacia hidrográfica do Ribeira apresenta os grupos homogêneos com os menores totais anuais de pluviosidade para a área em estudo. Contrário ao identificado para o Alto Iguaçu, nesta bacia hidrográfica a orografia controla distribuição espacial da pluviosidade, com maiores totais anuais para o grupo homogêneo III, com a média de $1.515 \mathrm{~mm}$ e altitude de 869 metros, e menores valores para o grupo homogêneo I, com média de $1.322 \mathrm{~mm}$ e altitude de 437 metros. Os postos pluviométricos anômalos apresentaram totais anuais de $1.821 \mathrm{~mm}$ e altitude de 818 metros (Figuras 34 e 35) e que apresentaram os maiores totais mensais de pluviosidade, principalmente nos meses de novembro a março. Destaca-se que o grupo homogêneo I apresenta os menores totais mensais de pluviosidade, com a maior redução nos meses de junho, julho e agosto, demarcando a maior condição de tropicalização da área de estudo. Embora os totais anuais apresentem uma diferença de apenas $60 \mathrm{~mm}$ entre os grupos homogêneos II e III, observa-se que o grupo II se caracteriza pelos maiores totais mensais de dezembro a fevereiro e, com maior proximidade com o clima Subtropical do Brasil Meridional, o 
grupo III caracteriza-se por uma maior homogeneidade mensal das chuvas e maiores valores nos meses de abril a novembro em relação ao grupo II (Figura 37).

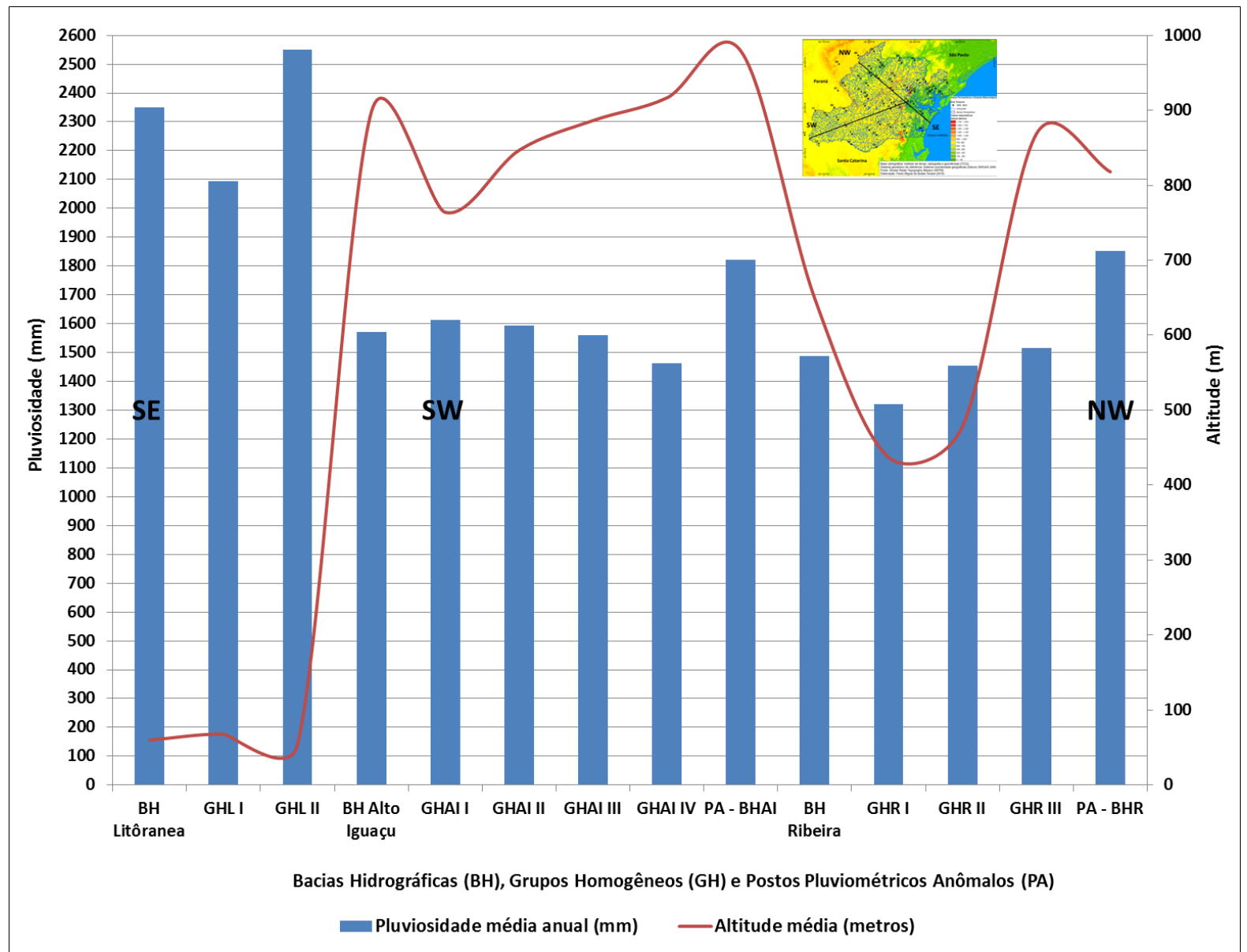

Figura 34 - Pluviosidade média anual (mm) e altitude média (metros) para os grupos homogêneos e postos pluviométricos anômalos para as bacias hidrográficas do Alto Iguaçu, Ribeira e Litorânea - Paraná. 


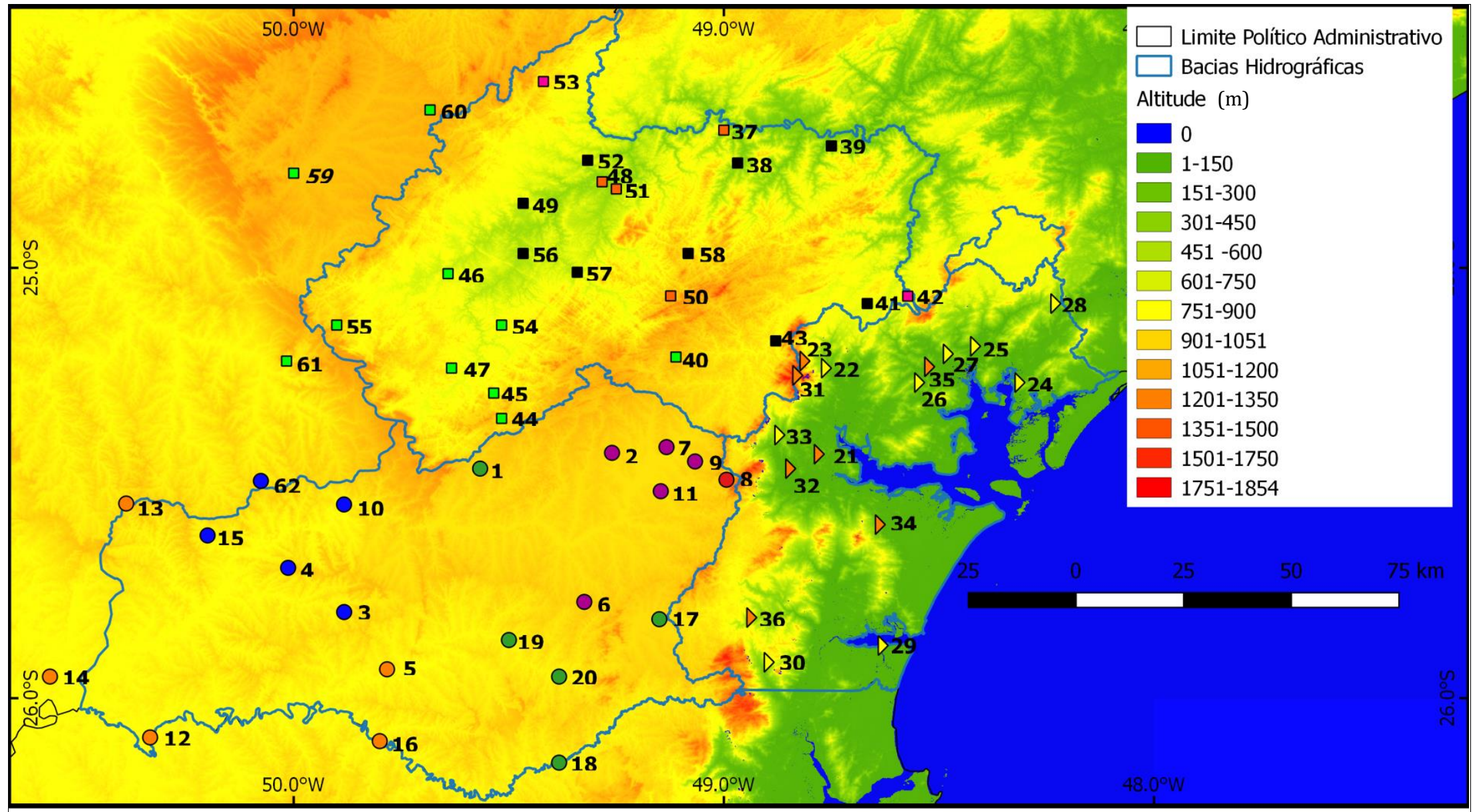

Bacia Litorânea Bacia do Rio Ribeira

$\begin{array}{llllll}\triangleright & \text { GHL I } & \square & \text { GHR I } & \\ \triangleright & \text { GHL II } & \square & \text { GHR II } & \\ & \square & \text { GHR III } & \\ & \square & \text { PA BHR } & & 0 & \text { GHAI II } \\ & & & 0 & \text { GHAI III } \\ & & & 0 & \text { PA BHAI }\end{array}$

Base: Bacias Hidrogŕaficas (ITCG, 2012) e divisão Político Administrativo IBGE (2010)

Fonte: Imagem SRTM (Shuttle Radar Topography Mission) Projeto TOPODATA (INPE, 2011).

Projeção: Sistema de Coordenadas Geográficas.

Datum Horizontal: SIRGAS 2000.

Elaboração: Paulo M. D. B. Terassi (2016)

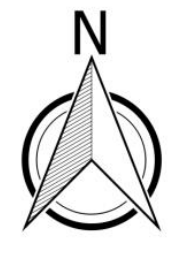

Figura 35 - Distribuição espacial dos grupos homogêneos $(\mathrm{GH})$ e dos postos pluviométricos anômalos (PA) pelo método Ward para as bacias hidrográficas do Alto Iguaçu, Ribeira e Litorânea - Paraná. 

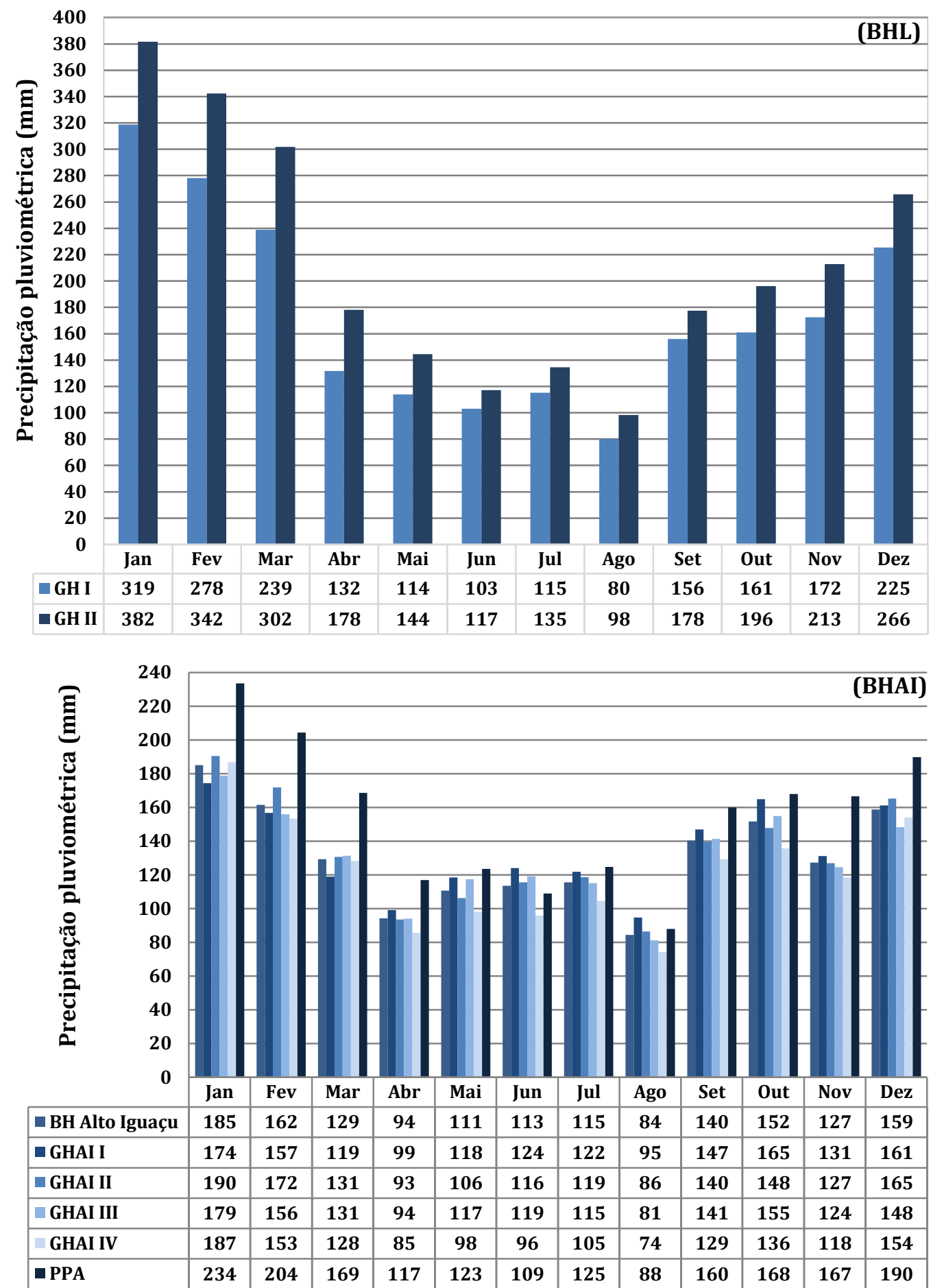

Figura 36 - Precipitação pluviométrica média mensal dos grupos homogêneos (GH) e do posto pluviométrico anômalo (PPA) das bacias hidrográficas Litorânea (BHL) e Alto Iguaçu (BHAI) - PR. 


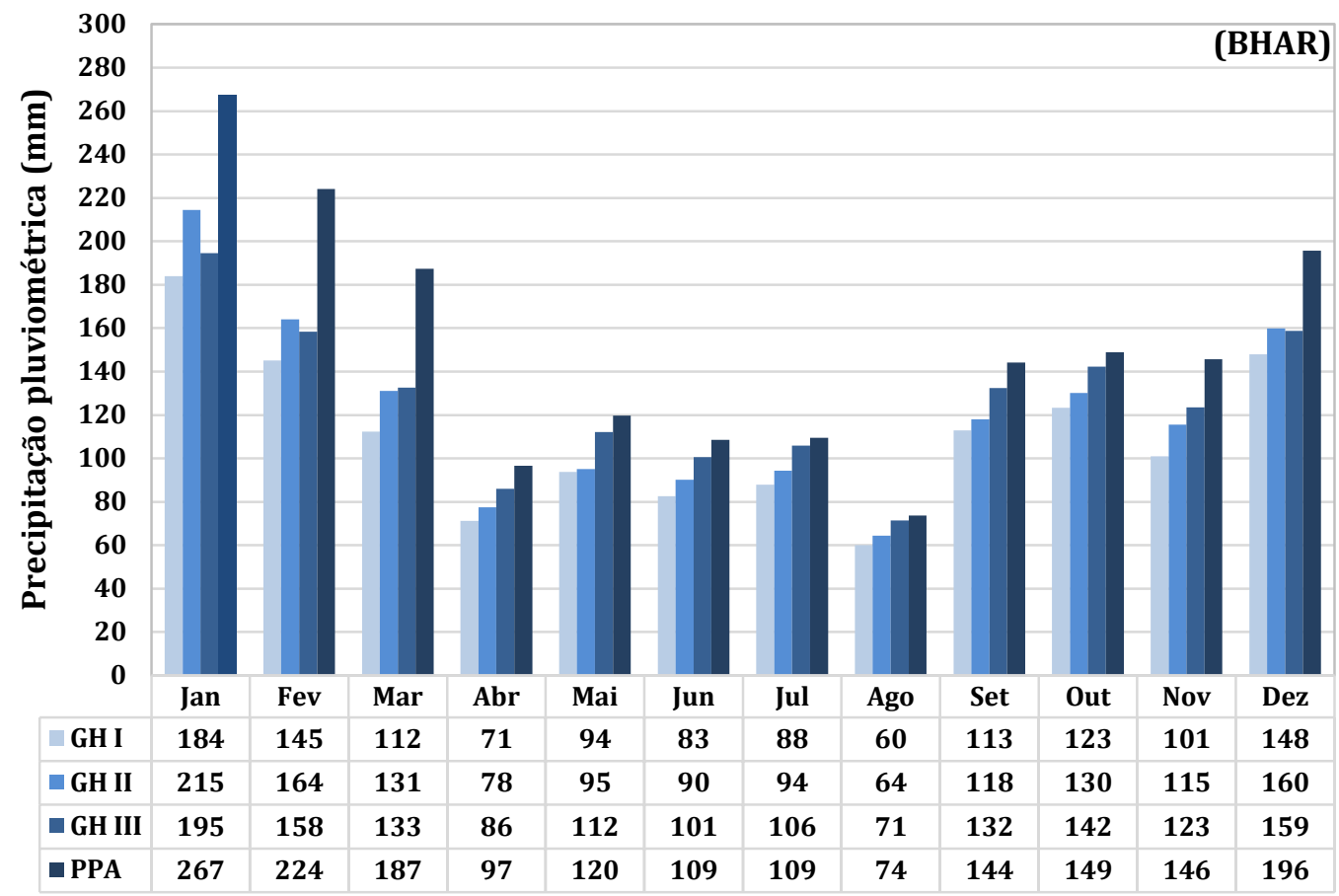

Figura 37 - Precipitação pluviométrica média mensal dos grupos homogêneos (GH) e do posto pluviométrico anômalo (PPA) das bacia hidrográfica do rio Ribeira (BHR) - PR.

Quanto à variabilidade anual, observa-se que a BH Litorânea apresenta uma relativa influência do modo de variabilidade ENOS para a ocorrência de menores ou maiores valores de pluviosidade. Considerando-se que a média de pluviosidade anual no GHI da BHL é de 2094,5 mm, nota-se uma considerável redução (<1.500 mm) neste setor para os anos de 1978 e 1985, anos nos quais prevaleceram as condições de neutralidade e La Niña de forte intensidade, nesta ordem. De modo inverso, a fase quente do ENOS esteve atuante nos anos de 1983, 1998 e 2010, períodos em que se registrou totais pluviais superiores a $2.500 \mathrm{~mm}$. Destaca-se que, ao contrário do esperado pela literatura, o ano de 2008 esteve parcialmente sob as condições de La Niña e, contudo, registrou-se totais pluviométricos superiores a $2.500 \mathrm{~mm}$ (Figura 38).

O setor mais chuvoso da BH Litorânea corresponde ao GH II (2.553,0 $\mathrm{mm}$ ), que apresenta totais anuais de precipitação pluviométrica superior a 3.000 
mm para os anos de 1983, 1998, 2008, 2010 e 2015, sendo que com exceção de 2008 (La Niña), todos os demais anos estiveram condicionados ao El Niño, o que demonstra a atuação incisiva deste fenômeno na variabilidade anual das chuvas neste setor da BHL. No entanto, nota-se que os anos de 1978, 1985, 2000 e 2007, em condições de La Niña, registraram totais de precipitação inferior a $2.100 \mathrm{~mm}$ e, abaixo deste mesmo limiar, observa-se que mesmo sob atuação do El Niña, o ano de 2006 registrou pluviosidade notavelmente abaixo da média climatológica deste setor da BH Litorânea (Figura 38).

Verifica-se que os maiores totais anuais da BHAI estão associados em sua maioria aos eventos mais intensos do modo de variabilidade climática ENOS. Os anos de 1983, 1998, 2010 e 2015 mostraram uma média anual superior a $1900 \mathrm{~mm}$ para a média da BHAI (Figura 38) e estiveram sob domínio parcial ou total da fase quente do ENOS (El Niño), que segundo Grimm et al. (2000), Nery e Carfan (2014) e Tedeschi et al. (2015), é o período de maior aumento da pluviosidade em função da atuação da fase quente do ENOS.

Por sua vez, a fase fria do ENOS (La Niña) mostrou-se preponderante ao determinar os menores totais anuais da ordem de $1200 \mathrm{~mm}$ nos anos de 1978 e 1985, sendo corroborado pelos resultados obtidos por Baldo et al. (2001) e Nery et al. (2005), de que a La Niña atua com menor intensidade e frequência para a redução da precipitação pluviométrica no estado Paraná em relação ao El Niño. Entretanto, destaca-se que não necessariamente um determinado período com a atuação do El Niño registrará totais anuais mais elevados, como houve em 2006 (1142,2 mm), e também em condições de La Niña não será observado impreterivelmente os menores totais de pluviosidade, como observado em 2011 (1804,9 mm), conforme demonstra a figura 38. 


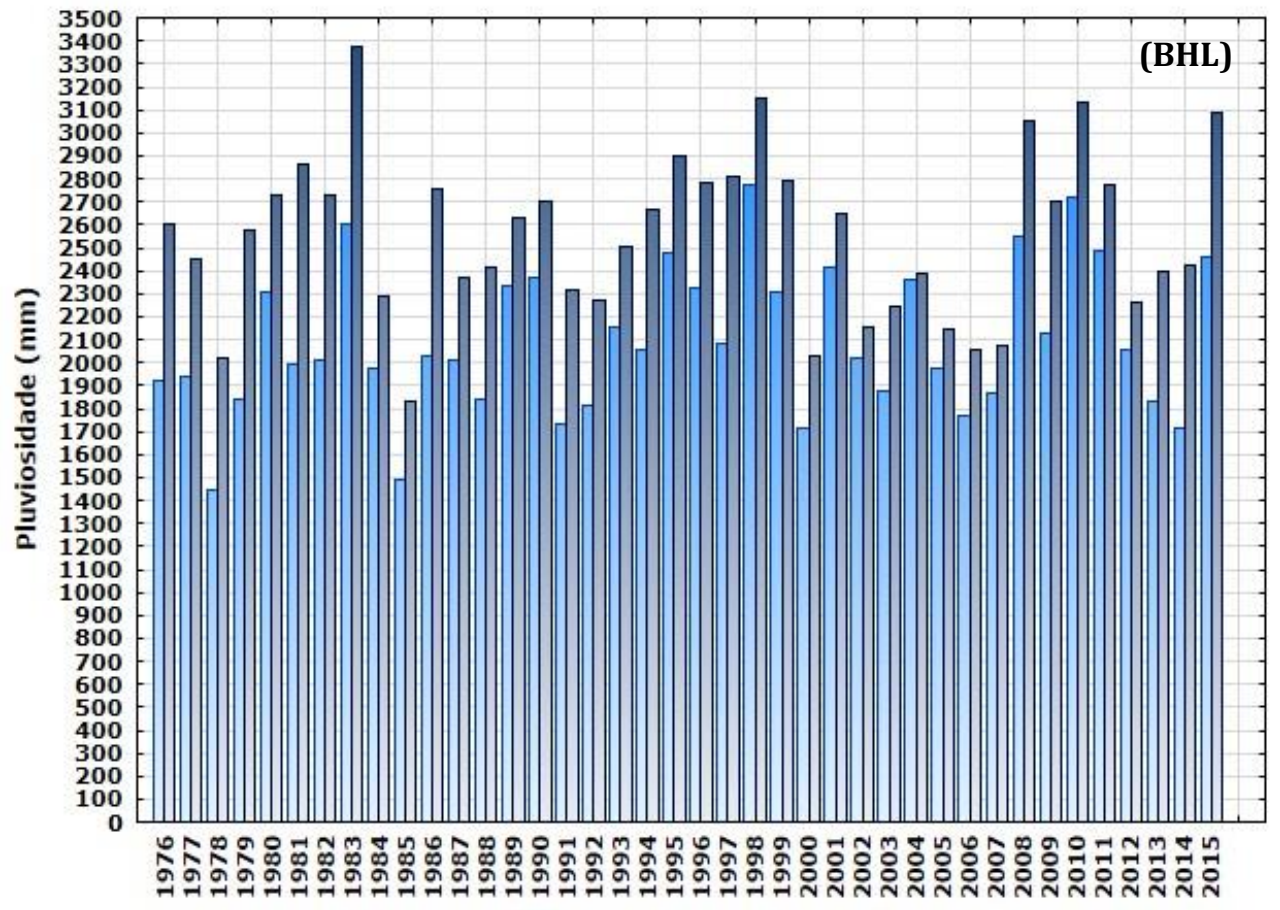

GH I $\square$ GH II

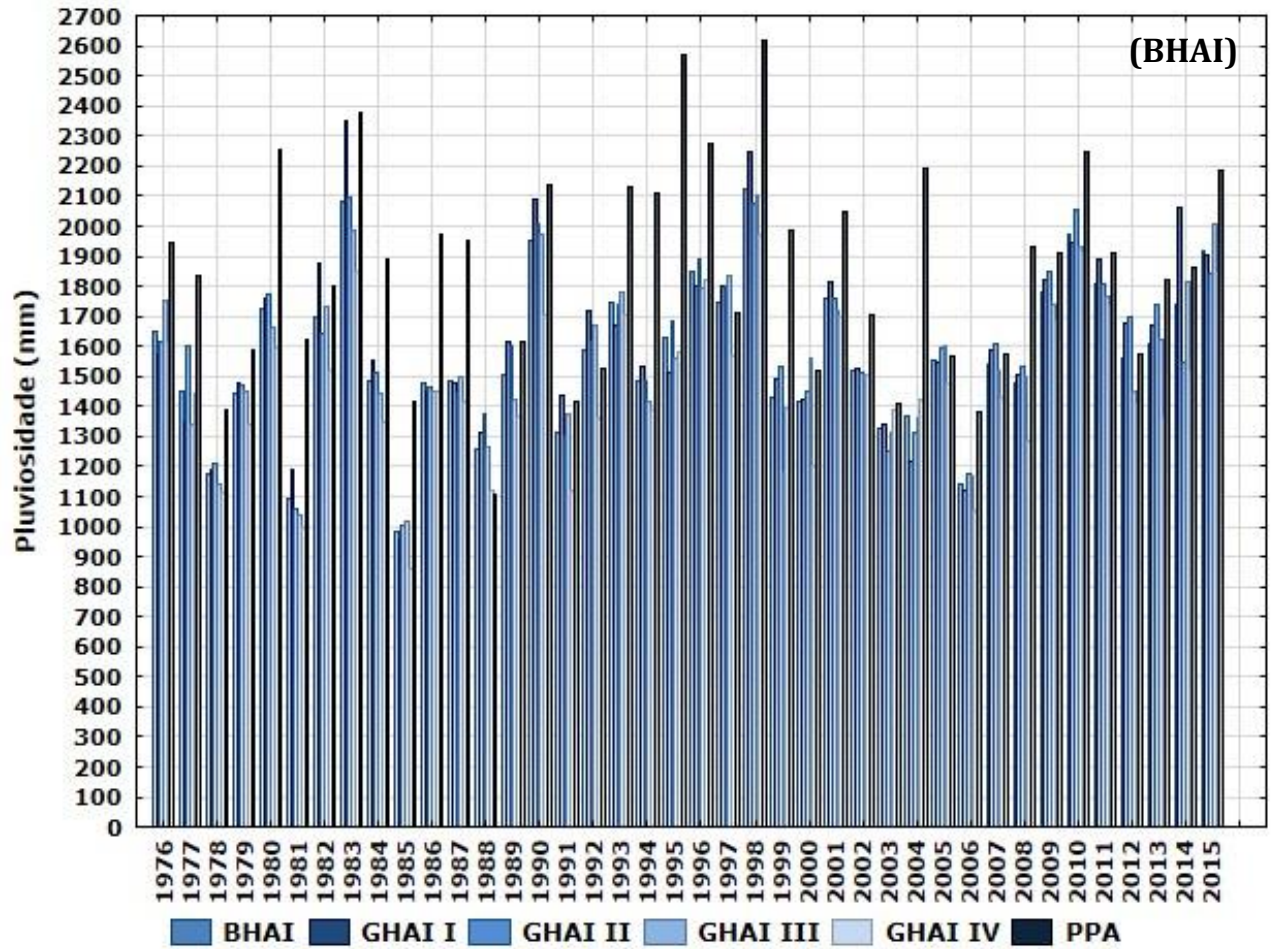

Figura 38 - Distribuição anual da precipitação pluviométrica $(\mathrm{mm})$ nas bacias hidrográficas Litorânea (BHL) e do Alto Iguaçu (BHAI) - PR. 
Para a BH do rio Ribeira, os anos de 1977, 1978, 1981, 1985 e 2006 apresentam predominantemente com precipitação pluviométrica média inferior a $1.250 \mathrm{~mm}$, sendo que a fase fria do ENOS esteve atuante em três destes anos e, no entanto, os anos de 1981, 1978 e 2006 estiveram em condições de neutralidade e El Niño para este último ano. Com média superior a $1.750 \mathrm{~mm}$ anuais, destacam-se os anos de 1983, 1995, 1996, 1997, 1998, 2001 e 2015, sendo que a fase quente (El Niño) esteve atuante em 1983, 1997, 1998 e 2015, ao passo que em 1995, 1996 e 2001 (Figura 39), houveram condições alternadas de neutralidade com La Niña de fraca intensidade (NOAA, 2016).

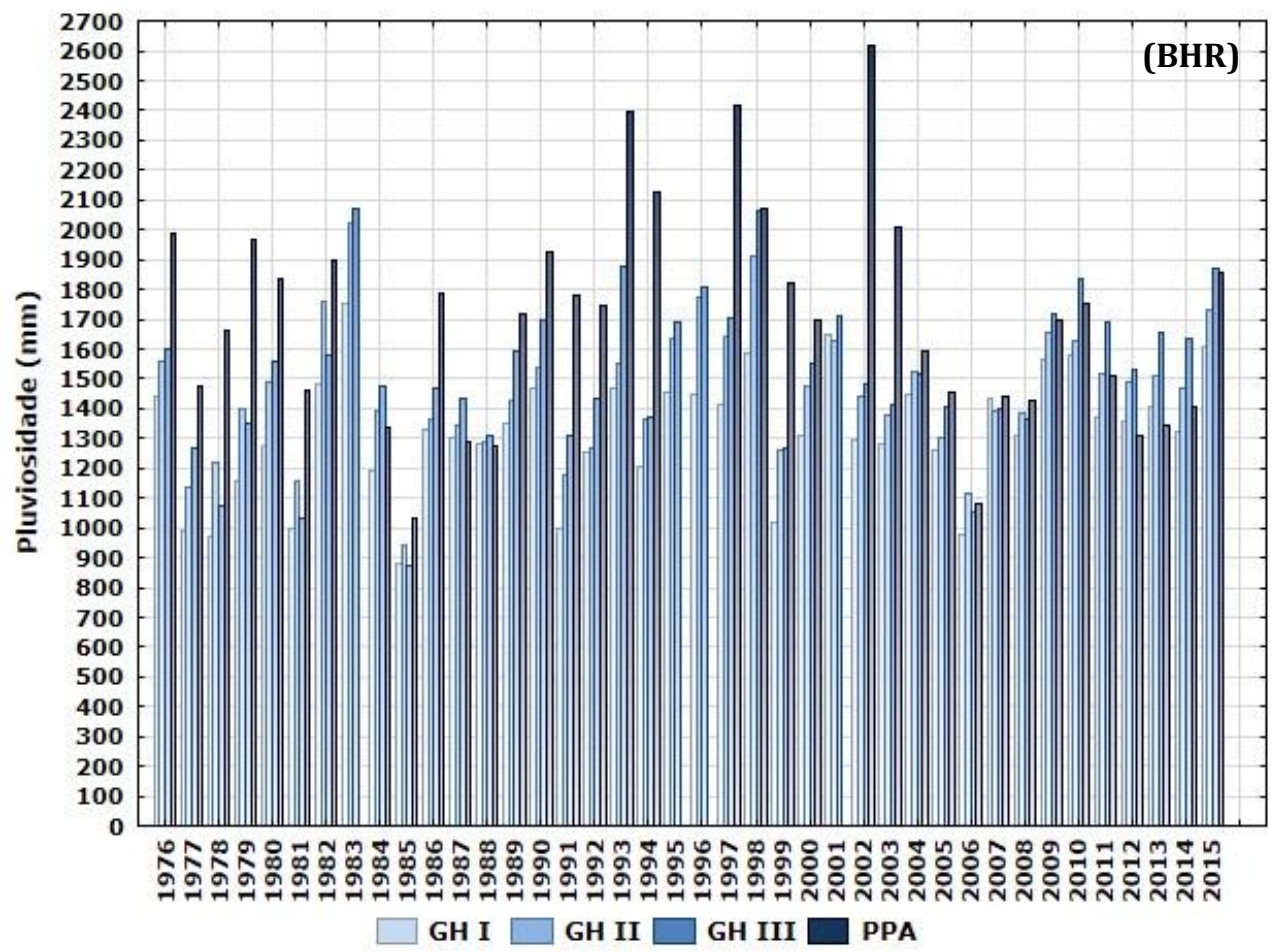

Figura 39 - Distribuição anual da precipitação pluviométrica $(\mathrm{mm})$ na bacia hidrográfica do rio Ribeira - PR.

Ressalta-se que o ano mais seco da série histórica na BH do rio Ribeira corresponde a 1985, com média de 931,8 mm, que esteve em condições de La Niña de forte intensidade, enquanto que o ano de 1983 destaca-se pela maior 
precipitação pluviométrica média desta área de estudo, com 2.141,2 mm, além da atuação forte do El Niño (Figura 39). Entretanto, destaca-se que esta relação entre os totais pluviais e as fases opostas do ENOS não se dá de forma linear e carecem de uma avaliação mais densa e robusta, a qual será apresentada no item “8.3.2 As anomalias pluviais e os indicadores climáticos oceânicos”. Igualmente importante para a elaboração desta pesquisa, será avaliada a influência das fases dos ENOS para a ocorrência das precipitações pluviométricas diárias extremas nas três principais estações meteorológicas convencionais do INMET (Castro, Curitiba e Paranaguá) no item "8.5. As chuvas diárias em Castro, Curitiba e Paranaguá”.

\subsubsection{Frequência e intensidade pluviométrica diária}

Os resultados descritos pelo boxplot mostram que o setor mais chuvoso (GHLII) da bacia hidrográfica Litorânea apresenta uma mediana das chuvas diárias equivalente a $9,5 \mathrm{~mm}$, ao passo que as chuvas fortes, equivalente a $95 \%$ dos quantis, obtiveram o valor de 50,6 mm, os outliers ou chuvas intensas são iguais a 93,8 mm e as chuvas extremas são aquelas superiores a 161,8 mm. Para o setor menos chuvoso da BH Litorânea (GHLI), os limiares das chuvas diárias são inferiores em relação ao GHLII: a mediana e as chuvas fortes são iguais a 7,4 mm e 46,8 mm; os outliers e os extremos são equivalentes a 84,6 mm e 149 $\mathrm{mm}$ (Figura 40). Estes resultados demonstram que o setor GHLII caracterizase pelas chuvas diárias de maior magnitude e, destacadamente, pelos maiores valores das chuvas intensas e extremas, sendo este o setor da área de estudo que se destaca pelos mais elevados totais destas classes de pluviosidade diária.

A classificação da precipitação pluviométrica diária conforme as classes dos quantis possibilita indicar alguns padrões temporais quanto à frequência e a intensidade deste atributo climático nesta escala temporal. Para o GHLI, foram 
selecionados os postos pluviométricos de Antonina (ID21) e Morretes (ID31), que apresentam a maior frequência e intensidade das chuvas diárias no trimestre de janeiro a março. Em Antonina, observa-se que de abril a agosto predominam as chuvas diárias $\leq$ a $25 \%$ dos quantis, enquanto que no período de setembro a março (exceto em novembro) é mais frequente as chuvas diárias $\geq$ a $75 \%$ dos quantis, ressaltando-se as maiores intensidades $(\geq Q 95)$ em janeiro e fevereiro. Em Morretes, as chuvas diárias mostram-se menos intensas em comparação à Antonina, uma vez que de abril a dezembro predominam os registros $\leq$ a $25 \%$ dos quantis, sendo que de janeiro a março há o aumento da frequência de chuvas diárias $\geq 50 \%$ dos quantis (Figura 41).

Para caracterizar o GHII da BH Litorânea, foram selecionados os postos pluviométricos Guaraqueçaba (IAPAR) e Guaraqueçaba (Rio Guaraqueçaba), que se referem aos ID's 26 e 28. Em Guaraqueçaba (ID26), as chuvas diárias mais frequentes em janeiro e fevereiro são $\geq Q 95$, enquanto que em março e dezembro predomina a classe pluvial $\geq Q 75$, sendo estes os quatro meses mais chuvosos da série temporal. Com a diminuição das médias mensais, no período de abril a setembro observa-se a maior frequência das chuvas diárias $\leq$ a $25 \%$ dos quantis, sendo que em outubro e novembro, com a chegada da primavera, nota-se o domínio de chuvas diárias entre Q25 e Q50. Em Guaraqueçaba (ID28), nota-se que as chuvas diárias mais intensas se dão em janeiro e fevereiro $(\geq Q 95)$ e em dezembro, março e abril ( $\geq Q$ 75). Com a diminuição das chuvas, verificase que a intensidade pluvial diária diminui com o predomínio dos registros $\leq$ a $25 \%$ dos quantis entre junho e novembro e entre $25 \%$ e $50 \%$ dos quantis no mês de maio (Figura 41).

Destaca-se que os postos pluviométricos analisados para a BH Litorânea indicam que este setor se caracteriza pela mais elevada intensidade e frequência das chuvas fortes e intensas dentre as BH's em estudo. Em Antonina (ID21) e Guaraqueçaba (ID26), observa-se que os registros das chuvas diárias entre as 
classes quantílicas de Q95 e Q99, ao longo das séries históricas, são superiores a 30 entre janeiro a março para ID21 e entre dezembro e março para ID26, sendo que as chuvas diárias $\geq Q 99$ mostram-se mais frequentes ( $\geq 10$ registros) entre dezembro e fevereiro em ID21 e entre janeiro e março para ID26 (Figura 41).

Dentre os postos pluviométricos selecionados para caracterizar a BHL, Morretes (ID31) mostra a menor frequência de chuvas diárias entre Q95 e Q99, com 25 registros entre dezembro e março, enquanto que Guaraqueçaba (ID28) obteve $\geq 40$ registros entre janeiro e março. Os registros das chuvas diárias $\geq Q 99$ são maiores que cinco em ID31 e a oito em ID28 para o período de dezembro a março, segmento temporal que demonstra, de modo geral, abranger as chuvas diárias mais intensas e extremas na BH Litorânea e requer maiores atenções aos problemas relacionados ao excessivo volume pluvial acumulado (Figura 41).

A estatística descritiva e exploratória aplicada à série temporal das precipitações diárias possibilitou indicar a intensidade deste atributo climático nos GH da BHAI. Os maiores extremos de precipitações diárias, indicados pelo quantis de 99\% (78,0 mm) e 99,9\% (139,9 mm) foram obtidos no PPA, sendo, desta forma, o setor da área de estudo com os registros diários mais intensos (Figura 42). No entanto, para os quantis de 50\% (mediana) e 95\%, os valores mais elevados foram observados no GH I, iguais a $10,2 \mathrm{~mm}$ e $47,0 \mathrm{~mm}$, nesta ordem. Sobretudo, os valores dos intervalos e o máximo de precipitações diárias foram substancialmente maiores no GH I em relação ao PPA, embora os resultados dos quantis tenha mostrado que a distribuição do conjunto de dados diários seja maior no PPA (Figura 44).

$\mathrm{O}$ mês de janeiro é isoladamente o mês com maior frequência de dias chuvosos para a área de estudo. O período de setembro a março concentra em média cerca de $70 \%$ do número de dias chuvosos na BHAI. Destaca-se que os postos pluviométricos representativos do GH II e IV apresentam similaridades na distribuição dos meses com maior registro de precipitações superiores a 99\% 
dos quantis, que são mais frequentes em junho, enquanto que nos GH I e no PPA o mês com maior registro de precipitações acima de tal limiar é identificada no mês de maio. Para o GH III, as precipitações acima de $99 \%$ dos quantis são mais frequentes em fevereiro (Figuras 43 e 45).

As precipitações entre 95\% e 99\% dos quantis são superiores a 15 dias para a série histórica em análise para todos os postos pluviométricos analisados em janeiro e dezembro, meses da estação do verão, e em setembro, no mês que dá início a primavera e há a regularização das precipitações. Para o PPA e os postos pluviométricos dos GH III e IV verifica-se que os meses de fevereiro e março registraram um número superior a 15 com precipitações entre o intervalo citado acima. Em outubro há um aumento significativo dos totais pluviais e da erosividade nos postos pluviométricos do GH I e III, que pode estar relacionado com o aumento de precipitações entre R95p e R99p. Sobre tal indicador, observa-se que em Quitandinha (GH II) e São Mateus do Sul (GH I) verifica-se um número superior a 15 dias de registros no mês de junho, atrelando-se a maior influência da FP na geração das precipitações mais intensas nestas áreas (Figuras 43 e 45).

A diminuição da frequência e da intensidade das precipitações no período invernal se deve a restrição dos FP na geração das precipitações, ao passo que durante o verão a alternância de sistemas atmosféricos intertropicais e a FP contribui para os totais mais elevados de precipitações, conclusões dadas a partir dos resultados obtidos por estes autores e à dinâmica atmosférica regional, conforme observações de Silva et al. (2006) e Reboita et al. (2010). Observa-se que por situar-se em mais próxima ao domínio climático subtropical, conforme indicam Dubreuil et al. (2017), as precipitações intensas ocorrem também com frequência no período invernal que se deve à atuação mais constante da FP na geração das precipitações no setor meridional paranaense, conforme observaram Borsato e Mendonça (2015). 

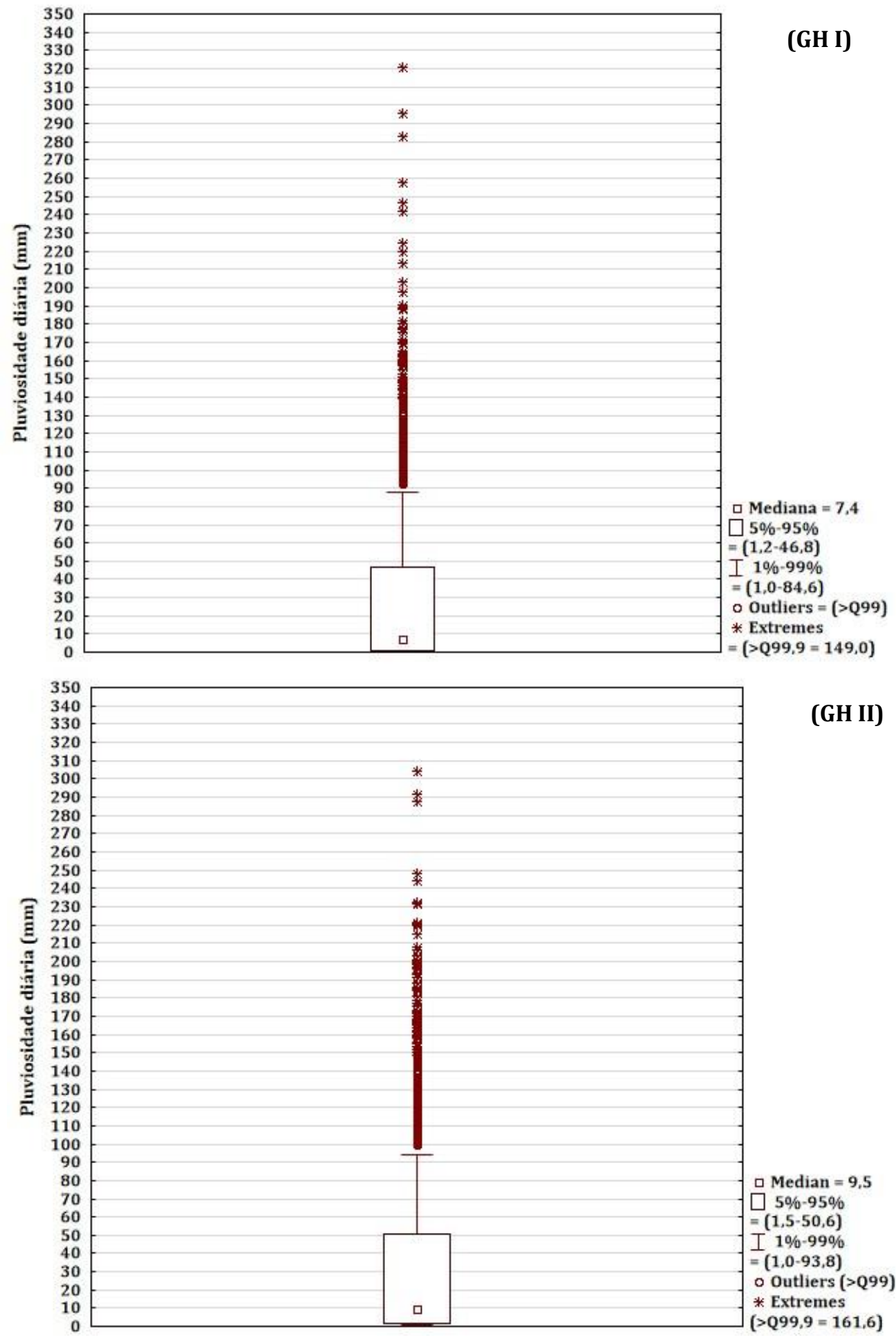

Figura 40 - Boxplots da pluviosidade diária $(\mathrm{mm})$ nos grupos homogêneos $(\mathrm{GH})$ da bacia hidrográfica Litorânea - PR. 

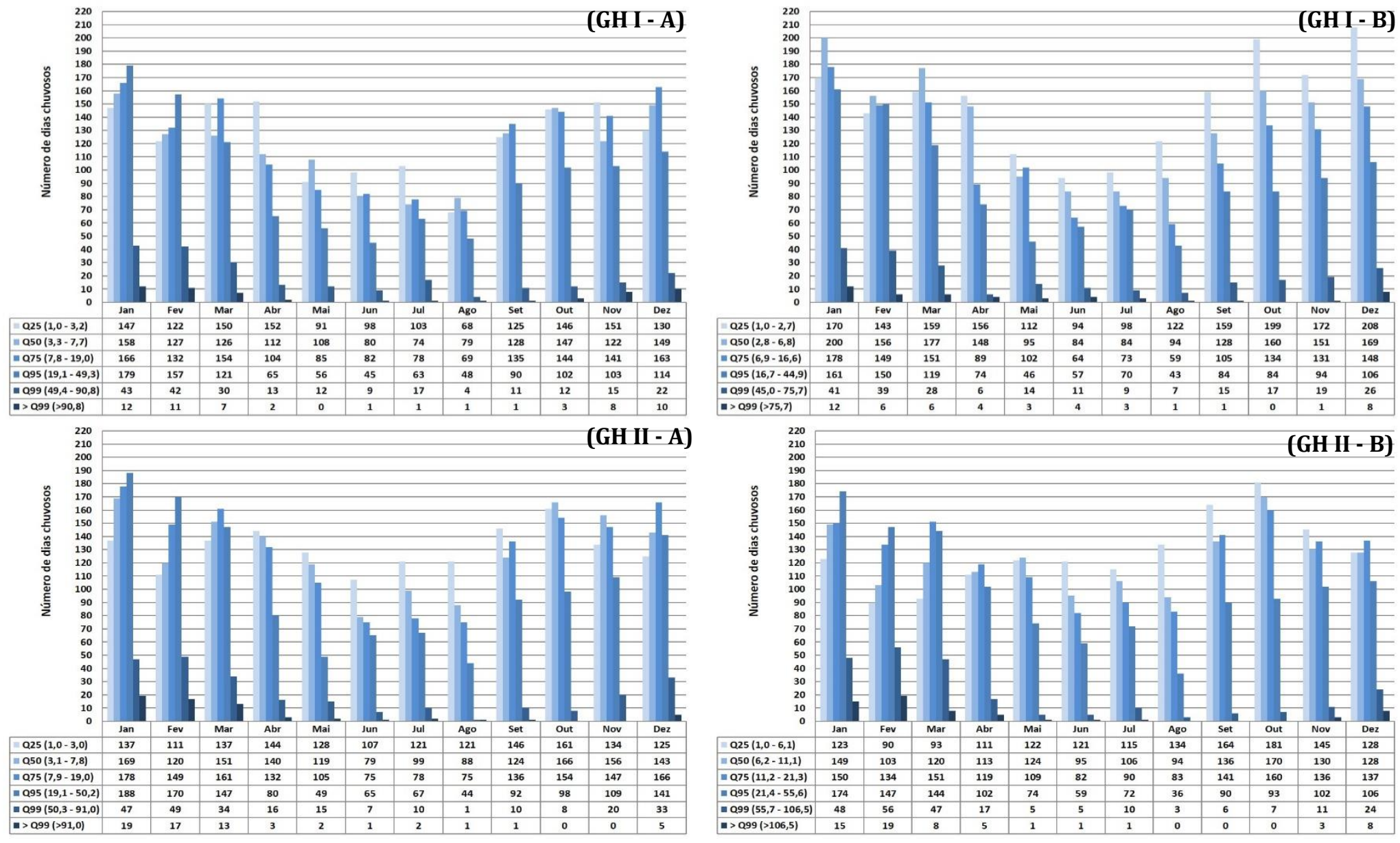

Figura 41 - Classes dos quantis e o número de dias chuvosos em Antonina - ID 21 (GH I-A), Morretes - ID 31 (GH I-B), Guaraqueçaba - ID 26 (GH II-A) e Guaraqueçaba - ID 28 (GH II - B) na bacia hidrográfica Litorânea - PR. 

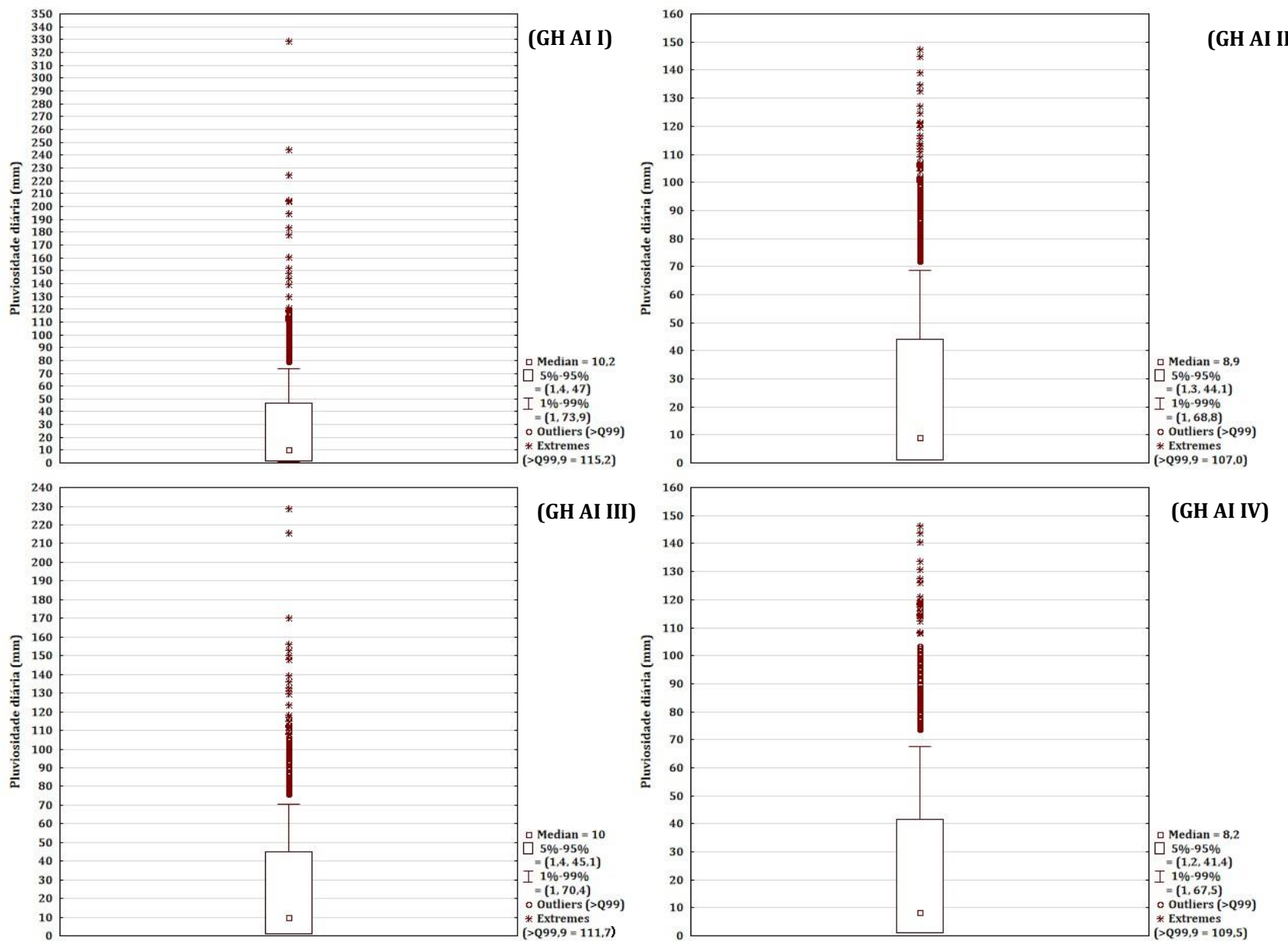

Figura 42 - Boxplots da pluviosidade diária $(\mathrm{mm})$ nos grupos homogêneos $(\mathrm{GH})$ da bacia hidrográfica do rio Alto Iguaçu - PR. 

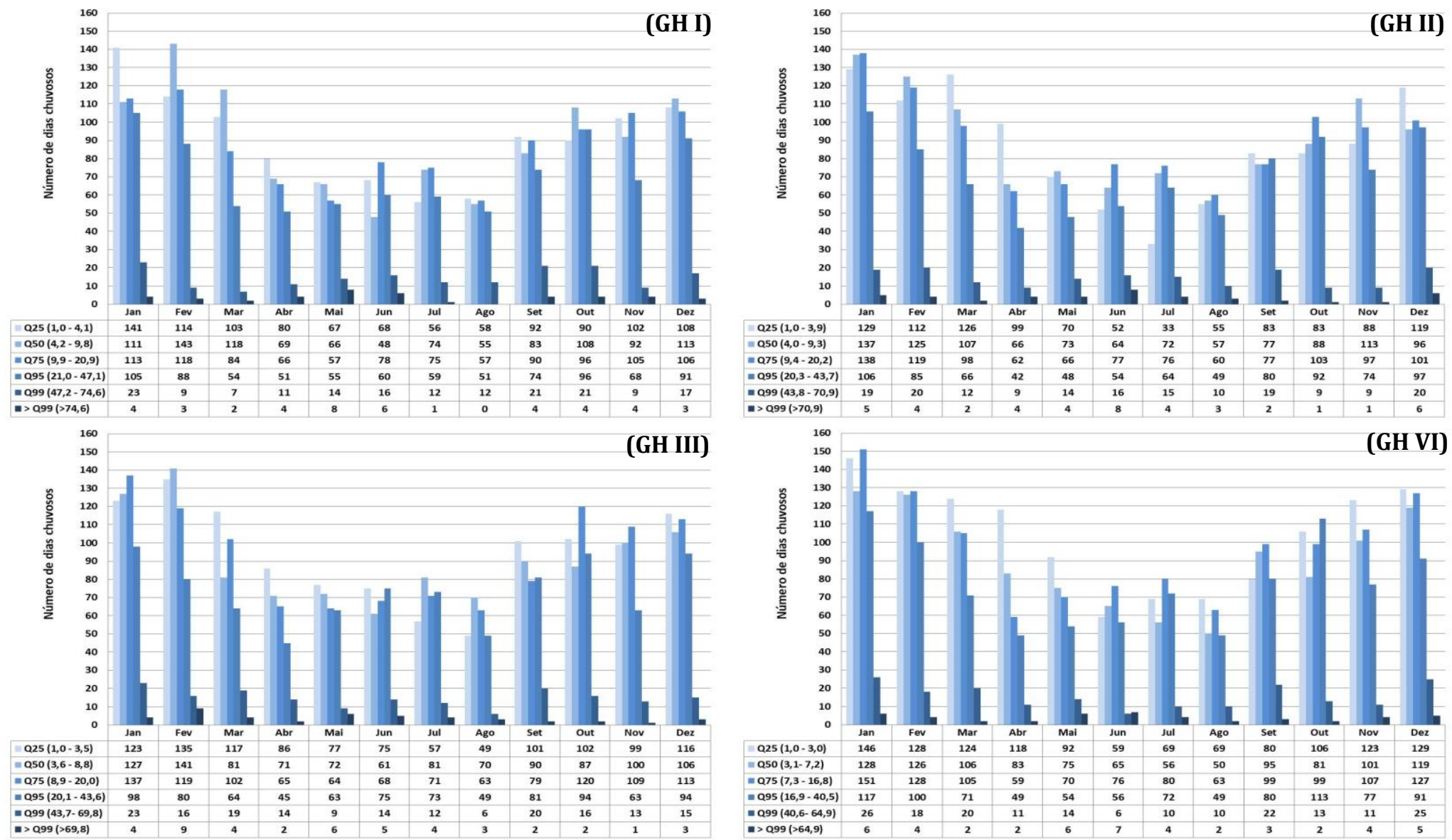

Figura 43 - Classes dos quantis e o número de dias chuvosos em São Mateus do Sul - ID 13 (GH I), Quitandinha ID - 20 (GH II), Lapa - ID 03 (GH III) e Pinhais ID - 07 (GH VI) na bacia hidrográfica do Alto Iguaçu - PR. 


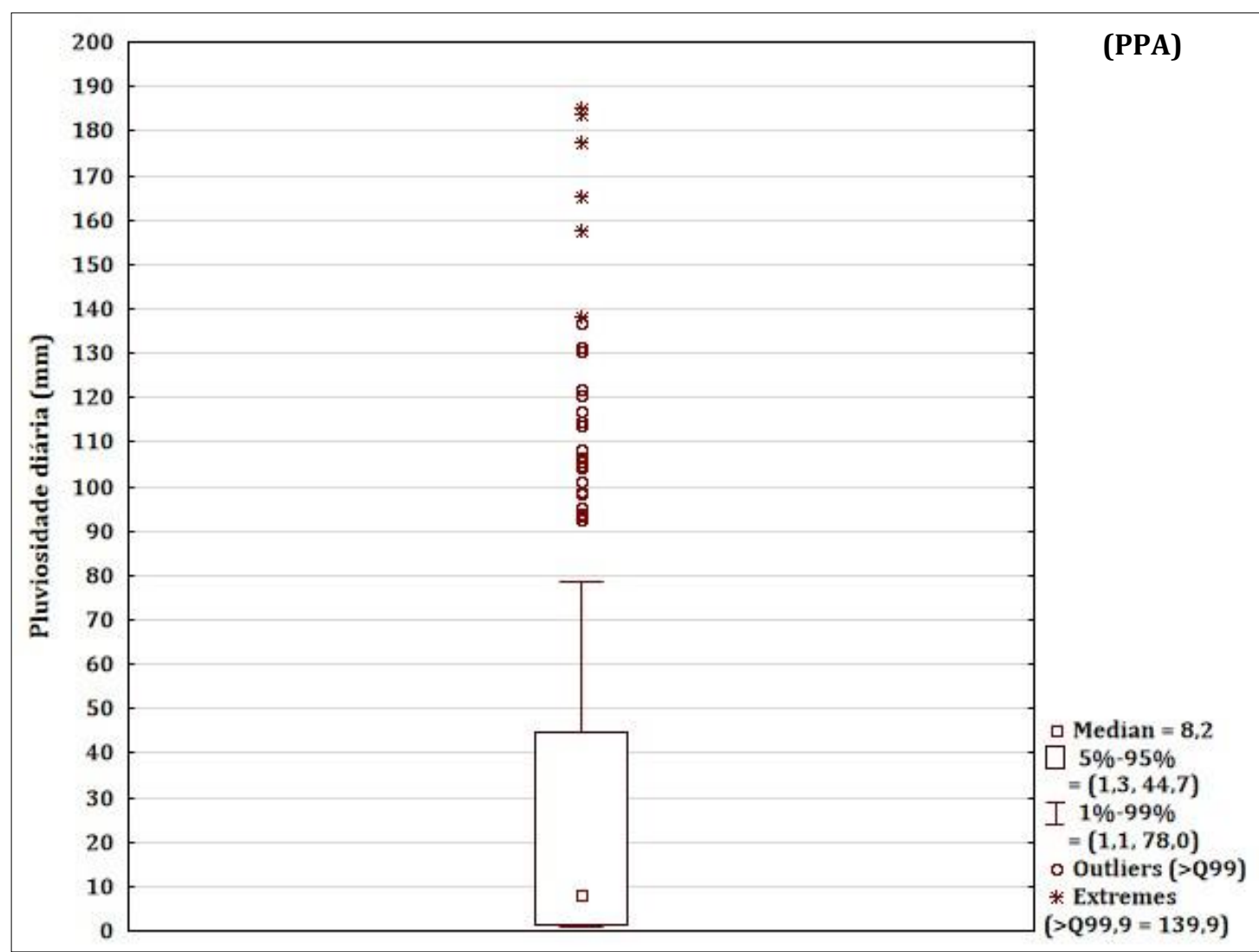

Figura 44 - Boxplot da pluviosidade diária $(\mathrm{mm})$ do posto pluviométrico anômalo (PPA) da bacia hidrográfica do rio Alto Iguaçu - PR.

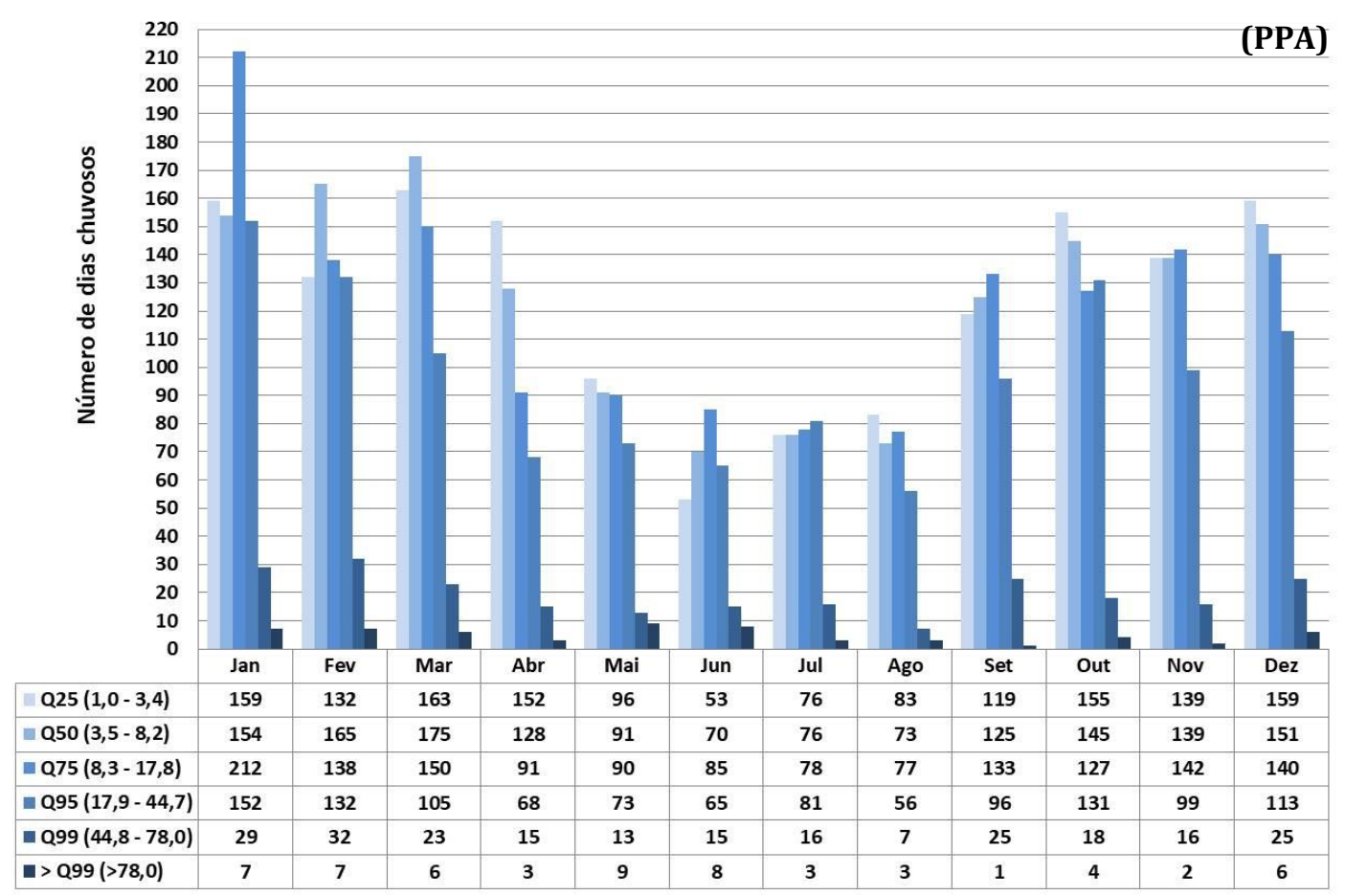

Figura 45 - Classes dos quantis e o número de dias chuvosos em Piraquara (Mananciais da Serra - PPA) na bacia hidrográfica do rio Alto Iguaçu - PR.

Ainda, Leite et al. (2001) observaram que os maiores percentuais da frequência de precipitações superiores a $50 \mathrm{~mm}$ em Ponta Grossa (PR), localidade próxima área em 
estudo, são mais elevados entre maio e julho, o que é um indicativo de maiores totais pluviais gerados pela FPA para a BHAI e em alguns setores da $\mathrm{BH}$ do rio Ribeira.

Para a bacia hidrográfica do rio Ribeira, observa-se que os maiores valores dos parâmetros estatísticos mediana $(10,2 \mathrm{~mm})$, dos quantis de $95 \%(47,4 \mathrm{~mm})$ e dos outliers (72,1 mm) foram observados nos postos pluviométricos anômalos (PPA), enquanto que os valores extremos foram mais elevados no GHIII (112,3 mm), exatamente os setores de maior pluviosidade da BHR. Inversamente, identifica-se os menores valores da mediana $(9,2 \mathrm{~mm})$ para o GHII, ao passo que as chuvas iguais a $95 \%$ dos quantis $(40,6 \mathrm{~mm})$, os outliers $(65,0 \mathrm{~mm})$ e os valores extremos $(100,9 \mathrm{~mm})$ foram menos elevados no GHI, sendo estes os setores de menores médias pluviais da BHR (Figura 46). Ressalva-se que os GHI e GHII são os setores com os menores valores das chuvas diárias mais elevadas, sobretudo aquelas superiores a 95\%, de toda a área em estudo desta pesquisa.

Observa-se que na BH do rio Ribeira o padrão de distribuição mensal das classes de intensidade da precipitação pluviométrica diária é bastante variável e, no entanto, é possível afirmar que as mais elevadas classes de pluviosidade apresentam as maiores frequências nos meses de primavera, destacadamente em setembro e outubro, e de verão, entre dezembro a fevereiro. Dentre os aspectos mais relevantes, observa-se que nos meses de janeiro e maio verificam-se frequentemente de $\geq 5$ registros de chuvas diárias $\geq Q 99$ nos quatro postos pluviométricos selecionados para representar os três GH's e o PPA da BHR e, para este mesmo limiar, notam-se observações do número de registros $\geq 5 \mathrm{em}$ julho e dezembro para Cerro Azul (ID51-GHI), em setembro para Tunas do Paraná (ID58GHII), em junho para Ponta Grossa (ID55-GHIII) e em fevereiro e junho para Doutor Ulysses (ID53-PPA), conforme demonstra a figura 47.

Os registros de precipitação pluviométrica diária entre Q95 e Q99 são superiores iguais ou superiores a $20 \mathrm{em}$ todas os postos pluviométricos selecionados em janeiro, que é isoladamente, o mês com a maior frequência das chuvas diárias de intensidade mais elevada e das maiores médias mensais de toda BHR. Contudo, em ID51, ID58 e ID53 nota-se que os registros deste limiar pluvial diária são iguais ou superiores a 20 no mês de dezembro e também em março e setembro, períodos de transição de estações do ano, em ID58, justamente no setor da BH do rio Ribeira que se caracteriza pela influência mais evidente das características e mecanismos atmosféricos do clima Subtropical. Esta última observação corrobora às afirmações de Leite et al. (2001) sobre as chuvas diárias e suas características próprias do clima Subtropical em Ponta Grossa. 

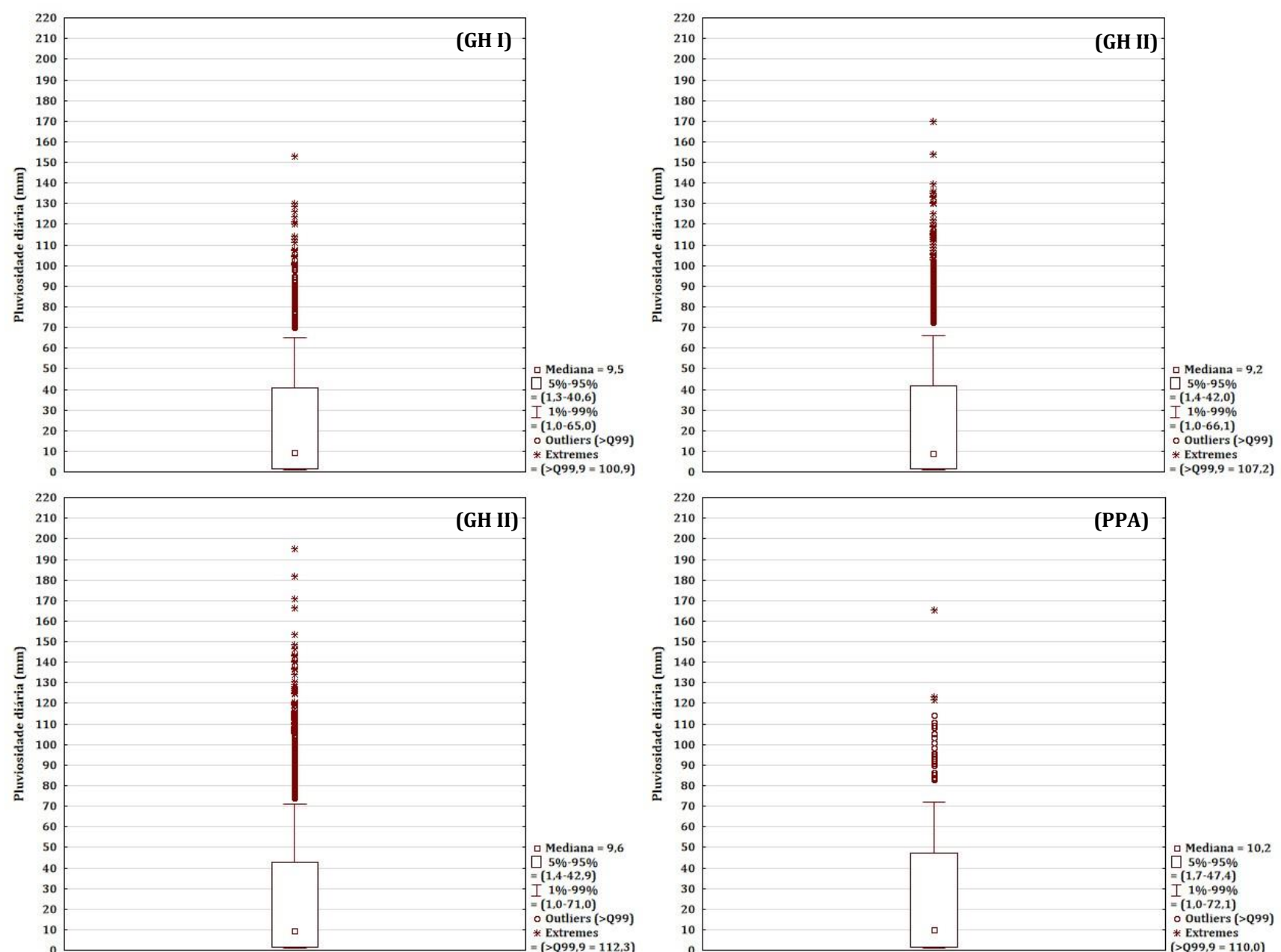

Figura 46 - Boxplots da pluviosidade diária (mm) nos grupos homogêneos (GH) e no posto pluviométrico anômalo (PPA) da bacia hidrográfica do rio Ribeira - PR 

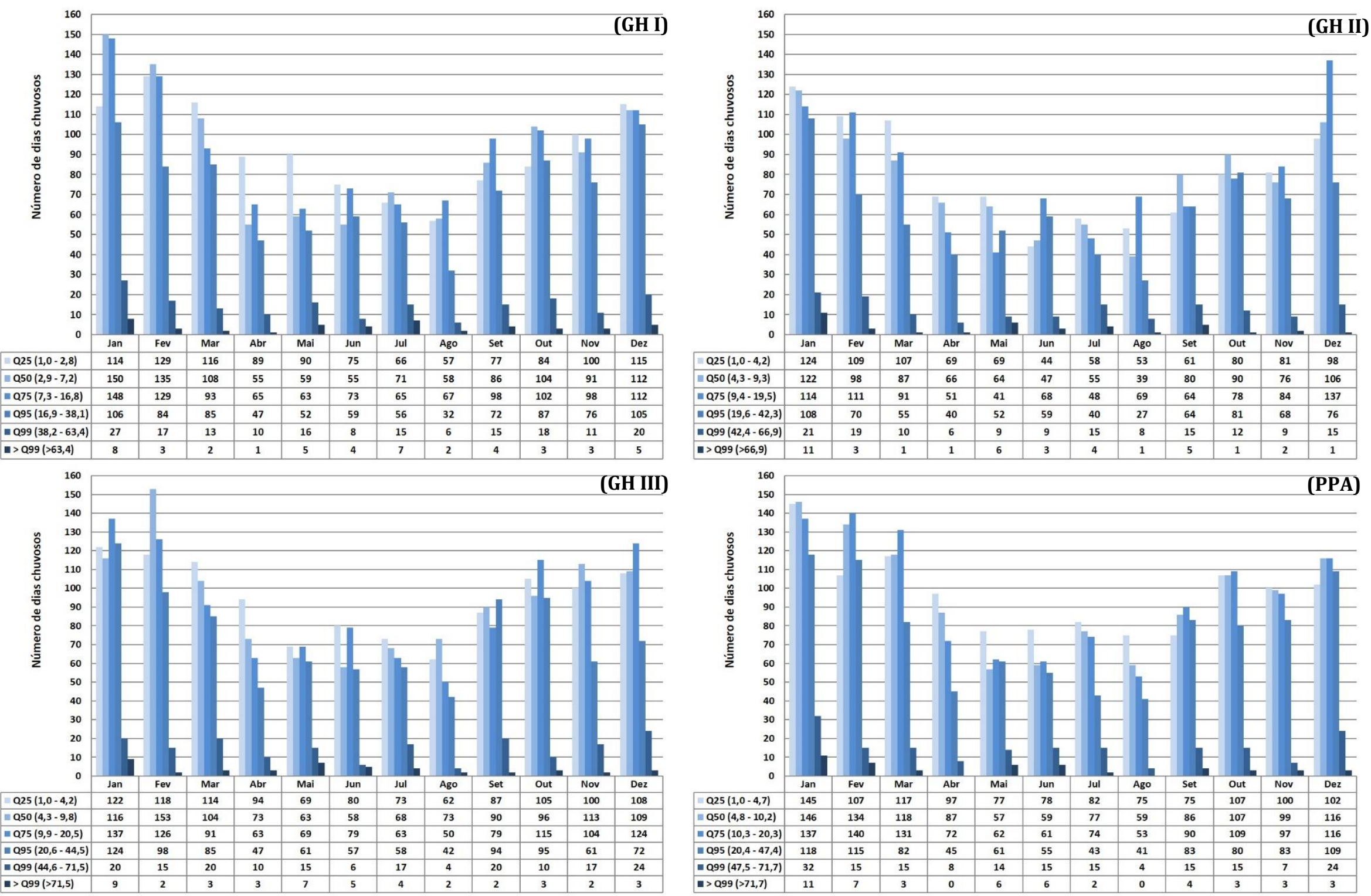

Figura 47 - Classes dos quantis e o número de dias chuvosos em Cerro Azul - ID 51 (GH I), Tunas do Paraná - ID 58 (GH II), Ponta Grossa - ID 55 (GH III) e Doutor Ulysses - ID 53 (PPA) na bacia hidrográfica do rio Ribeira - PR. 


\subsection{Variabilidade temporal pluviométrica e os indicadores climáticos oceânicos}

\subsubsection{Análise de agrupamento via método K-means}

Com a finalidade de delimitar grupos homogêneos de modo diferenciado e robusto estatisticamente em relação à aplicação anterior do método Ward, descreve-se neste item a utilização do método K-means para o agrupamento de postos pluviométricos similares. Desta forma, considerando a sua maior objetividade e rigidez em comparação ao método Ward, esta técnica mostra-se especificamente apropriada para verificar a relação entre a variabilidade temporal pluviométrica e os indicadores climáticos oceânicos.

O gráfico da figura 48 demonstra a média das silhuetas e a soma dos quadrados dentro dos grupos homogêneos. A definição do número ideal de grupos homogêneos em cada uma das bacias hidrográficas partiu de uma análise conjunta entre os dois parâmetros estatísticos descritos acima, tendo como critério o número máximo possível de GH. Para a BH Alto Iguaçu, delimita-se o número ideal de grupos homogêneos em 06, pois para a definição deste limiar de agrupamento obteve-se a soma dos quadrados dentro dos grupos superiores a 20 mil e a média da silhueta de cada grupo superior a 0,2. Na BH Litorânea define-se que o número ideal de grupos homogêneos a serem formados se dá ao maior valor médio da silhueta em 03 grupos, superior a 0,2 , sendo que a soma interna dos quadrados é acima de 40 mil. Na BH Ribeira, verifica-se que o ponto ideal de delimitação do número de GH se dá em 05, uma vez que neste limiar há um ligeiro aumento da média da silhueta em relação à formação de $04 \mathrm{GH}$ e, juntamente, a soma interna dos quadrados superior a 20 mil.

Posteriormente a definição do número ideal de grupos homogêneos em cada uma das $\mathrm{BH}$, os postos pluviométricos foram agrupados em seus respectivos $\mathrm{GH}$, seguindo os critérios do método K-means, conforme representa a figura 49, com a demonstração das distâncias de dissimilaridade entre os elementos e a formação dos GH. Desta forma, com a realização do agrupamento, observa-se que a área de estudo apresenta uma significativa variabilidade espacial da precipitação, com os GH da BH Litorânea caracterizando-se pelos mais elevados totais anuais, ao passo que os GH III e V da BH do Ribeira mostram as menores medianas da pluviosidade, ressaltando as discussões anteriores sobre o efeito da maritimidade para a ocorrência de maiores valores das chuvas na BH Litorânea, sendo que após a barreira orográfica da Serra do Mar e nos setores de menores altitudes da BH Ribeira há uma diminuição pluvial expressiva, que se deve a sua localização à sotavento da elevação supracitada (Figura 50). 

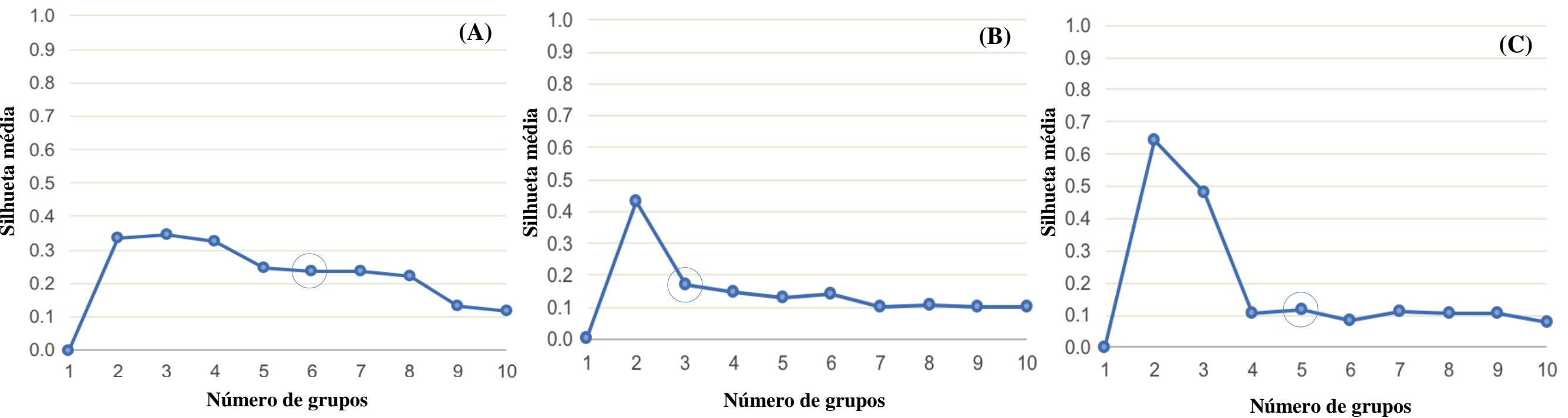

$$
120 \mathrm{M}
$$

(D)

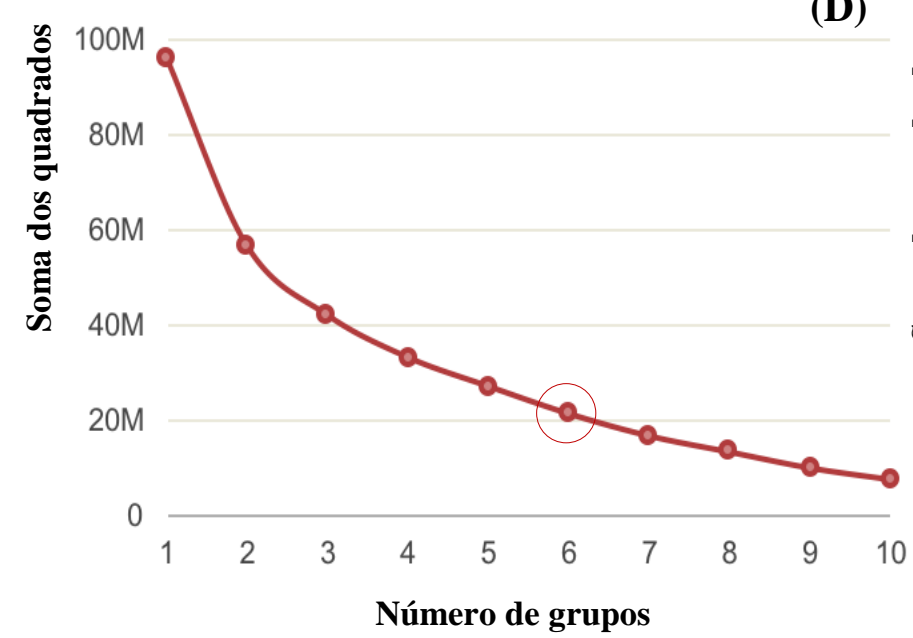

$30 \mathrm{M}$

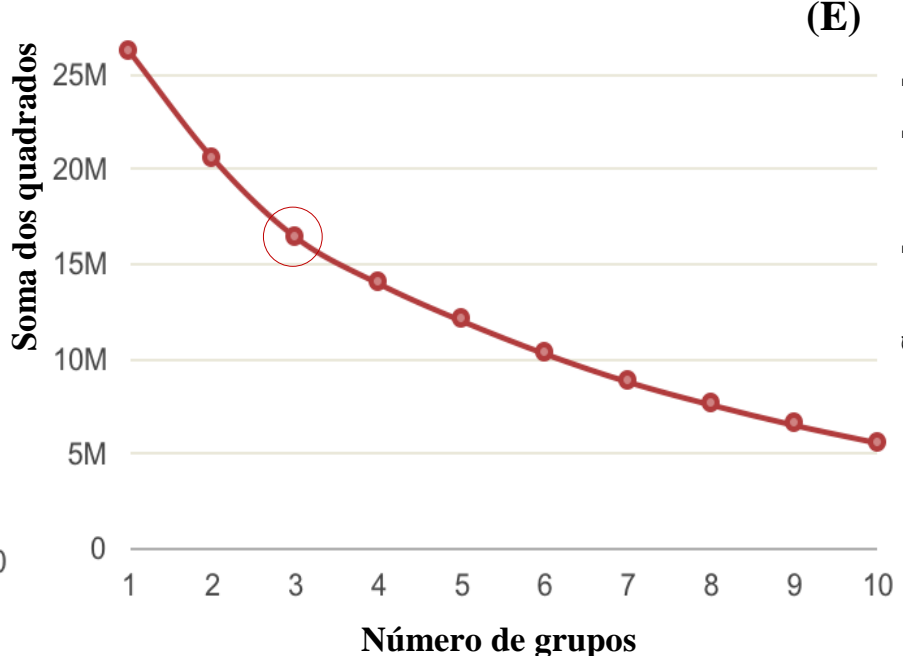

$80 \mathrm{M}$

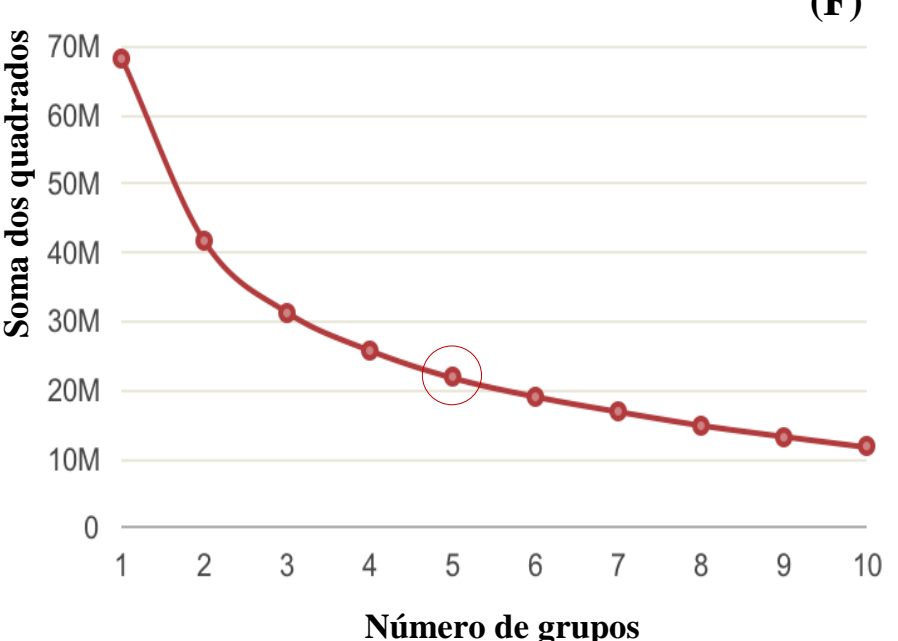

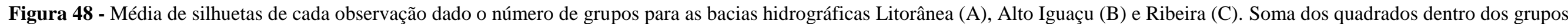
dado o número de grupos para as bacias hidrográficas Litorânea (D), Alto Iguaçu (E) e Ribeira (F). 
(A)

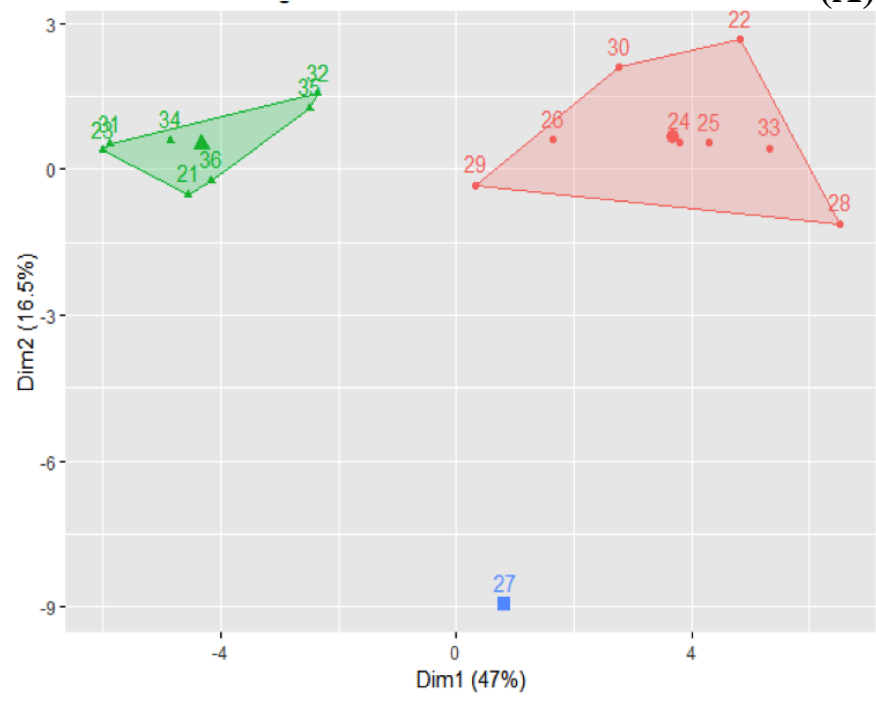

(C)

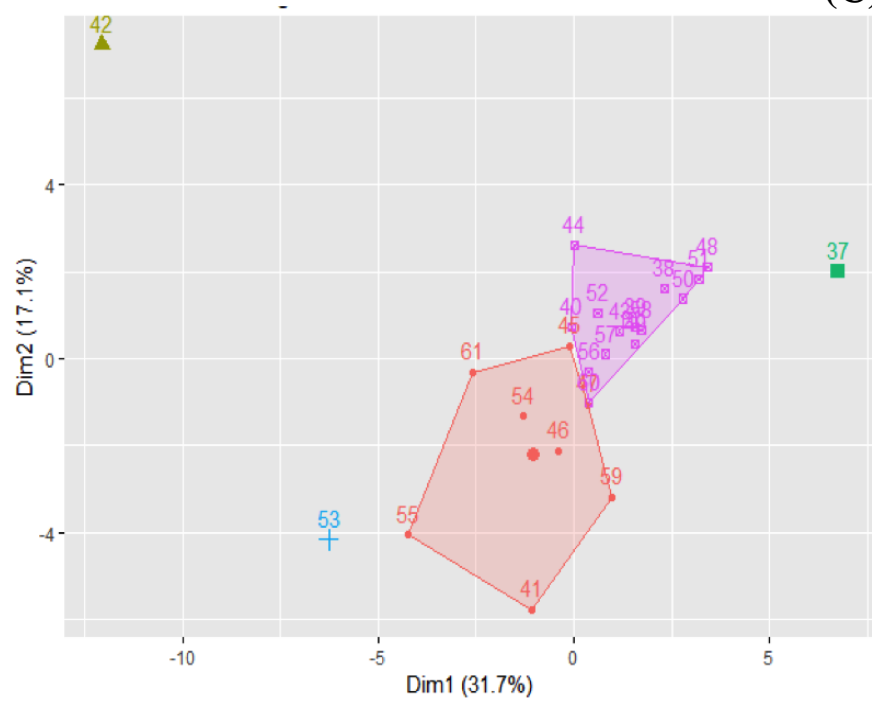

37

Figura 49 - Análise de cluster $(\mathrm{GH})$ pelo método K-means para as bacias hidrográficas do Litorânea (A), e boxplot da pluviosidade média anual (D) para as bacias hidrográficas.
(B)

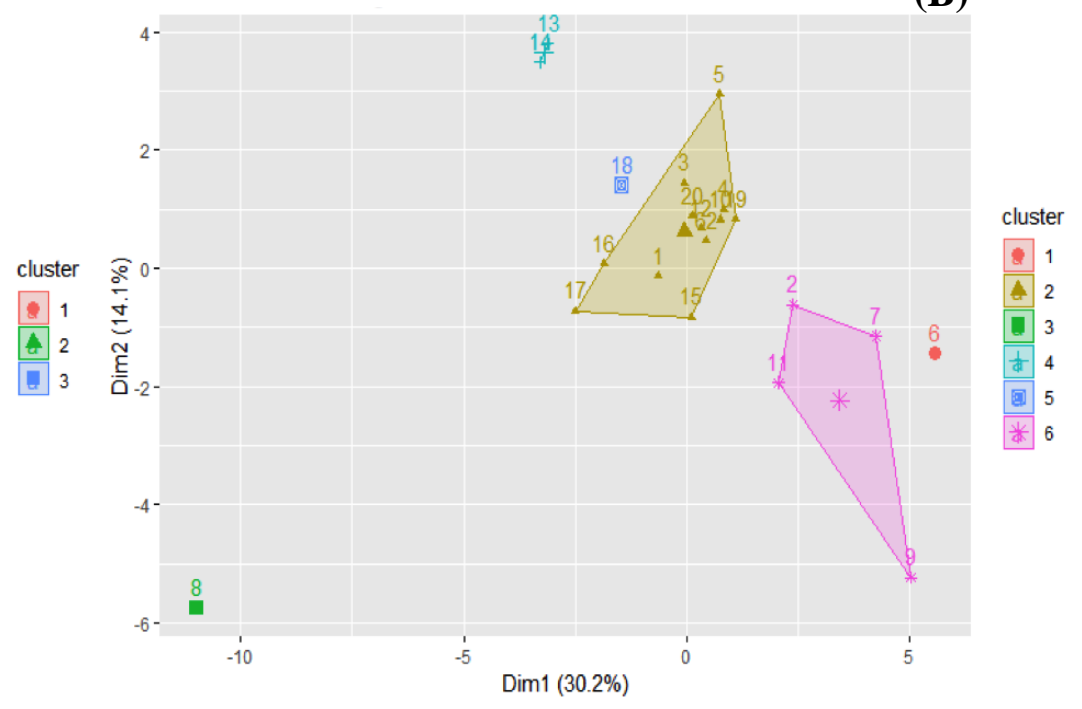

(D)

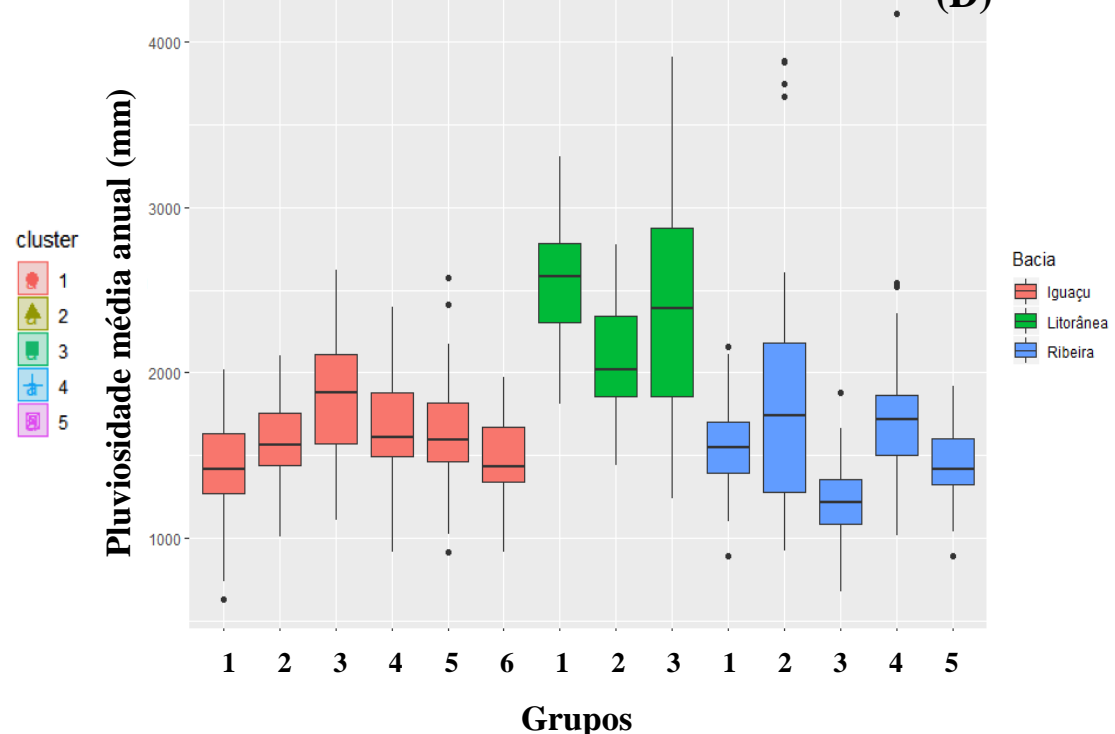




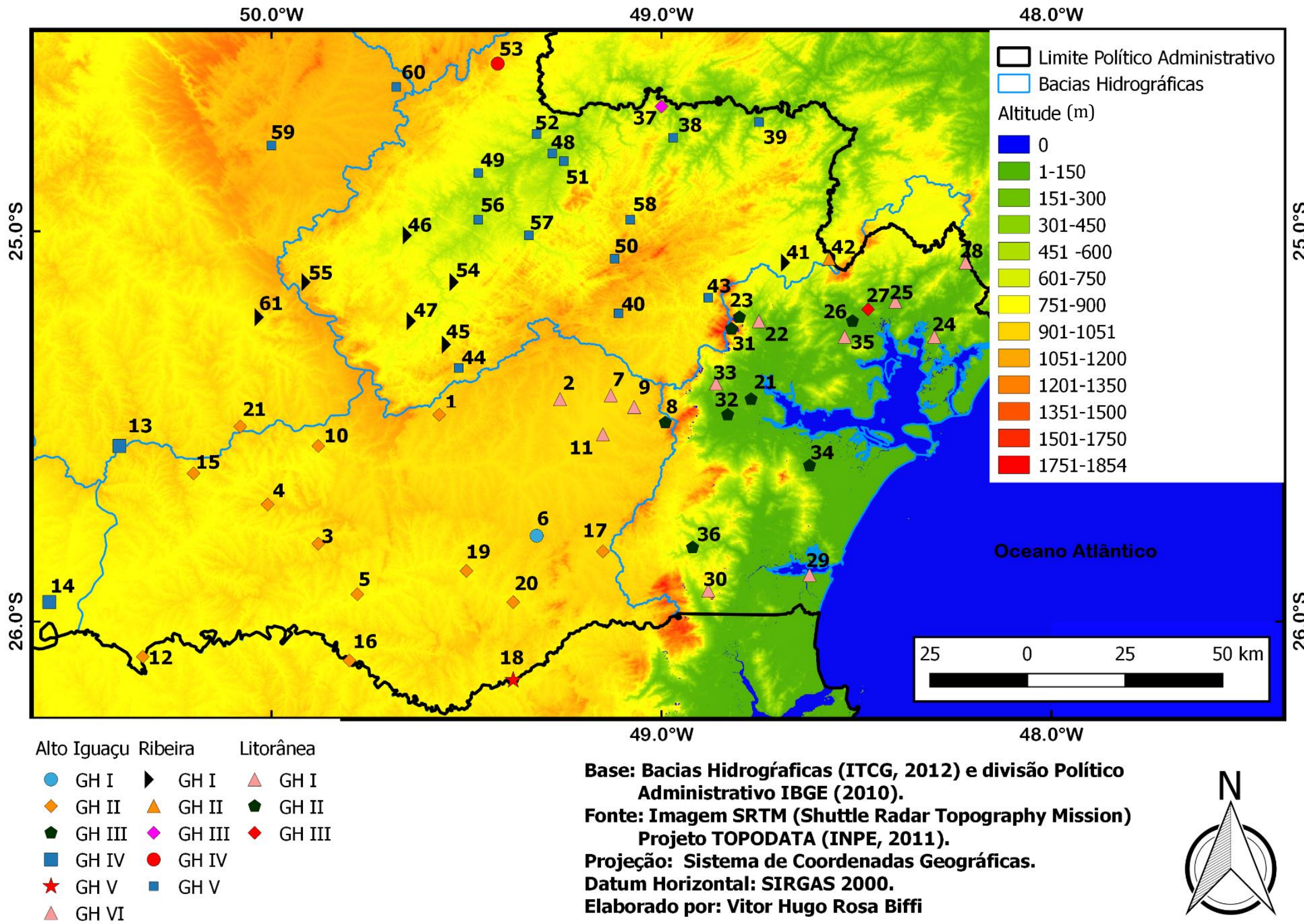

Figura 50 - Distribuição espacial dos grupos homogêneos (GH) pelo método K-means para as bacias hidrográficas do Alto Iguaçu, Ribeira e Litorânea - Paraná. 
Com seis grupos homogêneos, a BH Alto Iguaçu caracteriza-se basicamente pela menor variação entre os GH das bacias hidrográficas analisadas. Excepcionalmente, o GHIII formado pelo posto pluviométrico de Mananciais da Serra (ID08), anteriormente denominado de posto pluviométrico anômalo (PPA) na realização do agrupamento via método Ward, apresenta a maior pluviosidade média anual da BH Alto Iguaçu, com uma mediana de $1.877 \mathrm{~mm}$, condição que está atrelada a associação das maiores altitudes (979 metros) com a sua localização à barlavento da Serra do Mar (Figura 51 - Tabela 2).

Inversamente, os GHI e II situam-se a leste e nordeste desta $\mathrm{BH}$, em altitudes de aproximadamente 920 metros e apresentam totais anuais inferiores a $1.500 \mathrm{~mm}$, os menores da BH Alto Iguaçu, possivelmente a uma condição à barlavento em relação à Serra do Mar, o que explica a excepcionalidade de diminuição dos totais pluviométricos mesmo em maiores altitudes (Figura 51 - Tabela 2), o que se contrapõe ao que discorre a literatura sobre a influência do relevo na distribuição espacial pluviométrica. Exceção dada pelo GHIII, mostra-se na BHAI um padrão de diminuição da pluviosidade anual, o que está em acordo com as observações realizadas nos itens anteriores sobre a relação entre a distribuição espacial das chuvas e a orografia nesta BH.

Com uma pluviosidade próxima a mediana de 1.600 mm, os GH IV e V mostram uma altitude média de 765 e 790 metros e localizam-se nas bordas sudeste e oeste, nesta ordem, da BH Alto Iguaçu. O GH II situa-se no setor central e sul da BHAI e mostra-se como o que melhor caracteriza espacialmente grande parte da área de estudo, com valores da mediana $1.563 \mathrm{~mm}$ e em altitude média de 847 metros, além de abranger 11 dos 20 dos postos pluviométricos. Os três grupos homogêneos supracitados apresentam bastante similaridade nas médias e medianas da pluviosidade anual e, contudo, diferem-se quanto à variabilidade, uma vez que enquanto o GHII caracteriza-se pelo menor desvio padrão (289 mm) e menor coeficiente de variação (18,3\%), o GHV mostra os maiores valores destes parâmetros estatística, em $359 \mathrm{~mm}$ e 22,0\%, respectivamente. Por sua vez, o GHIV destoa dos demais grupos por apresentar a maior amplitude entre os valores máximos e mínimos pluviais anuais (Figura 51 - Tabela 2).

Para a BH Litorânea, o agrupamento pelo método K-means mostra que esta área pode ser dividida em 03 grupos homogêneos. Com 08 postos pluviométricos, o GHI situase nos setores sudeste e nordeste da BHL, caracteriza-se pela maior mediana (2.566 mm) da pluviosidade anual e, embora tenha maior amplitude pluvial, não apresenta os maiores valores do desvio padrão e do coeficiente de variação. Com os menores valores destes parâmetros estatísticos, com apenas $372 \mathrm{~mm}$ do desvio padrão e 17,8\% do CV, o GHII 
mostra-se como o setor de menor pluviosidade da BHL, com mediana de $2.086 \mathrm{~mm}$, sendo que está localizado majoritariamente à oeste e centro desta bacia hidrográfica. Destacase que o GH III é composto somente pelo posto pluviométrico ID27, à nordeste da área em estudo, com uma mediana de $2.388 \mathrm{~mm}$, sendo que se observa nesta localidade à maior variabilidade do conjunto de dados, com o desvio padrão de $664 \mathrm{~mm}$ e o coeficiente de variação em 28,1\%, os maiores da área de estudo (Figura 51 - Tabela 2). Posteriormente, observa-se que esta localidade (ID27) corresponde ao setor da mais elevada diminuição pluviométrica do recorte de estudo, conforme demonstram os resultados dos testes de tendência (TMK) e rupturas (TP), em um dos itens finais desta pesquisa, o que responde pelos maiores valores de desvio padrão e coeficiente de variação.

Na BH do Ribeira, os maiores valores da precipitação pluviométrica se dão nos GHII e IV, nos quais as medianas são superiores a $1.700 \mathrm{~mm}$, sendo que no primeiro GH, em ID42, verificam-se os maiores valores do desvio padrão $(786 \mathrm{~mm})$ e do coeficiente de variação $(41,9 \%)$ de toda área em estudo, enquanto que no segundo GH (ID53) verificase a maior amplitude pluvial $(3.154 \mathrm{~mm})$. Estes GH's caracterizam-se essencialmente por se localizarem em setores próximos ao divisor de bacias hidrográficas (interflúvio), nos quais a acentuada variação do relevo é responsável pelo aumento da variabilidade espacial e, como neste caso, temporal da pluviosidade (Figura 51 - Tabela 2).

O GHV da BH do Ribeira corresponde ao mais abrangente grupo homogêneo e ao setor que melhor caracteriza esta área de estudo, uma vez que apresenta uma altitude média de 580 metros e uma mediana de $1.427 \mathrm{~mm}$ para a pluviosidade dos quinze postos pluviométricos que o abrangem, destacando-se pelo menor valor do CV $(18,7 \%)$ desta BH. Pela distribuição espacial, nota-se que o GHV se situa especificamente nas menores elevações do Vale do Ribeira ou à sotavento da Serra do Mar, aspectos fisiográficos que são essenciais para a ocorrência da menor pluviometria neste GH. Contudo, o setor de menor pluviosidade anual corresponde ao GHIII (ID37), no qual a menor altimetria (180 m) determina a mediana de $1.218 \mathrm{~mm}$ e o desvio padrão de $264 \mathrm{~mm}$, os menores valores de toda a área em estudo (Figura 51 - Tabela 2).

Por sua vez, o GHI localiza-se no setor oeste da BH do Ribeira em uma altitude média de 802 metros e, devido às mais elevadas altitudes e maior distância em relação à condição sotavento da Serra do Mar, mostra uma mediana da precipitação pluviométrica anual de $1.543 \mathrm{~mm}$ na soma dos seis postos pluviométricos que compõe este GH. Destacase que o GHI do Ribeira apresenta características aproximadas dos parâmetros estatísticos 
empregados em relação à GHII da BHAI, o que está atrelado à continuidade da estrutura espacial pluviométrica entre os grupos homogêneos das duas $\mathrm{BH}$.

Em suma, observa-se que a orografia não é satisfatoriamente avaliada na BHL, devido à limitação das altitudes dos postos pluviométricos, que se restringe ao intervalo de 4,5 a 237 metros. Especula-se que a distribuição espacial das chuvas na BHL esteja atrelada à maior influência dos sistemas atmosféricos intertropicais e sua interação com os sistemas extratropicais no setor nordeste desta $\mathrm{BH}$, enquanto que ao centro e sul ocorre a maior restrição à mecanismos extratropicais na geração de chuvas, similar ao observado por Sant'Anna Neto (1994) para Zona Costeira do estado de São Paulo.

As menores elevações da BHR apresentam o menor total anual pluvial, enquanto que os setores a oeste desta mesma BH, mais distante da sombra de chuva da Serra do Mar e em maiores elevações mostram a maior pluviosidade anual. Contudo, os setores a sotavento da Serra do Mar na BHAI e BHR mostram efetivamente a influência orográfica de modo inverso, pois mostraram menores totais pluviais em relação às suas adjacências mesmo em maiores altitudes. Contrapondo-se ao que habitual ocorre em BH's, os setores de menores elevações da BHAI mostram os maiores totais anuais de pluviosidade, o que possivelmente esteja atrelado a situação meridional e mais exposta a entrada da FPA.

Deste modo, os resultados apresentados pelo agrupamento via método K-means mostra uma divisão em um maior número de grupos em relação à aplicação do método Ward, sendo assim mais apropriado para uma análise mais detalhada da relação entre a variabilidade pluvial temporal e dos indicadores climáticos oceânicos avaliados a seguir. Os parâmetros estatísticos como o desvio padrão, o coeficiente de variação e a amplitude mostraram que a principal diferença entre os grupos homogêneos não se dá somente pelos distintos totais de pluviosidade e destaca que a significativa variabilidade temporal da área de estudo se dá pela dissimetria da ocorrência das chuvas, aspecto determinado pela complexa interação entre aspectos climáticos estáticos e dinâmicos.

Os valores dos desvios padrões para a BHAI foram comumente os menores dentre os apresentados, entre 289 e $346 \mathrm{~mm}$, o que demonstra que os dados das séries temporais avaliadas apresentam menor variabilidade em relação à precipitação pluviométrica média anual, aspecto que é ressaltado pelos menores CV, entre 18,4 e 22,0\%. Por sua vez, notase na BHL valores dos desvios padrões ligeiramente mais elevados em relação à BHAI, o que está atrelado à maior magnitude dos totais anuais e, no entanto, os valores dos CV são mais próximos aos obtidos na BHAI, o que infere a ocorrência de semelhanças entre estas duas BH's na variabilidade interanual pluvial. Contudo, o GHIII da BHL demonstra 
as maiores magnitudes e dispersões em relação à média, com o desvio padrão de 664 e $\mathrm{CV}$ de $28,1 \%$, indicativo da mais elevada variabilidade pluvial interanual desta $\mathrm{BH}$ (Tabela 2). Neste último GH da BL observa-se que a elevada variação pluviométrica está relacionada à tendência predominante de redução da maioria dos indicadores climáticos para a precipitação pluviométrica, com destaque para a redução dos totais pluviais anuais ao longo da série em mais de $1.000 \mathrm{~mm}$

A BHR caracteriza-se como o setor que apresenta os maiores valores de desvio padrão, em 786 e 524 mm, e do CV, em 41,9\% e 29,7\%, verificados nos GHIV e GHII, nesta ordem. Contudo, embora estes grupos homogêneos outrora chamados de postos pluviométricos anômalos tenha apresentado os mais excepcionais valores da estatística descritiva para a BHR, os demais grupos homogêneos da BHR mostraram os menores valores do desvio padrão para toda área em estudo, com valor mínimo de $264 \mathrm{~mm}$ para o GHIII, sendo que neste mesmo setor observa-se o menor CV da BHR (18,7\%). Esta maior diferença entre os parâmetros estatísticos na mesma área ressaltam a condição de maior variabilidade espacial pluviométrica na BHR dentre as BH's analisadas (Tabela 2).

Os resultados dos desvios padrões nesta área de estudo estão alinhados em partes aos resultados obtidos por Sousa (2006) para o estado do Paraná, uma vez que esta autora identificou o predomínio de valores entre 260 e $340 \mathrm{~mm}$ no leste paranaense, setor no qual o CV este entre 18 e 24\%, intervalos nos quais estiveram a maior parte dos GH's. Os resultados dos desvios padrões e CV também estão em acordo com os resultados de Nery (2005) e Nery e Carfan (2014) para a região Sul do Brasil.

Tabela 2 - Estatística descritiva dos grupos homogêneos das BH`s conforme o método de K-means.

\begin{tabular}{c|c|c|c|c|c|c|c|c|c}
\hline $\begin{array}{c}\text { Bacia } \\
\text { Hidrográfica }\end{array}$ & $\begin{array}{c}\text { Grupo } \\
\text { Homogêneo }\end{array}$ & $\begin{array}{c}\text { Altitude } \\
\text { média } \\
\text { (metros) }\end{array}$ & $\begin{array}{c}\text { Média } \\
\text { (mm) }\end{array}$ & $\begin{array}{c}\text { Mediana } \\
\text { (mm) }\end{array}$ & $\begin{array}{c}\text { Desvio } \\
\text { Padrão } \\
\mathbf{( m m )}\end{array}$ & $\begin{array}{c}\text { Coeficiente } \\
\text { de } \\
\text { variação } \\
\text { (\%) }\end{array}$ & $\begin{array}{c}\text { Mínimo } \\
\text { (mm) }\end{array}$ & $\begin{array}{c}\text { Máximo } \\
\text { (mm) }\end{array}$ & $\begin{array}{c}\text { Amplitude } \\
(\mathbf{m m})\end{array}$ \\
\hline Alto Iguaçu & I & 920 & 1.420 & 1.421 & 308 & 21,7 & 633 & 2.017 & 1.384 \\
Alto Iguaçu & II & 847 & 1.573 & 1.563 & 289 & 18,4 & 884 & 2.506 & 1.622 \\
Alto Iguaçu & III & 979 & 1.853 & 1.877 & 346 & 18,7 & 1.109 & 2.621 \\
Alto Iguçu & IV & 765 & 1.659 & 1.599 & 334 & 20,1 & 900 & 2.670 & 1.512 \\
Alto Iguçu & V & 790 & 1.633 & 1.594 & 359 & 22,0 & 917 & 2.571 & 1.654 \\
Alto Iguaçu & VI & 917 & 1.474 & 1.471 & 290 & 19,7 & 766 & 2.366 & 1.600 \\
\hline Litorânea & I & 52 & 2.577 & 2.566 & 474 & 18,4 & 1.449 & 4.116 & 2.667 \\
Litorânea & II & 68 & 2.094 & 2.086 & 372 & 17,8 & 1.343 & 3.172 & 1.829 \\
Litorânea & III & 73 & 2.360 & 2.388 & 664 & 28,1 & 1.245 & 3.905 & 2.660 \\
\hline Ribeira & I & 802 & 1.541 & 1.543 & 313 & 20,3 & 706 & 2.503 & 1.797 \\
Ribeira & II & 642 & 1.875 & 1.743 & 786 & 41,9 & 922 & 3.884 & 2.962 \\
Ribeira & III & 180 & 1.215 & 1.218 & 264 & 21,7 & 678 & 1.877 & 1.199 \\
Ribeira & IV & 818 & 1.767 & 1.716 & 524 & 29,7 & 1.016 & 4.170 & 3.154 \\
Ribeira & V & 580 & 1.431 & 1.427 & 267 & 18,7 & 716 & 2.500 & 1.784 \\
\hline
\end{tabular}




\subsubsection{As anomalias pluviais e os indicadores climáticos oceânicos}

A aplicação do modelo de vetorial auto regressivo (VAR) indica significância estatística (95\%) entre o Índice de Oscilação-Sul (IOS) e variabilidade pluvial mensal somente para o GHLIII, que se trata do posto pluviométrico de Guaraqueçaba (ID27), justamente o posto pluviométrico com o maior coeficiente de variação $(28,1 \%)$ e desvio padrão $(664 \mathrm{~mm})$ da BHL. Deste modo, observa-se que o posto pluviométrico ID27 mostra uma relação influência comprovada estatisticamente da variação das fases opostas do ENOS, conforme delimitado pelo IOS, para o tempo de atraso de 1 mês (Lag 1), o que demonstra uma relação causal imediata entre o aumento/diminuição deste índice para a diminuição/aumento dos totais pluviais neste posto pluviométrico. Estatisticamente, destaca-se que este posto pluviométrico mostra os maiores valores das estimativas do modelo VAR $(-13,8)$ e o maior valor de $\mathrm{t}(2,12)$, que concordantes reafirmam a condição de maior influência entre o indicador climático IOS e a variabilidade das chuvas nesta localidade (Tabela 3).

No entanto, outros grupos homogêneos mostraram que, com menor rigidez do limiar de significância (>85\%), existe uma menor relação entre as alterações do IOS e as anomalias de precipitação para os seguintes grupos homogêneos: GHAI I, GHAI III, GHR II e GHR IV. Com valores similares, os dois grupos pertencentes a BHAI mostram significâncias próximas a 90\% (valor-p $=0,11$ ), com estimativas de $-7,18$ e valor-t igual a 1,61, ressaltando-se a proximidade espacial entre estes dois grupos, dos quais se tratam especificamente somente de dois postos pluviométricos (ID’S 06 e 08). Para a BHR notase que os dois GH's que chegaram mais próximos da significância estatística mostraram valor -p entre 0,11 e 0,14 , além de estimativas superiores a -8 e valor -t superior a 1,46, são justamente grupos homogêneos formados somente por um posto pluviométrico.

Deste modo, observa-se que os resultados mais satisfatórios para averiguar uma relação causal entre anomalia pluviométrica e o índice IOS foram obtidos apenas pelos grupos homogêneos compostos somente por um posto pluviométrico. Possivelmente, se estes resultados fossem aplicados individualmente por postos pluviométricos, teriam sido obtidas melhores valores de correlação, sendo estas uma das limitações reconhecidas por esta pesquisa.

Os estudos de Correa (2017) analisaram a relação entre a variabilidade pluvial e o IOS, utilizando-se do modelo GAMLSS (Modelos Aditivos Generalizados para Posição, Escala e Forma) e observaram que a maior confiabilidade para designar a relação entre o 
IOS e a precipitação pluviométrica na bacia hidrográfica do rio Piquiri, situada no oeste do Paraná, se dá com a defasagem de um a três meses. Este autor demonstra que a cada aumento de uma unidade do IOS, a precipitação pluviométrica diminui $1 \%$ naquela $\mathrm{BH}$. Conforme a tabela 3, as estimativas para o GH III da BH Litorânea mostram que a cada uma unidade de aumento do IOS, verifica-se a diminuição de $13,8 \mathrm{~mm}$ da anomalia pluvial em relação às normais climatológicas mensais.

Tabela 3 - Aplicação do modelo auto regressivo vetorial (VAR) para o IOS e respectivos lag's em grupos homogêneos (GH) das BH Alto Iguaçu (AI), Litorânea (L) e Ribeira (R) - Paraná.

\begin{tabular}{|c|c|c|c|c|c|}
\hline Variável Resposta & Variável Explicativa & Estimativa & Erro Padrão & Valor-t & Valor-p \\
\hline \multirow{2}{*}{$\begin{array}{c}\text { Precipitação pluvial } \\
\text { GH AI I }\end{array}$} & IOS.lag1 & $-7,18$ & 4,45 & $-1,61$ & 0,11 \\
\hline & IOS.lag2 & $-2,32$ & 4,47 & $-0,52$ & 0,60 \\
\hline \multirow{2}{*}{$\begin{array}{c}\text { Precipitação pluvial } \\
\text { GH AI II }\end{array}$} & IOS.lag1 & $-5,39$ & 4,36 & $-1,24$ & 0,22 \\
\hline & IOS.lag2 & $-3,82$ & 4,37 & $-0,87$ & 0,38 \\
\hline \multirow{2}{*}{$\begin{array}{c}\text { Precipitação pluvial } \\
\text { GH AI III }\end{array}$} & IOS.lag1 & $-7,18$ & 4,45 & $-1,61$ & 0,11 \\
\hline & IOS.lag2 & $-2,32$ & 4,47 & $-0,52$ & 0,60 \\
\hline \multirow{2}{*}{$\begin{array}{c}\text { Precipitação pluvial } \\
\text { GH AI IV }\end{array}$} & IOS.lag1 & $-3,86$ & 5,19 & $-0,74$ & 0,46 \\
\hline & IOS.lag2 & $-3,37$ & 5,18 & $-0,65$ & 0,52 \\
\hline \multirow{2}{*}{$\begin{array}{c}\text { Precipitação pluvial } \\
\text { GH AI V }\end{array}$} & IOS.lag1 & $-3,19$ & 5,06 & $-0,63$ & 0,53 \\
\hline & IOS.lag2 & $-3,11$ & 5,06 & $-0,62$ & 0,54 \\
\hline \multirow{2}{*}{$\begin{array}{c}\text { Precipitação pluvial } \\
\text { GH AI VI }\end{array}$} & IOS.lag1 & $-2,74$ & 4,33 & $-0,63$ & 0,53 \\
\hline & IOS.lag2 & $-0,46$ & 4,77 & $-0,10$ & 0,92 \\
\hline \multirow{2}{*}{$\begin{array}{c}\text { Precipitação pluvial } \\
\text { GH L I }\end{array}$} & IOS.lag1 & $-6,18$ & 5,41 & $-1,14$ & 0,25 \\
\hline & IOS.lag2 & 4,88 & 5,40 & 0,90 & 0,37 \\
\hline \multirow{2}{*}{$\begin{array}{c}\text { Precipitação pluvial } \\
\text { GH L II }\end{array}$} & IOS.lag1 & $-3,46$ & 4,98 & $-0,70$ & 0,49 \\
\hline & IOS.lag2 & 2,10 & 4,97 & 0,42 & 0,67 \\
\hline \multirow{2}{*}{$\begin{array}{c}\text { Precipitação pluvial } \\
\text { GH L III }\end{array}$} & IOS.lag1 & $-13,80$ & 6,50 & $-2,12$ & $0,03 *$ \\
\hline & IOS.lag2 & $-4,01$ & 6,55 & $-0,61$ & 0,54 \\
\hline \multirow{2}{*}{$\begin{array}{c}\text { Precipitação pluvial } \\
\text { GH R I }\end{array}$} & IOS.lag1 & $-4,03$ & 4,17 & $-0,97$ & 0,34 \\
\hline & IOS.lag2 & $-4,86$ & 4,18 & $-1,16$ & 0,25 \\
\hline \multirow{2}{*}{$\begin{array}{c}\text { Precipitação pluvial } \\
\text { GH R II }\end{array}$} & IOS.lag1 & $-9,89$ & 6,13 & $-1,61$ & 0,11 \\
\hline & IOS.lag2 & 2,05 & 6,61 & 0,31 & 0,76 \\
\hline \multirow{2}{*}{$\begin{array}{c}\text { Precipitação pluvial } \\
\text { GH R III }\end{array}$} & IOS.lag1 & $-3,14$ & 3,98 & $-0,79$ & 0,43 \\
\hline & IOS.lag2 & $-0,07$ & 4,28 & $-0,02$ & 0,99 \\
\hline \multirow{2}{*}{$\begin{array}{c}\text { Precipitação pluvial } \\
\text { GH R IV }\end{array}$} & IOS.lag1 & $-8,53$ & 5,82 & $-1,46$ & 0,14 \\
\hline & IOS.lag2 & $-5,84$ & 5,82 & $-1,00$ & 0,32 \\
\hline \multirow{2}{*}{$\begin{array}{c}\text { Precipitação pluvial } \\
\text { GH R V }\end{array}$} & IOS.lag1 & $-3,62$ & 3,75 & $-0,97$ & 0,33 \\
\hline & IOS.lag2 & $-4,04$ & 3,75 & $-1,08$ & 0,28 \\
\hline
\end{tabular}

Legenda: $*=95 \%$ de significância.

O Oceanic Niño Index (ONI) mostra-se como o indicador climático que obteve as mais significativas correlações com as anomalias pluviométricas na área de estudo. Notase que o grupo homogêneo II da bacia hidrográfica Alto Iguaçu corresponde ao setor de maior representatividade da correlação (90\%), pois abrange a 12 postos pluviométricos situados no setor centro-sul desta BH. Para o tempo de atraso de 2 meses (Lag 2), observase o aumento de $147,5 \mathrm{~mm}$ a cada unidade do ONI, com valor de -t equivalente a 1,65, enquanto que para a defasagem de 3 meses, esta relação inverte-se, tendo a diminuição 
de 173,95 mm, com o valor de -t igual a 1,64, tendo sido observado em ambos os casos uma significância de 90\%. Este mesmo panorama é observado também para o GH V da BH Alto Iguaçu, pois para a defasagem de 2 meses obteve-se um aumento de 175,2 mm com valor-t igual a 1,69, ao passo que para o tempo de atraso de 3 meses os resultados mostraram uma diminuição de 205,2 mm com valor-t de -1,66 (Tabela 4).

O padrão de diminuição das anomalias de chuva é observado para a defasagem de 3 meses nos grupos homogêneos I e III da BH Litorânea, que representam 9 postos pluviométricos ao todo, com valores de -220,8 e -363,4 mm e valores -t equivalentes a 1,66 e a -2,24 e significância de 90 e 95\%, nesta ordem. Isto demonstra que nestes grupos que o aumento do ONI implica em uma relação inversa ao esperado, pois ao invés das anomalias pluviais serem positivas com o aumento deste indicador climático, o modelo VAR demonstra o inverso. No entanto, ressalta-se que para o GH III da BHL, o VAR indica o aumento de $311,3 \mathrm{~mm}$ a cada unidade do ONI para o tempo de defasagem de 4 meses, com valor-t de 1,92 e significância de $90 \%$, sendo este um padrão climático próximo ao esperado (Tabela 4).

Deste modo, discorre-se que a defasagem de 2 meses mostra concordância com o aumento das anomalias positivas de precipitação pluviométrica nos GH's II e V da BH Alto Iguaçu, enquanto que, inversamente, as defasagens de 3 meses demonstram que para este período o aumento do ONI indica a diminuição das anomalias pluviais nos GH's II e V da BH Alto Iguaçu e GH's I e III da BH Litorânea, demonstrando toda a complexidade da relação entre a variável resposta e a variável explicativa. Controverso, nota-se ainda no GH III da BH Litorânea o aumento da pluviosidade para a defasagem de 4 meses, uma resposta completamente diferente do observado para a defasagem de 3 meses. Ressalvase ainda que nenhum dos grupos homogêneos da BH do rio Ribeira apresenta correlação significativa com o indicador ONI (Tabela 4).

Os resultados do modelo VAR indicaram também correlações significativas entre a Oscilação Decadal do Pacífico (ODP) e as anomalias de precipitação pluviométrica nos grupos homogêneos II e III da BH do rio Ribeira, que são os postos pluviométricos ID's 42 e 37, com as estimativas de aumento de 18,55 mm e 14,31 mm, valor -t de 1,74 e 2,07 e significância de $90 \%$ e 95\%, ordenadamente, considerando a defasagem de 2 meses (Lag 2). Contudo, quando se considera um atraso de 3 meses (Lag 3), nota-se uma relação inversa e a cada unidade da ODP verificam-se anomalias pluviais negativas de 15,15 mm e 10,05 mm, com valor de -t igual a 1,94 e 1,99 e significância estatística de 95\% para os GH II e III da BH do rio Ribeira (Tabela 5). 
Tabela 4 - Aplicação do modelo auto regressivo vetorial (VAR) para o ONI e respectivos lag's em grupos homogêneos (GH) das BH Alto Iguaçu (AI), Litorânea (L) e Ribeira (R) - Paraná.

\begin{tabular}{|c|c|c|c|c|c|}
\hline Variável Resposta & Variável Explicativa & Estimativa & Erro Padrão & Valor-t & $\overline{\text { Valor-p }}$ \\
\hline \multirow{5}{*}{$\begin{array}{c}\text { Precipitação pluvial } \\
\text { GH AI I }\end{array}$} & ONI.lag1 & $-21,02$ & 37,87 & $-0,56$ & 0,58 \\
\hline & ONI.lag2 & 101,93 & 90,64 & 1,13 & 0,26 \\
\hline & ONI.lag3 & $-147,24$ & 108,15 & $-1,36$ & 0,17 \\
\hline & ONI.lag4 & 113,90 & 108,13 & 1,05 & 0,29 \\
\hline & ONI.lag5 & $-12,44$ & 90,69 & $-0,14$ & 0,89 \\
\hline \multirow{5}{*}{$\begin{array}{c}\text { Precipitação pluvial } \\
\text { GH AI II }\end{array}$} & ONI.lag1 & $-42,70$ & 37,35 & $-1,14$ & 0,25 \\
\hline & ONI.lag2 & 147,47 & 89,26 & 1,65 & $0,10^{+}$ \\
\hline & ONI.lag3 & $-173,95$ & 106,38 & $-1,64$ & $0,10^{+}$ \\
\hline & ONI.lag4 & 83,52 & 106,37 & 0,79 & 0,43 \\
\hline & ONI.lag5 & 39,13 & 89,21 & 0,44 & 0,66 \\
\hline \multirow{5}{*}{$\begin{array}{c}\text { Precipitação pluvial } \\
\text { GH AI III }\end{array}$} & ONI.lag1 & $-8,91$ & 42,28 & $-0,21$ & 0,83 \\
\hline & ONI.lag2 & 62,43 & 101,10 & 0,62 & 0,54 \\
\hline & ONI.lag3 & $-94,37$ & 120,70 & $-0,78$ & 0,43 \\
\hline & ONI.lag4 & 91,43 & 120,40 & 0,76 & 0,45 \\
\hline & ONI.lag5 & $-53,05$ & 100,80 & $-0,53$ & 0,60 \\
\hline \multirow{5}{*}{$\begin{array}{c}\text { Precipitação pluvial } \\
\text { GH AI IV }\end{array}$} & ONI.lag1 & $-18,34$ & 44,25 & $-0,41$ & 0,68 \\
\hline & ONI.lag2 & 89,84 & 105,95 & 0,85 & 0,40 \\
\hline & ONI.lag3 & $-89,43$ & 126,34 & $-0,71$ & 0,48 \\
\hline & ONI.lag4 & 2,32 & 126,07 & 0,02 & 0,99 \\
\hline & ONI.lag5 & 75,24 & 105,55 & 0,71 & 0,48 \\
\hline \multirow{5}{*}{$\begin{array}{c}\text { Precipitação pluvial } \\
\text { GH AI V }\end{array}$} & ONI.lag1 & $-51,14$ & 43,50 & $-1,18$ & 0,24 \\
\hline & ONI.lag2 & 175,18 & 103,86 & 1,69 & $\mathbf{0 , 0 9}^{+}$ \\
\hline & ONI.lag3 & $-205,20$ & 123,94 & $-1,66$ & $0,10^{+}$ \\
\hline & ONI.lag4 & 91,68 & 123,97 & 0,74 & 0,46 \\
\hline & ONI.lag5 & 34,43 & 103,77 & 0,33 & 0,74 \\
\hline \multirow{5}{*}{$\begin{array}{c}\text { Precipitação pluvial } \\
\text { GH AI VI }\end{array}$} & IOS.lag1 & $-2,74$ & 4,33 & $-0,63$ & 0,53 \\
\hline & IOS.lag2 & $-0,46$ & 4,77 & $-0,10$ & 0,92 \\
\hline & IOS.lag3 & $-4,28$ & 4,88 & $-0,88$ & 0,38 \\
\hline & IOS.lag4 & 0,06 & 4,88 & 0,01 & 0,99 \\
\hline & IOS.lag5 & 0,08 & 4,77 & 0,02 & 0,99 \\
\hline \multirow{5}{*}{$\begin{array}{c}\text { Precipitação pluvial } \\
\text { GH L I }\end{array}$} & ONI.lag1 & $-49,62$ & 46,45 & $-1,07$ & 0,29 \\
\hline & ONI.lag2 & 161,51 & 111,32 & 1,45 & 0,15 \\
\hline & ONI.lag3 & $-220,81$ & 133,25 & $-1,66$ & $0,10^{+}$ \\
\hline & ONI.lag4 & 168,22 & 133,40 & 1,26 & 0,21 \\
\hline & ONI.lag5 & $-56,97$ & 111,41 & $-0,51$ & 0,61 \\
\hline \multirow{5}{*}{$\begin{array}{c}\text { Precipitação pluvial } \\
\text { GH L II }\end{array}$} & ONI.lag1 & $-44,39$ & 42,96 & $-1,03$ & 0,30 \\
\hline & ONI.lag2 & 134,20 & 102,80 & 1,31 & 0,19 \\
\hline & ONI.lag3 & $-183,20$ & 123,00 & $-1,49$ & 0,14 \\
\hline & ONI.lag4 & 150,60 & 123,00 & 1,23 & 0,22 \\
\hline & ONI.lag5 & $-52,81$ & 102,80 & $-0,51$ & 0,61 \\
\hline \multirow{5}{*}{$\begin{array}{c}\text { Precipitação pluvial } \\
\text { GH L III }\end{array}$} & ONI.lag1 & $-43,67$ & 55,62 & $-0,79$ & 0,43 \\
\hline & ONI.lag2 & 215,30 & 134,00 & 1,61 & 0,11 \\
\hline & ONI.lag3 & $-362,40$ & 161,60 & $-2,24$ & $\mathbf{0 , 0 3}^{*}$ \\
\hline & ONI.lag4 & 311,30 & 162,20 & 1,92 & $\mathbf{0 , 0 6}^{+}$ \\
\hline & ONI.lag5 & $-106,30$ & 134,80 & $-0,79$ & 0,43 \\
\hline \multirow{5}{*}{$\begin{array}{c}\text { Precipitação pluvial } \\
\text { GH R I }\end{array}$} & ONI.lag1 & $-16,81$ & 35,89 & $-0,47$ & 0,64 \\
\hline & ONI.lag2 & 92,02 & 85,87 & 1,07 & 0,28 \\
\hline & ONI.lag3 & $-140,32$ & 102,34 & $-1,37$ & 0,17 \\
\hline & ONI.lag4 & 99,10 & 102,31 & 0,97 & 0,33 \\
\hline & ONI.lag5 & 2,92 & 85,83 & 0,03 & 0,97 \\
\hline \multirow{5}{*}{$\begin{array}{c}\text { Precipitação pluvial } \\
\text { GH R II }\end{array}$} & ONI.lag1 & 34,02 & 50,66 & 0,67 & 0,50 \\
\hline & ONI.lag2 & $-7,51$ & 121,66 & $-0,06$ & 0,95 \\
\hline & ONI.lag3 & $-110,98$ & 145,78 & $-0,76$ & 0,45 \\
\hline & ONI.lag4 & 178,17 & 145,45 & 1,23 & 0,22 \\
\hline & ONI.lag5 & $-122,19$ & 121,17 & $-1,01$ & 0,31 \\
\hline
\end{tabular}




\begin{tabular}{c|c|c|c|c|c}
\hline \multirow{4}{*}{$\begin{array}{c}\text { Precipitação pluvial } \\
\text { GH R III }\end{array}$} & ONI.lag1 & 14,49 & 33,00 & 0,44 & 0,66 \\
\cline { 2 - 6 } & ONI.lag2 & 10,61 & 79,06 & 0,13 & 0,89 \\
\cline { 2 - 6 } & ONI.lag3 & $-73,27$ & 94,21 & $-0,78$ & 0,44 \\
\cline { 2 - 6 } & ONI.lag4 & 83,71 & 94,04 & 0,89 & 0,37 \\
\hline \multirow{4}{*}{$\begin{array}{c}\text { Precipitação pluvial } \\
\text { GH R IV }\end{array}$} & ONI.lag5 & $-20,54$ & 78,88 & $-0,26$ & 0,79 \\
\cline { 2 - 6 } & ONI.lag1 & 1,50 & 49,28 & 0,03 & 0,98 \\
\cline { 2 - 6 } & ONI.lag2 & 87,92 & 118,09 & 0,74 & 0,46 \\
\cline { 2 - 6 } & ONI.lag3 & $-179,58$ & 141,01 & $-1,27$ & 0,20 \\
\hline \multirow{4}{*}{$\begin{array}{l}\text { Precipitação pluvial } \\
\text { GH R V }\end{array}$} & ONI.lag5 & $-176,90$ & 140,92 & 1,26 & 0,21 \\
\cline { 2 - 6 } & ONI.lag1 & $-9,00$ & 118,00 & $-0,85$ & 0,39 \\
\cline { 2 - 6 } & ONI.lag2 & 62,83 & 77,29 & 0,81 & 0,42 \\
\cline { 2 - 6 } & ONI.lag3 & $-102,50$ & 92,13 & $-1,11$ & 0,27 \\
\cline { 2 - 6 } & ONI.lag4 & 78,55 & 92,00 & 0,85 & 0,39 \\
\hline ONI.lag5 & $-1,61$ & 77,17 & $-0,02$ & 0,98 \\
\hline
\end{tabular}

Legenda: $*=95 \%$ de significância; $+=90 \%$ de significância.

Tabela 5 - Aplicação do modelo auto regressivo vetorial (VAR) para a ODP e respectivos lag's em grupos homogêneos (GH) das BH Alto Iguaçu (AI), Litorânea (L) e Ribeira (R) - Paraná.

\begin{tabular}{|c|c|c|c|c|c|}
\hline Variável Resposta & Variável Explicativa & Estimativa & Erro Padrão & Valor-t & Valor-p \\
\hline $\begin{array}{c}\text { Precipitação pluvial } \\
\text { GH AI I }\end{array}$ & ODP.lag1 & 3,77 & 2,99 & 1,26 & 0,21 \\
\hline $\begin{array}{c}\text { Precipitação pluvial } \\
\text { GH AI II }\end{array}$ & ODP.lag1 & 3,44 & 2,93 & 1,17 & 0,24 \\
\hline $\begin{array}{c}\text { Precipitação pluvial } \\
\text { GH AI III }\end{array}$ & ODP.lag1 & 3,66 & 3,30 & 1,11 & 0,27 \\
\hline $\begin{array}{c}\text { Precipitação pluvial } \\
\text { GH AI IV }\end{array}$ & ODP.lag1 & 3,37 & 3,48 & 0,97 & 0,33 \\
\hline $\begin{array}{c}\text { Precipitação pluvial } \\
\text { GH AI V }\end{array}$ & ODP.lag1 & 0,32 & 3,39 & 0,09 & 0,93 \\
\hline \multirow{6}{*}{$\begin{array}{c}\text { Precipitação pluvial } \\
\text { GH AI VI }\end{array}$} & ODP.lag1 & $-2,20$ & 5,55 & $-0,40$ & 0,69 \\
\hline & ODP.lag2 & 12,06 & 7,58 & 1,59 & 0,11 \\
\hline & ODP.lag3 & $-4,69$ & 7,60 & $-0,62$ & 0,54 \\
\hline & ODP.lag4 & $-10,65$ & 7,58 & $-1,40$ & 0,16 \\
\hline & ODP.lag5 & 9,85 & 7,57 & 1,30 & 0,19 \\
\hline & ODP.lag6 & 0,10 & 5,55 & 0,02 & 0,99 \\
\hline $\begin{array}{c}\text { Precipitação pluvial } \\
\text { GH L I }\end{array}$ & ODP.lag1 & 1,46 & 3,63 & 0,40 & 0,69 \\
\hline $\begin{array}{c}\text { Precipitação pluvial } \\
\text { GH L II }\end{array}$ & ODP.lag1 & 0,77 & 3,34 & 0,23 & 0,82 \\
\hline $\begin{array}{c}\text { Precipitação pluvial } \\
\text { GH L III }\end{array}$ & ODP.lag1 & 15,07 & 4,45 & 3,39 & $<0,01^{* * *}$ \\
\hline $\begin{array}{c}\text { Precipitação pluvial } \\
\text { GH R I }\end{array}$ & ODP.lag1 & 3,03 & 2,82 & 1,08 & 0,28 \\
\hline \multirow{3}{*}{$\begin{array}{c}\text { Precipitação pluvial } \\
\text { GH R II }\end{array}$} & ODP.lag1 & $-2,38$ & 7,85 & $-0,30$ & 0,76 \\
\hline & ODP.lag2 & 18,55 & 10,69 & 1,74 & $\mathbf{0 , 0 8}^{+}$ \\
\hline & ODP.lag3 & $-15,15$ & 7,83 & $-1,94$ & $0,05 *$ \\
\hline \multirow{3}{*}{$\begin{array}{l}\text { Precipitação pluvial } \\
\text { GH R III }\end{array}$} & ODP.lag1 & $-5,25$ & 5,08 & $-1,03$ & 0,30 \\
\hline & ODP.lag2 & 14,31 & 6,90 & 2,07 & $0,04 *$ \\
\hline & ODP.lag3 & $-10,05$ & 5,06 & $-1,99$ & $\mathbf{0 , 0 5 *}$ \\
\hline $\begin{array}{c}\text { Precipitação pluvial } \\
\text { GH R IV }\end{array}$ & ODP.lag1 & 3,30 & 3,95 & 0,83 & 0,41 \\
\hline $\begin{array}{c}\text { Precipitação pluvial } \\
\text { GH R V }\end{array}$ & ODP.lag1 & 2,36 & 2,53 & 0,93 & 0,35 \\
\hline
\end{tabular}

Legenda: $* *=99 \%$ de significância; $*=95 \%$ de significância; $+=90 \%$ de significância. 
Ainda, observa-se que o grupo homogêneo III (ID27) da BH Litorânea apresenta uma correlação significativa de $99 \%$ para a anomalia pluviométrica e a ODP, sendo que a cada unidade deste indicador climático há o aumento de $15,07 \mathrm{~mm}$, considerando-se o valor -t de 3,39 (Tabela 5), o que ressalta que constantemente este posto pluviométrico apresenta anomalias suscetíveis às oscilações dos indicadores climáticos, sendo este um dos fatores provavelmente responsáveis pelas expressivas e significativas tendências e rupturas observadas no item posterior a este. Não foram observadas estimativas com significância estatística nos demais grupos homogêneos para correlacionar a ODP e as anomalias pluviométricas.

A aplicação do modelo VAR mostra-se pouco significativa para demonstrar as associações entre as anomalias pluviais e o Gradiente Meridional do Atlântico Meridional (GMAT) nas bacias hidrográficas em estudo. Contudo, observa-se que o grupo homogêneo VI da BHAI obteve uma significância de $90 \%$ para demonstrar a relação entre o GMAT e as anomalias pluviométricas, sendo que as estimativas indicam um aumento de 30,1 mm a cada unidade deste indicador climático, com valor -t igual a 1,64 (Tabela 6). Verifica-se que este grupo homogêneo situado no setor nordeste da BHAI, composto por 04 postos pluviométricos e mais próximos à costa litorânea em relação aos demais GH's desta BH, apresenta a maior influência do indicador GMAT para as anomalias da precipitação pluviométrica.

Esta influência em um setor de uma bacia hidrográfica continental, embora tenha sido observado nas proximidades do Oceano Atlântico, difere-se em relação ao esperado para a associação do indicador climático oceânico e as anomalias pluviais, uma vez que era pressuposto a observação de correlações significativas e mais expressivas para a BH Litorânea, setor no qual haveria supostamente uma mais representativa influência e, até mesmo, controle do indicador GMAT na variabilidade pluviométrica.

Entretanto, observa-se que o GHIV da BH do rio Ribeira mostra uma condição inversa em relação à associação observada para a anomalia pluviométrica e o GMAT no GH VI da BH Alto Iguaçu. Neste setor da BH do rio Ribeira, nota-se que o aumento de cada unidade do GMAT corresponde a diminuição de 21,75 mm, com o valor -t de $-1,79$ e significância estatística de 90\% (Tabela 6). Destaca-se que o GHIV da BH do Ribeira corresponde ao posto pluviométrico ID53, situado a 818 metros de altitude e à sotavento da Serra do Mar e com distância superior a 180 km em relação à zona costeira paranaense, fatores que conjugados podem ser responsáveis por esta relação inversa entre GMAT e as anomalias pluviométricas nesta localidade. 
Tabela 6 - Aplicação do modelo auto regressivo vetorial (VAR) para o GMAT e respectivos lag's em grupos homogêneos (GH) das BH Alto Iguaçu (AI), Litorânea (L) e Ribeira (R) - Paraná.

\begin{tabular}{|c|c|c|c|c|c|}
\hline Variável Resposta & Variável Explicativa & Estimativa & Erro Padrão & Valor-t & $\overline{\text { Valor-p }}$ \\
\hline $\begin{array}{c}\text { Precipitação pluvial } \\
\text { GH AI I }\end{array}$ & GMAT.lag1 & 6,94 & 9,22 & 0,75 & 0,45 \\
\hline $\begin{array}{c}\text { Precipitação pluvial } \\
\text { GH AI II }\end{array}$ & GMAT.lag1 & 2,78 & 9,02 & 0,31 & 0,76 \\
\hline $\begin{array}{c}\text { Precipitação pluvial } \\
\text { GH AI III } \\
\end{array}$ & GMAT.lag1 & 8,49 & 10,16 & 0,84 & 0,40 \\
\hline $\begin{array}{c}\text { Precipitação pluvial } \\
\text { GH AI IV } \\
\end{array}$ & GMAT.lag1 & $-0,30$ & 10,72 & $-0,03$ & 0,98 \\
\hline $\begin{array}{c}\text { Precipitação pluvial } \\
\text { GH AI V }\end{array}$ & GMAT.lag1 & 4,09 & 10,45 & 0,39 & 0,70 \\
\hline \multirow{6}{*}{$\begin{array}{c}\text { Precipitação pluvial } \\
\text { GH AI VI }\end{array}$} & GMAT.lag1 & 30,01 & 18,26 & 1,64 & $\mathbf{0 , 1 0 ^ { + }}$ \\
\hline & GMAT.lag2 & $-36,87$ & 25,38 & $-1,45$ & 0,15 \\
\hline & GMAT.lag3 & 24,32 & 25,37 & 0,96 & 0,34 \\
\hline & GMAT.lag4 & $-29,45$ & 25,34 & $-1,16$ & 0,25 \\
\hline & GMAT.lag5 & 14,60 & 25,38 & 0,58 & 0,57 \\
\hline & GMAT.lag6 & 7,45 & 18,15 & 0,41 & 0,68 \\
\hline $\begin{array}{c}\text { Precipitação pluvial } \\
\text { GH L I } \\
\end{array}$ & GMAT.lag1 & 5,88 & 11,19 & 0,53 & 0,60 \\
\hline $\begin{array}{c}\text { Precipitação pluvial } \\
\text { GH L II }\end{array}$ & GMAT.lag1 & 12,90 & 10,30 & 1,25 & 0,21 \\
\hline $\begin{array}{c}\text { Precipitação pluvial } \\
\text { GH L III } \\
\end{array}$ & GMAT.lag1 & $-8,14$ & 13,70 & $-0,59$ & 0,55 \\
\hline $\begin{array}{c}\text { Precipitação pluvial } \\
\text { GH R I } \\
\end{array}$ & GMAT.lag1 & 12,96 & 18,15 & 0,71 & 0,48 \\
\hline \multirow{3}{*}{$\begin{array}{c}\text { Precipitação pluvial } \\
\text { GH R II }\end{array}$} & GMAT.lag1 & 0,84 & 25,65 & 0,03 & 0,97 \\
\hline & GMAT.lag2 & $-45,37$ & 35,37 & $-1,28$ & 0,20 \\
\hline & GMAT.lag3 & 36,63 & 25,48 & 1,44 & 0,15 \\
\hline \multirow{3}{*}{$\begin{array}{l}\text { Precipitação pluvial } \\
\text { GH R III }\end{array}$} & GMAT.lag1 & 5,71 & 16,57 & 0,35 & 0,73 \\
\hline & GMAT.lag2 & $-2,09$ & 22,93 & $-0,09$ & 0,93 \\
\hline & GMAT.lag3 & $-0,39$ & 16,48 & $-0,02$ & 0,98 \\
\hline $\begin{array}{c}\text { Precipitação pluvial } \\
\text { GH R IV }\end{array}$ & GMAT.lag1 & $-21,75$ & 12,17 & $-1,79$ & $\mathbf{0 , 0 7 ^ { + }}$ \\
\hline $\begin{array}{c}\text { Precipitação pluvial } \\
\text { GH R V } \\
\end{array}$ & GMAT.lag1 & 1,87 & 7,80 & 0,24 & 0,81 \\
\hline
\end{tabular}

Legenda: $+=90 \%$ de significância.

Sinteticamente, observa-se que o indicador climático oceânico ONI apresenta as mais elevadas e expressivas correlações com as anomalias de precipitação pluviométrica, tendo sido verificada em 22 dos 62 postos pluviométricos das bacias hidrográficas da área de estudo. Predominaram na BH do Alto Iguaçu (GH's II e IV) a significância estatística para a defasagem de 2 a 3 meses, ao passo que este tempo de atraso é de 3 a 4 meses na BH Litorânea. Para a BH do rio Ribeira não se verificou nenhuma correlação significativa entre o ONI e as anomalias pluviais (Tabela 7).

Verifica-se que o modelo VAR indica uma correlação significativa entre o GMAT e as anomalias de precipitação pluviométrica para os GH VI da BH Alto Iguaçu e o GH $\mathrm{V}$ da $\mathrm{BH}$ do rio Ribeira, abrangendo 05 postos pluviométricos para a defasagem de 1 mês. Inversamente ao que era pressuposto, não se observa nenhuma correlação expressiva e 
significativa entre o GMAT e a as anomalias pluviais na BH Litorânea, descontruindo a hipótese de que este indicador climático, que representa a anomalia TSM do Oceano Atlântico uma das mais representativas e estudadas teleconexões para a ocorrência das anomalias pluviométricas em outras regiões brasileiras (DIAZ; STUDZINSKI, 1994; ALVES et al., 2014; REBOITA; SANTOS, 2014), em certo modo e intensidade exerceria uma influência nas anomalias pluviais na bacia hidrográfica do Litoral paranaense.

Tabela 7 - Síntese da aplicação do modelo auto regressivo vetorial (VAR), destacando-se a relação significativa entre os indicadores climáticos oceânicos e os atrasos (Lag) com significância estatística.

\begin{tabular}{|c|c|c|c|c|c|c|}
\hline \multirow{2}{*}{ Bacia Hidrográfica } & \multirow{2}{*}{ Grupo Homogêneo } & \multirow{2}{*}{$\begin{array}{l}\text { Número de Postos } \\
\text { Pluviométricos }\end{array}$} & \multicolumn{4}{|c|}{ Modelo VAR } \\
\hline & & & IOS & ODP & ONI & GMAT \\
\hline \multirow{6}{*}{ Alto Iguaçu } & GH I & 1 & & & & \\
\hline & GH II & 12 & & & $\begin{array}{l}\text { Lag } 2 \\
\text { Lag } 3\end{array}$ & \\
\hline & GH III & 1 & & & & \\
\hline & GH IV & 2 & & & $\begin{array}{l}\text { Lag } 2 \\
\text { Lag } 3\end{array}$ & \\
\hline & GH V & 1 & & & & \\
\hline & GH VI & 4 & & & & Lag 1 \\
\hline \multirow{3}{*}{ Litorânea } & GH I & 8 & & & Lag 3 & \\
\hline & GH II & 7 & & & & \\
\hline & GH III & 1 & Lag 1 & Lag 1 & $\begin{array}{l}\operatorname{Lag} 3 \\
\text { Lag } 4\end{array}$ & \\
\hline \multirow{5}{*}{ Ribeira } & GH I & 8 & & & & \\
\hline & GH II & 1 & & $\begin{array}{l}\text { Lag } 2 \\
\text { Lag } 3\end{array}$ & & \\
\hline & GH III & 1 & & $\begin{array}{l}\text { Lag } 2 \\
\text { Lag } 3\end{array}$ & & \\
\hline & GH IV & 1 & & & & Lag 1 \\
\hline & GH V & 14 & & & & \\
\hline
\end{tabular}


Demonstra-se que os GH's II e III da BH do rio Ribeira correspondem aos setores de maior influência do indicador climático ODP para a ocorrência das anomalias pluviais para a defasagem temporal de 2 e 3 meses. Inclusive, o GHII da BH Ribeira apresenta o mais elevado coeficiente de variação da precipitação pluviométrica $(41,9 \%)$, aspecto que pode estar relacionado à maior atuação deste indicador climático nesta localidade para a ocorrência das anomalias pluviais.

Por sua vez, o GHIII da BH Litorânea mostra que há uma influência significativa da ODP na variabilidade pluviométrica desta localidade, para uma defasagem de 1 mês. Ressalta-se ainda que este mesmo GHLIII mostra-se como o único setor de toda área de estudo na qual se verifica correlação significativa pelo modelo VAR para associar o indicador IOS e as anomalias de pluviosidade (Tabela 7), outra condição que se alinha às tendências e rupturas descritas no item a seguir, além do elevado CV da precipitação pluviométrica $(28,1 \%)$ deste posto pluviométrico dentre os setores da BH Litorânea.

Utilizado para identificar os resíduos da aplicação do modelo VAR, o teste BoxPierce averigua a significância estatística destes resíduos e, deste modo, quanto menor a significância destes resíduos, maior é a acurácia do emprego do referido modelo. Destacase que a menor significância $(\geq 0,99)$ dos resíduos do modelo VAR e, consequentemente maior eficácia de sua utilização, é observada nas seguintes associações: entre o ONI e as anomalias pluviométricas do GH's II e IV da BH Alto Iguaçu e do GH I da BH Litorânea; entre o IOS e as anomalias pluviométricas no GH III da BH Litorânea; e, por fim, entre o GMAT e as anomalias pluviais no GHR V da BH do rio Ribeira (Tabela 8).

Tabela 8 - Aplicação do teste Box-Pierce para resíduos do modelo VAR para os grupos homogêneos $(\mathrm{GH})$ das bacias hidrográficas $(\mathrm{BH})$ em conformidade ao indicador climático oceânico.

\begin{tabular}{c|c|c|c|c|c|c|c|c|c}
\hline \multirow{2}{*}{$\mathbf{B H}$} & \multirow{2}{*}{ GH } & \multicolumn{2}{|c}{ IOS } & \multicolumn{2}{c}{ ONI } & \multicolumn{2}{c}{ ODP } & \multicolumn{2}{c}{ GMAT } \\
\cline { 2 - 10 } & & Valor & Valor -p & Valor & Valor-p & Valor & Valor -p & Valor & Valor -p \\
\hline \multirow{5}{*}{ Alto Iguaçu } & I & 0,02 & 0,99 & 0,07 & $>0,99$ & 0,03 & 0,87 & 0,01 & 0,91 \\
\cline { 2 - 10 } & II & 0,01 & 0,99 & 0,01 & $>0,99$ & $<0,01$ & 0,95 & 0,00 & 0,96 \\
\cline { 2 - 10 } & III & 0,01 & 0,99 & 0,12 & $>0,99$ & 0,03 & 0,87 & 0,02 & 0,89 \\
\cline { 2 - 10 } & IV & 0,03 & 0,85 & 0,25 & $>0,99$ & $<0,01$ & 0,98 & $<0,01$ & 0,99 \\
\cline { 2 - 10 } & V & 0,04 & 0,98 & 0,12 & $>0,99$ & 0,04 & 0,84 & 0,03 & 0,85 \\
\cline { 2 - 10 } & VI & 0,03 & 0,99 & 0,02 & $>0,99$ & 0,03 & 0,99 & 0,02 & 0,88 \\
\hline \multirow{4}{*}{ Litorânea } & I & 0,01 & 0,99 & $<0,01$ & $>0,99$ & 0,83 & 0,66 & 0,01 & 0,93 \\
\cline { 2 - 10 } & II & 0,02 & 0,99 & $<0,01$ & $>0,99$ & 0,25 & 0,88 & 0,01 & 0,91 \\
\cline { 2 - 10 } & III & $<0,01$ & $>0,99$ & 0,09 & 0,96 & 0,67 & 0,72 & 0,06 & 0,80 \\
\hline \multirow{5}{*}{ Ribeira } & I & $<0,01$ & $>0,99$ & 0,14 & $>0,99$ & 0,01 & 0,94 & $<0,01$ & $>0,99$ \\
\cline { 2 - 9 } & II & 0,49 & 0,92 & 2,80 & 0,84 & 0,55 & 0,91 & 0,56 & 0,91 \\
\cline { 2 - 9 } & III & 0,14 & 0,99 & 0,17 & $>0,99$ & 0,13 & 0,99 & 0,10 & 0,99 \\
\cline { 2 - 9 } & IV & 0,47 & 0,79 & 0,62 & $<0,99$ & $<0,01$ & 0,97 & $<0,01$ & 0,96 \\
\cline { 2 - 9 } & V & $<0,01$ & $>0,99$ & 0,19 & $>0,99$ & $<0,01$ & $>0,99$ & $<0,01$ & $>0,99$ \\
\hline
\end{tabular}


Os resultados dos diferentes métodos de correlação estatística para investigar as relações significativas entre a variabilidade pluviométrica e os indicadores climáticos oceânicos mostram que o ONI é o índice que mostra uma maior significância e valores de correlação estatística dentre os avaliados nesta pesquisa em quase todas os grupos homogêneos das BH's em estudo, com exceção dos GH I e GH II da BH Litorânea, nos quais não houve nenhuma correlação significativa com nenhum dos indicadores de temperatura e pressão marítima (Tabela 9).

A bacia hidrográfica do Alto Iguaçu corresponde ao setor no qual houveram as principais correlações estatísticas significativas entre a variabilidade pluviométrica e o ONI, sendo que no GH I houve significância igual ou superior a 99\% para os três métodos utilizados. Por sua vez, para o GH II os métodos de Pearson e Spearman indicaram uma significância igual ou superior a 99\%, enquanto que a correlação de Kendall mostra uma significância de 95\%. Para os grupos homogêneos III, IV, V e VI, verifica-se correlação significativa pelos métodos de Spearman e, destacadamente, de Pearson, o qual obteve significância superior a 95\% em todos os GH's (Tabela 9).

Deste modo, destaca-se a significativa correlação entre variabilidade pluvial e o ONI na BH Alto Iguaçu, destacadamente nos setores GH I e GH II, que se situam no setor centro-sul desta área de estudo e correspondem a 13 postos pluviométricos. Os GH IV e V são os setores que obtiveram as menores correlações e níveis de significância e estão situados nos setores sudeste e nordeste da BHAI, com destaque para o GHV, que com 4 postos pluviométricos demonstram uma menor influência do ONI, possivelmente pela complexa interação entre atmosfera, continentalidade e maritimidade (Tabela 9).

Esta complexidade pode ser uma das principais razões para a baixa correlação e significância entre a variabilidade pluviométrica e os indicadores climáticos obtidos para a bacia hidrográfica Litorânea. Somente o GH III (ID27 - Guaraqueçaba) demonstra uma correlação igual a $95 \%$ conforme o método de Kendall e igual a 99,9\% para os métodos de Pearson e Spearman na associação entre a variabilidade pluvial e o ONI. Observa-se que há uma correlação significativa entre a variação das chuvas e a ODP para o GH III, destacando-se uma significância de 99,9\% conforme a correlação de Pearson e a 99\% pela correlação de Spearman, sendo estes os resultados mais expressivos entre as chuvas e a ODP em toda a área de estudo (Tabela 9).

Com diferentes níveis de correlação e significância, todos os grupos homogêneos da bacia hidrográfica mostram significância estatística entre a variabilidade pluviométrica e o indicador ONI. Os GH I, IV e V mostraram os maiores valores de correlação e as mais 
elevadas significâncias que atestam a relação entre causa e efeito acerca da pluviosidade, sua variabilidade e o ONI, ressaltando-se que estes GH's compreendem 23 dos 25 postos pluviométricos da bacia hidrográfica do rio Ribeira. Embora as correlações empregadas e as significâncias tenham sido menores em comparação à BH Alto Iguaçu, nesta BH a abrangência espacial é maior, dado o elevado número de postos pluviométricos inseridos em tais limiares (Tabela 9).

Destaca-se que o setor de menor correlação entre a variabilidade temporal e o ONI ocorre justamente no GH IV (ID 53 - Doutor Ulysses), no qual se verifica somente uma significância de $90 \%$ para a correlação de Pearson. Contudo, observa-se neste mesmo GH a significância estatística de $95 \%$ para a correlação de Pearson para associar as chuvas, sua variabilidade e a ODP, sendo este o único setor das bacias hidrográficas continentais o qual se tenha verificado correlação estatística entre a causa e efeito citados acima, como indica a tabela 9.

Portanto, as mais elevadas correlações e significâncias entre a variabilidade da precipitação pluviométrica e o ONI foram obtidas nas BHAI, destacando-se os valores elevados no setor centro-sul desta $\mathrm{BH}$, com abrangência de 13 postos pluviométricos e equivalentes a $57,1 \%$ dos postos pluviométricos da BHAI. Contudo, o maior número de postos pluviométricos com correlações significativas se dá na BHR, pois os GH's com o maior número de postos pluviométricos ( $\mathrm{I}$ e V) mostraram correlações com 99,9\% para o método de Pearson, compreendendo a 92\% dos postos pluviométricos utilizados nesta pesquisa para a BHR (Tabela 9). Pujantemente, destaca-se que estes resultados dão maior validade àqueles obtidos pelo modelo VAR, pois tanto esta modelagem quanto às correlações empregadas abaixo mostraram uma maior significância entre à variabilidade pluvial e o indicador ONI.

Com exceção da ODP, os demais indicadores climáticos oceânicos não mostraram significativas e expressivas correlações com a variabilidade pluviométrica, destacandose os baixos valores de correlação obtidos para a IOS, uma vez que resultados anteriores mostraram uma significativa correlação entre este indicador climático e a variabilidade das chuvas (CORREA, 2017). Em relação à ODP, observou-se que este indicador obteve uma resposta significativa somente para dois postos pluviométricos, sendo um na BHL e outro na BHR, sendo que nesta última verifica-se significância somente para a correlação de Pearson (Tabela 9).

Inclusive, a correlação de Pearson mostra os resultados mais elevados entre a variabilidade pluviométrica e os indicadores climáticos oceânicos, sobretudo o ONI, e 
com as mais elevadas significâncias estatísticas. Por sua vez, a correlação de Kendall demonstra com menor expressividade e significância as relações pressupostas por esta pesquisa, conforme indica a tabela 9.

Tabela 9 - Coeficientes de correlação e níveis de significância entre as séries de anomalias de precipitação pluviométrica e as anomalias de temperatura de superfície do mar.

\begin{tabular}{|c|c|c|c|c|c|c|}
\hline \multirow{2}{*}{ Bacia Hidrográfica } & \multirow{2}{*}{ Grupo Homogêneo } & \multirow{2}{*}{ Correlação } & \multicolumn{4}{|c|}{ Indicadores } \\
\hline & & & IOS & ODP & ONI & GMAT \\
\hline \multirow{18}{*}{ Alto Iguaçu } & \multirow{3}{*}{ GH I } & Kendall & $-0,03$ & 0,01 & $0,13^{* *}$ & 0,00 \\
\hline & & Pearson & 0,00 & 0,03 & $0,18^{* * * *}$ & 0,01 \\
\hline & & Spearman & $-0,04$ & 0,02 & $\mathbf{0 , 1 8 * * *}$ & 0,00 \\
\hline & \multirow{3}{*}{ GH II } & Kendall & $-0,02$ & 0,00 & $\mathbf{0 , 0 9}^{*}$ & $-0,01$ \\
\hline & & Pearson & 0,00 & 0,04 & $0,15^{* * *}$ & 0,00 \\
\hline & & Spearman & $-0,02$ & 0,01 & $\mathbf{0 , 1 3}{ }^{* *}$ & $-0,01$ \\
\hline & \multirow{3}{*}{ GH III } & Kendall & $-0,04$ & 0,00 & 0,07 & 0,02 \\
\hline & & Pearson & $-0,06$ & 0,04 & $\mathbf{0 , 1 3}^{* *}$ & 0,03 \\
\hline & & Spearman & $-0,06$ & 0,00 & $\mathbf{0 , 1 0}{ }^{*}$ & 0,03 \\
\hline & \multirow{3}{*}{ GH VI } & Kendall & 0,01 & $-0,01$ & 0,05 & 0,00 \\
\hline & & Pearson & 0,01 & 0,03 & $\mathbf{0 , 1 3}{ }^{* *}$ & $-0,02$ \\
\hline & & Spearman & 0,01 & $-0,01$ & $\mathbf{0 , 0 8}^{+}$ & 0,01 \\
\hline & \multirow{3}{*}{ GH V } & Kendall & 0,02 & $-0,01$ & 0,06 & 0,00 \\
\hline & & Pearson & 0,05 & 0,00 & $0,10^{*}$ & 0,00 \\
\hline & & Spearman & 0,04 & $-0,02$ & $0,09^{*}$ & 0,00 \\
\hline & \multirow{3}{*}{ GH VI } & Kendall & $-0,04$ & 0,02 & 0,08 & 0,01 \\
\hline & & Pearson & $-0,02$ & 0,04 & $\mathbf{0 , 1 3}{ }^{* *}$ & 0,02 \\
\hline & & Spearman & $-0,06$ & 0,03 & $\mathbf{0 , 1 2} 2^{* *}$ & 0,01 \\
\hline \multirow{9}{*}{ Litorânea } & \multirow{3}{*}{ GH I } & Kendall & 0,02 & $-0,02$ & 0,03 & 0,04 \\
\hline & & Pearson & 0,06 & $-0,01$ & 0,05 & 0,03 \\
\hline & & Spearman & 0,03 & $-0,03$ & 0,04 & 0,05 \\
\hline & \multirow{3}{*}{ GH II } & Kendall & 0,01 & $-0,02$ & 0,04 & 0,04 \\
\hline & & Pearson & 0,07 & $-0,02$ & 0,05 & 0,07 \\
\hline & & Spearman & 0,02 & $-0,03$ & 0,06 & 0,06 \\
\hline & \multirow{3}{*}{ GH III } & Kendall & $-0,08$ & $0,10^{*}$ & $0,11 *$ & $-0,02$ \\
\hline & & Pearson & $-0,13$ & $0,16^{* * * *}$ & $0,18^{* * * *}$ & $-0,04$ \\
\hline & & Spearman & $-0,12$ & $0,14^{* * *}$ & $0,16^{* * * *}$ & $-0,03$ \\
\hline \multirow{15}{*}{ Ribeira } & \multirow{3}{*}{ GH I } & Kendall & $-0,04$ & 0,03 & $0,09^{*}$ & 0,00 \\
\hline & & Pearson & $-0,03$ & 0,04 & $0,15^{* * * *}$ & 0,01 \\
\hline & & Spearman & $-0,05$ & 0,04 & $\mathbf{0 , 1 3}{ }^{* *}$ & 0,01 \\
\hline & \multirow{3}{*}{ GH II } & Kendall & $-0,04$ & 0,02 & 0,07 & $-0,01$ \\
\hline & & Pearson & $-0,02$ & 0,05 & $\mathbf{0 , 0 8}^{+}$ & 0,02 \\
\hline & & Spearman & $-0,05$ & 0,04 & $0,11^{*}$ & $-0,01$ \\
\hline & \multirow{3}{*}{ GH III } & Kendall & $-0,02$ & 0,00 & 0,05 & 0,01 \\
\hline & & Pearson & 0,02 & $-0,01$ & $\mathbf{0 , 0 8}^{+}$ & 0,02 \\
\hline & & Spearman & $-0,03$ & $-0,01$ & 0,07 & 0,01 \\
\hline & \multirow{3}{*}{ GH IV } & Kendall & $-0,06$ & 0,04 & $\mathbf{0 , 0 8}^{+}$ & $-0,06$ \\
\hline & & Pearson & $-0,08$ & $0,10^{*}$ & $0,15^{* * * *}$ & $-0,12$ \\
\hline & & Spearman & $-0,09$ & 0,06 & $\mathbf{0 , 1 2} 2^{* *}$ & $-0,09$ \\
\hline & \multirow{3}{*}{ GH V } & Kendall & $-0,04$ & 0,02 & $0,09^{*}$ & 0,00 \\
\hline & & Pearson & $-0,03$ & 0,04 & $0,15^{* * * *}$ & 0,00 \\
\hline & & Spearman & $-0,05$ & 0,04 & $0,13^{* *}$ & 0,00 \\
\hline
\end{tabular}

Legenda: $* * *=99,9 \%$ de significância; $* *=99 \%$ de significância; $*=95 \%$ de significância; $+=$ $90 \%$ de significância. 


\subsection{Tendências, rupturas e indicadores pluviométricos}

\subsubsection{Tendências e rupturas da precipitação pluviométrica anual}

A aplicação do teste Mann-Kendall (TMK) possibilitou averiguar as modificações nas séries temporais de precipitação pluviométrica total anual. Obteve-se na BHAI as menores significâncias estatísticas das alterações indicadas pelo TMK. As localidades de Lapa (ID3) e Mandirituba (ID6) e São Mateus do Sul (ID13), a um nível de 90\% de significância, obtiveram o aumento entre 6,97 e 10,45 mm/ano, equivalente a 278,8 mm e 418 mm. Verifica-se em Campo Largo (ID1), Porto Amazonas (ID10), São Mateus do Sul (ID12) e Piên (ID18), o aumento de 6,97 a 9,83 mm/ano, que mostra um acréscimo total de 278,8 mm e 393,2 mm, conforme indica a tabela 10, com 95\% de significância.

A BHL apresentou o menor número de postos pluviométricos com alterações dos totais anuais de precipitação pluviométrica. Com uma significância de 90\%, mostra-se em Morretes (ID31 e 32) o aumento anual de aproximadamente $9 \mathrm{~mm}$, correspondendo a cerca de $360 \mathrm{~mm}$ ao longo da série histórica. Observa-se em Guaraqueçaba (ID27) a única tendência de diminuição dos totais anuais pluviais, em -25,18 mm/ano, com significância estatística de 95\%, o que indica uma redução superior a $1.000 \mathrm{~mm}$ ao final do segmento temporal avaliado e, sobretudo, revela a maior alteração de chuvas anuais da área em estudo. De modo inverso, com significância de 95\% e 99,9\%, nesta ordem, observa-se em Paranaguá (ID35) e Antonina (ID 22) o acréscimo de 15,04 e 17,50 mm/ano, o que representa um aumento de 601,4 e $700 \mathrm{~mm}$ ao longo de 40 anos. Deste modo, discorrese que, mesmo com o menor número de tendências dentre as BH's estudadas, observouse no litoral paranaense as mais expressivas alterações dos totais anuais de pluviosidade (Tabela 11).

Mostra-se que a BHR é a área em que mais postos pluviométricos indicaram tendências significativas dos totais de precipitação anual para uma significância igual ou superior a 90\%. Deste modo, observa-se a significância estatística de 90\% em Campina Grande do Sul (ID41), Campo Largo (ID46), Cerro Azul (ID50) e Itaperuçu (ID54), com valores da curvatura de Sen entre 6,58 e 9,09, que indicam um aumento entre 263,2 mm e 363,6 mm nos totais pluviais anuais. Com uma significância estatística de 95\%, mostrase o aumento anual entre 6,58 e 11,56 mm na pluviosidade total anual de Adrianópolis (ID37), Campo Largo (ID47), Doutor Ulysses (ID52), Rio Branco do Sul (ID56) e Castro (ID60), aferindo uma elevação total de 263,2 $\mathrm{mm}$ e 462,4 $\mathrm{mm}$. As mais significativas tendências (99\%) foram observadas em Adrianópolis (ID39), Cerro Azul (ID48) e Castro 
(ID59), com acréscimo de 8,70 a 13,58 mm/ano, que ao final da série histórica equivale a $348,0 \mathrm{~mm}$ e 543,2 mm, como está descrito na tabela 12.

Quanto aos resultados decorrentes do teste Pettitt, observa-se apenas uma ruptura com significância estatística de 90\% para a BH, verificada em Mandirituba (ID6) no ano de 1995, sendo que nesta localidade o primeiro período (1976-1995) obteve média de 1.281,1 mm e a média do segundo período (1976-2015) esteve em 1.559,6 mm (Figura 53). Os demais postos pluviométricos e estações meteorológicas da BHAI não obtiveram significância estatística na identificação das rupturas e, contudo, dominam as rupturas não-significativas na década de 1990 e entre 2006 e 2009 (Tabela 10).

A principal ruptura que mostra o acréscimo dos totais anuais de chuvas na BHL foi verificada em Antonina (ID22) no ano de 1992, com 99,9\% de significância estatística, com média de 2.380,8 mm no primeiro período (1976-1992) e de 2.824,4 mm no segundo período (1993-2015). Com uma significância de 99,9\%, a mais pujante ruptura indicativa da diminuição da precipitação pluviométrica total anual na área de estudo é descrita em Guaraqueçaba (ID27), com média de 2.707,7 mm (1976-1998) ao longo do primeiro período e, posterior a ruptura em 1998, um média de 1890,7 mm para o segundo período (1999-2015). Em Paranaguá (ID35) obteve-se uma ruptura no ano de 1985 com 95\% de significância, sendo que entre 1976 e 1985 a média esteve em 1.798,4 mm e entre 1986 e 2015 houve o aumento para 2.317,1 mm (Figura 53). Destaca-se que as demais rupturas não-significativas na BHL ocorreram predominantemente na década de 1990, conforme demonstra a tabela 11.

Com o maior número de rupturas na área de estudo, verifica-se que as principais modificações na BHR ocorreram em Adrianópolis (ID39) e em Doutor Ulysses (ID52), com 99\% de significância estatística. Para a primeira localidade supracitada (ID39), entre os anos de 1976 e 1994 a média pluvial esteve em 1.270,9 mm e, após a ruptura em 1994, houve o aumento para 1.538,7 mm, entre os anos de 1995 e 2015. Obteve-se em Doutor Ulysses (ID52) a modificação em 1992, com média de 1.302,0 mm entre 1976 e 1992 e de 1.569,9 mm entre 1993 e 2015 (Figuras 54 e 55).

Outras rupturas associadas ao aumento da pluviosidade total anual ocorreram na BHR. Em Adrianópolis (ID37), com 90\% de significância, observa-se a ruptura ocorrida em 1999, indicando que de 1976 e 1999 a média pluvial foi de 1.131,8 mm e entre 2000 e 2015 houve o aumento para 1.340,8 mm. Com 95\% de significância, a ruptura em 1992 para Cerro Azul (ID48) mostra que a média da precipitação pluvial que era de 1.213,8 
mm entre 1976 a 1992 e, posteriormente, a média anual aumentou para 1.441,0 mm entre 1993 e 2015 (Figura 54).

A mais significativa (95\%) ruptura indicada pelo teste Pettitt para a redução anual do total de pluviosidade na BHR foi verificada em Doutor Ulysses (ID53), com uma média de 1.927,7 mm entre 1976 e 1998, reduzindo-se a 1.550,6 mm entre 1999 a 2015. Com 90\% de significância, observou-se em Campina Grande do Sul (ID42) a redução das chuvas a partir de 2004, uma vez que no período que antecede esta ruptura (1976-2004) a média pluvial esteve entre 2.067,8 mm e, após este período (2005-2015), este total se reduziu a média de 1.365,9 $\mathrm{mm}$. Sobretudo, observa-se que a principal semelhança entre estes postos pluviométricos se dá pelos elevados totais anuais a partir de 1993 até o ano de ruptura observado para estas localidades (Figuras 54 e 55).

Verifica-se o padrão predominante de ocorrência nas rupturas das séries temporais pluviais anuais na década de 1990, sendo este considerado um período de elevados totais anuais. Em Antonina (ID22), entre os anos de 1993, no início da ruptura, e 1998 a média anual de pluviosidade esteve em 2.946,4 mm, destoando dos 2.380,8 mm do período 1976 e 1992. Em Guaraqueçaba (ID27) indica-se que o período entre 1990 e 1998 caracterizouse pela elevada pluviosidade média anual $(2.680,7 \mathrm{~mm})$, enquanto que entre 1999 , ano de início da ruptura, e 2012 a média anual das chuvas esteve em 1.663,3 mm. Contudo, notase que nos três últimos anos da série histórica em ID27, as chuvas retornaram a valores totais anuais superiores a $2.500 \mathrm{~mm}$, podendo ser um indicativo de uma ruptura recente. Com menor significância em relação às demais (95\%), Paranaguá (ID35) obteve a mais antiga ruptura dentre as séries históricas analisadas, em 1985, pois se verifica após este ano o aumento dos totais pluviais superiores a $2.000 \mathrm{~mm}$. Não obstante, o período entre 1993 e 1998 destaca-se pela pluviosidade média de 2.528,0 mm, próxima a obtida neste mesmo período de tempo em Antonina e Guaraqueçaba (Figura 53).

Demonstrou-se na BHR rupturas dos totais anuais de pluviosidade com $95 \%$ ou 99\% de significância em quatro localidades. Situados nos setores leste e nordeste da BHR, nos quais ocorrem os menores totais anuais de precipitação pluviométrica, os postos pluviométricos de Adrianópolis (ID39) e Cerro Azul (ID48) mostraram rupturas em 1994 e 1992, destacando-se que o período de 1992 e 1998 nestas localidades obteve média de $1.834,3 \mathrm{~mm}$ e $1.545,8 \mathrm{~mm}$, nesta ordem, sendo que a média anual da série histórica é de aproximadamente $1.300 \mathrm{~mm}$ nesta região da BHR, conforme observa-se pela figura 54.

Os postos pluviométricos de Doutor Ulysses caracterizaram-se pela pluviosidade anual acima da média entre 1993 e 1998, sendo de 1.783,3 mm em ID52 e 2.202,2 mm 
em ID53. Contudo, enquanto que em 1993 houve o início de uma ruptura de tendência de aumento das chuvas em ID52, de 1999 em diante o posto pluviométrico ID53 mostra uma ruptura de tendência de diminuição das chuvas, com destaque para um período de chuvas consideravelmente abaixo da média entre 1999 e 2006 (1.438,8 mm), conforme nota-se pela figura 55.

Os resultados predominantes de elevação dos totais anuais de pluviosidade está de acordo com o observado por Jorge (2015) para o leste do Sul do Brasil, com destaque para os acrescimentos superiores a $15 \%$ nas séries históricas neste setor. Este autor também destaca o aumento dos totais pluviais no setor leste desta região para a primavera e o verão, especialmente no litoral de Santa Catarina e do Paraná. Contudo, esta análise não mostrou tendências de diminuição, conforme observou-se em Guaraqueçaba (ID27), em Campina Grande do Sul (ID42) e Doutor Ulysses (ID53) pelo teste Pettitt e apenas na primeira localidade citada pelo TMK.

A aplicação do TMK por Obregón e Marengo (2011) para o território brasileiro indicou as tendências nas séries de precipitação pluviométrica entre o período de 1951 e 2001. Para o Sul do Brasil, verificou-se a predominância de acréscimos com significância de $95 \%$ para a pluviosidade total anual, com ressalvas para o expressivo aumento de 13,3 $\mathrm{mm}$ ao ano em Dona Francisca, situada no centro-sul rio-grandense. Este mesmo estudo apontou que as localidades de União da Vitória e Morretes, no sul e leste do estado do Paraná, obtiveram o aumento significativo e expressivo igual ou superior a $60 \mathrm{~mm}$ e 120 mm por década, que ao longo dos cinquenta anos do segmento temporal avaliado, corresponde a um aumento de 300 e $600 \mathrm{~mm}$, nesta ordem, próximos ao averiguado para a maioria das localidades da presente pesquisa.

Segundo Minuzzi e Caramori (2011), o leste do estado do Paraná corresponde ao setor de mais expressiva elevação dos totais anuais de precipitação e, destacadamente, na primavera. Dentre as localidades inseridas na presente pesquisa, observou-se um aumento anual entre 4,6 mm (Quitandinha) e 9,5 mm (Morretes), que em 62 anos correspondem a um aumento entre 285,2 $\mathrm{mm}$ e $589 \mathrm{~mm}$. Mesmo utilizando-se de um segmento temporal mais abrangente em relação à desta pesquisa, observaram a descontinuidade da série anual de chuvas em 1991 para Morretes, próximo ao demonstrando (1992) tanto para Antonina e Morretes (Tabela 11).

Nascimento Júnior et al. (2013) mostraram que a década de 1990 corresponde ao principal período de ocorrência das rupturas verificadas nas séries pluviais no estado do Paraná, destacando o aumento mais expressivo para a primavera e o verão, abrangendo 
postos pluviométricos com significância estatística na Região Metropolitana de Curitiba (RMC) e o Litoral. Mostrou-se a diminuição do número de dias chuvosos, revelando um quadro em que o aumento da precipitação pluviométrica não está diretamente relacionado a sua frequência, sugerindo a concentração e intensificação das chuvas diárias. Ressaltase que esta tendência de aumento dos totais anuais de chuva e tendências à concentração foram reveladas anteriormente por Mendonça (2006) para a região Sul do Brasil.

Ely e Dubreuil (2017) que as proximidades da RMC e o norte do litoral paranaense são as áreas que apresentam as mais expressivas tendências de aumento dos totais anuais de precipitação pluviométrica. Considerando a série histórica de trinta e sete anos, entre 1977 e 2014, estes autores indicaram um aumento superior a $400 \mathrm{~mm}$, que em Curitiba e Paranaguá chegam a mais de $600 \mathrm{~mm}$ ao final do segmento temporal analisado.

Os resultados apresentados na presente pesquisa são aproximados aos observados por Ely e Dubreuil (2017) devido à semelhança entre o período de análise e, entretanto, as tendências apresentadas a seguir diferem-se em razão da maior densidade de postos pluviométricos selecionados para avaliar as mudanças nas séries temporais para a área em estudo. Como um exemplo, a região central do litoral obteve as maiores tendências positivas ao aumento da precipitação pluviométrica total anual, superiores a $600 \mathrm{~mm}$ em Paranaguá e Antonina, enquanto que a maior redução total (>1.000 mm) está justamente no norte do litoral (ID27), ao contrário do demonstrado por Ely e Dubreuil (2017).

Utilizando-se de séries temporais de 243 estações meteorológicas pertencentes ao INMET, Penereiro e Meschiatti (2018) mostraram que o Sul do Brasil apresentou o maior número de modificações nos totais anuais de precipitação pluviométrica, com um nível de significância entre $90 \%$ e 95\%, pujantemente no centro-leste desta região. Ressalta-se que das seis localidades identificadas com o aumento das chuvas anuais, três delas situamse no leste paranaense (em Castro, Curitiba e Paranaguá), corroborando as indicações de acréscimo da pluviometria observadas em Castro (ID59) e Paranaguá (ID35). Embora o TMK não tenha identificado tendência significativa para o aumento da pluviosidade total anual em Curitiba (Tabela 10), a aplicação dos índices climáticos no software RClimDex identifica o acréscimo anual de 8,22 mm, com 95\% de significância, da chuva total anual (PRCPTOT) na capital paranaense, conforme descreve a tabela 22.

As investigações de Pinheiro (2016) para as tendências nas séries de precipitação pluviométrica na BHAI destacam que apenas o posto pluviométrico de Palmeira (ID62) apresentou resultado significativo (>90\%) para o aumento da pluviosidade anual a partir do TMK, ao contrário das modificações dos totais anuais a partir deste teste para a BHAI 
na presente pesquisa, uma vez que se obteve tendências de aumento de chuvas anuais em sete postos pluviométricos, conforme indica a Tabela 10. Mostrou-se também tendências de acrescimento de pluviosidade em quatro postos pluviométricos durante a primavera, condizentes ao observado por Minuzzi e Caramori (2011).

Verifica-se que para a BHAI as tendências de aumento de pluviosidade total anual predominam nos setores central, oeste e sul, opondo-se a suposição de que as tendências se concentrariam nas proximidades do núcleo urbano de Curitiba. Por sua vez, obteve-se as principais tendências de aumento anual das chuvas nos setores centro e leste da BHL, destacadamente em Antonina, Morretes e Paranaguá, nas quais situam-se as mais antigas e povoadas cidades do leste paranaense, ao passo que um dos postos pluviométricos do município de Guaraqueçaba, ao norte da BHL e de menos de 8 mil habitantes, mostrou a mais expressiva redução da pluviosidade anual. O TMK mostrou tendências de aumento pluvial anual sem um padrão espacial bem definido na BHR, embora destaca-se o maior número de modificações nos setores $\mathrm{E}, \mathrm{NE}$ e W desta região da área de estudo, sobretudo nos municípios de Adrianópolis, Campo Largo, Castro, Cerro Azul e Doutor Ulysses.

Tabela 10 - Testes de tendências (Mann-Kendall) e rupturas (Pettitt) para a precipitação pluviométrica total anual $(\mathrm{mm})$ na BH do Alto Iguaçu - Paraná.

\begin{tabular}{|c|c|c|c|c|c|c|c|c|}
\hline \multirow[b]{2}{*}{ ID } & \multirow{2}{*}{$\begin{array}{l}\text { Postos pluviométricos e } \\
\text { Estações Meteorológicas }\end{array}$} & \multicolumn{4}{|c|}{ Teste Mann - Kendall } & \multicolumn{3}{|c|}{ Teste Pettitt } \\
\hline & & $\mathbf{Z}$ & Tau & p-value & $\mathrm{CS}$ & $\mathbf{K}$ & p-value & Ruptura \\
\hline 1 & Campo Largo & 1,97 & 0,218 & $0,049 *$ & 7,849 & 170 & 0,174 & 1991 \\
\hline 2 & Curitiba & 1,41 & 0,156 & 0,159 & 6,551 & 157 & 0,275 & 1992 \\
\hline 3 & Lapa & 1,81 & 0,200 & $\mathbf{0 , 0 7 1 ^ { + }}$ & 6,969 & 148 & 0,371 & 2007 \\
\hline 4 & Lapa & 1,64 & 0,182 & 0,100 & 6,386 & 141 & 0,453 & 2008 \\
\hline 5 & Lapa & 1,50 & 0,167 & 0,133 & 8,112 & 141 & 0,461 & 2008 \\
\hline 6 & Mandirituba & 1,83 & 0,203 & $\mathbf{0 , 0 6 7} 7^{+}$ & 7,468 & 194 & $\mathbf{0 , 0 7 0 ^ { + }}$ & 1995 \\
\hline 7 & Pinhais & 1,32 & 0,146 & 0,188 & 5,363 & 129 & 0,633 & 2008 \\
\hline 8 & Piraquara & 0,34 & 0,038 & 0,735 & 2,123 & 91 & 0,565 & 1992 \\
\hline 9 & Piraquara & $-0,06$ & $-0,008$ & 0,954 & $-0,333$ & 76 & 0,235 & 1999 \\
\hline 10 & Porto Amazonas & 2,25 & 0,249 & $\mathbf{0 , 0 2 5}{ }^{*}$ & 9,833 & 168 & 0,186 & 1989 \\
\hline 11 & São José do Pinhais & 1,64 & 0,182 & 0,100 & 4,450 & 161 & 0,233 & 1994 \\
\hline 12 & São Mateus do Sul & 2,02 & 0,223 & $0,044^{*}$ & 6,967 & 169 & 0,181 & 2006 \\
\hline 13 & São Mateus do Sul & 1,85 & 0,205 & $\mathbf{0 , 0 6 4}^{+}$ & 10,450 & 168 & 0,187 & 2007 \\
\hline 14 & São Mateus do Sul & 1,48 & 0,164 & 0,139 & 7,387 & 136 & 0,530 & 2007 \\
\hline 15 & São João do Triunfo & 1,06 & 0,118 & 0,289 & 4,946 & 103 & 0,835 & 2008 \\
\hline 16 & Rio Negro & 0,93 & 0,104 & 0,351 & 3,757 & 109 & 0,972 & 2009 \\
\hline 17 & Tijucas do Sul & 0,36 & 0,041 & 0,718 & 1,137 & 111 & 0,986 & 1988 \\
\hline 18 & Piên & 2,20 & 0,244 & $\mathbf{0 , 0 2 8 *}$ & 9,503 & 144 & 0,276 & 1993 \\
\hline 19 & Quitandinha & 0,50 & 0,218 & 0,049 & 1,555 & 99 & 0,759 & 1988 \\
\hline 20 & Quitandinha & 0,97 & 0,156 & 0,159 & 4,397 & 125 & 0,713 & 2006 \\
\hline 62 & Palmeira & 1,60 & 0,177 & 0,110 & 6,802 & 168 & 0,188 & 1989 \\
\hline
\end{tabular}

Legenda: $* * *=99,9 \%$ de significância; $* *=99 \%$ de significância; $*=95 \%$ de significância; $+=90 \%$ de significância. 
Tabela 11 - Testes de tendências (Mann-Kendall) e rupturas (Pettitt) para a precipitação pluviométrica total anual $(\mathrm{mm})$ na BH Litorânea - Paraná.

\begin{tabular}{c|c|c|c|c|c|c|c|c}
\hline & Postos pluviométricos e & \multicolumn{3}{|c|}{ Teste Mann - Kendall } & \multicolumn{3}{c}{ Teste Pettitt } \\
\cline { 3 - 9 } ID & Estações Meteorológicas & $\mathbf{Z}$ & Tau & p-value & CS & K & p-value & Ruptura \\
\hline $\mathbf{2 1}$ & Antonina & $-0,45$ & $-0,051$ & 0,650 & $-3,402$ & 94 & 0,638 & 1999 \\
\hline $\mathbf{2 2}$ & Antonina & 3,55 & 0,392 & $\mathbf{0 , 0 0 0}$ & 17,498 & 277 & $\mathbf{0 , 0 0 1}$ & 1992 \\
\hline $\mathbf{2 3}$ & Antonina & 1,06 & 0,123 & 0,289 & 6,539 & 116 & 0,579 & 1992 \\
\hline $\mathbf{2 4}$ & Guaraqueçaba & 0,01 & 0,003 & 0,991 & 0,132 & 80 & 0,320 & 1983 \\
\hline $\mathbf{2 5}$ & Guaraqueçaba & $-0,06$ & $-0,008$ & 0,954 & $-0,773$ & 74 & 0,217 & 2001 \\
\hline $\mathbf{2 6}$ & Guaraqueçaba & 1,32 & 0,146 & 0,188 & 9,064 & 132 & 0,572 & 2007 \\
\hline $\mathbf{2 7}$ & Guaraqueçaba & $-2,41$ & $-0,267$ & $\mathbf{0 , 0 1 6}$ & $-25,183$ & 285 & $\mathbf{0 , 0 0 1}$ & 1998 \\
\hline $\mathbf{2 8}$ & Guaraqueçaba & 0,17 & 0,021 & 0,861 & 1,077 & 96 & 0,680 & 2007 \\
\hline $\mathbf{2 9}$ & Guaratuba & 0,38 & 0,044 & 0,701 & 3,010 & 132 & 0,575 & 2007 \\
\hline $\mathbf{3 0}$ & Guaratuba & $-0,71$ & $-0,079$ & 0,477 & $-6,734$ & 106 & 0,899 & 1983 \\
\hline $\mathbf{3 1}$ & Morretes & 1,85 & 0,205 & $\mathbf{0 , 0 6 4}$ & 8,825 & 155 & 0,298 & 1992 \\
\hline $\mathbf{3 2}$ & Morretes & 1,83 & 0,203 & $\mathbf{0 , 0 6 7 ^ { + }}$ & 9,008 & 177 & 0,128 & 1992 \\
\hline $\mathbf{3 3}$ & Morretes & $-0,03$ & $-0,005$ & 0,972 & $-0,794$ & 88 & 0,476 & 1999 \\
\hline $\mathbf{3 4}$ & Paranaguá & 1,32 & 0,146 & 0,188 & 7,318 & 118 & 0,820 & 1993 \\
\hline $\mathbf{3 5}$ & Paranaguá & 2,16 & 0,238 & $\mathbf{0 , 0 3 1 *}$ & 15,043 & 204 & $\mathbf{0 , 0 4 9} *$ & 1985 \\
\hline $\mathbf{3 6}$ & São José dos Pinhais & 0,20 & 0,0231 & 0,8430 & 0,807 & 79 & 0,380 & 1988 \\
\hline
\end{tabular}

Legenda: $* * *=99,9 \%$ de significância; $* *=99 \%$ de significância; $*=95 \%$ de significância; $+=90 \%$ de significância.

Tabela 12 - Testes de tendências (Mann-Kendall) e rupturas (Pettitt) para a precipitação pluviométrica total anual $(\mathrm{mm})$ na BH do rio Ribeira - Paraná.

\begin{tabular}{|c|c|c|c|c|c|c|c|c|}
\hline \multirow[b]{2}{*}{ ID } & \multirow{2}{*}{$\begin{array}{l}\text { Postos pluviométricos e } \\
\text { Estações Meteorológicas }\end{array}$} & \multicolumn{4}{|c|}{ Teste Mann - Kendall } & \multicolumn{3}{|c|}{ Teste Pettitt } \\
\hline & & $\mathbf{Z}$ & Tau & p-value & CS & $\mathbf{K}$ & p-value & Ruptura \\
\hline 37 & Adrianópolis & 2,06 & 0,228 & $0,039^{*}$ & 7,394 & 198 & $0,060^{+}$ & 1999 \\
\hline 38 & Adrianópolis & 0,43 & 0,049 & 0,666 & 1,004 & 119 & 0,809 & 1994 \\
\hline 39 & Adrianópolis & 2,83 & 0,313 & $0,005^{* *}$ & 9,991 & 235 & $0,007^{* *}$ & 1994 \\
\hline 40 & Bocaiúva do Sul & 1,34 & 0,149 & 0,180 & 5,572 & 165 & 0,224 & 1988 \\
\hline 41 & Campina Grande do Sul & 1,81 & 0,200 & $\mathbf{0 , 0 7 1 ^ { + }}$ & 8,655 & 174 & 0,155 & 2003 \\
\hline 42 & Campina Grande do Sul & $-0,01$ & $-0,003$ & 0,991 & $-0,103$ & 191 & $\mathbf{0 , 0 7 8}^{+}$ & 2004 \\
\hline 43 & Campina Grande do Sul & 0,03 & 0,005 & 0,972 & 0,122 & 82 & 0,361 & 2001 \\
\hline 44 & Campo Largo & $-0,34$ & $-0,038$ & 0,735 & $-1,166$ & 139 & 0,476 & 2002 \\
\hline 45 & Campo Largo & 0,73 & 0,082 & 0,463 & 3,334 & 109 & 0,977 & 2008 \\
\hline 46 & Campo Largo & 1,92 & 0,213 & $\mathbf{0 , 0 5 5 ^ { + }}$ & 9,090 & 179 & 0,159 & 1992 \\
\hline 47 & Campo Largo & 2,27 & 0,251 & $\mathbf{0 , 0 2 3}^{*}$ & 11,565 & 174 & 0,125 & 1981 \\
\hline 48 & Cerro Azul & 2,62 & 0,290 & $0,009^{* *}$ & 8,714 & 213 & $0,032 *$ & 1992 \\
\hline 49 & Cerro Azul & 1,43 & 0,159 & 0,152 & 3,731 & 131 & 0,596 & 1992 \\
\hline 50 & Cerro Azul & 1,95 & 0,215 & $\mathbf{0 , 0 5 2}^{+}$ & 6,638 & 171 & 0,166 & 1994 \\
\hline 51 & Cerro Azul & 0,45 & 0,051 & 0,650 & 1,699 & 75 & 0,223 & 2006 \\
\hline 52 & Doutor Ulysses & 2,37 & 0,262 & $\mathbf{0 , 0 1 8}^{*}$ & 8,862 & 231 & $0,010^{* * *}$ & 1992 \\
\hline 53 & Doutor Ulysses & $-1,48$ & $-0,164$ & 0,139 & $-5,629$ & 221 & $\mathbf{0 , 0 2 5}^{*}$ & 1998 \\
\hline 54 & Itaperuçu & 1,70 & 0,189 & $\mathbf{0 , 0 8 9}^{+}$ & 6,577 & 157 & 0,279 & 1992 \\
\hline 55 & Ponta Grossa & $-0,29$ & $-0,033$ & 0,771 & $-0,079$ & 116 & 0,876 & 2009 \\
\hline 56 & Rio Branco do Sul & 2,02 & 0,223 & $0,044^{*}$ & 6,781 & 147 & 0,387 & 1988 \\
\hline 57 & Rio Branco do Sul & 1,36 & 0,151 & 0,173 & 5,188 & 159 & 0,249 & 1992 \\
\hline 58 & Tunas do Paraná & 0,85 & 0,095 & 0,395 & 3,025 & 121 & 0,785 & 1992 \\
\hline 59 & Castro & 2,78 & 0,308 & $0,005^{* *}$ & 13,580 & 192 & 0,190 & 2008 \\
\hline 60 & Castro & 2,16 & 0,238 & $\mathbf{0 , 0 3 1}{ }^{*}$ & 6,583 & 171 & 0,172 & 1990 \\
\hline 61 & Ponta Grossa & 0,62 & 0,069 & 0,537 & 2,626 & 117 & 0,864 & 1988 \\
\hline
\end{tabular}

Legenda: $* * *=99,9 \%$ de significância; $* *=99 \%$ de significância; $*=95 \%$ de significância; $+=90 \%$ de significância. 

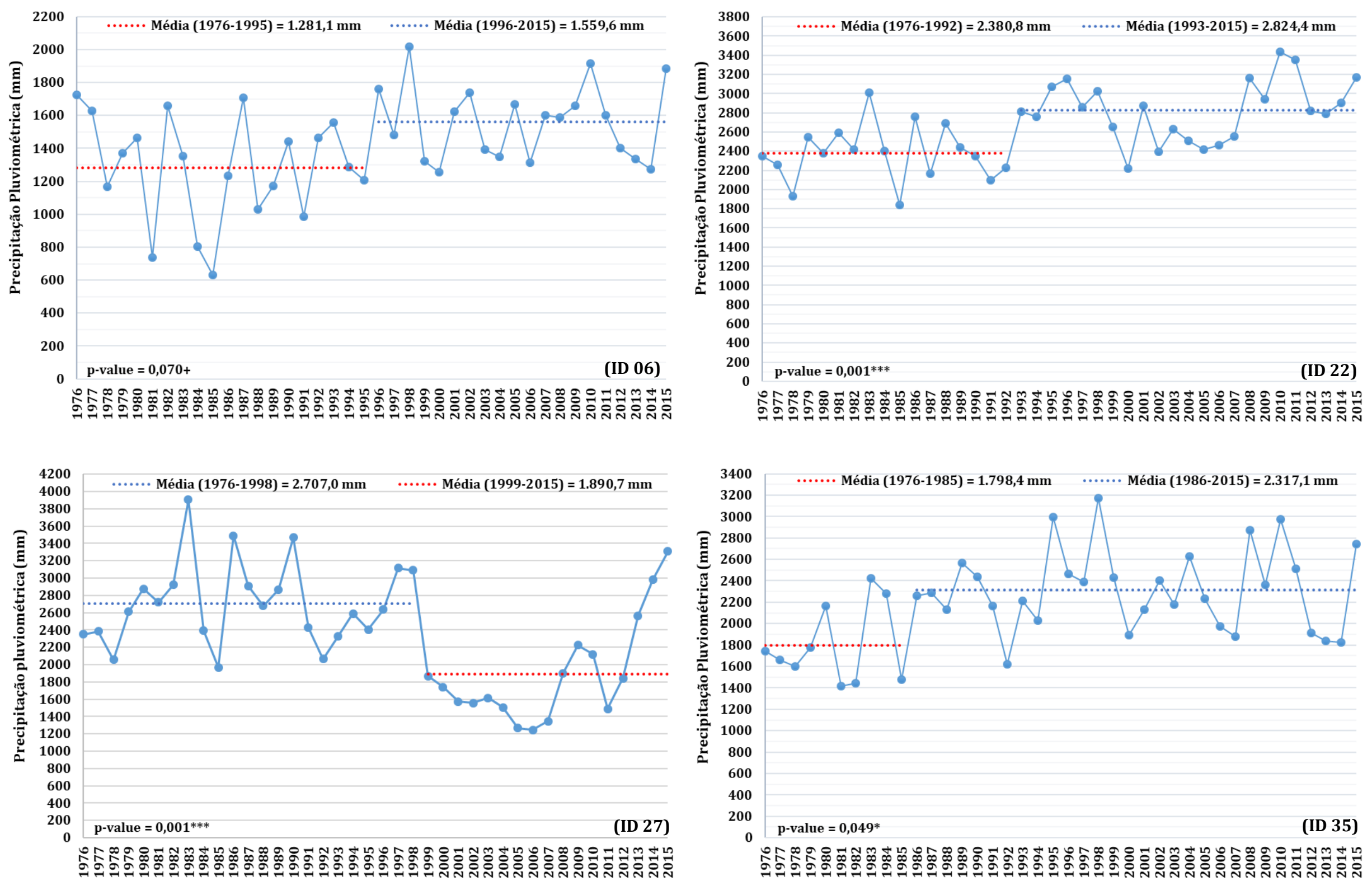

Figura 51 - Variabilidade pluviométrica anual (mm) e rupturas identificadas nas séries históricas de Mandirituba (ID 06), Antonina (ID 22), Guaraqueçaba (ID 27) e Paranaguá (ID 35) - Paraná. 

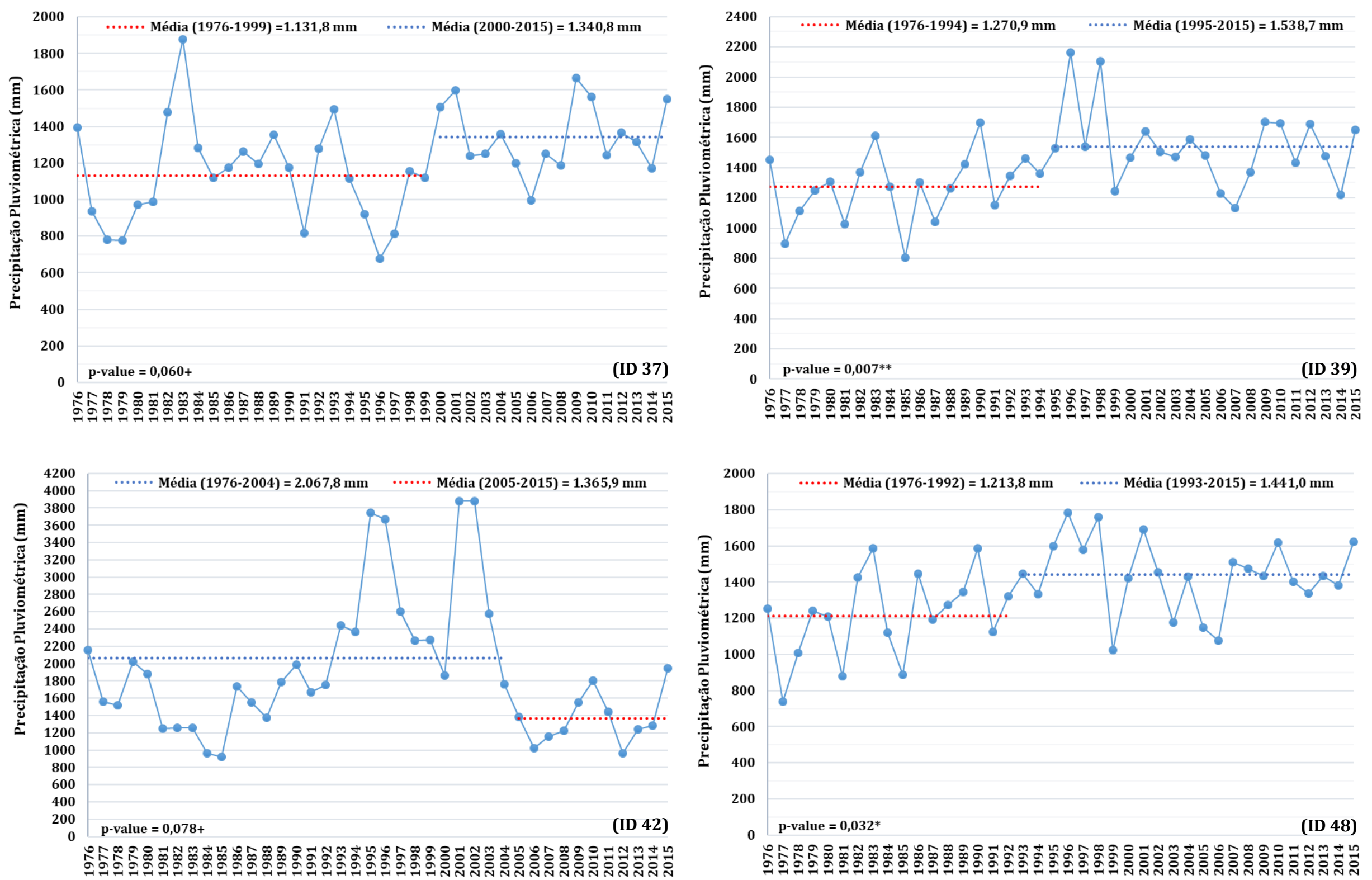

Figura 52 - Variabilidade pluviométrica anual (mm) e rupturas identificadas nas séries históricas de Adrianópolis (ID 37 e 39), Campina Grande do Sul (ID 42) e Cerro Azul (ID 48) - Paraná. 

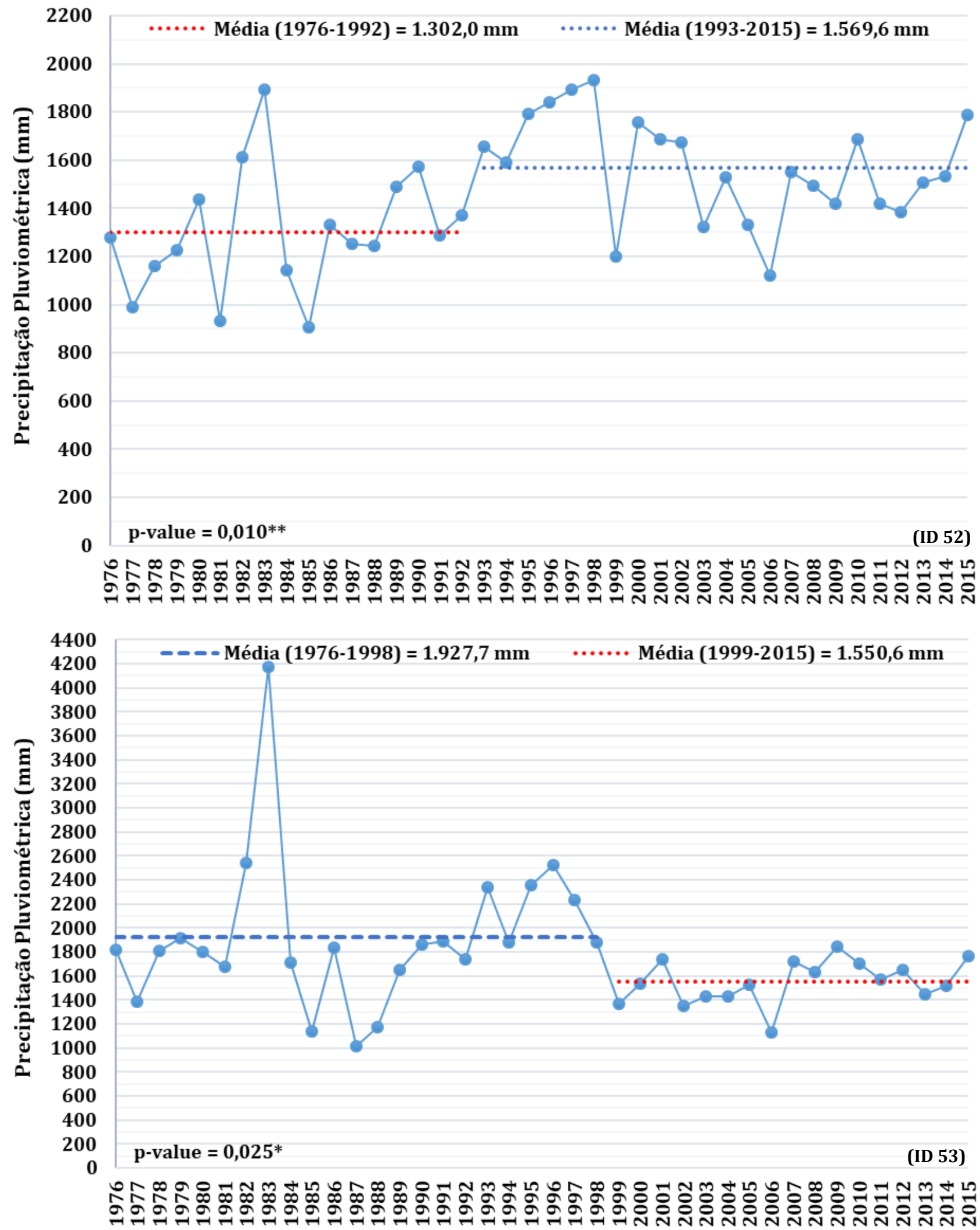

Figura 53 - Variabilidade pluviométrica anual $(\mathrm{mm})$ e rupturas identificadas nas séries históricas de Doutor Ulysses (ID 52 e ID 53) - Paraná. 


\subsubsection{Tendências e rupturas da precipitação pluviométrica máxima anual}

A aplicação do teste Mann-Kendall para os totais pluviométricos máximos diários demonstra o aumento deste indicativo climático em alguns setores da BH Alto Iguaçu. Com uma significância de 95\%, verificou-se para os postos pluviométricos ID02 e ID12 o aumento igual ou superior a $0,82 \mathrm{~mm} / \mathrm{ano}$ da chuva máxima diária, que ao final da série histórica corresponde a um aumento de $33 \mathrm{~mm}$. Com uma menor significância (90\%), os postos pluviométricos ID03 e ID09 mostraram um aumento anual superior a 0,53 mm, o que significa que ao final do segmento temporal a chuva máxima diária anual aumentou em no mínimo 21,2 mm. Os demais postos pluviométricos não apresentaram significância estatística e apresentam em sua maioria generalizada o aumento da chuva máxima diária anual (Tabela 13).

A BH Litorânea obteve os mais significativos resultados de redução dos totais de chuva diária máxima dentre as BH’s analisadas. Observa-se a diminuição desta categoria pluvial é mais intensa em Guaraqueçaba (ID27), em cerca de 0,94 mm/ano, enquanto que em Morretes (ID33) verificou-se uma diminuição de $0,76 \mathrm{~mm} / \mathrm{ano}$, sendo que em ambas houve $95 \%$ de significância estatística. Verifica-se a diminuição dos totais diários anuais máximos em Antonina (ID21) em 0,53 mm/ano e, contudo, com uma menor significância estatística (90\%). Por sua vez, no posto pluviométrico ID22 (Antonina) mostra-se a única tendência de aumento da precipitação pluviométrica máxima diária em 1,06 mm/ano, com 95\% de significância. Deste modo, considerando os quarenta anos da série histórica, nota-se uma diminuição de 37,6 mm das chuvas diárias em Guaraqueçaba (ID27), enquanto que em Antonina (ID22) há uma tendência de aumento de 42,4 mm (Tabela 14).

A BH Ribeira caracteriza-se pela mais extensiva tendência de aumento das chuvas máximas diárias anuais. Verifica-se a única tendência com 99\% de significância em Cerro Azul (ID48), com um aumento é de 0,57 mm/ano ou de 22,6 $\mathrm{mm}$ em quarenta anos, sendo que em Castro (ID60) e em Campo Largo (ID45), com uma significância de 95\%, obteve-se um aumento anual de $0,65 \mathrm{~mm}$ e $0,75 \mathrm{~mm}$, o que representa ao final da série temporal analisada um aumento de $26 \mathrm{~mm}$ e $30 \mathrm{~mm}$, nesta ordem. Considerando o limiar de $90 \%$ de significância estatística, os postos pluviométricos ID40, ID46, ID49 e ID52 mostram um aumento anual de $0,48 \mathrm{~mm}$ a $0,72 \mathrm{~mm}$, o que representa um aumento entre $19,2 \mathrm{~mm}$ e $28,8 \mathrm{~mm}$ em quarenta anos. Embora sem significância estatística, observa-se o aumento da precipitação pluviométrica máxima diária nos demais postos pluviométricos da BH Ribeira (Tabela 15). 
A principal ruptura observada na BH Alto Iguaçu deu-se em Curitiba (ID02), com 95\% de significância estatística, no ano de 1994. Entre os anos de 1976 e 1994 a média da chuva máxima diária na capital paranaense era de $68,3 \mathrm{~mm}$ e, posteriormente, houve o aumento para 91,9 mm, uma adição de aproximadamente 35\%. Com uma significância de $90 \%$ e 95\%, nesta ordem, identificaram-se rupturas em São Mateus do Sul (ID12), no ano de 1991, e em Palmeira (ID62), em 1988. Durante o segmento temporal desde o início da série histórica e até a ruptura identificada, observa-se no posto pluviométrico ID62 uma média de 68,6 mm e, após este período (1989-2015), a média da chuva máxima diária subiu para 87,2 mm. Em São Mateus do Sul (ID12), entre 1976 e 1991 a média da chuva diária máxima anual era de 73,2 mm e, em seguida, aumentou para 99,7 mm (Tabela 13 - Figura 57).

As duas únicas rupturas identificadas pelo teste Pettitt na BH Litorânea deram-se em Guaraqueçaba (ID27) e Morretes (ID33), com 90\% de significância estatística. Para Guaraqueçaba observa-se que no período anterior ao ano de 1989, a média da precipitação pluviométrica máxima diária anual era de $110,6 \mathrm{~mm}$ e, posteriormente a ruptura, a média destas alturas pluviais decaíram para 93,7 mm, em aproximadamente 15\%. Em Morretes, entre 1976 e 1996 a média da mais intensa chuva diária anual era de 130,1 mm e, a partir de 1997, esta média diminuiu para 100,4 mm, representando uma queda de 22,8\% do total pluviométrico máximo diário. Tratam-se, portanto, das únicas rupturas que mostraram a redução das chuvas diárias anuais mais elevadas (Tabela 14 - Figuras 57 e 58 ).

Verificou-se em Castro (ID60) a mais significativa ruptura (99\%) para o aumento da precipitação pluviométrica máxima diária da BH Ribeira, sendo que entre 1976 e 1996 a média esteve entre $66,5 \mathrm{~mm}$ e, a partir de 1997 , aumentou para $85,9 \mathrm{~mm}$ e em cerca de $30 \%$. Com uma significância de 90\%, os postos pluviométricos de Campina Grande do Sul (ID42) e Doutor Ulysses (ID52) obtiveram rupturas no final da década de 1980, com médias de 73,6 mm e 69,1 $\mathrm{mm}$ e, no período posterior ao ano das rupturas, estas médias da chuva máxima diária anual aumentou para 100,3 mm e 88,3 mm, sendo que o aumento após a ruptura na da década de 1980 em Campina Grande do Sul indicam um aumento de 35,9\% nos totais máximos diários anuais nesta localidade. Dentre as séries históricas analisadas, identificou-se a mais recente ruptura em Cerro Azul (ID48), considerando uma significância estatística de 90\%, no ano de 1999, pois o período que antecedeu esta ruptura apresenta média de $66,0 \mathrm{~mm}$ da chuva máxima diária anual e, posteriormente a este ano, as chuvas máximas diárias intensificaram-se a uma média de 88,3 mm (Tabela 15 - Figuras 56 e 58). 
Portanto, observa-se que o aumento da precipitação pluviométrica máxima diária se deu de forma mais frequente e consistente na BH Ribeira, enquanto que na BH Litorânea nota-se a diminuição desta variável climática, tanto pelo teste Mann-Kendall quanto pelo teste Pettitt. De modo geral, o principal período de ocorrência das rupturas ocorreu entre 1987 e 1999, período similar ao identificado pelo teste Pettitt para o total pluviométrico anual, sendo que rupturas que se deram entre 1988 e 1996 estiveram dentre as mais significativas.

Como um exemplo, o posto pluviométrico de Castro (ID60) mostra a maior frequência de chuvas máximas anuais inferiores a 70 mm entre 1976 e 1996, enquanto que a partir de 1998 todos os registros máximos anuais são superiores a este limiar, com exceção do ano de 2010 (Figura 56). Em Curitiba (ID02), as chuvas máximas diárias ficaram mais frequentes a partir da segunda metade da década de 1990, sendo mais constantes os valores superiores a $90 \mathrm{~mm}$ entre 1997 e 1999 e entre 2010 e 2014, períodos de expressivo aumento da chuva diária. Antes da ruptura no ano de 1994, as chuvas superiores a $90 \mathrm{~mm}$ em Curitiba ocorreram somente nos anos de 1982, 1983 e 1993, sendo que os dois primeiros anos estiveram associado às condições de forte El Niño, conforme discorre Zanella (2007) e está disposto na figura 57. Portanto, nestas duas localidades, a década de 1990 foi o principal período em que ocorreu o aumento das chuvas diárias máximas.

O gráfico da figura 58 representa a diminuição das chuvas máximas diárias anuais em Morretes (ID33) e observa-se que entre 1976 e 1996 os totais pluviais ultrapassaram os $120 \mathrm{~mm}$ constantemente, enquanto que após o ano de 1997 os acumulados diários superaram tais valores somente em 2004 e 2010. Em Guaraqueçaba (ID27), o período entre 1977 e 1989 obteve totais diários máximos anuais superiores a $100 \mathrm{~mm}$ em onze anos deste segmento temporal (de um total de 13), enquanto que entre 1990 e 2015, as chuvas diárias superaram este limiar somente cinco vezes em vinte e cinco anos (Figura 57). Deste modo, os resultados do teste Pettitt para os dois postos pluviométricos supracitados indicaram a diminuição das chuvas diárias máximas como um padrão predominante para as séries históricas analisadas nestas localidades no final dos anos de 1980 e na segunda metade da década de 1990.

Estas rupturas nestes períodos estão em acordo com os apresentados anteriormente por Nascimento Júnior et al. (2013) e, no entanto, nenhum trabalho anterior na literatura avaliou a ocorrência de rupturas de chuvas máximas em região próxima à área de estudo. Em relação ao teste MK, Silva et al. (2015) não obtiveram tendências significativas para o RX1day, indicador de tendência das chuvas máximas diárias anuais, para todo o estado do Paraná. 
Tabela 13 - Testes de tendências (Mann-Kendall) e rupturas (Pettitt) para a precipitação pluviométrica diária máxima anual $(\mathrm{mm})$ na BH do Alto Iguaçu - Paraná.

\begin{tabular}{|c|c|c|c|c|c|c|c|c|}
\hline \multirow[b]{2}{*}{ ID } & \multirow{2}{*}{$\begin{array}{l}\text { Postos pluviométricos e } \\
\text { Estações Meteorológicas }\end{array}$} & \multicolumn{4}{|c|}{ Teste Mann - Kendall } & \multicolumn{3}{|c|}{ Teste Pettitt } \\
\hline & & $\mathbf{Z}$ & Tal & p-value & CS & $\mathbf{K}$ & p-value & Ruptura \\
\hline 1 & Campo Largo & 1,18 & 0,131 & 0,239 & 0,402 & 149 & 0,353 & 2005 \\
\hline 2 & Curitiba & 2,34 & 0,259 & 0,019* & 0,840 & 209 & $0,036 *$ & 1994 \\
\hline 3 & Lapa & 1,89 & 0,209 & $\mathbf{0 , 0 5 9} 9^{+}$ & 0,557 & 147 & 0,394 & 1990 \\
\hline 4 & Lapa & 1,50 & 0,167 & 0,133 & 0,375 & 155 & 0,301 & 2006 \\
\hline 5 & Lapa & $-0,78$ & $-0,087$ & 0,435 & $-0,161$ & 122 & 0,752 & 1993 \\
\hline 6 & Mandirituba & 1,42 & 0,158 & 0,155 & 0,455 & 168 & 0,189 & 1985 \\
\hline 7 & Pinhais & 1,53 & 0,169 & 0,127 & 0,320 & 132 & 0,591 & 1985 \\
\hline 8 & Piraquara & $-0,79$ & $-0,089$ & 0,428 & $-0,407$ & 164 & 0,217 & 1998 \\
\hline 9 & Piraquara & 1,81 & 0,200 & $\mathbf{0 , 0 7 1 ^ { + }}$ & 0,531 & 165 & 0,207 & 1992 \\
\hline 10 & Porto Amazonas & $-0,06$ & $-0,008$ & 0,954 & $-0,012$ & 86 & 0,456 & 2009 \\
\hline 11 & São José do Pinhais & 1,41 & 0,157 & 0,159 & 0,397 & 144 & 0,417 & 2001 \\
\hline 12 & São Mateus do Sul & 2,16 & 0,257 & $\mathbf{0 , 0 3 1} *$ & 0,818 & 150 & $\mathbf{0 , 0 9 9}^{+}$ & 1991 \\
\hline 13 & São Mateus do Sul & 0,06 & 0,008 & 0,954 & 0,012 & 84 & 0,400 & 2003 \\
\hline 14 & São Mateus do Sul & 0,75 & 0,083 & 0,456 & 0,194 & 90 & 0,548 & 1987 \\
\hline 15 & São João do Triunfo & $-0,07$ & $-0,009$ & 0,944 & $-0,037$ & 82 & 0,374 & 2002 \\
\hline 16 & Rio Negro & 0,84 & 0,094 & 0,401 & 0,223 & 107 & 0,940 & 2007 \\
\hline 17 & Tijucas do Sul & $-0,79$ & $-0,089$ & 0,428 & $-0,181$ & 113 & 0,927 & 2001 \\
\hline 18 & Piên & 1,26 & 0,046 & 0,697 & 0,128 & 85 & 0,576 & 1990 \\
\hline 19 & Quitandinha & 1,34 & 0,149 & 0,180 & 0,334 & 141 & 0,444 & 1988 \\
\hline 20 & Quitandinha & 0,55 & 0,062 & 0,584 & 0,162 & 107 & 0,941 & 2006 \\
\hline 62 & Palmeira & 1,29 & 0,144 & 0,196 & 0,323 & 212 & $\mathbf{0 , 0 3 6} *$ & 1988 \\
\hline
\end{tabular}

Legenda: $* * *=99,9 \%$ de significância; $* *=99 \%$ de significância; $*=95 \%$ de significância $;+=90 \%$ de significância.

Tabela 14 - Testes de tendência (Mann-Kendall) e rupturas (Pettitt) para a precipitação pluviométrica diária máxima anual $(\mathrm{mm})$ na BH Litorânea - Paraná.

\begin{tabular}{c|c|c|c|c|c|c|c|c}
\hline & Postos pluviométricos e & \multicolumn{3}{|c}{ Teste Mann - Kendall } & \multicolumn{3}{|c}{ Teste Pettitt } \\
\cline { 3 - 9 } ID & Estaçóes Meteorológicas & $\mathbf{Z}$ & Tal & p-value & CS & K & PVA & Ruptura \\
\hline $\mathbf{2 1}$ & Antonina & $-1,74$ & $-0,192$ & $\mathbf{0 , 0 8 3}^{+}$ & $-0,526$ & 147 & 0,381 & 1986 \\
\hline $\mathbf{2 2}$ & Antonina & 2,18 & 0,242 & $\mathbf{0 , 0 2 9}^{*}$ & 1,056 & 173 & 0,159 & 1993 \\
\hline $\mathbf{2 3}$ & Antonina & 0,88 & 0,102 & 0,381 & 0,376 & 126 & 0,436 & 1987 \\
\hline $\mathbf{2 4}$ & Guaraqueçaba & 0,55 & 0,034 & 0,772 & 0,217 & 112 & 0,766 & 1987 \\
\hline $\mathbf{2 5}$ & Guaraqueçaba & 1,44 & 0,160 & 0,149 & 1,010 & 160 & 0,253 & 2005 \\
\hline $\mathbf{2 6}$ & Guaraqueçaba & 1,29 & 0,151 & 0,179 & 0,735 & 110 & 0,918 & 1988 \\
\hline $\mathbf{2 7}$ & Guaraqueçaba & $-1,96$ & $-0,217$ & $\mathbf{0 , 0 5 0}$ & $-0,940$ & 186 & $\mathbf{0 , 0 9 2}$ & 1989 \\
\hline $\mathbf{2 8}$ & Guaraqueçaba & $-0,48$ & $-0,054$ & 0,633 & $-0,295$ & 142 & 0,440 & 1983 \\
\hline $\mathbf{2 9}$ & Guaratuba & 0,00 & 0,001 & 1,000 & 0,000 & 99 & 0,744 & 1982 \\
\hline $\mathbf{3 0}$ & Guaratuba & $-1,07$ & $-0,119$ & 0,284 & $-0,729$ & 125 & 0,700 & 1983 \\
\hline $\mathbf{3 1}$ & Morretes & 1,46 & 0,162 & 0,145 & 0,462 & 148 & 0,372 & 2009 \\
\hline $\mathbf{3 2}$ & Morretes & 1,36 & 0,151 & 0,173 & 0,500 & 143 & 0,428 & 1988 \\
\hline $\mathbf{3 3}$ & Morretes & $-2,06$ & $-0,228$ & $\mathbf{0 , 0 3 9}$ & $-0,759$ & 187 & $\mathbf{0 , 0 9 6}$ & 1996 \\
\hline $\mathbf{3 4}$ & Paranaguá & 1,08 & 0,121 & 0,279 & 0,584 & 149 & 0,358 & 2000 \\
\hline $\mathbf{3 5}$ & Paranaguá & 0,00 & $-0,001$ & 1,000 & $-0,011$ & 102 & 0,805 & 2005 \\
\hline $\mathbf{3 6}$ & São José dos Pinhais & 0,24 & 0,028 & 0,807 & 0,071 & 68 & 0,123 & 2002 \\
\hline
\end{tabular}

Legenda: $* * *=99,9 \%$ de significância; $* *=99 \%$ de significância; $*=95 \%$ de significância; $+=90 \%$ de significância. 
Tabela 15 - Testes de tendências (Mann-Kendall) e rupturas (Pettitt) para a precipitação pluviométrica diária máxima anual $(\mathrm{mm})$ na $\mathrm{BH}$ do rio Ribeira - Paraná.

\begin{tabular}{|c|c|c|c|c|c|c|c|c|}
\hline \multirow[b]{2}{*}{ ID } & \multirow{2}{*}{$\begin{array}{l}\text { Postos pluviométricos e } \\
\text { Estações Meteorológicas }\end{array}$} & \multicolumn{4}{|c|}{ Teste Mann - Kendall } & \multicolumn{3}{|c|}{ Teste Pettitt } \\
\hline & & $\mathbf{Z}$ & Tal & p-value & $\mathrm{CS}$ & $\mathbf{K}$ & p-value & Ruptura \\
\hline 37 & Adrianópolis & 1,58 & 0,176 & 0,113 & 0,406 & 161 & 0,236 & 1990 \\
\hline 38 & Adrianópolis & 0,73 & 0,082 & 0,463 & 0,221 & 153 & 0,321 & 1994 \\
\hline 39 & Adrianópolis & 0,55 & 0,062 & 0,584 & 0,085 & 166 & 0,203 & 2009 \\
\hline 40 & Bocaiúva do Sul & 1,90 & 0,210 & $\mathbf{0 , 0 5 8}{ }^{+}$ & 0,717 & 164 & 0,216 & 1985 \\
\hline 41 & Campina Grande do Sul & 1,61 & 0,181 & 0,108 & 0,511 & 164 & 0,178 & 1997 \\
\hline 42 & Campina Grande do Sul & 1,06 & 0,120 & 0,287 & 0,356 & 184 & $\mathbf{0 , 0 7 5}^{+}$ & 1987 \\
\hline 43 & Campina Grande do Sul & 0,20 & 0,023 & 0,843 & 0,070 & 111 & 0,981 & 1981 \\
\hline 44 & Campo Largo & 1,57 & 0,175 & 0,116 & 0,480 & 126 & 0,679 & 1979 \\
\hline 45 & Campo Largo & 2,25 & 0,249 & $0,025^{*}$ & 0,752 & 177 & 0,135 & 2006 \\
\hline 46 & Campo Largo & 1,84 & 0,204 & $\mathbf{0 , 0 6 6}^{+}$ & 0,657 & 142 & 0,444 & 2009 \\
\hline 47 & Campo Largo & 0,80 & 0,090 & 0,421 & 0,346 & 140 & 0,476 & 1979 \\
\hline 48 & Cerro Azul & 2,73 & 0,302 & $0,006^{* *}$ & 0,565 & 198 & $0,057^{+}$ & 1999 \\
\hline 49 & Cerro Azul & 1,95 & 0,215 & $0,052^{+}$ & 0,484 & 158 & 0,258 & 1991 \\
\hline 50 & Cerro Azul & 1,39 & 0,154 & 0,166 & 0,431 & 140 & 0,470 & 2009 \\
\hline 51 & Cerro Azul & 1,60 & 0,177 & 0,110 & 0,429 & 125 & 0,705 & 1980 \\
\hline 52 & Doutor Ulysses & 1,76 & 0,195 & $\mathbf{0 , 0 7 8}^{+}$ & 0,550 & 194 & $0,068^{+}$ & 1988 \\
\hline 53 & Doutor Ulysses & 0,98 & 0,109 & 0,328 & 0,229 & 126 & 0,669 & 1987 \\
\hline 54 & Itaperuçu & 1,26 & 0,140 & 0,208 & 0,378 & 117 & 0,868 & 1994 \\
\hline 55 & Ponta Grossa & $-0,29$ & $-0,033$ & 0,771 & $-0,079$ & 116 & 0,876 & 2009 \\
\hline 56 & Rio Branco do Sul & $-0,50$ & $-0,061$ & 0,619 & $-0,200$ & 123 & 0,326 & 1997 \\
\hline 57 & Rio Branco do Sul & 1,50 & 0,167 & 0,133 & 0,358 & 169 & 0,173 & 2001 \\
\hline 58 & Tunas do Paraná & 0,51 & 0,058 & 0,608 & 0,202 & 120 & 0,789 & 1989 \\
\hline 59 & Castro & 1,54 & 0,127 & 0,261 & 0,392 & 100 & 0,868 & 1996 \\
\hline 60 & Castro & 2,54 & 0,282 & $\mathbf{0 , 0 1 1 ^ { * }}$ & 0,652 & 255 & $\mathbf{0 , 0 0 3}{ }^{* *}$ & 1996 \\
\hline 61 & Ponta Grossa & 0,80 & 0,090 & 0,421 & 0,133 & 98 & 0,718 & 1988 \\
\hline
\end{tabular}

Legenda: $* * *=99,9 \%$ de significância; $* *=99 \%$ de significância; $*=95 \%$ de significância; $+=90 \%$ de significância.

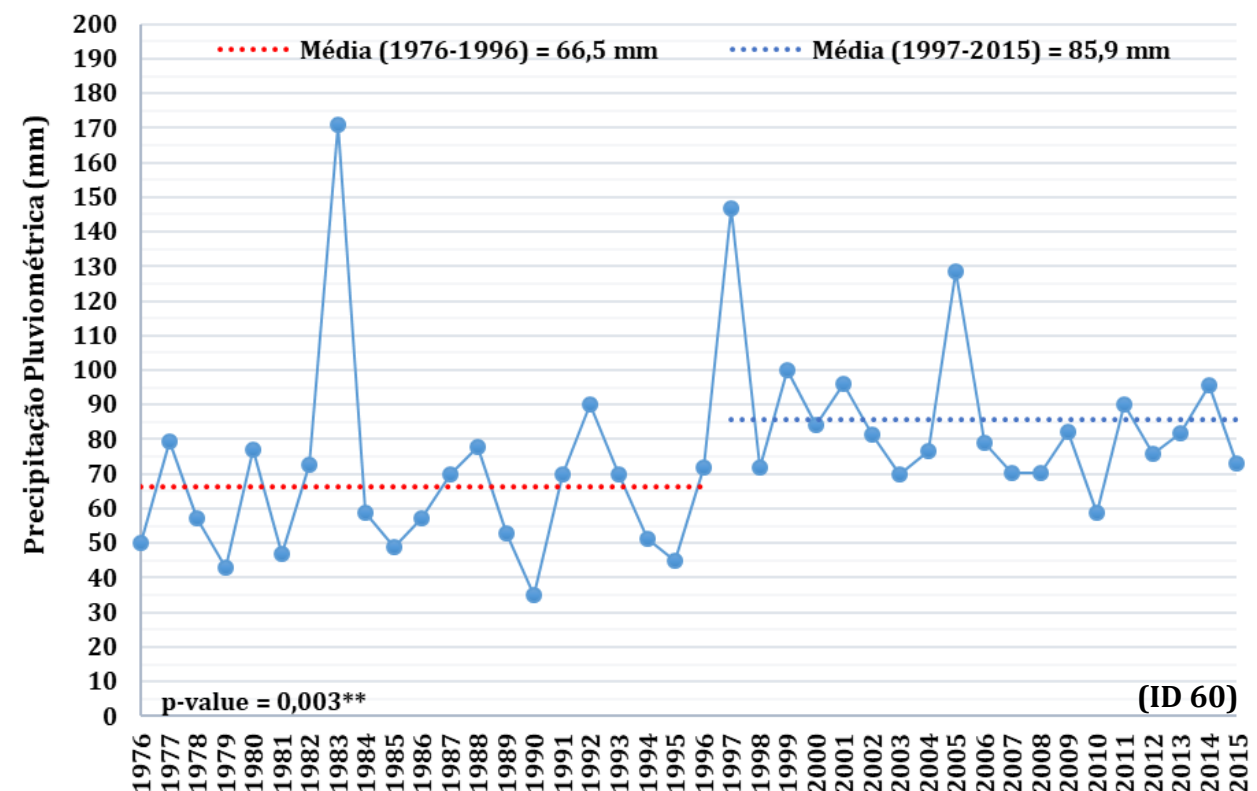

Figura 54 - Precipitação pluviométrica máxima diária $(\mathrm{mm})$ e ruptura identificada na série histórica de Castro (ID 60) - Paraná 

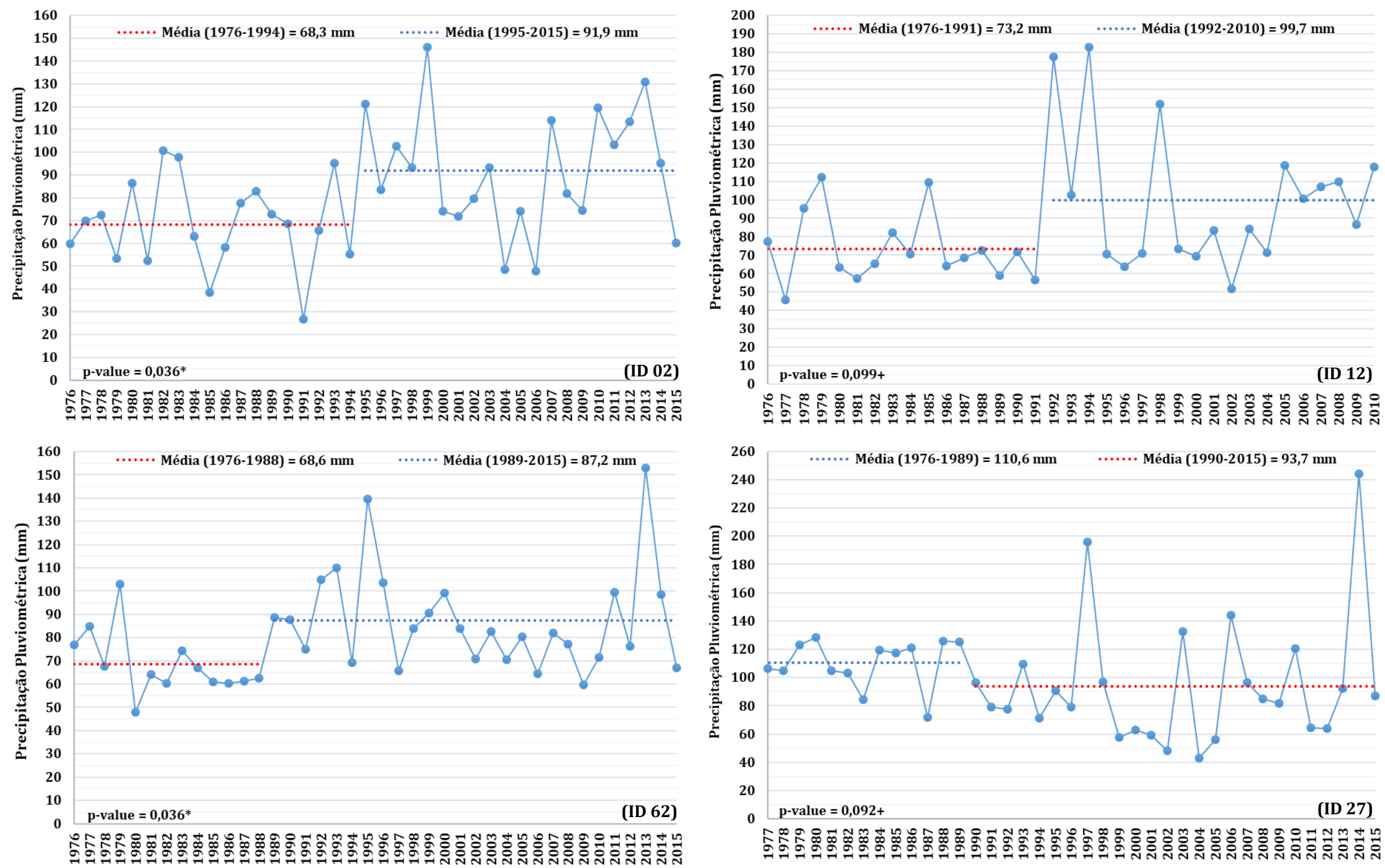

Figura 55 - Precipitação máxima diária (mm) e rupturas identificadas nas séries históricas de Curitiba (ID 02), São Mateus do Sul (ID 12), Palmeira (ID 62) e Guaraqueçaba (ID 27) - Paraná. 

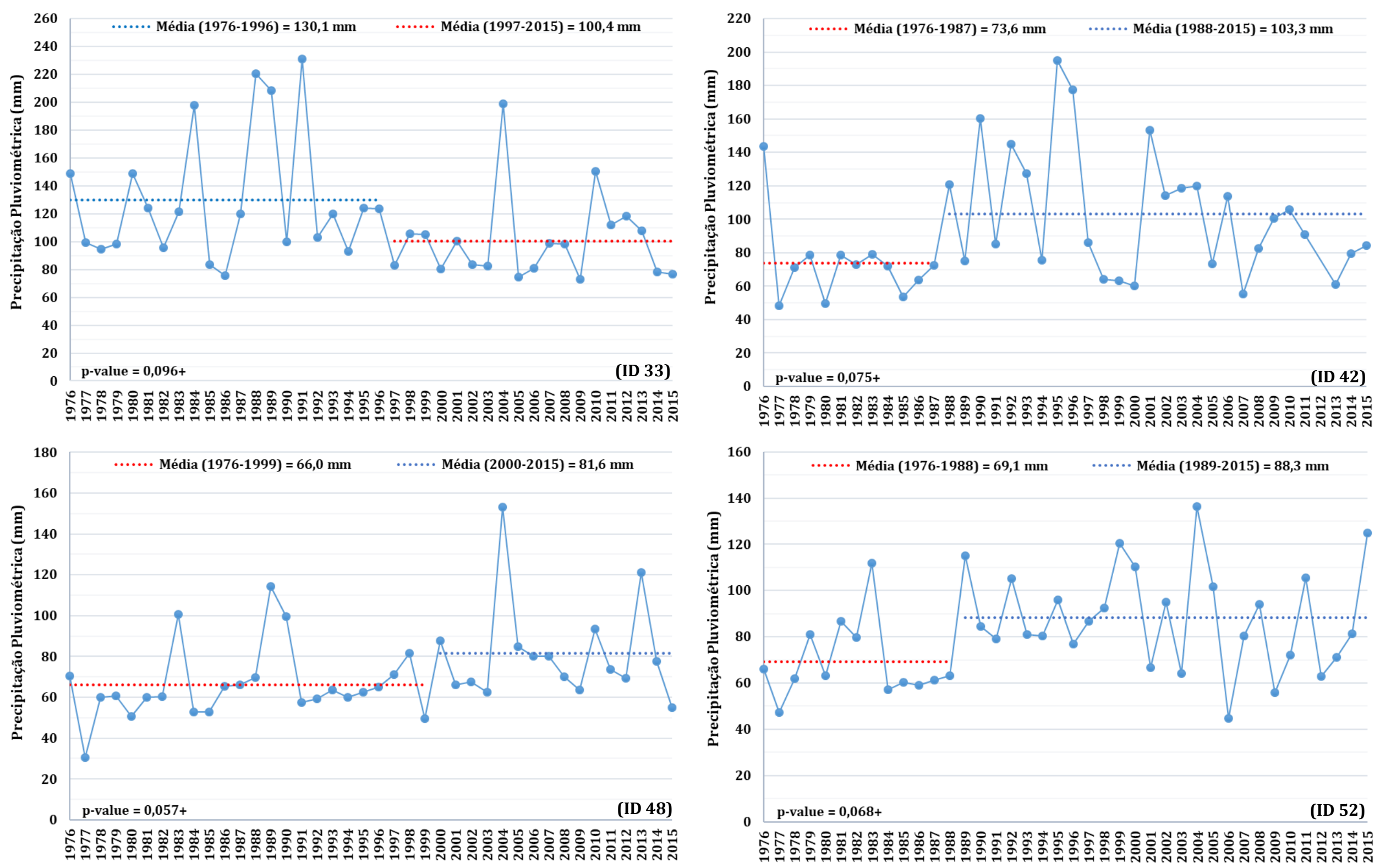

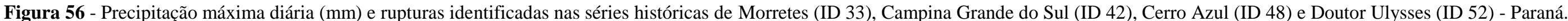




\subsubsection{Tendências e rupturas de chuvas fortes (R95p) e chuvas muito fortes (R99p)}

As tendências e rupturas obtidas para as chuvas fortes (R95p) foram menos frequentes em relação ao total pluviométrico anual e às chuvas máximas diárias anuais. Para a BH do Alto Iguaçu, observa-se a identificação de tendências positivas e com $95 \%$ de significância para os postos pluviométricos de São Mateus do Sul (ID12) e Quitandinha (ID19), nas quais as chuvas iguais ou superiores a $95 \%$ dos quantis aumentaram em $0,18 \mathrm{~mm}$ e $0,12 \mathrm{~mm} / \mathrm{ano}$, ou seja, em um total de 7,32 mm e 4,86 mm em quarenta anos (Tabela 16). Na BH do Ribeira, identificouse a diminuição das chuvas deste limiar (R95p) em 0,12 mm/ano em Adrianópolis (ID38), com uma significância de 95\%, enquanto que em Cerro Azul (ID50) verificou-se um aumento destas chuvas fortes em 0,10 mm/ano com $90 \%$ de significância e, assim, demonstram-se tendências de uma redução de 4,96 mm em ID38 e um aumento de 4,12 mm em ID50 (Tabela 17).

Considerando uma significância estatística de 90\%, observa-se o aumento das chuvas fortes em Antonina (ID22) e Morretes (ID31), a uma ordem 0,13 mm e 0,10 mm ao ano, o que significa que estes totais pluviométricos se tornaram $5,08 \mathrm{~mm}$ e 4,00 $\mathrm{mm}$ mais elevados em 40 anos avaliados. Em contraposição, em Guaraqueçaba (ID27) e Morretes (ID33) mostraram-se a redução das chuvas fortes em $0,11 \mathrm{~mm}$ e 0,14 mm/ano, com uma significância de $90 \%$ e 95\%, nesta ordem. Esta tendência negativa demonstra a redução total do período em 4,24 mm e 5,52 mm durante a série histórica para este limiar das chuvas diárias (Tabela 18).

Dentre as observações mais pertinentes em relação às rupturas de chuvas fortes, destacase que a BH Ribeira não apresentou nenhuma modificação significativa estatisticamente, sendo que outras sete foram averiguadas para a BH Alto Iguaçu e Litorânea. Em São Mateus do Sul (ID14), Guaraqueçaba (ID27) e Morretes (ID33), com uma significância de 95\%, obtiveram-se rupturas entre 1989 e 1995, com reduções deste limiar das chuvas entre 4,6 mm e 9,3 mm ao longo dos segmentos temporais, sendo estas localidades as únicas nas quais foram observadas a diminuição pluvial (Figuras 60 e 61).

As rupturas identificadas nas localidades de São Mateus do Sul (ID12) e Quitandinha (ID19), ambas situadas na BH do Alto Iguaçu, foram observadas entre 1992 e 1989, com 90\% e 95\% de significância estatística, nesta ordem. Sobretudo, estas rupturas indicaram o aumento das chuvas fortes em 9,7 mm e 5,5 mm, respectivamente, sendo que é possível notar que entre os anos de 1992 e 1998 há uma maior frequência das chuvas diárias superiores a 80 mm, como é possível observar a representação da figura 60. 
Foram identificadas rupturas mais recentes em relação às demais apresentadas para os totais anuais e chuvas máximas diárias. Localizada na BH Alto Iguaçu, observa-se em São João do Triunfo (ID15), com 95\% de significância, o aumento das chuvas fortes a partir de 2008 e, no entanto, representa um aumento de somente 2,3 mm (Figura 60). Com 99\% de significância, destaca-se a ruptura ocorrida no ano de 2009 em Guaratuba (ID29), o que demonstra o aumento de 9,1 mm ao longo da série analisada (Figura 59).

A aplicação do teste Mann-Kendall para as chuvas intensas (R99p) mostrou a tendência de redução das precipitações diárias equivalente ou superior a este limiar diário em três postos pluviométricos das bacias hidrográficas analisadas. A única modificação observada na BH Alto Iguaçu se deu em Mandirituba (ID06), com 90\% de significância, mostra a diminuição de 0,32 mm/ano das chuvas diárias intensas, em cerca de 12,8 mm em 40 anos de observações. Na BH do Ribeira, obteve-se a redução das chuvas R99p em Ponta Grossa (ID55), com a significância estatística de $95 \%$, equivalente a $-0,37 \mathrm{~mm} /$ ano ou a um total de $-14,72 \mathrm{~mm}$ ao longo da série histórica. Contrapondo-se, também se observou na BH do Ribeira o aumento das chuvas iguais ou superiores a R99p em Campo Largo (ID45), com 99,9\% de significância estatística, a maior dentre as analisadas para as chuvas fortes e intensas, e que indica o acréscimo de 0,53 mm/ano desta categoria pluvial e a um total de aproximadamente 21,3 mm (Tabelas 19 e 21).

Na BH Litorânea, os resultados demonstram tendências estatisticamente significativas de aumento em dois postos pluviométricos, sendo que nas localidades de Antonina (ID22) e em Morretes (ID32) obteve-se o acréscimo de $0,30 \mathrm{~mm}$ e $0,24 \mathrm{~mm}$ ao ano, considerando-se $90 \%$ e 95\% de significância, o que corresponde a $11,8 \mathrm{~mm}$ e a $9,6 \mathrm{~mm}$ ao longo do segmento temporal avaliado, nesta ordem. Entretanto, em Antonina (ID21) e em Guaraqueçaba (ID24) mostra-se a diminuição das chuvas intensas em 0,34 mm e 0,44 mm/ano, com uma significância estatística de $95 \%$ e $90 \%$, o que mensura uma diminuição de $13,8 \mathrm{~mm}$ a 17,8 mm das chuvas R99p nestas localidades ao longo da série temporal (Tabela 20).

De modo geral, predominaram as rupturas entre o período de 1986 e 1994, identificadas em cinco das sete séries com a significância estatística pelo teste Pettitt. Identificou-se em São Mateus do Sul (ID13) a primeira ruptura dentre as obtidas pelo referido teste estatístico, no ano de 1986, com 95\% de significância estatística, sendo que anteriormente a este período a média das chuvas intensas equivalia a $83,0 \mathrm{~mm}$ e, após a ruptura, aumentou para 100,3 mm. No posto pluviométrico de Campo Largo (ID45), a uma significância de 90\%, verifica-se o aumento da média das chuvas intensas de 76,0 mm para 87,6 mm após a ruptura observada no ano de 1988 . 
Também com uma significância de 90\%, a ruptura ocorrida em 1994 no posto pluviométrico de Antonina (ID22) demonstra o acréscimo da média das chuvas R99p de 99,4 mm para 113,1 mm (Tabelas 19, 20 e 21 - Figuras 62 e 64).

Ainda no segmento temporal principal das rupturas observadas para as chuvas intensas, em Antonina (ID21) verifica-se a diminuição das chuvas intensas com a ruptura no ano de 1989, com $95 \%$ de significância, sendo que o período anterior a esta mudança se caracteriza por uma média de 123,8 mm e, em seguida, diminui para 107,2 mm. Em Ponta Grossa (ID55), com 95\% de significância, demonstra-se a redução das chuvas R99p a partir de 1991, uma vez que antes desta modificação a média destas alturas pluviométricas diária equivalia a 99,6 mm e decaiu para 86,3 mm no período seguinte (Tabelas 20 e 21 - Figura 63).

Com $90 \%$ de significância, as únicas rupturas que se destoam temporalmente em relação às descritas acima se deram em Mandirituba (ID06) e em Campina Grande do Sul (ID41). Nesta última localidade, observa-se que a ruptura ocorreu logo no primeiro ano da série temporal, em 1976, no qual ocorreram elevados totais pluviais diários intensos, com uma média de 101,1 mm e, no restante dos anos analisados a média deste limiar pluvial esteve em 77,5 $\mathrm{mm}$. No primeiro posto pluviométrico, a diminuição das chuvas intensas ocorreram em 2002, com um decréscimo de $88,7 \mathrm{~mm}$ para $75,5 \mathrm{~mm}$ da média dos registros de chuvas iguais ou superiores ao referido total (Tabelas 19 e 21 - Figura 63).

As tendências de aumento de chuvas diárias fortes e intensas estão em conformidade ao esperado para a área de estudo e, entretanto, os trabalhos anteriores realizados nesta região ou em suas proximidades não tenham avaliado restritamente estes totais pluviais diários de modo individualizado como realizado nesta pesquisa. Como exemplo, Silva et al. (2015) utilizaramse dos totais anuais de R95p e R99p para investigar as tendências de modificações destas chuvas no estado do Paraná e, contudo, observaram somente a diminuição estatisticamente significativa dos acumulados de chuvas fortes na região Norte paranaense, resultados próximos observados para a redução destes registros pluviais em Guaraqueçaba (ID27) e Morretes (ID33).

As modificações encontradas nas séries temporais de chuvas fortes e intensas estão em acordo com as observações de Pinheiro (2013) para a região Sul do Brasil, uma vez que estes autores identificaram o aumento significativo das chuvas em Curitiba a partir de 1997 e destaca que a maioria dos postos pluviométricos do estado do Paraná tiveram modificações nas séries temporais entre as décadas de 1980 e 1990. Estas tendências temporais estão em acordo também com as observações anteriores de Minuzzi e Caramori (2011) e Nascimento Júnior et al. (2013). 
Tabela 16 - Testes de tendências (Mann-Kendall) e rupturas (Pettitt) para a precipitação pluviométrica diária superior a 95\% dos quantis na BH do Alto Iguaçu - Paraná.

\begin{tabular}{|c|c|c|c|c|c|c|c|}
\hline \multirow[b]{2}{*}{ ID } & \multirow{2}{*}{$\begin{array}{l}\text { Postos pluviométricos e } \\
\text { Estações Meteorológicas }\end{array}$} & \multicolumn{3}{|c|}{ Teste Mann - Kendall } & \multicolumn{3}{|c|}{ Teste Pettitt } \\
\hline & & Tal & p-value & $\mathrm{CS}$ & $\mathbf{K}$ & p-value & Ruptura \\
\hline 1 & Campo Largo & 0,007 & 0,888 & 0,009 & 1749 & 0,530 & 1991 \\
\hline 2 & Curitiba & 0,029 & 0,455 & 0,038 & 2780 & 0,588 & 1992 \\
\hline 3 & Lapa & 0,053 & 0,216 & 0,065 & 1864 & 0,956 & 2008 \\
\hline 4 & Lapa & 0,069 & 0,118 & 0,074 & 2090 & 0,429 & 2009 \\
\hline 5 & Lapa & $-0,027$ & 0,572 & $-0,030$ & 1086 & 0,608 & 1995 \\
\hline 6 & Mandirituba & $-0,025$ & 0,566 & $-0,029$ & 1722 & 0,952 & 1998 \\
\hline 7 & Pinhais & 0,033 & 0,379 & 0,042 & 2712 & 0,914 & 1994 \\
\hline 8 & Piraquara & $-0,025$ & 0,495 & $-0,038$ & 3698 & 0,302 & 1995 \\
\hline 9 & Piraquara & 0,044 & 0,302 & 0,048 & 2681 & 0,202 & 1993 \\
\hline 10 & Porto Amazonas & $-0,017$ & 0,695 & $-0,017$ & 1355 & 0,337 & 1995 \\
\hline 11 & São José do Pinhais & 0,045 & 0,334 & 0,057 & 1514 & 0,825 & 2001 \\
\hline 12 & São Mateus do Sul & 0,107 & $0,046^{*}$ & 0,183 & 1642 & $\mathbf{0 , 0 6 4 ^ { + }}$ & 1992 \\
\hline 13 & São Mateus do Sul & $-0,037$ & 0,422 & $-0,045$ & 1521 & 0,832 & 1992 \\
\hline 14 & São Mateus do Sul & $-0,018$ & 0,698 & $-0,020$ & 747 & $0,045^{*}$ & 1993 \\
\hline 15 & São João do Triunfo & 0,010 & 0,832 & 0,011 & 616 & $0,022^{*}$ & 2008 \\
\hline 16 & Rio Negro & 0,061 & 0,171 & 0,071 & 1749 & 0,739 & 2010 \\
\hline 17 & Tijucas do Sul & $-0,018$ & 0,676 & $-0,021$ & 1351 & 0,544 & 2005 \\
\hline 18 & Piên & 0,042 & 0,340 & 0,040 & 1486 & 0,746 & 2009 \\
\hline 19 & Quitandinha & 0,104 & $0,021^{*}$ & 0,117 & 2901 & $\mathbf{0 , 0 3 7 *}$ & 1988 \\
\hline 20 & Quitandinha & $-0,031$ & 0,505 & $-0,031$ & 2257 & 0,184 & 1992 \\
\hline 62 & Palmeira & $-0,006$ & 0,901 & $-0,006$ & 921 & 0,224 & 2001 \\
\hline
\end{tabular}

Legenda: $* * *=99,9 \%$ de significância; $* *=99 \%$ de significância $; *=95 \%$ de significância; $+=90 \%$ de significância.

Tabela 17 - Testes de tendências (Mann-Kendall) e rupturas (Pettitt) para a precipitação pluviométrica diária superior a $95 \%$ dos quantis na BH Litorânea - Paraná.

\begin{tabular}{c|c|c|c|c|c|c|c}
\hline & Postos pluviométricos e & \multicolumn{2}{c}{ Teste Mann - Kendall } & \multicolumn{3}{|c}{ Teste Pettitt } \\
\cline { 3 - 8 } ID & Estações Meteorológicas & Tal & p-value & CS & K & PVA & Ruptura \\
\hline $\mathbf{2 1}$ & Antonina & $-0,019$ & 0,622 & $-0,043$ & 2599 & 0,674 & 1982 \\
\hline $\mathbf{2 2}$ & Antonina & 0,066 & $\mathbf{0 , 0 6 5}^{+}$ & 0,127 & 3640 & 0,596 & 1986 \\
\hline $\mathbf{2 3}$ & Antonina & 0,002 & 0,947 & 0,000 & 1951 & 0,262 & 2003 \\
\hline $\mathbf{2 4}$ & Guaraqueçaba & 0,017 & 0,687 & 0,041 & 1838 & 0,836 & 1987 \\
\hline $\mathbf{2 5}$ & Guaraqueçaba & 0,046 & 0,234 & 0,092 & 2882 & 0,585 & 1994 \\
\hline $\mathbf{2 6}$ & Guaraqueçaba & 0,037 & 0,327 & 0,077 & 3117 & 0,596 & 2001 \\
\hline $\mathbf{2 7}$ & Guaraqueçaba & $-0,063$ & $\mathbf{0 , 0 8 2}^{+}$ & $-0,106$ & 5450 & $\mathbf{0 , 0 4 9} *$ & 1989 \\
\hline $\mathbf{2 8}$ & Guaraqueçaba & $-0,032$ & 0,403 & $-0,070$ & 2237 & 0,826 & 2010 \\
\hline $\mathbf{2 9}$ & Guaratuba & 0,000 & 0,997 & 0,000 & 1054 & $\mathbf{0 , 0 0 3}$ & 2009 \\
\hline $\mathbf{3 0}$ & Guaratuba & $-0,014$ & 0,702 & $-0,019$ & 1815 & 0,218 & 1986 \\
\hline $\mathbf{3 1}$ & Morretes & 0,064 & $\mathbf{0 , 0 9 6}$ & 0,100 & 3686 & 0,231 & 1990 \\
\hline $\mathbf{3 2}$ & Morretes & 0,058 & 0,111 & 0,100 & 3874 & 0,385 & 2003 \\
\hline $\mathbf{3 3}$ & Morretes & $-0,075$ & $\mathbf{0 , 0 3 8}$ & $-0,138$ & 6002 & $\mathbf{0 , 0 1 7}$ & 1995 \\
\hline $\mathbf{3 4}$ & Paranaguá & 0,016 & 0,699 & 0,030 & 1896 & 0,875 & 1996 \\
\hline $\mathbf{3 5}$ & Paranaguá & 0,019 & 0,624 & 0,040 & 2213 & 0,708 & 1991 \\
\hline $\mathbf{3 6}$ & São José dos Pinhais & 0,058 & 0,123 & 0,096 & 4292 & 0,102 & 1994 \\
\hline
\end{tabular}

Legenda: $* * *=99,9 \%$ de significância; $* *=99 \%$ de significância; $*=95 \%$ de significância; $+=90 \%$ de significância. 
Tabela 18 - Testes de tendências (Mann-Kendall) e rupturas (Pettitt) para a precipitação pluviométrica diária superior a 95\% dos quantis para a BH do rio Ribeira - Paraná.

\begin{tabular}{|c|c|c|c|c|c|c|c|}
\hline \multirow[b]{2}{*}{ ID } & \multirow{2}{*}{$\begin{array}{l}\text { Postos pluviométricos e } \\
\text { Estações Meteorológicas }\end{array}$} & \multicolumn{3}{|c|}{ Teste Mann - Kendall } & \multicolumn{3}{|c|}{ Teste Pettitt } \\
\hline & & Tal & p-value & CS & $\mathbf{K}$ & p-value & Ruptura \\
\hline 37 & Adrianópolis & 0,011 & 0,841 & 0,012 & 884 & 0,725 & 1991 \\
\hline 38 & Adrianópolis & $-0,098$ & $0,035^{*}$ & $-0,124$ & 2025 & 0,241 & 2002 \\
\hline 39 & Adrianópolis & 0,067 & 0,179 & 0,077 & 1283 & 0,679 & 1998 \\
\hline 40 & Bocaiúva do Sul & $-0,042$ & 0,363 & $-0,064$ & 1787 & 0,531 & 1995 \\
\hline 41 & Campina Grande do Sul & 0,025 & 0,535 & 0,035 & 2254 & 0,790 & 2010 \\
\hline 42 & Campina Grande do Sul & $-0,008$ & 0,872 & $-0,009$ & 942 & 0,211 & 2003 \\
\hline 43 & Campina Grande do Sul & $-0,004$ & 0,926 & 0,000 & 1342 & 0,918 & 1982 \\
\hline 44 & Campo Largo & $-0,035$ & 0,459 & $-0,036$ & 1206 & 0,848 & 2000 \\
\hline 45 & Campo Largo & 0,002 & 0,960 & 0,000 & 1291 & 0,470 & 2005 \\
\hline 46 & Campo Largo & 0,071 & 0,163 & 0,099 & 1192 & 0,709 & 2001 \\
\hline 47 & Campo Largo & $-0,049$ & 0,292 & $-0,058$ & 1893 & 0,366 & 1993 \\
\hline 48 & Cerro Azul & $-0,007$ & 0,880 & 0,000 & 1377 & 0,701 & 1990 \\
\hline 49 & Cerro Azul & $-0,066$ & 0,165 & $-0,085$ & 1919 & 0,215 & 2007 \\
\hline 50 & Cerro Azul & 0,086 & $\mathbf{0 , 0 8 6}^{+}$ & 0,103 & 1420 & 0,446 & 2003 \\
\hline 51 & Cerro Azul & 0,050 & 0,267 & 0,067 & 1454 & 0,927 & 2001 \\
\hline 52 & Doutor Ulysses & $-0,055$ & 0,250 & $-0,067$ & 1581 & 0,577 & 1993 \\
\hline 53 & Doutor Ulysses & $-0,007$ & 0,870 & 0,000 & 1707 & 0,889 & 1989 \\
\hline 54 & Itaperuçu & 0,036 & 0,428 & 0,050 & 1454 & 0,513 & 2007 \\
\hline 55 & Ponta Grossa & $-0,009$ & 0,836 & $-0,010$ & 1466 & 0,866 & 2007 \\
\hline 56 & Rio Branco do Sul & 0,028 & 0,625 & 0,067 & 758 & 0,888 & 1990 \\
\hline 57 & Rio Branco do Sul & 0,001 & 0,986 & 0,000 & 1043 & 0,970 & 1992 \\
\hline 58 & Tunas do Paraná & $-0,055$ & 0,247 & $-0,059$ & 1453 & 0,737 & 2010 \\
\hline 59 & Castro & 0,012 & 0,803 & 0,018 & 1199 & 0,942 & 1990 \\
\hline 60 & Castro & 0,063 & 0,198 & 0,075 & 1648 & 0,333 & 1996 \\
\hline 61 & Ponta Grossa & 0,000 & 0,997 & 0,000 & 2097 & 0,360 & 2010 \\
\hline
\end{tabular}

Legenda: $* * *=99,9 \%$ de significância; $* *=99 \%$ de significância; $*=95 \%$ de significância; $+=90 \%$ de significância.

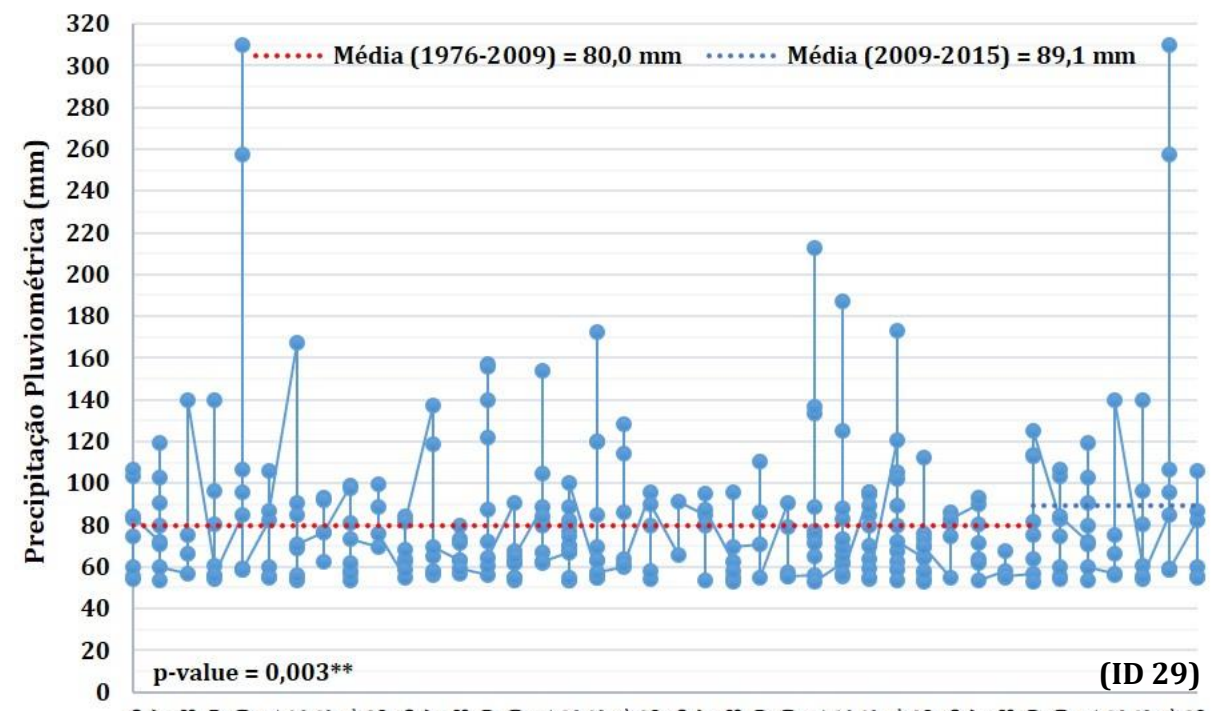

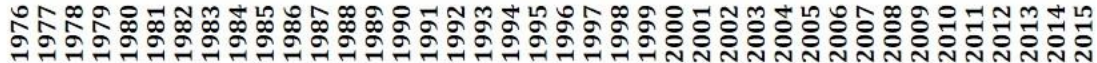

Figura 57 - Registros de chuvas fortes (R95p) e ruptura identificada na série histórica de Guaratuba (ID29) - Paraná. 

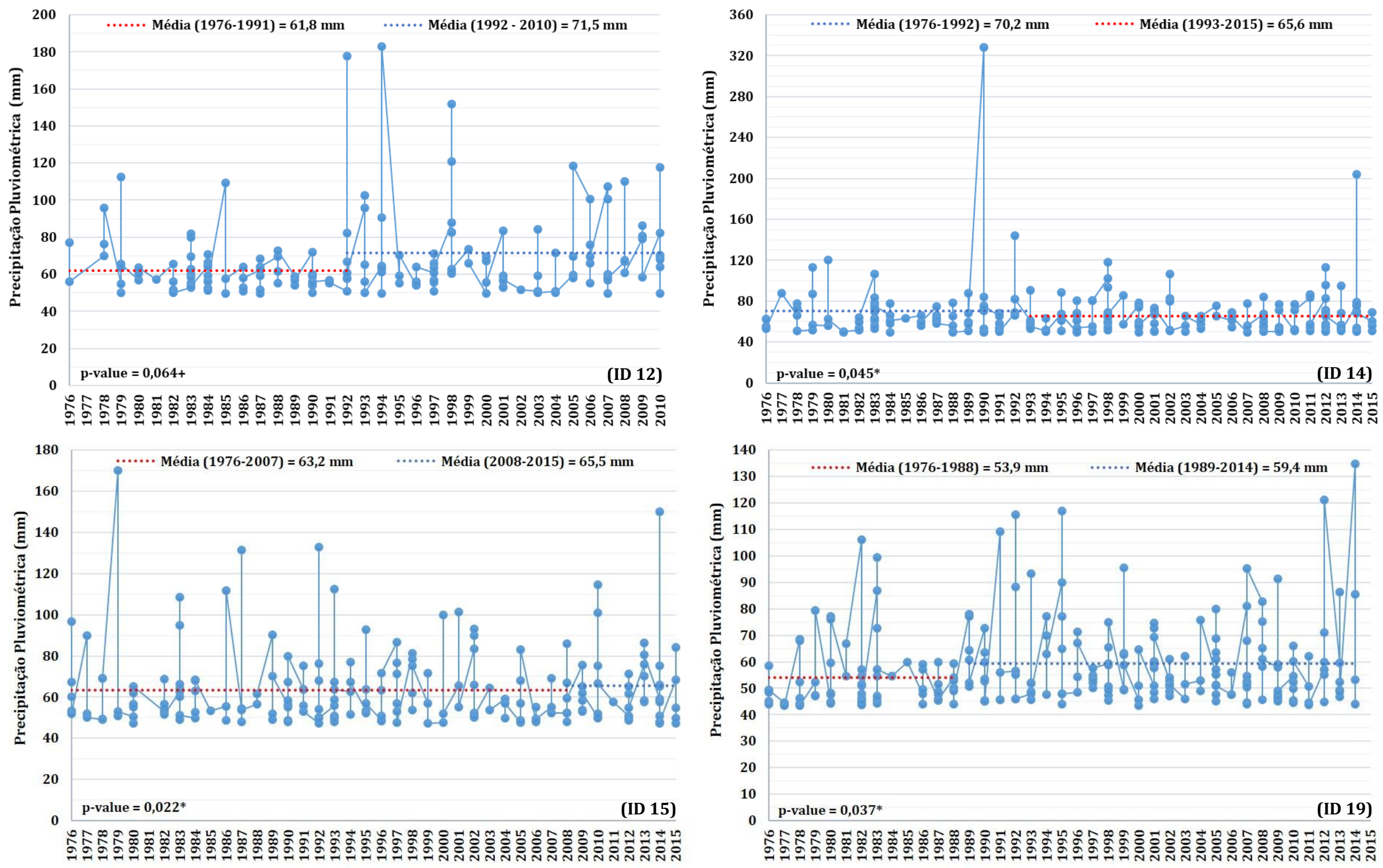

Figura 58 - Registros de chuvas fortes (R95p) e rupturas identificadas nas séries históricas de São Mateus do Sul (ID 12 e ID 14), São José do Triunfo (ID 15) e Quitandinha (ID 19) - Paraná. 


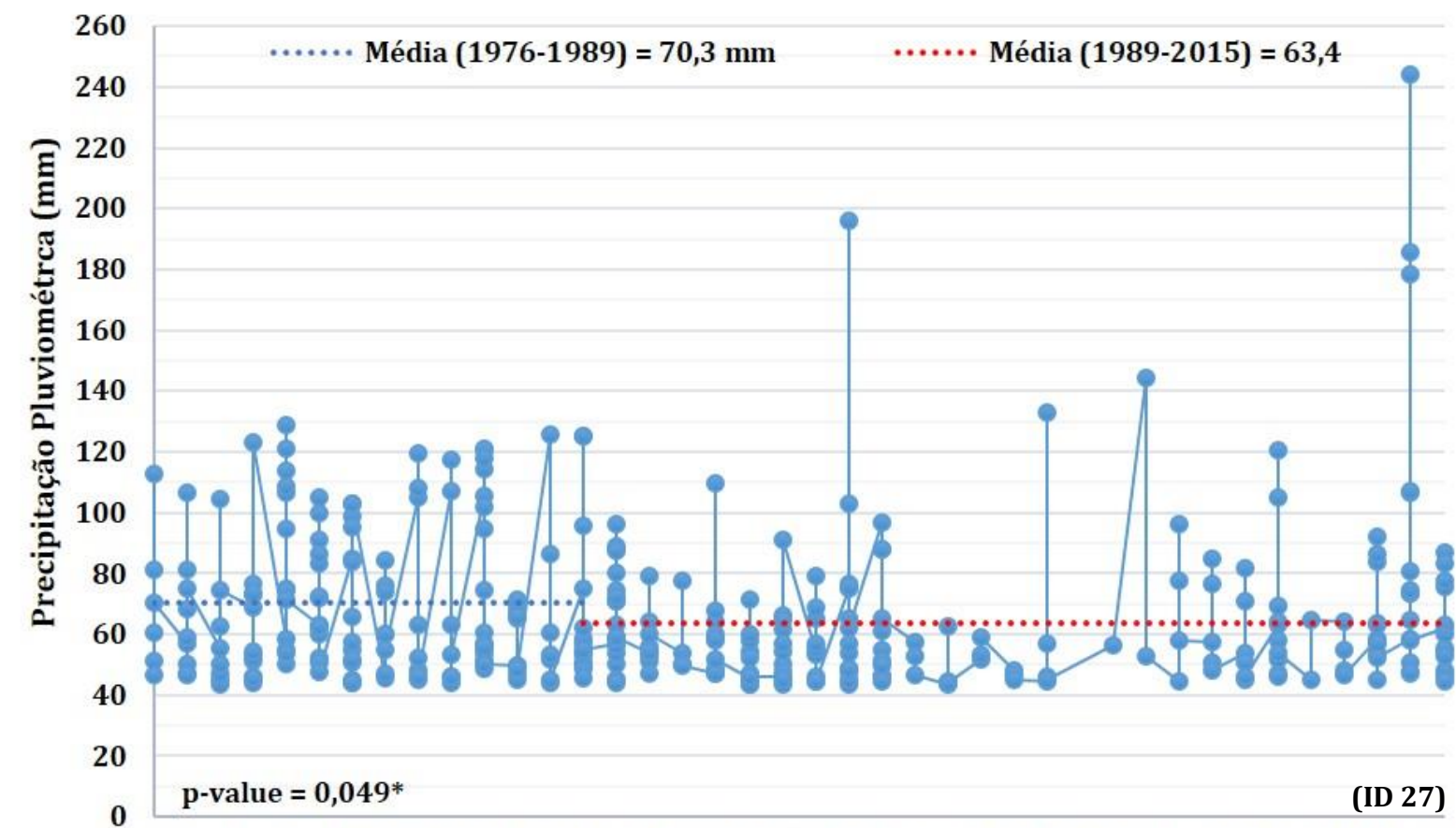

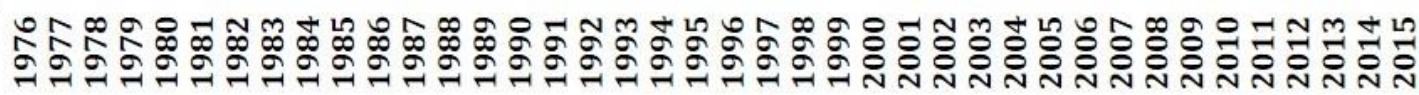

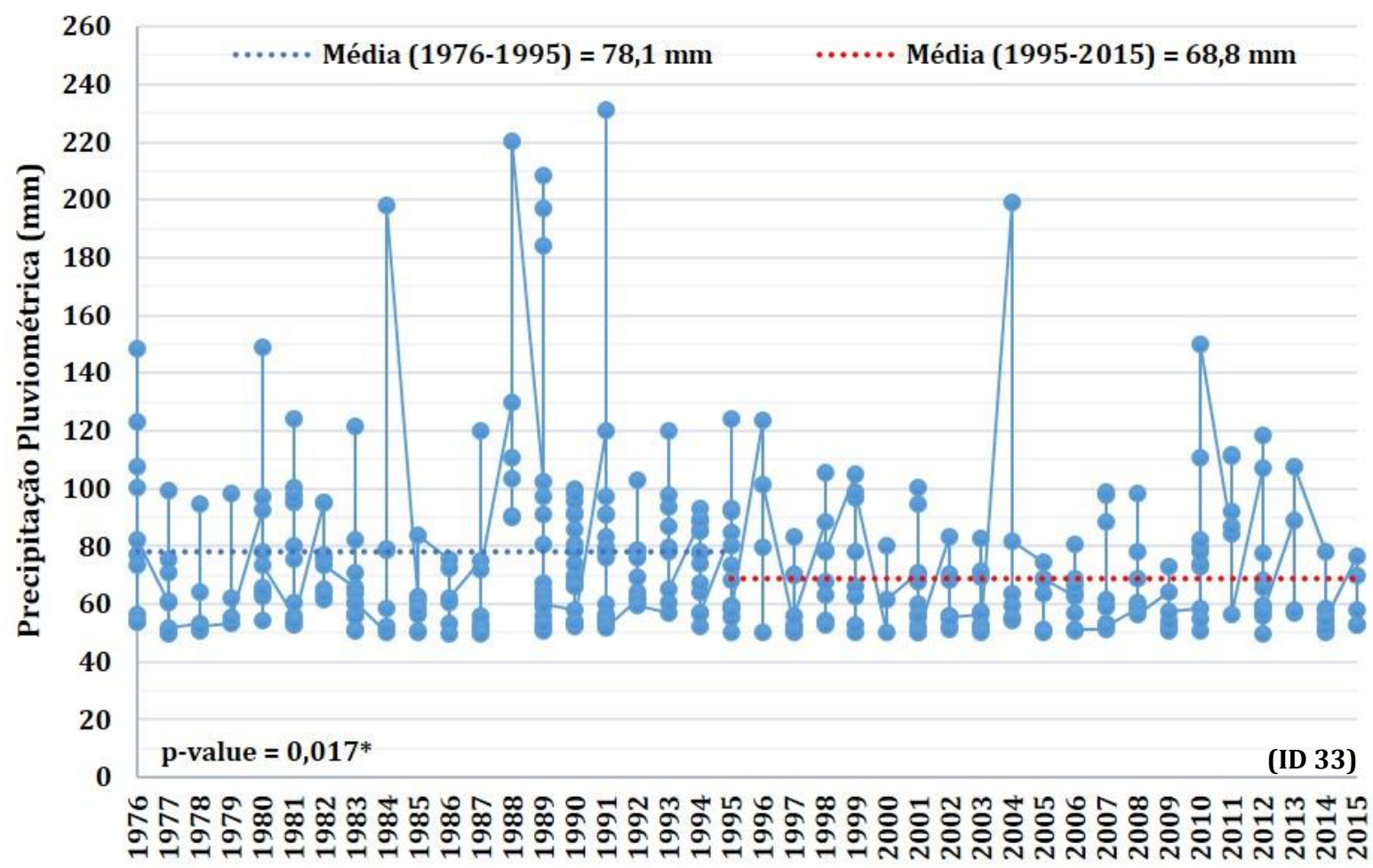

Figura 59 - Registros de chuvas fortes (R95p) e rupturas identificadas na série histórica de Guaraqueçaba (ID27) e Morretes (ID 33) - Paraná. 
Tabela 19 - Testes de tendências (Mann-Kendall) e rupturas (Pettitt) para a precipitação pluviométrica diária superior a 99\% dos quantis para a BH do Alto Iguaçu - Paraná.

\begin{tabular}{|c|c|c|c|c|c|c|c|}
\hline \multirow[b]{2}{*}{ ID } & \multirow{2}{*}{$\begin{array}{l}\text { Postos pluviométricos e } \\
\text { Estações Meteorológicas }\end{array}$} & \multicolumn{3}{|c|}{ Teste Mann - Kendall } & \multicolumn{3}{|c|}{ Teste Pettitt } \\
\hline & & Tal & p-value & $\mathrm{CS}$ & $\mathbf{K}$ & p-value & Ruptura \\
\hline 1 & Campo Largo & 0,057 & 0,601 & 0,071 & 108 & 0,707 & 2012 \\
\hline 2 & Curitiba & 0,131 & 0,142 & 0,164 & 246 & 0,576 & 1995 \\
\hline 3 & Lapa & 0,112 & 0,255 & 0,173 & 184 & 0,622 & 2010 \\
\hline 4 & Lapa & 0,065 & 0,527 & 0,074 & 121 & 0,658 & 1986 \\
\hline 5 & Lapa & $-0,063$ & 0,576 & $-0,093$ & 111 & 0,984 & 1983 \\
\hline 6 & Mandirituba & $-0,177$ & $\mathbf{0 , 0 7 2}^{+}$ & $-0,319$ & 265 & $\mathbf{0 , 0 8 8}^{+}$ & 2002 \\
\hline 7 & Pinhais & 0,047 & 0,589 & 0,056 & 170 & 0,403 & 2010 \\
\hline 8 & Piraquara & $-0,018$ & 0,838 & $-0,020$ & 170 & 0,322 & 1995 \\
\hline 9 & Piraquara & 0,081 & 0,412 & 0,129 & 119 & 0,398 & 1986 \\
\hline 10 & Porto Amazonas & $-0,067$ & 0,498 & $-0,093$ & 226 & 0,247 & 1995 \\
\hline 11 & São José do Pinhais & 0,157 & 0,134 & 0,144 & 170 & 0,446 & 2011 \\
\hline 12 & São Mateus do Sul & 0,024 & 0,858 & 0,053 & 68 & 0,686 & 1983 \\
\hline 13 & São Mateus do Sul & 0,167 & 0,116 & 0,186 & 234 & $\mathbf{0 , 0 3 5}{ }^{*}$ & 1986 \\
\hline 14 & São Mateus do Sul & $-0,032$ & 0,779 & $-0,027$ & 85 & 0,354 & 1998 \\
\hline 15 & São João do Triunfo & $-0,181$ & 0,108 & $-0,360$ & 163 & 0,176 & 1989 \\
\hline 16 & Rio Negro & 0,115 & 0,269 & 0,111 & 164 & 0,515 & 2002 \\
\hline 17 & Tijucas do Sul & 0,067 & 0,511 & 0,071 & 113 & 0,431 & 1978 \\
\hline 18 & Piên & $-0,025$ & 0,813 & $-0,040$ & 92 & 0,211 & 1983 \\
\hline 19 & Quitandinha & 0,056 & 0,597 & 0,125 & 116 & 0,709 & 2012 \\
\hline 20 & Quitandinha & 0,040 & 0,708 & 0,055 & 108 & 0,613 & 2012 \\
\hline 62 & Palmeira & 0,047 & 0,672 & 0,090 & 133 & 0,724 & 1991 \\
\hline
\end{tabular}

Legenda: $* * *=99,9 \%$ de significância; $* *=99 \%$ de significância; $*=95 \%$ de significância; $+=90 \%$ de significância.

Tabela 20 - Testes de tendências (Mann-Kendall) e rupturas (Pettitt) para a precipitação pluviométrica diária superior a 99\% dos quantis na BH Litorânea - Paraná.

\begin{tabular}{c|c|c|c|c|c|c|c}
\hline & Postos pluviométricos e & \multicolumn{2}{|c|}{ Teste Mann - Kendall } & \multicolumn{3}{|c}{ Teste Pettitt } \\
\cline { 6 - 8 } ID & Estações Meteorológicas & Tal & p-value & CS & K & p-value & Ruptura \\
\hline $\mathbf{2 1}$ & Antonina & $-0,203$ & $\mathbf{0 , 0 2 5} *$ & $-0,344$ & 378 & $\mathbf{0 , 0 3 0}$ & 1989 \\
\hline $\mathbf{2 2}$ & Antonina & 0,154 & $\mathbf{0 , 0 5 9}^{+}$ & 0,295 & 454 & $\mathbf{0 , 0 9 1}$ & 1994 \\
\hline $\mathbf{2 3}$ & Antonina & 0,027 & 0,752 & 0,057 & 180 & 0,368 & 2001 \\
\hline $\mathbf{2 4}$ & Guaraqueçaba & $-0,170$ & $\mathbf{0 , 0 7 4}$ & $-0,444$ & 236 & 0,327 & 2008 \\
\hline $\mathbf{2 5}$ & Guaraqueçaba & 0,057 & 0,510 & 0,187 & 196 & 0,697 & 2004 \\
\hline $\mathbf{2 6}$ & Guaraqueçaba & 0,005 & 0,958 & 0,000 & 319 & 0,320 & 1983 \\
\hline $\mathbf{2 7}$ & Guaraqueçaba & $-0,004$ & 0,968 & $-0,006$ & 207 & 0,452 & 1983 \\
\hline $\mathbf{2 8}$ & Guaraqueçaba & $-0,062$ & 0,482 & $-0,085$ & 191 & 0,754 & 1983 \\
\hline $\mathbf{2 9}$ & Guaratuba & 0,010 & 0,917 & 0,000 & 128 & 0,145 & 1980 \\
\hline $\mathbf{3 0}$ & Guaratuba & $-0,107$ & 0,211 & $-0,206$ & 319 & 0,320 & 1983 \\
\hline $\mathbf{3 1}$ & Morretes & $-0,021$ & 0,813 & $-0,029$ & 245 & 0,718 & 1986 \\
\hline $\mathbf{3 2}$ & Morretes & 0,162 & $\mathbf{0 , 0 5}$ & 0,240 & 378 & 0,203 & 2003 \\
\hline $\mathbf{3 3}$ & Morretes & 0,006 & 0,942 & 0,017 & 227 & 0,736 & 1989 \\
\hline $\mathbf{3 4}$ & Paranaguá & 0,106 & 0,266 & 0,233 & 170 & 0,997 & 1986 \\
\hline $\mathbf{3 5}$ & Paranaguá & 0,030 & 0,734 & 0,109 & 192 & 0,728 & 1985 \\
\hline $\mathbf{3 6}$ & São José dos Pinhais & $-0,018$ & 0,840 & $-0,014$ & 172 & 0,436 & 1989 \\
\hline
\end{tabular}

Legenda: $* * *=99,9 \%$ de significância; $* *=99 \%$ de significância; $*=95 \%$ de significância; $+=90 \%$ de significância. 
Tabela 21 - Testes de tendências (Mann-Kendall) e rupturas (Pettitt) para a precipitação pluviométrica diária superior a 99\% dos quantis para a BH do rio Ribeira - Paraná.

\begin{tabular}{|c|c|c|c|c|c|c|c|}
\hline \multirow[b]{2}{*}{ ID } & \multirow{2}{*}{$\begin{array}{l}\text { Postos pluviométricos e } \\
\text { Estações Meteorológicas }\end{array}$} & \multicolumn{3}{|c|}{ Teste Mann - Kendall } & \multicolumn{3}{|c|}{ Teste Pettitt } \\
\hline & & Tal & p-value & $\mathrm{CS}$ & $\mathbf{K}$ & p-value & Ruptura \\
\hline 37 & Adrianópolis & 0,130 & 0,280 & 0,163 & 113 & 0,489 & 1985 \\
\hline 38 & Adrianópolis & 0,083 & 0,448 & 0,139 & 118 & 0,994 & 1982 \\
\hline 39 & Adrianópolis & 0,133 & 0,255 & 0,107 & 132 & 0,353 & 1990 \\
\hline 40 & Bocaiúva do Sul & 0,094 & 0,373 & 0,200 & 123 & 0,923 & 2010 \\
\hline 41 & Campina Grande do Sul & $-0,023$ & 0,811 & $-0,031$ & 106 & $0,092^{+}$ & 1976 \\
\hline 42 & Campina Grande do Sul & 0,003 & 0,983 & 0,003 & 95 & 0,479 & 1991 \\
\hline 43 & Campina Grande do Sul & $-0,085$ & 0,435 & $-0,218$ & 131 & 0,763 & 1983 \\
\hline 44 & Campo Largo & 0,028 & 0,807 & 0,038 & 84 & 0,402 & 2010 \\
\hline 45 & Campo Largo & 0,336 & $0,001^{* * * *}$ & 0,532 & 248 & $\mathbf{0 , 0 7 0 ^ { + }}$ & 1988 \\
\hline 46 & Campo Largo & 0,077 & 0,523 & 0,126 & 102 & 0,703 & 2010 \\
\hline 47 & Campo Largo & $-0,092$ & 0,391 & $-0,152$ & 140 & 0,685 & 1996 \\
\hline 48 & Cerro Azul & 0,185 & 0,102 & 0,150 & 133 & 0,487 & 2002 \\
\hline 49 & Cerro Azul & 0,156 & 0,154 & 0,287 & 159 & 0,316 & 2003 \\
\hline 50 & Cerro Azul & 0,138 & 0,241 & 0,267 & 109 & 0,645 & 1989 \\
\hline 51 & Cerro Azul & 0,132 & 0,201 & 0,200 & 184 & 0,349 & 2001 \\
\hline 52 & Doutor Ulysses & 0,075 & 0,500 & 0,107 & 87 & 0,380 & 2002 \\
\hline 53 & Doutor Ulysses & 0,070 & 0,492 & 0,151 & 125 & 0,700 & 1979 \\
\hline 54 & Itaperuçu & 0,001 & 1,000 & 0,005 & 100 & 0,392 & 2010 \\
\hline 55 & Ponta Grossa & $-0,211$ & $0,042 *$ & $-0,368$ & 244 & $0,044 *$ & 1991 \\
\hline 56 & Rio Branco do Sul & $-0,125$ & 0,363 & $-0,366$ & 84 & 0,395 & 1997 \\
\hline 57 & Rio Branco do Sul & $-0,094$ & 0,435 & $-0,122$ & 108 & 0,578 & 1983 \\
\hline 58 & Tunas do Paraná & $-0,127$ & 0,254 & $-0,168$ & 132 & 0,586 & 1990 \\
\hline 59 & Castro & 0,012 & 0,923 & 0,023 & 74 & 0,266 & 1989 \\
\hline 60 & Castro & $-0,060$ & 0,589 & $-0,042$ & 101 & 0,697 & 2014 \\
\hline 61 & Ponta Grossa & 0,114 & 0,268 & 0,150 & 151 & 0,760 & 1988 \\
\hline
\end{tabular}

Legenda: $* * *=99,9 \%$ de significância; $* *=99 \%$ de significância $* *=95 \%$ de significância; $+=90 \%$ de significância.

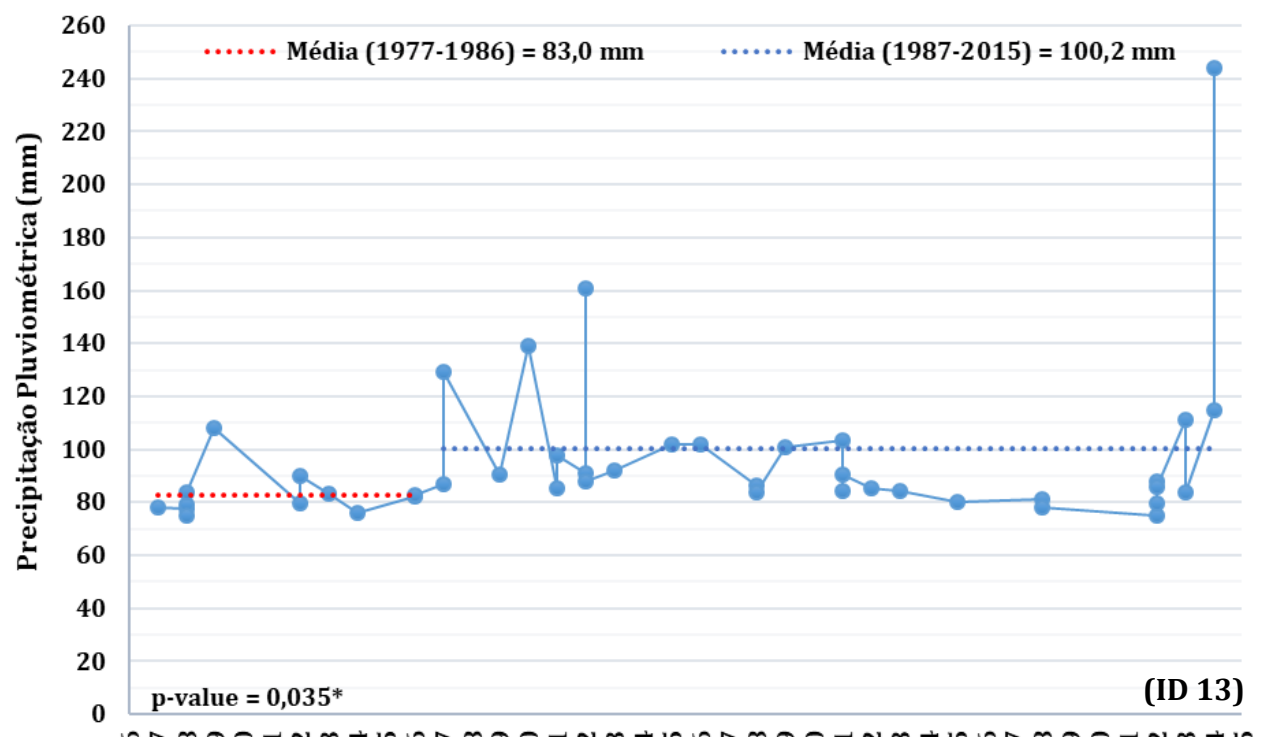

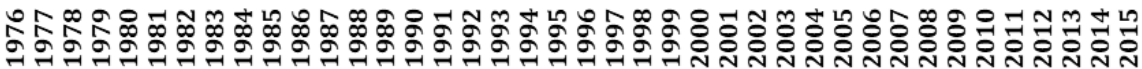

Figura 60 - Registros de chuvas muito fortes (R99p) e ruptura identificada na série histórica de São Mateus do Sul (ID 13) - Paraná. 

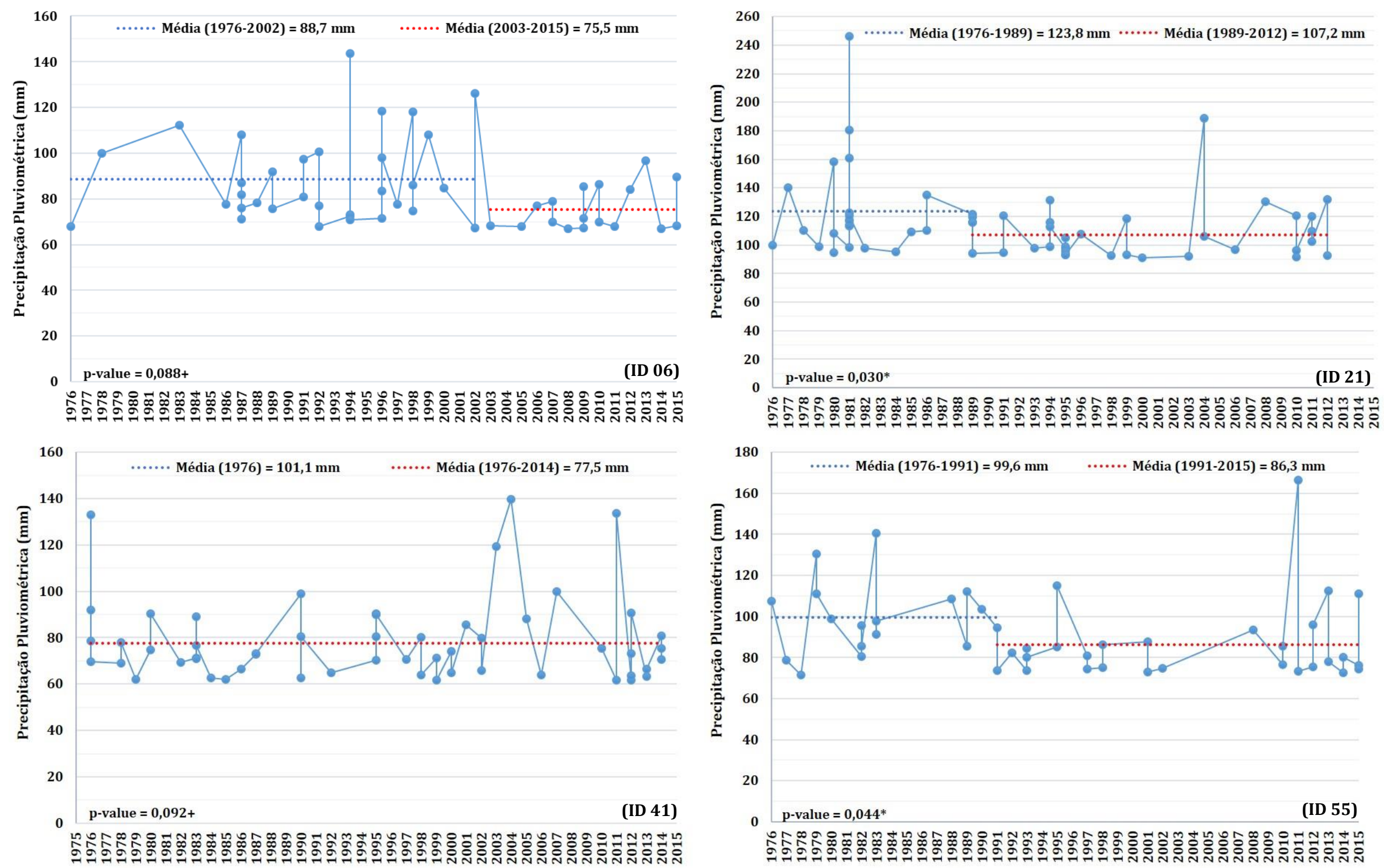

Figura 61 - Registros de chuvas muito fortes (R99p) e rupturas identificadas nas séries históricas de Mandirituba (ID 06), Antonina (ID 21), Campina Grande do Sul (ID 41) e Ponta Grossa (ID 55) - Paraná. 


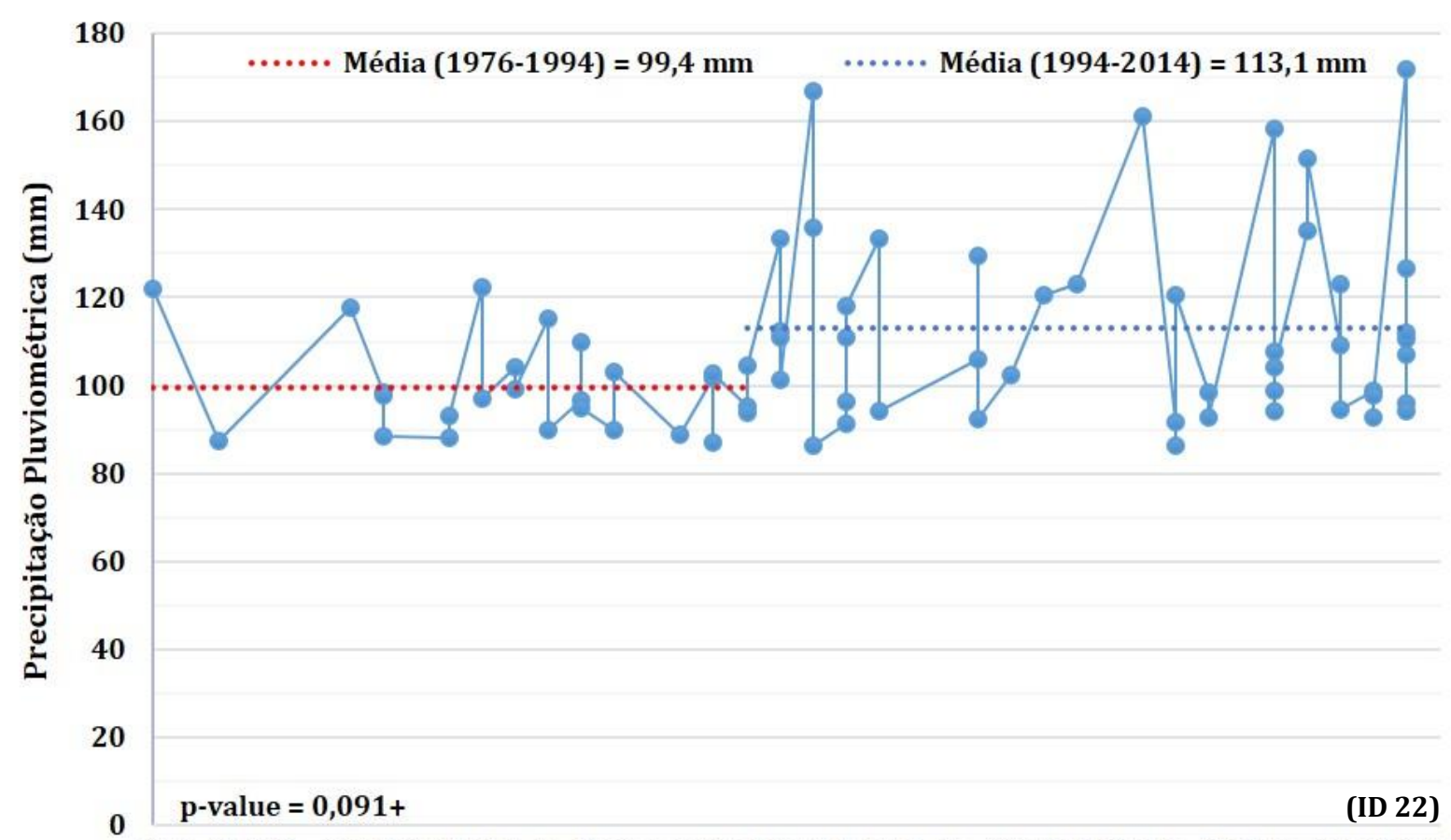

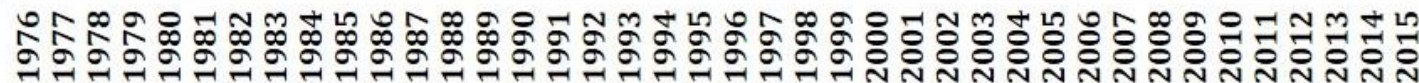

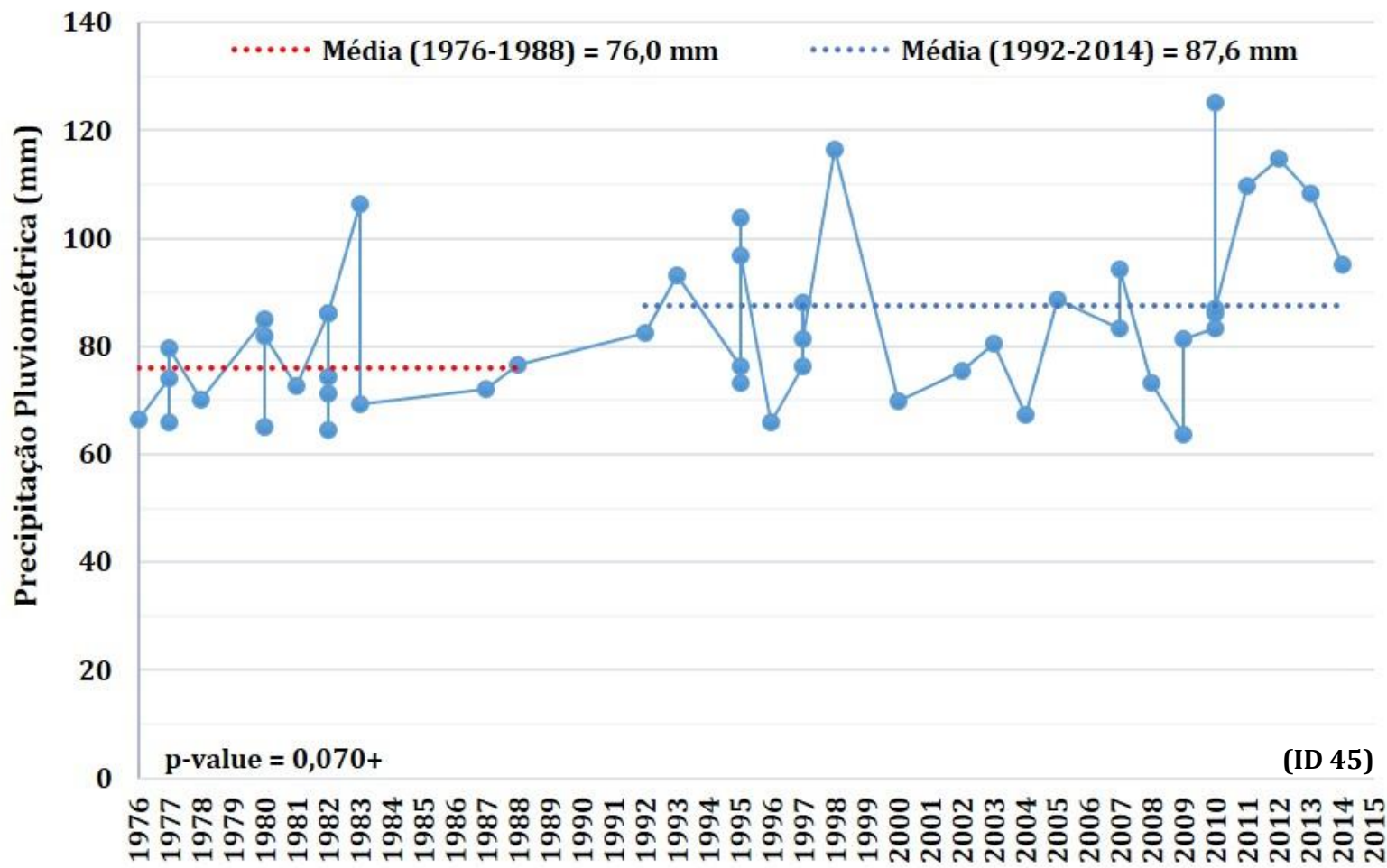

Figura 62 - Registros de chuvas muito fortes (R99p) e rupturas identificadas na série histórica de Antonina (ID 22) e Campo Largo (ID 45) - Paraná. 


\subsubsection{Indicadores de tendências da precipitação pluviométrica}

O indicador de tendências da precipitação pluviométrica que obteve os resultados mais expressivo para a área de estudo corresponde ao índice simples da intensidade diária (SDII), uma vez que se identifica modificações significativas em vinte e sete dos sessenta e dois postos pluviométricos. Na BH Alto Iguaçu, observa-se a significância estatística igual ou superior a $99 \%$ em oito localidades, com valores entre 0,07 a $0,16 \mathrm{~mm} / \mathrm{dia}$, sendo que se obteve este último valor para o posto pluviométrico de São Mateus do Sul (ID12). $\mathrm{Na}$ BH Ribeira, mostra-se o aumento da concentração das chuvas pela adição significativa do SDII em doze postos pluviométricos, sendo que dez deles obtiveram significância $\geq$ $99 \%$ e intervalos entre 0,06 a $0,21 \mathrm{~mm} /$ dia e, destacadamente se dá expressivamente mais elevado em quatro localidades (ID’s 40, 44, 50 e 57), nas quais se verificam o acréscimo de 0,16 a $0,21 \mathrm{~mm} /$ dia (Tabelas 22 e 24).

A BH Litorânea corresponde ao setor em que o SDII obteve os resultados menos expressivos, mostrando o aumento de $0,12 \mathrm{~mm} /$ dia e $99,9 \%$ de significância estatística em Guaraqueçaba (ID25) e, com 90\% de significância em Guaratuba (ID29) e Morretes (ID30), localidades em que o aumento foi de 0,08 e 0,04 mm/dia. Observa-se que a única redução do SDII, com 90\% de significância, foi verificada em Guaraqueçaba (ID27), com o decréscimo de $0,10 \mathrm{~mm} /$ dia (Tabela 23), o que se alinha as diminuições da pluviosidade total anual, das chuvas máximas diárias e das chuvas fortes anteriormente descrita para este posto pluviométrico. Desta forma, a concentração das chuvas diárias em toda área de estudo tem aumento entre 2,8 a $8,4 \mathrm{~mm} / \mathrm{dia}$, o que está de acordo com o resultado obtido para as tendências majoritárias de aumento das chuvas máximas diárias anuais.

O aumento da concentração pluvial diária é reforçado pelo aumento do número de dias consecutivos secos (CDD) e pela diminuição do número de dias consecutivos úmidos (CWD). Com 95\% de significância, nota-se o aumento do CDD de 0,15 a 0,23 dias/ano em Antonina (ID21) e Guaraqueçaba (ID28), enquanto que em Guaraqueçaba (ID25) há um aumento de 0,15 dias/ano para uma significância de 90\% (Tabela 23). Enquanto não se verifica modificação significativa do CDD para a BH Alto Iguaçu, na BH Ribeira há a elevação de 0,28 a 0,39 dia/ano deste indicador em Campina Grande do Sul (ID43) e em Campo Largo (ID44), com 95\% e 99\% de significância, nesta ordem. Em Tunas do Paraná (ID58) e Ponta Grossa (ID61), com 90\% de significância, atenta-se ao aumento de 0,17 dias secos consecutivos por ano em ambas as localidades (Tabelas 22 e 24). Ao final da 
série histórica, conforme os limites da significância estatística, verifica-se o aumento de 6,0 a 15,6 dias secos consecutivos.

Não foram verificadas tendências significativas do CWD para a BH Litorânea e, contudo, a BH Ribeira obteve em quatro postos pluviométricos a diminuição de 0,06 a 0 , 14 dia/ano, com 90\% de significância, e de 0,11 dia/ano em Bocaiúva do Sul, com 95\% de significância (Tabelas 23 e 24). Na BH Alto Iguaçu verifica-se a diminuição do CWD em 0,05 e 0,06 dia/ano, com 95\% de significância estatística, em Quitandinha (ID's 19 e 20), ao passo que em Piraquara (ID09), a diminuição foi de 0,12 dia/ano com 99,9\% de significância. Ao contrário ao identificado na maioria das tendências do índice CWD com significância, verifica-se em Tijucas do Sul (ID17) o aumento de 0,09 dias/ano, com 90\% de significância (Tabela 22). Desta forma, discorre-se que o padrão descrito acima mostra uma diminuição de dias chuvosos consecutivos entre 2,0 e 5,6 dias ao final do segmento temporal de quarenta anos.

O indicador de tendências de precipitação pluviométrica (PRCPTOT) demonstra o aumento dos totais anuais em 21 postos pluviométricos da área de estudo. Observa-se na BH Alto Iguaçu o aumento significativo da precipitação total anual em 06 localidades, dentre as quais nos postos pluviométricos de Campo Largo (ID01) e Lapa (ID03) obtevese $90 \%$ de significância para o acréscimo anual de 7,63 $\mathrm{mm}$ e 6,65 mm, nesta ordem, que corresponde a um aumento total de $305,2 \mathrm{~mm}$ e 266,0 $\mathrm{mm}$. Com 95\% de significância, em Curitiba (ID02), Mandirituba (ID06) e Porto Amazonas (ID10) verifica-se o aumento de 8,22 a $8,96 \mathrm{~mm} /$ ano, que demonstra uma elevação de $328,8 \mathrm{~mm}$ a $358,4 \mathrm{~mm}$. De modo mais expressivo e com $99 \%$ de significância, o aumento da pluviosidade total anual em São Mateus do Sul corresponde a 11,13 mm/ano e demonstra uma elevação final de 445,2 mm em relação ao início do segmento temporal estudado (Tabela 22 - Figura 65).

Na BH Litorânea, obteve-se o maior aumento anual da precipitação pluviométrica anual e a única tendência de diminuição do PRCTOT dentre todas localidades da área de estudo. Em Antonina (ID22) o aumento anual de 17,85 mm, com 99,9\% de significância, demonstra que atualmente a precipitação anual total desta localidade é 714,0 mm mais elevada em relação à metade da década de 1970. Em contraposição, verifica-se que em Guaraqueçaba (ID27) ocorre a única tendência de diminuição do PRCTOT, com 95\% de significância, como uma redução anual de 22,10 mm e que, ao final da série histórica, representa um total de $884,0 \mathrm{~mm}$ (Tabela 23 - Figura 65).

Com 95\% de significância, nota-se o aumento dos totais pluviométricos anuais em Morretes (ID32) em 9,22 mm/ano, equivalente a 368,8 mm em quarenta anos. Com menor 
significância estatística (90\%), em Paranaguá (ID35) mostra-se o aumento anual de 11,75 $\mathrm{mm}$, correspondente a $470 \mathrm{~mm}$ ao longo da série histórica (Figura 65). Igualmente com 90\% de significância, em Antonina (ID23), Morretes (ID31) e Paranaguá (ID34) dão-se os aumentos anuais de 7,83 a 9,86 mm, que na somatória do segmento temporal mostra a elevação de 313,2 mm a 394,4 mm (Tabela 23).

As tendências de aumento da precipitação pluviométrica total anual na BH Ribeira ocorrem de modo mais significativo (99\%) em Campo Largo (ID47) e Cerro Azul (ID48) a uma ordem anual de 12,61 e 8,86 mm, destacando o acréscimo equivalente a 504,4 mm e 354,4 mm. Com 95\% de significância, observa-se o aumento da pluviosidade total anual em cinco postos pluviométricos (ID's 39, 46, 49, 50 e 52), com valores que oscilam entre 5,88 a 9,20 mm/ano e que mostram um aumento total entre $235,2 \mathrm{~mm}$ e $368,0 \mathrm{~mm}$. Dentre as tendências observadas para a BH Ribeira, as menos significativas (90\%) ocorrem em Adrianópolis (ID39) e Bocaiúva do Sul (ID40), localidades nas quais os aumento anuais estão entre 6,44 e 8,17 e representam a elevação de 257,6 mm e 326,8 mm, nesta ordem (Tabela 24). Os gráficos da figura 65 destacam as tendências de aumento do PRCPTOT mais significativos e mais elevados dentre os observados para a BH Ribeira, destacandose às identificadas em Adrianópolis (ID39), Campo Largo (ID46), Campo Largo (ID47) e em Cerro Azul (ID48).

Estes resultados contradizem os obtidos por Silva et al. (2015) para o Paraná, uma vez que estes autores discorrem que a maior parte dos indicadores climáticos associados à precipitação pluviométrica não apresentaram significância estatística, com a utilização de um segmento temporal similar ao da presente pesquisa (1976-2010). No entanto, estes resultados são confirmados por Obregón e Marengo (2007), pois estes autores obtiveram o aumento significativo e expressivo em dos totais pluviométricos anuais, destacando-se a estação meteorológica de Morretes, na qual verificaram o aumento de mais de $600 \mathrm{~mm}$ em relação ao início da série temporal avaliada.

Gonçalves e Back (2018) avaliaram as tendências da precipitação pluviométrica na região Sul do Brasil e indicaram que no estado do Paraná o aumento significativo dos totais anuais são prevalecentes no setor centro-sul paranaense, bem como no centro-leste catarinense, nas proximidades da área em estudo. Observa-se também a representação da tendência de diminuição da pluviosidade total anual nas proximidades de Guaraqueçaba, corroborando a redução apontada nesta pesquisa para o posto pluviométrico desta mesma localidade (ID27). Em relação à concentração das chuvas apontadas pelo índice SDII, os autores aplicaram o Índice de Concentração da Precipitação (ICP), formulado por Oliver 
(1980), e mostraram tendências significativas de aumento da concentração pluviométrica pujantemente no centro-norte catarinense e leste do estado do Paraná, mostrando que este setor também está apresentando uma tendência de concentração das chuvas em um menor período de tempo.

Zandonadi et al. (2015) mostraram para Castro e Curitiba o aumento superior a 10,0 mm do PRCPTOT e, contudo, destacam que para a série temporal utilizada, entre 1986 e 2010, não se verifica a significância estatística (95\%). Tendo este limiar como um parâmetro da significância da tendência, observam o aumento do índice SDII em Campos do Jordão, Goiânia e São Paulo (0,10 mm/dia) e, entretanto, nenhuma destas modificações mostram-se expressivas como as verificadas em como nesta pesquisa, uma vez que o SDII se mostra igual ou superior a $0,16 \mathrm{~mm} /$ dia em seis postos pluviométricos, ressaltando-se que nestas localidades a significância estatística obtida é de 99,9\%.

Murara et al. (2018) identificaram tendências de aumento do PRCPTOT em todas as tendências estatisticamente significativas (90\%) na BH do rio Itajaí (SC), com valores que estiveram entre 3,22 a 8,01 mm/ano e representam o aumento entre 273,7 $\mathrm{mm}$ e 483,8 $\mathrm{mm}$ ao longo das séries temporais analisadas, concordantes com os aumentos mostrados pelo indicador climático nesta pesquisa. Indicaram também o aumento do SDII na maioria dos resultados com significância, destacando-se o acréscimo entre 0,13 e 0,19 mm/dia no setor noroeste da BH Itajaí, justamente nas localidades mais próximas à área deste estudo. Porém, os autores supracitados obtiveram resultados diferenciados e sem padrão definido dos indicadores climáticos CDD e CWD.

Silva e Dereczynski (2014), utilizando-se do RClimDex, avaliaram as tendências de mudanças dos indicadores climáticos no estado do Rio de Janeiro e mostraram que os totais pluviais anuais estão em uma elevação de 4,0 a 32,0 mm na mesorregião da Baixada Litorânea, tendo como parâmetro a significância de 95\%. Destacaram que as chuvas neste setor do estado estão mais concentradas, pois além de verificarem o acréscimo anuais dos totais anuais (PRCPTOT), observaram que as chuvas fortes (R95p) estão elevando-se e, simultaneamente, o CDD obteve aumente entre 0,1 a 0,6 dia/ano, resultados aproximados ao observados nas bacias hidrográficas do leste do estado do Paraná.

Os estudos de Regoto et al. (2018) para o estado do Espírito Santo demonstram o a tendência de aumento dos totais anuais de pluviosidade, com 95\% de significância, de 5,1 e 10,3 mm ao ano. Estes autores também indicaram o aumento do CDD, entre 0,2 e 0,4 dia/ano, indicando um prolongamento da estação seca e a elevação da concentração pluvial, conforme observado na Baixada Litorânea do Rio de Janeiro e nesta pesquisa. 
Tabela 22 - Indicadores de tendências da precipitação pluviométrica na BH do Alto Iguaçu - Paraná.

\begin{tabular}{|c|c|c|c|c|c|c|c|c|c|c|c|}
\hline ID & $\begin{array}{c}\text { Postos } \\
\text { pluviométricos }\end{array}$ & SDII & CDD & CWD & PRCPTOT & RX1day & RX5day & $\begin{array}{l}\text { R10 } \\
\text { mm }\end{array}$ & $\begin{array}{l}\text { R20 } \\
\text { mm }\end{array}$ & R95p & R99p \\
\hline 1 & Campo Largo & $\mathbf{0 , 0 9}^{* * * *}$ & 0,06 & $-0,04$ & $7, \mathbf{6 3}^{+}$ & 0,37 & 0,55 & 0,18 & $0,23^{* * *}$ & 3,44 & 1,20 \\
\hline 2 & Curitiba & $0,06^{*}$ & $-0,15$ & $-0,02$ & $8,22^{*}$ & $0,66^{*}$ & 0,91 & 0,20 & $\mathbf{0 , 1 7 ^ { + }}$ & $4,96^{*}$ & 1,40 \\
\hline 3 & Lapa & $0,07^{* * * *}$ & $-0,03$ & $-0,01$ & $6,65^{+}$ & $0,75^{+}$ & 0,53 & 0,12 & $\mathbf{0 , 1 8}{ }^{+}$ & $4, \mathbf{0 3}^{+}$ & $2,3^{+}$ \\
\hline 4 & Lapa & $\mathbf{0 , 1 0}{ }^{* * * *}$ & 0,09 & $-0,05$ & 5,50 & 0,59 & 1,00 & 0,01 & $0,17^{+}$ & $4,58^{*}$ & 2,02 \\
\hline 5 & Lapa & 0,02 & $-0,04$ & $-0,01$ & 5,6 & 0,24 & 0,94 & 0,16 & 0,14 & 1,54 & $-0,06$ \\
\hline 6 & Mandirituba & $0,09^{* *}$ & $-0,11$ & $-0,02$ & $8,23^{*}$ & 0,32 & 0,67 & 0,21 & $\mathbf{0 , 3 3} 3^{* * * *}$ & $5,21^{*}$ & 0,27 \\
\hline 7 & Pinhais & $\mathbf{0 , 0 4 ^ { + }}$ & 0,14 & 0,00 & 5,99 & 0,40 & 0,46 & 0,24 & 0,09 & 3,77 & $2,5^{+}$ \\
\hline 8 & Piraquara & $-0,06$ & $-0,12$ & $-0,06$ & $-12,33$ & $-0,58$ & $-1,67^{+}$ & $-0,18$ & $-0,17$ & $-9,09$ & $-5,34$ \\
\hline 9 & Piraquara & $0,07^{* *}$ & 0,06 & $-0,12^{* * * *}$ & 0,57 & 0,44 & 0,08 & 0,01 & 0,03 & 2,17 & 0,67 \\
\hline 10 & Porto Amazonas & 0,01 & $-0,09$ & 0,04 & $8,96 *$ & 0,24 & 0,71 & $\mathbf{0 , 2 2 ^ { + }}$ & 0,14 & 1,46 & 0,12 \\
\hline 11 & São José dos Pinhais & 0,05 & 0,08 & $-0,02$ & 5,24 & 0,41 & 0,10 & 0,15 & 0,13 & 2,32 & 1,80 \\
\hline 12 & São Mateus do Sul & $0,16{ }^{* * *}$ & 0,20 & $-0,05$ & 1,70 & 0,79 & 0,98 & $-0,08$ & 0,19 & 3,52 & $3,20^{*}$ \\
\hline 13 & São Mateus do Sul & $0,06 *$ & 0,11 & 0,00 & $11,13^{* *}$ & 0,39 & $1,69^{*}$ & $0,35^{* *}$ & $\mathbf{0 , 1 8}{ }^{+}$ & $4,51^{+}$ & 0,49 \\
\hline 14 & São Mateus do Sul & 0,02 & $-0,16$ & $-0,04$ & 3,92 & 0,14 & 0,54 & 0,04 & 0,06 & 4,01 & $-0,09$ \\
\hline 15 & São José do Triunfo & $\mathbf{0 , 0 8}{ }^{* *}$ & 0,04 & $-0,03$ & 3,10 & $-0,20$ & 0,22 & 0,06 & 0,07 & 2,41 & 1,33 \\
\hline 16 & Rio Negro & 0,00 & $-0,02$ & 0,02 & 3,23 & 0,49 & 0,58 & 0,07 & 0,03 & 1,35 & $-0,19$ \\
\hline 17 & Tijucas do Sul & 0,02 & 0,10 & $0,09^{+}$ & 2,25 & 0,11 & 0,16 & 0,00 & 0,01 & 0,99 & 0,04 \\
\hline 18 & Piên & 0,01 & $-0,04$ & 0,01 & 6,28 & 0,14 & 0,51 & 0,05 & 0,14 & 5,31 & $3,35^{+}$ \\
\hline 19 & Quitandinha & 0,03 & $-0,09$ & $-0,06 *$ & 0,62 & 0,08 & 0,01 & 0,02 & $-0,01$ & 0,33 & 0,14 \\
\hline 20 & Quitandinha & $\mathbf{0 , 0 8}^{* * * *}$ & 0,06 & $-0,05 *$ & 3,83 & 0,26 & 0,45 & 0,09 & 0,09 & 2,37 & 0,35 \\
\hline 62 & Palmeira & 0,02 & 0,05 & 0,03 & 5,90 & 0,47 & $1,11^{+}$ & 0,17 & 0,13 & 1,64 & 0,98 \\
\hline
\end{tabular}

Legenda: ${ }^{* * *}=99,9 \%$ de significância $;{ }^{* *}=99 \%$ de significância $;{ }^{*}=95 \%$ de significância; ${ }^{+}=90 \%$ de significância.

Tabela 23 - Indicadores de tendências da precipitação pluviométrica na BH Litorânea - Paraná.

\begin{tabular}{|c|c|c|c|c|c|c|c|c|c|c|c|}
\hline ID & $\begin{array}{c}\text { Postos } \\
\text { pluviométricos }\end{array}$ & SDII & CDD & CWD & PRCPTOT & RX1day & RX5day & R10 mm & R20 mm & R95p & R99p \\
\hline 21 & Antonina & $-0,04$ & $0,15^{*}$ & 0,00 & $-5,26$ & $-0,71$ & $-1,06$ & $-0,05$ & $-0,05$ & $-6,47$ & $-4,29$ \\
\hline 22 & Antonina & 0,00 & $-0,04$ & 0,09 & $17,85^{* * *}$ & $1,04^{* *}$ & $1,86^{*}$ & $0,35^{*}$ & $0, \mathbf{1 6}^{+}$ & $8,48^{*}$ & $5,27^{*}$ \\
\hline 23 & Antonina & 0,02 & $-0,05$ & 0,33 & $9,86^{+}$ & 0,53 & $2,11^{*}$ & 0,23 & 0,10 & 6,40 & $4,26^{+}$ \\
\hline 24 & Guaraqueçaba & $-0,03$ & $-0,02$ & 0,02 & 3,61 & 0,42 & 0,07 & $-0,01$ & 0,097 & 1,33 & 3,42 \\
\hline 25 & Guaraqueçaba & $0,12 * * *$ & $0,15^{+}$ & 0,01 & 1,89 & 1,12 & 0,99 & 0,12 & 0,06 & 0,36 & $4,44^{+}$ \\
\hline 26 & Guaraqueçaba & 0,00 & 0,05 & 0,00 & 7,35 & 0,39 & 0,01 & 0,26 & 0,17 & $-0,92$ & 1,55 \\
\hline 27 & Guaraqueçaba & $-0,10^{+}$ & 0,13 & $-0,03$ & $-22,10 *$ & $-0,26$ & 1,20 & $-0,80^{* * * *}$ & $-0,57^{* * * *}$ & $-9,75^{+}$ & $-3,80$ \\
\hline 28 & Guaraqueçaba & 0,02 & $\mathbf{0 , 2 3} *$ & $-0,02$ & 0,21 & $-0,27$ & 0,51 & 0,22 & 0,02 & $-2,45$ & $-0,82$ \\
\hline 29 & Guaratuba & 0,01 & 0,02 & 0,03 & 4,24 & 0,07 & $-0,15$ & 0,14 & 0,08 & 1,32 & 0,61 \\
\hline 30 & Guaratuba & $\mathbf{0 , 0 8}^{+}$ & 0,09 & $-0,05$ & $-14,1$ & $-0,59$ & $-0,77$ & $-0,38$ & $-0,32^{+}$ & $-6,69$ & $-1,47$ \\
\hline 31 & Morretes & $0,04^{+}$ & 0,07 & $-0,04$ & $7, \mathbf{8 3}^{+}$ & $1,17 *$ & 0,90 & $\mathbf{0 , 2 3}^{+}$ & 0,10 & 3,25 & $3,84^{+}$ \\
\hline 32 & Morretes & 0,00 & $-0,09$ & 0,11 & $9,22^{*}$ & 0,96 & 0,85 & 0,21 & 0,10 & 2,54 & 3,18 \\
\hline 33 & Morretes & $-0,02$ & $-0,02$ & $-0,03$ & 0,75 & $-1,03^{+}$ & $-2,44 *$ & 0,12 & 0,10 & $-3,37$ & $-3,40$ \\
\hline 34 & Paranaguá & 0,02 & $-0,04$ & 0,00 & $8,60^{+}$ & 0,67 & 0,33 & 0,23 & 0,16 & 1,75 & 1,44 \\
\hline 35 & Paranaguá & 0,04 & 0,07 & $-0,01$ & $11,75^{+}$ & 0,43 & 0,65 & $\mathbf{0 , 3 1 ^ { + }}$ & $0,25^{+}$ & 4,33 & 0,71 \\
\hline 36 & São J. dos Pinhais & 0,02 & 0,09 & 0,04 & 2,65 & 0,37 & 0,28 & 0,07 & 0,04 & 0,78 & 0,40 \\
\hline
\end{tabular}

Legenda: ${ }^{* * *}=99,9 \%$ de significância; ${ }^{* *}=99 \%$ de significância; ${ }^{*}=95 \%$ de significância; ${ }^{+}=90 \%$ de significância. 
Tabela 24 - Indicadores de tendências da precipitação pluviométrica na BH do rio Ribeira - Paraná.

\begin{tabular}{|c|c|c|c|c|c|c|c|c|c|c|c|}
\hline ID & $\begin{array}{c}\text { Postos } \\
\text { pluviométricos }\end{array}$ & SDII & CDD & CWD & PRCPTOT & RX1day & RX5day & $\begin{array}{l}\text { R10 } \\
\text { mm }\end{array}$ & $\begin{array}{l}\text { R20 } \\
\text { mm }\end{array}$ & R95p & R99p \\
\hline 37 & Adrianópolis & 0,06 & 0,09 & $-0,04$ & $6,44^{+}$ & 0,44 & 0,87 & 0,17 & 0,12 & 2,62 & 1,04 \\
\hline 38 & Adrianópolis & 0,01 & 0,05 & $-0,05$ & $-0,45$ & 0,23 & 0,07 & $-0,05$ & 0,00 & 1,83 & 0,96 \\
\hline 39 & Adrianópolis & $0,08^{* * * *}$ & 0,08 & 0,00 & $9,20 *$ & 0,16 & 0,42 & $0,30^{+}$ & $0,43^{* * *}$ & $-0,20$ & 1,39 \\
\hline 40 & Bocaiúva do Sul & $0,18^{* * * *}$ & 0,15 & $-0,11 * *$ & $8,17^{+}$ & $0,69^{*}$ & $1,37^{*}$ & 0,19 & $\mathbf{0 , 2 3}{ }^{*}$ & $6,92^{* * *}$ & 2,00 \\
\hline 41 & Campina G. do Sul & 0,03 & 0,09 & $-0,04$ & 3,53 & $0,62^{+}$ & 0,81 & $-0,03$ & 0,05 & $3,98^{+}$ & 1,32 \\
\hline 42 & Campina G. do Sul & $-0,10$ & $-0,05$ & 0,07 & 2,68 & 0,29 & 0,83 & 0,00 & 0,04 & 2,20 & 1,71 \\
\hline 43 & Campina G. do Sul & 0,00 & $0,28^{*}$ & $-0,05$ & $-6,49$ & $-0,55$ & $-0,54$ & 0,04 & $-0,23^{*}$ & $-4,11$ & $-2,67$ \\
\hline 44 & Campo Largo & $0,16^{* * * *}$ & $\mathbf{0 , 3 9} 9^{* *}$ & $-0,09^{+}$ & 0,04 & $0, \mathbf{4 6}^{+}$ & $-0,26$ & 0,01 & 0,06 & $3,41^{+}$ & 1,04 \\
\hline 45 & Campo Largo & $-0,03$ & 0,00 & 0,04 & 4,19 & $0,62 *$ & $1, \mathbf{0 8}^{+}$ & 0,10 & 0,02 & 1,25 & 0,25 \\
\hline 46 & Campo Largo & 0,02 & $-0,08$ & 0,03 & 9,07* & $0,69^{+}$ & 1,07 & 0,27 & 0,12 & 4,08 & 3,22 \\
\hline 47 & Campo Largo & $0,10^{*}$ & $-0,10$ & 0,00 & $12,61^{* *}$ & 0,30 & 0,31 & $0,42^{* * *}$ & $0,40^{* * * *}$ & $5,27^{+}$ & 0,48 \\
\hline 48 & Cerro Azul & $0,08^{* * *}$ & 0,13 & 0,03 & $8,86^{* *}$ & $0,76^{*}$ & $1,06^{*}$ & 0,17 & $0,16^{*}$ & $6,47^{* * *}$ & $2,79^{*}$ \\
\hline 49 & Cerro Azul & $\mathbf{0 , 0 6}^{* *}$ & 0,03 & $-0,04$ & $5,88^{*}$ & $0,74^{*}$ & 0,65 & $\mathbf{0 , 1 8 ^ { + }}$ & $\mathbf{0 , 1 3}{ }^{+}$ & $5,18^{\text {*** }}$ & 1,67 \\
\hline 50 & Cerro Azul & $0,20^{* * * *}$ & 0,09 & $-0,07^{+}$ & $7,14^{*}$ & 0,52 & $0,81^{+}$ & 0,17 & 0,10 & 2,44 & 1,00 \\
\hline 51 & Cerro Azul & $0,04^{+}$ & 0,13 & 0,04 & 1,64 & 0,32 & 0,06 & $-0,02$ & 0,03 & 3,63 & 2,30 \\
\hline 52 & Doutor Ulysses & $\mathbf{0 , 0 6}^{* *}$ & $-0,11$ & 0,00 & $8,70^{*}$ & $0,51^{+}$ & $0,92^{+}$ & 0,16 & $0,15^{*}$ & $5,13^{*}$ & 1,52 \\
\hline 53 & Doutor Ulysses & 0,05 & 0,02 & $-0,14^{+}$ & $-9,99$ & 0,28 & $-0,91$ & $-0,29$ & $-0,14$ & $-2,50$ & -1.07 \\
\hline 54 & Itaperuçu & $0,06^{* *}$ & 0,04 & $-0,01$ & 6,02 & 0,30 & 0,81 & 0,08 & 0,10 & $3,99^{+}$ & 2,15 \\
\hline 55 & Ponta Grossa & 0,00 & $-0,19$ & 0,01 & 5,86 & 0,09 & $-0,09$ & 0,14 & 0,13 & 1,37 & 0,09 \\
\hline 56 & Rio Branco do Sul & 0,10 & 0,01 & 0,05 & 2,68 & 0,33 & 0,40 & 0,15 & $-0,01$ & 0,16 & $-0,81$ \\
\hline 57 & Rio Branco do Sul & $0,21^{* * * *}$ & 0,19 & $-0,06^{+}$ & 4,70 & 0,14 & 0,46 & 0,11 & $\mathbf{0 , 2 1}{ }^{*}$ & $3,95^{+}$ & 0,78 \\
\hline 58 & Tunas do Paraná & $0,10^{* * * *}$ & $\mathbf{0 , 1 7 ^ { + }}$ & $-0,05$ & 2,59 & 0,40 & 0,68 & $-0,03$ & 0,10 & $3,92^{+}$ & 0,38 \\
\hline 59 & Castro & 0,02 & 0,00 & 0,04 & 7,05 & 0,20 & 0,83 & 0,19 & 0,16 & 3,10 & 0,30 \\
\hline 60 & Castro & 0,05 & $-0,01$ & $-0,03$ & 6,59 & 0,35 & 0,53 & 0,01 & 0,11 & $5,63 *$ & 2,14 \\
\hline 61 & Ponta Grossa & 0,02 & $\mathbf{0 , 1 7 ^ { + }}$ & 0,02 & 1,47 & 0,30 & 0,87 & $-0,04$ & 0,05 & 2,47 & 1,17 \\
\hline
\end{tabular}

Legenda: ${ }^{* * *}=99,9 \%$ de significância; ${ }^{* *}=99 \%$ de significância; ${ }^{*}=95 \%$ de significância; ${ }^{+}=90 \%$ de significância.

As análises de Dufek e Ambrizzi (2008) sobre as tendências de precipitação anual mostram que 59,3\% do estado de São Paulo caracterizaram-se pelo aumento estaticamente significativo (95\%) do indicador climático PRCPTOT, enquanto que 8,5\% do território paulista obteve significância para a diminuição dos totais anuais de precipitação pluviométrica. Destacam que para a série de dados mais recentes (1990-1999), verifica-se o aumento significativo de dias secos consecutivos (CDD) e o aumento de dias de chuva superior a $20 \mathrm{~mm}$ (R20mm), que associados à significativa diminuição do número máximo de 5 dias com chuva (RX5day), mostram de modo consistente a concentração pluvial, como observado anteriormente para os estados do Rio de Janeiro e Espírito Santo.

Estes resultados se diferem aos observados por Silva et al. (2018) em bacias hidrográficas do estado da Paraíba, uma vez que obtiveram a tendência dominante de redução dos totais pluviais anuais associados ao aumento do CDD e à diminuição do SDII. Deste modo, mostraram que a diminuição anual das chuvas está associada a maior duração dos períodos secos e não relacionada ao aumento da concentração pluvial como averiguado nesta pesquisa e anteriormente em setores dos estados de São Paulo, Rio de Janeiro e Espírito Santo. 


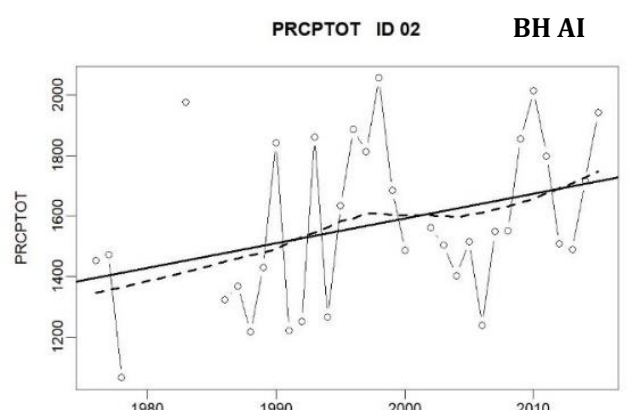

${ }_{1980}^{1980} \underset{\substack{\text { Year } \\ R 2=12}}{2000} \begin{gathered}2010 \\ \text { p-value }=0.048\end{gathered}$

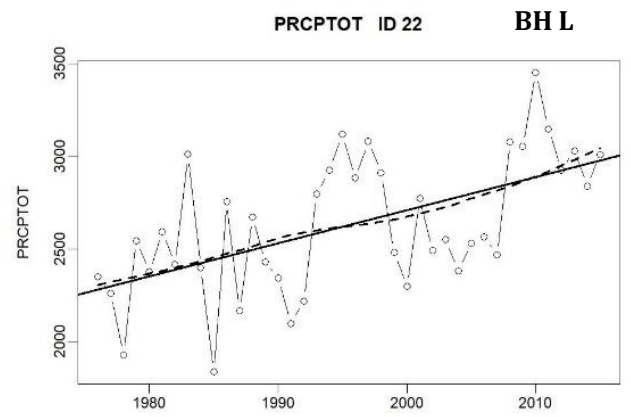

$R 2=32.6$ p-value= 0 Slope estimate= 17.852 slope error $=4.159$

PRCPTOT ID $39 \quad$ BH R

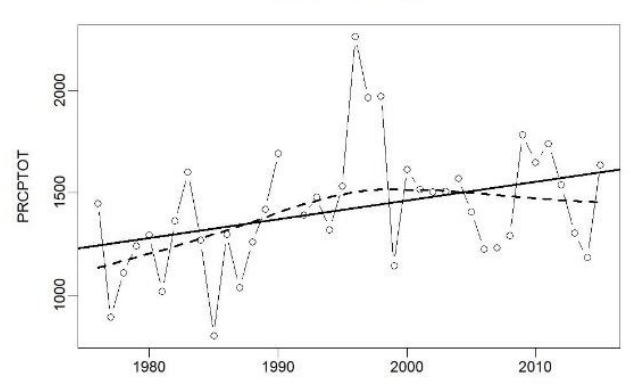

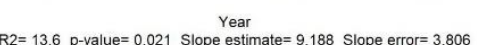

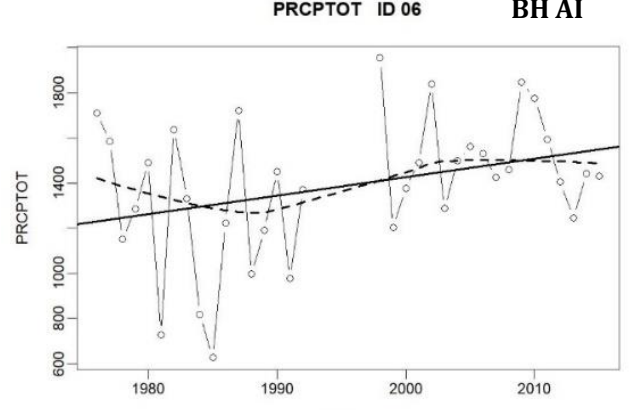

R2=11.3 p-value= 0.049 Slope estimate= 8.237 Slope error $=4.025$

PRCPTOT ID $27 \quad$ BH L

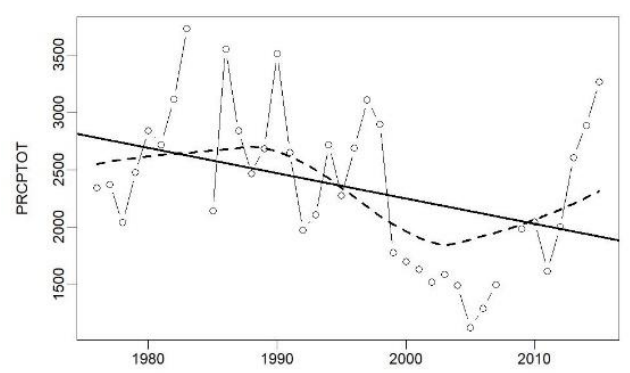

R2= 151 p-value $=0.016$ Slope estimate $=-22.102$ slope error $=8.727$

PRCPTOT ID $46 \quad$ BH R

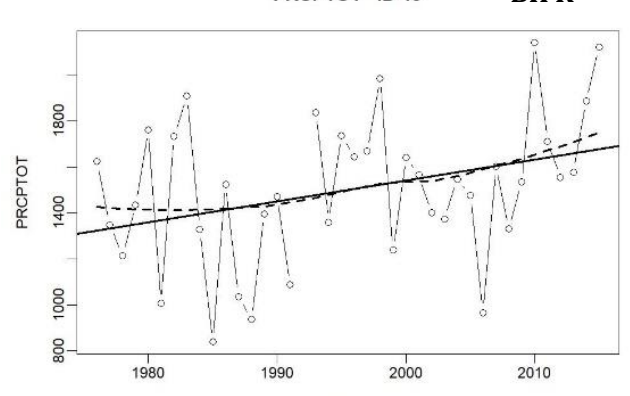

Year

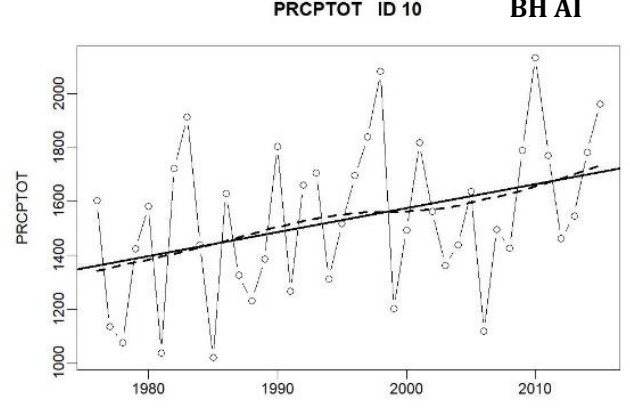

$R 2=13.8$ p-value= 0.018 Slope estimate= 8.956 Slope error $=3.628$

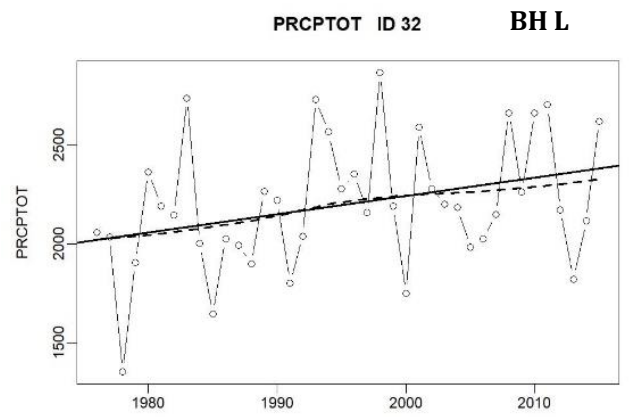

$R 2=10.8$ p-value $=0.039$ Slope estimate $=9.222$ slope error 4.31

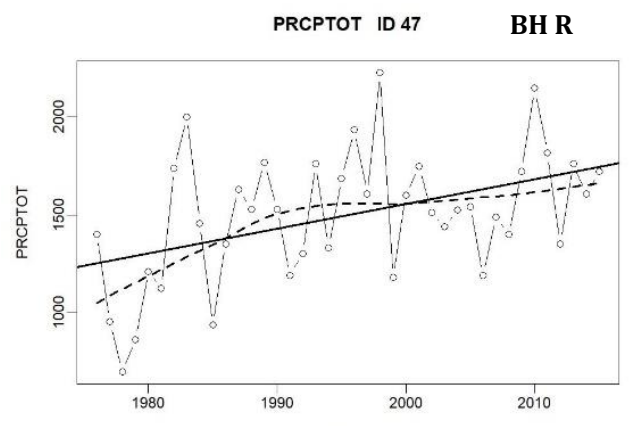

Year

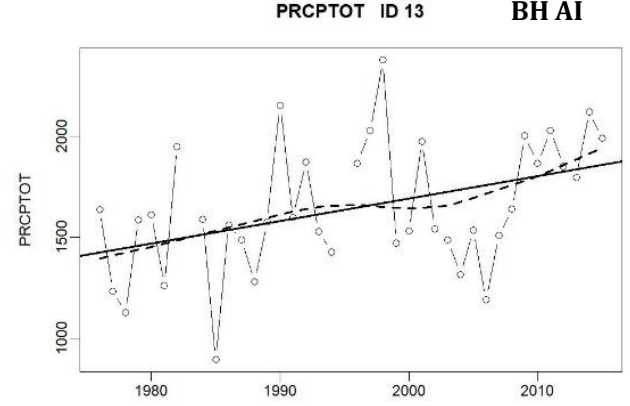

$R 2=16.9$ p-value= 0.01 Slope estimate 11.131 slope error= 4.114

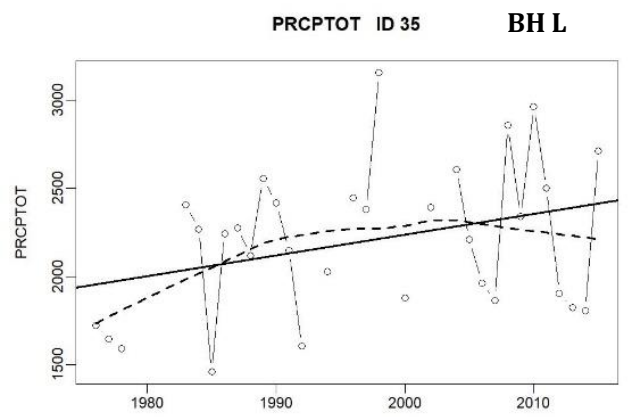

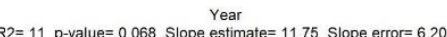

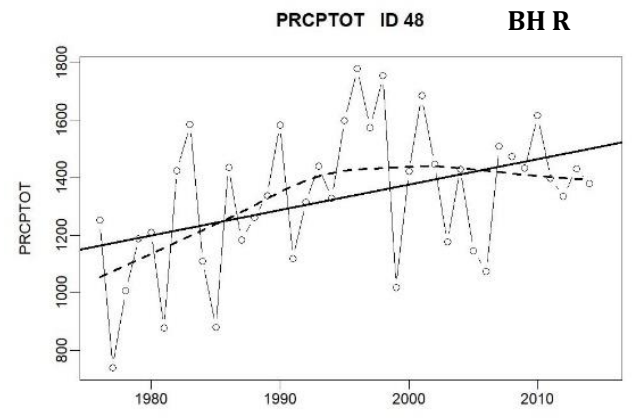

Year

Figura 63 - Tendências da precipitação pluviométrica total anual (PRCPTOT) nas BH do Alto Iguaçu (AI), Litorânea (L) e Ribeira (R) - Paraná. 
Os resultados referentes às chuvas máximas diárias em um mês (RX1day) indicam tendências mais expressivas deste índice para a BH Ribeira, sendo que em quatro postos pluviométricos (ID's 40, 45, 48 e 49) obteve-se o aumento de 0,62 a 0,76 mm/ano com significância de 95\%. Com uma menor significância (90\%), demonstra-se o aumento de 0,46 a 0,62 mm/ano destas alturas pluviométricas em três localidades da BH Ribeira (ID's 41, 44 e 46), conforme demonstram a tabela 24 e a figura 66. Considerando os resultados com maior significância, ao final do segmento temporal verifica-se o aumento entre 24,8 e 30,4 mm da chuva máxima diária, o que reforça os resultados observados anteriormente e as tendências de concentração das chuvas em um menor período de tempo.

$\mathrm{Na}$ BH Alto Iguaçu, obteve-se em Curitiba (ID02) o aumento de 0,66 mm/ano da RX1day, com 95\% de significância, o que significa que ao longo da série histórica a chuva máxima diária aumentou em 26,4 mm na capital paranaense. Em Lapa (ID03), com 90\% de significância, observa-se o aumento de $0,75 \mathrm{~mm} / \mathrm{ano}$, equivalente a $30 \mathrm{~mm}$ em 40 anos. $\mathrm{Na}$ BH Litorânea este mesmo índice demonstra o aumento das chuvas máximas diárias em 1,04 e 1,17 mm/ano em Antonina (ID22) e Morretes (ID31), nesta ordem, com 99\% e $95 \%$ de significância, que corresponde ao aumento de 41,6 mm e 46,8 $\mathrm{mm}$. A exceção dentre os resultados obtidos se dá pela diminuição do RX1day para Morretes (ID33) em $1,03 \mathrm{~mm} / \mathrm{ano}$, com 90\% de significância, e que indica chuvas máximas diárias com menor intensidade 41,2 $\mathrm{mm}$ nesta localidade (Tabela 24 - Figura 66).

Dentre os principais resultados obtidos a partir do RX5day, destaca-se a tendência predominante do aumento dos totais máximos anuais em cinco dias consecutivos em 08 postos pluviométricos. A tendência de aumento entre 1,06 e 2,11 mm/ano em localidades como São Mateus do Sul (ID13) na BH Alto Iguaçu, em Antonina (ID’s 22 e 23) na BH Litorânea, em Bocaiúva do Sul (ID40) e Cerro Azul (ID48) na BH Ribeira, com 95\% de significância. Isto indica que os totais pluviais máximos anuais concentrados em cinco dias consecutivos estão 42,4 mm a 84,4 mm mais elevados (Tabela 24 - Figura 67).

Com $90 \%$ de significância, o RX5day indica a elevação de 0,81 a 1,11 mm/ano em Palmeira (ID62) na BH Alto Iguaçu, em Campo Largo (ID45) e Cerro Azul (ID50) na BH Ribeira. Com tendência significativa (95\%) de redução deste indicador climático (-2,44 mm/ano), revela-se uma diminuição de 97,6 mm do total anual máximo acumulado anual em cinco dias consecutivos em Morretes (ID33), posto pluviométrico no qual o indicador RX1day também demonstra redução dos totais máximos diários anuais. Em Piraquara (ID08), na BH Alto Iguaçu revela-se uma diminuição do RX5day em 1,67 mm/ano com 90\% de significância (Tabela 24 - Figura 67). 


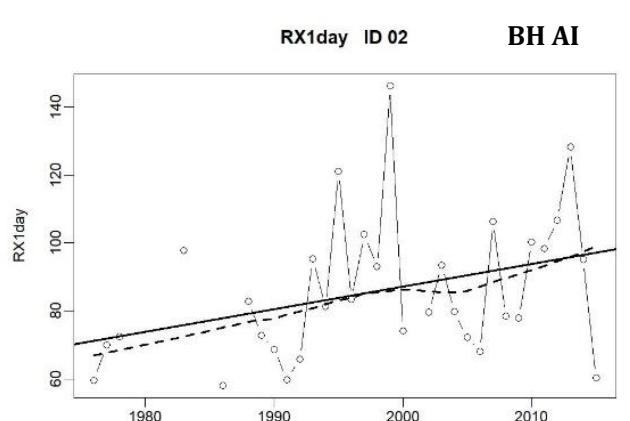

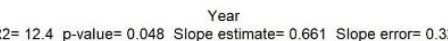

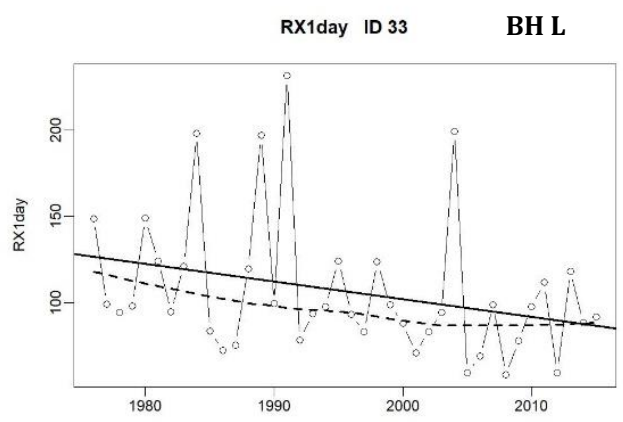

$R 2=9$ p-value $=0.06$ Slope estimate $=-1.029$ Slope error $=0.53$

RX1day ID $45 \quad$ BH R

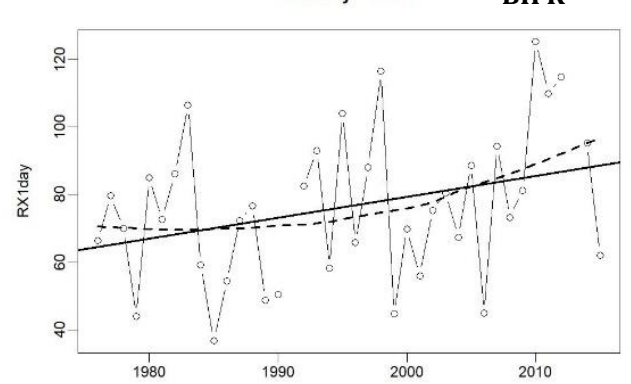

$R 2=10.6$ p-value $=0.046$ Slope estimate $=0.616$ Slope error $=0.299$

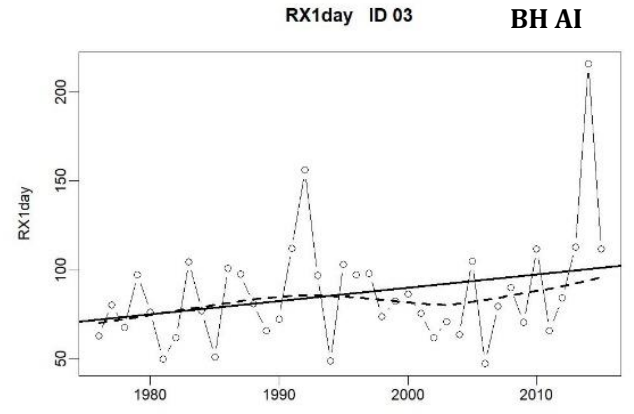

$R 2=82$ p-value $=0.072$ Slope estimate $=0.749$ Slope error $=0.406$

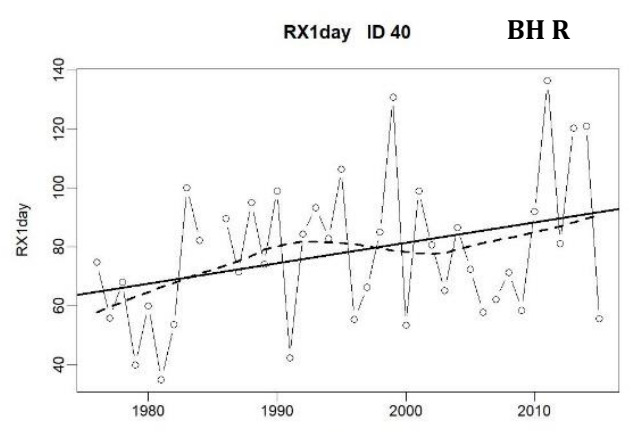

$R 2=11.3 p$-value $=0.036$ Slope estimate $=0.694$ Slope error= 0.319

RX1day ID $46 \quad$ BH R

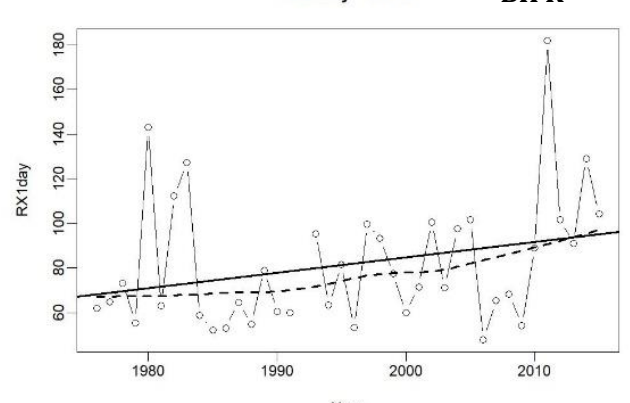

$R 2=7.9$ p-value $=0.083$ Slope estimate $=0.69$ Slope error $=0.387$

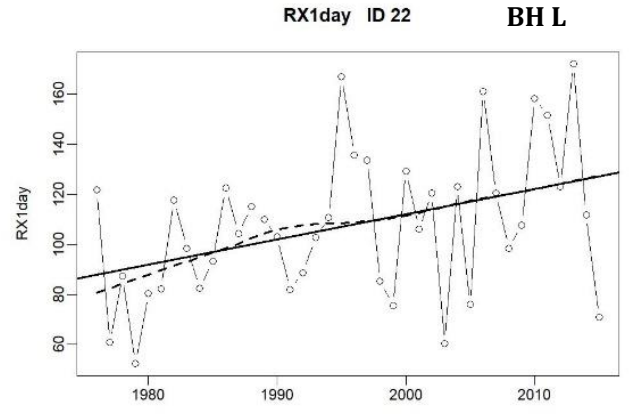

R2= 16 p-value= 0.01 Slope estimate $=1.004$ Slope error 0.373

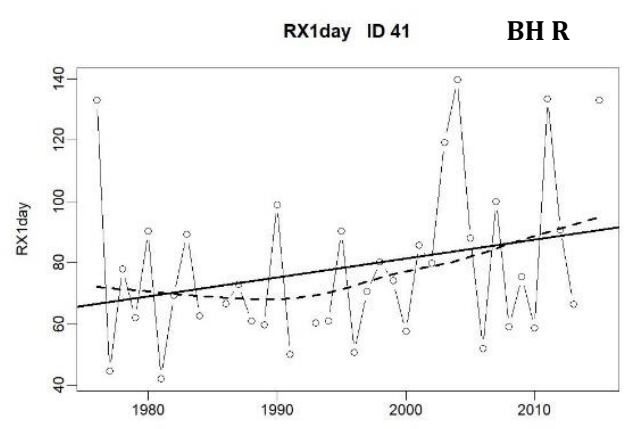

$R 2=7.6$ p-value $=0.098$ Slope estimate $=0.617$ Slope error $=0.363$

RX1day ID $48 \quad$ BH R

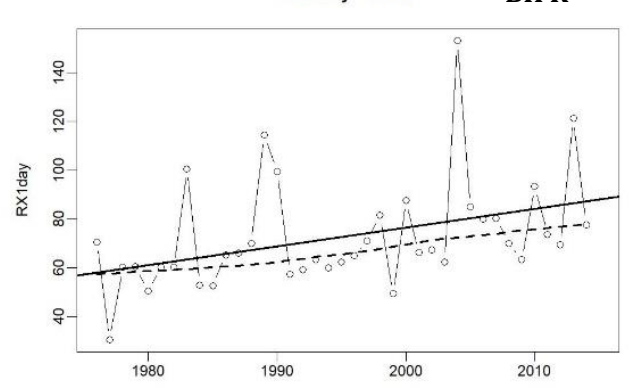

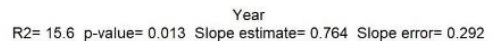

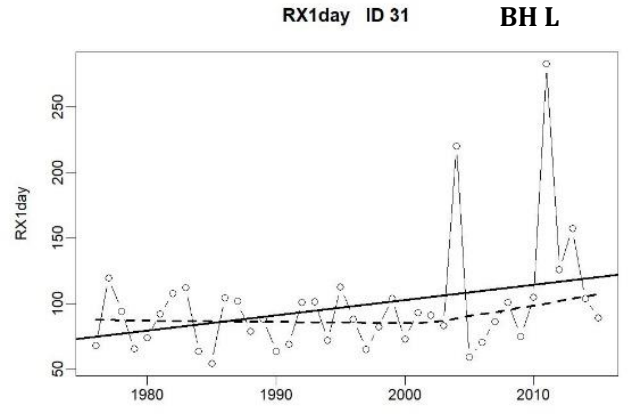

$R 2=10.7$ p-value $=0.04 \begin{gathered}\text { Year } \\ \text { Slope estimate }=1.171 \text { Slope error }=0.55\end{gathered}$

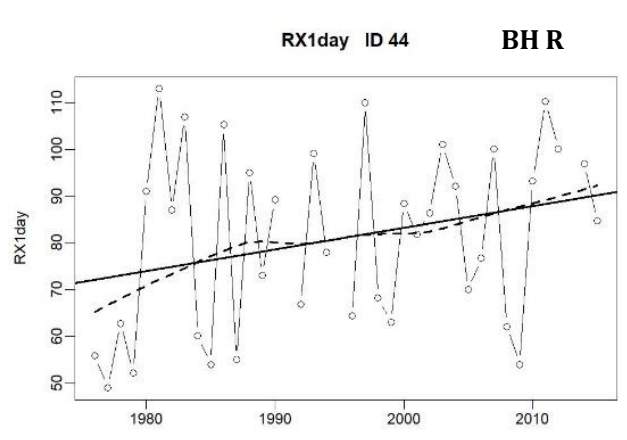

$\mathrm{R} 2=8$ p-value $=0.09$ Slope estimate $=0.463$ Slope error $=0.265$

RX1day ID $49 \quad$ BH R

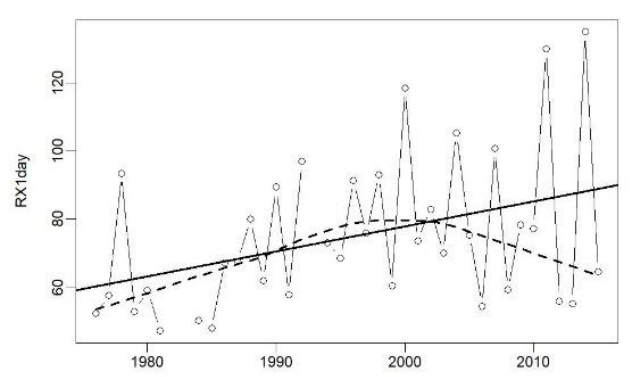

R2=15.1p p-value $=0.018$ slope estimate $=0.737$ Slope error $=0.296$

Figura 64 - Tendências da precipitação pluviométrica máxima diária anual (RX1day) nas BH do Alto Iguaçu (AI), Litorânea (L) e Ribeira (R) - Paraná. 


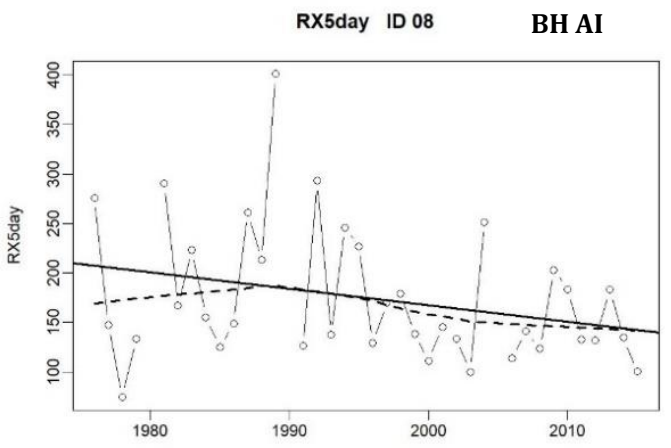

$R 2=8.2$ p-value $=0.085$ Slope estimate $=-1.67$ Slope error $=0.943$

RX5day ID 22

BH L

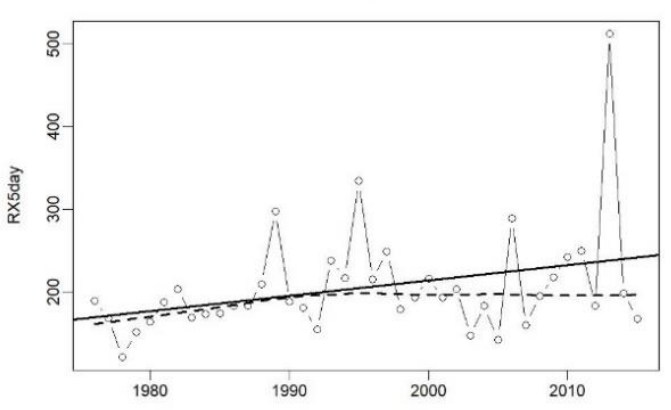

$R 2=11$ p-value $=0.037$ Slope estimate= 1.863 slope error= 0.86

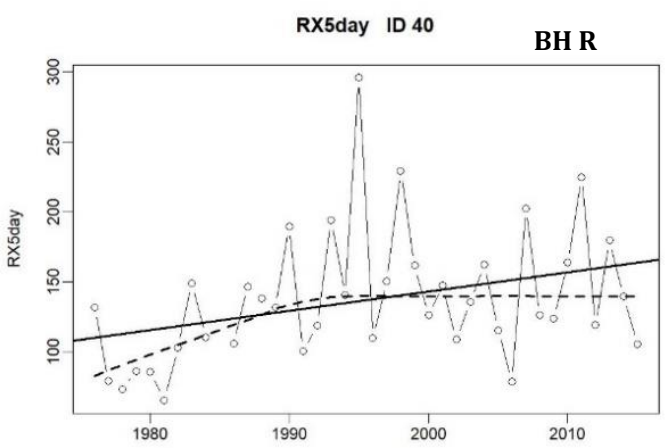

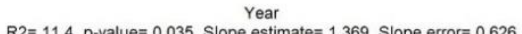

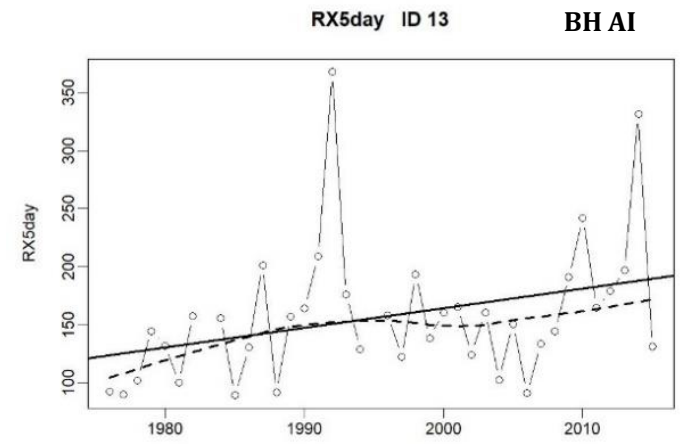

$R 2=11.5$ p-value $=0.038$ Slope estimate= 1.695 Slope error $=0.786$

RX5day ID 23

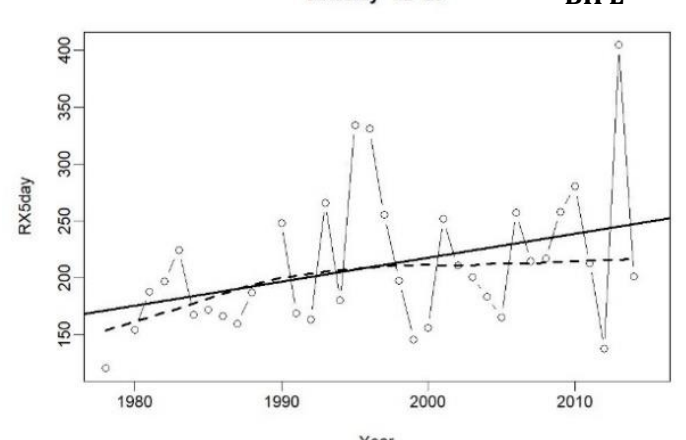

$R 2=13.6$ p-value $=0.029 \begin{gathered}\text { Year } \\ \text { slope estimate }=2.105 \text { slope error }=0.924\end{gathered}$

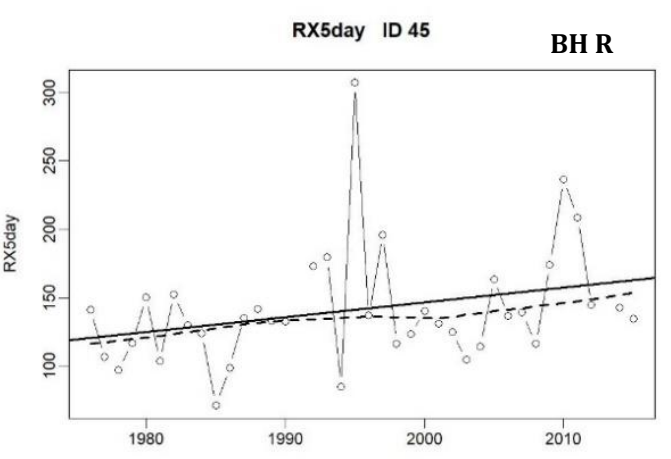

$\begin{gathered}\text { Year } \\ \text { R2 }\end{gathered}=86$ p-value $=0.074$ Slope estimate $=1084$ Slope error $=0.588$

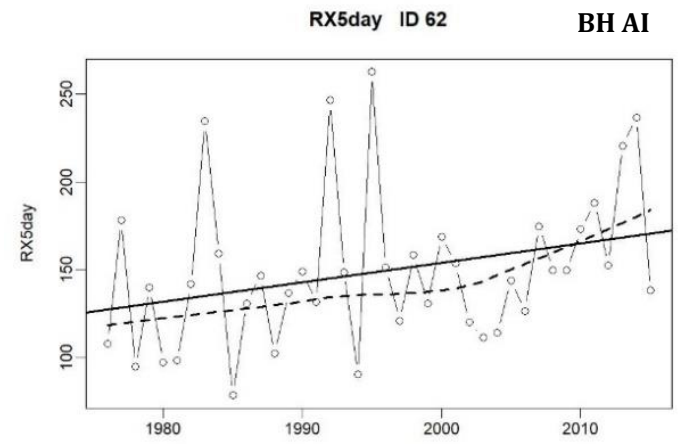

$R 2=9$ p-value $=0.06$ Slope estimate= 1.111 Slope error= 0.574

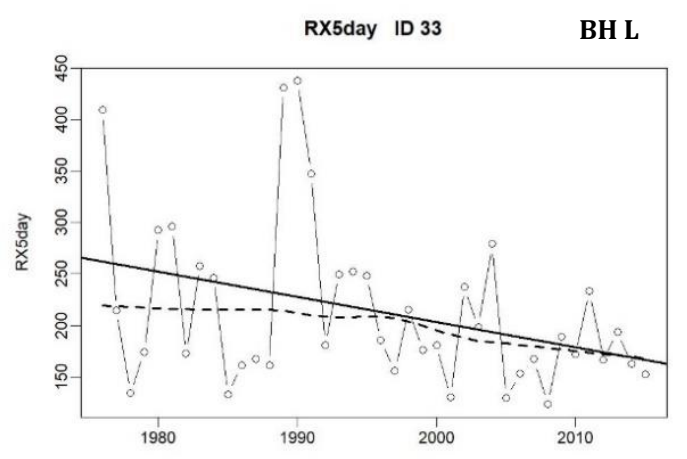

$R 2=12.7$ p-value $=0.024$ Slope estimate= $=-2.435$ Slope error $=1.038$

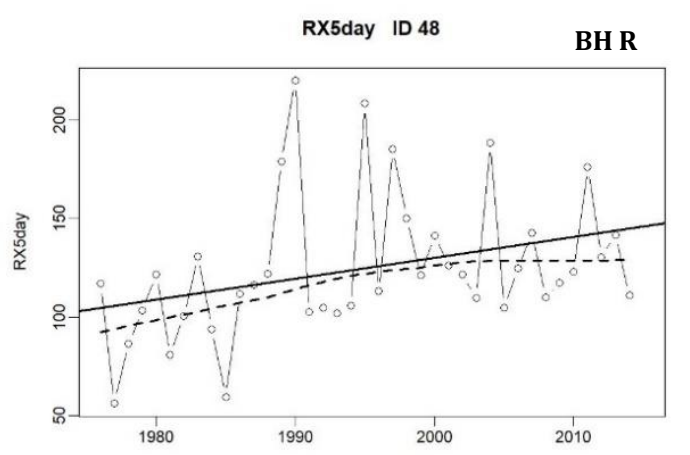

$R 2=11.4$ p-value $=0.035$ Slope estimate $=1.063$ slope error $=0.486$

Figura 65 - Tendências da precipitação pluviométrica máxima anual em cinco dias consecutivos (RX5day) nas BH do Alto Iguaçu (AI), Litorânea (L) e Ribeira (R) - Paraná. 
Mostra-se o aumento significativo do número anual de dias de chuva diária igual ou superior a $10 \mathrm{~mm}$ em oito postos pluviométricos da área em estudo. Em São Mateus do Sul (ID13) na BH Alto Iguaçu e em Campo Largo (ID47) na BH Ribeira, com 99\% de significância, observa-se o aumento de 0,35 e 0,42 dia/ano do R10 mm, inferindo que ao final da série histórica nota-se o acréscimo de até 14 a 16,8 dias com precipitação pluvial igual ou superior a 10 mm. Com 95\% de significância, verifica-se em Antonina (ID22), o aumento anual de 0,35 dia/ano deste mesmo índice (Tabela 24).

Em Porto Amazonas (ID10) na BH Alto Iguaçu, em Morretes (ID31) e Paranaguá (ID35) na BH Litorânea e em Adrianópolis (ID39), Cerro Azul (ID49) na BH Ribeira, com $90 \%$ de significância, obteve-se o aumento de 0,18 a 0,31 dia/ano do R10 mm. Com 99,9\% de significância, em Guaraqueçaba (ID27), situada na BH Litorânea, demonstrase a redução de 0,80 dia/ano dos dias anuais do mesmo índice, o que se entende por uma diminuição total de 32 dias das chuvas diárias que atingem tal limiar (Tabela 24).

O número anual de chuvas iguais ou superiores a $20 \mathrm{~mm}$ (R20 mm) demonstra um aumento mais significativo e expressivo na BH Ribeira. Destaca-se que em Adrianópolis (ID39) e Campo Largo (ID47) o aumento de 0,43 e 0,40 dia/ano deste limiar pluvial, com 99,9\% de significância, representa um acréscimo superior a 16 dias anuais para a série temporal. Considerando a significância de 95\%, infere-se o aumento anual de 0,15 a 0,23 dia deste índice nos postos pluviométricos de Bocaiúva do Sul (ID40), Cerro Azul (ID48), Doutor Ulysses (ID52) e Rio Branco do Sul (ID57). Em Cerro Azul (ID49) verifica-se o aumento de 0,13 dia/ano do R20 mm, com 90\% de significância, enquanto que a única tendência de diminuição deste índice é identificada em Campina Grande do Sul (ID43), com $95 \%$ de significância, a uma ordem anual de -0,23 dia/ano e refere-se a uma redução total de 9,2 dias de chuva diária igual ou superior a $20 \mathrm{~mm}$ (Tabela 24).

Verifica-se na BH Alto Iguaçu somente tendências de aumento do R20 mm, com destaque para as elevações averiguadas em Campo Largo (ID01) e Mandirituba (ID06) em 0,23 e 0,33 dia/ano, com 99\% e 99,9\% de significância, o que representa o acréscimo de 9,2 e 13,2 dias anuais com chuvas diárias iguais ou mais elevadas que $20 \mathrm{~mm}$, nesta ordem. As demais tendências obtiveram $90 \%$ de significância e valores entre 0,17 e 0,18 dia/ano, sendo identificadas em Curitiba (ID02), Lapa (ID’s 03 e 04) e em São Mateus do Sul (ID13), conforme representa a tabela 24.

Em Guaraqueçaba (ID27) identifica-se a maior redução do R20 mm, com 99,9\% de significância, sendo verificado a diminuição de 0,57 dia/ano ou de 22,8 dias anuais de chuva diária equivalentes ao limiar definido por este índice. A diminuição deste índice 
também foi observada em Guaratuba (ID30), com 90\% de significância, a uma ordem de 0,32 dia/ano. Contudo, em Antonina (ID22) e Paranaguá (ID35), considerando-se 90\% de significância, nota-se o aumento de 0,16 a 0,25 dia/ano destes totais pluviais (Tabela 24).

Deste modo, ressalta-se que o indicador climático R20 mm demonstra de modo mais expressivo o aumento da frequência de dias anuais de chuva em relação ao $\mathrm{R} 10 \mathrm{~mm}$, com tendências significativas em 15 postos pluviométricos, sendo que sete delas foram verificadas na BH Ribeira e em outras seis deram-se BH Alto Iguaçu. Sobretudo, estes resultados corroboram os indicativos anteriores da propensão de elevação pluvial junto à concentração das chuvas em um menor período temporal, com a elevação do PRCPTOT, do RX1day e do R20 mm e, principalmente, pela diminuição/aumento do CWD/CDD, o que possibilita afirmar que a área em estudo apresenta o aumento do número de dias com pluviosidade mais intensa concentrada.

Outro indicador da ocorrência das chuvas fortes é o R95p, que se mostra bastante expressivo para apontar tendências de modificações nas características pluviais diárias da BH do Ribeira, uma vez que onze postos pluviométricos mostram tendências de elevações dos totais anuais acumulados de chuvas iguais ou superiores a $95 \%$ dos percentis. Para a localidade de Campina Grande do Sul (ID40) observa-se o aumento de 6,92 mm/ano das chuvas fortes, com uma significância de 99,9\%, que ao final da série histórica representa que tais alturas pluviais estão 276,8 mm mais elevadas. Com 99\% de significância, notase o aumento entre 5,18 a 6,47 mm/ano em Cerro Azul (ID's 48 e 49), que equivale a uma elevação 207,2 mm a 258,8 mm em quarenta anos de estudos. Em Doutor Ulysses (52) e em Castro (ID60), com 95\% de significância, os totais anuais de chuvas fortes elevaramse em 5,13 e 5,63 mm/ano, correspondendo a um aumento total de 205,2 $\mathrm{mm}$ e 225,2 mm, nesta ordem. Outras seis tendências de aumento dos totais anuais acumulados de chuvas fortes foram obtidas na BH Ribeira, com 90\% de significância, em Campina Grande do Sul (ID41), Campo Largo (ID’s 44 e 47), Itaperuçu (ID54), Rio Branco do Sul (ID57) e Tunas do Paraná (ID58), com valores de 3,21 a 5,27 mm/ano (Tabela 24 - Figura 67).

Observa-se o aumento dos totais anuais de chuvas fortes em Curitiba (ID02), Lapa (ID04), Mandirituba (ID06), na BH Alto Iguaçu, e em Antonina (ID22), na BH Litorânea, com 95\% de significância, com valores entre 4,58 e 8,48 mm/ano, sendo que ao longo do segmento temporal isto corresponde a um aumento de $183,2 \mathrm{~mm}$ a $339,2 \mathrm{~mm}$, destacandose que este maior acréscimo da R95p tenha ocorrido na localidade litorânea. Com 90\% de significância, observa-se o aumento de 4,51 a 4,58 mm/ano das chuvas fortes em Lapa 
(ID03) e São Mateus do Sul (ID13), ao passo que em Guaraqueçaba (ID27) mostra-se a diminuição de tais alturas pluviais em 9,75 mm/ano, sendo que ao final da série temporal neste posto pluviométrico demonstra-se uma redução de $390 \mathrm{~mm}$ nos totais anuais de chuvas fortes (Tabela 24 - Figura 68).

O indicador climático de tendências das chuvas intensas (R99p) obteve resultados menos expressivos em relação às chuvas fortes. Com $95 \%$ de significância, destaca-se o aumento do R99p em São Mateus do Sul (ID12), Antonina (ID22) e Cerro Azul (ID48), com aumentos que estão entre 2,78 a 5,27 mm/ano, pujantemente mais elevado em ID22, no qual esta tendência positiva representa um acréscimo total $210,8 \mathrm{~mm}$ das chuvas fortes, sendo este o resultado mais demonstrativo das alterações do R99p. Considerando-se 90\% de significância, indica-se que as chuvas fortes aumentaram ao longo da série histórica entre 2,30 e 4,44 mm/ano nas localidades de Lapa (ID03), Pinhais (ID07) e Piên (ID18) na BH Alto Iguaçu, Antonina (ID23), Guaraqueçaba (ID25) e Morretes (ID31) na BH Litorânea, como representado pela tabela 24 e a figura 68 . 


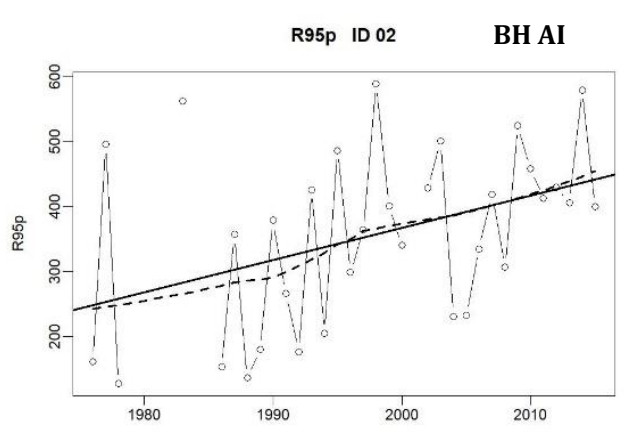

$R 2=16.8$ p-value $=0.018$ Slope estimate 4.96 Slope error $=1.981$

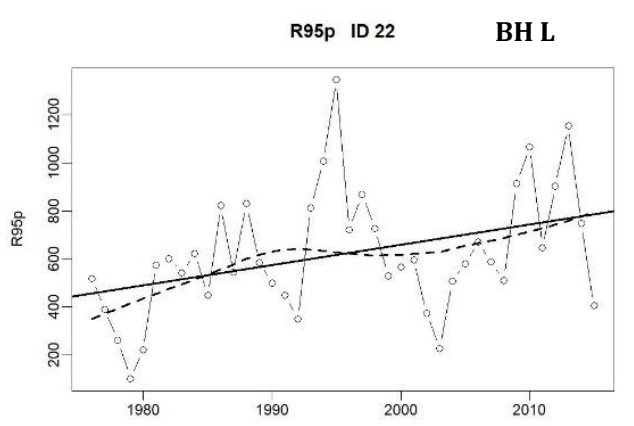

R2= 14.6 p-value $=0.015$ Slope estimate 8.48 slope error $=3332$

R95p ID $48 \quad$ BH R

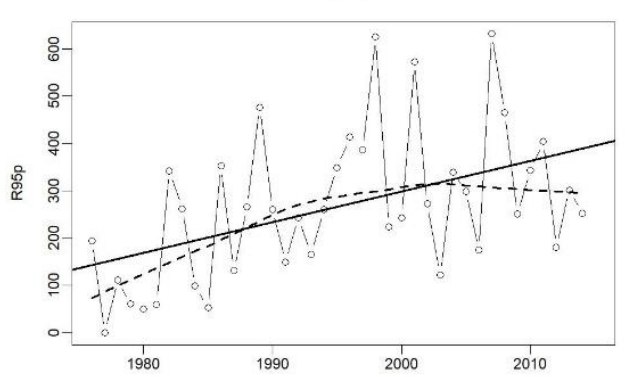

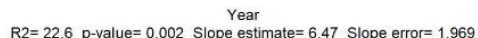

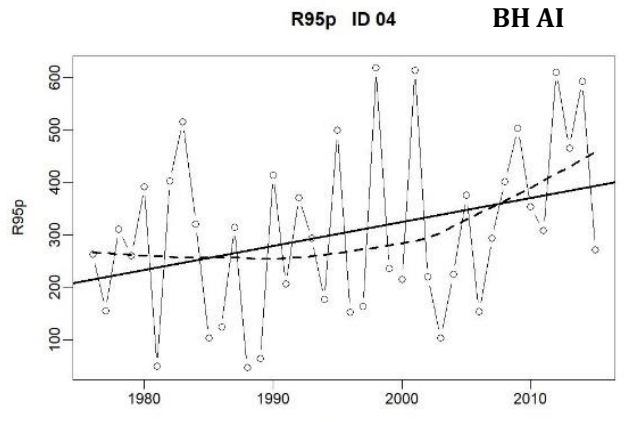

$R 2=11$ p-value $=0.037$ Slope estimate $=4.578$ slope error $=2.115$

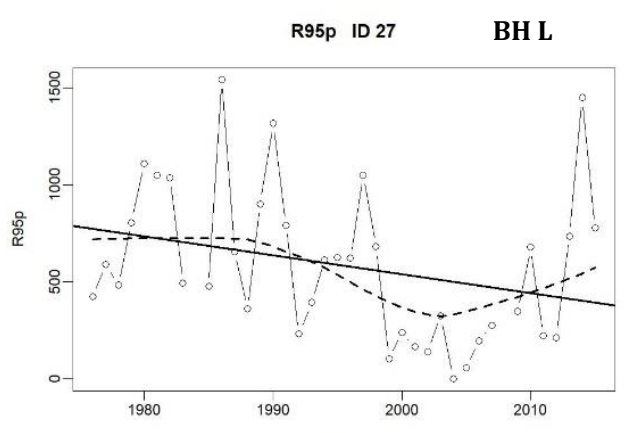

$R 2=8.5$ p-value $=0.076$ Slope $\begin{gathered}\text { Year } \\ \text { stimate }=-9.953 \text { slope error }=5.341\end{gathered}$

R95p ID $49 \quad$ BH R

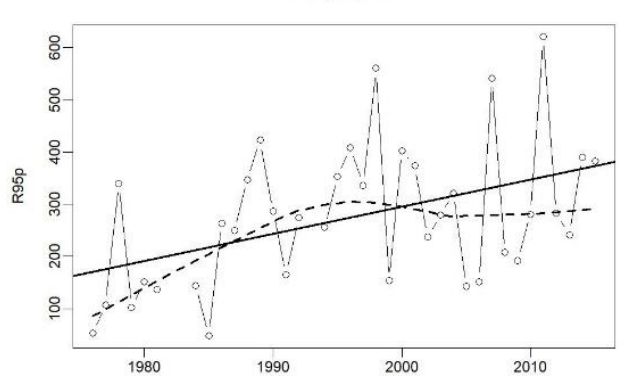

Year

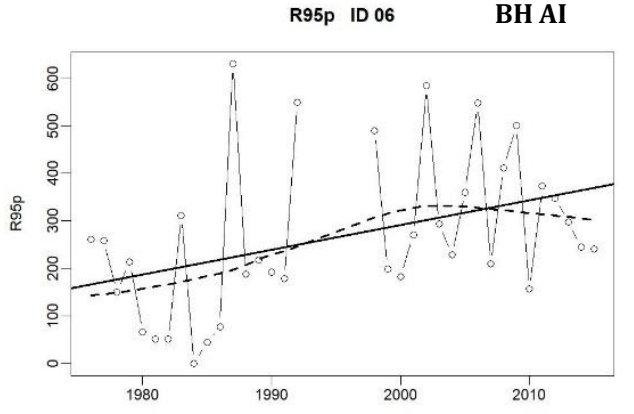

$R 2=15.9$ p-value $=0.018$ Slope estimate $=5.206$ Slope error= 2.083

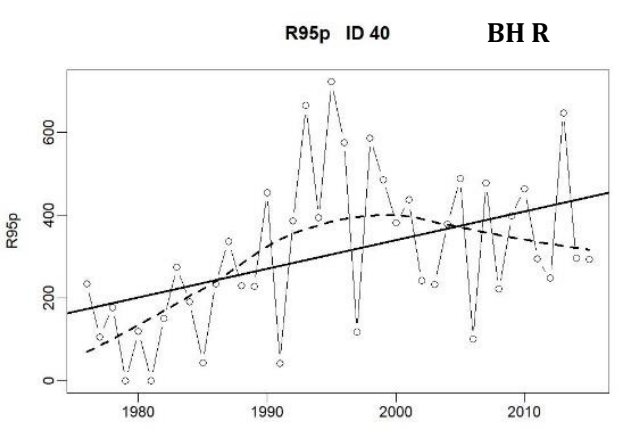

$R 2=19.1$ p-value $=0.005$ slope estimate 6.922 slope error $=2.31$

R95p ID $52 \quad$ BH R

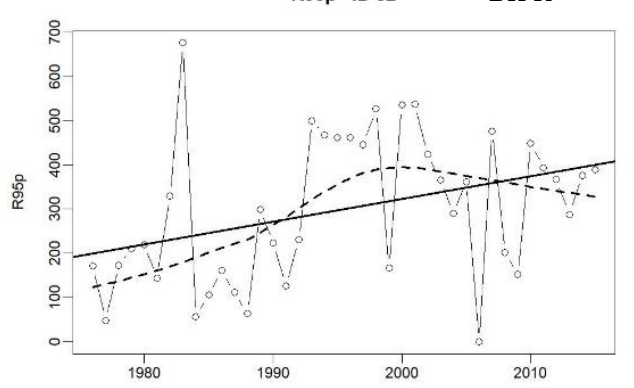

Year

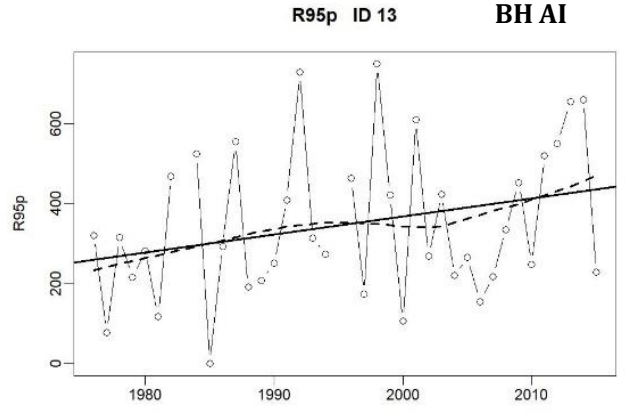

$R 2=81$ p-value $=0.083$ Slope estimate $=4.505$ Slope error= 2.528

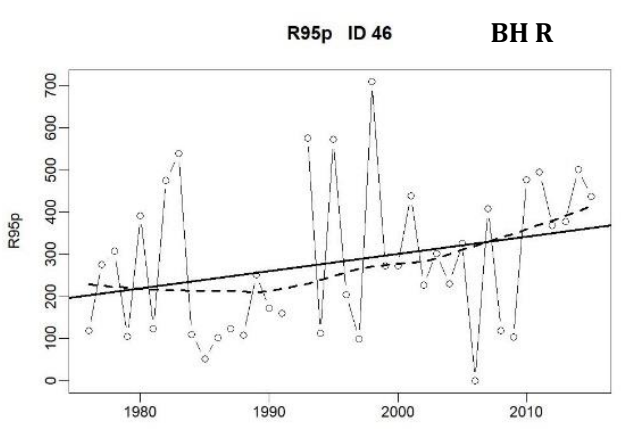

$R 2=7.5$ p-value $=0.091$ Slope estimate 4.083 Slope error $=2.352$

R95p ID $60 \quad$ BH R

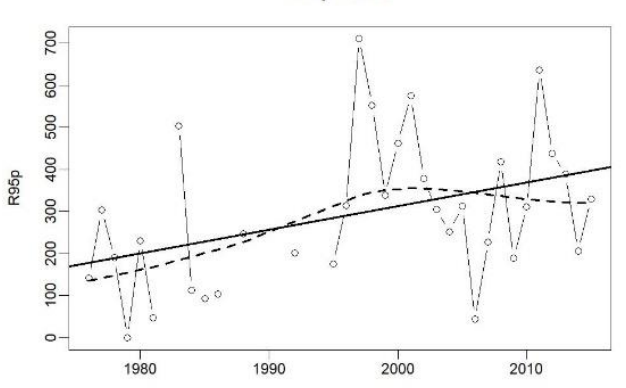

$R 2=16.1$ p-value= 0.021 Slope estimate $=5.63$ slope error $=2.312$

Figura 66 - Tendências da precipitação pluviométrica diária superior a 95\% dos percentis dos quantis (R95p) nas BH do Alto Iguaçu (AI), Litorânea (L) e Ribeira (R) - Paraná. 


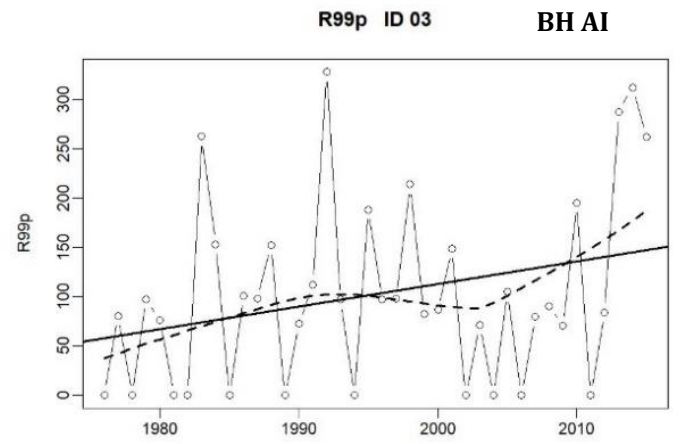

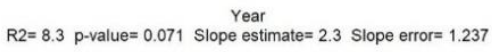

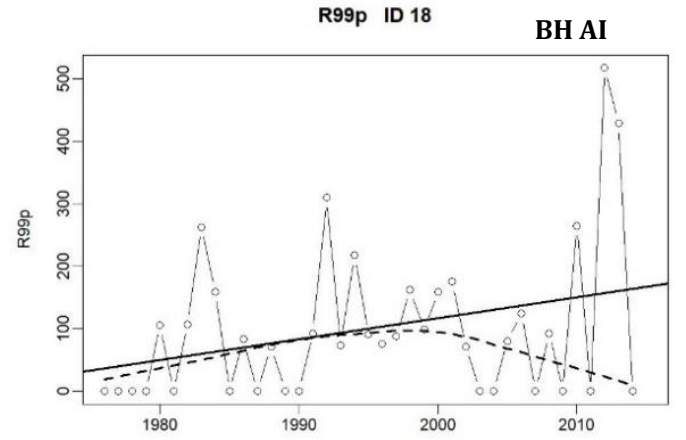

$R 2=9.8$ p-value $=0.052$ Slope estimate $=3.347$ slope error= $=1668$

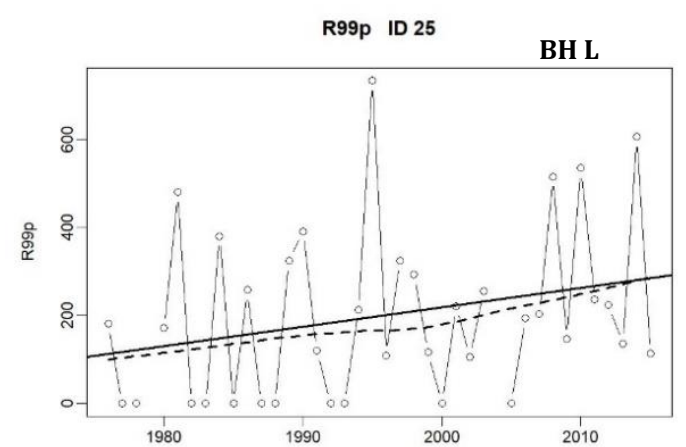

$R 2=73$ p.value= 0.1 Slope $\begin{gathered}\text { Year } \\ \text { estimate }=4436 \text { Slope error }=2631\end{gathered}$

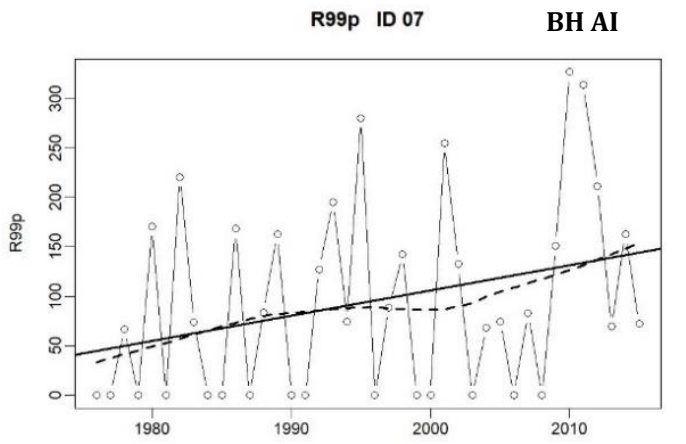

$R 2=9.4$ p-value $=0.055$ Slope estimate $=2.545$ Slope error $=1.284$

R99p ID 22

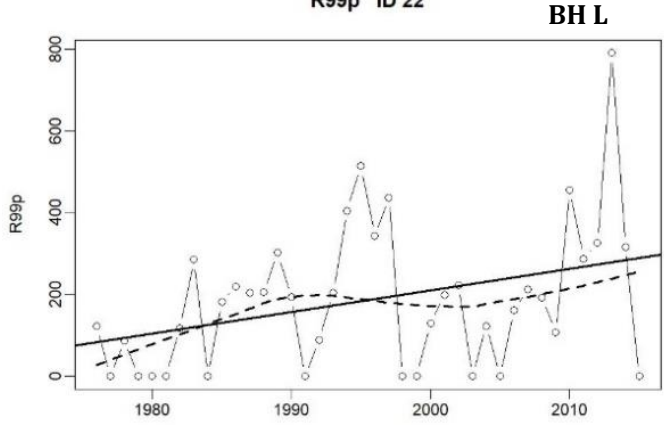

$R 2=12.6$ p-value $=0.025$ Slope estimate $=5.269$ Slope error $=2.255$

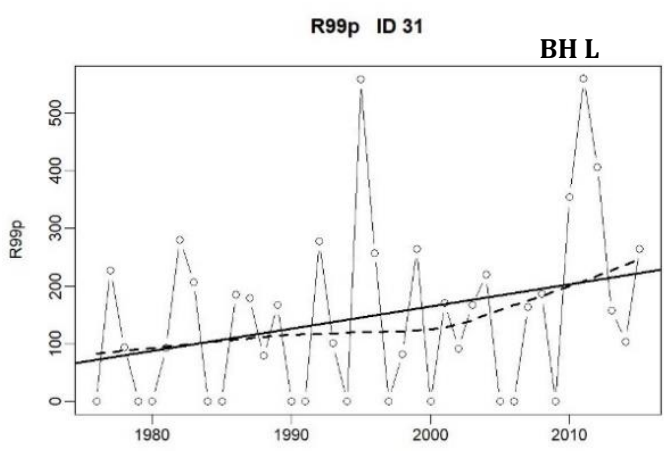

Year
P2

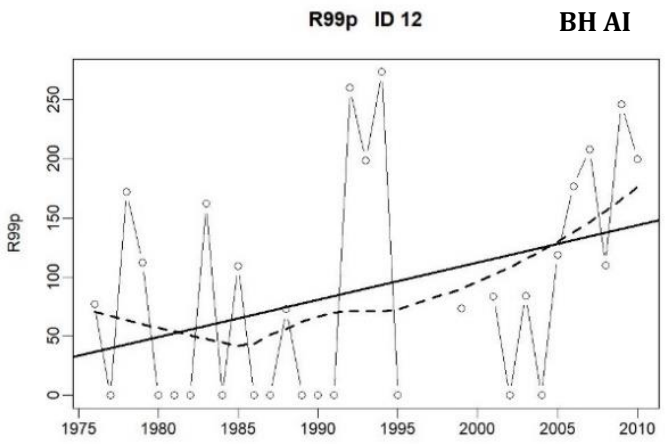

$R 2=13.7$ p-value $=0.04$ Slope estimate $=3.16$ Slope error= 1.47

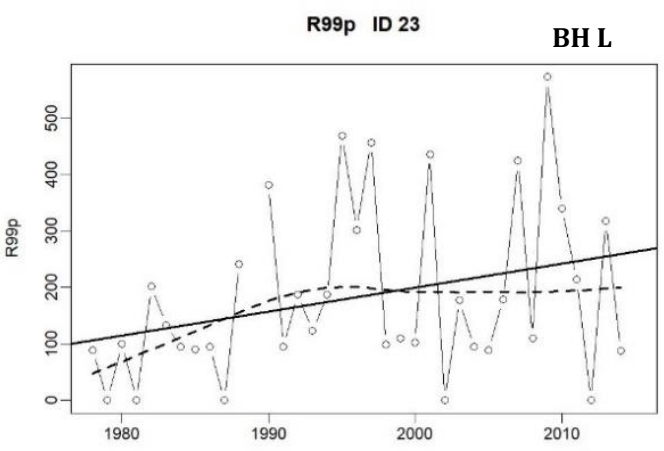

$R 2=9.4$ p-value= $0.069 \begin{gathered}\text { Year } \\ \text { slope estimate }=4.259 \text { Slope error= } 2.267\end{gathered}$

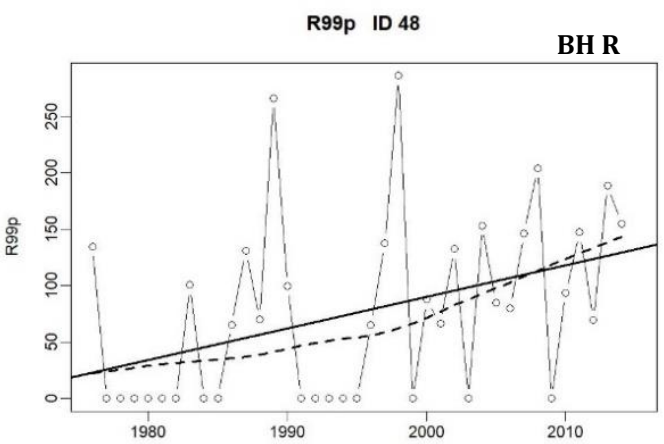

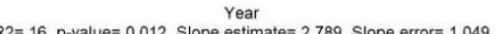

Figura 67 - Tendências da precipitação pluviométrica diária superior a 99\% dos percentis dos quantis (R99p) nas BH do Alto Iguaçu (AI), Litorânea (L) e Ribeira (R) - Paraná. 


\subsection{As chuvas diárias em Castro, Curitiba e Paranaguá}

\subsubsection{Frequência e intensidade das chuvas diárias}

Os resultados obtidos indicaram que uma chuva diária muito forte, com o limiar de $99 \%$ dos quantis, em Castro é de 70,5 mm, Curitiba com 69,5 mm e Paranaguá com 95,6 mm. Na categoria chuvas fortes, equivalente a 95\% dos quantis, correspondem aos registros de $43 \mathrm{~mm}$ (Castro), 40,9 $\mathrm{mm}$ (Curitiba) e $50 \mathrm{~mm}$ (Paranaguá), conforme indica a figura 69. Tais resultados mostram diferenças marcantes entre as categorias adotadas e isso se deve a influência marcante da maritimidade para a geração de chuvas intensas no litoral paranaense, seguido da orografia para os menores valores pluviométricos na região de Castro e Curitiba, mais distantes do oceano e posteriores ao setor de máxima influência orográfica, que se dá até aproximadamente os 900 metros de altitude, conforme estimam Pellegatti e Galvani (2010), Correa e Galvani (2017) e Terassi e Galvani (2017).

Destaca-se que estes resultados estão próximos aos obtidos por Zandonadi et al. (2015) para Curitiba com $60 \mathrm{~mm}$ para o $98 \%$ dos quantis, e o valor de $41 \mathrm{~mm}$ para $94 \%$ dos quantis para Goiânia (GO). Comparativamente, Paranaguá se assemelha ao resultado obtido por Souza et al. (2012) para a cidade do Recife (PE), localizada na costa Nordeste brasileira, e que obteve 55,3 $\mathrm{mm}$ para $95 \%$ dos percentis dos quantis.

Os registros pluviométricos de menores magnitudes mantiveram os valores da mediana próximos a 8,4 mm em Castro, 7,8 $\mathrm{mm}$ em Curitiba e a 8,1 $\mathrm{mm}$ para Paranaguá. Contudo, as chuvas diárias superiores a $99 \%$ dos quantis foram discrepantes entre Castro e Curitiba em relação à Paranaguá. Os outliers, que compreende os registros entre 99 a $99,9 \%$, mostraram eventos entre $70,3 \mathrm{~mm}$ a $114,8 \mathrm{~mm}$ para Castro, $69,6 \mathrm{~mm}$ a $113,7 \mathrm{~mm}$ para Curitiba e entre 95,7 mm e 170,9 mm para Paranaguá. Definidos pelos registros superiores a 99,9\% dos quantis, os extremos da série histórica foram identificados entre $114,8 \mathrm{~mm}$ e $153,6 \mathrm{~mm}$ para Castro, $113,7 \mathrm{~mm}$ e 146,2 $\mathrm{mm}$ para Curitiba e entre 170,9 mm e 295,8 mm para Paranaguá (Figura 69).

A classificação da chuva diária para Castro, Curitiba e Paranaguá (Figuras 69 e 70) mostraram a predominância dos registros de chuvas de menores intensidade. De modo geral, em conformidade ao obtido por Leite et al. (2001) para Ponta Grossa (PR), a maior frequência de chuva diária nas menores classes foi verificada para a maioria dos meses. Em Paranaguá, a frequência da chuva diária é superior em relação à Castro e Curitiba, dada que os números dos registros foram maiores em quase todos os meses, condição 
atribuída ao desempenho da maritimidade aliada às maiores temperaturas em ocasionar mais frequentemente chuvas de origem convectiva, sobretudo no verão.
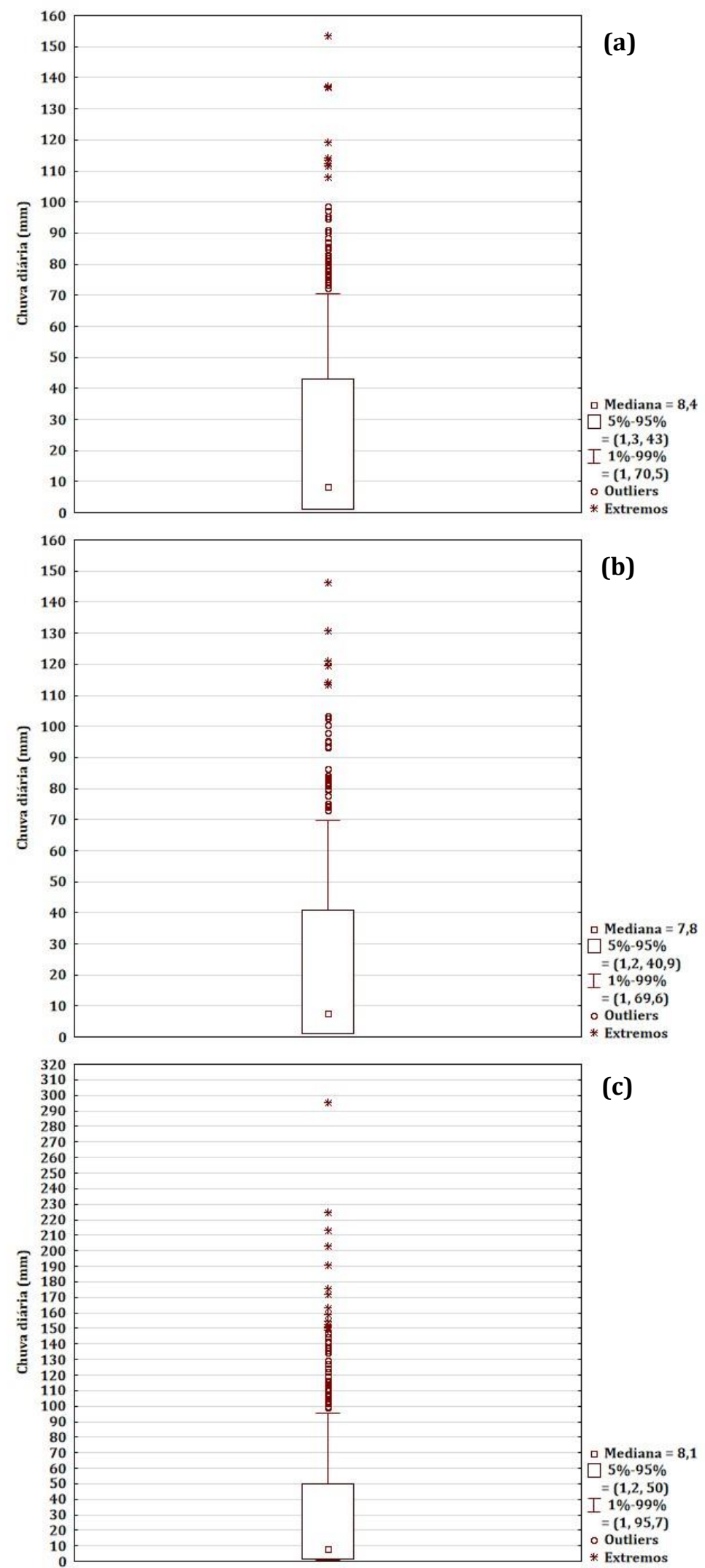

Figura 68 - Boxplot da chuva diária (mm) para Castro (a), Curitiba (b) e Paranaguá (c). 
Em Castro, observa-se o predomínio de chuvas diárias até 25\% dos quantis entre fevereiro e maio e em agosto, outubro e novembro. Três dos meses mais chuvosos, janeiro, setembro e dezembro obtiveram a maioria das chuvas diárias entre $50 \%$ e $75 \%$ dos quantis, enquanto que em junho e julho predominaram as chuvas entre $25 \%$ a $50 \%$ dos quantis. Destaca-se que os meses de janeiro, março, maio e outubro são os que apresentaram a maior frequência de chuvas fortes $(>43,1 \mathrm{~mm})$, iguais ou superiores a 15 registros, ao passo que as chuvas intensas $(>70,3 \mathrm{~mm})$ se deram mais frequentemente em janeiro, maio, junho, julho e dezembro, com cinco ou mais registros (Figura 70a).

Em Curitiba, notou-se a predominância das chuvas diárias superiores a 50\% e inferiores a $75 \%$ dos quantis em janeiro, julho, setembro e dezembro. Entre fevereiro e maio e em agosto e novembro demonstraram o predomínio de chuvas diárias inferiores a $25 \%$ dos quantis. Em junho, as classes de chuvas foram mais amplas e mostraram-se dominantes entre $25 \%$ e $75 \%$ do quantis. No mês de outubro, período que marca o início da estação chuvosa, houve a maioria de chuvas diárias superiores a $75 \%$ e inferiores a $95 \%$ dos quantis. Os meses com a maior frequência de chuvas fortes $(>43,0 \mathrm{~mm})$ se dão em janeiro, fevereiro, março, setembro e outubro, com 17 ou mais registros, sendo que as chuvas intensas (>69,6 mm) ocorreram em cinco ou mais registros em janeiro, fevereiro, maio, junho e dezembro (Figura 70b).

Em Paranaguá, nota-se em janeiro a predominância de chuvas diárias superiores a $75 \%$ e inferiores a $95 \%$ dos quantis, condizente com os maiores totais médios mensais, equivalentes a $325,7 \mathrm{~mm}$. Os meses de fevereiro e dezembro mostraram o predomínio de chuvas superiores a $50 \%$ e inferiores a $75 \%$ dos quantis, enquanto que os meses de março, maio, junho, julho e novembro obtiveram a predominância de chuvas inferiores a $50 \%$ e superiores a $25 \%$ dos quantis. Os meses com a maior frequência de chuvas diárias de menor intensidade são abril, setembro e outubro, com o domínio dos registros inferiores a $25 \%$ dos quantis. Mesmo que não corresponda a um mês de redução da pluviosidade média mensal $(163,5 \mathrm{~mm})$, outubro obteve o predomínio de chuvas inferiores a $25 \%$ dos quantis e, entretanto, as demais classes apresentaram número de registro superiores em relação aos meses de setembro e novembro, tornando-o com totais pluviais mais elevados devido ao aumento da frequência das chuvas (Figura 70c).

Inversamente ao verificado em Castro e Curitiba, as chuvas diárias mais fortes em Paranaguá ocorreram concentradamente no verão, com registros superiores a 30 chuvas intensas $(>50,1 \mathrm{~mm})$ entre dezembro e março, sendo que as chuvas intensas $(>95,7$ $\mathrm{mm}$ ) foram iguais ou superiores a 10 registros em janeiro, fevereiro e março (Figura 70c). 

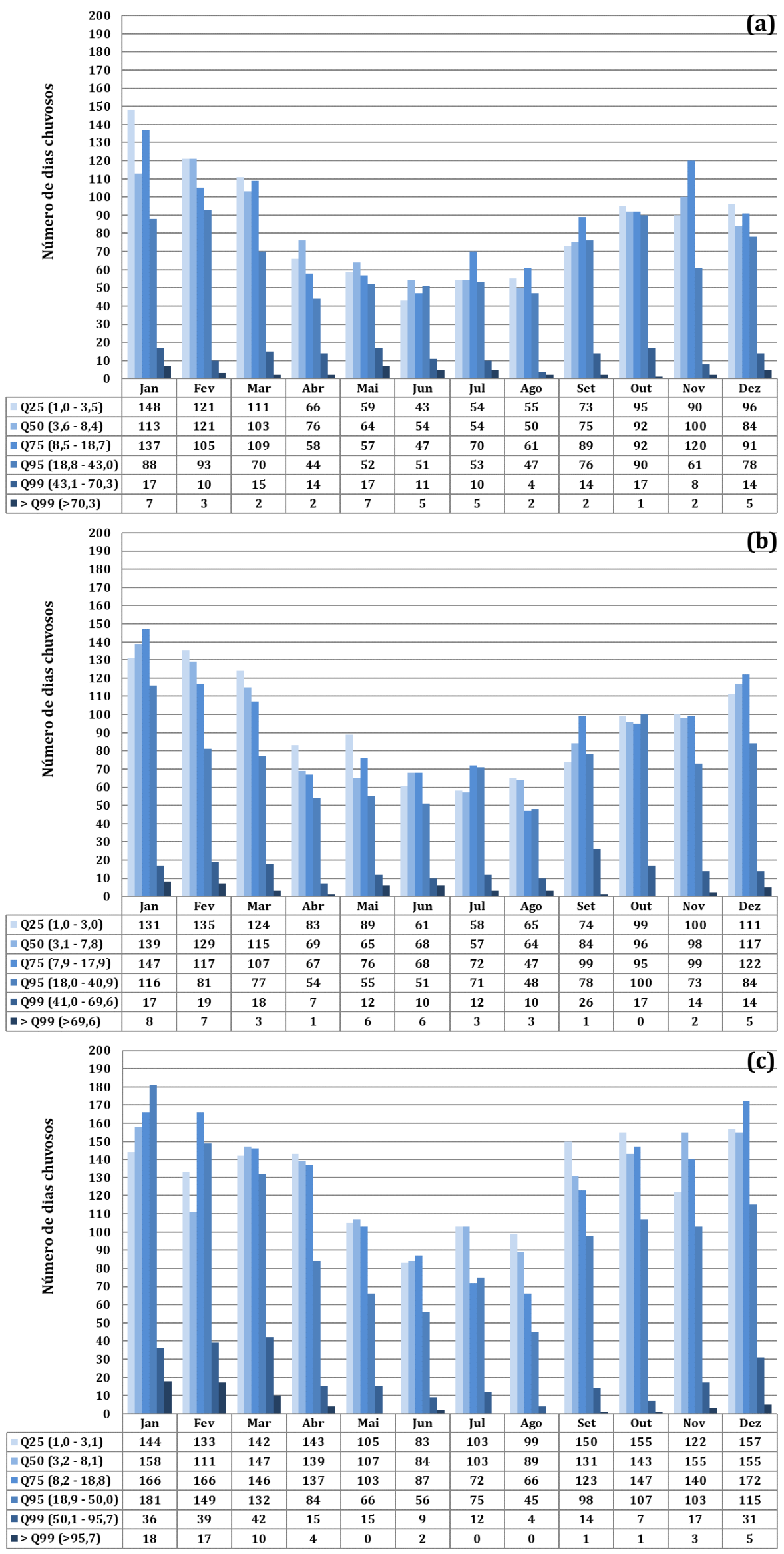

Figura 69 - Classes de quantis e o número de registros de dias chuvosos em Castro (a), Curitiba (b) e Paranaguá (c). 
Destaca-se que a menor frequência de chuvas fortes em Castro ocorre nos meses de agosto e novembro, com menos de 10 registros, e as chuvas intensas para toda a série histórica ocorreu duas vezes ou menos em março, abril e entre agosto e novembro, o que sugere que o início do outono e o final do inverno/início e meio da primavera é o período de menor frequência das chuvas de maiores totais ( $\leq 02$ dias), conforme representa a figura 70a. Por sua vez, em Curitiba as frequências equivalentes ou inferiores a 10 dias de chuvas fortes ocorreram em abril, junho e agosto e as chuvas intensas foram menos observadas ( $\leq 02$ dias) em abril, setembro e outubro e novembro (Figura 70b). Nota-se em Paranaguá características mais definidas quanto ao período de menores registros de chuvas fortes, que se dão entre junho e agosto ( $\leq 12$ dias), e das chuvas intensas, menos frequentes ( $\leq 02$ dias) entre maio e outubro, demarcando o período do final do outono e início da primavera como de menor frequência de chuvas mais intensas (Figura 70c).

Mesmo que seja o mês em que tenha ocorrido o maior total de chuva diária (153,6 $\mathrm{mm}$ ), em agosto são registrados os menores totais pluviais diários em Castro, pois o gráfico boxplot demonstra que neste mês se dão os menores limiares de chuvas fortes $(35,7 \mathrm{~mm})$ e intensas $(45,3 \mathrm{~mm})$, o que está de acordo com a menor pluviosidade média mensal (77,6 mm). Embora não sejam os meses mais chuvosos em Castro, registrou-se o maior limiar de chuvas fortes em maio $(58,2 \mathrm{~mm})$ e de chuvas intensas em junho $(77,2$ $\mathrm{mm})$, enquanto que em janeiro, o mais chuvoso da série histórica $(177,9 \mathrm{~mm})$, destoa-se pela maior frequência de chuvas diárias e dos registros de outliers (Figura 71a).

Defidamente em condições mais próximas ao clima subtropical, observa-se que em Curitiba os limiares da classificação de chuvas diárias são mais uniformes ao longo dos meses em relação à Castro. Ressalta-se que em maio ocorrem os maiores valores para chuvas fortes $(49,1 \mathrm{~mm})$ e intensas $(73,5 \mathrm{~mm})$, enquanto que em outubro registram-se as menores R95p (37,5 mm) e em novembro as menores R99p (52,4 mm). Observa-se no mês de janeiro, o mais chuvoso (193,3 mm), ocorreram a maior frequência de outliers (08 dias) e em junho se deram a maior frequência dos extremos (04 dias) - (Figura 71b).

Em Paranaguá, o mês de fevereiro sobressai-se pelas mais elevadas chuvas fortes $(68,6 \mathrm{~mm})$ e intensas $(101,7 \mathrm{~mm})$, ao passo que em agosto tais limiares delitaram valores de 34,0 $\mathrm{mm}$ e 49,8 $\mathrm{mm}$ em agosto, o mês de menor pluviosidade média (75,5 mm). Entre dezembro e março ocorrem os maiores valores de precipitação pluviométrica diária, com a maior frequência de outliers e extremos pluviais, com um padrão alinhado às médias mensais de precipitação pluvial superior a $200 \mathrm{~mm}$ (Figura 71c). 

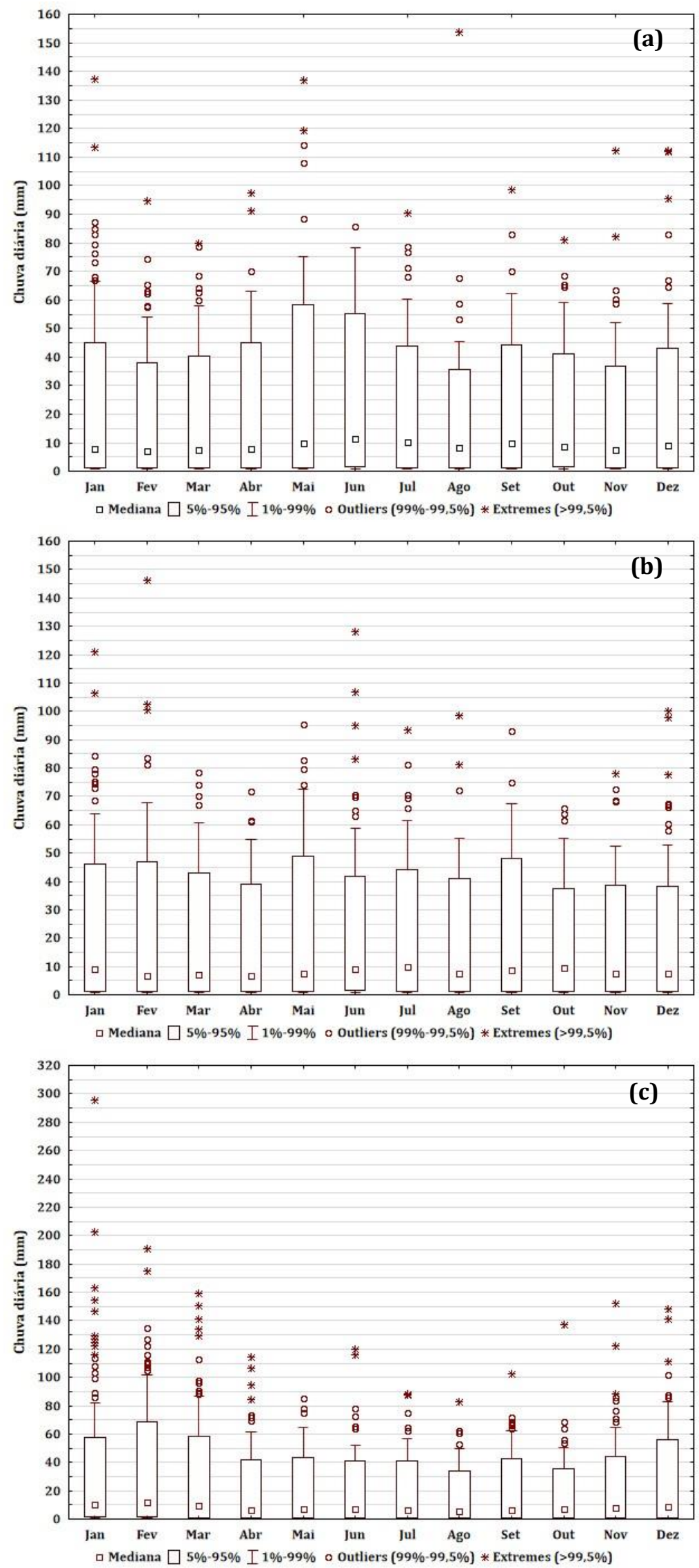

Figura 70 - Variabilidade mensal das chuvas diárias (mm) em Castro (a), Curitiba (b) e Paranaguá (c) - Paraná. 
Os registros máximos de chuva diária (Figura 72) indicaram totais mais elevados entre setembro e abril em Paranaguá, ressaltando o desempenho da maritimidade para a ocorrência de chuvas de maior intensidade para a bacia litorânea paranaense durante a estação quente e chuvosa, conforme indicaram Mello et al. (2017) e Terassi e Galvani (2017). Durante o período entre janeiro e março a pluviosidade máxima diária supera os 200 mm em Paranaguá, enquanto que em maio, julho e agosto os totais máximos diários não ultrapassam os $90 \mathrm{~mm}$, condição atrelada à diminuição térmica e à diminuição da influência de sistemas intertropicais (ZCAS e mEc) na geração das chuvas.

Situadas à sotavento da Serra do Mar e a uma altitude superior a 900 m, Castro e Curitiba caracterizam-se pelos maiores totais diários entre maio e agosto, destacando o desempenho orográfico frente à predominância da atuação dos (SF) durante o inverno nesta região (REBOITA et al., 2011; ZANDONADI et al., 2015). Em Castro, observa-se as chuvas mais intensas dentre as três localidades nos meses de maio, julho e agosto, ao passo que em Curitiba verifica-se o máximo de precipitação diária apenas em junho. Em Curitiba, os maiores totais de chuva diária ocorrem em janeiro, fevereiro e junho (>120 $\mathrm{mm}$ ), enquanto que em Castro a pluviosidade diária é maior em janeiro, maio e agosto (>130 mm). Nota-se uma redução dos totais pluviais diários no início do outono (abril) e no começo da primavera (setembro e outubro) em Castro e Curitiba, conforme representa a figura 72, e em conformidade ao discorrido acima para a frequência pluvial diária.

Para selecionar os eventos pluviais para a análise das condições atmosféricas que os ocasionaram, empregou-se a técnica de agrupamento para todos os registros de chuvas intensas nas localidades de Castro, Curitiba e Paranaguá. Deste modo, observou-se alguns padrões temporais das precipitações pluviais diárias mais intensas (R99p), sendo que em Castro das 10 mais elevadas chuvas, 05 delas ocorreram em maio e, portanto, selecionouse o registro pluvial mais recente para este mês, no ano de 2005. Observou-se que o evento pluvial mais intenso da série histórica em Castro se deu em agosto de 2011 e dentre os 10 registros o mais recente ocorreu em dezembro de 2014, sendo assim, eleitas uma condição de inverno e verão, nesta ordem, além daquela destacada para maio de 2005, todos os três eventos pluviais superiores a 107,9 mm (Figura 73).

Constata-se que dos 39 eventos pluviais de chuvas superiores a 99\% dos quantis observadas em Castro, 08 ocorreram em janeiro e outros 07 em maio, portanto, os meses de maior concentração de chuvas destas magnitudes. Ao contrário, em abril e entre agosto e novembro verifica-se o menor número de chuvas intensas $(\leq 02)$, que correspondem ao período de início do outono e final do inverno/início da primavera. Em relação à variação 
anual destes eventos extremos, a década de 1980 registrou 14 eventos pluviais extremos, sendo que 05 destas chuvas ocorreram entre1982 e 1983, decorrente da atuação de um forte El Niño. No período mais recente da série histórica, identificaram-se 10 registros entre 2011 e 2015, o que poderia sugerir o aumento das chuvas dessas magnitudes e, no entanto, as análises de tendências especificamente para a estação meteorológica de Castro e descritas no decorrer desta pesquisa não comprovaram esta suposição (Figura 73).

Em Curitiba, o dendograma separou os 06 mais intensos registros diários (>100,3 $\mathrm{mm}$ ) dentre os 60 eventos pluviais extremos superiores a 99\% dos quantis. O critério de seleção para avalias as condições atmosféricas associadas às maiores alturas pluviais foi escolher os dois registros mais recentes em condições de inverno, sendo uma delas a mais elevada chuva diária da série histórica da localidade (em junho de $2013=130,8 \mathrm{~mm}$ ), e a mais recente precipitação pluvial intensa em condições de verão (em dezembro de 2010). Estas suposições seguiram a premissa de que avaliar as condições sazonais mais distintas pode associar estes extremos pluviais à diferentes mecanismos atmosféricos, enfatizando o inverno, no qual as chuvas diárias foram mais elevadas na capital paranaense em relação à Paranaguá, na costa litorânea (Figura 74a).

Nota-se que exatamente metade dos registros ocorreram entre dezembro e março, período de elevação das chuvas em Curitiba e, embora os eventos pluviais tenham sido mais intensos em relação à Paranaguá no período invernal, houve uma menor frequência de chuvas intensas, notadamente em abril e entre agosto e novembro $(\leq 03)$, no início do outono e final do inverno/início da primavera, identificando para estes períodos a menor suceptibilidade à frequentes precipitações elevadas. Ainda que as normais climatológicas indiquem que seja mais habitual a redução da precipitação pluvial, verifica-se em maio e junho o registro expressivo de chuvas intensas (07) ao longo da série histórica em Curitiba (Figura 74a).

NA década de 1990 observou-se o maior número (22) de chuvas intensas, sendo que 14 concentraram-se entre 1995 e 1998, pujantemente durante o El Niño de 1997 a 1998, anos que somados registram-se 07 chuvas superiores a 69,6 mm. Outro evento de El Niño que repercutiu em chuvas diárias intensa em Curitiba foi identificado entre 1982 a 1983, nos quais registraram-se 09 das 14 chuvas intensas da década de 1980, elevada concentração pluvial diária que, conforme Zanella (2007), gerou diversas avarias, perdas materiais e humanas na capital paranaense. Apenas em um período de seis anos (2010 a 2014), verificou-se em Curitiba o registro de 12 chuvas intensas, o que sugere o aumento da pluviosidade diária igual ou superior a este limiar, o que é um pressuposto corroborado 
pela aplicação do teste Mann-Kendall e descrito no item a seguir. Destaca-se que das 06 chuvas mais intensas, 04 delas ocorreram entre 2007 e 2014 (Figura 74a), corroborando a mudança indicada pelo TMK para as chuvas máximas diárias (Tabela 13).

Em Paranaguá, observou-se que das 07 mais elevadas chuvas diárias, 05 se deram em janeiro ou fevereiro, e todas entre janeiro e abril, destacadamente o período de maior intensidade pluvial. O período entre janeiro e março concentra 46 dos 62 eventos pluviais extremos identificados, enquanto que nos meses de maio, julho e agosto, as chuvas diárias não atingiram 95,7 mm (Figura 74b). Esta característica de uma frequência mais elevada de chuvas intensas no verão está em acordo com o regime de chuvas no litoral, de médias mensais superiores a $200 \mathrm{~mm}$ entre janeiro e março, e que diferenciam as características pluviais deste setor do Paraná em relação às demais áreas estudadas.

Selecionou-se o evento pluvial extremo mais recente para a condição de inverno (junho de 2012), em situação pouco comum de chuva intensa nesta sazonalidade, e dois eventos no período de verão, observados em janeiro de 2004, sendo este o maior total pluvial diário de toda série histórica em Paranaguá, e em março de 2011, com o intuito de investigar condições típicas de chuvas intensas no litoral paranaense. Em Paranaguá, não se seguiu à risca a definição dos mais elevados totais de chuva conforme estabelecido pelo dendograma, pois alguns destes casos apresentaram ausência de registros dos dados meteorológicos, o que impediria uma análise rítmica apropriada (Figura 74b).

Uma boa parte dos eventos pluviais extremos em Paranaguá foram registrados na década de 1990 (22), destacando-se que 05 chuvas intensas foram registradas em 1995 e 03 delas somente no mês de janeiro deste mesmo ano. Observa-se que a ocorrência do El Niño foi determinante para a ocorrência de 05 precipitações extremas entre 1997 e 1998 , enquanto durante esta mesma anomalia em 1982 e 1983 registrou-se apenas uma chuva intensa em Paranaguá, a contrário do observado para Curitiba e Castro. Dos 62 eventos pluviais extremos, notou-se que 10 concentraram-se entre nos seis últimos anos de série histórica (Figura 74 b), ressaltando a condição de aumento das chuvas mais elevadas em Paranaguá conforme descrito no próximo item com as análises do TMK, embora estas condições de tendência tenham sido menos expressivas em relação à Curitiba.

Deste modo, mostra-se que a área em estudo apresenta características peculiares das chuvas intensas diárias, com uma condição definida no verão em Paranaguá e mais variável em Castro e Curitiba, localidades em que se destacam a frequência destes eventos extremos também nos meses de maio e junho. Observou-se uma nítida concentração das chuvas intensas na década de 1990 em Curitiba e Paranaguá e de 1980 em Castro. 


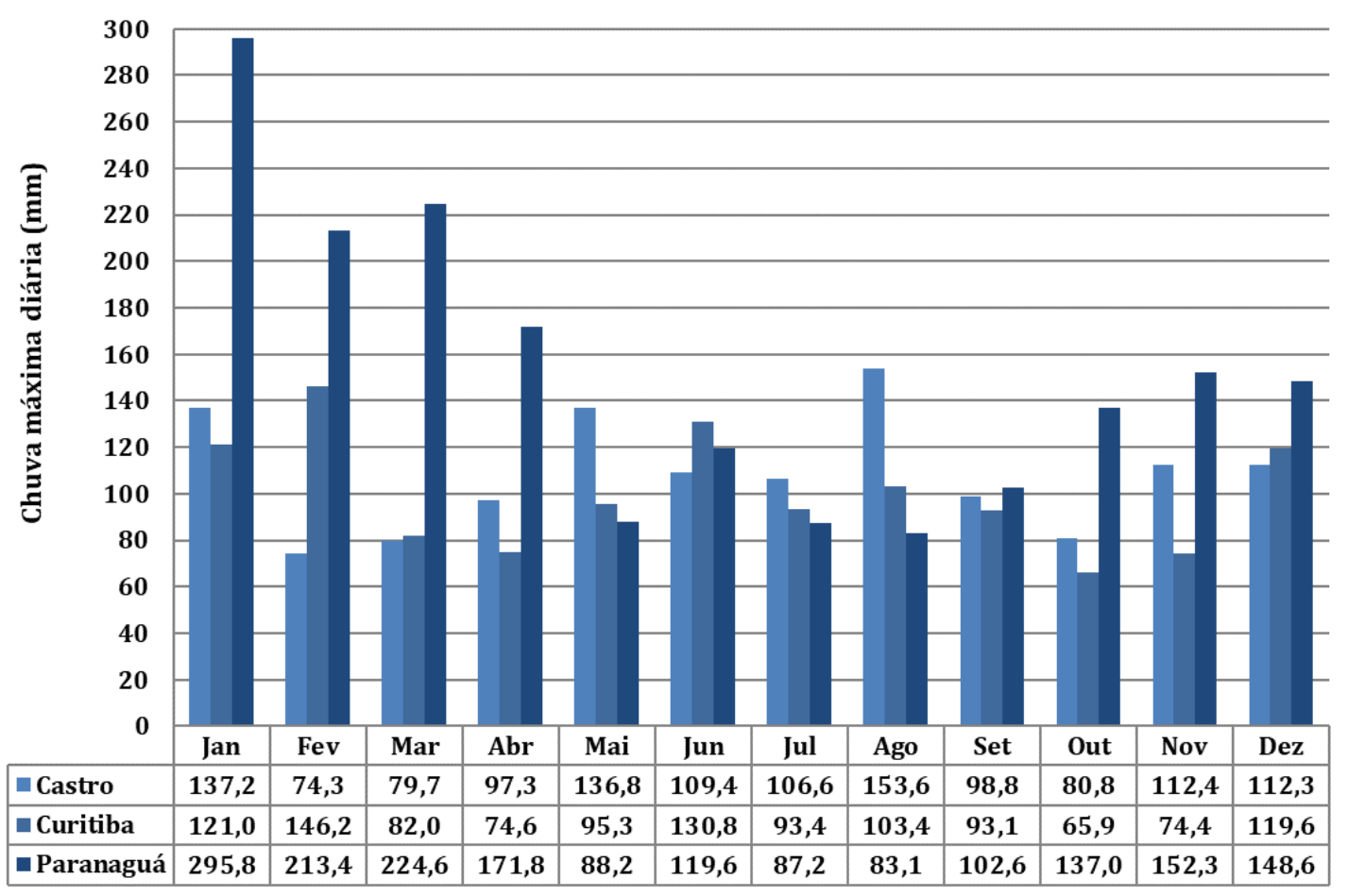

Figura 71 - Registro de chuva máxima diária mensal (mm) em Castro, Curitiba e Paranaguá - Paraná.

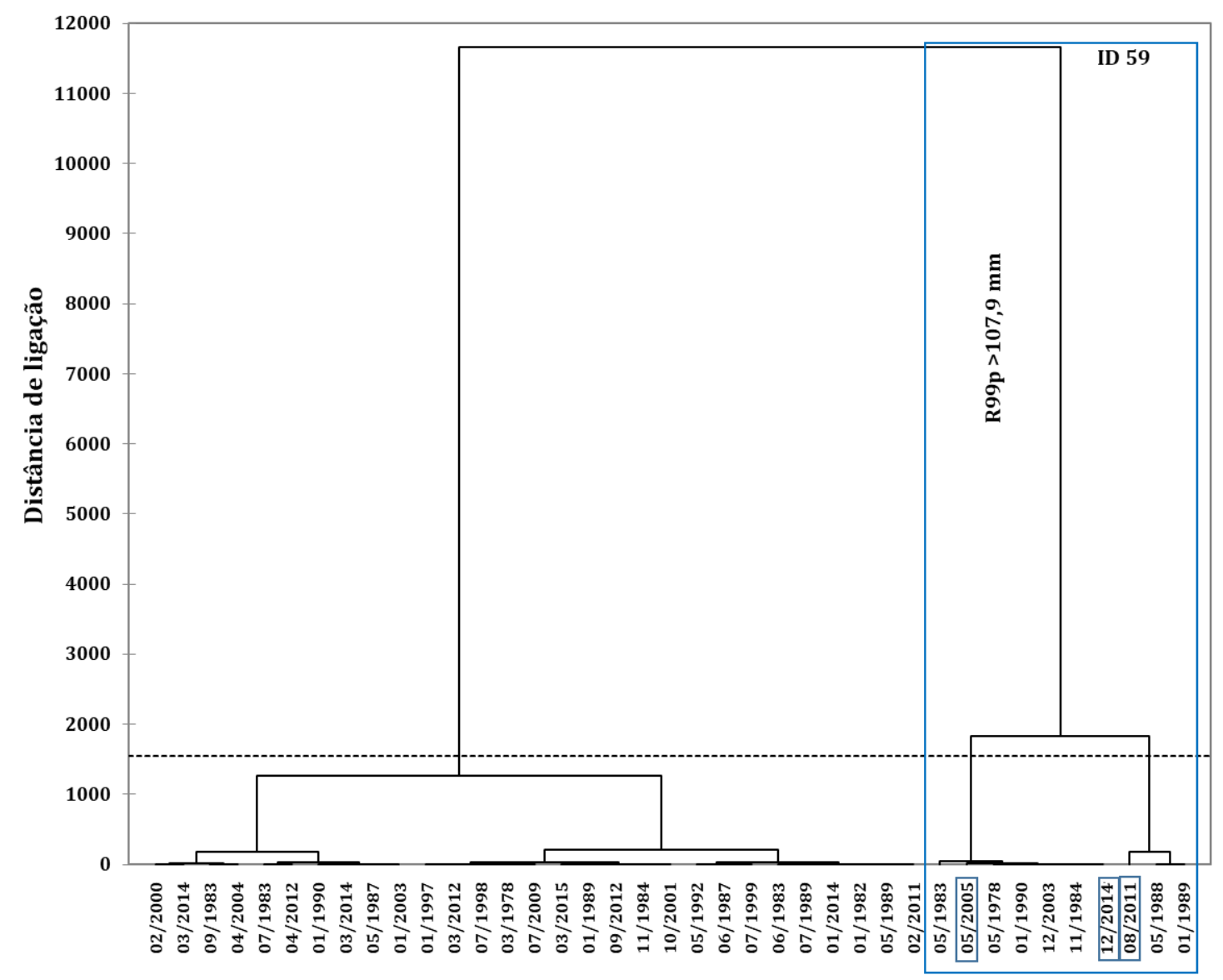

Figura 72 - Agrupamento das chuvas diárias superiores a 99\% dos quantis e a identificação da ocorrência dos maiores totais pluviais diários em Castro (ID 59) - Paraná. 

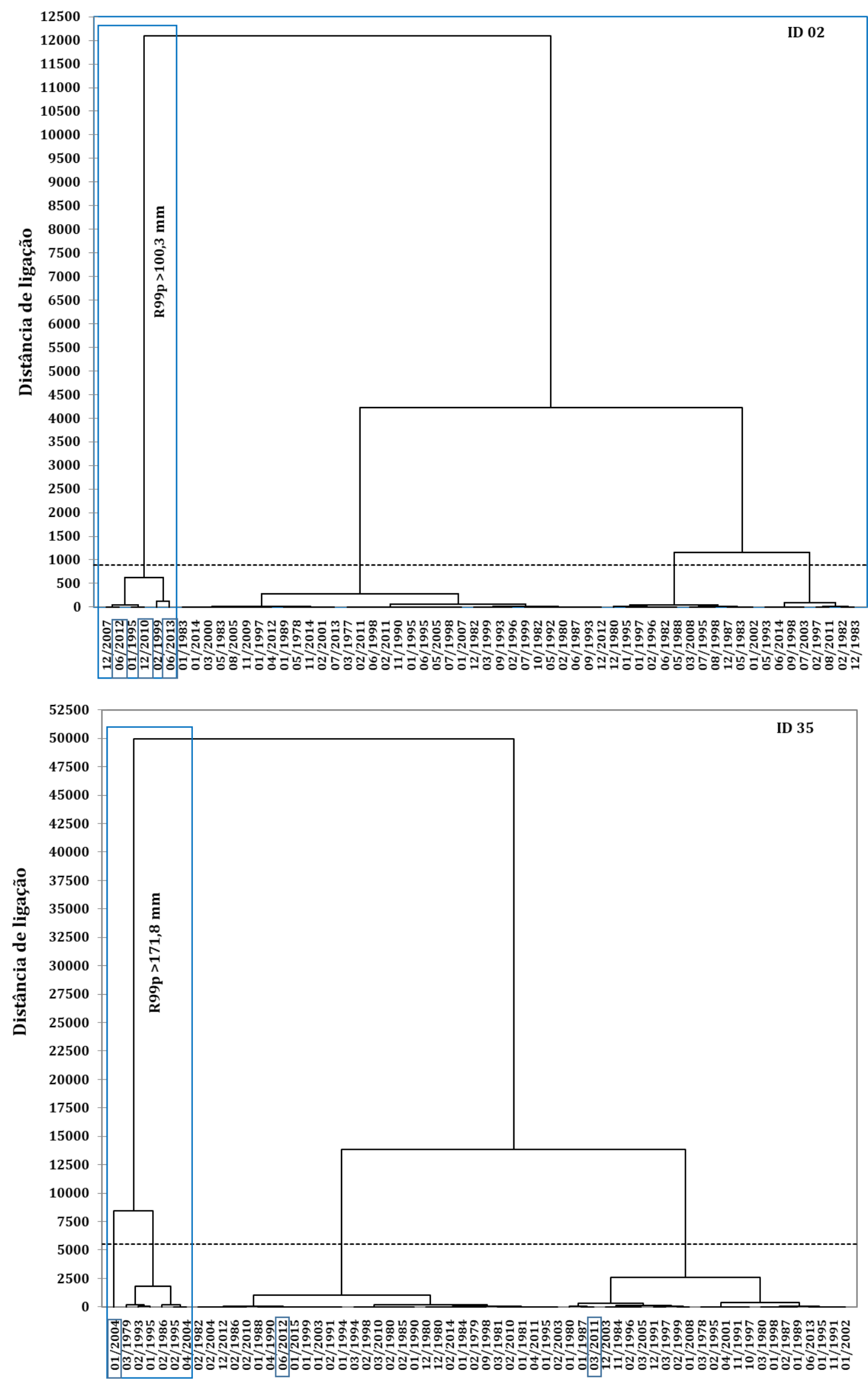

Figura 73 - Agrupamento das chuvas diárias superiores a 99\% dos quantis e a identificação da ocorrência dos maiores totais pluviais diários em Curitiba (ID 02) e Paranaguá (ID 35) - Paraná 


\subsubsection{Estatística exploratória, tendências e rupturas}

Os resultados do teste Run das chuvas diárias na escala anual para a localidade de Castro mostrou a predominância da normalidade dos intervalos adotados dos valores críticos de Z, exceto o aumento em 1978 e uma redução em 2006. Para Curitiba, o teste Run demonstrou valores superiores a 1,96 somente para o ano de 1976 e 2004 e inferiores a -1,96 somente para os anos de 1977 e 1988. Por fim, Paranaguá não apresentou nenhum ano com $\mathrm{Z}$ superiores ao valor crítico de 1,96 e, contudo, observou-se os registros de sete anos com $\mathrm{Z}$ inferiores a -1,96 (Figura 73).

Para Castro, os dois anos que estiveram fora do valor crítico de $\mathrm{Z}$ mostraram o aumento e a diminuição significativa dos totais diários de chuva, uma vez que em 1978 os resultados de Q95 e Q99 foram de 41,0 e 85,5 mm, enquanto que em 2006 observaram valores de 28,3 e $42 \mathrm{~mm}$, respectivamente. Ao contrário, em Curitiba notou-se que mesmo nos anos que estiveram acima do valor crítico de Z, os valores de Q95 e Q99 foram inferiores ao da série histórica, por exemplo, entre 33,6 a 44,3 mm e 42,3 e 57,6 mm. As exceções foram os anos de 1995 e 2000, sendo abaixo do valor crítico de Z. Em Paranaguá, os quantis de 95\% e 99\% mostraram que as chuvas foram entre 43,4 e 55,6 mm e entre78,4 e 99,0 mm. Destaca-se que no ano de 2000 observou-se a maior redução das chuvas equivalentes a $99 \%$ dos quantis $(52,7 \mathrm{~mm})$ e em 1995 o maior aumento de chuvas das classes dos quantis (157,8 mm) - (Figura 74).

Um dos mecanismos de maior importância na variabilidade interanual das chuvas na região Sul do Brasil (GRIMM et al., 1998; GRIMM; TEDESCHI, 2009; PENALBA; RIVERA, 2015) o El Niño-Oscilação Sul (ENSO) não mostrou-se incisivo e bastante variável para determinar os anos que estiveram fora dos padrões dos valores críticos de Z. O ano de 1978 que demonstrou um aumento significativos para Castro esteve sob condições de neutralidade, enquanto em 2006 houveram chuvas diárias de menores totais mesmo durante a fase quente do El Niño, do qual espera-se que as chuvas diárias acima da normalidade. Em Curitiba, os anos de aumento das chuvas diárias (1976 e 2004) estiveram associadas à ocorrência do El Niño, enquanto que a redução dos registros diárias em 1977 e 1988, nos quais observaram-se um período de El Niño (Fraco) e La Niña (Forte), nesta ordem. Nos anos de chuvas diárias abaixo do valor crítico, observouse que a La Niña foi atuante nos anos de 1995, 1996, 2000 e 2008, enquanto que em 2010 observou-se uma transição de El Niño para La Niña e a neutralidade desta anomalia TSM para os anos de 1978 e 1981 (NOAA, 2016; TERASSI et al., 2018). 


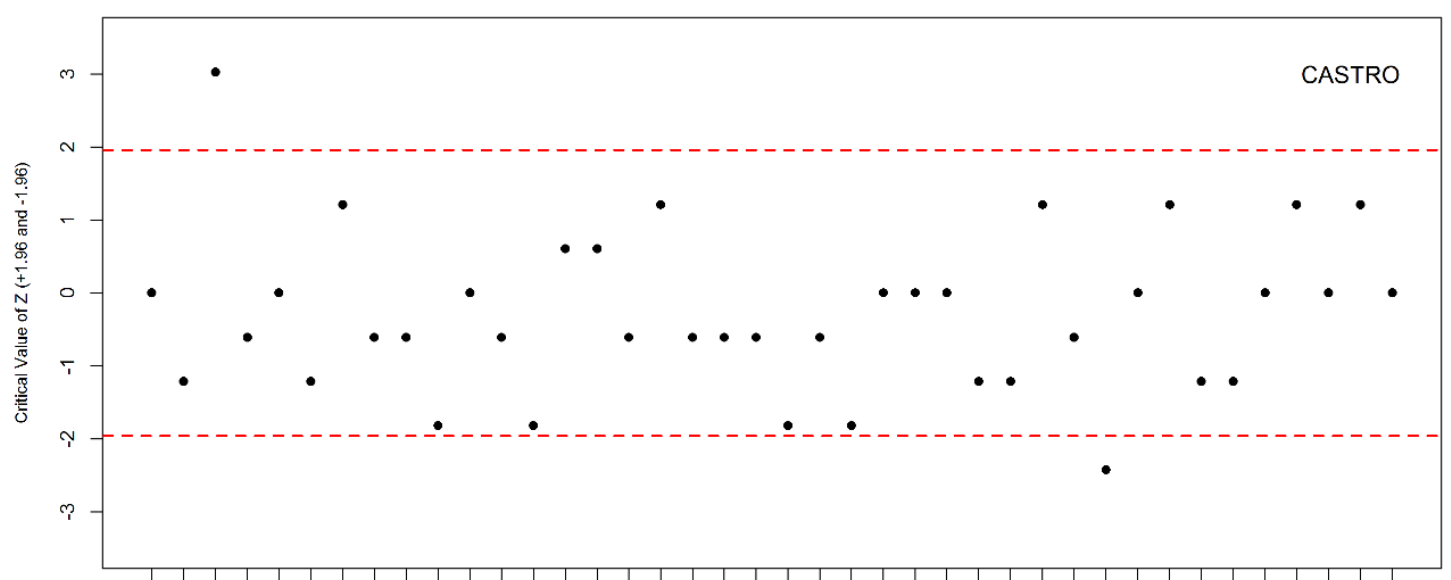

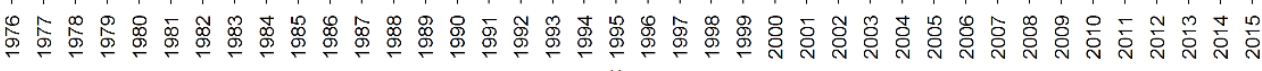

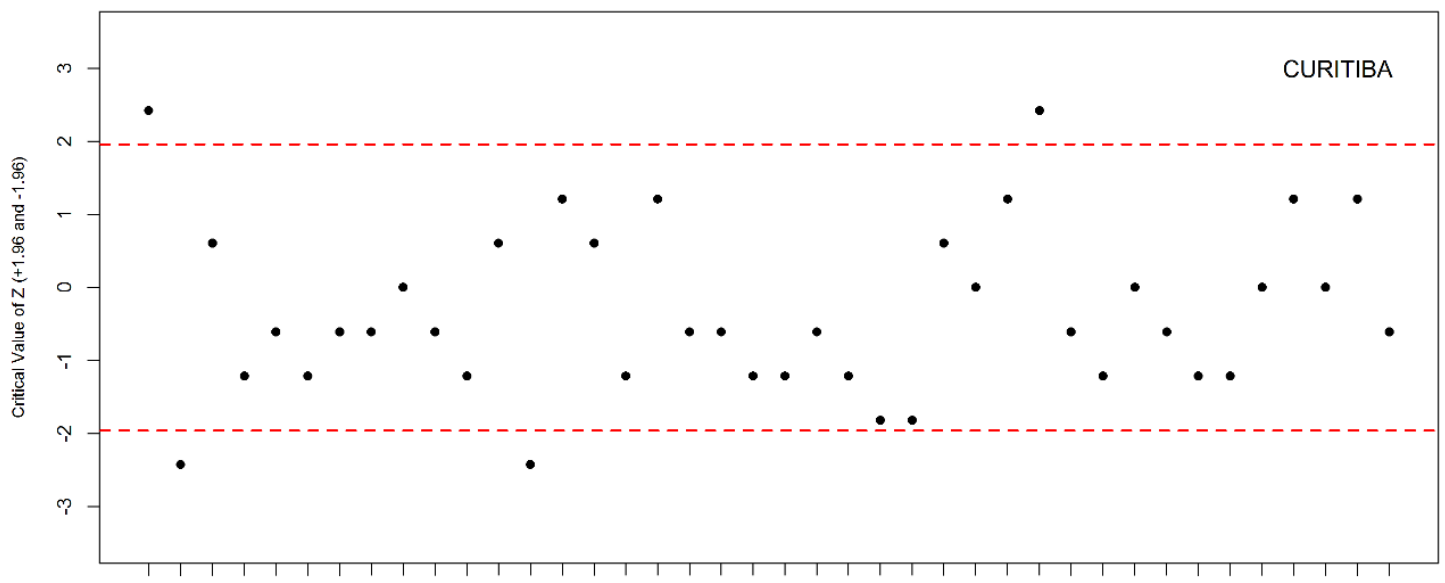

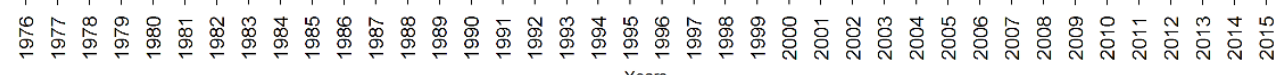

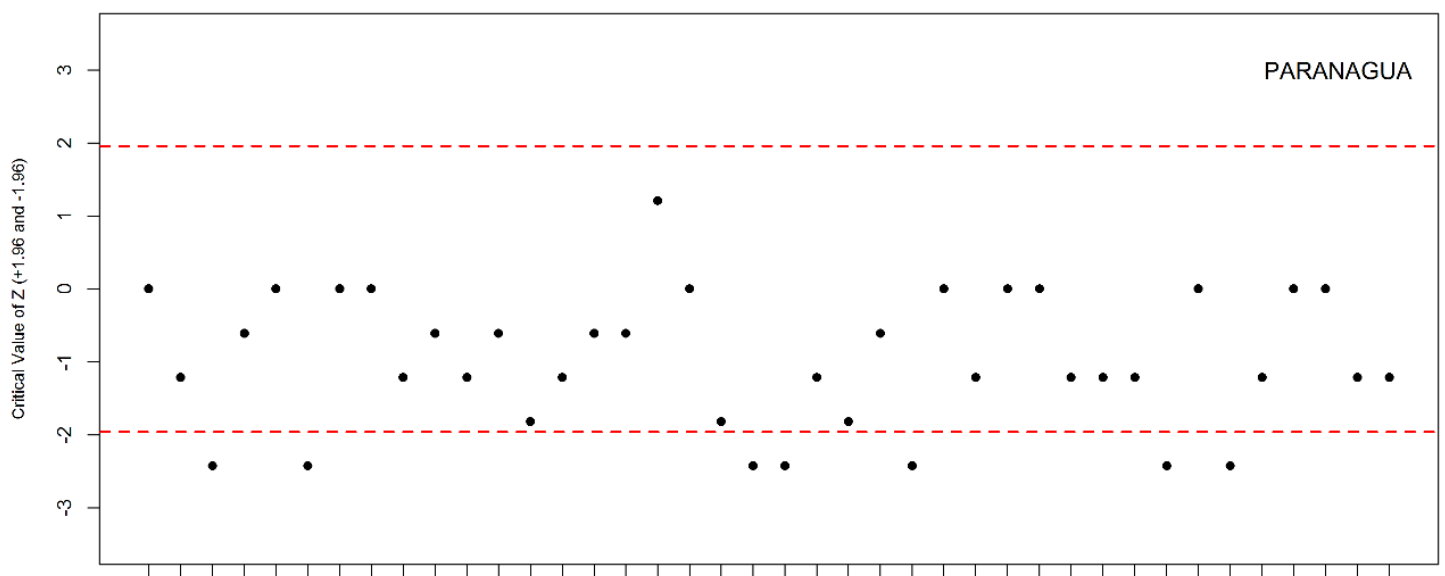

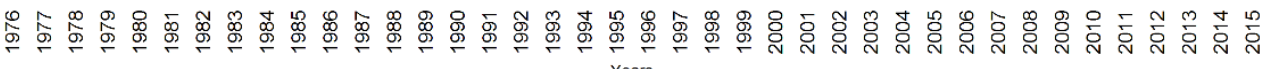

Figura 74 - Valores do teste Run na escala anual das chuvas diárias para a área de estudo. 


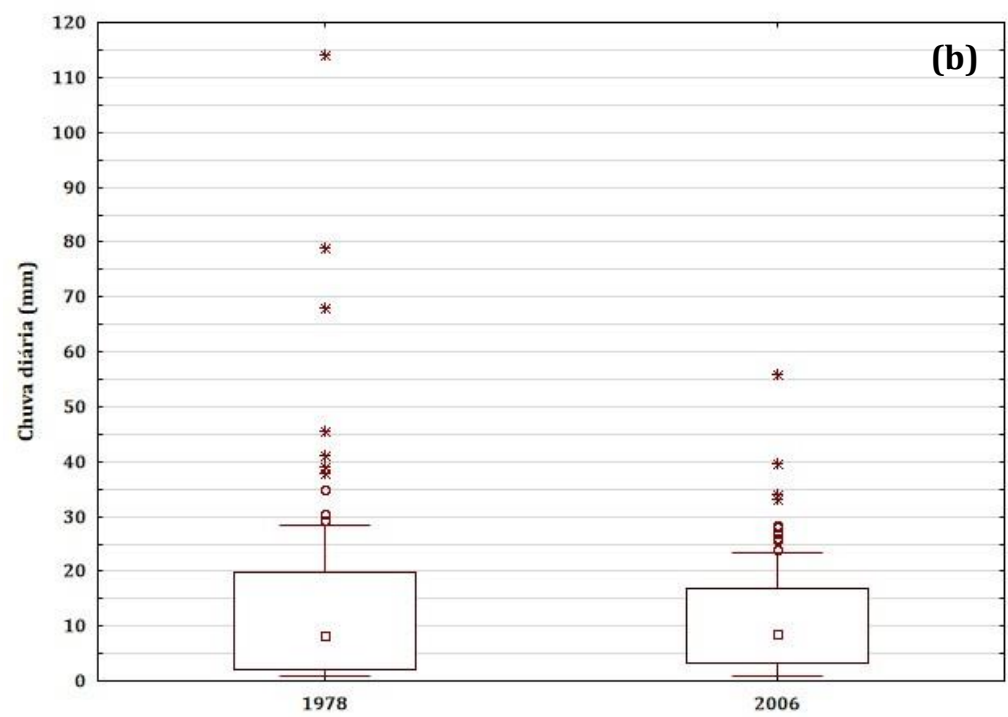

$\square$ Mediana $\square 25 \%-75 \%$ 工 75\%-99\% 。 Outliers (99\%-99,5\%) * Extremes (>99,5\%)
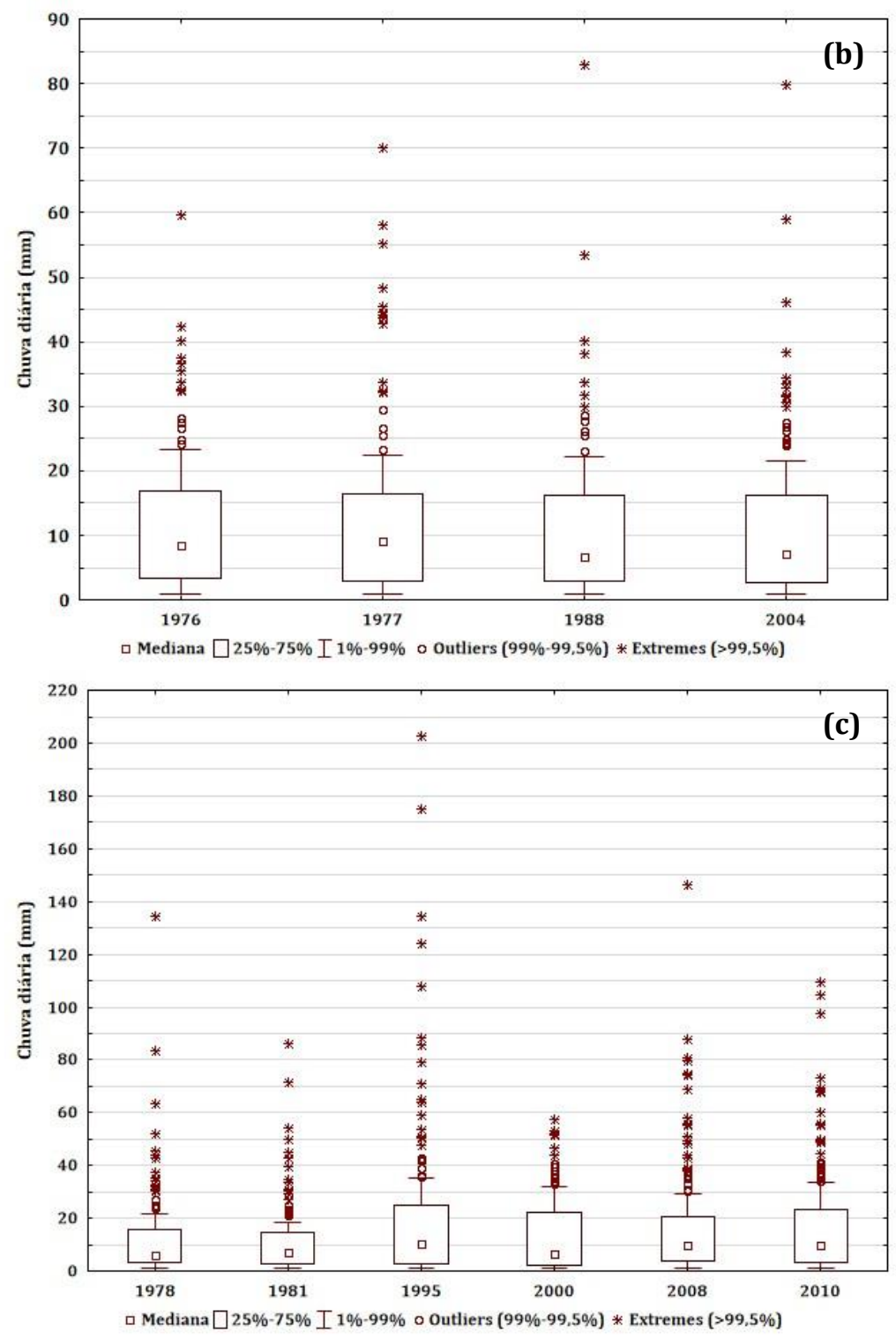

Figura 75 - Boxplot das chuvas diárias (mm) dos anos abaixo ou acima dos limites críticos de Z para Castro (a), Curitiba (b) e Paranaguá (c) - Paraná. 
O TMK identificou o aumento das chuvas diárias para todas as classes de quantis nas três localidades em estudo. Entretanto, apenas em Curitiba obteve-se a significância estatística, para qual o aumento da chuva diária nos diferentes limiares quantílicos esteve entre 2,56 e 2,62 mm.ano ${ }^{-1}$. O aumento da chuva diária em Paranaguá obteve intervalos entre 1,74 e 1,76 mm.ano ${ }^{-1}$, enquanto que em Castro observou-se um aumento entre 0,72 e $0,82 \mathrm{~mm}^{\mathrm{ano}} \mathrm{o}^{-1}$ (Tabela 25 ).

Zandonadi et al. (2015) identificaram em Castro o aumento de 1,6 e 0,8 mm.ano ${ }^{-}$ ${ }^{1}$ para os indicadores R95p e R99p, nesta ordem, similares aos resultados obtidos neste estudo. Os autores supracitados indicaram o aumento de 7,3 e 2,00 mm.ano ${ }^{-1}$ em Curitiba para os indicadores de R95p e R99p, respectivamente, sendo que o primeiro indicador superou em $285 \%$ o aumento identificado nesta pesquisa. A tendência significativa de aumento das chuvas na região de Curitiba e, gradativamente, em menores proporções no entorno de Paranaguá e Castro, foi também observada por Ely e Dubreuil (2017).

Pedron et al. (2017) obtiveram o aumento da chuva diária nos meses de verão, outono e inverno para Curitiba, Brasil. Verificaram que a frequência de chuvas iguais ou superiores a 95\% (R95p) está relacionada significativamente com o Índice Oscilação Sul (IOS), a ZCAS, a Anomalia de Temperatura de Superfície do Mar (ATSM), a Oscilação Multidecadal do Atlântico (OMA) e o Índice de larga escala de monção da América do Sul (ILMAS). Estes autores acrescentam a necessidade de uma avaliação consistente dos efeitos decorrentes de fatores de menor escala como a urbanização, a poluição do ar e as circulações atmosféricas locais.

De modo geral, os estudos de Haylock et al. (2006) mostraram que o leste do estado do Paraná apresentou resultados com significância estatística para o aumento dos totais de precipitação pluviométrica total anual e, mormente, para os totais e a frequência das chuvas diárias superiores a 95\% e 99\% dos quantis. Observaram também a elevação da frequência de chuvas diárias superiores a $10 \mathrm{~mm}$ e $20 \mathrm{~mm}$ como uma das principais características de tendências de mudança das chuvas no sudeste da América do Sul.

A aplicação do teste Pettit mostrou que as principais alterações nas séries diárias pluviométricas na região leste do estado do Paraná ocorreram entre os anos de 1990 e 1995. Curitiba, uma das maiores cidades brasileiras, a modificação ocorreu entre setembro e novembro de 1990, enquanto os municípios menos populosos apresentaram uma mudança mais tardia: entre outubro e novembro de 1994 para Paranaguá e entre julho e outubro de 1995 para Castro. Este resultado mostra claramente a influência de efeitos da urbanização mais intensificada de Curitiba para as características pluviais, conforme 
apontam os estudos anteriores de Zanela (2006), Zandonadi et al. (2015) e Pedron et al. (2017).

Ainda, estes resultados são aproximados ao identificado por Nascimento-Júnior (2013) para o estado do Paraná, pois verificou que as maiores frequências das rupturas ocorreram entre 1990 e 1994 para os totais pluviais anuais. Inclusive, estes resultados do teste Pettitt ressaltam a elevada ocorrência dos eventos pluviais na década de 1990, como demonstrado pelos dendogramas da figura 74, nos quais se observa que 36,7\% das chuvas intensas ocorreram nos anos 1990.

Tabela 25 - Mudanças e rupturas da intensidade da precipitação pluviométrica diária em acordo com o teste Mann-Kendall e o teste de ruptura de Pettit.

\begin{tabular}{|c|c|c|c|c|c|c|c|}
\hline \multirow{2}{*}{$\begin{array}{c}\text { Estações } \\
\text { Meteorológicas e } \\
\text { quantis }\end{array}$} & \multicolumn{3}{|c|}{ Teste Mann - Kendall } & \multicolumn{4}{|c|}{ Teste Pettit } \\
\hline & Tau & p-value & $\mathbf{Z}$ & $\mathbf{K}$ & POS & p-valor & Ruptura \\
\hline Castro - R25p & 0,0089 & 0,4108 & 0,82 & 93148 & 2937 & 0,797707 & Out - 1995 \\
\hline Castro - R50p & 0,0089 & 0,4108 & 0,82 & 93148 & 2937 & 0,797707 & Out - 1995 \\
\hline Castro - R75p & 0,0086 & 0,4254 & 0,80 & 93052 & 2909 & 0,778484 & Ago - 1995 \\
\hline Castro - R95p & 0,0078 & 0,4739 & 0,72 & 87790 & 2909 & 0,8624 & Ago - 1995 \\
\hline Castro - R99p & 0,0079 & 0,4685 & 0,72 & 88661 & 2908 & 0,84748 & Jul - 1995 \\
\hline Curitiba - R25p & 0,0260 & $0,0097^{* *}$ & 2,58 & 283075 & 2224 & $0,007278^{* *}$ & Nov - 1990 \\
\hline Curitiba - R50p & 0,0261 & $0,0097^{* *}$ & 2,59 & 281569 & 2218 & $\mathbf{0 , 0 0 7 2 9 6}^{* *}$ & Out -1990 \\
\hline Curitiba - R75p & 0,0265 & $\mathbf{0 , 0 0 8 8}^{* *}$ & 2,62 & 282077 & 2209 & $0,00672^{* *}$ & Set -1990 \\
\hline Curitiba - R95p & 0,0260 & $0,0101^{*}$ & 2,57 & 278039 & 2209 & $0,007841^{* *}$ & Set -1990 \\
\hline Curitiba - R99p & 0,0259 & $0,0106 *$ & 2,56 & 277977 & 2208 & $0,007801^{* *}$ & Set - 1990 \\
\hline Paranaguá - R25p & 0,0151 & $\mathbf{0 , 0 7 8 4}^{+}$ & 1,76 & 392232 & 2799 & $\mathbf{0 , 0 3 3 1 3 6}^{*}$ & Nov - 1994 \\
\hline Paranaguá - R50p & 0,0151 & $\mathbf{0 , 0 7 8 7 ^ { + }}$ & 1,76 & 389716 & 2785 & $\mathbf{0 , 0 3 3 1 3 9 *}^{*}$ & Out - 1994 \\
\hline Paranaguá - R75p & 0,0152 & $\mathbf{0 , 0 7 8 2}^{+}$ & 1,76 & 385253 & 2781 & $0,035594^{*}$ & Out - 1994 \\
\hline Paranaguá - R95p & 0,0149 & $\mathbf{0 , 0 8 2 3}^{+}$ & 1,74 & 382738 & 2781 & $\mathbf{0 , 0 3 7 4 3 6}^{*}$ & Out - 1994 \\
\hline Paranaguá - R99p & 0,0150 & $\mathrm{0,0815}^{+}$ & 1,74 & 385938 & 2780 & $0,034947^{*}$ & Out - 1994 \\
\hline
\end{tabular}

Legenda: ${ }^{* *}=99 \%$ de significância; ${ }^{*}=95 \%$ de significância; ${ }^{+}=90 \%$ de significância.

Um dos principais indicativos de aumento dos limiares das classes de precipitação são decorrentes do aumento de temperatura do ar. Devido à impermeabilização dos solos urbanos decorrente do processo de urbanização, supôs-se que o aumento de temperatura do ar das localidades em estudo seja um dos fatores pujantes nas mudanças observadas pelo teste TMK para as classes diárias de chuva. Portanto, os resultados que associam o aumento das temperaturas do ar à elevação da intensidade dos eventos pluviais extremos são condizentes ao obtido pelos modelos climáticos empregados por Allan e Soden (2008) para o globo terrestre. Deste modo, atribui-se ao aumento das tendências das classes diárias de precipitação na área em estudo ao aumento das cidades, pujantemente observado em Curitiba, onde as ICU foram recentemente investigadas por Krüger e Rossi (2015) e Lunardon (2017), sendo que esta última pesquisa revelou diferenças térmicas de até $8^{\circ} \mathrm{C}$ entre a área urbana e adjacências. 


\subsection{Avaliação das condições atmosféricas associadas aos eventos pluviais extremos}

O principal método empregado para a avaliação das condições atmosféricas que geraram os eventos extremos pluviais destacados anteriormente foi a Análise Rítmica Climatológica (ARC) difundida por Monteiro (1971), que permitiu uma visão conjuntiva dos aspectos climáticos na geração das chuvas durante os segmentos temporais analisados a seguir. Este caráter integrado na identificação dos tipos de tempo associados mostraram a singularidade entre os atributos climáticos e a dinâmica atmosférica, uma vez que esta relação se dá de modo não necessariamente uniforme e linear.

O evento pluvial extremo de maio de 2005 identificado para a localidade de Castro foi precedido por um período de estiagem, com o registro de chuvas muito fracas $(0,2$ $\mathrm{mm}$ ) até o dia $16 \mathrm{e}$, posteriormente a esta data, chuvas pouco expressivas $(<10 \mathrm{~mm})$ que se deram devido à atuação dos CCM's e à associação de um Cavado ao Jato Subtropical. A junção dos CCM's ao Jato Subtropical se deu no dia 23 e gerou uma precipitação de 16,4 mm, com o aumento expressivo da UR (>98\%) e a ausência de horas de brilho solar. Com a incursão da FPA com atuação conjugada do Jato Subtropical no dia 24, houve a diminuição da temperatura média do $\operatorname{ar}\left(<13^{\circ} \mathrm{C}\right)$, a redução da pressão atmosférica $(898,5$ $\mathrm{mb}$ ) e a ocorrência da chuva de 107,9 mm. Após a entrada abrupta da FPA, nota-se que houve a queda acentuada da temperatura mínima, com destaque para os $3,8^{\circ} \mathrm{C}$ registrado no dia 25 , o aumento gradativo da pressão atmosférica $(>908 \mathrm{mb}$ ) e a queda da UR $(<80 \%)$, condições dos atributos climáticos que se devem a entrada de uma intensa MPA, que nos dias seguintes adquiriu características tropicais, especialmente pelo aumento da temperatura máxima $\left(>22^{\circ} \mathrm{C}\right)$, conforme demonstra a figura 76.

Em Castro, a pluviosidade total mensal em maio de 2005 se deu em 141,2 mm, cerca de $20 \%$ acima da média histórica, especificamente concentrada no dia 24 . Este evento extremo pluvial equivaleu a $92,2 \%$ do total médio de precipitação do mês de maio em Castro, em condições atmosféricas principais associadas a incursão da frente polar atlântica (Figura 77) e, especialmente pela associação ao Jato Subtropical, que reforçou as condições atmosféricas para a geração das chuvas concentradas e intensas. Conforme descrito no Boletim de Monitoramento e Análise Climática (CLIMANÁLISE, 2005), as chuvas no mês de maio na região Sul do Brasil se deram acima da média, notadamente no noroeste do Rio Grande do Sul, em Santa Catarina e no sudoeste do Paraná devido à atuação dos CCM's, sistema atmosférico que não esteve diretamente associado aos maiores volumes de precipitação ocorridos na área em estudo. Neste mesmo documento, 
destaca-se a maior intensidade do Jato Subtropical na região Norte da Argentina e no Sul do Brasil, sobretudo entre os dias 17 e 22 de maio, em que atingiu uma magnitude superior a $70 \mathrm{~m} / \mathrm{s}$.

Em estudo para a bacia hidrográfica do rio Paraná, Zandonadi (2013) avaliou a participação dos sistemas atmosféricos nos diferentes tipos de tempo nesta área de estudo. Destacou que durante o outono de 2005 houve o aumento da atuação dos sistemas polares em relação ao verão e, que até mesmo mecanismos que habitualmente geram condições de estabilidade, tiveram participação significativa na formação de chuvas, com destaque para os $27 \%$ das chuvas geradas pela $\mathrm{mPa}$ em Curitiba. Contudo, em localidades como Guarapuava e Foz do Iguaçu (PR), a FPA respondeu por 55\% e 61\% das condições de chuva durante o outono do referido ano. Durante esta mesma sazonalidade deste mesmo ano, os tipos de tempo estiveram sob condições da mPaT em 33\% e 47\% dos dias em Foz do Iguaçu e Curitiba (PR), próximos aos resultados obtidos nesta pesquisa, pois em Castro observou-se que esta condição tropicalizada da mPa esteve atuante em 38,7\% dos dias avaliados em maio de 2005 e não houveram chuvas superiores a $0,1 \mathrm{~mm}$ durante a sua atuação, o que leva a supor que em Curitiba as chuvas durante a ocorrência da $\mathrm{mPa}$ e a $\mathrm{mPaT}$ se deve em função da proximidade desta localidade em relação ao litoral, pois se situa a menos de $100 \mathrm{~km}$ da costa.

Em 01 agosto de 2011 foi registrado em Castro o evento extremo pluvial de maior magnitude dentre os registrados na série histórica desta estação meteorológica, com uma intensidade de 153,6 mm em 24 horas. A repercussão do sistema frontal que ocasionou tais chuvas iniciou-se no dia 30 de julho, com o aumento da UR (>96\%), a diminuição da temperatura do ar, a queda da pressão atmosférica, além do registro de chuvas de baixos valores (7,6 mm). No dia 31, a FPAE avançou sob o Paraná e reforçou as condições de instabilidade atmosférica, com o registro de $54,6 \mathrm{~mm}$, associado à gradativa queda da temperatura do ar e ao aumento da UR. O primeiro dia de agosto continuou sob o domínio da FPAE e com a manutenção das características dos atributos climáticos do dia anterior, houve o registro do evento extremo pluvial de agosto de 2011. Com a intensificação do Jato Subtropical e a formação de um Vórtice Ciclônico no Norte da Argentina, no dia 02 de agosto verificou-se a ocorrência de um Ciclone Extratropical, que favoreceu o total pluvial de 42,8 mm nesta data (Figuras 78 e 79).

Nos dias posteriores, a entrada da MPA repercutiu na estabilidade atmosférica, na queda acentuada de UR e, pujantemente, da temperatura do ar, que registrou mínima de $1^{\circ} \mathrm{C}$, destacando-se o deslocamento da FPA entre o oeste da região $\mathrm{N}$ e o litoral do SE do 
Brasil (Figura 79). Nota-se que os dias seguintes do mês de agosto foram característicos dos tipos de tempo desta localidade, com a constante entrada dos sistemas atmosféricos extratropicais determinando os atributos climáticos, mais expressivamente com a MPA na redução das chuvas e a FPA e/ou Cavados geração das chuvas (Figura 78). Espera-se em agosto os menores totais de chuvas, pois é o mês de menor pluviosidade $(66,9 \mathrm{~mm})$ e, contudo, a atividade frontal mais intensa decorrente da atuação do jato em baixos níveis contribuiu para a ocorrência de chuvas fortes e intensas em quase toda a Região Sul (CLIMANÁLISE, 2011). Destaca-se uma anomalia positiva da temperatura mínima do ar com um desvio superior a $2^{\circ} \mathrm{C}$ na região de Castro, que possivelmente tenha favorecido à instabilidade atmosférica desta localidade em agosto de 2011, que registrou ao longo do mês um total de $357,8 \mathrm{~mm}$, que equivale a um desvio de aproximadamente $435 \% \mathrm{em}$ relação à média da série histórica.

A ocorrência de evento extremo de junho de 2012 foi identificada em Curitiba e Paranaguá. No primeiro dia do mês, verificou-se a presença de uma FPAE que ocasionou chuva moderada ( $<22 \mathrm{~mm}$ ) em ambas as localidades, sendo precedida pelas condições de tempo de dissipação deste sistema atmosférico. No entanto, no dia 03 a entrada de outro sistema frontal pela região Sul do Brasil repercutiu no aumento da temperatura média, na diminuição expressiva da pressão atmosférica e em ventos das direções $\mathrm{N}$ e NW, que são condições tipicamente da aproximação da FPA. No dia 04, a entrada da FPA ocasionou chuvas entre 15 e $17 \mathrm{~mm}$, com a diminuição das temperaturas e o aumento da UR e, no dia seguinte, com o eixo principal da FPA entre o oeste do Mato Grosso e o Sul de São Paulo, registrou-se o maior total pluviométrico diário em Curitiba e Paranaguá, igual a $106,8 \mathrm{~mm}$ e 115,6 mm. No dia 06, o sistema atmosférico tornou-se uma FPAE e manteve o seu posicionamento do dia anterior e, contudo, com o registro de chuvas entre 2 e $6 \mathrm{~mm}$ nas localidades analisadas (Figuras 80 e 81).

Mesmo com o recuo da FPAE no dia 07, as condições atmosféricas locais geraram apenas chuvas fracas $(<8 \mathrm{~mm})$ em ambas localidades e, destacadamente, com o aumento da pressão atmosférica e a diminuição das temperaturas haviam indicativos da entrada da MPA, que nos dias seguintes repercutiu em temperaturas mínimas de até $7^{\circ} \mathrm{C}$ e $12^{\circ} \mathrm{C} \mathrm{em}$ Curitiba e Paranaguá, nesta ordem. Nos dias posteriores, verificou-se que a MPA adquiriu características tropicais, com o aumento das temperaturas máximas diárias e a redução da UR. Observa-se que os demais dias do mês de junho mostrou uma similaridade do ritmo climático, mostrando a incursão de sistemas atmosféricos extratropicais na mudança dos tipos de tempo e, entretanto, nenhuma outra frente fria gerou totais pluviais elevados e a 
chuva diária mais expressiva deu-se no dia 11 (>30 mm) devido à formação de um Cavado (Figuras 80 e 81).

Ao longo do mês de junho de 2012 a passagem de oito sistemas frontais pelo Sul do Brasil repercutiu em pluviosidade acima da normal climatológica no Paraná, gerando eventos extremos pluviais em diversas regiões do estado em diferentes dias do mês. Em Curitiba e Paranaguá choveu 225,5 e 239,8 mm, enquanto que a série de 40 anos utilizada nesta pesquisa indica médias de pouco mais de $100 \mathrm{~mm}$ para este mês. Especificamente em relação ao evento extremo registrado no dia 05, é possível que esteja relacionado à forte magnitude da MPA que estava na retaguarda, sistema atmosférico destacado como o mais intenso dentre aqueles identificado neste período analisado e o choque de ar de diferentes conteúdos de temperatura e umidade tenha repercutido em chuvas intensas (CLIMANÁLISE, 2012). A intensidade desta MPA é sugerida pelo rápido deslocamento da FPA entre os dias 03 e 04 e pelo significativo aumento da abrangência das isóbaras do Anticiclone Migratório Polar, conforme demonstrado pela Figura 82.

O segundo maior evento pluvial extremo diário registrado em Curitiba ocorreu em 20 de junho de 2013, com um total diário de 128,2 mm. Observa-se que até o dia 19 do referido mês, o ritmo climático se deu dominado pelas condições de alternância entre os sistemas atmosféricos extratropicais que geraram condições sucessivas de chuva até aproximadamente $30 \mathrm{~mm}$, redução das temperaturas e, posteriormente, o aumento da temperatura máxima diária, mostrando a incursão e/ou formação da FPA ou FPAE, mPa e mPaT. A formação de um cavado sob a região Sul do Brasil no dia 19 gerou 9,7 mm de chuva em Curitiba e, no dia seguinte, o rápido avanço da FPA e evolução para FPAE foi o mecanismo responsável pelos elevados totais de chuva na capital paranaense. O recuo da FPAE no dia 21 continuou a gerar instabilidade atmosférica e repercutiu em uma chuva de 39,6 mm, acompanhada pelo aumento da velocidade média dos ventos $\left(2,8 \mathrm{~m} / \mathrm{s}^{-1}\right) \mathrm{e}$ queda acentuada da pressão atmosférica (906 mb) - (Figuras 83 e 84).

No dia seguinte, houve a acentuada queda de temperatura, com mínima de $6^{\circ} \mathrm{C}$, o aumento da pressão atmosférica (>911 mb) e estabilidade atmosférica associada a atuação da $\mathrm{mPa}$. Nos dias posteriores, mesmo com a incursão da última mPa supracitada, houve a identificação da atuação dos Cavados, dos Jatos Subtropicais e, sobretudo, da atuação conjugada destes mecanismos atmosféricos, que ocasionou entre os dias 22 e 29 chuvas diárias entre 3,3 e 35,2 mm e temperaturas médias diárias entre 13 e $18^{\circ} \mathrm{C}$. No último dia do mês (30), nota-se a queda acentuada de temperatura média $\left(11,0^{\circ} \mathrm{C}\right)$, o aumento da UR (96\%) e a chuva de 21,2 mm, condições atribuídas a entrada da FPA (Figuras 83 e 84). 
O mês de junho em 2013 mostrou uma pluviosidade de 330,1 mm, sendo que a média deste mês é de 104,4 mm. O evento pluvial extremo do dia 20 se deu de forma intensa devido à passagem da corrente de jato na alta troposfera, que contribuiu para a intensifica da FPAE e pelos valores expressivos de precipitação pluviométrica no estado do Paraná. Durante a segunda quinzena de junho do referido ano, a atividade frontal foi intensificada pelos jatos de baixos níveis e às passagens dos cavados na média e alta troposfera, fatores que contribuíram para as anomalias de chuva no Paraná, superiores a $200 \mathrm{~mm}$ (CLIMANÁLISE, 2013). É provável que a anomalia de até $3^{\circ} \mathrm{C}$ da temperatura média mínima em relação à normal climatológica tenha sido um fator condicionante à intensificação do evento extremo pluvial analisado.

Deste modo, afirma-se que os eventos extremos pluviais em condições de outono e inverno para a área de estudo estiveram associados a dominante atuação dos sistemas atmosféricos extratropicais na geração destas chuvas e a sua associação à mecanismos da média e/ou alta atmosfera, como os Jatos Subtropicais e, principalmente, os Cavados. Os resultados descritos acima sobre da participação dos sistemas atmosféricos no período de outono e inverno para a geração das chuvas extremas estão em acordo com os observados nestas mesmas regiões ou em suas proximidades em obras anteriores. A análise de Baldo (2006) para Guarapuava (PR), situada no Centro-Sul paranaense, indicou que durante o ano padrão habitual (2001) entre $79 \%$ e $93 \%$ dos totais pluviais ocorridos naquele ano durante o outono e inverno, nesta ordem, foram gerados pelos sistemas frontais, com uma elevada participação da FPAE nos meses de inverno (33\%) para a ocorrência pluvial. Em Maringá, situada na região Norte do estado do Paraná, durante o mesmo ano habitual, os sistemas frontais foram os mecanismos atmosféricos responsáveis por $82 \%$ e $97 \%$ do total precipitado naquela localidade durante o outono e inverno, respectivamente.

Considerando como habitual o ano de 2005, Zandonadi (2013) indicou que gênese das chuvas no outono e inverno foi atribuída a $80 \%$ e $89 \%$ em Curitiba, nesta ordem, e em menores proporções em Guarapuava, equivalente a $62 \%$ e $78 \%$, pois nesta última localidade as Linhas de Instabilidades Tropicais (LIT) decorrentes da antecipação da FPA foram mais expressivas em relação à capital paranaense. Seluchi et al (2011) mostraram que a atuação de uma FPAE durante seis dias em julho de 2004 no litoral do Paraná e de São Paulo ocasionaram chuvas intensas e deslizamentos na Serra do Mar destes estados, destacando-se que em Santos (SP) o total precipitado neste período foi de 241,5 mm. 


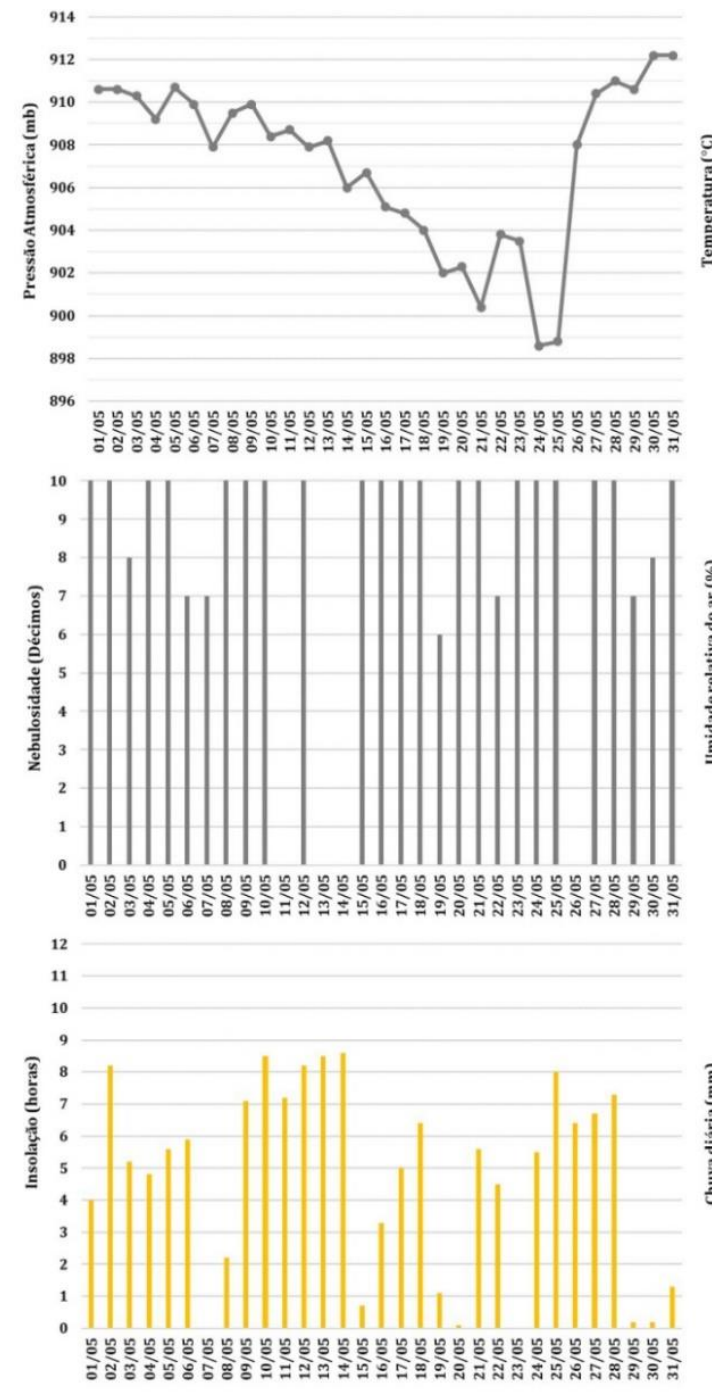

$+2$

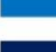

Frente Polar Atlântica (FPA)

Frente Polar Attântica Estacionária (FPAE)

Repercussão da FPA
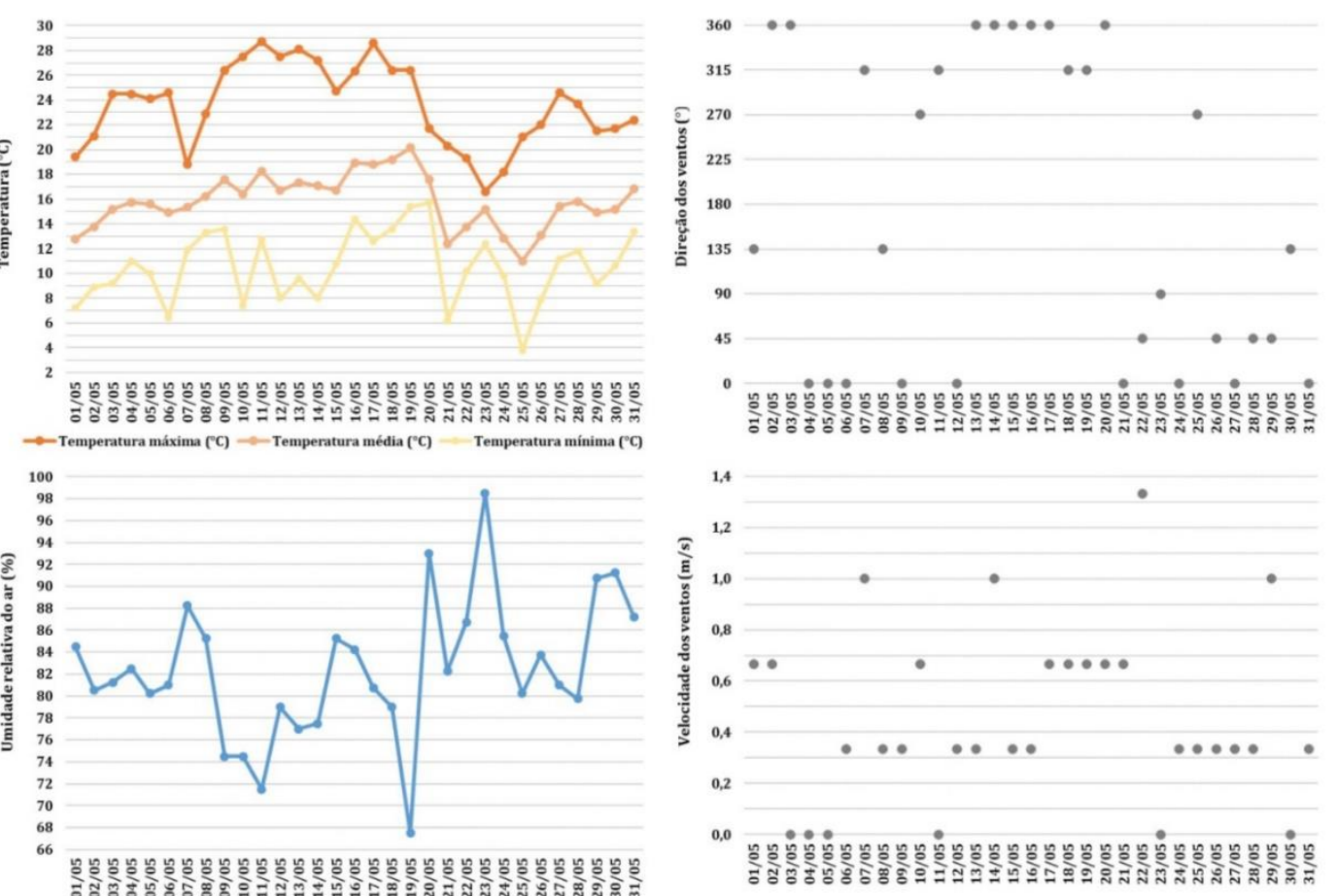

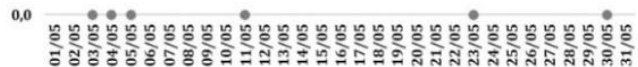
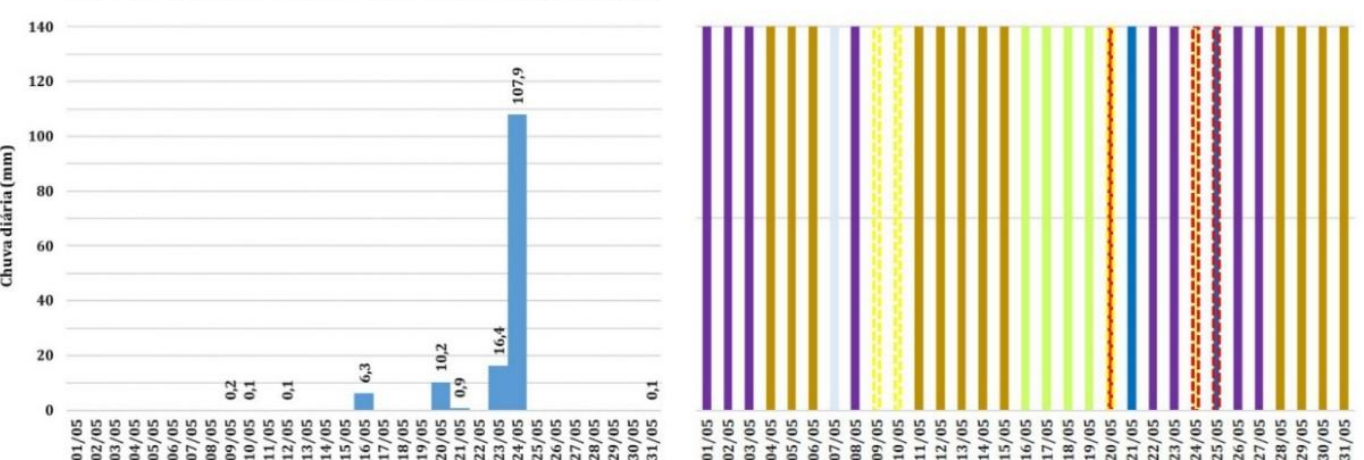

Sistemas Atmosféricos

Massa Polar Attântica (mPa)

Massa Polar Atlântica Tropicalizada (mPaT)

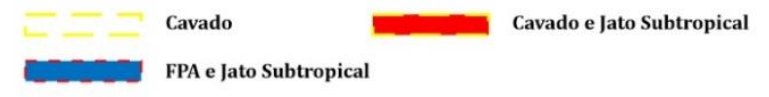

Figura 76 - Análise rítmica climática do evento pluvial de maio de 2005 em Castro - Paraná. 


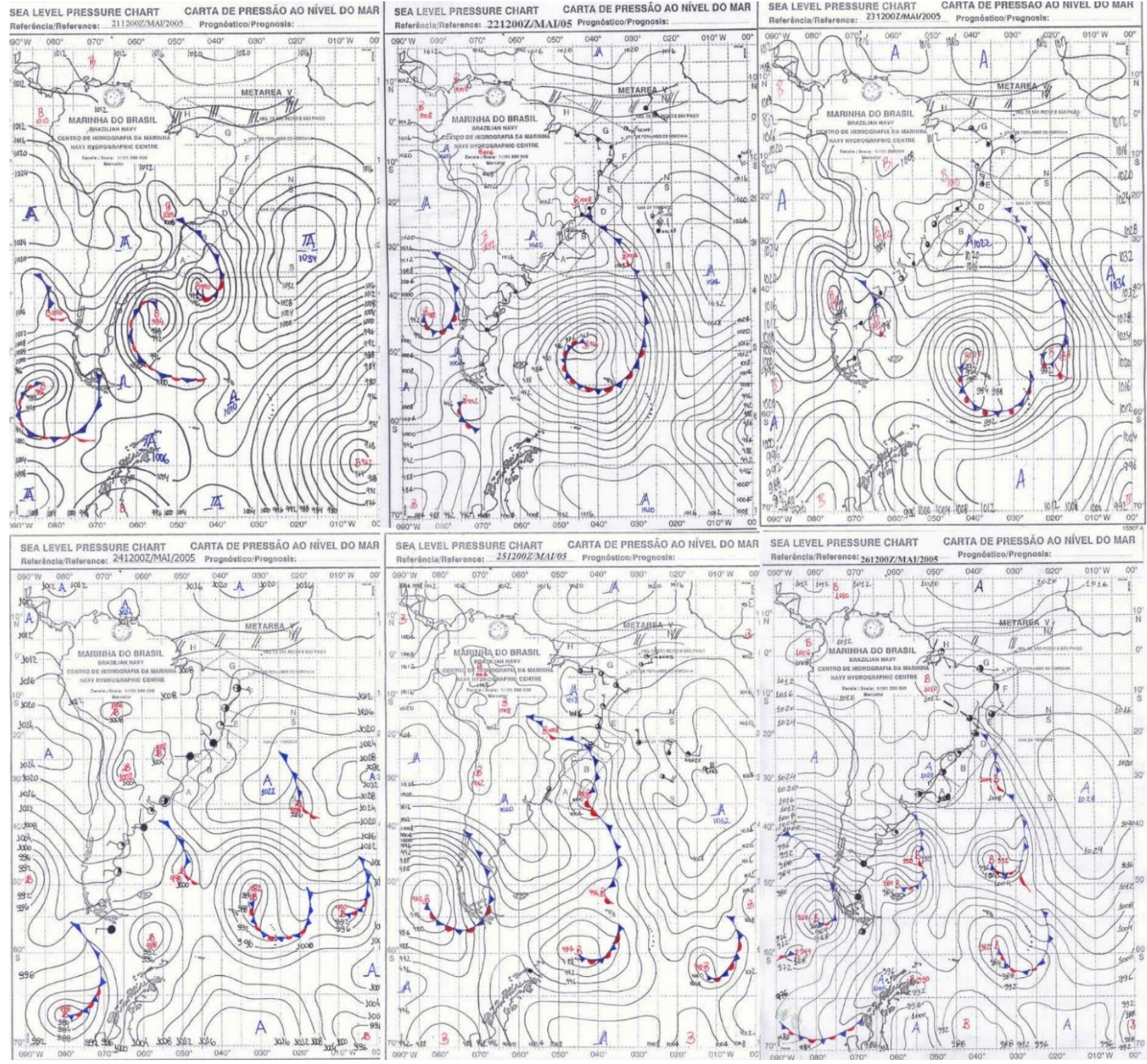

Figura 77 - Cartas sinóticas da América do Sul entre os dias 21 e 26 de maio de 2005. 

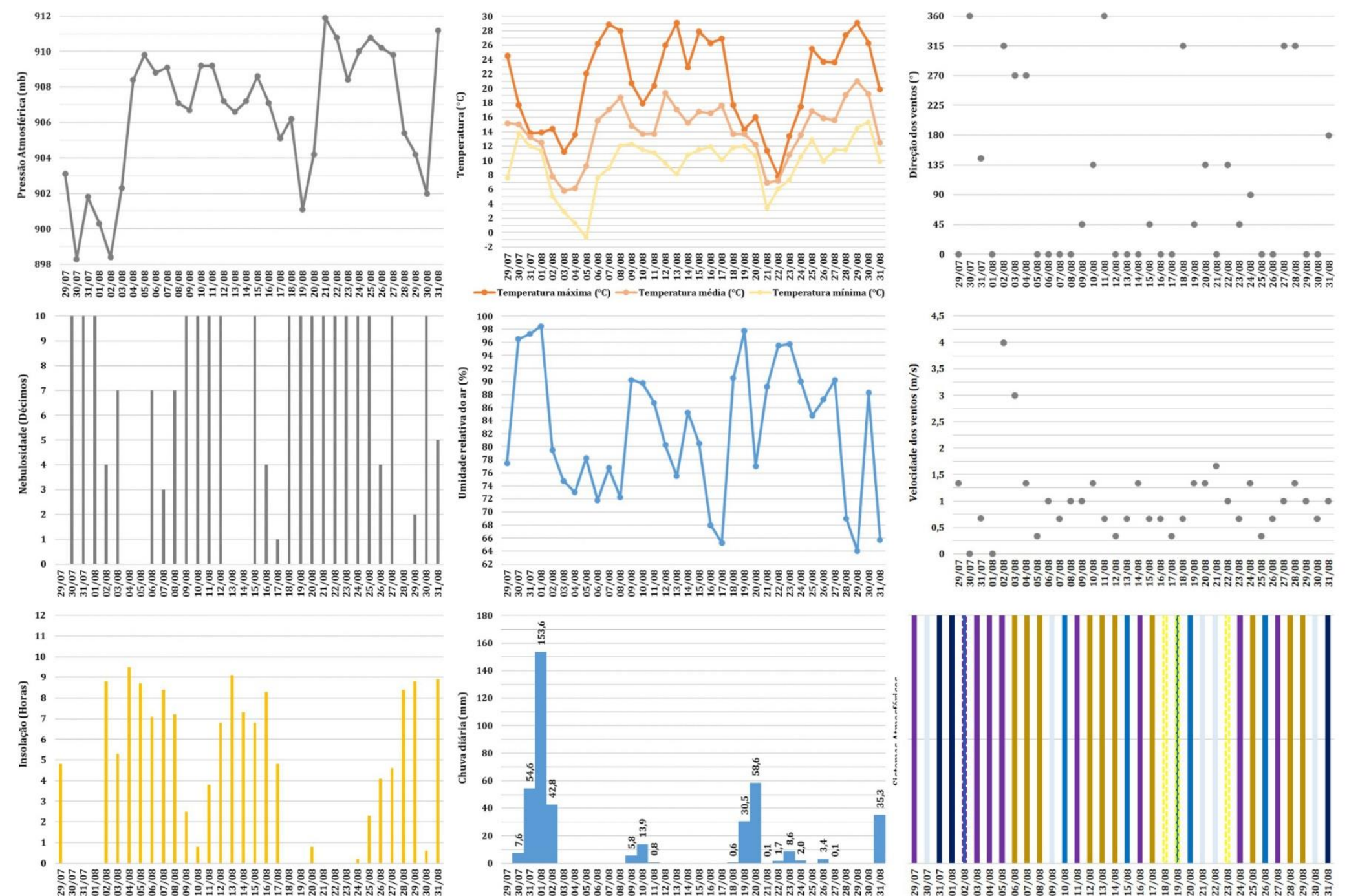

Sistemas Atmosféricos

Frente Polar Atlântica (FPA)
Frente Polar Atlântica Estacionária (FPAE)
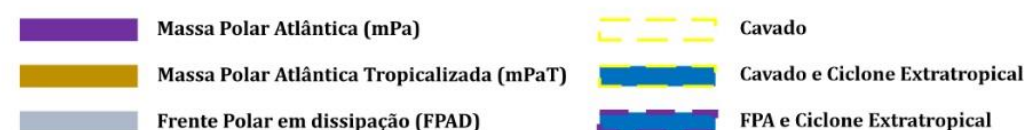

Repercussão da FPA

Figura 78 - Análise rítmica climática do evento pluvial de agosto de 2011 em Castro - Paraná. 


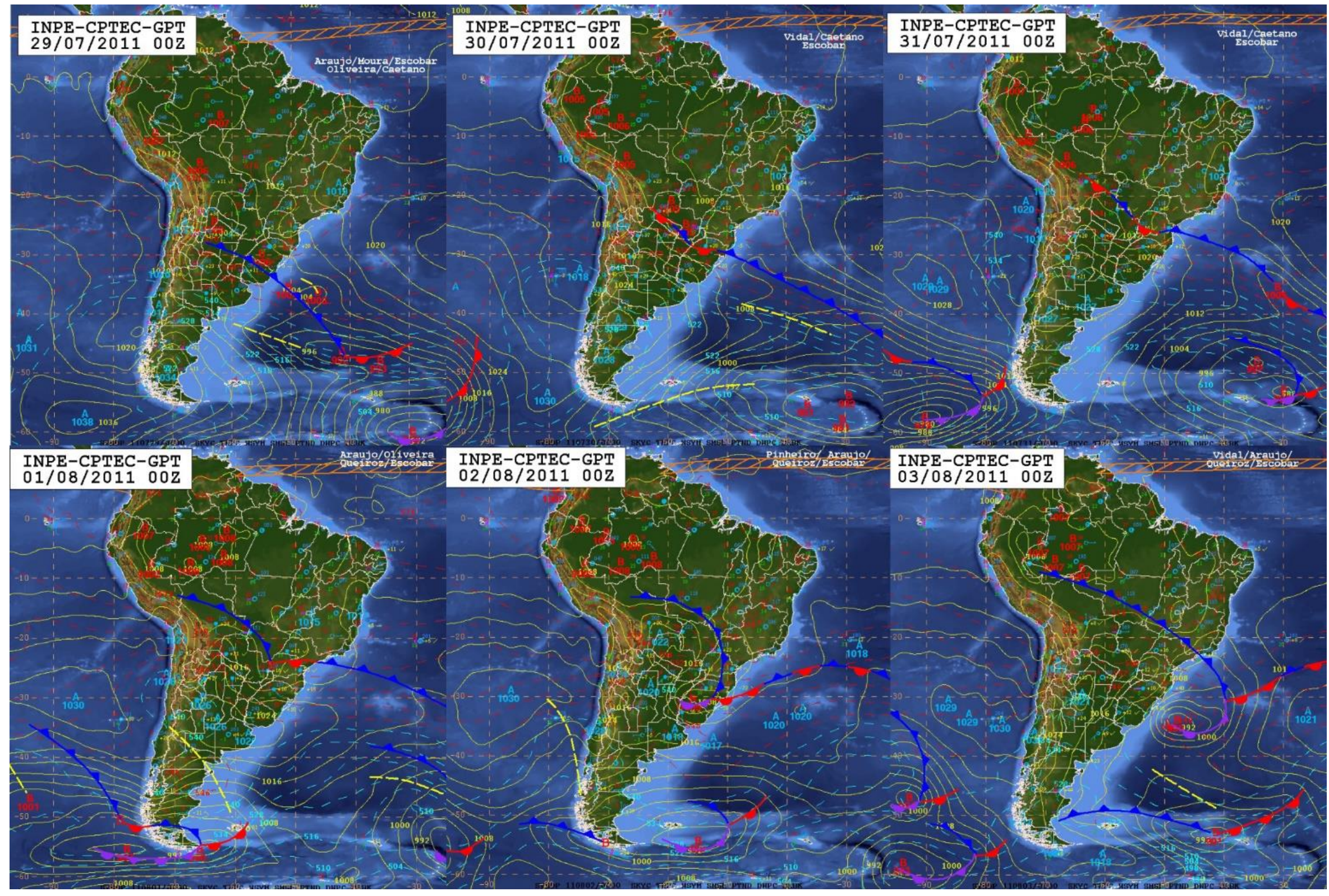

Figura 79 - Cartas sinóticas da América do Sul entre os dias 29 de julho e 03 de agosto de 2011. 

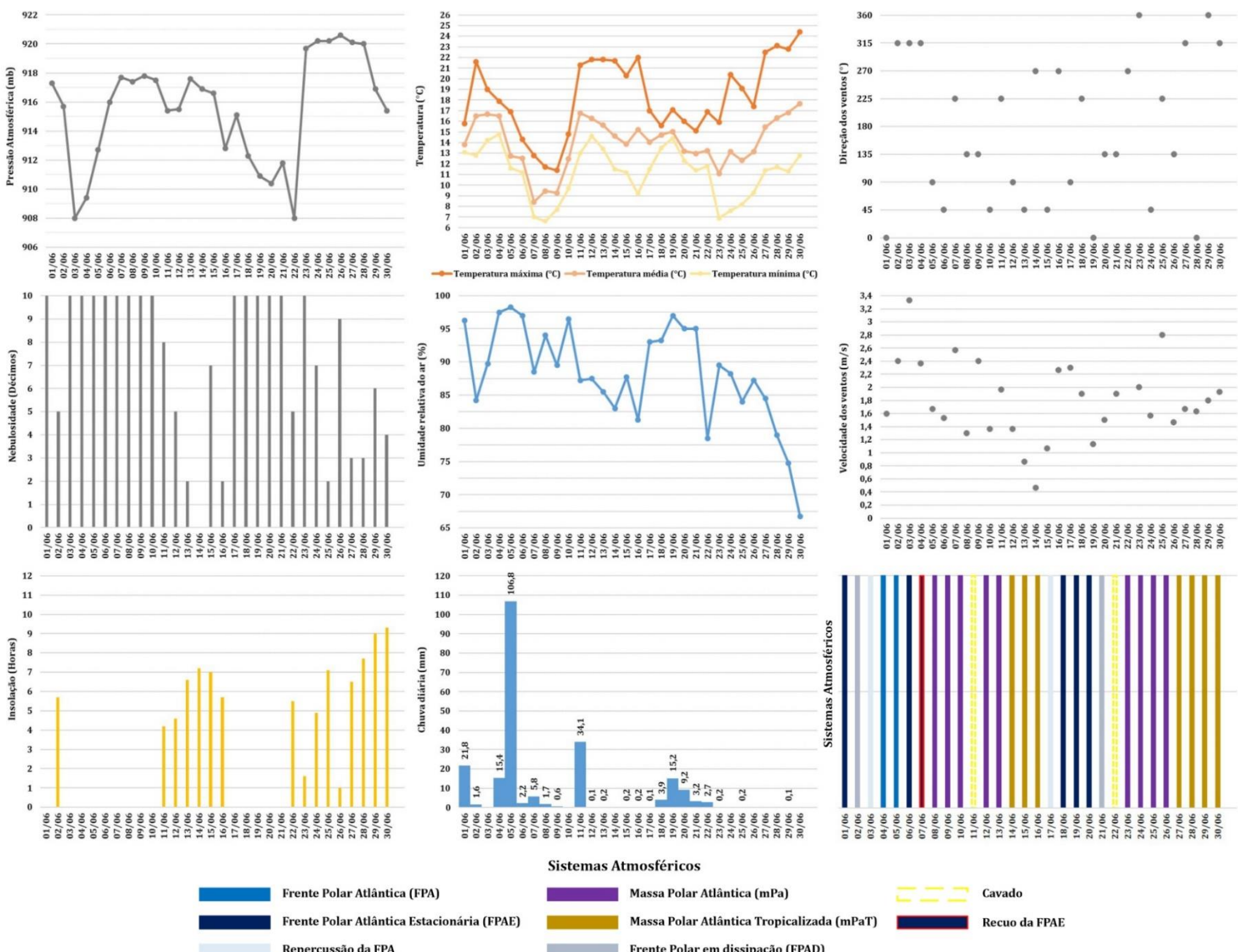

Sistemas Atmosféricos

Figura 80 - Análise rítmica climática do evento pluvial de junho de 2012 em Curitiba - Paraná 

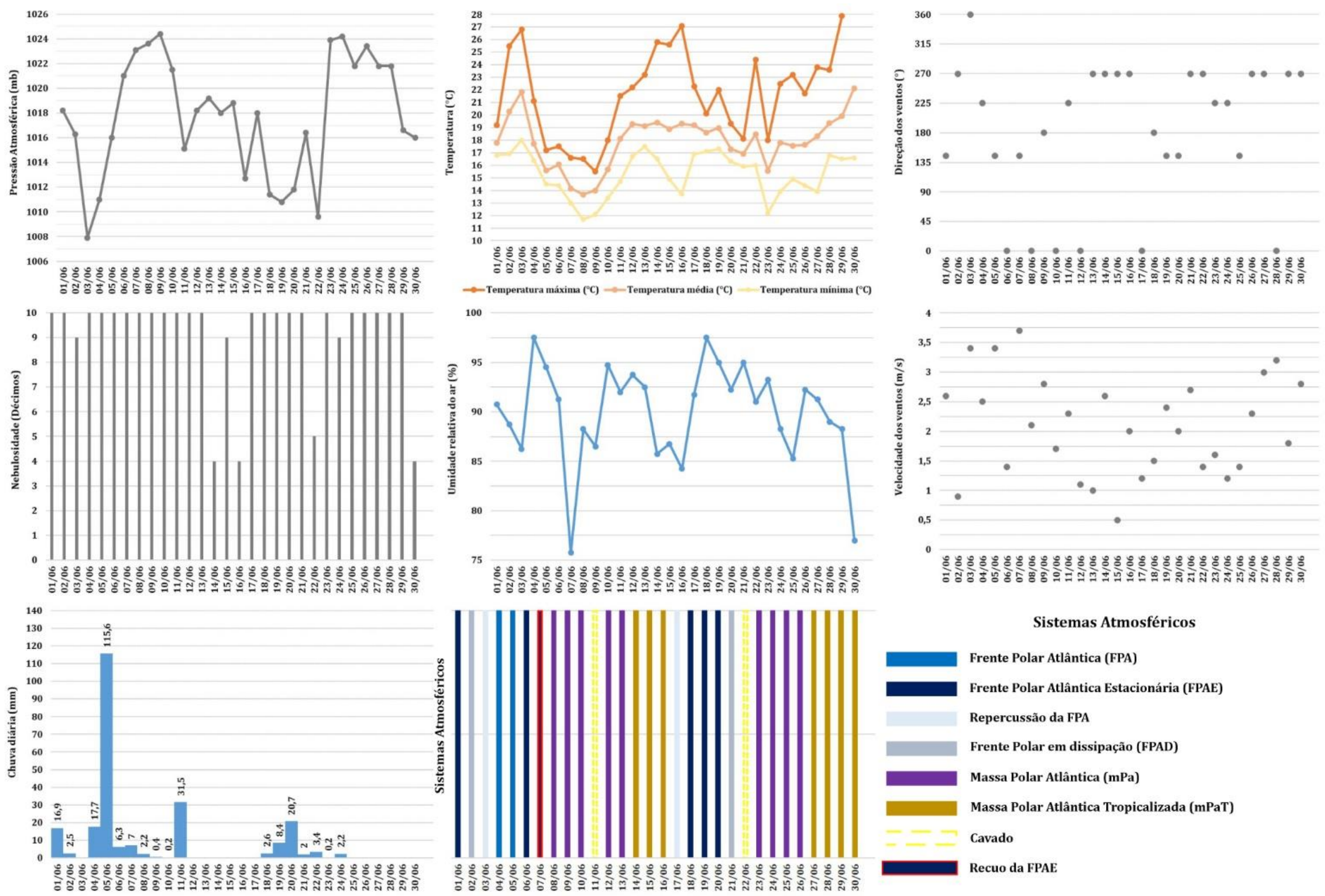

Sistemas Atmosféricos

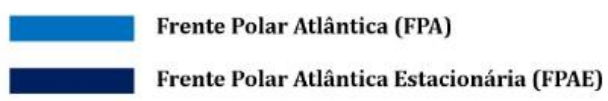

Repercussão da FPA

Frente Polar em dissipação (FPAD)

Massa Polar Atlântica (mPa)

Massa Polar Atlântica Tropicalizada (mPaT)

Cavado

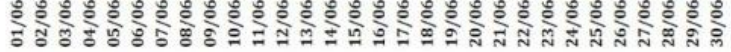

Recuo da FPAE

Figura 81 - Análise rítmica climática do evento pluvial de junho de 2012 em Paranaguá - Paraná. 


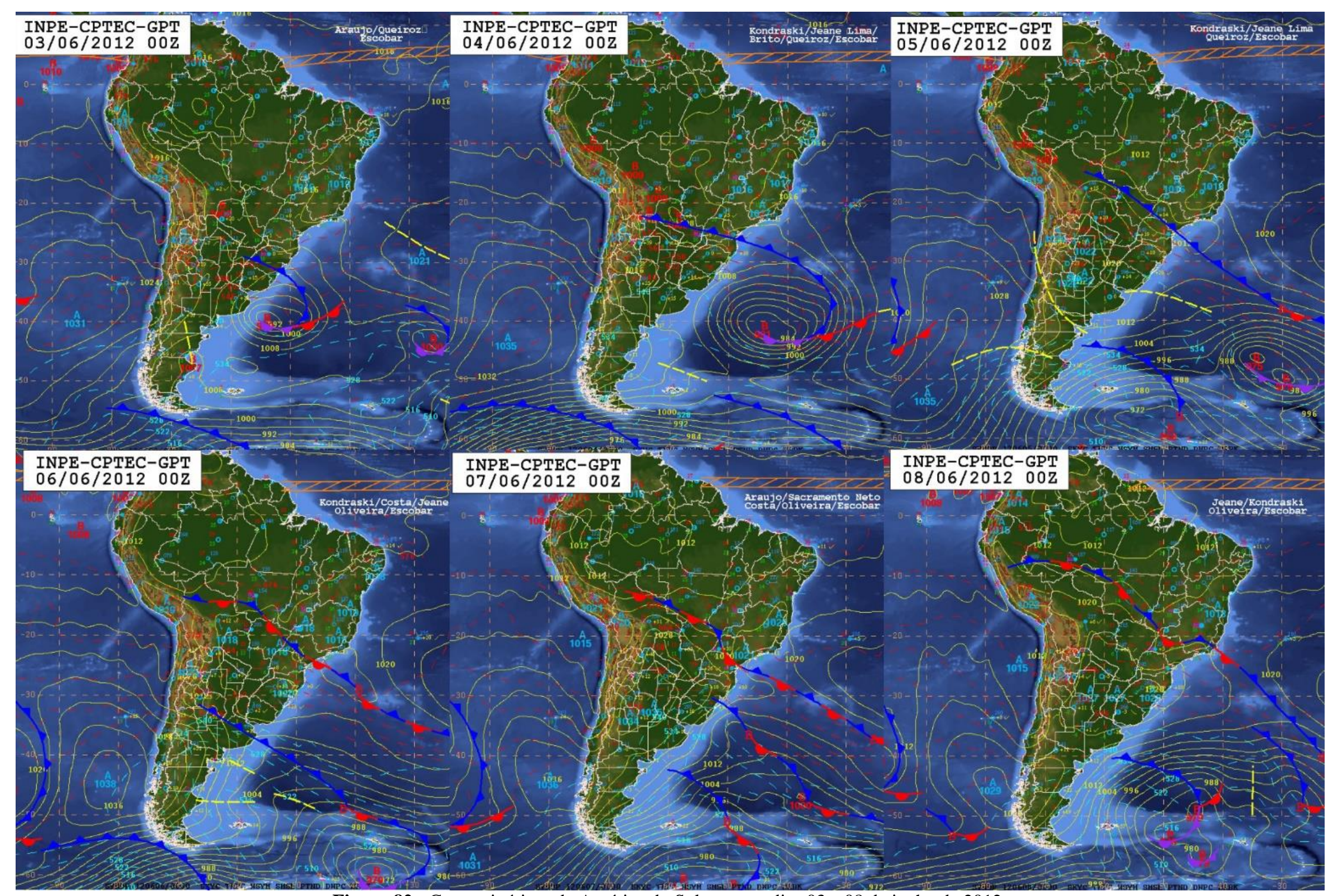

Figura 82 - Cartas sinóticas da América do Sul entre os dias 03 e 08 de junho de 2012. 

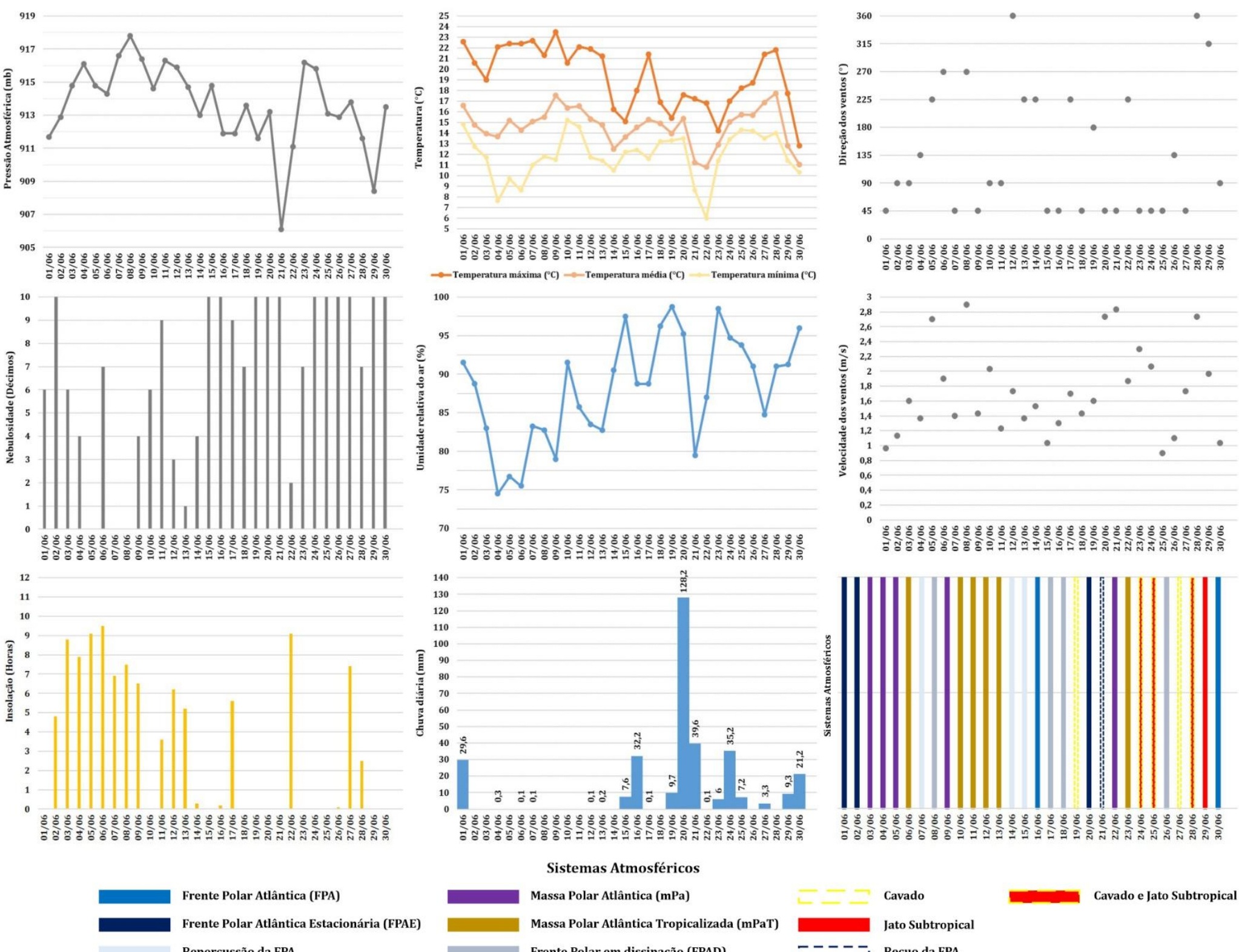

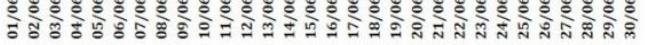

Sistemas Atmosférico

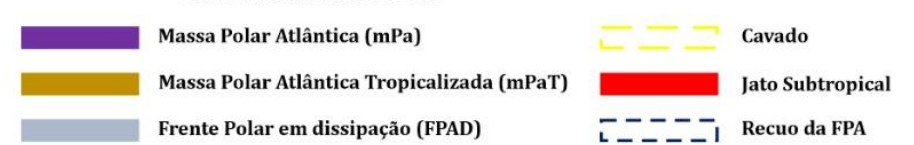

Figura 83 - Análise rítmica climática do evento pluvial de junho de 2013 em Curitiba - Paraná. 


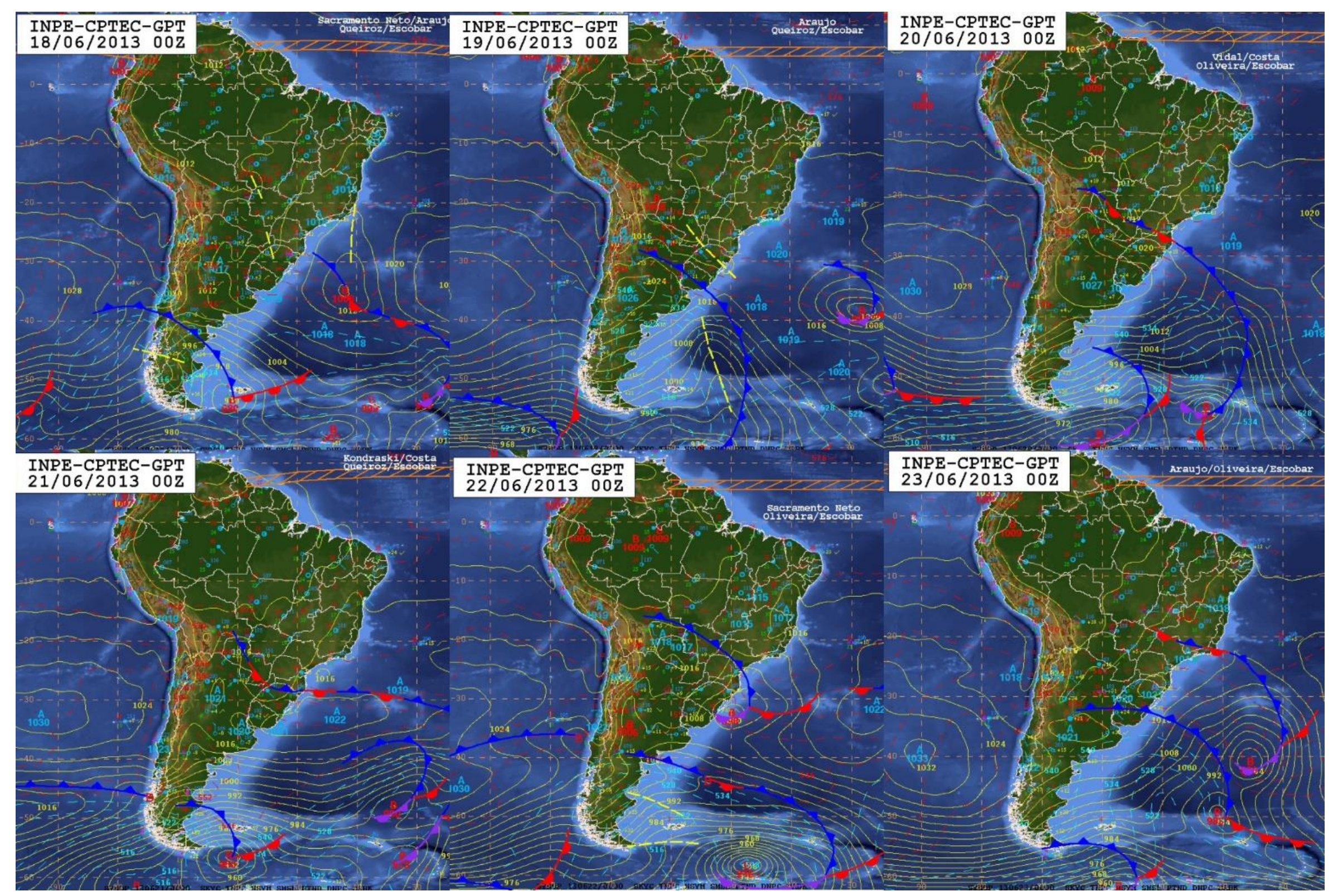

Figura 84 - Cartas sinóticas da América do Sul entre os dias 18 e 23 de junho de 2013. 
O registro de evento extremo pluvial de dezembro de 2014 em Castro se deu no dia 22 mostrou uma chuva concentrada equivalente a 112,3 mm e, contudo, neste mesmo mês registrou-se outro evento pluvial extremo, que em Castro equivale a 70,3 mm, igual a $95,4 \mathrm{~mm}$ no dia 13. Este mês registrou uma pluviosidade total de $379,4 \mathrm{~mm}$, sendo que a média histórica em dezembro é de 140,7 mm, ou seja, choveu cerca de 170\% acima do que habitualmente se espera nesta localidade, o que pode estar relacionado à diversidade dos mecanismos atmosféricos que atuaram ao longo do mês na região de Castro. Durante os primeiros dias do mês, observou-se a entrada de uma FPA que ocasionou uma chuva de 9,2 $\mathrm{mm}$ e, posteriormente, em sua retaguarda a $\mathrm{mPa}$ repercutiu na diminuição da temperatura mínima para abaixo dos $10^{\circ} \mathrm{C}$, além da queda da UR e o aumento da pressão atmosférica (Figuras 85 e 86).

No dia 12 de dezembro de 2014, destaca-se que houve a formação de uma Linha de Instabilidade Tropical que gerou uma chuva de $30,4 \mathrm{~mm}$. O primeiro evento extremo de dezembro de 2014 em Castro se deu sob condições da associação entre um Cavado e o Jato Subtropical no dia 13, pujantemente destacado pela redução da pressão do ar (<899 $\mathrm{mb}$ ), condição atmosférica persistente nos dias seguintes e que, entretanto, não foi o suficiente para gerar chuvas expressivas. No dia 21 , como um prenúncio da entrada da FPA, os ventos passaram a predominar da direção NW $\left(315^{\circ}\right)$ e tiveram uma elevação da intensidade $\left(2,75 \mathrm{~m} / \mathrm{s}^{-1}\right)$, houve a diminuição das horas de insolação $(<3$ horas), a queda da pressão atmosférica $(<901 \mathrm{mb})$ e o aumento da UR $(>86 \%)$. No dia 22, com a entrada da FPAE, houve a ocorrência do segundo evento extremo pluvial (112,3 mm), com o aumento da temperatura mínima e o aumento da temperatura máxima, o aumento da UR (>96\%), a total nebulosidade e ausência de insolação (Figuras 85 e 86).

Estas características dos atributos climáticos observadas durante este segundo evento pluviométrico de dezembro de 2014 foram mantidas com a atuação conjugada da FPAE à Zona de Convergência de Umidade, que favoreceram à geração de chuvas de 58,8 e 10,2 mm nos dias 23 e 24. Durante o restante do mês, as chuvas de maiores volumes ocorreram entre nos dias 28 e 30 e estiveram associados à massa Tropical atlântica e às Linhas de Instabilidades Tropicais (Figuras 85 e 86). Deste modo, observa-se que a FPA, os Cavados e os Jatos Subtropicais foram os mecanismos atmosféricos que geraram as chuvas de totais mais elevados durante o período analisado e que, contudo, os sistemas intertropicais associados foram expressivos na formação das chuvas, pois são importantes por ocasionar e reforçar com maior frequência as condições de instabilidade atmosférica durante o período analisado. 
Após um período demarcado pela estabilidade atmosférica e, sobretudo no Brasil Tropical, das chuvas escassas e da deficiência hídrica, Fontão et al. (2018) ressalvam que em São Paulo (SP) a primavera iniciou-se com uma baixa atividade dos sistemas frontais e no predomínio dos tipos de tempo seco e de elevadas temperaturas. Entretanto, com a condição de maior atividade frontogenética sobre a região a partir de dezembro, passaram a predominar em São Paulo as condições de tempo mais úmidos e de maiores totais de chuva, destacando-se o evento pluvial do dia $22(88,6 \mathrm{~mm})$, ocorrido no mesmo dia em que Castro (PR) registrou um total pluvial de 112,3 mm, evidenciando que as condições de chuva gerada pela FPA se dão de espacialmente de modo mais homogêneo em relação à demais mecanismos atmosféricos.

O mês de dezembro caracteriza-se como o mês com a terceira maior precipitação média mensal (155,2 mm) em Curitiba e em 2010 registrou um total de 336,2 mm, sendo assim uma anomalia positiva próxima a $115 \%$, que se deu devido à atuação constante de diversos sistemas atmosféricos, de origem extratropical e intertropical. Como um retrato disto, os dois primeiros dias estiveram em condições de instabilidade atmosférica sob a atuação conjugada de um Jato Subtropical e um Ciclone Extratropical, com o registro de chuvas diárias próximas a $15 \mathrm{~mm}$. No dia 04, observou-se que a formação de uma Linha de Instabilidade Tropical gerou uma precipitação de 19,1 mm e, no dia seguinte, a entrada de uma FPA promoveu os declínios das temperaturas e uma chuva de 7,1 mm. No dia 07, mesmo em condições da mTa, com elevadas temperaturas e queda significativa da UR $(<75 \%)$, registrou-se um total de chuva de $22,3 \mathrm{~mm}$, possivelmente atrelada às formação de chuvas convectivas. Nos dias posteriores, observou-se o predomínio da estabilidade atmosférica ocasionada pela mTa, pela aproximação pouco efetiva da FPA e a incursão de uma $\mathrm{mPa}$ de fraca intensidade no dia 10 (Figura 87).

Contudo, no dia 12 com a queda da pressão atmosférica $(905 \mathrm{mb})$, a ausência de horas de insolação, a queda expressiva da temperatura e o aumento da UR (>95\%), ventos de origem SW, o prenúncio da FPA se deu com uma chuva de 36,2 mm. Ao ingressar no estado do Paraná, a FPA tornou-se estacionária no dia 13 e teve como características a mais acentuada queda de pressão atmosférica $(901 \mathrm{mb})$, a redução da temperatura média $\left(12,1^{\circ} \mathrm{C}\right)$, o aumento da UR $(96,3 \%)$ e a ocorrência de $100,3 \mathrm{~mm}$. Notou-se que nos dias anteriores a entrada desta FPAE, as temperaturas máximas diárias em Curitiba estiveram acima dos $29^{\circ} \mathrm{C}$, o que possivelmente tenha embebido as condições de instabilidade frente a este mecanismo atmosférico e gerado o evento extremo pluvial. Os dias seguintes a este evento extremo foram marcados pelo declínio da temperatura, pela baixa insolação diária 
e a ocorrência de chuvas fracas $(<10 \mathrm{~mm})$ até o dia 17 , no qual o posicionamento mais ao sul da Zona de Convergência de Umidade (ZCOU) foi responsável por uma chuva de 12,8 mm (Figuras 87 e 88).

Entre os dias 18 e 20, observou-se o aumento da pressão atmosférica (>909 mb), da temperatura média $\left(>22^{\circ} \mathrm{C}\right)$, a redução da UR, o aumento das horas de insolação e a ausência de chuva devido ao predomínio da mTa. Posteriormente, entre os dias 21 e 26, notou-se que a atuação frequente da mEc e das Linhas de Instabilidade Tropical geraram condições favoráveis a chuvas de intensidade variável combinada às temperaturas médias do ar superior a $20^{\circ} \mathrm{C}$. Destaca-se o evento pluvial do dia 22 de dezembro, no qual a UR superior a $87 \%$ e a elevada temperatura do ar registrada nos dias anteriores (máximas > $28^{\circ} \mathrm{C}$ ) foram condições favoráveis a formação de uma chuva equivalente a 44,4 $\mathrm{mm}$. No restante do mês, entre os dias 26 e 31, a mTa manteve as condições de elevada temperatura do ar, menores valores de UR e estabilidade atmosférica, pois as chuvas registradas foram inferiores a $2 \mathrm{~mm}$.

Uma das principais características do mês de dezembro em Curitiba e região é a diminuição da atuação dos sistemas extratropicais a partir da segunda quinzena de deste mês dados pelos seguintes aspectos: durante a primeira quinzena, a frequente entrada da FPA e da mPa em sua retaguarda diminui mais expressivamente a temperatura média do ar, que nos quinze primeiros dias registraram uma média de $18,9^{\circ} \mathrm{C}$, enquanto que os dezesseis dias restantes do mês obteve média igual a $20,9^{\circ} \mathrm{C}$; durante os primeiros quinze dias do mês, nota-se que a velocidade média do ar é de $2,41 \mathrm{~m} / \mathrm{s}^{-1}$, reduzindo-se a 2,17 $\mathrm{m} / \mathrm{s}^{-1}$ nos demais dezesseis dias do mês. Observa-se que até a primeira metade do mês de dezembro houve um padrão da alternância de registros dos ventos de $\mathrm{E}$, que caracterizam a estabilidade atmosférica decorrente da Alta Subtropical do Atlântico Sul, e os ventos predominantes de SW e N, associados à entrada da FPA e mPa. No entanto, a partir da segunda quinzena deste mês, verifica-se que o padrão de ventos é de $\mathrm{S}$ a $\mathrm{W}$, possivelmente associados a maior atuação dos sistemas atmosféricos intertropicais (Figura 87).

Fontão et al. (2018) caracterizaram os tipos de tempo na cidade de São Paulo (SP) para o ano de 2010, considerado como um ano-padrão chuvoso, e descreveram que o período de primavera foi excepcionalmente chuvoso, o que foi atribuído a grande alternância dos tipos de tempo naquela localidade, sobretudo pela formação de Linhas de Instabilidade Tropicais que favoreceram a formação de chuvas convectivas. Observaram o avanço de 13 sistemas frontais nos três últimos meses de 2010 e enfatizaram o estacionamento do sistema frontológico entre os dias 11 e 18 de dezembro, justamente o 
mesmo período em que ocorreram os mesmos totais extremos de precipitação em Curitiba e Paranaguá e que em São Paulo ocasionou chuvas diárias superiores a $40 \mathrm{~mm}$.

O principal evento extremo dentre os selecionados para Paranaguá ocorreu em janeiro de 2004, pois após semanas com chuvas escassas, no dia 25 de janeiro houve o registro de uma pluviosidade diária concentrada de $295,8 \mathrm{~mm}$. O primeiro dia deste mês esteve sob condições da FPA e com a ocorrência de uma chuva de 16,1 mm e, contudo, os dias seguintes mostraram a predominância da atmosférica, uma vez que os sistemas identificados foram a $\mathrm{mPa}$, a $\mathrm{mPaT}$, a $\mathrm{mTa}$ e a $\mathrm{mTc}$, que se alteraram com os Cavados, sendo que este último mecanismo não gerou chuvas expressivas ( $<4 \mathrm{~mm})$. Mesmo tendo sido identificada a sua aproximação, a FPA que esteve sob a região Sul deslocou para o Oceano Atlântico antes mesmo de sua chegada no território paranaense no dia 12, gerando totais de chuva de 9,6 mm, sendo que entre os dias 13 e 15 o posicionamento mais ao sul das ZCAS foi a condição atmosférica responsável por chuvas diárias entre 3,4 e 24,6 mm em Paranaguá. No dia 16, mesmo com a incursão da mTa, com o aumento da temperatura do ar e da pressão atmosférica, registrou-se chuva de 37,2 mm, exceção para um período (16 a 22 de janeiro) em que as condições térmicas, hígricas e anemométricas, além dos registros de chuvas fracas reforçaram as condições de estabilidade atmosférica do sistema atmosférico supracitado (Figuras 89 e 90).

Novamente, no dia 22 a entrada uma FPA pelo Sul do Brasil apenas repercutiu no aumento de UR (84\%), na diminuição da pressão atmosférica (<1001 mb) e em ventos de direção W. Nos dias que precederam a entrada de outra FPA, os Cavados modificaram as condições de tempo com um total pluvial próximo a $55 \mathrm{~mm}$ acumulados nos dias $23 \mathrm{e}$ 24. Sobretudo, a entrada abrupta de uma FPAE associada a formação de uma ZCAS gerou os maiores volumes de chuva acumulada em 24 horas em Paranaguá, com indícios de instabilidade atmosférica como os ventos de direção $\mathrm{SW}$, a redução expressiva da pressão atmosférica e o aumento da UR. Nos dias seguintes (26 e 27), verificou-se que a FPAE esteve associada ao posicionamento sul da ZCAS e, embora favorece condições de chuvas intensas, apenas ocorreram totais nos dois dias que somaram apenas $15 \mathrm{~mm}$. Como um efeito de dissipação da FPAE, a pressão atmosférica aumentou nos dias posteriores e, contudo, nos dias 28 e 29 a atuação das ZCAS mantiveram condições de chuvas, entre 5 e $30 \mathrm{~mm} /$ dia, sendo que durante os dias 30 e 31 observou-se o predomínio da mTa, que inibiu a formação de chuvas, aumentou a pressão atmosférica e a temperatura média foi próxima a $27^{\circ} \mathrm{C}$ (Figuras 89 e 90 ). 
Destaca-se que janeiro é o mês mais chuvoso para Paranaguá, com uma média de 325,7 mm para a série analisada, e no ano de 2004 mostrou um total acumulado de 510,5 $\mathrm{mm}$, ou seja, choveu 56,8\% acima do normal. A fraca atuação dos sistemas frontais sobre o Sul do país contribuiu para o predomínio da pluviosidade abaixo da média em quase toda esta região e, entretanto, o litoral do estado do Paraná teve condições anômalas de chuvas marcadamente pelo posicionamento central da ZCAS no litoral Sul de São Paulo. O escoamento em altos níveis manteve o VCANS mais próximo ao litoral do Nordeste do Brasil e manteve a ZCAS sobre o sul da região Sudeste e, com a frente fria estacionária sob o Oceano Atlântico, houve o reforço nas condições de instabilidade atmosférica e de chuvas intensas no litoral do Paraná (CLIMANÁLISE, 2004), sendo que a restrição desta influência da ZCAS a este setor paranaense na formação de elevados totais pluviais está demonstrada na tabela 26, com valores acumulados em cinco dias superiores a $250 \mathrm{~mm}$ em Antonina, Morrestes e Paranaguá.

Um dos principais eventos extremos selecionados em condições de primavera e verão ocorreu em 12 de março de 2011 em Paranaguá, com um total de chuva equivalente a $159 \mathrm{~mm}$ em 24 horas, expressamente inferior ao identificado em janeiro de 2004, mas que esteve em condições de totais significativos de precipitação pluviométrica nos dias próximos a sua ocorrência. Durante os dias 03 e 04, a atuação da ZCAS gerou um total de chuvas equivalente a 48,2 mm em 48 horas e, nos dias 05 e 07, as chuvas de 36,6 e 22 mm foram ocasionadas pela circulação de altos níveis (Cavados e Jatos Subtropicais). Entre os dias 08 e 13, a formação de um Cavado e, destacadamente, combinado a atuação de um Vórtice Ciclônico entre os dias 09 e 12, condicionou uma grande instabilidade atmosférica e geraram chuvas que entre os dias 11 e 12 somaram $243 \mathrm{~mm}$, sendo que o total médio do mês de março em Paranaguá é de 208,3 mm. Posteriormente a este período de elevados totais pluviométricos, observaram menores totais de chuvas diárias inferiores a $20 \mathrm{~mm}$ até o dia 27, sendo que a mTa foi determinante em tipos de tempo de elevação da temperatura e da pressão atmosférica e redução da UR, ao passo que as chuvas foram geradas pela entrada da FPA ou pelo Jato Subtropical (Figuras 91 e 92).

Ao todo, choveu no mês de março em Paranaguá o equivalente a 511,3 mm, cerca de $145 \%$ além da média climatológica para esta localidade. Destaca-se que em quase toda região Sul do Brasil houveram chuvas acima da média, particularmente pela ocorrência de chuvas fortes e intensas entre os dias 10 e 13, destacando-se a formação de Cavados e Vórtices Ciclônicos em $500 \mathrm{hPa}$ na ocorrência deste período de instabilidade atmosférica. Ressalta-se que a partir da segunda metade de março a atuação pujante do Jato Subtropical 
e uma maior frequência de entrada da FPA gerou o aumento de chuvas e, deste modo, o frequente registro de chuvas (CLIMANÁLISE, 2011). Em outras localidades do litoral do Paraná, notou-se que o acumulado mensal chegou a 760,5 mm em Morretes (ID 32) e $555,2 \mathrm{~mm}$ em Antonina (ID 21), muito superior à média aproximada de $240 \mathrm{~mm}$ destes postos pluviométricos e que no período de quatro dias destacados acima, registraram 537,7 e $379,2 \mathrm{~mm}$, nesta ordem.

Embora os Cavados e os Vórtices Ciclônicos tenham gerado chuvas de elevada magnitude no Sul do Brasil, estes mecanismos não atuaram de forma generalizada, pois setores como o oeste do Rio Grande do Sul e o Centro-Leste do Paraná (Vale do Ribeira e Região Metropolitana de Curitiba) mostraram o registro de anomalia negativa de chuva superior a $50 \mathrm{~mm}$, pois a FPA que é o sistema atmosférico que causa a chuva de maneira mais generalizada mostrou-se pouco atuante durante o referido mês (CLIMANÁLISE, 2011). Um exemplo desta chuva mensal total reduzida nos setores destacados acima da área de estudo, em Castro e Curitiba registrou-se um total de 97,5 e $72 \mathrm{~mm}$, sendo que nestes meses a média histórica é de 135,8 e 142,8 mm, nesta ordem. A peculiar diferença da precipitação ocorrida neste mês de março demonstra uma característica típica espacial das chuvas ao longo dos meses de verão da área em estudo, especialmente pelo grande aumento pluvial nesta sazonalidade para a BH litorânea, destacando-se o desempenho da maritimidade em favorecer condições mais frequentemente de chuvas fortes e intensas.

Em uma análise dos mecanismos deflagradores dos eventos e episódios extremos para o município do Rio de Janeiro, Armond e Sant'Anna Neto (2017) avaliaram que por sua característica de transição climática entre os domínios Tropical e Subtropical, a cidade tem em sua maioria absoluta $(81,4 \%)$ dos eventos extremos pluviais decorrentes de tipos de tempo associados à atuação da FPA e somente 14,8\% dos eventos extremos avaliados estiveram sob condições da ZCAS. Deste modo, discorreram que esta análise está em alinhado ao descrito em obras anteriores sobre a dinâmica atmosférica regional (MONTEIRO, 1969; CONTI, 1975; SANT'ANNA NETO, 1995) e destacaram que a localização transicional da capital carioca entre os sistemas tropicais e polares tornam as chuvas majoritariamente de natureza frontal. Conquanto, Baldo (2006) e Zandonadi (2013) ressaltaram que no verão e na primavera em localidades do estado do Paraná há uma elevação da participação dos sistemas intertropicais e de sua associação àqueles de origem extratropicais na formação e geração pluvial, sendo que estes autores se limitaram a averiguar a atuação dos mecanismos atmosférico em gerar os totais acumulados e não em ocasionar os eventos pluviais diários extremos. 


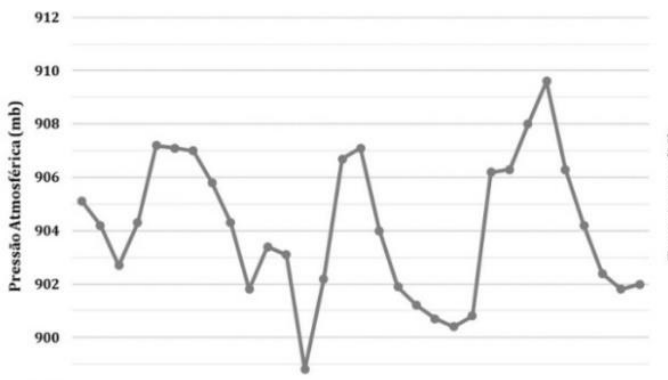

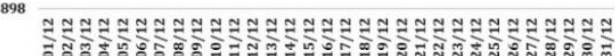

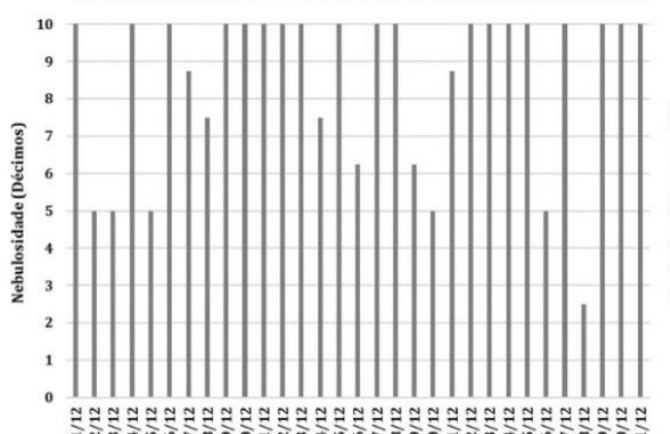

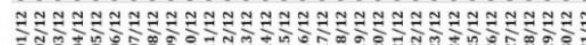

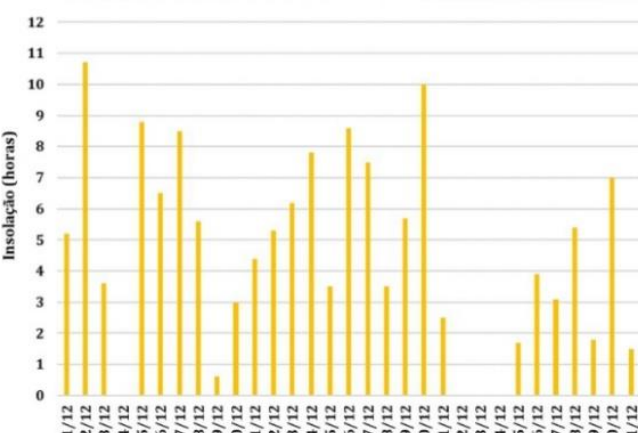

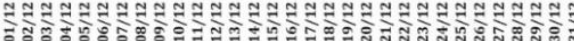

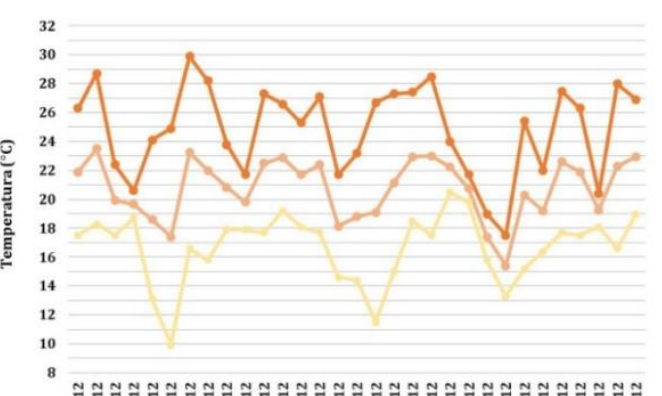

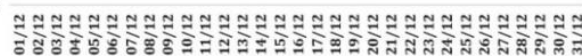
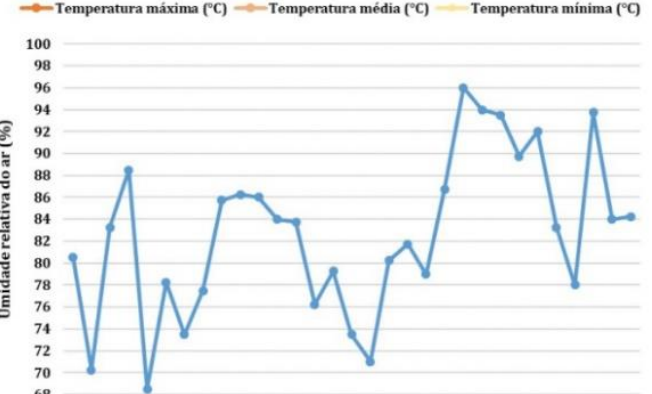

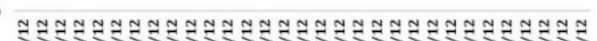

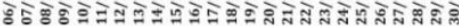

140

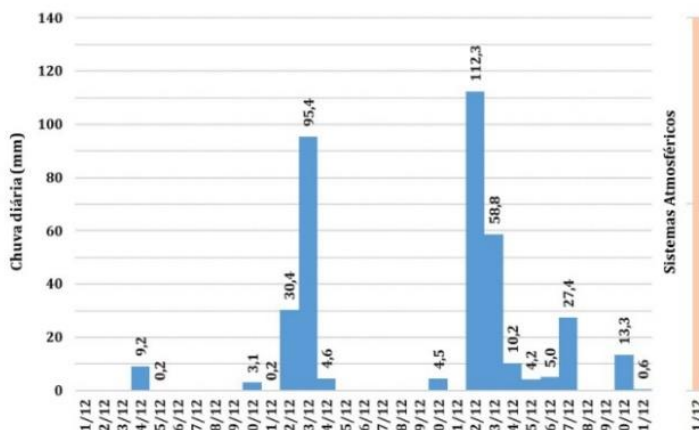

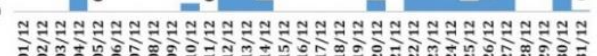

\section{Sistemas Atmosféricos}

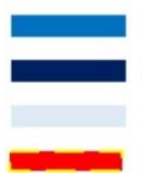

Frente Polar Atlântica (FPA)

Polar Atlântica Estacionária (FPAE)

Repercussão da FPA

Jato Subtropical e Cava

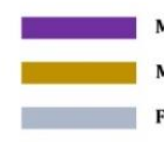

Massa Polar Atlântica (mPa)

Massa Polar Atlântica Tropicalizada (mPaT)

Frente Polar em dissipação (FPAD)
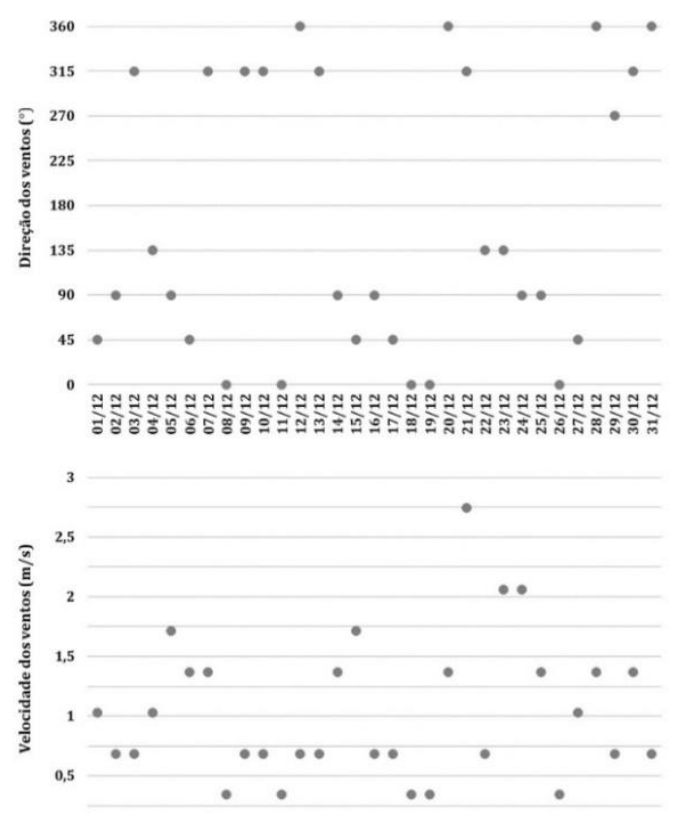

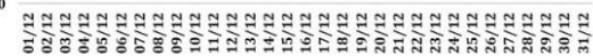

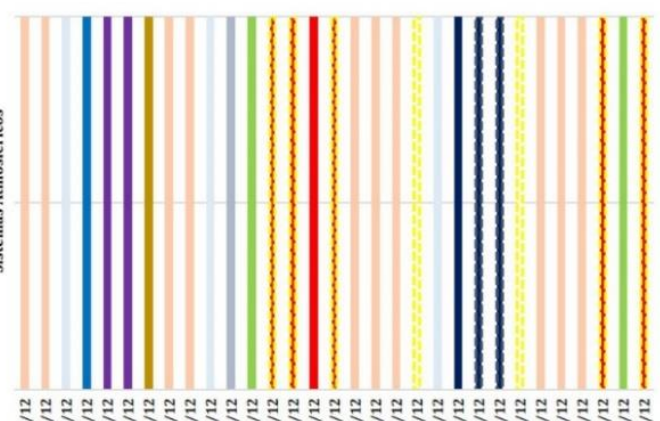

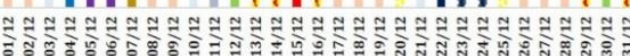

Figura 85 - Análise rítmica climática do evento pluvial de dezembro de 2014 em Castro - Paraná. 


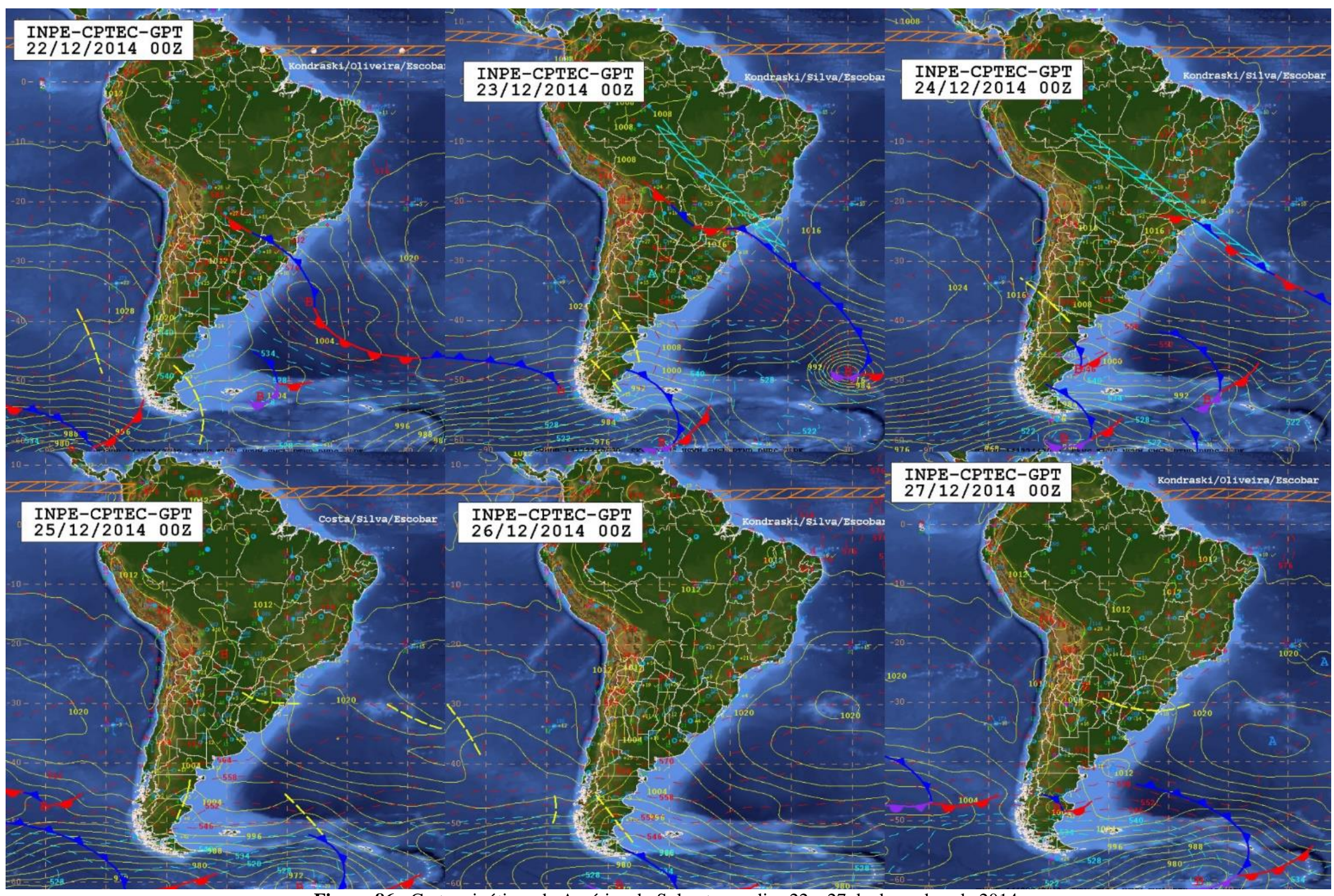

Figura 86 - Cartas sinóticas da América do Sul entre os dias 22 e 27 de dezembro de 2014. 

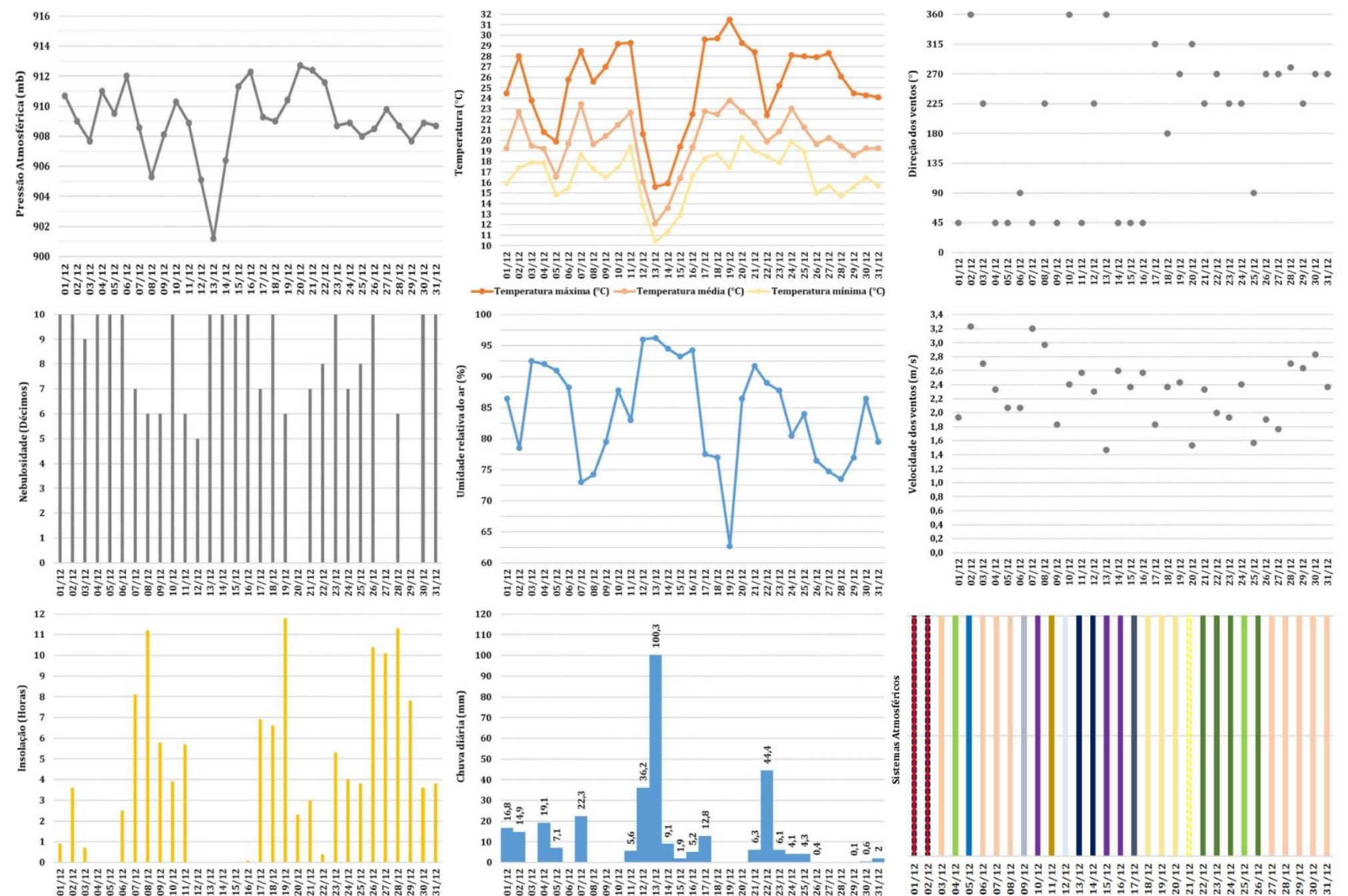

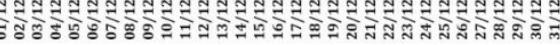
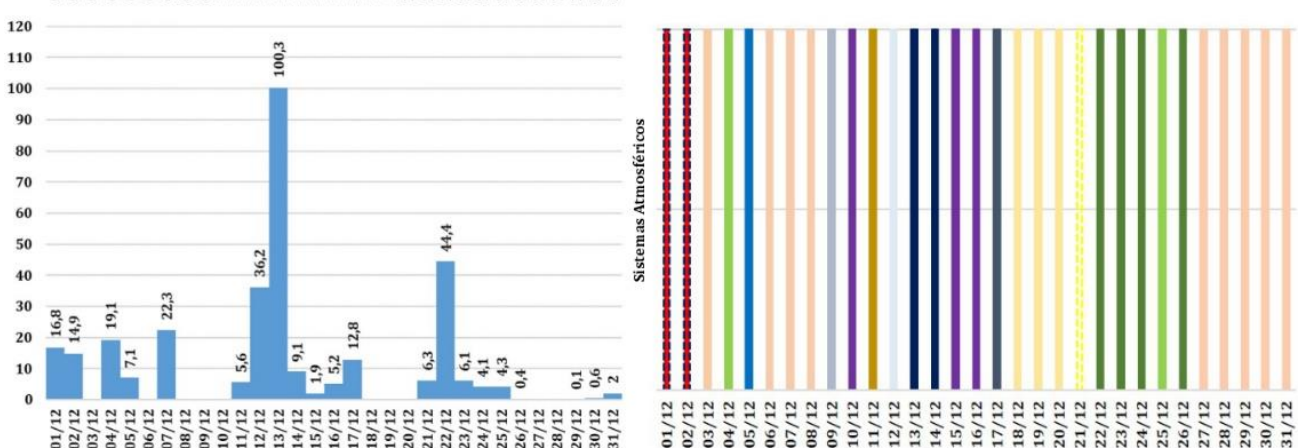

Sistemas Atmosféricos

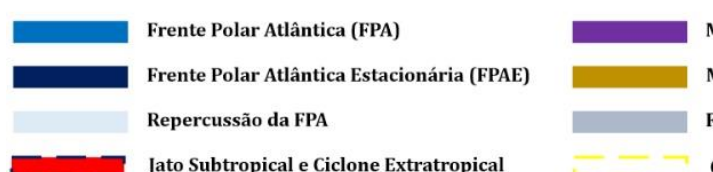

\section{Massa Polar Atlântica (mPa) \\ Massa Polar Atlântica Tropicalizada (mPaT) \\ Frente Polar em dissipação (FPAD)}

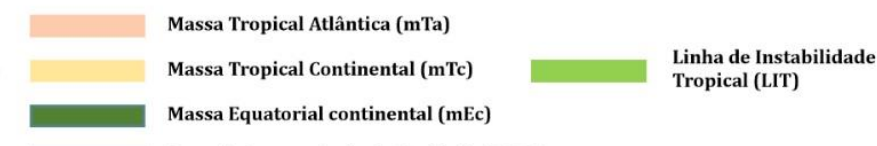

Figura 87 - Análise rítmica climática do evento pluvial de dezembro de 2010 em Curitiba - Paraná. 


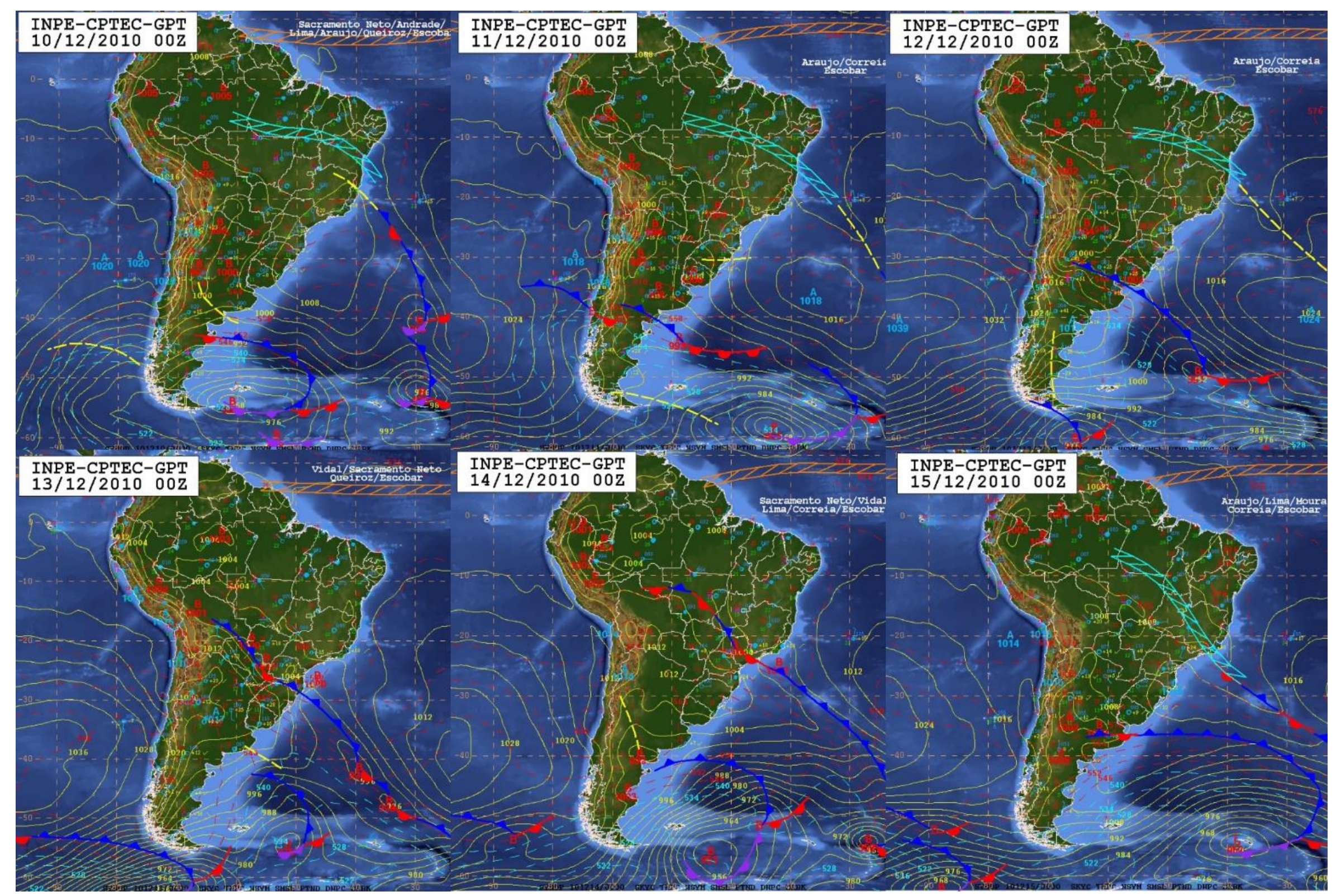

Figura 88 - Cartas sinóticas da América do Sul entre os dias 10 e 15 de dezembro de 2010. 

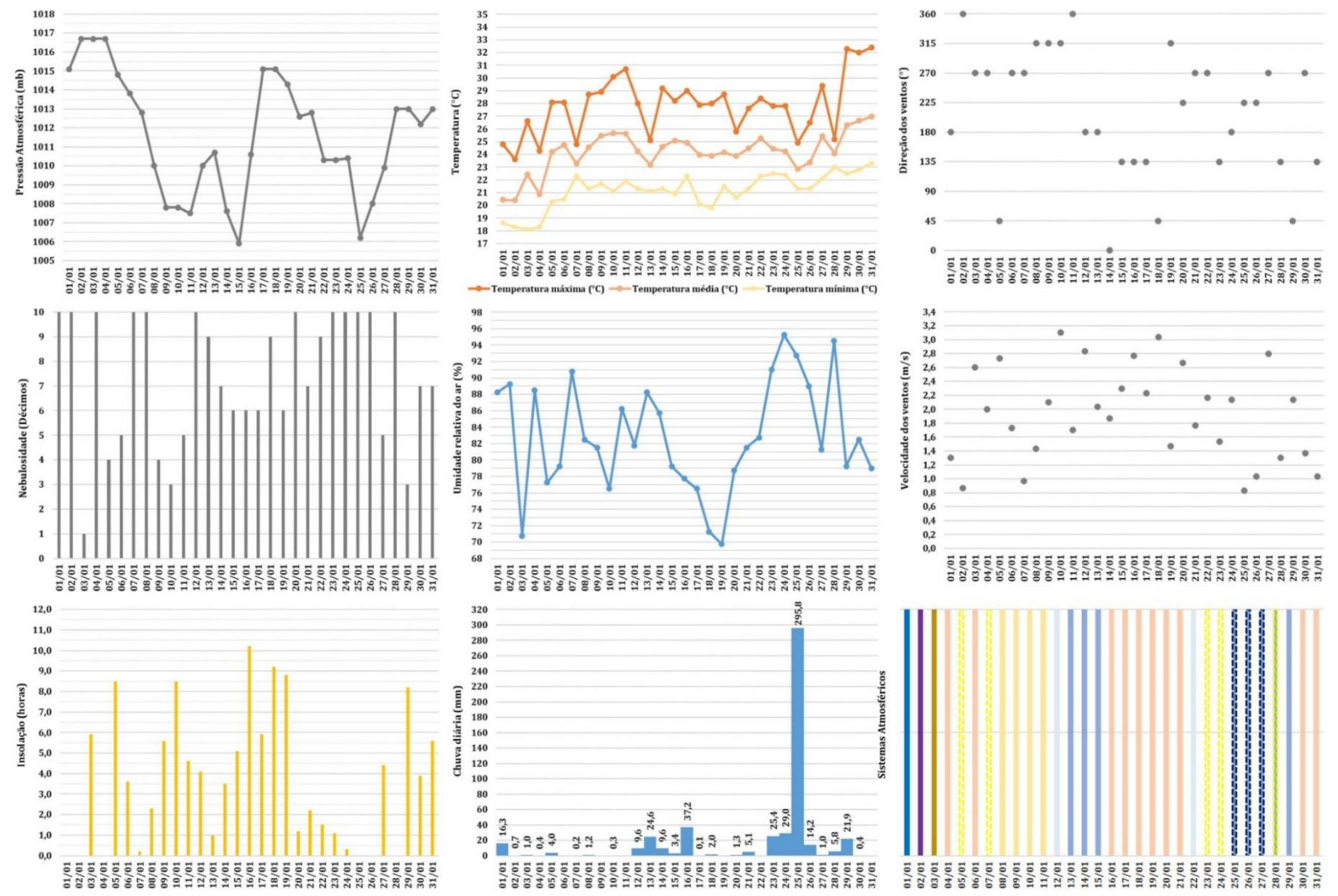

Sistemas Atmosféricos

Frente Polar Atlântica (FPA)

Repercussão da FPA

Cavado

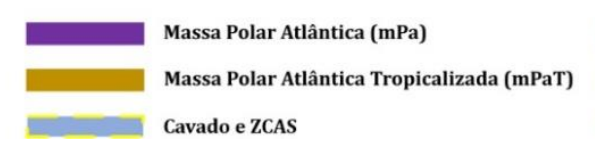

Massa Tropical Atlântica (mTa)

Massa Tropical Continental (mTc)

Figura 89 - Análise rítmica climática do evento pluvial de janeiro de 2004 em Paranaguá - Paraná 


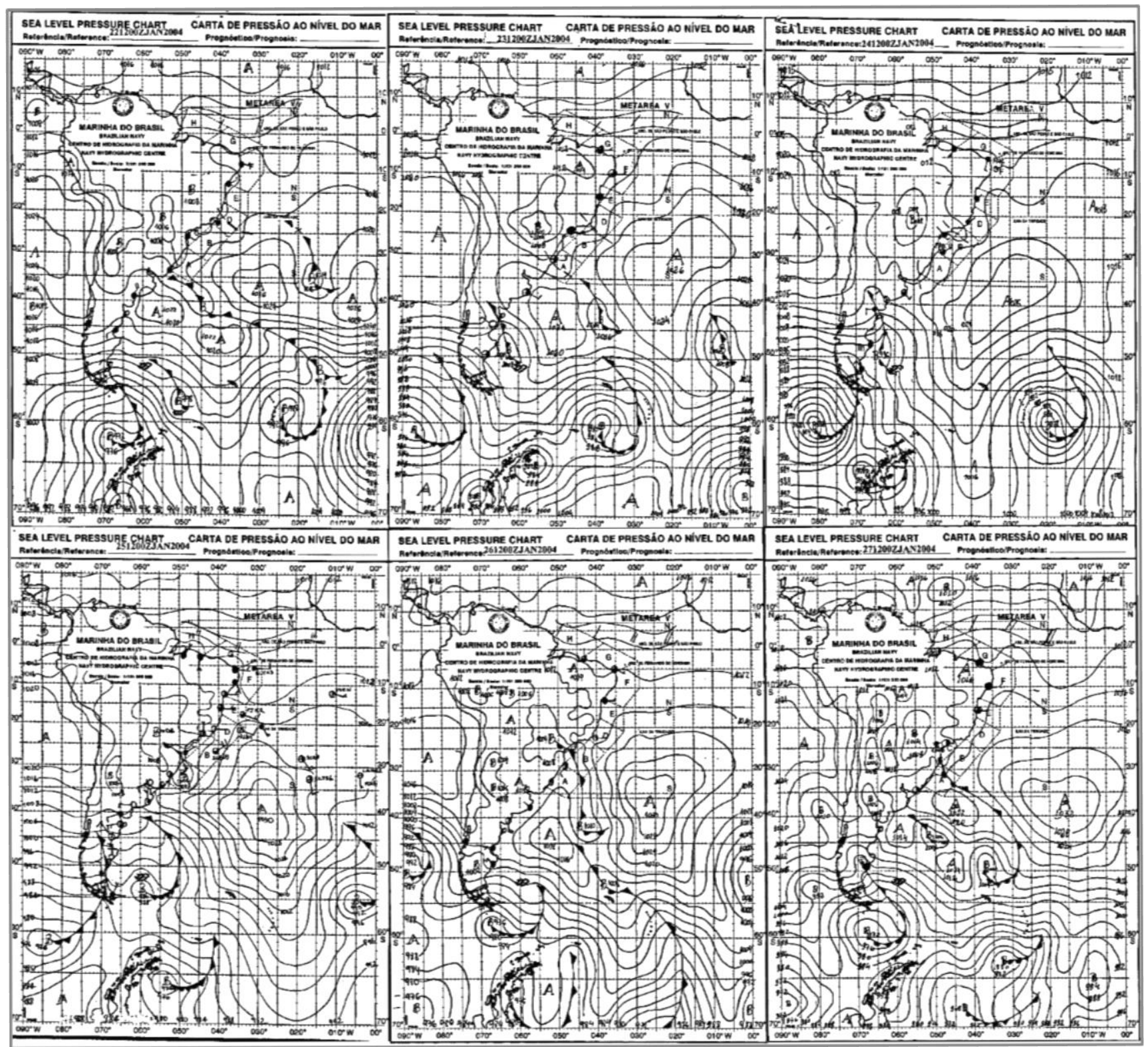

Figura 90 - Cartas sinóticas da América do Sul entre os dias 22 e 27 de janeiro de 2004. 

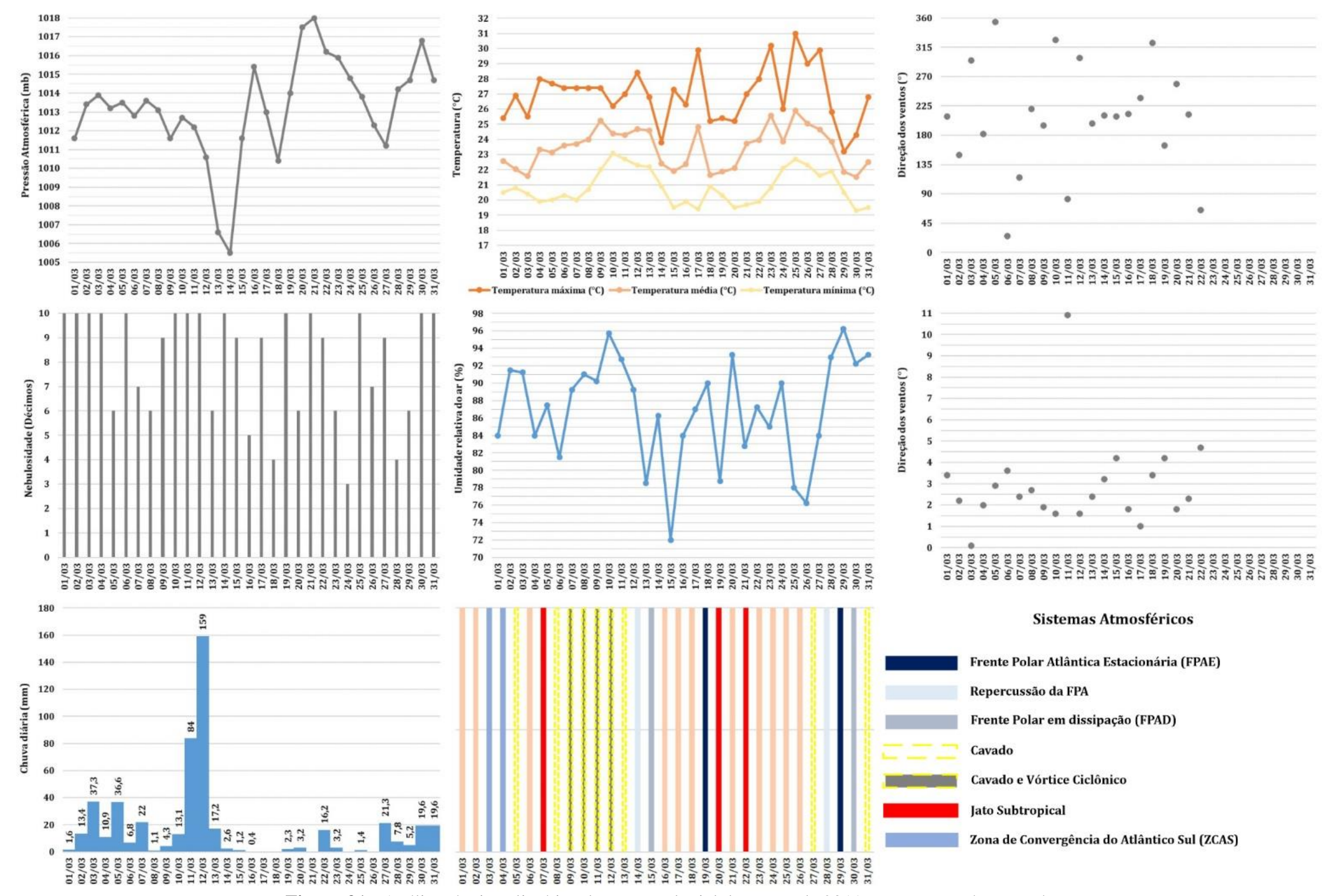

Figura 91 - Análise rítmica climática do evento pluvial de março de 2011 em Paranaguá - Paraná. 


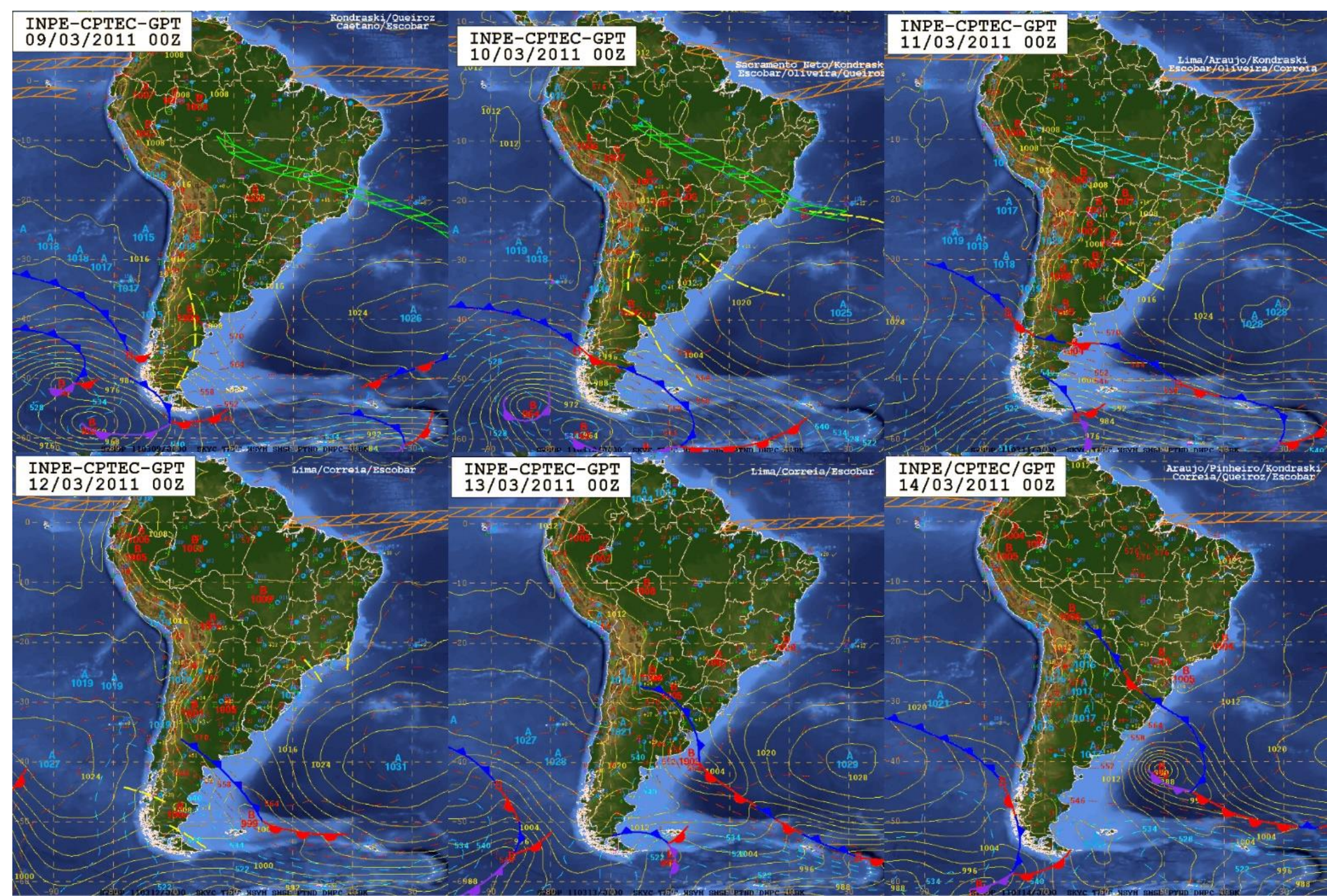

Figura 92 - Cartas sinóticas da América do Sul entre os dias 09 e 14 de março de 2011. 
Com a finalidade de analisar a repercussão dos diferentes sistemas atmosféricos para a ocorrência dos eventos extremos pluviais nas demais estações meteorológicas da área em estudo, foram selecionados os registros dos totais pluviométricos acumulados durante os dois dias anteriores e posteriores à ocorrência da anomalia pluvial destacada. Em suma, observa-se que os eventos extremos de chuva diária ocorreram em diferentes magnitudes nas localidades da área em estudo, condição atribuída ao sistema atmosférico atuante e à localização geográfica da estação meteorológica, mostrando sinteticamente a interação entre fatores estáticos e dinâmicos na formação e geração das chuvas.

O primeiro evento extremo pluvial em análise, identificado em Castro e em maio e 2005, teve sua condição pujantemente associada à formação dos CCM's junto ao Jato Subtropical e, em segundo plano, aos sistemas atmosféricos extratropicais, o que explica a homogeneidade pluvial durante o episódio em relação às demais localidades, dados os baixos valores de amplitude $(51,4)$ e o segundo menor coeficiente de variação $(19,6 \%)$ dentre os eventos extremos estudados. Nota-se um arranjo espacial, com totais acima de $90 \mathrm{~mm}$ acumulados para Castro (125,2 mm), Cerro Azul (92,2 mm) e Guaraqueçaba (98,2 $\mathrm{mm}$ ), justamente nos setores leste (E) e nordeste (NE) das BH's (Tabela 26).

$\mathrm{O}$ evento extremo que ocorreu de forma mais homogênea dentre os analisados se deu em junho de 2012, com valores médios de $140 \mathrm{~mm}$, amplitude de $60 \mathrm{~mm}$ e o menor CV $(11,9 \%)$. Os maiores totais acumulados se deram na BH Litorânea, Castro e Pinhais (>145 mm), enquanto que em Cerro Azul foram registros os menores valores (101,2 mm), relativa homogeneidade que se deve à atuação da FPA na geração das chuvas. Durante a análise dos totais acumulados no evento extremo de junho 2013, nota-se um maior CV $(25,6 \%)$ e que os maiores totais se deram na BH Alto Iguaçu e Litorânea, destacando Curitiba e Morretes (>175 mm), sendo que FPAE foi a condição atmosférica responsável destes elevados totais pluviométricos. Exceção na BH Litorânea, em Guaraqueçaba e junto a Castro e Cerro Azul, situadas à E e NE das BH's, os totais pluviométricos foram inferiores a $115 \mathrm{~mm}$, com destaque para os 72,0 mm registrados em Cerro Azul (Tabela 26). Os menores totais máximos absolutos em Cerro Azul correspondem a um padrão atribuído a sua localização, pois situa-se na região do Vale do Ribeira, onde a influência do clima tropical e as baixas altitudes determinam os menores totais pluviais durante o inverno. No entanto, como descrito a seguir, afirma-se que este é apenas um padrão esperado e predominante, tendo suas exceções como o ocorrido em agosto de 2011.

A maior amplitude dentre os episódios analisados ocorreu em agosto de 2011 (CV $=26,4 \%$ ), com totais superiores a $200 \mathrm{~mm}$ nas estações meteorológicas da BH do Ribeira 
(Castro, Cerro Azul e Ponta Grossa), enquanto que na BH Litorânea identificou-se os menores registros de chuva acumulada, inferiores a $150 \mathrm{~mm}$ em Antonina, Morretes e Paranaguá, o que reforça o identificado pela figura 71, que demonstrou valores máximos diários mais intensos para Curitiba e Castro durante o período de inverno em relação à Paranaguá, sugerindo uma atuação mais consistente dos sistemas extratropicais nestas localidades. Em condição intermediária, as estações meteorológicas da BH Alto Iguaçu mostraram totais acumulados entre 150 e $180 \mathrm{~mm}$, mostrando que a FPAE atuou de modo diferenciado nos diferentes setores das BH's (Tabela 26). Contudo, mesmo que a maior amplitude deste evento pluvial e em seus dias anteriores e posteriores nas situações de outono e inverno, em comparação aos eventos selecionados para a primavera e verão, a variação espacial ainda é inferior, dada às características próprias à gênese pluvial do evento de agosto de 2011.

O evento pluvial diário de maior magnitude em Paranaguá se deu em janeiro de 2004 em condições atmosféricas associadas à atuação conjugada das ZCAS com a FPA. Como esperado para um sistema atmosférico intertropical, as chuvas ocorreram de modo irregular nos diferentes setores das BH's, com uma concentração mais elevada na região litorânea, com os totais mais elevados em Antonina, Morretes e Paranaguá (>250 mm) e, inversamente, menores em Castro e Ponta Grossa, localidades mais distantes do litoral e nas quais os acumulados em cinco dias foram menores que $40 \mathrm{~mm}$. Os valores do desvio padrão inferem sobre a grande magnitude deste evento extremo $(111,8)$ e, entretanto, os demais parâmetros estatísticos indicam a heterogeneidade espacial, com uma amplitude de 329,4 mm e um CV igual a 67,9\% (Tabela 26).

A característica heterogênea das chuvas de verão é destacada pelo evento pluvial de março de 2011, dada a amplitude de 398 mm e um CV equivalente a 100,3\%. Tratase do evento pluvial de maior magnitude para a área em estudo $(\mathrm{s}=152,2)$, com totais pluviométricos equivalentes a 411,0 e 335,1 mm para Morretes e Antonina, nesta ordem, ao longo de 5 dias consecutivos, condição atmosférica atribuída aos Cavados e/ou a associação dos Cavados aos Vórtices Ciclônicos. Enquanto ocorriam valores extremos elevados no setor litorâneo, uma vez que a formação do Vórtice Ciclônico transportou umidade oceânica para este setor, em localidades como Curitiba e Ponta Grossa os totais pluviais foram próximos a $15 \mathrm{~mm}$ (Tabela 26). Os totais pluviométricos observados em Morretes correspondem aos maiores valores observados em cinco dias consecutivos e demonstram com veracidade a magnitude deste evento extremo pluvial. 
A FPAE foi o mecanismo responsável pela geração da chuva extrema registrada em dezembro de 2010 que atingiu com maior intensidade Pinhais e Curitiba (>150 mm) e em menores totais as localidades litorâneas (>100 mm). Mesmo gerada sob condições da FPAE, este sistema atmosférico gerou acumulados consideravelmente inferiores em Castro e Ponta Grossa ( $<55 \mathrm{~mm}$ ) e, devido às diferenças entre os valores acumulados nas demais estações meteorológicas, observou-se um CV igual a 39,2\%. Em atmosféricas condições similares (FPAE) e posteriormente reforçado pela atuação da ZCOU, o evento extremo de dezembro de 2014 foi majoritariamente expressivo em todas as localidades em estudo, destacando-se os 185,5 e 145,5 mm registrados em Castro e Antonina e, inversamente, os menores valores em Cerro Azul, Morretes e Ponta Grossa ( $<95 \mathrm{~mm}$ ), correspondendo ao evento pluvial extremo de maior homogeneidade dentre os observados no verão na área estudo, com um CV equivalente a 27,6\% (Tabela 26).

Tabela 26 - Totais pluviométricos acumulados $(\mathrm{mm})$ durante os eventos extremos e nos dois dias anteriores e posteriores a sua ocorrência em estações meteorológicas do IAPAR, INMET e SIMEPAR.

\begin{tabular}{|c|c|c|c|c|}
\hline \multirow{2}{*}{$\begin{array}{c}\text { Estação } \\
\text { Meteorológica }\end{array}$} & \multicolumn{4}{|c|}{ Outono - Inverno } \\
\hline & $22 / 05-26 / 05 / 2005$ & $30 / 07-03 / 08 / 2011$ & 03/06 - 07/06/2012 & $18 / 06-22 / 06 / 2013$ \\
\hline Curitiba & 76 & 154,6 & 130,2 & 177,9 \\
\hline Pinhais & 75,8 & 172,8 & 145,2 & 154,4 \\
\hline Antonina & 77,4 & 142,6 & 148,7 & 135,0 \\
\hline Guaraqueçaba & 98,2 & 186,8 & 140,2 & 114,0 \\
\hline Morretes & 73,8 & 144,7 & 161,2 & 179,4 \\
\hline Paranaguá & 84,8 & 140,0 & 146,6 & 133,7 \\
\hline Castro & 125,2 & 258,6 & 145,1 & 106,3 \\
\hline Cerro Azul & 92,2 & 206,6 & 101,2 & 72,0 \\
\hline Ponta Grossa & 73,8 & 268,2 & 141,6 & 154,4 \\
\hline Média (mm) & 86,4 & 186,1 & 140,0 & 136,3 \\
\hline Amplitude & 51,4 & 128,2 & 60,0 & 107,4 \\
\hline DP & 16,96 & 49,14 & 16,68 & 34,97 \\
\hline $\mathrm{CV}(\%)$ & 19,6 & 26,4 & 11,9 & 25,6 \\
\hline Estação & \multicolumn{4}{|c|}{ Primavera - Verão } \\
\hline Meteorológica & $23 / 01-27 / 01 / 2004$ & $11 / 12-15 / 12 / 2010$ & $09 / 03$ - 13/03/2011 & $20 / 12-24 / 12 / 2014$ \\
\hline Curitiba & 80,9 & 151,2 & 15,0 & 96,9 \\
\hline Pinhais & 124,4 & 173,8 & 25,6 & 104,2 \\
\hline Antonina & 250,4 & 131,9 & 335,1 & 145,5 \\
\hline Guaraqueçaba & 176,5 & 134,0 & 153,0 & 117,8 \\
\hline Morretes & 268,5 & 134,0 & 411,0 & 94,9 \\
\hline Paranaguá & 365,4 & 101,7 & 277,6 & 115,8 \\
\hline Castro & 36,0 & 53,5 & 49,3 & 185,5 \\
\hline Cerro Azul & 140,2 & 79,8 & 86,6 & 94,9 \\
\hline Ponta Grossa & 39,8 & 47,6 & 13,0 & 83,6 \\
\hline Média (mm) & 164,7 & 111,9 & 151,8 & 115,5 \\
\hline Amplitude & 329,4 & 126,2 & 398,0 & 101,9 \\
\hline DP & 111,8 & 43,9 & 152,2 & 31,9 \\
\hline $\mathrm{CV}(\%)$ & 67,9 & 39,2 & 100,3 & 27,6 \\
\hline
\end{tabular}


Portanto, os eventos pluviais extremos em condições atmosféricas decorrentes de mecanismos extratropicais durante a primavera e o verão obtiveram valores ligeiramente superiores do $\mathrm{CV}$ em relação àqueles gerados por sistemas atmosféricos semelhantes no outono e inverno devido às mais elevadas temperaturas do ar, especialmente nos setores de menores elevações do terreno, pois o aquecimento da superfície possivelmente exerça condições locais favoráveis às atividades convectivas e, sobretudo, favoreça a ocorrência dos maiores totais pluviais. Contudo, os sistemas atmosféricos extratropicais mostraram condições à ocorrência de chuva generalizada (espacialmente) e de menores magnitudes em relação aos eventos decorrentes ou embebidos por sistemas atmosféricos intertropicais (ZCAS e ZCOU) e, especialmente no caso de março de 2011, em que o Vórtice Ciclônico em alto mar mostrou-se determinante para a concentração pluvial na faixada litorânea.

Embora tenha sido observado um padrão predominante homogêneo dos sistemas frontais na geração de chuvas e, até mesmo em algumas condições os valores máximos diários tenham sido mais elevados no setor continental (BH Alto Iguaçu e Ribeira), os SF atuaram particular em cada um dos eventos pluviais extremos identificados e analisados. Assim, reconhece-se as limitações da abrangência espacial desta pesquisa, uma vez que as incursões dos sistemas atmosféricos nesta escala de análise ocorrem de modo peculiar e complexo nos diferentes setores das BH's selecionadas para este estudo. Sugere-se que em um estudo posterior, seja empregada uma análise rítmica climatológica mais detalhada e sistematizada, com a utilização de o maior número possível de eventos pluviais e com a abrangência de dados meteorológicos das demais localidades.

Destaca-se que os eventos pluviais extremos ocorridos durante o outono e inverno são de magnitudes inferiores aos verificados para a primavera e verão, dado os menores valores destes registros e dos desvios-padrões. Isto se dá porque no outono e inverno as condições térmicas regionais são igualmente mais homogêneas e o menor aquecimento superficial desfavorece a atividade convectiva e, consequentemente, o incremento de umidade local na formação e geração das chuvas. Conforme destacado por Baldo (2006) para a bacia hidrográfica do rio Ivaí (PR), às condições atmosféricas regionais desta latitude durante o inverno diminuem os totais pluviométricos devido à maior restrição aos sistemas atmosféricos extratropicais na geração das chuvas daquela região, enquanto que a interação entre sistemas extratropicais e intertropicais corresponde ao principal fator da elevação dos registros de precipitação.

Esta característica de predominância dos sistemas frontais na geração de chuvas na região Sul do Brasil é destacada por Borsato e Souza Filho (2010), posto que os totais 
pluviais decorrentes de sistemas frontais é superior a 68\% em Maringá (PR), sobretudo no período de abril e outubro, com um aumento da participação da mEc e ZCAS entre novembro e março, período no qual os sistemas intertropicais interagem frequentemente com a FPA. Comparativamente, mostraram que em Goiânia (GO) os sistemas frontais são responsáveis somente por $12 \%$ dos totais de pluviosidade para o período de 1980 a 2003 , evidenciando a restrição das chuvas no Brasil Central aos mecanismos atmosféricos de origem tropical e equatorial.

Analisando as características dos sistemas frontais e as situações sinóticas capazes de provocar chuvas intensas na região serrana do estado do Rio de Janeiro, Seluchi et al. (2016) concluíram que estes mecanismos extratropicais se situam sob o Uruguai 48 horas antes de chegar às serras cariocas e estão associados a uma onda zonal e barotrópica que permitem o incremento de ventos de noroeste em grande parte da região Sul e Sudeste e, deste modo, de instabilidade convectiva, que provoca a intensificação do sistema frontal. Estes autores descrevem que o maior contraste térmico na baixa troposfera, aliada à alta advecção da vorticidade ciclônica nos médios níveis, à divergência nos altos níveis e aos altos teores de umidade nos baixos níveis são os elementos que explicam a ocorrência dos altos acumulados pluviométricos na região serrana do Rio de Janeiro. Estas conclusões estão próximas aos resultados obtidos para as localidades do leste do estado do Paraná, pois em algumas condições atmosféricas os ventos sopraram de noroeste na antecipação da FPA, que por vezes esteve associada aos Vórtices Ciclônicos e aos Cavados.

Teixeira e Satyamurty (2007) investigaram as características dinâmicas e sinóticas de episódios de chuvas fortes no Sul do Brasil e destacaram que o jato de baixo nível a leste dos Andes corresponde a mais frequente fonte de umidade para os sistemas frontais, mas não é exclusivamente o único aspecto específico de intensificação da instabilidade, pois também observaram que comumente é observada uma forte área de divergência de umidade sobre o leste do Brasil e o Atlântico Sul adjacente durante a ocorrência de chuvas intensas. Especificaram que a mistura do fluxo de convergência a $700 \mathrm{hPa}$ é a principal característica associada às chuvas intensas na primavera e verão, enquanto que durante o inverno a variável mais importante para a indicação de pluviosidade elevada é advecção quente que antecede a entrada dos sistemas frontais. Estes autores utilizaram-se do limiar de $50 \mathrm{~mm} /$ dia para definir uma chuva diária intensa e identificaram que a região Sul não tem um padrão sazonal de maior frequência de eventos extremos, com exceção da região costeira de Santa Catarina, nas proximidades do litoral do Paraná, onde estas chuvas são mais frequentes entre dezembro e fevereiro. 
Avaliando as condições sinóticas associadas às ocorrências de chuvas orográficas em Santa Catarina, Rodrigues (2015) discorre que a situação semiestacionária da alta pressão (ASAS) no mar junto a formação de ciclones em níveis médios são condições sinóticas que favorecem o transporte de umidade para a costa catarinense e favorecem chuvas intensas persistentes. Obteve-se em fevereiro o maior número de casos de chuvas extremas para o litoral catarinense, o que pode ser explicado por ser um dos meses, assim como março, em que a temperatura da superfície do mar está mais aquecida e, ao mesmo tempo, é um dos meses em que, juntamente com janeiro, verifica-se uma maior frequência de formação de Cavados na altura do litoral de SP. Deste modo, as condições de chuvas extremas observadas no leste do estado do Paraná associada a formação de Cavados e ao transporte de umidade do oceano decorrente da persistência de ventos oriundos da ASAS foram previamente observadas em uma região próxima, caracterizada essencialmente por uma dinâmica atmosférica peculiar e, contudo, similar à analisada nesta pesquisa.

Averiguando os impactos decorrentes dos eventos pluviais extremos em Curitiba, Zanella (2007) discorre que ao longo da série estudada (1982-2000) foram evidenciadas condições de extrema calamidade, com a população sendo retirada de suas residências, perdas materiais, doenças e até mesmo perdas humanas, impactos decorrentes dos eventos extremos de chuva, destacando-se a partir do acúmulo superior a $60 \mathrm{~mm}$ em 24 horas. Esta autora ressalta ainda que a FPA foi o principal mecanismo atmosférico associado aos eventos pluviais extremos ocorridos e que, embora com menor importância, as LIT e as ZCAS também contribuíram na geração dos eventos de maiores intensidades pluviais.

Ao analisa a variabilidade pluviométrica da BH Alto Iguaçu, Caldana et al. (2018), identificaram que ao longo de 18 anos (2000-2017) as chuvas intensas foram responsáveis pela ocorrência de 861 casos de alagamentos, enxurradas ou inundações, afetando ao todo cerca de 872 mil pessoas. Notaram que a região Metropolitana de Curitiba (RMC), mesmo não sendo o setor de maiores totais pluviométricos, é o setor de maior susceptibilidade aos impactos decorrentes dos eventos extremos pluviais, pois a urbanização acentuada e desordenada ocorrida na capital paranaense e seu entorno geram condições vulneráveis à ambientes propícios às desordens e desarranjos territoriais, como observaram Armond e Sant'Anna Neto (2017) para a cidade do Rio de Janeiro e Amorim e Monteiro (2010) nas localidades de Presidente Prudente (Brasil) e em Porto (Portugal).

Nascimento Júnior e Sant'Anna Neto (2014) avaliaram que a RMC corresponde a um dos setores paranaense de maior susceptibilidade à ocorrência de alagamentos, enchentes e enxurradas, sobretudo nos meses mais chuvosos (entre outubro a março), com 
a atribuição significativa aos sistemas frontais e sua associação ao escoamento da baixa e média troposfera na gênese dos eventos pluviais de maiores magnitudes. Em acordo ao discorrido por Nascimento Júnior e Sant'Anna Neto (2015), estes extremos pluviais em condições deflagradoras evidenciam os diversos níveis de vulnerabilidade e desigualdade socioambiental, especialmente em setores do estado do Paraná em que a urbanização se deu de modo mais acentuado e desordenado como em suas regiões metropolitanas.

Os estudos de Caldana et al. (2019) observaram que a FPA foi um dos principais mecanismos atmosféricos responsáveis pela ocorrência de chuvas de granizo na região Centro-Sul do estado do Paraná, destacadamente pelo choque de massas de ar de distintos conteúdos (mPa e mTc/mTa) e por mudanças abruptas dos tipos de tempo naquela região. Evidenciaram em que a maior frequência de eventos de precipitação do granizo ocorrem entre março e maio, período de transição entre do verão para o inverno e, destacadamente, em setembro e outubro, nos quais o frequente choque das massas de ar citadas acima e a incursão frequente da FPA geram elevada instabilidade e, em condições mais propícias, as chuvas de granizo.

Em estudo para o Oeste paulista, Boin (2000) identificou que a FPA e a FPAE são as condições atmosférica que geram os maiores totais pluviais e, consequentemente, o maior potencial erosivo das chuvas, especialmente sob condições do último mecanismo, no qual a elevada intensidade pluvial deflagra com maior afinco os processos erosivos. $\mathrm{O}$ referido autor discorre que seu resultado sobre o potencial erosivo das chuvas no Oeste do estado de São Paulo está em acordo com as características pluviais identificadas por Monteiro (1973) e, conforme descrito anteriormente por Monteiro (1969), a FPA em seu eixo principal e reflexo corresponde ao principal mecanismo de geração das chuvas em todas as estações do ano, atingindo o ápice e quase totalidade da participação na geração das chuvas durante o inverno.

No entanto, a análise rítmica realizada por Mello et al. (2017) para Paranaguá em condições de verão destaca que, de cinco eventos extremos pluviais recentes, entre 2011 e 2015, somente um esteve relacionado à incursão da FPA. Observou-se que em três condições sinóticas, o mecanismo atmosférico responsável pelos elevados totais de chuva foi a ZCOU e em outro evento extremo verificou-se o predomínio da influência da mTa. Os resultados desta pesquisa estão em partes concordantes com a análise supracitada, pois em condições da associação da FPAE com a ZCAS, foram registrados elevados totais de pluviosidade em Paranaguá em janeiro de 2004, justamente o evento pluvial de maior magnitude dentre os analisados e verificou-se também que a associação entre a FPAE e 
ZCOU repercutiu em 68,0 mm em 48 horas para Castro em dezembro de 2014. Deste modo, em tipos de tempo em que há associação entre os mecanismos intertropicais como a ZCAS ou ZCOU durante o verão e o reforço da FPA, verifica-se que há o favorecimento à formação de chuvas de elevada intensidade.

Em estudo para averiguar padrões sinóticos associados a casos de deslizamentos na Serra do Mar no Sudeste brasileiro, Seluchi e Chou (2009) identificaram que a maioria dos episódios de chuvas fortes e intensas e movimentos de terra estiveram associadas às passagens dos sistemas frontais (FPA) e, preeminentemente, à ZCAS. Observaram que a condição de bloqueio da Alta Subtropical do Atlântico Sul (ASAS) associada à circulação de altos níveis da latitude subtropical, destacadamente os Cavados e os Jatos Subtropicais, são as mais propiciais para manter à ZCAS mais ao sul de sua posição climatológica e gerar chuvas de totais elevados em dias consecutivos, condição climática persistente que repercute frequentemente em deslizamentos e escorregamentos de terra na Serra do Mar.

Sobre a atuação da ZCAS na formação e geração de chuvas extremas no Oeste do estado de São Paulo e Norte do Paraná, Berezuk e Sant'Anna Neto (2006) discorrem que este mecanismo atmosférico atinge aquela região com maior frequência no período entre dezembro e fevereiro e caracteriza-se pela maior diferença nos totais de chuva entre as localidades estudadas, o que é uma característica inerente aos sistemas extratropicais. A heterogeneidade espacial decorrente da atuação destes mecanismos é notável pelos totais pluviais identificados pelos eventos extremos descritos em janeiro de 2004 e em março de 2011.

Borsato et al. (2012) destacam a análise na participação da ZCAS em condições de tipos de tempo em Maringá, na região Norte do estado do Paraná, durante os meses de verão e sua significativa influência na geração de chuvas naquela localidade. Contudo, os resultados de Zandonadi (2013) contrapõe-se aos demais observados acima, pois mostrou que a ZCAS em alguns anos-padrão não gerou chuvas em nenhuma das três localidades paranaenses estudadas (Curitiba, Foz do Iguaçu e Guarapuava), com exceção do verão de 1999 em que $21 \%$ do total precipitado em Guarapuava esteve sob condições deste sistema atmosférico. Desta forma, a ZCAS é um mecanismo atmosférico pouco estudado em sua atuação sob no estado paranaense, demonstrando a carência de estudos mais amplos sobre sua abrangência e frequência em formar chuvas, tanto em sua participação nas normais climatológicas, quanto em sua representatividade para os eventos pluviais extremos. 


\subsection{Gênese pluvial e a "Spatial Synoptic Classification"}

Os resultados da aplicação da técnica SSC para Castro demonstra que o tipo de tempo mais frequente entre os primeiros dias de setembro e o último decêndio de março, com exceção do segundo decêndio de dezembro e o primeiro decêndio de março, é o MM (Moderado Úmido), caracterizando-se pela principal condição atmosférica predominante no período mais chuvoso nesta localidade, condição próxima à observada por Fontão et al. (2018) para a cidade de São Paulo. O mês mais seco da série histórica, agosto destacase pela participação do tipo de tempo DM (Moderadamente Seco), com valores superiores a $20 \%$ nos três decêndios deste mês e, contudo, o período que este tipo de tempo é mais frequente é o primeiro decêndio de março $(35,6 \%)$, como observa-se pela figura 93A.

Verifica-se, contudo, que ao longo do inverno há o aumento significativo dos tipos de tempo associados às entradas da Frente Polar Atlântica (FPA) e a massa de ar Polar atlântica (mPa), com os tipos de tempo mais frequentes MP (Polar Úmido) e DP (Polar Seco), nesta ordem. Observa-se que o tipo de tempo MP atinge o percentual de $44,4 \%$ dos tipos de tempo observados para a segunda semana de maio, associados às condições de frio, umidade e alta nebulosidade, ao passo que no segundo decêndio de janeiro há a menor frequência $(1,1 \%)$. O tipo de tempo DP é mais frequente no primeiro decêndio de maio $(25,6 \%)$ e de junho $(22,2 \%)$, sendo que sua menor frequência relativa ocorre no último decêndio de dezembro (1,0\%). Os tipos de tempo de transição (TR) foram mais frequentes $(>19,0 \%)$ no segundo decêndio de fevereiro e nos terceiros decêndios dos meses de novembro e dezembro, período no qual se verifica a diminuição expressiva da participação dos tipos de tempo Polar (DP e MP), conforme indica a figura 93A.

Destaca-se que em Castro o tipo de tempo DT (Tropical Seco) ocorre com maior frequência relativa no período entre o terceiro decêndio de agosto e o primeiro decêndio de setembro (>10\%), condição possivelmente atrelada à participação das mTa e mTc, em um período de transição do período seco para o chuvoso. Inclusive, no segundo decêndio de setembro, seguinte a esta maior frequência de tempo DT, verifica-se a maior frequência dos tipos de tempo MT+ (Tropical Úmido Plus), com 16,7\% de participação. Não se verificou tipos de tempo denominados MT++ (Tropical Úmido Double Plus), o que se deve a localização de maior continentalidade de Castro (Figura 93A).

Em Curitiba, nota-se que alguns padrões são similares ao observado em Castro. $\mathrm{O}$ tipo de tempo DP ocorre com a maior frequência entre o terceiro decêndio de maio e o segundo decêndio de junho $(>17,0 \%)$ e o tipo de tempo MP tem frequência $\geq 20 \%$ entre a 
o segundo decêndio de abril e o terceiro decêndio de julho, basicamente caracterizando as situações mais comuns e próprias ao inverno na região Sul do Brasil (Figura 93B).

Outro padrão similar à Castro, a tipologia DM mostra uma frequência $\geq a 28 \% \mathrm{em}$ todo mês de agosto e, contudo, é mais frequente no primeiro decêndio de março. Também caracterizando o período mais seco, o tipo de tempo DT é mais comum $(\geq 8,9 \%)$ entre o segundo decêndio de agosto e os primeiros dez dias de setembro. Por sua vez, o tipo de tempo TR é superior a $11 \%$ entre o segundo decêndio de novembro e o segundo decêndio de dezembro, justamente o período em que há a redução da participação das tipologias polares. Bem como verificado em Castro, não se verifica em Curitiba a ocorrência da tipologia MT++ (Figura 93B).

Entretanto, alguns padrões se diferem em relação à Castro, pois em Curitiba o tipo de tempo MM está associado aos períodos de transição entre as estações do ano, sendo igual ou superior a $30 \%$ no terceiro decêndio de maio (outono/inverno) e entre o primeiro decêndio de setembro e o segundo decêndio de outubro. Com exceção do verificado para o segundo decêndio de novembro, o período entre o final de outubro e o final de fevereiro corresponde ao período de maior frequência da tipologia MT, ao passo que o tipo MT+ tem sua frequência $\geq$ a $8,9 \%$ entre o segundo decêndio de outubro e o segundo decêndio de janeiro, sendo estas duas tipologias as mais associadas às condições de maiores alturas pluviais em Curitiba (Figura 93B). Estas condições de associação do período chuvoso à maior frequência da tipologia MT foram observadas por Armond (2014) para a cidade do Rio de Janeiro.

Em Paranaguá, as mais elevadas temperaturas em relação às demais localidades é o fator preponderante para a obtenção mais restrita dos tipos de tempos polares. O tipo DP ocorre somente entre o final de abril e o final de julho, delimitando o período invernal e tem sua maior participação no primeiro decêndio de junho (14,4\%). Por exemplo, o tipo de tempo MP é expressivamente menos frequente em relação às demais localidade, sendo que entre o segundo decêndio de dezembro e o terceiro decêndio de janeiro não se verifica sua ocorrência, que tem seu ápice no segundo decêndio de maio $(21,1 \%)$. Por sua vez, a tipologia DM tem sua maior frequência (>13\%) no primeiro decêndio de agosto e terceiro decêndio de setembro, provavelmente associada à condição de transição entre o inverno e a primavera (Figura 94). 


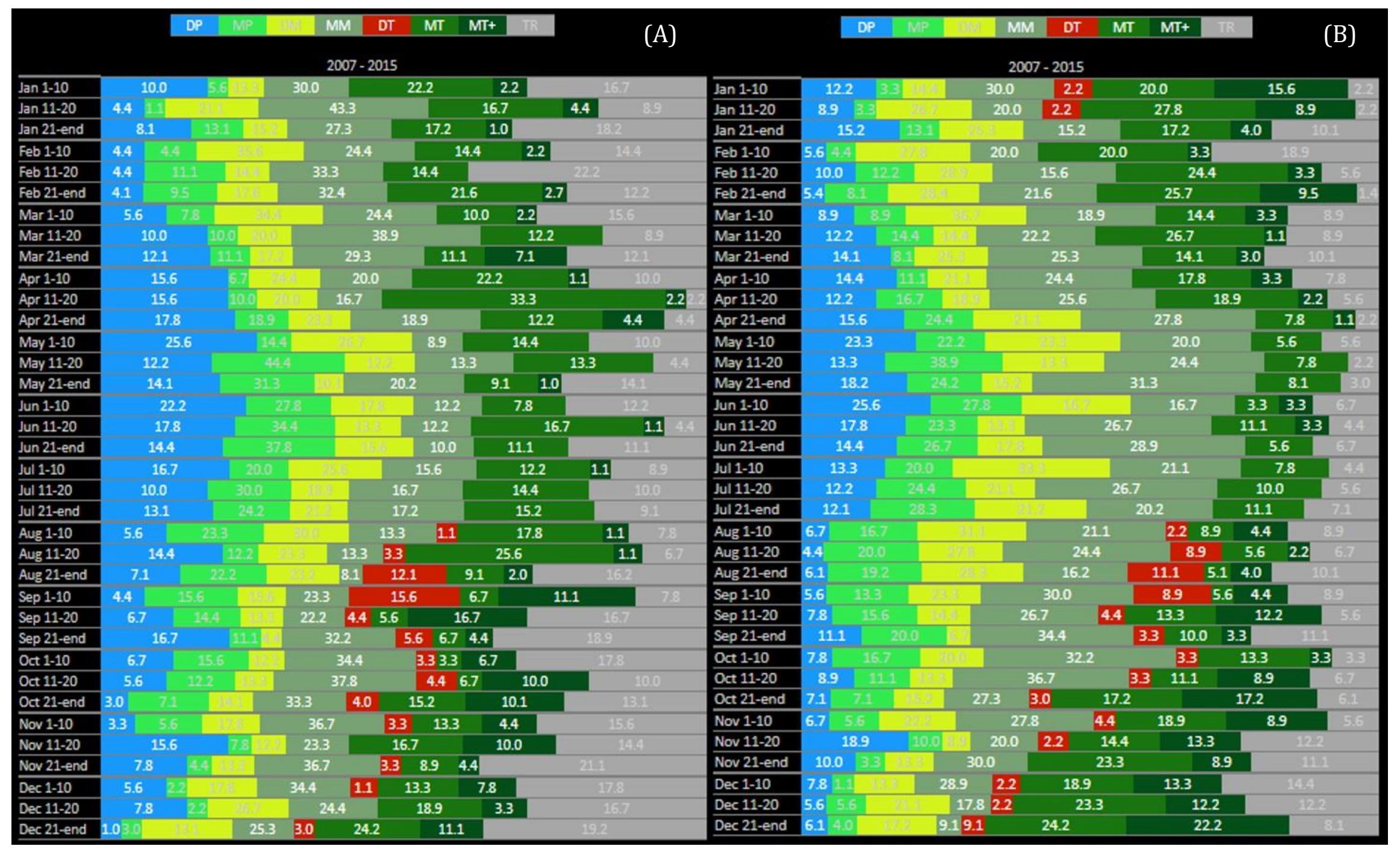

Figura 93 - Frequência decendial (\%) dos tipos de tempo conforme o método SSC para o período de 2007 a 2015 em Castro (A) e Curitiba (B), Paraná. Fonte: Sheridan (2019). 


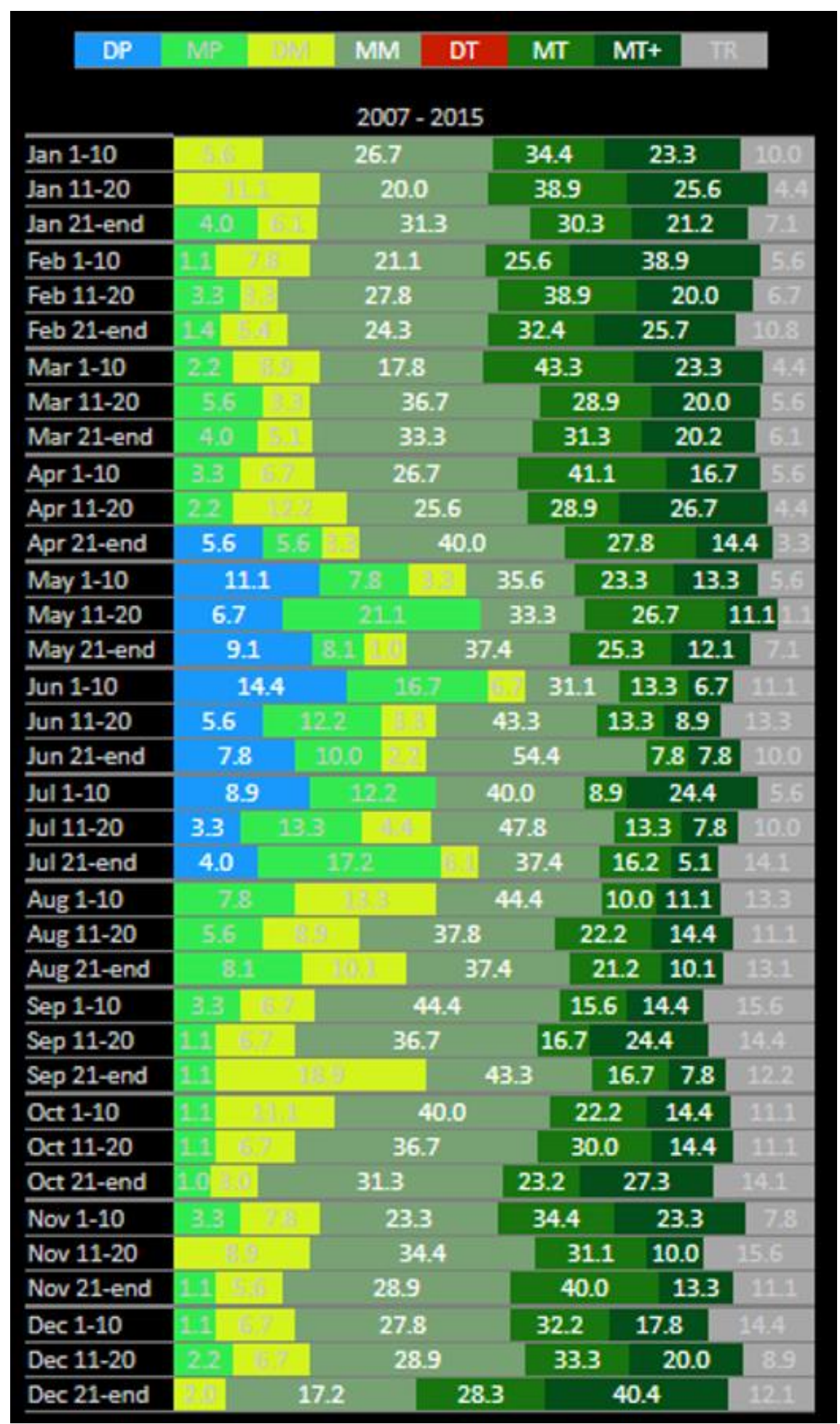

Figura 94 - Frequência decendial (\%) dos tipos de tempo conforme o método SSC para o período de 2007 a 2015 em Paranaguá, Paraná. Fonte: Sheridan (2019).

Em Paranaguá, a tipologia MM é a que apresenta a maior frequência (>30\%) ao longo dos meses de maio, junho, julho, agosto, setembro e outubro, além de registrar percentuais acima de 30\% nos tipos de tempo no terceiro decêndio de janeiro, nos segundo e terceiros decêndios de março, terceiro decêndio de abril e segundo decêndio de novembro, sendo assim, o estado atmosférico mais comumente associado à redução 
de menor pluviosidade em uma localidade que apresenta elevados totais de pluviosidade ao longo do ano todo. O tipo de tempo MT está mais diretamente associado às elevações dos totais de chuvas na área de estudo, sendo que sua frequência é menos elevada $(<10 \%)$ em todo mês de junho, nos segundo e terceiro decêndio de julho e terceiro decêndio de setembro. Por sua vez, a tipologia MT+ destaca-se pelos valores mais elevados entre o segundo decêndio de setembro e o terceiro decêndio de março (>20\%), período no qual ocorre os mais elevados totais pluviais em Paranaguá (Figura 94).

Em Castro, a média de pluviosidade anual para o segmento temporal avaliado é de 1.713,8 mm. O tipo de tempo mais frequentemente associado à gênese pluvial é o MM, responsável por gerar em média 55,8\% dos totais pluviais ao longo dos anos de 2007 a 2015. Destacadamente, no ano de 2009 este tipo de tempo esteve associado a 64,5\% dos totais pluviais, ao passo que em 2007 esta participação esteve próxima a 42\%. Em média, cerca de $16 \%$ dos totais pluviais estão atrelados à condição MP, sendo que nos anos de 2010 e 2013 esta participação esteve próxima a 25\% e acima dos 400 mm. Em seguida, durante a ocorrência da tipologia MT é responsável por 10,5\% dos totais de precipitação pluviométrica em Castro ao longo da série analisada, destacando-se o ano de 2007, no qual cerca de $32,5 \%$ das chuvas se deram a partir deste tipo de tempo, o que está associado à concentração das chuvas em cerca de $70 \%$ nos meses de verão e primavera, entre janeiro e março e entre outubro e dezembro (INMET, 2019). Por fim, as condições de transição mostraram-se responsáveis por 9,1\% dos totais de chuvas no período, com valor superior a 16\% no ano de 2011 (Figura 95A).

A condição DT, associado comumente a estabilidade atmosférica, e o MT++, que aparece com muito pouco frequência nos tipos de tempo em Castro, são as tipologias que ocasionaram os menores totais de chuva. Pela condição de estabilidade atmosférica e a sua baixa frequência relativa, nesta ordem, os tipos de tempo DP e MT+ mostraram-se favoráveis por menos de $2 \%$ dos totais pluviais. Por sua vez, o tipo de tempo DM mostra uma participação de 4,8\% da gênese pluvial, com totais superiores a $100 \mathrm{~mm}$ entre os anos de 2008 a 2010 e em 2015 (Figura 95A).

Em relação à frequência absoluta dos tipos de tempo, observa-se que em Castro aproximadamente cerca de 87 dias do ano em média estiveram em condições MM e, em seguida, 68 dias mostraram a tipologia DM. Nota-se o predomínio do tipo de tempo MM no período entre 2009 a 2015, sendo superior a 100 dias nos anos de 2009 e 2015, os quais obtiveram totais de pluviosidade superior a $2.000 \mathrm{~mm}$. Dentre os anos de menores 
totais pluviais $(\leq 1.500 \mathrm{~mm})$, verifica-se o predomínio da tipologia MT e DM nos anos de 2007 e 2008, nesta ordem (Figura 95B).
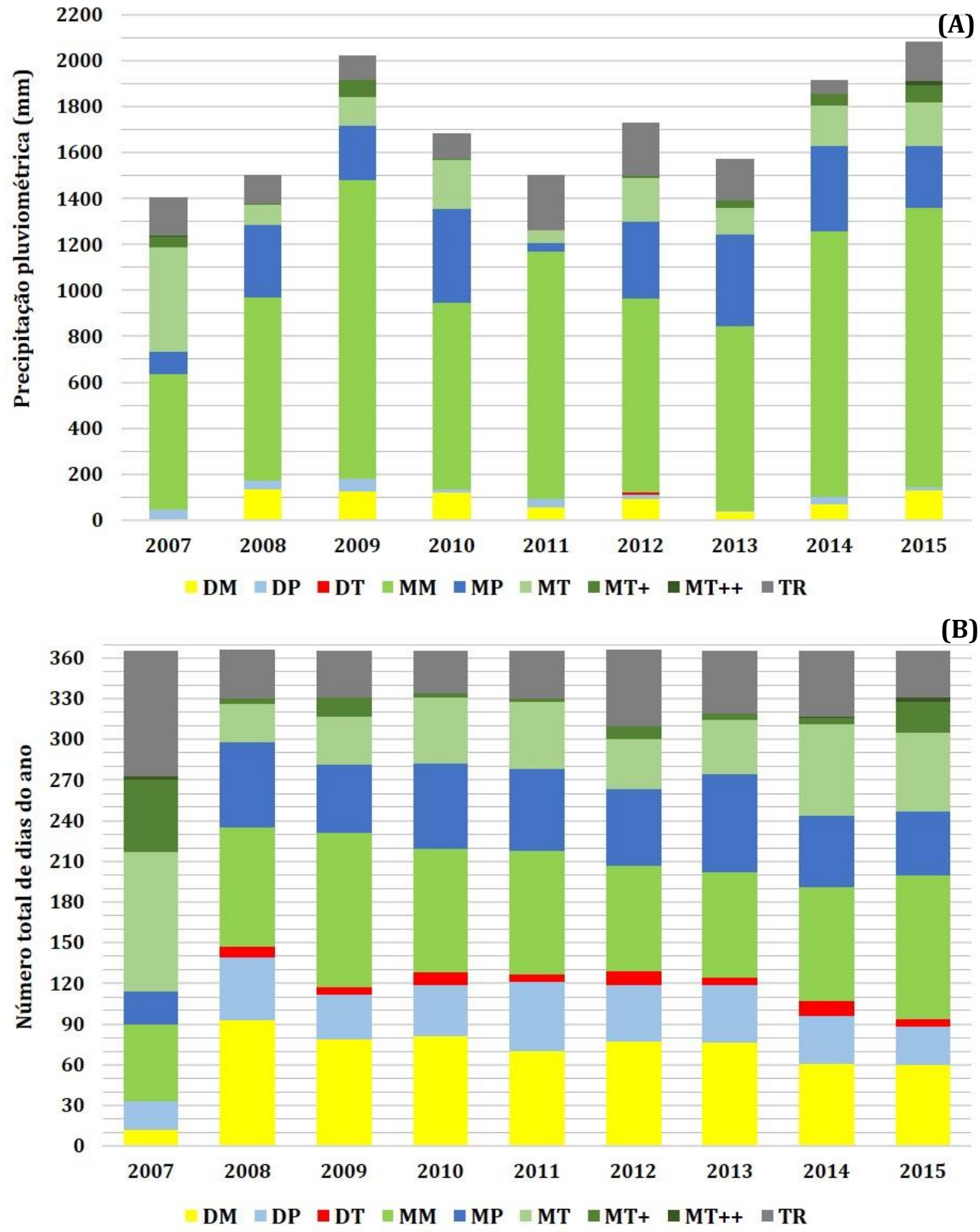

Figura 95 - Gênese pluvial (A) e tipos de tempo (B) em Castro, Paraná, entre 2007 e 2015. 
Ao longo dos nove anos analisados, a média pluvial anual em Curitiba é de 1.730,8 mm. Observa-se que em média 43,0\% dos totais pluviométricos se deram em condições da tipologia MM, tendo sido mais frequente nos anos de 2009 e 2015, com uma média de $53,0 \%$ e 59,8\% da participação na geração dos totais anuais, nesta ordem. O tipo de tempo polar úmido mostra-se como o segundo mais efetivo, com uma média de 18,2\% dos totais pluviais do período analisado, sendo que em 2010 este percentual foi de 27,1\%. Em seguida, o MT é o terceiro tipo de tempo com a maior participação média na geração das chuvas $(15,5 \%)$ e, contudo, em 2007 este valor chegou a 27,2\%, semelhante ao observado em Castro. As condições de transição (TR) foram responsáveis por 8,9\% do total pluvial médio, superando os 20\% no ano de 2013 (Figura 96A).

Na capital paranaense, os tipos de tempo MT++ e DT foram responsáveis por uma média dos totais pluviométricos inferiores a $1 \% \mathrm{e}$, portanto, são as tipologias com a menor frequência na geração das chuvas. O tipo de tempo MT+ mostra-se atuante em cerca de $5 \%$ do total precipitado, superando os $10 \%$ em 2009. Observa-se que as tipologias DM e DP estiveram atuantes em 5,7\% e 2,8\% do volume total e no ano de 2012 mostraram as suas atuações mais eficazes, com uma participação de 12,4\% e 8,2\%, nesta ordem (Figura 96A).

Observa-se que em Curitiba predomina o tipo de tempo MM, com uma média de 88 dias ao ano, tendo sido superior a 90 dias em 2008, 2009, 2010 e 2015, anos nos quais os totais de precipitação pluvial é superior a $1.800 \mathrm{~mm}$, com exceção do ano de 2008. Em seguida, o tipo de tempo DM ocorre em média 75 dias ao ano e superior a 80 dias em 2007, 2011, 2012 e 2013, sendo que com exceção do ano de 2011, nota-se em todos estes anos uma pluviosidade total anual inferior a $1.600 \mathrm{~mm} \mathrm{O}$ tipo de tempo menos frequente é o MT++ ocorre com a menor frequência, em média de 2 dias ao ano, e mais frequente em 2009 (07 dias), no qual verificou-se o maior percentual de chuvas decorrentes deste tipo de tempo (Figura 96B).

Outras tipologias, como MP e MT ocorreram com uma frequência superior a 50 dias em média ao ano. $\mathrm{O}$ ano de 2011 caracterizou-se pela maior frequência da tipologia MP (71 dias), enquanto que em 2010 observou-se a maior participação do tipo de tempo MT (59 dias). Dentre os aspectos mais relevantes, aponta-se que o ano de 2011 também foi caracterizado pela maior frequência da tipologia DP, sugerindo uma provável elevada participação dos sistemas atmosféricos polares (mPa) ao longo deste ano (Figura 96B). 


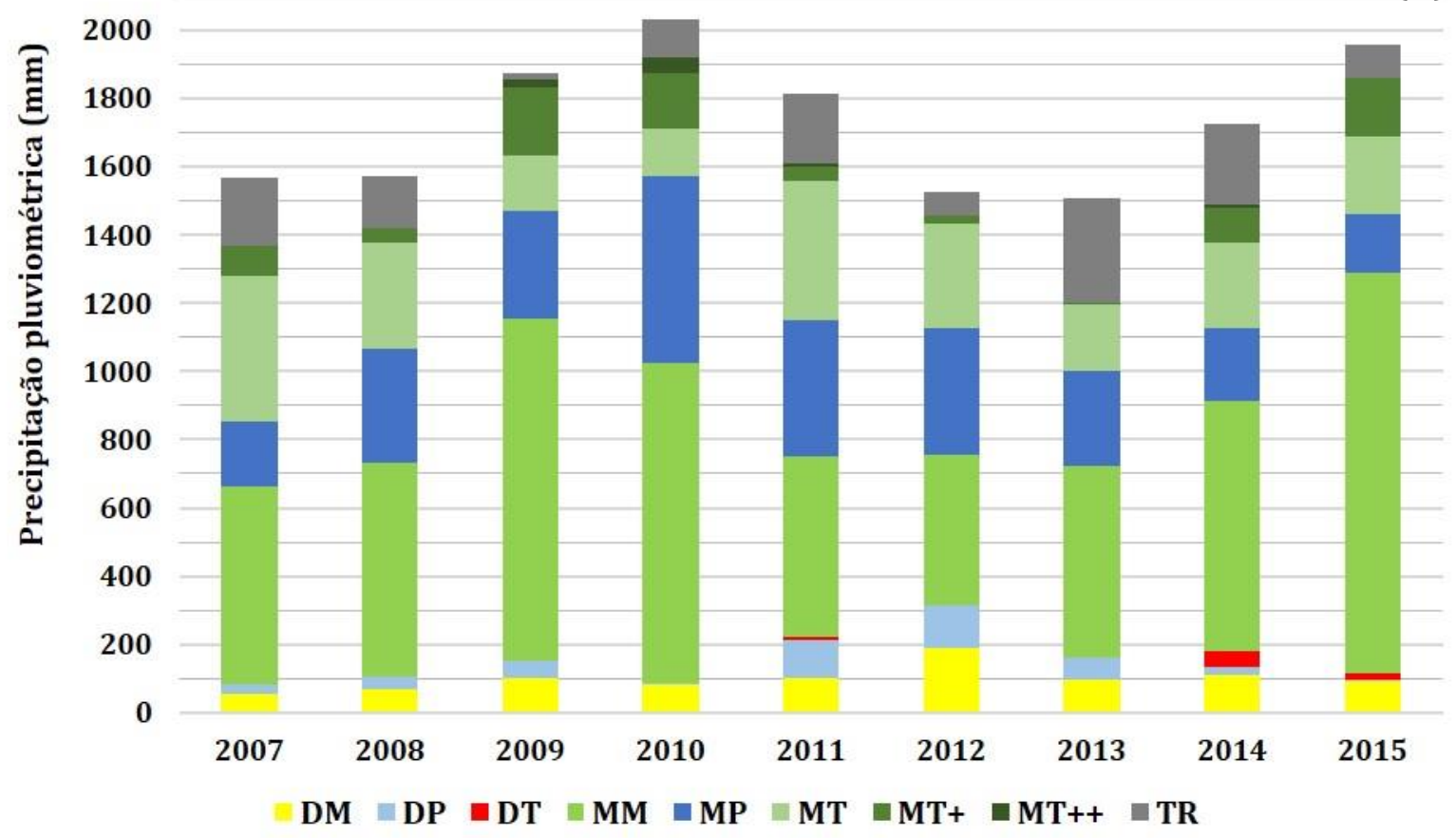

(B)

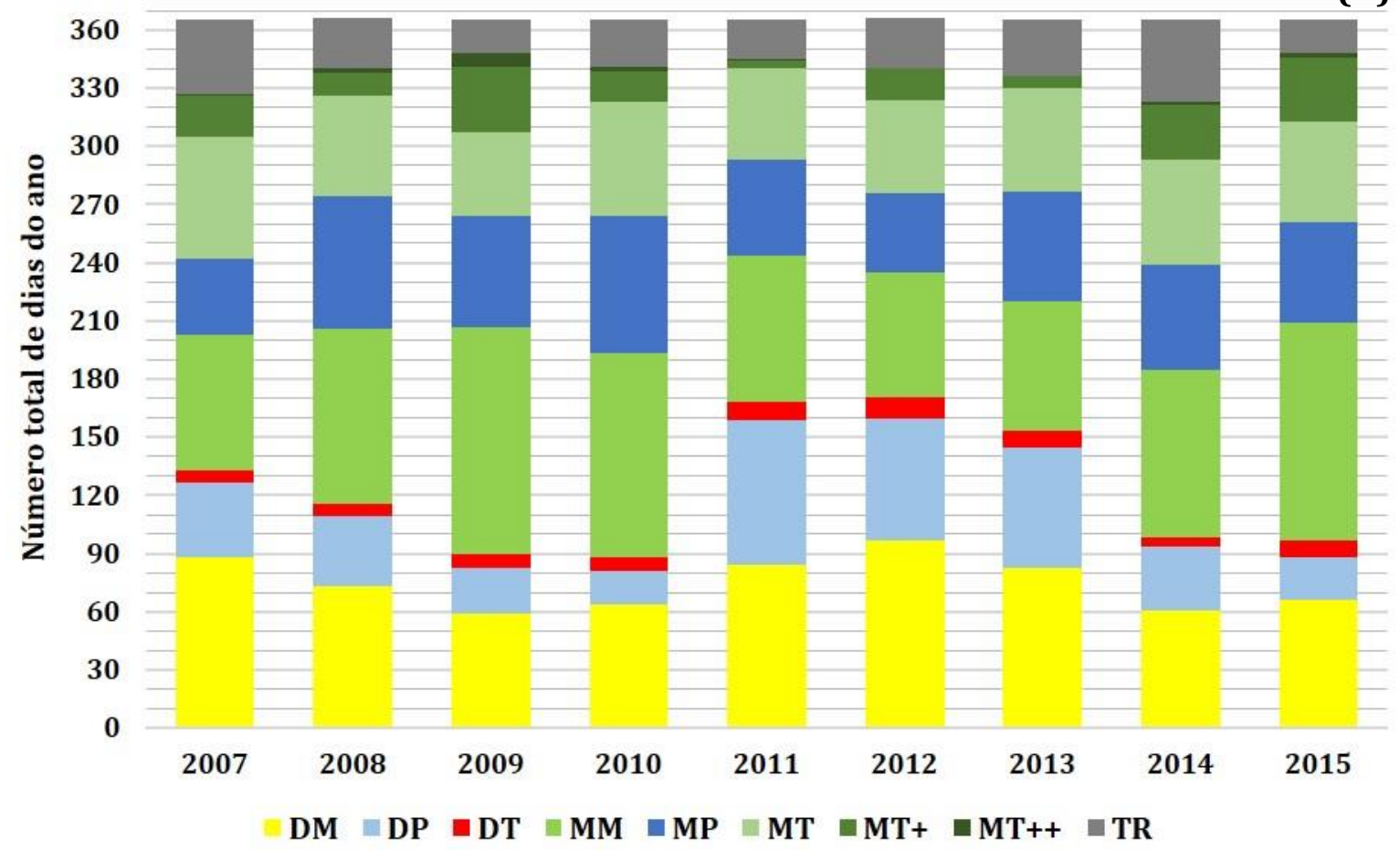

Figura 96 - Gênese pluvial (A) e tipos de tempo (B) em Curitiba, Paraná, entre 2007 e 2015.

Considerando o segmento temporal de 2007 a 2015, a precipitação pluviométrica média anual em Paranaguá é de 2.322,3 mm. Isoladamente, o tipo de tempo MM é o que apresenta a maior participação na gênese pluvial (48,6\%), sendo que para o ano de 2008 este valor superou os 60\%, sendo o ano de maior participação desta tipologia. Em seguida, a tipologia MT apresenta uma média de 21,1\% na gênese pluvial, com valores superiores 
a 27\% para os anos de 2008 e 2011. Com 8,8\% de participação na gênese pluvial deste período em análise, o tipo de tempo TR apresentou valores superiores a 13\% nos anos de 2014 e 2015 (Figura 97A).

Com uma média de 8,6\% de participação na gênese pluvial, a tipologia MP foi responsável pela ocorrência de $28,5 \%$ da precipitação pluviométrica ocorrida no ano de 2015. Com uma significativa variabilidade ao longo dos anos, a tipologia MT+ aparece como o tipo de tempo responsável por 7,2\% dos totais pluviais no período avaliado, sendo que no ano de 2009 este valor superou os 14\%, contrapondo-se ao observado em 2015, no qual este valor foi inferior a $0,01 \%$ (Figura 97A).

Tendo a atuação do tipo de tempo DM, observa-se uma gênese pluvial equivalente a 3,3\%, chegando a cerca de $19 \%$ (>500 $\mathrm{mm}$ ) no ano de 2015 e, bem como a tipologia DM, apresenta uma expressiva variabilidade, com valor inferior a $0,05 \%(0,2 \mathrm{~mm}) \mathrm{em}$ 2012. O tipo de tempo MT++ gerou 1,8\% dos totais de pluviosidade, sendo que 2007 esta participação esteve em 6,4\%. A tipologia DP mostra-se atuante para a geração de somente $0,5 \%$ dos totais pluviais, com uma participação de 2,25\% no ano de 2015 . Por fim, a tipologia DT não foi verificada em nenhum dia do período analisado e, desta forma, não esteve atuante em nenhuma condição de chuva (Figura 97A).

As características tropicais úmidas foram responsáveis pelos tipos de tempo de 159 dias em média, destacando-se que os tipos de tempo mais comuns é o MT (94 dias) e MT+ (50 dias). Devido ao efeito da maritimidade, nota-se a maior frequência do tipo de tempo MT++ (15 dias) em relação às demais localidades. No entanto, o tipo de tempo mais comum é o MM, com uma média de 122 dias, amplamente relacionada às condições de ocorrência de chuvas. As condições de Transição (TR) estiveram atuantes em média de 34 dias e Moderadamente Seco (DM) em 23 dias. Por fim, o tipo de tempo polar seco (DP) esteve atuante em média durante 8 dias (Figura 97B).

Observa-se que a tipologia MM foi identificada mais frequentemente e superior a 140 dias em 2008, 2011 e 2013, enquanto que o tipo de tempo MT se mostra superior a 120 dias nos anos de 2008 e 2014. Apesar da alta pluviosidade (>2.700 mm), o ano de 2015 apresentou com maior frequência as tipologias DM (120 dias), TR (57 dias) e DP (25 dias), conforme indica a figura 97B. 


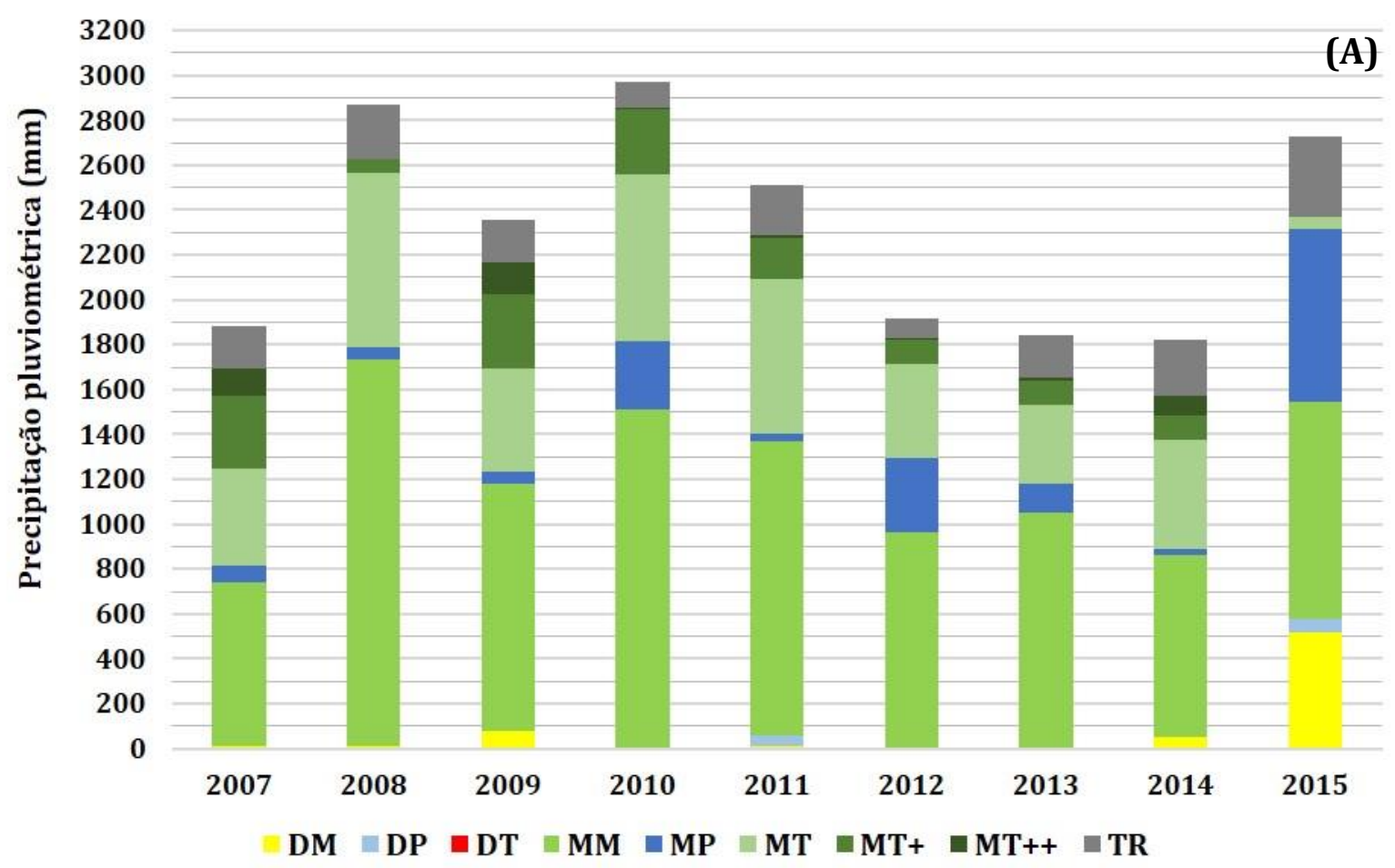

(B)

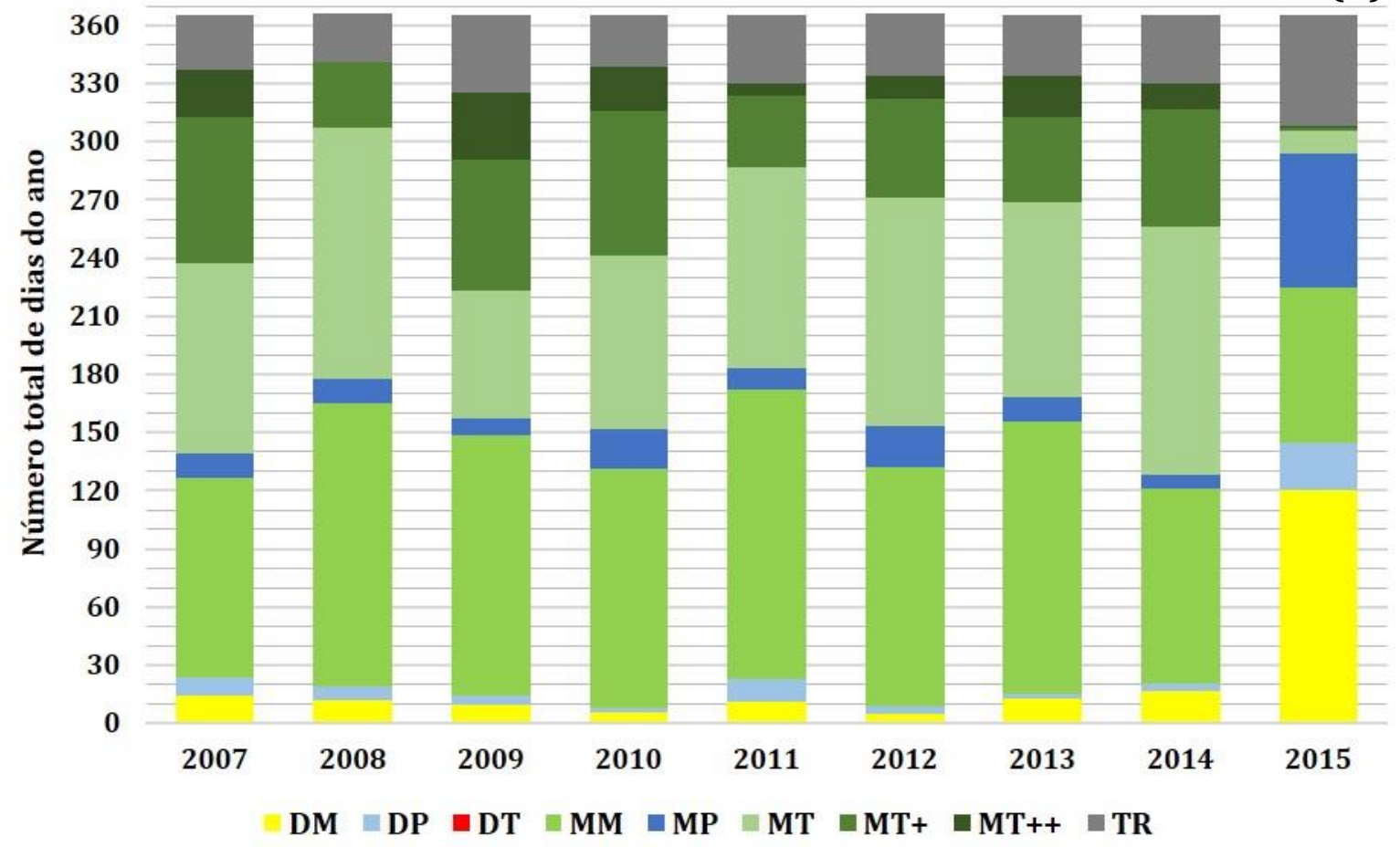

Figura 97 - Gênese pluvial (A) e tipos de tempo (B) em Paranaguá, Paraná, entre 2007 e 2015.

Em 2009, verifica-se a maior frequência absoluta do número de dias com as tipologias MT+ (68 dias) e MT++ (34 dias), ressaltando-se a influência destes tipos de tempo para a gênese pluvial deste ano, que somadas geraram cerca de $20 \%$ dos totais de pluviosidade (Figura 97B). 


\section{CONCLUSÕES}

Os resultados demonstraram que a bacia hidrográfica Litorânea caracteriza-se pela maior precipitação pluviométrica média, com registros de postos pluviométricos em que as médias anuais foram próximos a $2.700 \mathrm{~mm}$, demonstrando o papel desempenhado pela maritimidade para o acréscimo dos totais de pluviosidade neste setor da área em estudo. Com a barreira orográfica da Serra do Mar, a bacia hidrográfica do rio Ribeira obteve os menores valores da precipitação pluvial média anual, com postos nos quais a média anual esteve próxima a $1.200 \mathrm{~mm}$. Dado ao suposto desempenho orográfico da Serra do Mar, a bacia hidrográfica do Alto Iguaçu apresenta igualmente menores médias anuais de chuva em relação à bacia hidrográfica Litorânea e, devido à relativa pouca variação da hipsometria, observou-se uma relativa homogeneidade da distribuição espacial da precipitação pluvial nesta bacia hidrográfica.

A área em estudo caracteriza-se pela concentração dos maiores totais de pluviosidade no período de primavera e verão, que vai de setembro a março, e a redução no outono e inverno, de abril a agosto. Os meses de inverno mostraram as menores diferenças de pluviosidade entre as bacias hidrográficas, o que se atribui a atuação homogênea dos sistemas frontais, principal mecanismo de geração das chuvas durante este período. Observou-se que a bacia hidrográfica Litorânea apresenta os maiores totais médios de precipitação pluvial em todos os meses do ano, com maiores aumentos de pluviosidade nos meses de verão dada a sua condição de proximidade ao Oceano Atlântico. Devido à sua proximidade com o domínio climático subtropical, notou-se que a bacia hidrográfica do Alto Iguaçu apresenta a maior regularidade mensal das precipitações, enquanto que para a bacia hidrográfica do Ribeira obteve-se de forma mais notável similaridades com o clima tropical do Brasil Central dada a concentração pluvial nos meses de primavera e verão e a redução durante o inverno.

Destaca-se que a aplicação dos métodos de agrupamentos (Ward e K-Means) permitiu a identificação da variabilidade espacial da pluviosidade e suas relações com os efeitos da influência da maritimidade, da orografia da Serra do Mar e da dinâmica atmosférica regional. Portanto, observou-se que o emprego desta técnica permitiu uma aplicação satisfatória da análise de cluster para compreender a interação entre os fatores geográficos do clima, destacando o papel desempenhado pela influência oceânica para os maiores totais pluviométricos na BH Litorânea, o efeito orográfico para a chuva redução das bacias hidrográficas do Alto Iguaçu e Ribeira, e a interferência de dinâmica na 
distribuição mensal de chuvas. Assim, constitui uma importante análise da distribuição espacial das chuvas em uma região de transição de um clima tropical para um subtropical e com uma importante barreira orográfica, a saber, a Serra do Mar no território paranaense.

A aplicação dos métodos de agrupamento permitiu a identificação dos grupos homogêneos pluviométricos para cada uma das bacias hidrográficas e a associação da variabilidade pluvial com os efeitos da influência da maritimidade, a barreira orográfica da Serra do Mar e a dinâmica atmosférica regional subjacente. Portanto, observou-se que o emprego desta técnica de análise espacial mostrou-se eficaz na compreensão da interação entre os fatores geográficos do clima, destacando o papel desempenhado pela maritimidade para a ocorrência dos maiores totais pluviométricos na bacia hidrográfica Litorânea, do efeito orográfico para a redução pluvial nas bacias hidrográficas do Alto Iguaçu e Ribeira, uma vez que estas bacias hidrográficas situam-se a sotavento da Serra do Mar, e a interferência de dinâmica atmosférica regional na distribuição mensal da precipitação pluviométrica.

Os resultados da frequência e intensidade das chuvas diárias mostraram que a área de estudo apresenta os limiares mais elevados no setor oeste das bacias hidrográficas do Alto Iguaçu e do rio Ribeira e, principalmente, devido à atuação da maritimidade, na bacia hidrográfica Litorânea. O período da mais elevada frequência das chuvas mais intensas se dá no período entre dezembro e março, tendo como ápice o mês de janeiro, sendo que em todos os postos pluviométricos este mês destaca-se pela maior frequência de chuvas diárias iguais ou superiores a 95\% dos quantis. Entretanto, devido à predominância do clima subtropical, alguns setores mostraram maior da ocorrência das precipitações entre 95\% e $99 \%$ dos quantis, sobretudo em maio e junho na BH Alto Iguaçu, o que pode estar atrelado à maior influência dos mecanismos atmosféricos extratropicais nesta $\mathrm{BH}$.

Em relação aos indicadores climáticos oceânicos e as anomalias de pluviosidade, a partir da aplicação do modelo VAR, conclui-se que as séries de anomalias de chuvas apresentam dependência de dados pretéritos, principalmente em relação segundo mês anterior dos indicadores climáticos oceânicos. Dentre os resultados mais expressivos, destaca-se que o indicador ONI causa no sentido as anomalias de chuvas de alguns grupos das bacias Litorânea e Alto Iguaçu, uma vez que a equação de séries de anomalia de chuvas também apresenta a do indicador ONI e a equação do indicador só depende dele mesmo. Destaca-se que a anomalia de chuvas destes grupos está relacionada a dois (sinal positivo, diretamente proporcional), três (sinal negativo, inversamente proporcional) ou 
quatro (sinal positivo, diretamente proporcional) meses anteriores ao valor do indicador. A ODP também causa as anomalias de chuvas de alguns grupos das bacias Litorâneas e Ribeira, sendo que a existência desta causalidade está vinculada aos valores de um ou dois meses anteriores deste indicador, sendo que se os valores aumentam, as anomalias também aumentam.

Para o indicador IOS, observa-se que ele se correlaciona apenas às anomalias de chuvas do grupo 3 da bacia Litorânea, causalidade que aparece no valor do mês anterior e com sinal negativo, sendo inversamente proporcional. Apesar de ser o único indicador marítimo do oceano Atlântico, o indicador GMAT possui relação somente com o GHIV da BH Alto Iguaçu, havendo um mês de atraso e sinal positivo e, inversamente, com o GHIV da BH do rio Ribeira, igualmente com um mês de defasagem e sinal negativo. Ao contrário do esperado, o indicador climático do Oceano Atlântico não é efetivo para a ocorrência das anomalias de precipitação pluviométrica na BH Litorânea.

No entanto, algumas das séries de anomalias de chuvas quando relacionadas aos indicadores não apresentam dependência do seu passado (Lag). Como exemplo, nota-se o caso do grupo 4 do Alto Iguaçu com os indicadores IOS e ODP e do grupo 1 do Ribeira com os indicadores GMAT, IOS e ODP. Assim, dos 15 grupos formados neste presente estudo, 6 deles possuem anomalias de chuvas que possuem alguma relação com algum dos três indicadores marítimos (IOS, ODP ou ONI). Isto significa que 24 postos possuem suas informações de anomalias de chuvas mensais sendo influenciadas por um destes indicadores marítimos.

O emprego do teste Mann-Kendall para as séries temporais na área de estudo demonstra modificações significativas dos totais pluviais. Quanto aos totais anuais, com uma significância estatística de 90\%, observa-se tendência de aumento em sete postos pluviométricos da BHAI e em doze postos pluviométricos na BHR. Contudo, embora as tendências sejam menos comuns na BHL, nota-se que as modificações mais expressivas se deram nesta $\mathrm{BH}$, com o aumento anual de 17,5 mm em Antonina (ID22) e a diminuição anual de 25,2 mm em Guaraqueçaba (ID27), destacando-se que esta compreende uma das poucas tendências significativas de diminuição para a área em estudo. O teste de Pettitt demonstra que as principais rupturas significativas estatisticamente ocorreram entre 1985 e 2004, sendo que em sua maioria ocorreram nos anos 1990, para os totais pluviométricos anuais.

Para a chuva máxima diária anual, obteve-se o aumento dos totais diários em sete postos pluviométricos na BHR e em quatro postos pluviométricos da BHAI, considerando 
a significância de 90\%. Na BHL, observa-se o mais expressivo aumento da chuva máxima diária em Antonina (ID22), na ordem de 1,06 mm/ano, enquanto que as únicas tendências de diminuição da área em estudo ocorreram em outros três postos pluviométricos desta $\mathrm{BH}$, destacando-se a redução em 0,94 mm/ano em Guaraqueçaba (ID27). As principais rupturas nas séries temporais se deram entre os anos de 1988 e 1999, concordantes com os resultados anteriores e ao identificado para o total pluviométrico anual.

Para as chuvas diárias superiores a 95\% dos quantis, obtiveram-se o aumento em dois postos pluviométricos na BHAI e na BHL e um outro na BHR, destacando-se São Mateus do Sul (ID12) da BHAI, com a tendência positiva de 0,18 mm/ano, com 95\% de significância. Inversamente, verificou-se a diminuição das chuvas diárias superiores a 95\% dos quantis em dois postos pluviométricos da BHL e um da BHR, sendo que nesta primeira BH obteve-se a diminuição de 0,14 mm/ano em Morretes (ID33) para uma significância de 95\%. Para as chuvas diárias superiores a 99\% dos quantis, houve o aumento destas alturas pluviais em dois postos pluviométricos da BHL e em um posto pluviométrico na BHR, com destaque para a tendência positiva observada em Campo Largo (ID45), em 0,53 mm/ano e com uma significância estatística de 99,9\%. Para este mesmo limiar das chuvas diárias, notam-se outras duas tendências negativas na BHL, uma para a BHAI e outra para a BHR, na qual a diminuição no posto pluviométrico de Ponta Grossa (ID55) esteve na ordem de $0,37 \mathrm{~mm} /$ ano com $95 \%$ de significância.

Em suma, conclui-se que os indicadores climáticos mostraram que a área em estudo apresenta a preponderância da elevação dos totais pluviométricos anuais associada ao aumento da precipitação pluviométrica diária concentrada, sendo este um indicativo da variabilidade climática. Os indicadores de tendências da precipitação pluviométrica indicaram que a BHAI apresenta o aumento expressivo da concentração pluvial, pois 11 postos pluviométricos mostraram tendência positiva do índice SDII, o índice simples da precipitação diária, ao passo que em 06 postos pluviométricos foram verificados às tendências de aumento dos totais anuais de precipitação (PRCPTOT) e do número anual de chuvas diárias superiores a $20 \mathrm{~mm}$ (R20mm). O posto pluviométrico de São Mateus do Sul (ID13) apresentou a tendência de aumento de seis indicadores de precipitação (SDII, PRCPTOT, RX5day, R10mm, R20mm e R95p), sendo esta a modificação mais expressiva da BHAI.

Para a BH Litorânea, o PRCPTOT mostrou-se como o indicador mais expressivo de tendências de modificações da precipitação pluviométrica, destacando-se o aumento em seis postos pluviométricos e a redução em um deles. Verificou-se em Antonina (ID22) 
a tendência de aumento de sete indicadores (PRCPTOT, RX1day, RX5day, R10mm, R20 mm, R95p e o R99p), ressaltando-se o aumento de 17,85 mm/ano do PRCPTOT. Por sua vez, o posto pluviométrico de Guaraqueçaba (ID27) demostrou a tendência de diminuição de cinco indicadores (SDII, PRCPTOT, R10mm, R20mm, R95p), sendo que se verificou a mais expressiva redução da precipitação pluviométrica anual, em 22,1mm/ano.

Por sua vez, a BH do rio Ribeira obteve expressivos resultados de aumento dos indicadores de tendência de precipitação pluviométrica, dos quais se destacam o SDII e R95p, os quais obtiveram modificações positivas em 12 e 11 postos pluviométricos, nesta ordem. Ainda, observa-se o aumento das tendências dos totais pluviométricos anuais (PRCPTOT) e do número anual de chuvas superiores a $20 \mathrm{~mm}$ (R20 mm) em 9 e 8 postos pluviométricos, ordenadamente. Os postos pluviométricos de Bocaiúva do Sul (ID40) e Cerro Azul (ID48) apresentaram o aumento de 6,92 $\mathrm{mm}$ e 6,48 $\mathrm{mm} /$ ano do indicador R95p, sendo este um dos mais expressivos aumentos de indicadores da precipitação diária da área de estudo.

O estudo específico para as três estações meteorológicas principais mostraram que a maritimidade é atributo climático essencial na determinação maiores valores das chuvas extremas diárias para Paranaguá. Por sua vez, Castro e Curitiba localizadas a sotavento da Serra do Mar, a geração das chuvas mais intensas são restritas a atuação dos sistemas frontais. O período de maior ocorrência das chuvas superiores a 95\% e 99\% dos quantis ocorre de janeiro a março, sobretudo em Paranaguá. Contudo, salienta-se a ocorrência de eventos extremos (>99\%) nos meses de maio e junho em Castro e Curitiba.

Observou-se uma tendência de acréscimo dos totais de chuva diária em todas as classes de quantis com significância estatística em Curitiba, para qual atribui-se ao adensamento urbano pelo maior aumento dos totais de chuvas diárias, e sem significância estatística para Castro e Paranaguá, com grau de urbanização de menor porte. As rupturas mais frequentes para as classes de chuva dos quantis ocorreram entre 1990 e 1995 , alinhando-se às observações anteriores para o estado do Paraná realizadas para as chuvas totais anuais.

A avaliação das condições atmosféricas associadas aos eventos pluviais extremos demostrou que os maiores volumes diários acumulados estiveram sob a atuação da Frente Polar Atlântica (FPA), seja em sua condição estacionária (FPAE) ou associada aos Jatos Subtropicais, o que é condizente com as observações anteriores da dinâmica atmosférica regional. Ressalta-se que esta associação entre a entrada da FPA e a ocorrência das chuvas extremas se dá de modo mais linear durante o outono e inverno, período de maior atuação 
dos sistemas frontais e, sobretudo, devido à abrangência deste mecanismo atmosférico, as chuvas ocorrem de modo mais uniforme, o que é comprovado pelo menor coeficiente de variação da precipitação pluviométrica observada nas estações meteorológicas da área de estudo durantes estas excepcionalidades pluviais $(<27 \%)$. Entretanto, durante o verão e a primavera, com a maior participação dos sistemas atmosféricos intertropicais, há uma maior complexidade na gênese pluvial destes eventos extremos, pois os eventos pluviais extremos de 2004 e 2011 estiveram associados às condições atmosféricas da atuação das ZCAS e aos Cavados. Uma das principais características dos eventos pluviais extremos que ocorrem durante a primavera e o verão é a sua irregularidade espacial, tendo como principal exemplo o que ocorreu em março de 2011, com um coeficiente de variação de 100,3\%, precipitou em cinco dias consecutivos um total de $411 \mathrm{~mm}$ em Morretes e, de modo inverso, em Ponta Grossa choveu apenas $13 \mathrm{~mm}$.

A utilização do método híbrido "Spatial Synoptic Classification" demonstrou as principais diferenças dos tipos de tempo entre Castro, Curitiba e Paranaguá. Enquanto que em Paranaguá não se verifica a ocorrência do tipo de tempo DT (Dry Tropical), em Castro e Curitiba este tipo ocorre com uma frequência maior entre o final de agosto e meados de setembro, sendo associada ao tempo quente e seco, sendo características da atuação da massa Tropical continental. Os tipos de tempo MT, MT+ e MT++ ocorreram com maior frequência em Paranaguá em relação as demais localidades, justamente devido às mais elevadas temperaturas e a influência da maritimidade para o aumento da umidade relativa do ar. Os tipos de tempo polares (DP e MP) ocorreram com maior frequência entre o final de abril e o final de julho em todas as estações meteorológicas, associadas à atuação à mais frequente atuação da massa Polar atlântica e à Frente Polar Atlântica.

Quanto à gênese pluvial, verificou-se que o tipo de tempo frequentemente mais associado à ocorrência de chuvas é o Moist Moderate (MM), que em Castro chega a até $55,8 \%$ do total pluviométrico médio. Contudo, o segundo tipo de tempo frequentemente mais associado à gênese pluvial é o Moist Polar (MP) para Castro $(16,0 \%)$ e em Curitiba $(18,2 \%)$ e, entretanto, em Paranaguá o segundo tipo de tempo que atua com maior força na geração de chuvas é o MT (Moist Tropical), associado às mais elevadas temperaturas, à influência marítima e, principalmente, ao aumento expressivo dos volumes de chuvas nos meses de verão, uma vez que em Paranaguá entre janeiro e março as médias mensais são superiores a $300 \mathrm{~mm}$ nesta localidade.

Em suma, destaca-se que esta tese atingiu os objetivos delimitados e, em partes, obteve as respostas definidas pela hipótese. Verificou-se a complexidade da interação dos 
atributos climáticos (maritimidade, a orografia e os mecanismos atmosféricos) para a geração das chuvas e, principalmente, na estrutura pluviométrica das bacias hidrográficas. Contudo, ressalta-se que a variabilidade temporal pluviométrica está restrita às anomalias de temperatura e pressão da superfície do Oceano Pacífico, dadas pelo indicador ONI, sendo que o indicador referente às condições térmicas do Atlântico (GMAT) restringiu sua influência somente em setores isoladas das bacias hidrográficas do Alto Iguaçu e do rio Ribeira. Ao contrário do que se esperava, a bacia hidrográfica Litorânea não apresenta a influência deste indicador climático oceânico como controlador da variabilidade anual da precipitação pluviométrica.

Conclui-se que esta pesquisa excedeu os objetivos delimitados, uma vez que as conclusões descritas acima superam a hipótese e os propostos iniciais, sobretudo devido à incorporação do suporte teórico e, principalmente, metodológico robusto oriundo de áreas correlatas como a Meteorologia e a Estatística. A utilização de técnicas decorrentes destas áreas do conhecimento avaliou mais densamente os aspectos quantitativos da variabilidade pluviométrica, especialmente com a aplicação da modelagem VAR, que indicou satisfatoriamente a influência dos indicadores climáticos para averiguar a influência dos Oceanos Pacífico e Atlântico sobre as anomalias pluviais, e com o emprego dos testes estatísticos (Mann-Kendall e Pettitt), que mostraram que a área em estudo apresenta a preponderância da elevação dos totais pluviométricos anuais associada ao aumento da precipitação pluviométrica diária concentrada, sendo este um indicativo de mudanças climáticas neste recorte de estudo.

Espera-se que esta pesquisa tenha aprimorado a compreensão das características da variabilidade pluviométrica e dos eventos pluviais extremos na área de estudo, seja como um contributo para a Climatologia Geográfica, base teórica da qual esta tese está fundamentada, seja para a Meteorologia, que possibilitou a compreensão mais ampla e complexa da dinâmica atmosférica regional, e até mesmo para o Planejamento Ambiental e Territorial, que pode se utilizar destes conhecimentos para minimizar os impactos decorrentes das excepcionalidades pluviométricas. Embora a ampla utilização de diversos procedimentos metodológicos seja um dos principais méritos desta pesquisa, reconhecese que esta abrangência impossibilitou o aprofundamento de diversos aspectos ao longo desta tese de doutoramento. 


\section{REFERÊENCIAS}

ALCÁNTARA-AYALA, I. Geomorphology, natural hazards, vulnerability and prevention of natural disasters in developing countries. Geomorphology, Amsterdam, v.47, n.2-4, p.107-124, 2002.

ALEXANDER, L.V.; ZHANGE, X.; PETERSON, T.C.; CAESAR, J.; GLEASON, B.; TANK, A.M.G.K.; HAYLOCK, M.; COOLINS, D.; TREWIN, B.; RAHIMZADEH, F.; TAGINPOUR, A.; RUPA, K.K.; REVADEKAR, J.; GRIFFITHS, G.; VICENT, L.; STEPHENSON, D.B.; BURN, J.; AGUILAR, E.; BRUNET, M.; TAYLOR, M.; NEW, M.; ZHAI, P.; RUSTICUCCI, M.; VAZQUEZ-AGUIRRE, J. L. Global observed changes in daily climate extremes of temperature and precipitation. Journal of Geophysical Research (Atmosphere), New Jersey, v.111, n.5, p.1-22, 2006.

ALLAN, R.P.; SODEN, B.J. Atmospheric warming and the amplification of precipitation extremes. Science, Londres, v.321, n.5895, p.1481-1484, 2008.

ALMEIDA, F.F.M.; CARNEIRO, C.D. Origem e evolução da Serra do Mar. Revista Brasileira de Geociências, São Paulo, v.28, n.2, p.135-150, 1998.

ÁLVARES, C.A.; STAPE, J.L.; SENTELHAS, P.C.; DE MORAES GONÇALVES, J.L.; SPAROVEK, G. Köppen's climate classification map for Brazil. Meteorologische Zeitschrift, Berlin, v.22, n.6, p.711-728, 2013.

ALVES, J.M.B.; CHAVES, R.R.; SERVAIN, J.; SOUZA, E.B.; SILVA, E.M.; SANTOS, A.C.S.; BARBOSA, A.C.B.; OLIVEIRA, C.J.; SOMBRA, S.S.; COSTA, A.A.; PINHEIRO, F.G.M. Modelos acoplados do IPCC-AR4 e o Gradiente Meridional de Temperatura da Superfície do Mar no Atlântico Tropical: Relações com a precipitação no Norte do Nordeste. Revista Brasileira de Meteorologia, São Paulo, v.29, n.4, p.568, 2014.

AMBRIZZI, T. El Niño/Oscilação Sul e teleconexões atmosféricas no hemisfério austral. 2003. 201f. Tese (Livre-Docência). Instituto de Astronomia, Geofísica e Ciências Atmosféricas. Universidade de São Paulo, São Paulo, 2003.

AMBRIZZI, T.; FERRAZ, S.E.T. An objective criterion for determining the South Atlantic Convergence Zone. Frontier in Environmental Sciences, Lausanne, v.3, n.1, p.1-23, 2015.

AMORIM, M.C.C.T.; MONTEIRO, A. Episódios extremos de precipitação e fragilidade dos ambientes urbanos: exemplos de Portugal e do Brasil. Territorium, Coimbra, v.17, n.1, p.5-15, 2010.

ANANIAS, D.S.; SOUZA, E.B.; SOUZA, P.F.S.; SOUZA, A.M.L.; VITORINO, M.I.; TEIXEIRA, G.M.; FERREIRA, D.B. Climatologia da estrutura vertical da atmosfera em novembro para Belém - PA. Revista Brasileira de Meterologia, São Paulo, v.25, n.2, p.218-226, 2010. 
ANDRADE, A. R.; NERY, J. T. Análise da precipitação pluviométrica diária, mensal e interanual da bacia hidrográfica do Rio Ivaí, Brasil. Investigaciones Geográficas. Cidade do México, v.52, n.1, p.7-30, 2003.

ANDRADE, K.M.; PINHEIRO, H.R.; DOLIF NETO, G. Evento extremo de chuva: análise sinótica, previsão numérica e comparação com eventos anteriores. Ciência e Natura, Santa Maria, v.37, Edição Especial do Simpósio Internacional de Climatologia, p.175-180, 2015.

ANDRÉ, R.G.B.; MARQUES, V.S.; PINHEIRO, F.M.A.; FERRAUDO, A.S. Identificação de regiões pluviometricamente homogêneas no estado do Rio de Janeiro, utilizandose valores mensais. Revista Brasileira de Meteorologia, São Paulo, v.23, n.4, p.501509, 2008.

ANDREOLI, R.V.; KAYANO, M.T.; GUEDES, R.L.; OYAMA, M.D.; ALVES, M.A. S. A influência da temperatura da superfície do mar dos Oceanos Pacífico e Atlântico na variabilidade de precipitação em Fortaleza. Revista Brasileira de Meteorologia, São Paulo, v.19, n.3, p.337-344, 2004.

ANDRIOTTI, J.L.S. Fundamentos de Estatística e Geoestatística. São Leopoldo: Editora Unisinos, 2003.165p.

ANJOS, I. B.; NERY, J. T. Variáveis meteorológicas associadas ao rendimento de grãos no estado do Paraná. Acta Scientiarum Agronomy, Maringá, v. 27, n.1, p. 133-144, 2005.

APARECIDO, L.E.O; ROLIM, G.S.; RICHETTI, J.; SOUZA, P.S.; JOHANN, J. A. Köppen, Thornthwaite and Camargo climate classifications for climatic zoning in the State of Paraná, Brazil. Ciência e Agrotecnologia (Online), Lavras, v.40, n.4, p. 405417, 2016.

ARAKI, R.; NUNES, L.H. Vulnerability associated with precipitation and anthropogenic factors on Guarujá City (São Paulo, Brazil) from 1965 to 2001. Terræ. Geosciences, Geography and the Environment (Online), Campinas, v.3, n.1, p. 54-57, 2008.

ARAÚJO, L.E.; SOUSA, F.A.S.; RIBEIRO, M.A.F.M.; SANTOS, A.S.; MEDEIROS, P.C. Análise estatística de chuvas intensas na bacia hidrográfica do rio Paraíba. Revista Brasileira de Meteorologia, São Paulo, v.23, n.2, p.162-169, 2008.

ARMANI, G.; GALVANI, E. Fluxos polares e o ritmo dos sistemas atmosféricos no nordeste do estado de São Paulo. Sociedade \& Natureza, Uberlândia, v.23, n.1, p. 7-23, 2011.

ARMOND, N.B. Entre eventos e episódios: as excepcionalidades das chuvas e os alagamentos no espaço urbano do Rio de Janeiro. 2014. 239f. Dissertação (Mestrado). Programa de Pós-Graduação em Geografia. Universidade Estadual Paulista "Júlio de Mesquita Filho", Presidente Prudente, 2014. 
ARMOND, N.B. Sobre formas e processos na gênese das chuvas no município do Rio de Janeiro. In: SANT'ANNA NETO, J. L.; AMORIM, M. C.C.T.; SILVA, C.A. (Org.). Clima e gestão do território. 1ªEdição. Jundiaí: Paco Editorial, v.1, p.137-154, 2016.

ARMOND, N. B.; SANT'ANNA NETO, J. L. Entre eventos e episódios: ritmo climático e excepcionalidades para uma abordagem geográfica do clima no município do Rio de Janeiro. Revista Brasileira de Climatologia, Curitiba, v.20, n.13, p.5-28, 2017.

ARMOND, N.B. Dinâmica climática, excepcionalidades e vulnerabilidades: contribuições para uma classificação geográfica do clima do estado do Rio de Janeiro. 2018. 170f. Tese (Doutorado). Programa de Pós-Graduação em Geografia. Universidade Estadual Paulista "Júlio de Mesquita Filho", Presidente Prudente, 2018.

ARMOND, N.B.; OSCAR JUNIOR, A.C.S. Análise rítmica em Climatologia: da física da atmosfera ao clima como fenômeno geográfico. In: OSCAR JUNIOR, A.C.S; ARMOND, N.B. (Org.). A Climatologia Geográfica no Rio de Janeiro: Reflexões, Metodologias e Técnicas Para Uma Agenda de Pesquisa. $1^{a}$ Edição. Curitiba: Appris, v.1, p.233-269, 2018.

ARMOND, N.B.; SANT'ANNA NETO, J.O. The Urban Climate System and the Impacts of Flooding on Rio de Janeiro, Brazil. In: HENRÍQUEZ, C.; ROMERO, H. (Org.). Urban Climates in Latin America. $1^{\text {a}}$ Edição. Switzerland: Springer International Publishing, v.1, p.259-2801, 2019.

ÁVILA, A.; JUSTINO, F.; WILSON A.; BROMWICH, D.; AMORIM, M. Recent precipitation trends, flash floods and landslides in southern Brazil. Environmental Research Letters, Bristol, v.11 n.11, p.1-13. 2016.

AYOADE, J.O. Introdução à climatologia para os trópicos. $8^{\mathrm{a}}$ Edição. Rio de Janeiro: Bertrand Brasil. 2002. 332p.

AZEVEDO, L.C. Análise da precipitação pluvial da bacia do Rio Iguaçú - Paraná. 2006. 123 f. Dissertação (Mestrado). Programa de Pós-Graduação em Geografia, Universidade Estadual de Maringá, Maringá, 2006.

AZEVEDO, L.C.; NERY, J.T.; ANDRADE, A.R.; SOUSA, P.A Influência do fenômeno El Niño na vazão do Rio Iguaçu - Paraná. Perspectiva Geográfica, Marechal Cândido Rondon, v.2, n.2, p.5-65, 2006.

BACK, A.J. Aplicação de análise estatística para identificação de tendências climáticas. Pesquisa Agropecuária Brasileira, Brasília, v.36, n.5, p. 717-726, 2001.

BALDO, M.C.; NERY, J.T.; MARTINS, M.O.F. Análise da estrutura da precipitação pluviométrica na região Sul do Brasil. Boletim de Geografia (UEM), Maringá, v.19, n.1, p.115-128, 2001.

BALDO, M.C. Variabilidade Pluviométrica e a Dinâmica Atmosférica da Bacia do Rio Ivaí. 2006. 153 f. Tese (Doutorado). Programa de Pós-Graduação em Geografia. Universidade Estadual Paulista "Júlio de Mesquita Filho", Presidente Prudente, 2006. 
BANCO MUNDIAL. Avaliação de perdas e danos: inundações e deslizamentos na região Serrana do Rio de Janeiro - Janeiro de 2011. 2012. Disponível em: < http://mi.gov.br/pt/c/document_library/get_file?uuid=74dde46c-544a-4bc4-a6e1-852 d4c09be06\&groupId=10157>. Acesso em 28 de novembro de 2016.

BARATTO, J.; WOLLMANN, C.A. ; HOPPE, I.L. Variabilidade termo-higrométrica no Parque Estadual do Espinilho, em Barra do Quaraí (RS), sob domínio Tropical Continental. Revista Brasileira de Geografia Física, Recife, v.6, n.6, p.1734-1743, 2013.

BARROS, J. R.; ZAVATTINI, J. A. Bases conceituais em Climatologia Geográfica. Mercator, Fortaleza, v.8, n.16, p.255-261, 2009.

BARROS, M. V. F.; MENDES, C.; CASTRO, P.H.M. Vulnerabilidade socioambiental à inundação na área urbana de Londrina - PR. Confins, Paris, v. 24, n.1, p.1-22, 2015.

BEIJO, L. A.; MUNIZ, J. A.; CASTRO NETO, P. Tempo de retorno das precipitações máximas em Lavras (MG) pela distribuição de valores extremos do tipo I. Ciência e Agrotecnologia, Lavras, v. 29, n. 3, p.657-667, 2005.

BEREZUK, A.G.; SANT'ANNA NETO, J.L. Eventos climáticos extremos no oeste paulista e no norte do Paraná nos anos de 1997, 1998 e 2001. Revista Brasileira de Climatologia, Curitiba, v.2, n.2, p.9-22, 2006.

BEREZUK, A. G.; GARCIA, M. R. Estudo de tendências do ritmo pluviométrico da bacia hidrográfica do Rio Pardo - MS. Revista Brasileira de Climatologia, Curitiba, v.9, n.7, p. 7-20, 2011.

BERNARDES, L.R.M; AGUILAR, A.P.; ABE, S. Frequência de ocorrência de veranicos no Estado do Paraná. Boletim de Geografia, Maringá, v.6, n.1, p.83-108, 1988.

BERTONI, J.C.; TUCCI, C.E.M. Precipitação. In: TUCCI, C. E. M. (Org.) Hidrologia: Ciência e Aplicação. $2^{a}$ Edição. Porto Alegre: Editora da Universidade Federal do Rio Grande do Sul/Associação Brasileira de Recursos Hídricos, p. 727-768, 1997.

BERTONI, J.C.; LOMBARDI NETO, F. Conservação do Solo. $8^{\text {a }}$ Edição. São Paulo: Editora Ícone, 2012. 355p.

BERZ, W.; KRON, G.; LOSTER, T.; RAUCH, E.; SCHIMETSCHEK, J.; SCHMIEDER, J.; SIEBERT, A.; SMOLKA, A.; WIRTZ, A. World map of natural hazards - a global view of the distribution and intensity of significant exposures. Natural Hazards, Berlin, v.23, n.2, p.443-465, 2001.

BOIN, M.N. Chuvas e erosões no oeste paulista: uma análise climatológica aplicada. 2000. 264f. Tese (Doutorado). Programa de Pós-Graduação em Geociências e Meio Ambiente, Universidade Estadual Paulista “Júlio de Mesquita Filho", Rio Claro, 2000. 
BORSATO, V. A.; SOUZA FILHO, E.E. A participação dos sistemas atmosféricos atuantes na Bacia do rio Paraná no período de 1980 a 2003. Revista Brasileira de Climatologia, Curitiba, v.7, n.6, p.83-102, 2010.

BORSATO, V.A.; HIERA, M.D.; MARCON, L.S. A Zona de Convergência do Atlântico Sul e a dinâmica atmosférica para o Noroeste do Paraná. Revista Brasileira de Climatologia, Curitiba, v.11, n.8, p.104-118, 2012.

BORSATO, V.A.; MENDONÇA, F.A. Participação da massa polar atlântica na dinâmica dos sistemas atmosféricos no Centro Sul do Brasil. Mercator, Fortaleza, v.14, n.1, p.113$130,2015$.

BOWER, D.; MCGREGOR, G. R.; HANNAH, D. M.; SHERIDAN, S. C. Development of a spatial synoptic classification scheme for western Europe. International Journal of Climatology, Oxford, v.27, n.15, p.2017-2040, 2007.

BRITO, T.T.; OLIVEIRA JÚNIOR, J.F.; LYRA, G.B.; GOIS, G.; ZERI, M. Multivariate analysis applied to monthly rainfall over Rio de Janeiro state, Brazil. Meteorology and Atmospheric Physics, Berlin, v.128, n.5, p.469-478, 2016.

BRITTO, P.F.; BARLETTA, R.; MENDONÇA, M. Variabilidade espacial e temporal da precipitação pluvial no Rio Grande do Sul: Influência do fenômeno El Niño - Oscilação Sul. Revista Brasileira de Climatologia, Curitiba, v.3, n.3, p.37-48, 2008.

CALDANA, N.F.S.; YADA JÚNIOR, G.M.; MOURA, D.A.V.; COSTA, A.B.F.; CARAMORI, P.H. Ocorrências de alagamentos, enxurradas e inundações e a variabilidade pluviométrica na bacia hidrográfica do rio Iguaçu. Revista Brasileira de Climatologia, Curitiba, n.14, v.23, p.343- 355, 2018.

CALDANA, N.F.S.; RUDKE, A.P.; SILVA, I.; NITSCHE, P.R.; CARAMORI, P.H. Gênese, impacto e a variabilidade das precipitações de granizo na mesorregião CentroSul paranaense, Brasil. Caderno de Geografia, Belo Horizonte, v.29, n.56, 61-80, 2019.

CÂNDIDO, D. H.; NUNES, L. H. Influência da orografia na precipitação da área entre o vale do rio Tietê e a Serra da Mantiqueira. Geousp, São Paulo, v.1, n.24, p.08-27, 2008.

CARDOZO, A. B.; REBOITA, M. S.; GARCIA, S. R. Climatologia de Frentes Frias na América do Sul e sua relação com o Modo Anular Sul. Revista Brasileira de Climatologia, Curitiba, v.17, p. 9-29, 2015.

CARMELLO, V; SANT'ANNA NETO, J. L. Rainfall variability and soybean yield in Paraná State, Southern Brazil. International Journal of Environmental \& Agriculture Research, Mandsaur, v.2, n.1, p.86-97, 2016.

CARVALHO, L.M.V.; JONES, C.; LIEBMANN, B. Extreme precipitation events in Southern South America and large-scale convective patterns in South Atlantic Convergence Zone. Journal of Climate, Boston, v.15, n.17, p.2377-2394, 2002. 
CARVALHO, J.R.P.; ASSAD, E.D. Análise espacial da precipitação pluviométrica no estado de São Paulo: comparação de métodos de interpolação. Engenharia Agrícola, Jaboticabal, v.25, n.2, p.377-384, 2005.

CARVALHO, R. G. As bacias hidrográficas enquanto unidades de planejamento e zoneamento ambiental no Brasil. Caderno Prudentino de Geografia, Presidente Prudente, v. Especial, n.36, p. 26-43, 2014.

CASTELLANO, M. S.; NUNES, L. H. Avaliação espaço-temporal das precipitações extremas e seus impactos no meio urbano: um caso brasileiro. Territorium, Coimbra, v. 17, n.1, p. 35-44, 2010.

CAVAGLIONE, J. H.; KIIHL, L. R. B.; CARAMORI, P. H.; OLIVEIRA, D. Cartas climáticas do Paraná. Londrina: IAPAR, 2000. CD ROM.

CAVALCANTI; I.F.A.; AMBRIZZE, T. Teleconexões e suas influências no Brasil. In: CAVALCANTI, I.F.A.; FERREIRA, N.J.; SILVA, M.G.A.J.; SILVA DIAS, M.A.F (Org.). Tempo e clima no Brasil. $1^{\text {a }}$ Edição. São Paulo, Oficina de Textos. p.318-335, 2009.

CERA, J. C.; FERRAZ, S. E. T. Variações climáticas na precipitação no Sul do Brasil no clima presente e futuro. Revista Brasileira de Meteorologia, São Paulo, v. 30, n.1, p. 81-88, 2015.

CHIERICE, R.A.F.; LANDIM, P.M.B. Variabilidade espacial e temporal de precipitação pluviométrica na bacia hidrográfica do rio Mogi Guaçu. Geociências, São Paulo, v.33, n.1, p.157-171, 2014.

CHRISTOFOLETTI, A. Geomorfologia. São Paulo: Edgard Blücher, 2ª́Edição, 1980.188p.

CHU, P.S.; ZHAO, X.; RUAN, Y.; GRUBBS, M. Extreme rainfall events in the Hawaiian Islands. Journal of Applied Meteorology and Climatology, Boston, v.48, n.3, p.502$516,2009$.

CLIMANÁLISE. Boletim de Monitoramento e Análise Climática. Centro de Previsão de Tempo e Estudos Climáticos (CPTEC) - Instituto Nacional de Pesquisas Espaciais (INPE). Disponível em: <http://climanalise.cptec.inpe.br/ rclimanl/boletim/>. Acesso em 15 de agosto de 2016.

COELHO, C.A.S.; DRUMOND, A.R.M.; AMBRIZZI, T.; SAMPAIO, G. Estudo climatológico sazonal da precipitação sobre o Brasil em episódios extremos da Oscilação Sul. Revista Brasileira de Meteorologia, São Paulo, v.14, n.1, p.49-65, 1999.

COELHO, C.A.S.; UVO, C.B.; AMBRIZZI, T. Exploring the impacts of the tropical Pacific SST on the precipitation patterns over South America during ENSO periods. Theoretical and Applied Climatology, Viena, v.71, n.3, p.185-197, 2002.

COHEN, L.; HOLLIDAY, M.G. Statistics for social scientists: an introductory text with computer programs in basic. London: Hagerstown: Harper \& Row; 1982. 382p. 
CONTI, J.B. Circulação secundária e efeito orográfico na gênese das chuvas na região lesnordeste paulista. 1975. 82f. Tese (Doutorado). Programa de Pós-Graduação em Geografia, Faculdade de Filosofia, Letras e Ciências Humanas, Universidade de São Paulo, São Paulo, 1975.

CONTI, J. B. Geografia e Climatologia. Geousp, São Paulo, v.1, n.9, p.91-95, 2001.

CORREA, M.G.G. Distribuição espacial e variabilidade da precipitação pluviométrica na bacia do rio Piquiri - PR. 2013.102f. Dissertação (Mestrado). Programa de Pós-Graduação em Geografia Física, Universidade de São Paulo, São Paulo, 2013.

CORREA, M.G.G.; TERASSI, P.M.B.; GALVANI, E. Efeito orográfico: Estudo comparativo nas bacias hidrográficas do rio Piquiri e Pirapó - PR. In: XII Simpósio Brasileiro de Climatologia Geográfica, Goiânia, p.1986-1997, 2016.

CORREA, M.G.G. Dinâmica hidroclimática e o fenômenos ENOS na bacia hidrográfica do rio Piquiri - PR. 2017. 129f. Tese (Doutorado). Programa de PósGraduação em Geografia Física, Universidade de São Paulo, São Paulo, 2017.

CORREA, M.G.G.; GALVANI, E. Variabilidade espacial e temporal da precipitação pluviométrica na bacia hidrográfica do rio Piquiri - PR. Revista do Departamento de Geografia (USP), São Paulo, v.34, n.1, p.21-30, 2017.

COSTA, T.O.; WOLLMANN, C.A. Eventos de precipitação extrema e impacto meteórico na bacia hidrográfica do Igarapé Cereja, área urbana de Bragança - PA, durante o inverno amazônico de 2014. Revista do Departamento de Geografia (USP), São Paulo, Volume Especial de 40 anos de Teoria e Clima Urbano, p.51-69, 2016.

CPTEC (Centro de Previsão de Tempo e Estudos Climáticos) - Instituto Nacional de Pesquisas Espaciais (INPE). EI Niño e La Niña. 2016. Disponível em: < http://enos.cpt ec.inpe.br/>. Acesso em 27 de novembro de 2016.

CREPANI, E.; MEDEIROS, J.S. DE; HERNANDEZ FILHO, P.; FLORENZANO, T.G.; DUARTE, V.; BARBOSA, C.C.F. Sensoriamento remoto e geoprocessamento aplicados ao zoneamento ecológico-econômico e ao ordenamento territorial. São José dos Campos: INPE, 2001.124p.

CUNHA, A. C.; VILHENA, J.E.S.; SANTOS, E.; SARAIVA,J. B.; KUHN, P.A.F.; BRITO, D.C.; SOUZA, E.B.; ROCHA， E.P.; CUNHA， H.F.A.; BRITO, A.U.; BRASIL-JUNIOR, A.C.P.; PACA, V. H.; SANTOS, P.V.C.J. Evento extremo de chuva-vazão na bacia hidrográfica do rio Araguari, Amapá, Brasil. Revista Brasileira de Meteorologia, São Paulo, v. 29, n. especial, p.95-110, 2014.

DIAS, M.F.A.; DIAS, J.; CARVALHO, L.M.V.; FREITAS, E.D.; DIAS, P.L.S. Changes in extreme daily rainfall for São Paulo, Brazil. Climatic Change, Berlin, v.116, n.3-4, p.705-722, 2013. 
DIAZ, A.; STUDZINSKI, C.D.S. Rainfall anomalies in the Uruguay-Southern Brazil region related to SST in the Pacific and Atlantic Oceans using cannonical correlation analysis. In: VIII Congresso Brasileiro de Meteorologia, Sociedade Brasileira de Meteorologia, Belo Horizonte, p.42-45, 1994.

DICKEL, M.E.G.; GODOY, M.B.R.B. Desastres ambientais e impactos socioambientais: inundações no município de Itaóca - SP: Bacia hidrográfica como unidade de planejamento e gestão de riscos. Caderno de Geografia, Belo Horizonte, v.26, n.47, p.737-749, 2016.

DOURADO, C.S.; OLIVEIRA, S.R.; AVILA, A.M.H. Análise de zonas homogêneas em séries temporais de precipitação no estado da Bahia. Bragantia, Campinas, v.72, n.2, p.192-198, 2013.

DU, H.; XIA, J.; ZENG, S. Regional frequency analysis of extreme precipitation and its spatiotemporal characteristics in the Huai River Basin, China. Natural Hazards, Amsterdam, v.70, n.1, p.195-215. 2014.

DUBREUIL, V.; FANTE, K.P.; PLACHON, O.; SANT'ANNA NETO, J.L. Les types de climats annuels au Brésil: une application de la classification de Köppen de 1961 à 2015. EchoGéo, Paris, v.3, n.41, p.1-27, 2017.

DUFEK, A.S.; AMBRIZZI, T. Precipitation variability in São Paulo State, Brazil. Theoretical and Applied Climatology, Viena, v.93, n.3/4, p.167-178, 2008.

EASTERLING, D. R.; MEEHL, G. A.; PARMESAN, C.; CHANGNON, S. A.; KARL, T. R.; MEARNS, L. O. Climate extremes: observations, modeling, and impacts. Science, Washington, v.289, n.22, 2068-2074, 2000.

ELY, D.F.; DUBREUIL, V. Análise de tendências espaço-temporais das precipitações anuais para o estado do Paraná - Brasil. Revista Brasileira de Climatologia, Curitiba, v. 21, n.13, p.553-569, 2017.

EMPRESA BRASILEIRA DE PESQUISA AGROPECUÁRIA (EMBRAPA). Serviço Nacional de Levantamento e Conservação de Solos. Súmula da 10. Reunião Técnica de Levantamento de Solos. Rio de Janeiro, 1979. 83p.

EMPRESA BRASILEIRA DE PESQUISA AGROPECUÁRIA (EMBRAPA). Mapa de Solos do Estado do Paraná. Rio de Janeiro, Centro Nacional de Pesquisa de Solos: EMBRAPA - Solos e Florestas, 2007. 95p.

EVERITT, B.S. Cluster Analysis. $3^{\text {a }}$ Edição. London: Heinemann Educational Books, $1993.122 \mathrm{p}$.

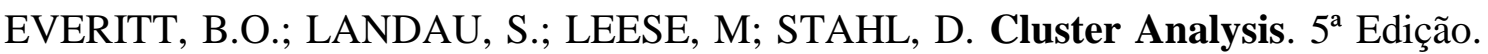
London: Wiley, 2011. 346p.

FIALHO, E. S., BRANDÃO, A. M. de P. M. As Chuvas e a (Des) Organização do Espaço Urbano Carioca. GeoUERJ, Rio de Janeiro, v.4, n.8, p. 39-53, 2000. 
FEDOROVA, N.; KHAN, V. Análise de complexo convectivo de mesoescala sobre o sul do Brasil. Revista Brasileira de Meteorologia, São Paulo, v.14, n.1, p.35-48, 1999.

FONTANA, D.C.; BERLATO, M.A. Influência do El Niño Oscilação Sul sobre a precipitação pluvial no estado do Rio Grande do Sul. Revista Brasileira de Agrometeorologia, Santa Maria, v.5, n.1, p.127-132, 1997.

FONTÃO, P.A.B; ZAVATTINI, J.A. Regionalização das chuvas anuais na bacia do Pardo, Brasil. Caderno Prudentino de Geografia, Presidente Prudente, Volume Especial, n.36, p.143-158, 2014.

FONTÃO, P.A.B.; ZAVATTINI, J.A.; SHERIDAN, S.C.; ARMOND, N.B. Gênese das chuvas em São Paulo (SP): estudo comparativo entre a "Spatial Synoptic Classification" e a "Análise Rítmica em Climatologia". Revista Brasileira de Climatologia, Curitiba, v.23, n.14, p.267-288, 2018.

FORGIARINI, F.R.; VENDRUSCULO, D.S.; RIZZI, E.S. Análise de chuvas orográficas no centro do estado do Rio Grande do Sul. Ciência e Natura, Santa Maria, v.36, n.2, p.193-200, 2014.

FREITAS, E.D. Variabilidade sazonal e intrasazonal da precipitação no estado do Paraná.1998.133f. Dissertação (Mestrado). Programa de Pós-Graduação em Meteorologia, Instituto de Astronomia, Geofísica e Ciências Atmosféricas, Universidade de São Paulo, São Paulo, 1998.

FRITZSONS, E.; MANTOVANI, L. E.; WREGE, M. S.; CHAVES NETO, A. Análise da pluviometria para definição de zonas homogêneas no estado do Paraná. RA'E GA: o Espaço Geográfico em Análise, Curitiba, v.23, n.1, p.555-572, 2011.

GANESHAN, M.; MURTUGUDDE, R.; IMHOFF, M.L. A multi-city analysis of the UHI - influence on warm season rainfall. Urban Climate, Boston, v.6, n.1, p.1-23, 2013.

GAZETA DO POVO. Prefeitura declara estado de alerta em Curitiba. 2014. Disponível em: < http://www.gazetadopovo.com.br/vida-e-cidadania/prefeitura-declaraestado-de-alerta-em-curitiba-9a41fbhed1tntv724q1zrqo26>. Acesso em 23 de novembro de 2016.

GOIS, G.; DELGADO, R.C.; OLIVEIRA-JÚNIOR, J.F. Modelos teóricos transitivos aplicados na interpolação espacial do standardized precipitation index (SPI) para os episódios de El Niño forte no estado do Tocantins, Brasil. Irriga, Botucatu, v.20, n.2, p. 371-387, 2015.

GONÇALVES, F.N.; BACK, A.J. Análise da variação espacial e sazonal e de tendências na precipitação da região sul do Brasil. Revista de Ciências Agrárias, Lisboa, v.41, n.3, p.592-602, 2018.

GRIMM, A.M.; FERRAZ, S.E.T.; GOMES, J. Precipitation anomalies in southern Brazil associated with El Niño and La Niña Events. Journal of Climate, Boston, v.11, n.1, p.2863-2880, 1998. 
GRIMM, A. M.; BARROS, V. R.; DOYLE, M. E. . Climate variability in Southern South America associated with El Niño and La Niña events. Journal of Climate, Boston, v.13, n.1, p.35-58, 2000.

GRIMM, A. M. The El Niño impact on the summer monsoon in Brazil: regional processes versus remote influences. Journal of Climate, Boston, v.16, n.1, p.263-280, 2003.

GRIMM, A.M. Clima na Região Sul. In: CAVALCANTI, I.F.A.; FERREIRA, N.J.; SILVA, M.G.A.J.; SILVA DIAS, M.A.F (Org.). Tempo e Clima no Brasil. $1^{\text {a }}$ Edição. São Paulo, Oficina de Textos, p.259-275, 2009.

GRIMM, A.M.; TEDESCHI, R.G. ENSO and extreme rainfall events in South America. Journal of Climate, Boston, v.22, n.7, p.1589-1609, 2009.

HAYLOCK, M.R.; PETERSON, T.C.; ALVES, L.M.; AMBRIZZI, T.; ANUNCIAÇÃO, Y.M.T.; BAEZ, J.; BARROS, V.R.; BERLATO, M.A.; BIDEGAIN, M.; CORONEL, G.; CORRADI, V.; GARCIA, V.J.; GRIMM, A.M.; KAROLY, D.; MARENGO, J.A.; MARINO, M.B.; MONCUNILL, D.F.; NECHET, D.; QUINTANA, J.; REBELLO, E.; RUSTICUCCI, M.; SANTOS, J. L.; TREBEJO, I.; VINCENT, L.A. Trends in total and extreme South American Rainfall in 1960-2000 and links with sea surface temperature. Journal of Climate, Boston, v.19, n.8, p.1490-1512, 2006.

HIRSCH, R.M.; SLACK, J.R. A nonparametric trend test for seasonal data with serial dependence. Water Resources Research, Washington, v.20, n.6, p.727-732, 1984.

HOYOS, N.; WAYLEN P.; JARAMILLO A. Seazonal and spatial patterns of erosivity in a tropical watershed of the Colombian. Journal of Hidrology, Amsterdam, v.314, n. 1-4, p.177-191, 2005.

IBGE (Instituto Brasileiro de Geografia e Estatística). Censo Demográfico 2010. Disponível em: < http://www.ibge.gov.br/home/estatistica/populacao/censo2010/default _uf.shtm>. Acesso em 28 de agosto de 2016.

INPE (Instituto de Pesquisas Espaciais). Projeto TOPODATA. 2011. Disponível em: $<$ http://www.dsr.inpe.br/topodata/>. Acesso em 28 de agosto de 2016.

INPE (Instituto Nacional de Pesquisas Espaciais). Boletim Técnico - CPTEC (Centro de previsão do tempo e estudos climáticos. 2019. Disponível em: <http://tempo.cptec. inpe.br/boletimtecnico/pt>. Acesso em

IPARDES (Instituto Paranaense de Desenvolvimento Econômico e Social). Perfil avançado dos municípios. 2016. Disponível em: <http://www.ipardes.gov.br/index.ph p?pg_conteudo=1\&cod_conteudo=29>. Acesso em 25 de novembro de 2016.

ITCG (Instituto de Terras, Cartografia e Geodésia). Produtos Cartográficos. Disponível em: <http://www.itcg.pr.gov.br/modules/conteudo/conteudo.php? conteudo=47. Acesso em 28 de agosto de 2016.

JORGE, F.V.; MENDONCA, F.A. O clima no litoral do Estado do Paraná. Revista Brasileira de Climatologia, Curitiba, v.3, n.3, p.49-64, 2008. 
JORGE, F.V.; MENDONÇA, F.A. O clima da fachada atlântica sul do Brasil: uma atualização introdutória. Revista Brasileira de Climatologia, Curitiba, v.5, n.5, p.119$131,2009$.

JORGE, F.V. Fachada atlântica sul do Brasil: dinâmicas e tendências climáticas regionais no contexto das mudanças globais. 2009. 169f. Dissertação (Mestrado). Programa de Pós-Graduação em Geografia, Universidade Federal do Paraná, Curitiba, 2009.

JORGE, F.V. A dinâmica pluvial do clima subtropical: variabilidade e tendência no Sul do Brasil. 2015. 181f. Tese (Doutorado). Programa de Pós-Graduação em Geografia, Universidade Federal do Paraná, Curitiba, 2015.

KALKSTEIN, L. S.; NICHOLS, M. C.; BARTHEL, C. D.; GREENE, J. S. A new spatial synoptic classification: application to air-mass analysis. International Journal of Climatology, Oxford, v.16, n.9, p.983-1004, 1996.

KALKSTEIN, L. S.; SHERIDAN, S.; GRAYBEAL, D. A determination of character and frequency changes in air masses using a Spatial Synoptic Classification. International Journal of Climatology, Oxford, v.18, n.11, p.1223-1236, 1998.

KELLER FILHO, T.; ASSAD, E.D.; LIMA, P.R.S.R. Regiões pluviometricamente homogêneas no Brasil. Revista Brasileira de Pesquisa Agropecuária, Brasília, v.40, n.4, p.311-322, 2005.

KOGA-VICENTE, A.; NUNES, L. H. Impactos socioambientais associados à precipitação em municípios do litoral paulista. Geografia, Rio Claro, v.36, n.3, p.571588, 2011.

KÖPPEN, W. Climatologia: com un estúdio de los climas de la tierra. México. Ed. Fondo de Cultura Econômica, 1948.

KOUSKY, V.E.; KAYANO, M.T.; CAVALCANTI, I.F.A. A review of the southern oscillation oceanic atmospheric circulation changes and related rainfall anomalies. Tellus, Estocolmo, v.36, n.5, p.490-504, 1984.

KRÜGER, E.; ROSSI, F. Quantificação da ilha de calor de Curitiba considerando aspectos de estabilidade atmosférica. Revista Brasileira de Meteorologia, São Paulo, v.30, n.4, p.394-404, 2015.

LEITE, M.L.; ADACHESKI, P.A.; VIRGENS FILHO, J.S. Análise da frequência e da intensidade das chuvas em Ponta Grossa, estado do Paraná, no período entre 1954 e 2001. Acta Scientiarum. Technology, Maringá, v.33, n.1, p.57-64, 2001.

LEOPOLD, L.B. The interaction of trade wind and e sea breeze. Journal of Meteorology, Washington, v.6, n.5, p.312-320, 1949. 
LIEBMANN, B.; VERA, C.; CARVALHO, L.M.V.; SAULO, C.; ALLURED, D. An observed trend in Central South American precipitation. Journal of Climate, Boston, v.17, n.22, p.4357-4367, 2004.

LIMBERGER, L. Variabilidade da vazão de regiões homogêneas da bacia hidrográfica amazônica brasileira: teleconexões com a temperatura de superfície do mar (TSM) de 1976-2010. 2015. 483f. Tese (Doutorado). Programa de Pós-Graduação em Geografia Física, Universidade de São Paulo, São Paulo, 2015.

LIMBERGER, L. Estudos de teleconexões atmosféricas e possibilidades de avanços na climatologia geográfica: conceitos, fontes de dados e técnicas. Revista Brasileira de Climatologia, Curitiba, v.19, n.1, p.10-19, 2016.

LUNARDON, K.A.F. Aspectos do clima urbano de Curitiba/PR: Uma abordagem do campo térmico e sua influência sobre a ocorrência da dengue. In: Os desafios da Geografia Física na fronteira do conhecimento. Campinas: Instituto de Geociências (Universidade Estadual de Campinas), v.1, p.2572-2576, 2017.

LUZ, R.; RODRIGUES, C.; Anthropogenic changes urbanised hidromorphological systems in a humid tropical environment River Pinheiros, São Paulo, Brasil. Zeitschrift fur Geomorphologie, Stuttgart, v.59, n.2, p.109-135, 2015.

LYRA, G.B.; OLIVEIRA-JÚNIOR, J. F.; ZERI, M. Cluster analysis applied to the spatial and temporal variability of monthly rainfall in Alagoas state, Northeast of Brazil. International Journal of Climatology, Reading, v.34, n.13, p.3546-3558, 2014.

MA, X.; YANDONG, H.; XU, J.; VAN NOORDWIJK, M; LU, X. Spatial and temporal variation in rainfall erosivity in a Himalayan watershed. Catena, Amsterdam, v.121, n.1, p.248-259, 2012.

MAACK, R. Geografia Física do Estado do Paraná. Curitiba: Clichês. 1968.350p

MAACK, R. Geografia Física do Estado do Paraná. 4ª Edição. Ponta Grossa: Editora UEPG. 2012. 526p.

MACHADO, C.B; BRAND, V.S.; CAPUCIM, M.N.; MARTINS, L.D.; MARTINS, J.A. Eventos extremos de precipitação no estado do Paraná. Ciência \& Natura, Santa Maria, Edição Especial VIII Workshop Brasileiro de Micrometeorologia, p.81-83, 2013.

MAGAlHÃES, G. B.; ZANELLA, M. E. Comportamento climático da Região Metropolitana de Fortaleza. Mercator, Fortaleza, v.10, n.23, p.129-145, 2011.

MARCELINO, E. V.; NUNES, L. H.; KOBIYAMA, M. Mapeamento de riscos de desastres naturais no estado de Santa Catarina. Caminhos da Geografia (UFU), Uberlândia, v.7, n.17, p.72-81, 2006.

MARENGO, J.A.; CAMARGO, C.C. Surface air temperature trends in Southern Brazil for 1960-2002. International Journal of Climatology, Oxford, v.28, n.7, p.893-904, 2008. 
MARENGO, J.A.; RUSTICUCCI, M.; PENALBA, O.; RENOM, M. An intercomparison of observed and simulated extreme rainfall and temperature events during the last half of the Twentieth Century: part 2: Historical Trends. Climatic Change, Berlin, v.98, n.3-4, p.509-529, 2010.

MCBEAN, G. Climate change and extreme weather: a basis for action. Natural Hazards, Berlin, v.31, n.1, p.177-190, 2004.

MCPHADEN, M.J. Genesis and evolution of the 1997-1998 El Niño. Science, Washington, v.283, n.1, p.950-954, 1999.

MELLO, Y.R.; OLIVEIRA, T.M.N. Análise estatística e geoestatística da precipitação média para o município de Joinville (SC). Revista Brasileira de Meteorologia, São Paulo, v.31, n.2, p.229-239, 2016.

MELLO, Y.R.; LOPES, F.C.A.; ROSEGHINI, W.F.F. Características climáticas e análise rítmica aplica a episódios de eventos extremos de precipitação e temperatura no município de Paranaguá, PR. Revista Brasileira de Climatologia, Curitiba, v.20, n.13, p.313-336, 2017.

MELO, M. S.; GUIMARÃES, G.B.; RAMOS, A.F.; PRIETO, C.C. Relevo e hidrografia dos Campos Gerais. In: MELO, M. S.; MORO, R. S.; GUIMARÃES, G. B. Patrimônio natural dos Campos Gerais do Paraná. Ponta Grossa: Editora UEPG, p.49-58, 2007.

MENDONCA, F.A.; DANNI-OLIVEIRA, I.M. Dinâmica atmosférica e tipos climáticos predominantes na bacia do rio Tibagi. In: MEDRI, M.; BIANCHINI, E.; SHIBATTA, O. A.; PIMENTA, J. O. (Org.). A bacia do Rio Tibagi. Londrina: Moacir E. Medri Editores, v.1, p.63-68. 2002.

MENDONÇA, F.A. Aquecimento global e suas manifestações regionais e locais: alguns indicadores da região Sul do Brasil. Revista Brasileira de Climatologia, Curitiba, v.2, n. 2, p.71-86, 2006.

MENDONÇA, F. A; DANNI-OLIVEIRA, I. M. Clima: Noções básicas e climas do Brasil. São Paulo: Editora Oficina de Textos, 2007.207p.

MENG, W.; YEN, J.; HU, H. Urban effects and summer thunderstorms in a tropical cyclone affected situation over Guangzhou City. Science in China Series D: Earth Sciences, Beijing, v.50, n.12, p.1867-1876, 2007.

MILANESI, M.A. Avaliação do efeito orográfico na pluviometria de vertentes opostas da Ilha de São Sebastião (Ilhabela - SP). 2007. 141f. Dissertação (Mestrado). Programa de Pós-Graduação em Geografia Física, Universidade de São Paulo, São Paulo, 2007.

MILANESI, M.A.; GALVANI, E. Efeito orográfico na Ilha de São Sebastião (Ilha Bela - SP). Revista Brasileira de Climatologia, Curitiba, v.2, n.9, p.68-79, 2011.

MINUZZI, R.B.; CARAMORI, P.H. Variabilidade climática sazonal e anual da chuva e veranicos no estado do Paraná. Ceres, Viçosa, v.58, n.5, p.593-602, 2011. 
MINEROPAR. Atlas Geológico do estado do Paraná. 2001. Minerais do Paraná, Curitiba. 2001. 125p. CD ROM.

MINEROPAR. Atlas Geomorfológico do Estado do Paraná. Minerais do Paraná; Universidade Federal do Paraná, Curitiba. 2006. 63p. CD ROM.

MONTEIRO, C.A.F. Clima. In: Geografia do Brasil: Grande Região Sul. 2ªdição, v. 4, Tomo I, Rio de Janeiro, IBGE (Instituto Brasileiro de Geografia e Estatística), p.114$166,1968$.

MONTEIRO, C.A.F. A frente polar atlântica e as chuvas de inverno na Fachada SulOriental do Brasil (Contribuição metodológica à análise rítmica dos tipos de tempo no Brasil). Série Teses e Monografias, IGEOG/USP, São Paulo, 1969.68p.

MONTEIRO, C.A.F. Análise rítmica em climatologia: problemas da atualidade climática em São Paulo e achegas para um programa de trabalho. Climatologia. São Paulo, 1971. $21 \mathrm{p}$.

MONTEIRO, C.A.F. A dinâmica climática e as chuvas no estado de São Paulo: estudo em forma de atlas. Série Teses e Monografias, IGEOG/USP, São Paulo, 1973.129p.

MONTEIRO, C.A.F. O clima e a organização do espaço no Estado de São Paulo: problemas e perspectivas. Série Teses e Monografias, USP/IGEOG, São Paulo, 1976. 54p.

MONTEIRO, C.A.F. Clima e excepcionalismo: conjecturas sobre o desempenho da atmosfera como fenômeno geográfico. Florianópolis: EDUFSC, 1991. 241p.

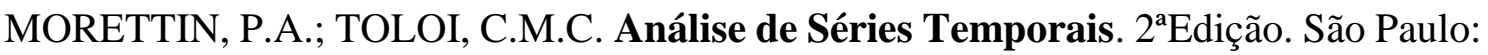
Blucher, 2006. 538p.

MORETTIN, P.A. Econometria financeira: um curso em séries temporais financeiras. $3^{\text {a} E d i c ̧ a ̃ o . ~ S a ̃ o ~ P a u l o: ~ E d g a r d ~ B l u ̈ c h e r, ~ 2017.583 p . ~}$

MOTA, L.T. História do Paraná: Pré-História, Colônia e Império. Maringá: EDUEM, 2011.143p.

MURARA, P.; ACQUAOTTA, F.; GARZENA, D.; FRATIANNI, S. Daily precipitation extremes and their variations in the Itajaí River Basin, Brazil. Meteorology and Atmospheric Physics, Berlim, v.130, n.1, p.11-12, 2018.

NASA (National Aeronautics and Space Administration). Goddard Earth Sciences Data and Information Services Center: Tropical Rainfall Measurement Mission (TRMM). 2016. Disponível em: <http://disc.sci.gsfc.nasa.gov/SSW/\#keywords=TRM M_3B42_daily\%207>. Acesso em 31 de agosto de 2016.

NASCIMENTO, E. R.; SALAMUNI, E.; SANTOS, L. J. C. Morphostructural map of Serra do Mar relief in the Paraná State. Journal of Maps, London, v.12, n.1, p.1-8, 2016. 
NASCIMENTO JÚNIOR, L. As chuvas no Paraná: variabilidade, teleconexões, e impactos de eventos extremos. 2013.157f. Dissertação (Mestrado). Programa de PósGraduação em Geografia, Universidade Estadual Paulista "Júlio de Mesquita Filho", Presidente Prudente, 2013.

NASCIMENTO JÚNIOR, L.; SILVESTRE, M.R.; DUBREUIL, V.; SANT’ANNA NETO, J.L. Rupturas e tendências em séries históricas no Paraná. In: XV Simpósio Brasileiro de Geografia Física Aplicada, Vitória, p.298-307, 2013.

NASCIMENTO JÚNIOR, L.; SANT'ANNA NETO, J.L. Impactos de eventos pluviais extremos no estado do Paraná - Brasil. In: Associação Portuguesa de Riscos, Prevenção e Segurança. Multidimensão e territórios de risco. $1^{\text {a} E d i c ̧ a ̃ o, ~ G u i m a r a ̃ e s: ~ I m p r e n s a ~ d a ~}$ Universidade de Coimbra, p.251-257, 2014.

NASCIMENTO JÚNIOR, L.; SANT'ANNA NETO, J. L. As excepcionalidades das chuvas no estado do Paraná. In: XI Encontro Nacional da ANPEGE (Associação Nacional de Pós-Graduação e Pesquisa em Geografia) Presidente Prudente, p.7654-7666, 2015 .

NASCIMENTO JÚNIOR, L.; SANT'ANNA NETO, J.L. Contribuição aos estudos da precipitação no estado do Paraná: a oscilação decadal do Pacífico - ODP. RA'E GA: o Espaço Geográfico em Análise, Curitiba, v.35, n.2, p.314-343, 2016.

NERY, J. T.; MARTINS, M. L. F.; SANTANNA NETO, J. L. Variabilidade da precipitação no Brasil Meridional. Acta Scientiarum Technology (UEM), Maringá, v. 24, n.6, p.1687-1695, 2002.

NERY, J. T.; STIVARI, S. M. S.; MARTINS, M. L. O. F.; SILVA, E. S.; SOUSA, P. Estudo da precipitação do estado do Paraná e sua associação à temperatura da superfície do Oceano Pacífico. Revista Brasileira de Agrometeorologia, Santa Maria, v.13, n.1, p.161-171, 2005.

NERY, J. T. Dinâmica climática da região Sul do Brasil. Revista Brasileira de Climatologia, Curitiba, v.1, n.1, p. 61-75, 2006.

NERY, J.T.; DENIG, E.; AZEVEDO, L.C.; MARTINS, M.L.O.F. Estudo da variabilidade interanual da precipitação na bacia do rio Uruguai. Revista Brasileira de Recursos Hídricos, Porto Alegre, v.11, n.2, p.149-159, 2006.

NERY, J.T.; CARFAN, A.C. Re-analysis of pluvial precipitation in southern Brazil. Atmosféra, Cidade do México, v.27, n.2, p.103-114, 2014.

NICHOLLS, N. Atmospheric and climatic hazards: improved monitoring and prediction for disaster mitigation. Natural Hazards, Berlin, v.23, n.2, p.137-155, 2001.

NIMER. E. Climatologia do Brasil. $2^{\text {a }}$ Edição. Rio de Janeiro: Instituto Brasileiro de Geografia e Estatística, 1989. 421p.

NOAA (National Oceanic and Atmospheric Administration). El Niño - Southern Oscillation (ENSO). 2016. Disponível em: <http://www.cpc.ncep.noaa.gov/-products/pr 
ecip/CWlink/MJO/enso.shtml>. Acesso em: 20 de maio de 2016.

NÓBREGA, M.T.; SERRA, E.; SILVEIRA, H.; TERASSI, P.M.; BONIFÁCIO, C.M. Landscape structure in the Pirapó, Paranapanema 3 and 4 Hydrographic Unit, in the state of Paraná, Brazil. Brazilian Journal of Biology (Online), São Carlos, v.27, n.4, s. 2, p.113, 2015.

NÓBREGA, R.S.; FARIAS, R.F.L.; DOS SANTOS, C.A. Variabilidade temporal e espacial da precipitação pluviométrica em Pernambuco através de índices de extremos climáticos. Revista Brasileira de Meteorologia, São Paulo, v.30, n.2, p.171 - 180, 2015.

NÓBREGA, R.S.; FARIAS, R.F.L. Eventos extremos pluviais em Jaboatão dos Guararapes - Climatologia e Estudo de Caso. Revista do Departamento de Geografia (USP), São Paulo, Volume Especial de 40 anos de Teoria e Clima Urbano, p.70-82, 2016.

NUNES, L. H.; MODESTO, R. P. Comportamento pluviométrico nos municípios atendidos pelo Plano Preventivo de Defesa Civil - PPDC. Revista do Instituto Geológico, São Paulo, v.13, n.1, p.47-57, 1992.

NUNES, L. H. A escala nas ciências atmosféricas. Revista do Instituto Geológico, São Paulo, v.19, n.1-2, p.71-73, 1998.

NUNES, L. H. Compreensões e ações frente aos padrões espaciais e temporais de riscos e desastres. Territorium, Coimbra, v.16, n.1, p.181-189, 2009.

NUNES, L. H. Riscos do clima ou riscos da comunicação? A cobertura jornalística do furacão Sandy (2012) em um periódico nacional. Revista Brasileira de Climatologia, Curitiba, v.19, n.1, p.54-73, 2016.

NUNES, J.O.R.; SANT'ANNA NETO, J.L.; AMORIM, M. C. C. T.; TOMMASELLI, J.T.G.; PERUSI, M. C. A influência dos métodos científicos na Geografia Física. Terra Livre, v.1, n.27, p.121-132, 2006.

OBREGÓN, G.; MARENGO, J.A. Caracterização do clima do século XX no Brasil: Tendências de chuvas e temperaturas médias e extremas. Mudanças climáticas globais e efeitos sobre a biodiversidade. Brasília: Ministério do Meio Ambiente, 2007. 91p.

OKA-FIORI, C.; CANALI, N. E.; KOZCIAK, S. Geomorfologia do Litoral Paranaense. In: VI Congresso Internacional de Geógrafos Latino-Americanos, Buenos Aires, p.1-8, 1997.

OLÍMPIO, J. L.; CAMARA, C. F.; ZANELLA, M. E. Episódios hidrometeóricos concentrados e impactos no sítio urbano de Fortaleza/CE: o caso do bairro Autran Nunes. RAE'GA: o Espaço Geográfico em Análise, Curitiba, v.26, n.16, p.51-74, 2012.

OLIMPIO, J. L. S.; VIEIRA, P. M.; ZANELLA, M. E.; SALES, M. C. L. Episódios pluviais extremos e a vulnerabilidade socioambiental do município de Fortaleza: o episódio do dia 27/03/2012. Geo UERJ, Rio de Janeiro, v.1, n.24, p.181-206, 2013. 
OLÍMPIO, J.L.S.; ZANELLA, M.E. Distribuição espaço-temporal dos desastres naturais associados à dinâmica climática no estado do Ceará. Revista do Departamento de Geografia (USP), São Paulo, v.30, n.1, p.110-131, 2015.

OLIVEIRA, L.F.C.; FIOREZE, A.P.; MEDEIROS, A.M.M.; SILVA, M.A.S. Comparação de metodologias de preenchimento de falhas em séries históricas de precipitação pluvial anual. Revista Brasileira de Engenharia Agrícola e Ambiental, Campina Grande, v.14, n.11, p.1186-1192, 2010.

OLIVEIRA, P.T.S.; WENDLAND, E.; NEARING, M.A. Rainfall erosivity in Brazil: a review. Catena, Amsterdam, v.100, n.1, p.139-147, 2013.

OLIVEIRA-JÚNIOR, J.F.; TERASSI, P.M.B.; GOIS, G. Estudo da circulação dos ventos na baía de Guanabara/RJ, entre 2003 e 2013. Revista Brasileira de Climatologia, Curitiba, v.21, n.1, p.59-80, 2017.

OSCAR JÚNIOR, A.C. Extremos atmosféricos e desastres hidrometeorológicos em Duque de Caxias (RJ). Revista Brasileira de Climatologia, Curitiba, v.17, n.11, p.189-205, 2015 .

PANAGOS, P.; BORELLI, P.; MEUSBURGER, K.; YU, B.; KLIK, A.; JAE LIM, K.; YANG, J.E.; NI, J.; MIAO, C.; CHATTOPADHYAY, N.; SADEGHI, S.H.; HAZBAVI, Z.; ZABIHI, M.; LARIONOV, G.A.; KRASNOV, S.F.; GOROBETS, A.V.; LEVI, Y.; ERPUL, G.; BIRKEL, C.; HOYOS, N.; NAIPAL, V.; OLIVEIRA, P.T.S.; BONILLA, C.A.; MEDDI, M.; NEL, W.; AL DASHTI, H.; BONI, M.; DIODATO, N.; VAN OOST, K.; NEARING, M.; BALLABIO, C. Global rainfall erosivity assessment based on hightemporal resolution rainfall records. Nature, Londres, v.7, n.4175, p.1-12, 2017.

PARANÁ (Agência Estadual de Notícias). Dilma garante apoio ao Governador Beto Richa para ações no Litoral. 2011. Disponível em: < http://www.aen.pr.gov.br/module s/noticias/article.php?storyid=62546\&tit=Dilma-garante-apoio-ao-governador-BetoRich a-para-acoes-no-Litoral>. Acesso em 23 de novembro de 2016.

PARANÁ (Governo de Estado do Paraná). Sistema Integrado da Defesa Civil do Paraná. Coordenadoria estadual da defesa civil. Casa Militar. Ocorrências de desastres. Disponível em: <http://www4.pr.gov.br/sdc/publico/lis_ocorrenciapublica.p>. Acesso em 20 de maio de 2016.

PAUL, S.; GHOSH, S.; MATTHEW, M.; DEVANAND, A.; KARMAKAR, S.; NIYOGI, D. Increased spatial variability and intensification of extreme monsoon rainfall due to urbanization. Scientific Reports, Londres, v.8, n.1, p.1-10, 2018.

PELL, M.C.; FINLAYSON, B.L.; MCMAHON, T.A. Update world map of the Köppen - Geiger climate classification. Hydrology and Earth System Sciences, Munich, v.11, n.1, p.1633-1644, 2007.

PELLEGATTI, C. H. G.; GALVANI, E. Avaliação da precipitação na Serra do Mar - SP: eventos de diferentes intensidade e duração. Geousp, São Paulo, v.13, n.27, p.132-148, 2010. 
PENEREIRO, J.C.; MESCHIATTI, M.C. Tendências em séries anuais de precipitação e temperaturas no Brasil. Engenharia Sanitária e Ambiental, Rio de Janeiro, v.23, n.2, p. 319-331, 2018.

PEREIRA, A.R.; ANGELOCCI, L.R.; SENTELHAS, P.C. Agrometeorologia: fundamentos e aplicações práticas. Guaíba: Editora Agropecuária, 2002. 478p.

PETTITT, A.N. A non-parametric approach to the change-point problem. Applied Statistics, London, v.28 n.2, p.126-135, 1979.

PINHEIRO, A.; GRACIANO, R.L.G.; SEVERO, D.L. Tendência das series temporais de precipitação da região sul do Brasil. Revista Brasileira de Meteorologia, São Paulo, v.28 n.3, p.281-290, 2013.

PINHEIRO, G.M. Variabilidade temporo-espacial da pluviosidade na bacia hidrográfica do Alto Iguaçu. 2016. 274f. Tese (Doutorado). Programa de PósGraduação em Geografia, Universidade Federal do Paraná, Curitiba, 2016.

PIVETTA, M. Da garoa à tempestade. Pesquisa FAPESP, São Paulo, Edição 192, 2012. Disponível em: <http://revistapesquisa.fapesp.br/2012/05/11/da-garoa-a-tempestade/>. Acesso em 06 de maio de 2019.

PORTO, M.F.A.; PORTO, R.L.L. Gestão de bacias hidrográficas. Estudos Avançados, São Paulo, v.22, n.63, p.43-60, 2008.

QUADRO, M.F.L.; SILVA DIAS, M.A.F.; HERDIES, D.L. Análise de um Vórtice Ciclônico de Mesoescala associado à ZCAS em janeiro de 2009. Revista Brasileira de Meteorologia, São José dos Campos, v.31, n.3, p.273-287, 2016.

QUADRO, M. F. L.; SILVA DIAS, M. A. F.; HERDIES, D. L.; GONCALVES, L. G. G. Análise climatológica da precipitação e do transporte de umidade na região da ZCAS através da nova geração de reanálises. Revista Brasileira de Meteorologia, São Paulo, v. 27, n.2, p. 287-294, 2012.

QUEIROZ, E. F.; SILVA, R. J. B.; OLIVEIRA, M.C. N. Modelo de análise de regressão periódica da precipitação mensal, da bacia atlântico sudeste, no Estado do Paraná. Pesquisa Agropecuária Brasileira, Brasília, v. 36, n.5, p. 727-742, 2001.

R DEVELOPMENT CORE TEAM. R: A language and environment for statistical computing. R Foundation for Statistical Computing, Vienna, Austria. ISBN 3-90005107- 0, URL http://www.R-project.org. 2016.

RAO, V.B., HADA E K. Characteristics of rainfall over Brazil: annual variation and connections with Southern Oscillation. Theoretical and Applied Climatology, Viena, v.42, n.2, p.81-91, 1990.

REBOITA, M.S.; GAN, M.A.; ROCHA, R.P.; AMBRIZZI, T. Regimes de precipitação na América do Sul. Revista Brasileira de Meteorologia, São Paulo, v.25, n.2, p.185204, 2010. 
REBOITA, M.S.; SANTOS, I.A. Influência de alguns padrões de teleconexão na precipitação do Norte e Nordeste do Brasil. Revista Brasileira de Climatologia, Curitiba, v.15, n.10, p.28-48, 2014.

REGO, T. L.; BARROS, J. R. Alagamentos e inundações em Goiânia: uma análise a partir da imprensa local e dos registros da Defesa Civil. Formação, Presidente Prudente, v. 1, n.21, p. 170-185, 2014.

REGOTO, P.; DERECZYNSKI, C.; SILVA, W.L.; SANTOS, R.; CONFALONIERI, U. Tendências de extremos de precipitação para o estado do Espírito Santo. Anuário do Instituto de Geociências, Rio de Janeiro, v.41, n.1, p.365-381, 2018.

RIBEIRO, A. G. Caracterização termo pluviométrica da bacia hidrográfica do rio Pirapó - PR. Boletim de Geografia. Maringá, v.5, n.1, p.91-135, 1987.

RIBEIRO, A.G. As escalas do clima. Boletim de Geografia Teorética, Rio Claro, v.23, n.46, p.288-294, 1993.

RIBEIRO, A. G. A climatologia dinâmica na perspectiva da análise rítmica. Sociedade \& Natureza, Uberlândia, v. 12, n.24, p. 47-62, 2000.

RIBEIRO, C.M. A variabilidade do clima: um fenômeno natural? Caderno de Geografia, Belo Horizonte, v.6, n.8, p.71-77, 1996.

RITTER, L.M.O; ALMEIDA, C.G.; MORO, R.S. Caracterização fitofisionômica dos fragmentos campestres com fáceis de cerrado em Ponta Grossa, Paraná. Revista Brasileira de Biociências, Porto Alegre, v.5, s.2, p.192-194, 2007.

RODERJAN, C. V.; GALVÃO, F.; KUNIYOSHI, Y. S.; HATSCHBACH, G. G. As unidades fitogeográficas do estado do Paraná. Ciência \& Ambiente, Santa Maria, v.24, n.1, p.75-92, 2002.

RODRIGUES, M.L.G.; FRANCO, D.; SUGAHARA, S. Climatologia de frentes frias no litoral de Santa Catarina. Revista Brasileira de Geofísica, Rio de Janeiro, v.22, n.2, p. 135-151, 2004.

RODRIGUES, M.L.G. Eventos de chuva orográfica em Santa Catarina: Climatologia e Simulações Numéricas. 2015. 113 f. Dissertação (Mestrado). Instituto de Astronomia, Geofísica e Ciências Atmosféricas, Universidade de São Paulo, São Paulo, 2015.

ROPELEWSKI, C.F.; HALPERT, M.S. Global and regional scale precipitation patterns associated with the El Niño/Southern Oscillation. Monthly Weather Review, Boston, v. 115, n.8, p. 1606-1626, 1987.

ROSEGHINI, W.F.F. Ocorrência de eventos climáticos extremos e sua repercussão socioambiental no litoral norte paulista. 2007.135f. Dissertação (Mestrado). Programa de Pós-Graduação em Geografia, Universidade Estadual Paulista "Júlio de Mesquita Filho", Presidente Prudente, 2007. 
ROSS, J.L.S. Brazilian Relief: strutures and Forms. Revista do Departamento de Geografia (USP), São Paulo, v.25, n.1, p.42-58, 2013.

SALVIANO, M.F.; GROPPO, J.D.; PELLEGRINO, G.Q. Análise de tendências em dados de precipitação e temperatura no Brasil. Revista Brasileira de Meteorologia, São Paulo, v.31, n.1, p.64-73, 2016.

SANT'ANNA NETO, J.L. Ritmo climático e a gênese das chuvas na zona costeira paulista. 1990. 156f. Dissertação (Mestrado). Programa de Pós-Graduação em Geografia Física, Universidade de São Paulo, São Paulo, 1990.

SANT'ANNA NETO, J.L. Dinâmica atmosférica e o caráter transicional do clima na Zona Costeira Paulista. Revista do Departamento de Geografia (USP), São Paulo, v. 8, n.1, p. 35-49, 1994.

SANT'ANNA NETO, J.L. Clima e organização do espaço. Boletim de Geografia, Maringá, v.15, n.1, p.119-131, 1998.

SANT'ANNA NETO, J.L. Por uma Geografia do Clima. Terra Livre, São Paulo, v.1, n.17, p.49-62, 2001.

SANT'ANNA NETO, J.L. Da climatologia geográfica à geografia do clima: gênese, paradigmas e aplicações clima como fenômeno geográfico. Revista da ANPEGE, Uberlândia, v.4, n.1, p.51-72, 2008.

SANTOS, A.P.P.; ARAGÃO, M.R.S.; SOUZA, J.R.S.; SANTOS, S.R.Q.; LINDEMANN, D.S. Aplicação da técnica dos quantis à precipitação no Leste da Amazônia e suas relações com o fenômeno ENOS no Período 1998 - 2008. In: IV Simpósio Internacional de Climatologia, João Pessoa, p.1-5, 2011.

SANTOS, A.P.P.; ARAGÃO, M.R.S.; CORREIA, M.F.; SANTOS, S.R.Q.; SILVA, F. D.S.; ARAÚJO, H.A. Precipitação na cidade de Salvador: variabilidade temporal e classificação em Quantis. Revista Brasileira de Meteorologia, São Paulo, v.31, n.4, p.114, 2016.

SANTOS, C.A.C.; MANZI, A.O. Eventos extremos de precipitação no estado do Ceará e suas relações com a temperatura dos oceanos Tropicais. Revista Brasileira de Meteorologia, São Paulo, v.26, n.1, p.157-165, 2011.

SANTOS, C.N. El Niño, La Niña e a erosividade das chuvas no Estado do Rio Grande do Sul. 2008. 138f. Tese (Doutorado). Programa de Pós-Graduação em Agronomia, Universidade Federal de Pelotas, Pelotas, 2008.

SANTOS, L.J.C.; FIORI, C.O.; CANALI, N.E.; FIORI, A.P.; SILVEIRA, C. T.; SILVA, J.M.F.; ROSS, J.L.S. Mapeamento Geomorfológico do Estado do Paraná. Revista Brasileira de Geomorfologia, São Paulo, v. 7, n.2, p.3-12, 2006. 
SANTOS, L.J.C.; FIORI, C.O.; CANALI, N.E.; FIORI, A.P.; SILVEIRA, C.T.; SILVA, J.M.F. Morphostructural Mapping of Parana State, Brazil. Journal of Maps, London, v. 5, n.1, p. 170-178, 2009.

SANTOS, G.G; GRIEBELER, N.P; OLIVEIRA, L.F.C. Chuvas intensas relacionadas à erosão hídrica. Revista Brasileira de Engenharia Agrícola e Ambiental. Campina Grande, v.14, n.2, p.115-123, 2010.

SANTOS, W.A.; ARAÚJO, H.M. Clima e condições meteorológicas da sub-bacia hidrográfica do rio Contiguiba - SE. Boletim de Geografia, Maringá, v.31, n.1, p. 41$52,2013$.

SANTOS, D.; GALVANI, E. Distribuição sazonal e horária das precipitações em Caraguatatuba - SP e a ocorrência de eventos extremos nos anos de 2007 e 2011. Ciência \& Natura, Santa Maria, v.36, n.2, p.214-229, 2014.

SELUCHI, M.E.; CHOU, S.C. Synoptic patterns associated with landslides events in the Serra do Mar, Brazil. Theoretical and Applied Climatology, Viena, v.98, n.1, p.67-77, 2009.

SELUCHI, M.E.; CHOU, S.C.; GRAMANI, M. A case study of a winter heavy rainfall event over the Serra do Mar in Brazil. Geofísica Internacional, México, v.50, n.1, p.41$56,2011$.

SELUCHI, M.E.; BEU, C.M.L.; ANDRADE, K.M. Características das frentes frias com potencial para provocar chuvas intensas na região serrana do Rio de Janeiro. Revista Brasileira de Climatologia, Curitiba, v.12, n.18, p.361-376, 2016.

SEPÚLVEDA, S.A.; PETLEY, D.N. Regional trends and controlling factors of fatal landslides in Latin America and the Caribbean. Natural Hazards and Earth System Sciences. Munich, v.15, n.8, p.1821-1833, 2015.

SHASTRI, H.; PAUL, S.; GOSH, S.; KARMAR, S. Impacts of urbanization on Indian summer monsoon rainfall extremes. Journal of Geophysical Research (Atmospheres), Washington, v.120, n.2, p.496-516, 2015.

SHELTON, M.L. Hydroclimatology: Perspectives and applications. Cambridge: Cambridge University Press, 2009. 440p.

SHERIDAN, S. The redevelopment of a weather-type classification scheme for North America. International Journal of Climatology, v. 22, n.1, p.51-68, 2002.

SILVA, F. M.; LERMEN, V. K.; NERY, J.T. Variabilidade interanual da precipitação na Bacia do Rio Iguaçu. Acta Scientiarum Technology, Maringá, v. 23, n.6, p. 1439-1444, 2001.

SILVA, M. E. S.; GUETTER, A. K. Mudanças climáticas regionais observadas no estado do Paraná. Terra Livre, São Paulo, v. 1, n.20, p. 111-126, 2003. 
SILVA, A.M. Rainfall erosivity map for Brazil. Catena, Amsterdam, v.57, n.3, p.251259. 2004.

SILVA, B.C.; CLARKE, R.T. Análise estatística de chuvas intensas na bacia do rio São Francisco. Revista Brasileira de Meteorologia, São Paulo, v.19, n.3, p.265-272, 2004.

SILVA, E.S. Variabilidade da precipitação pluviométrica nas regiões Sudeste e Sul do Brasil. 2006. 187f. Tese (Doutorado). Programa de Pós-Graduação em Agronomia (Energia na Agricultura). Universidade Estadual Paulista "Júlio de Mesquita Filho", Botucatu, 2006.

SILVA, C.B.; SANT'ANNA NETO, J.L.; TOMMASELLI, J.T.G.; PASSOS, M.M. Dinâmica atmosférica e análise geoestatística do clima na área de integração paisagística 'Raia Divisória' SP/PR/MS: uma proposta de tipologia climática. Revista Brasileira de Climatologia, Curitiba, v. 2, n.1, p. 53-70, 2006.

SILVA, D.F.; SOUSA, F.A.S.; KAYANO, M.T. Uso de ferramentas estatísticas para acompanhamento climático e prevenção de riscos na bacia hidrográfica do rio Mandaú (Brasil). Territorium, Coimbra, v.17, n.1, p. 17-26, 2010.

SILVA, G. M. F.; CARAMORI, P. H.; FARIA, R. T. Precipitações pluviais extremas em Londrina - PR. Revista Geografar, Curitiba, v. 7, n.2, p.153-172, 2012.

SILVA, M.E.S.; SILVA, C.B. Variabilidade climática - Processos físicos e dinâmicos nos oceanos e atmosfera. Revista do Departamento de Geografia (USP), v. Especial 30 anos, n.3, p.372-406, 2012.

SILVA, E.R.L.D.G.; SILVA, M.E.S. Memória dos eventos ENOS na precipitação na América do Sul. Revista do Departamento de Geografia (USP), São Paulo, v.30, n.1, p.34-55, 2015.

SILVA, W.L.; DERECZYNSKI, C. Caracterização climatológica e tendências observadas em extremos climáticos no estado do Rio de Janeiro. Anuário do Instituto de Geociências, Rio de Janeiro, v.37, n.2, p.123-138, 2014.

SILVA, W.L.; DERECZYNSKI, C.; CHANG, M.; FREITAS, M.; MACHADO, B.J.; TRISTÃO, L.; RUGGERI, J. Tendências observadas em indicadores de extremos climáticos de temperatura e precipitação no Estado do Paraná. Revista Brasileira de Meteorologia, São Paulo, v.30, n.2, p.181-194, 2015.

SILVA, C.B.; SILVA, M.E.S.; AMBRIZZI, T. Climatic variability of river outflow in the Pantanal region and the influence of sea surface temperature. Theoretical and Applied Climatology, Viena, v.123, p.1-13, 2016.

SILVA, R.O.B.; MONTENEGRO, S.M.G.L.; SOUZA, W.M. Tendências de mudanças na precipitação pluviométrica nas bacias hidrográficas do estado do Pernambuco. Engenharia Ambiental e Sanitária, Rio de Janeiro, v.22, n.3, p.579-589, 2017.

SILVA, P.E.; ANDRADE, L.M.B.; REIS, J.S. Regiões pluviométricas e saúde no Rio Grande do Norte. Confins, Paris, v.34, p.1-18, 2018. 
SILVEIRA, L.M. Os sistemas atmosféricos e a variação do tempo em Maringá, Estado do Paraná, Brasil. Acta Scientiarum Technology, Maringá, v.28, n.1, p.79-84, 2006.

SILVEIRA, C.T.; FIORI, A.P.; SCHILIPACK, P.; DIAS, S.M. Mapeamento preliminar da suscetibilidade natural a movimentos de massa da Serra do Mar paranaense apoiado na análise digital do relevo. Revista Brasileira de Geomorfologia, São Paulo, v.15, n.1, p.3-22, 2014.

SMIT, B.; BURTON, I.; KLEIN, R.; WANDEL, J. An anatomy of adaptation to climate change and variability. Climate Change, New York, v.45, n.1, p.223-251, 2000.

SNEYERS, R. Sur l'analyse statistique des séries d'observations. Genève: Organisation Météorologique Mondial, 1975. 192 p.

SOARES, F. S.; MEDRI, M.E. Alguns aspectos da colonização do rio Tibagi. In: MEDRI, M.; BIANCHINI, E.; SHIBATTA, O. A.; PIMENTA, J. O. (Org.). A bacia do Rio Tibagi. Londrina: Moacir E. Medri Editores, v. 1, p. 69-79, 2002.

SORRE, M. Le Climat. In: SORRE, M. Les Fondements de la Géographie Humaine. Paris: Armand Colin, p.13-43, 1951.

SOUSA, P. Estudo da precipitação no estado do Paraná associada à anomalia TSM do Oceano Pacífico. 2006. 72f. Dissertação (Mestrado). Programa de Pós-Graduação em Geografia, Universidade Estadual de Maringá, Maringá, 2006.

SOUSA, F.A.S.; VIEIRA, V.R.; SILVA, V.P.R.; MELO, V.S.; GUEDES, R.W.S. Estimativas dos riscos de chuvas extremas nas capitais do Nordeste do Brasil. Revista Brasileira de Geografia Física, Recife, v.9, n.2, p.430-439, 2016.

SOUZA, V.; GASPARETTO, N. V. L. Aplicação da equação universal de perdas de solo (EUPS) na bacia do córrego Pinhalzinho Segundo, noroeste do Paraná. Revista Brasileira de Geomorfologia, Uberlândia, v.13, n.3, p. 267-278, 2012.

SOUZA, W.M.; AZEVEDO, P.V.; ARAÚJO, L.E. Classificação da precipitação diária e impactos decorrentes dos desastres associados às chuvas na cidade do Recife - PE. Revista Brasileira de Geografia Física, Recife, v.5, n.2, p.250-268, 2012.

STEINKE, E.T.; SOUZA, M.R.; CAVALCANTI, L. Sistemas atmosféricos geradores de eventos extremos de precipitação em outubro de 2006 no Distrito Federal: uma análise geográfica dos desastres. Revista Brasileira de Climatologia, Curitiba, v.2, n.1, p.2334, 2007.

STEINKE, E.T.; BARROS, J. R. Tipos de tempo e desastres urbanos no Distrito Federal entre 2000 e 2015. Revista Brasileira de Geografia Física, Recife, v.8, n.5, p.1435$1453,2015$.

STENSETH, N.C.; OTTERSEN, G.; HURRELL, J.W.; MYSTERUD, A.; LIMA, M.; CHAN, K.S.; YOCCOZ, N.G.; ADLANDSVIK, B. Studying climate effects on ecology through the use of climate indices: the North Atlantic Oscillation, El Niño Southern 
Oscillation and beyond. Proceedings of the Royal Society of London - Biology Science, London, v. 270, n.1529, p.2087-2096, 2003.

STRAHLER, A. N. Physical Geography. New York: John Willey \& Sons, 1951.442p.

TAVARES, A.C. Variabilidade e Mudanças Climáticas. 2001. 228f. Tese (LivreDocência). Programa de Pós-Graduação em Geografia, Universidade Estadual Paulista "Júlio de Mesquita Filho", Rio Claro, 2001.

TAVARES, A.C.; SILVA, A.C.F. Urbanização, chuvas de verão e inundações: uma análise episódica. Climatologia e Estudos da Paisagem, Rio Claro, v.3, n.1, p.04-18, 2008.

TEODORO, P.E.; DE OLIVEIRA-JÚNIOR, J.F.; DA CUNHA, E. R.; CORREA, C.C. G.; TORRES, F.E.; BACANI, V. M.; GOIS, G.; RIBEIRO, L. P. Cluster analysis applied to the spatial and temporal variability of monthly rainfall in Mato Grosso do Sul State, Brazil. Meteorology and Atmospheric Physics, Berlin, v.128, n.6, p.197-209, 2015.

TEIXEIRA, M.S.; SATYAMURTY, P. Dynamical and synoptic characteristics of heavy rainfall episodes in Southern Brazil. Monthly Weather Review, Boston, v.135, n.2, 598617, 2007.

TERASSI, P. M. B.; SILVEIRA, H.; GRAÇA, C. H. Regiões pluviométricas homogêneas e a erosividade das chuvas na unidade hidrográfica Pirapó, Paranapanema III e IV-Paraná. Caderno de Geografia, Belo Horizonte, v.26, n.46, p.507-521, 2016.

TERASSI, P.M.B.; GALVANI, E. O efeito orográfico da Serra do Mar e o potencial erosivo das chuvas nas bacias hidrográficas do Ribeira e Litorânea - Paraná. Revista Brasileira de Climatologia, Curitiba, v.21, n.1, p.327-345, 2017.

TERASSI, P.M.B.; CORREA, M.G.G.; GALVANI, E. Avaliação do potencial erosivo das chuvas na bacia hidrográfica do rio Piquiri - Paraná. Geoambiente On-Line, Jataí, v.30, n.1, p.1-19, 2018.

THOMAZ, S. L. Sinopse sobre a geologia do Paraná. Boletim de Geografia, Maringá, v.2, n.2, p.76-90, 1984.

TONETTI, E. L.; NUCCI, J. C.; SOUZA, F. X. S.; VALASKI, S. Alagamentos frequentes na área urbana de Paranaguá - PR. Geografia, Londrina, v.22, n.2, p.43-56, 2013.

TRENBERTH, K. E. The definition of El Niño. Bulletin of the American Meteorology Society, Boston, v.78, n.12, p.2771-2777. 1997.

TRINDADE，A.L.F.; OLIVEIRA， P.T.S.; ANACHE， J.A.A.; WENDLAND， E. Variabilidade espacial das chuvas no Brasil. Revista de Pesquisa Agropecuária, Brasília, v.51, n.12, p.1918-1928, 2016.

TROPPMAIR, H. Perfil Fitoecológico do Estado do Paraná. Boletim de Geografia, Maringá, v.8, n.1, p.67-80, 1990. 
TUCCI, C.E.M. Hidrologia: Ciência e Aplicação. $3^{\text {a }}$ Edição. Porto Alegre: Universidade Federal do Rio Grande do Sul/Associação Brasileira de Recursos Hídricos. 2004.943p.

VALVERDE, M. C.; MARENGO, J. A. Extreme Rainfall Indices in the Hydrographic Basins of Brazil. Open Journal of Modern Hydrology, Irvine, v.4, n.1, p.10-26, 2014.

VAREJÃO-SILVA, M.A. Meteorologia e Climatologia. Recife, Versão Digital 2, 2012. 449p. Disponível em: <http://www.icat.ufal.br/laboratorio/clima/data/uploads/pdf

/METEOROLOGIA_E_CLIMATOLOGIA_VD2_Mar_2006.pdf>. Acesso em 29 de setembro de 2016.

VELASCO, I.; FRITSCH, J. M. Mesoscale convective complexes in the Americas. Journal of Geophysical Research, Washington, v. 92, n.8, p. 9591-9613, 1987.

VIANELLO, R. L.; ALVES, A. R. Meteorologia básica e aplicações. Viçosa: UFV, 1991, 449p.

VINCENT, L.A.; PETERSON, T.C.; BARROS, V.R.; MARINO, M.B.; RUSTICUCCI, M.; CARRASCO, G.; RAMIREZ, E.; ALVES, L.M.; AMBRIZZI, T.; BERLATO, M. A.; GRIMM, A.M.; MARENGO, J.A.; MOLION, L.; MONCUNILL, D.F.; REBELLO, E.; ANUNCIAÇÃO, Y.M.T.; QUINTANA, J.; SANTOS, J.L.; BAEZ, J.; CORONEL, G.; GARCIA, J.; TREBEJO, I.; BIDEGAIN, M.; HAYLOCK, M.R.; KAROLY, D. Observed trends in indices of daily temperature extremes in South America 1960-2000. Bulletin of the American Meteorological Society, Boston, v.18, n.23, p.5011-5023, 2005.

VICENTE, A.K.; NUNES, L.H. Extreme precipitation events in Campinas, Brazil. Terræ. Geosciences, Geography and the Environment (Online), Campinas, v.1, n.1, p.60-63, 2004.

VILLELA, S. M.; MATTOS, A. Hidrologia aplicada. São Paulo: McGraw-Hill do Brasil, 1975. 245p.

XAVIER, T. M. B. S.; XAVIER, A.F. S. Caracterização de períodos secos ou excessivamente chuvosos no estado do Ceará através da técnica dos Quantis: 1964-1998. Revista Brasileira de Meteorologia, São Paulo, v.14, n.2, p.63-78, 1999.

WALKER, G.T. Correlation in seasonal variation of weather, IX. A further study of world weather. Memoirs of the India Meteorological Departament, Calcutá, v.24, p.275333, 1924.

WALTRICK, P. C.; MACHADO, M. A. M.; DIECKOW, J.; OLIVEIRA, D. Estimativas da erosividade de chuvas no estado do Paraná pelo método da pluviometria: Atualização com dados de 1986 a 2008. Revista Brasileira de Ciência do Solo, Viçosa, v.39, n.1, p.256-267, 2015.

WISCHMEIER, W. H.; SMITH, D. D. Predicting rainfall erosion losses, a guide to conservation planning. Agricultural Handbook, Washington, n.537, 1978, 58p. 
WOLlMANN, C. A.; SARTORI, M. G. B. Sazonalidade dos episódios de enchentes ocorridos na bacia hidrográfica do rio Caí - RS, e sua relação com a atuação do Fenômeno El Niño, no período de 1982 a 2005. Revista Brasileira de Climatologia, Curitiba, v.7, n.1, p.103-118, 2010.

WOllmanN, C. A. Enchentes no Rio Grande do Sul do Século XXI. Mercator, Fortaleza, v.13, n.1, p.79-91, 2014.

WREGE, M.S.; STEINMETZ, S.; REISSER JÚNIOR, C.; ALMEIDA, I.R. Atlas Climático da Região Sul do Brasil: Estados do Paraná, Santa Catarina e Rio Grande do Sul. Pelotas: Embrapa Clima Temperado; Colombo: Embrapa Florestas, 2011. 336 p.

WREGE, M.S.; FRITZSONS, E.; CARAMORI, P. H.; RICCE, W.S.; RADIN, B.; STEINMETZ, S.; REISSER JÚNIOR, C. Regiões com similaridade de comportamento hídrico no Sul do Brasil. RA'E GA: o Espaço Geográfico em Análise, Curitiba, v.38, p.363-382, 2016.

YAKAMOTO, J.K.; LANDIM, P.M.B. Geoestatística: Conceitos e Aplicações. $1^{\text {a }}$ Edição. São Paulo: Oficina de Textos, 2013. 215p.

ZANDONADI, L. As chuvas da bacia do rio Paraná, Brasil: Um estudo do ritmo climático e algumas considerações sobre a vazão hídrica. 2013. 206f. Tese (Doutorado). Programa de Pós-Graduação em Geografia, Universidade Estadual Paulista "Júlio de Mesquita Filho", Rio Claro, 2013.

ZANDONADI, L.; ACQUAOTTA, F.; FRATIANNI, S.; ZAVATTINI, J. A. Changes in precipitation extremes in Brazil (Paraná River Basin). Theoretical and Applied Climatology, Viena, v.119, n.1, p.741-756, 2015.

ZANELLA, M.E. Inundações urbanas em Curitiba/PR: Impactos, riscos e vulnerabilidade socioambiental no bairro Cajuru. 2006. 256f. Programa de Pós-Graduação em Meio Ambiente e Desenvolvimento, Universidade Federal do Paraná, Curitiba, 2006a.

ZANELLA, M. E. Eventos pluviométricos intensos e impactos gerados na cidade de Curitiba/PR-Bairro Cajuru: um destaque para as inundações urbanas. Mercator, Fortaleza, v.5, n.9, p.61-74, $2006 \mathrm{~b}$.

ZANELLA, M.E. Impactos pluviais no Bairro Cajuru - Curitiba - PR. Mercator, Fortaleza, v.6, n.11, p.93-105, 2007.

ZANELLA, M. E.; SALES, M. C. L.; ABREU. N.J. Análise das Precipitações diárias intensas e impactos gerados em Fortaleza - CE. Geousp, São Paulo, v.25, n.1, p.53-68, 2009.

ZHANG, X. YANG, F. RClimDex (1.0) - User Manual. Climate Research Branch Environment Canada Downsview, Ontario, Canada, 2004.22p.

ZHANG, G.H.; NEARING, M.A.; LIU, B.Y. Potencial effects of climate change on rainfall erosivity in the Yellow river basin of China. Transactions of the American Society of Agriculture Engineers, Washington, v.48, n.2, p.511-517, 2005. 


\section{APÊNDICE}

Equação 17 - Modelo VAR para o grupo 1 do Alto do Iguaçu e o indicador TSA

$\left\{\begin{array}{l}C H \widehat{U V A} S_{t}=0,14 * C H U V A S_{t-1} \\ \widehat{T S A}_{t}=0,02+0,87 * T S A_{t-1}\end{array}\right.$

Equação 18 - Modelo VAR para o grupo 1 do Alto do Iguaçu e o indicador IOS

$$
\left\{\begin{array}{c}
\text { CHUVA } \\
\widehat{I_{t}}=0,13 * C H U V A S_{t-1} \\
=0,48 * I O S_{t-1}+0,27 * I O S_{t-2}
\end{array}\right.
$$

Equação 19 - Modelo VAR para o grupo 1 do Alto do Iguaçu e o indicador ODP

$$
\left\{\begin{aligned}
C H \widehat{U V A} S_{t} & =0,14 * C H U V A S_{t-1} \\
\widehat{O D P}_{t} & =0,86 * O D P_{t-1}
\end{aligned}\right.
$$

Equação 20 - Modelo VAR para o grupo 1 do Alto do Iguaçu e o indicador ONI

$$
\left\{\begin{array}{c}
\operatorname{CHUVA}_{t}=0,10 * \widehat{C H U V A S}_{t-1}+0,10 * C_{\text {CHUVAS }} \\
\widehat{\mathrm{ONI}}_{t}=2,28 * \mathrm{ONI}_{t-1}-1,79 * \mathrm{ONI}_{t-2}+0,99 * \mathrm{ONI}_{t-4}-0,90 * \mathrm{ONI}_{t-5}+0,27 * \mathrm{ONI}_{t-6}
\end{array}\right.
$$

Equação 21 - Modelo VAR para o grupo 2 do Alto do Iguaçu e o indicador TSA

$$
\left\{\begin{array}{l}
\text { CHUVAS } \\
\widehat{T S A_{t}}=0,02+0,87 * \operatorname{CHUVAS}_{t-1} \\
\text { TSA } A_{t-1}
\end{array}\right.
$$

Equação 22 - Modelo VAR para o grupo 2 do Alto do Iguaçu e o indicador IOS

$$
\left\{\begin{array}{c}
\text { CHUVAS } \\
\widehat{\operatorname{IOS}_{t}}=0,49 * \operatorname{IOS}_{t-1}+0,26 * I O S_{t-2}
\end{array}\right.
$$

Equação 23 - Modelo VAR para o grupo 2 do Alto do Iguaçu e o indicador ODP

$$
\left\{\begin{array}{c}
C H \widehat{U V A} S_{t}=(\text { sem equação }) \\
\widehat{O D P} \widehat{t}_{t-1}=0,86 * O D P_{t}
\end{array}\right.
$$

Equação 24 - Modelo VAR para o grupo 2 do Alto do Iguaçu e o indicador ONI

$$
\left\{\begin{array}{c}
C H \widehat{U V A} S_{t}=147,47 * O N I_{t-2}-173,95 * O N I_{t-3} \\
\widehat{O N I}_{t}=2,28 * O N I_{t-1}-1,79 * O N I_{t-2}+0,99 * O N I_{t-4}-0,89 * O N I_{t-5}+0,27 * O N I_{t-6}
\end{array}\right.
$$

Equação 25 - Modelo VAR para o grupo 3 do Alto do Iguaçu e o indicador TSA

$$
\left\{\begin{array}{l}
C H \widehat{U V A} S_{t}=0,17 * C H U V A S_{t-1} \\
\widehat{T S A}_{t}=0,02+0,87 * T S A_{t-1}
\end{array}\right.
$$


Equação 26 - Modelo VAR para o grupo 3 do Alto do Iguaçu e o indicador IOS

$\left\{\begin{array}{c}\text { CHUVAS } \\ \widehat{I O S_{t}}=0,48 * I O S_{t-1}+0,27 * I O S_{t-2}\end{array}\right.$

Equação 27 - Modelo VAR para o grupo 3 do Alto do Iguaçu e o indicador ODP

$$
\left\{\begin{aligned}
C H \widehat{U V A} S_{t} & =0,17 * C H U V A S_{t-1} \\
\widehat{O D P}_{t} & =0,86 * O D P_{t-1}
\end{aligned}\right.
$$

Equação 28 - Modelo VAR para o grupo 3 do Alto do Iguaçu e o indicador ONI

$$
\left\{\begin{array}{c}
C H \widehat{U V A} S_{t}=0,15 * C H U V A S_{t-1} \\
\widehat{O N I}_{t}=2,28 * O N I_{t-1}-1,79 * O N I_{t-2}+0,98 * O N I_{t-4}-0,90 * O N I_{t-5}+0,27 * O N I_{t-6}
\end{array}\right.
$$

Equação 29 - Modelo VAR para o grupo 4 do Alto do Iguaçu e o indicador TSA

$$
\left\{\begin{array}{l}
\widehat{C H U V A} S_{t}=0,17 * C H U V A S_{t-1} \\
{\widehat{T S A_{t}}}_{t}=0,02+0,87 * T_{S A} A_{t-1}
\end{array}\right.
$$

Equação 30 - Modelo VAR para o grupo 4 do Alto do Iguaçu e o indicador IOS

$$
\left\{\begin{array}{c}
C H \widehat{U V A} S_{t}=(\text { sem equação }) \\
\overparen{I O S_{t}}=0,49 * I O S_{t-1}+0,26 * I O S_{t-2}
\end{array}\right.
$$

Equação 31 - Modelo VAR para o grupo 4 do Alto do Iguaçu e o indicador ODP

$$
\left\{\begin{array}{c}
C H \widehat{U V A}_{t}=(\text { sem equação }) \\
\widehat{O D P}_{t}=0,86 * O D P_{t-1}
\end{array}\right.
$$

Equação 32 - Modelo VAR para o grupo 4 do Alto do Iguaçu e o indicador ONI

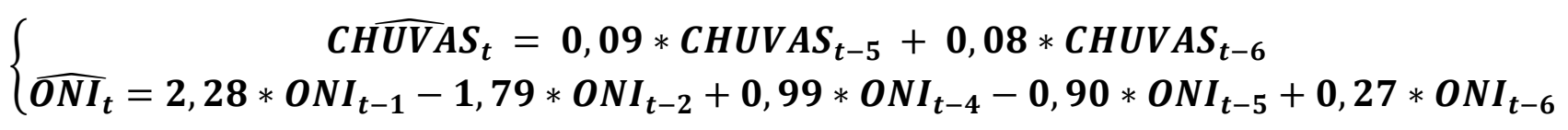

Equação 33 - Modelo VAR para o grupo 5 do Alto do Iguaçu e o indicador TSA

$$
\left\{\begin{array}{l}
\text {CHUVA }_{t}=0,09 * \text { CHUVAS } \\
\widehat{T S A}_{t}=0,02+0,87 * T S A_{t-1}
\end{array}\right.
$$

Equação 34 - Modelo VAR para o grupo 5 do Alto do Iguaçu e o indicador IOS

$$
\left\{\begin{array}{c}
C H \widehat{U V A} S_{t}=0,08 * C H U V A S_{t-1}+0,10 * C H U V A S_{t-2} \\
\widetilde{I O S_{t}}=0,49 * I O S_{t-1}+0,26 * I O S_{t-2}
\end{array}\right.
$$

Equação 35 - Modelo VAR para o grupo 5 do Alto do Iguaçu e o indicador ODP 
$\left\{\begin{array}{c}\text { CHUVAS }_{\mathrm{t}}=0,09 * \text { CHUVAS }_{\mathrm{t}-1} \\ \widehat{\mathrm{ODP}}_{\mathrm{t}}=0,86 * \mathrm{ODP}_{\mathrm{t}-1}\end{array}\right.$

Equação 36 - Modelo VAR para o grupo 5 do Alto do Iguaçu e o indicador ONI

$\left\{\begin{array}{c}\text { CHUVAS }_{\mathrm{t}}=0,08 * \text { CHUVAS }_{\mathrm{t}-2}+175,18 * \mathrm{ONI}_{\mathrm{t}-2}-205,20 * \mathrm{ONI}_{\mathrm{t}-2} \\ \widehat{\mathrm{ONI}}_{\mathrm{t}}=2,27 * \mathrm{ONI}_{\mathrm{t}-1}-1,79 * \mathrm{ONI}_{\mathrm{t}-2}+0,98 * 0 \mathrm{NI}_{\mathrm{t}-4}-0,90 * 0 \mathrm{NI}_{\mathrm{t}-5}+0,27 * \mathrm{ONI}_{\mathrm{t}-6}\end{array}\right.$

Equação 37 - Modelo VAR para o grupo 6 do Alto do Iguaçu e o indicador TSA

$$
\left\{\begin{array}{c}
\text { CHUVA }_{t}=0,10 * C H U V A S_{t-1}+0,10 * C H U V A S_{t-6} \\
T S A_{t}=0,03+0,96 * T S A_{t-1}
\end{array}\right.
$$

Equação 38 - Modelo VAR para o grupo 6 do Alto do Iguaçu e o indicador IOS

$$
\left\{\begin{array}{l}
\text { CHUVA } \\
\widehat{I O S_{t}}=0,46 * I O S_{t-1}+0,25 * I O S_{t-2}+0,13 * I O S_{t-3}
\end{array}\right.
$$

Equação 39 - Modelo VAR (6) para o grupo 6 do Alto do Iguaçu e o indicador ODP

$$
\left\{\begin{array}{c}
C H \widehat{U V A} S_{t}=0,10 * C H U V A S_{t-1}+0,10 * C H U V A S_{t-6} \\
\widehat{O D P}_{t}=0,93 * O D P_{t-1}
\end{array}\right.
$$

Equação 40 - Modelo VAR para o grupo 6 do Alto do Iguaçu e o indicador ONI

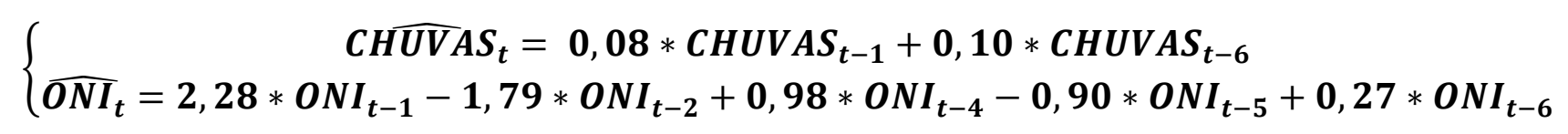

Equação 41 - Modelo VAR para o grupo 1 da bacia Litorânea e o indicador TSA

$$
\left\{\begin{array}{c}
\widehat{C H U V A} S_{t}=0,11 * C H U V A S_{t-1} \\
\widehat{T S A_{t}}=0,02+0,87 * T S A_{t-1}
\end{array}\right.
$$

Equação 42 - Modelo VAR para o grupo 1 da bacia Litorânea e o indicador IOS

$$
\left\{\begin{array}{c}
\text { CHUVAS } \\
\widehat{I O S_{t}}=0,48 * I O S_{t-1}+0,28 * I O S_{t-2}
\end{array}\right.
$$

Equação 43 - Modelo VAR para o grupo 1 da bacia Litorânea e o indicador ODP

$$
\left\{\begin{array}{c}
C H \widehat{C V A} S_{t}=0,11 * C H U V A S_{t-1} \\
\widehat{O D P}_{t}=0,86 * O D P_{t-1}
\end{array}\right.
$$

Equação 44 - Modelo VAR para o grupo 1 da bacia Litorânea e o indicador ONI

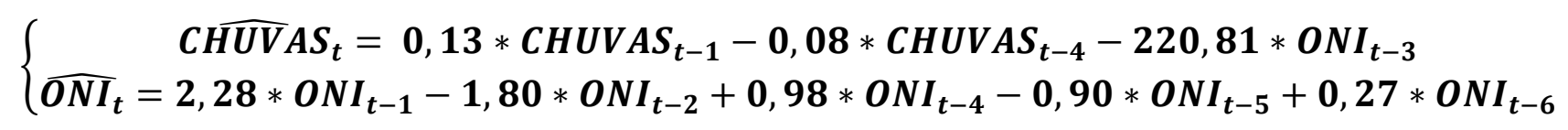


Equação 45 - Modelo VAR para o grupo 2 da bacia Litorânea e o indicador TSA

$$
\left\{\begin{array}{c}
C H \overline{U V A} S_{t}=0,12 * C H U V A S_{t-1} \\
\widetilde{T S A_{t}}=0,02+0,87 * T S A_{t-1}
\end{array}\right.
$$

Equação 46 - Modelo VAR para o grupo 2 da bacia Litorânea e o indicador IOS

$$
\left\{\begin{array}{c}
C \widehat{H U V A S} S_{t}=0,13 * C H U V A S_{t-1} \\
I \widehat{O S} S_{t}=0,48 * I O S_{t-1}+0,28 * I O S_{t-2}
\end{array}\right.
$$

Equação 47 - Modelo VAR para o grupo 2 da bacia Litorânea e o indicador ODP

$$
\left\{\begin{aligned}
C H \widehat{U V A S}_{t} & =0,13 * C H U V A S_{t-1} \\
\widehat{O D P}_{t} & =0,86 * O D P_{t-1}
\end{aligned}\right.
$$

Equação 48 - Modelo VAR para o grupo 2 da bacia Litorânea e o indicador ONI

$$
\left\{\begin{array}{c}
\text { CHUVAS } \\
\widehat{O N I}_{t}=2,28 * 0,14 * C H U V A S_{t-1}-0,08 * C H U V A S_{t-4} \\
O N I_{t-1}-1,79 * O N I_{t-2}+0,97 * O N I_{t-4}-0,89 * O N I_{t-5}+0,27 * O N I_{t-6}
\end{array}\right.
$$

Equação 49 - Modelo VAR para o grupo 3 da bacia Litorânea e o indicador TSA

$$
\left\{\begin{array}{c}
C \widehat{H U V} A S_{t}=0,27 * C H U V A S_{t-1} \\
\widehat{T S A_{t}}=0,02+0,88 * T S A_{t-1}
\end{array}\right.
$$

Equação 50 - Modelo VAR para o grupo 3 da bacia Litorânea e o indicador IOS

$$
\left\{\begin{array}{c}
\text { CHUVAS } \\
\widehat{I O S}_{t}=0,48 * I O S_{t-1}+0,27 * I O S_{t-2}
\end{array}\right.
$$

Equação 51 - Modelo VAR para o grupo 3 da bacia Litorânea e o indicador ODP

$$
\left\{\begin{array}{c}
C \widehat{H U V A} S_{t}=0,25 * C H U V A S_{t-1}+15,07 * O D P_{t-1} \\
\widehat{O D P}_{t}=0,86 * O D P_{t-1}
\end{array}\right.
$$

Equação 52 - Modelo VAR para o grupo 3 da bacia Litorânea e o indicador ONI

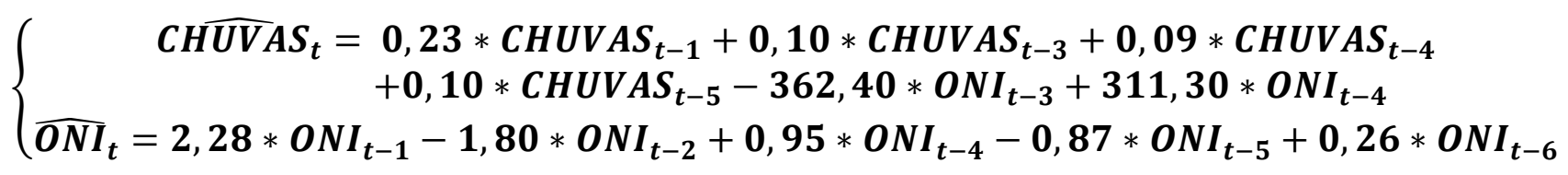

Equação 53 - Modelo VAR para o grupo 1 do Ribeira e o indicador TSA

$$
\left\{\begin{array}{c}
\text { CHUVA } S_{t}=(\text { sem equação }) \\
\widehat{T S A}_{t}=0,02+0,97 * T S A_{t-1}-0,11 * T S A_{t-2}
\end{array}\right.
$$

Equação 54 - Modelo VAR para o grupo 1 do Ribeira e o indicador IOS 


$$
\left\{\begin{array}{c}
\text { CH } \widehat{U V A} S_{t}=(\text { sem equação }) \\
\widehat{I O S_{t}}=0,48 * I O S_{t-1}+0,27 * I O S_{t-2}
\end{array}\right.
$$

Equação 55 - Modelo VAR para o grupo 1 do Ribeira e o indicador ODP

$$
\left\{\begin{array}{c}
C H \widehat{U V A} S_{t}=(\text { sem equação }) \\
\widehat{O D P}_{t}=0,86 * O D P_{t-1}
\end{array}\right.
$$

Equação 56 - Modelo VAR para o grupo 1 do Ribeira e o indicador ONI

$$
\left\{\begin{array}{c}
C H \widehat{U V A} S_{t}=0,10 * C H U V A S_{t-6} \\
\widehat{O N I}_{t}=2,28 * O N I_{t-1}-1,79 * O N I_{t-2}+0,98 * O N I_{t-4}-0,90 * O N I_{t-5}+0,27 * O N I_{t-6}
\end{array}\right.
$$

Equação 57 - Modelo VAR para o grupo 2 do Ribeira e o indicador TSA

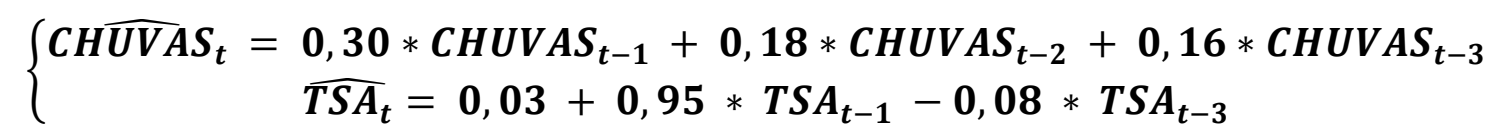

Equação 58 - Modelo VAR para o grupo 2 do Ribeira e o indicador IOS

$$
\left\{\begin{array}{c}
\text { CHUVAS } \\
\widehat{I O S}_{t}=0,30 * C_{\text {CHUVAS }}+0,18 * I O S_{t-1}+0,23 * I O S_{t-2}+0,09 * I O S_{t-3}
\end{array}\right.
$$

Equação 59 - Modelo VAR para o grupo 2 do Ribeira e o indicador ODP

$$
\left\{\begin{array}{c}
\text { CHUVAS }_{t}=0,30 * C_{\text {CHUVAS }}+0,18 * C H U V A S_{t-2}+18,55 * O D P_{t-2} \\
+0,16 * C H U V A S_{t-3}-15,15 * O D P_{t-3} \\
\widehat{O D P}_{t}=0,05+0,93 * O D P_{t-1}
\end{array}\right.
$$

Equação 60 - Modelo VAR para o grupo 2 do Ribeira e o indicador ONI

$$
\left\{\begin{array}{c}
C \widehat{H U V A S_{t}}=0,29 * C H U V A S_{t-1}+0,17 * C H U V A S_{t-2}+0,13 * C H U V A S_{t-3} \\
+0,11 * C H U V A S_{t-6} \\
\widehat{O N I}_{t}=2,29 * O N I_{t-1}-1,81 * O N I_{t-2}+0,96 * O N I_{t-4}-0,89 * O N I_{t-5} \\
+0,27 * O N I_{t-6}
\end{array}\right.
$$

Equação 61 - Modelo VAR para o grupo 3 do Ribeira e o indicador TSA

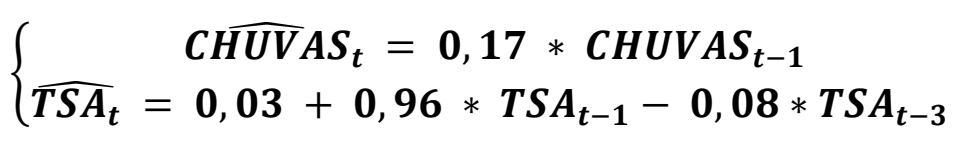

Equação 62 - Modelo VAR para o grupo 3 do Ribeira e o indicador IOS

$$
\left\{\begin{array}{c}
C H \widehat{U V A} S_{t}=0,13 * C H U V A S_{t-1}+0,14 * C H U V A S_{t-3} \\
\widehat{I O S}_{t}=0,46 * I O S_{t-1}+0,22 * I O S_{t-1}+0,10 * I O S_{t-3}
\end{array}\right.
$$

Equação 63 - Modelo VAR para o grupo 3 do Ribeira e o indicador ODP 


$$
\left\{\begin{array}{c}
\text { CHUVA }_{t}=0,14 * C H U V A S_{t-1}+14,31 * O D P_{t-2}+0,13 * C H U V A S_{t-3}-10,05 * O D P_{t-3} \\
\widehat{O D P}_{t}=0,05+0,93 * O D P_{t-1}
\end{array}\right.
$$

Equação 64 - Modelo VAR para o grupo 3 do Ribeira e o indicador ONI

$$
\left\{\begin{array}{c}
\operatorname{CHUVAS}_{t}=0,12 * \widehat{C H U V A S}_{t-1}+0,12 * C_{\text {CHUVAS }} \\
\widehat{O N I}_{t}=2,28 * \mathrm{ONI}_{t-1}-1,80 * \mathrm{ONI}_{t-2}+0,99 * \mathrm{ONI}_{t-4}-0,91 * \mathrm{ONI}_{t-5}+0,27 * \mathrm{ONI}_{t-6}
\end{array}\right.
$$

Equação 65 - Modelo VAR para o grupo 4 do Ribeira e o indicador TSA

$$
\left\{\begin{array}{c}
\text { CHUVA } S_{t}=0,24 * C H U V A S_{t-1}-21,75 * T S A_{t-1} \\
\widehat{T_{S A}}=0,02+0,88 * T S A_{t-1}
\end{array}\right.
$$

Equação 66 - Modelo VAR para o grupo 4 do Ribeira e o indicador IOS

$$
\left\{\begin{array}{c}
\text { CHUVAS } \\
\widehat{I O S_{t}}=0,48 * I O S_{t-1}+0,27 * I O S_{t-2}
\end{array}\right.
$$

Equação 67 - Modelo VAR para o grupo 4 do Ribeira e o indicador ODP

$$
\left\{\begin{array}{c}
C H \widetilde{U V A} S_{t}=0,24 * C H U V A S_{t-1} \\
\widehat{O D P}_{t}=0,04+0,85 * O D P_{t-1}
\end{array}\right.
$$

Equação 68 - Modelo VAR para o grupo 4 do Ribeira e o indicador ONI

$$
\left\{\begin{array}{c}
\operatorname{CHUVAS}_{t}=0,20 * \widehat{C H U V A S}_{t-1}+0,15 * C_{\text {CHUVAS }} \\
\widehat{O N I}_{t}=2,28 * \mathrm{ONI}_{t-1}-1,79 * \mathrm{ONI}_{t-2}+0,98 * \mathrm{ONI}_{t-4}-0,89 * \mathrm{ONI}_{t-5}+0,27 * \mathrm{ONI}_{t-6}
\end{array}\right.
$$

Equação 69 - Modelo VAR para o grupo 5 do Ribeira e o indicador TSA

$$
\left\{\begin{array}{l}
\text { CHUVAS } \\
\widehat{T S A}_{t}=0,02+0,87 * T_{S A} A_{t-1}
\end{array}\right.
$$

Equação 70 - Modelo VAR para o grupo 5 do Ribeira e o indicador IOS

$$
\left\{\begin{array}{c}
\text { CHUVAS } \\
\widehat{I O S_{t}}=0,48 * I O S_{t-1}+0,27 * I O S_{t-2}
\end{array}\right.
$$

Equação 71 - Modelo VAR para o grupo 5 do Ribeira e o indicador ODP

$$
\left\{\begin{aligned}
\boldsymbol{C H U V A S _ { t }} & =0,10 * C H U V A S_{t-1} \\
\widehat{O D P}_{t} & =0,86 * O D P_{t-1}
\end{aligned}\right.
$$

Equação 72 - Modelo VAR para o grupo 5 do Ribeira e o indicador ONI

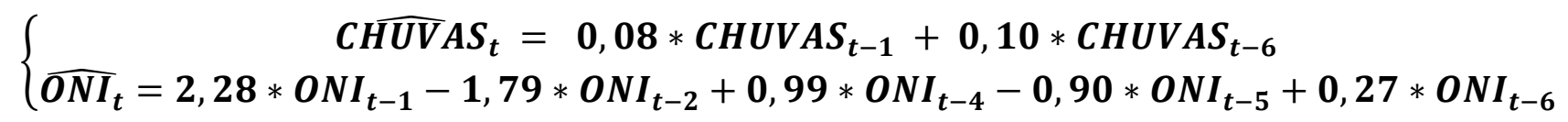

